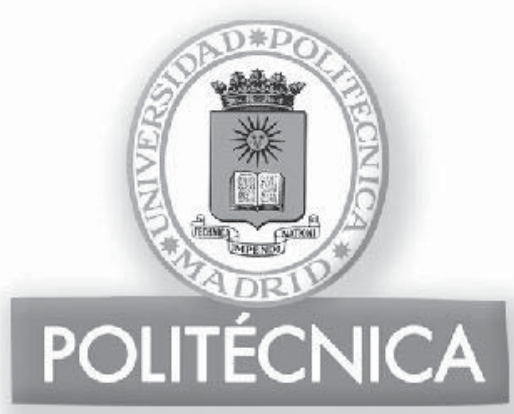

Universidad Politécnica de Madrid

Escuela Técnica Superior de Arquitectura de Madrid

\title{
SEgovia y SUS MURALlas EN la ALta EdAd Media. ARQUEOLOGÍA URBANA Y CONSTRUCCIÓN HISTÓRICA.
}

Tesis Doctoral

Miguel Ángel Martín Blanco

Arquitecto

Director

Dr. Fernando Vela Cossío

Madrid 2017 



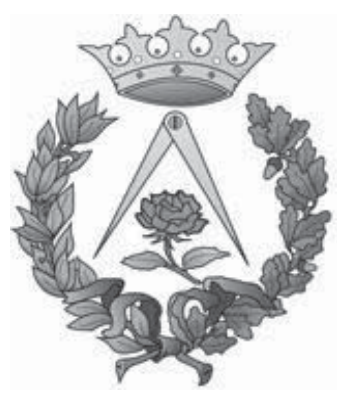

Escuela Técnica Superior de Arquitectura de Madrid Conservación y Restauración del Patrimonio Arquitectónico

\title{
SEgOVIA Y SUS MURALlaS EN LA ALTA EDAD MEDIA. ARQUEOLOGÍA URBANA Y CONSTRUCCIÓN HISTÓRICA.
}

\author{
Tesis Doctoral
}

Miguel Ángel Martín Blanco

Arquitecto

Director

Dr. Fernando Vela Cossío

Madrid 2017 

SEgovia y sus murallas en la Alta EdAd Media. ARQUEOLOGÍA URBANA Y CONSTRUCCIÓN HISTÓRICA. 



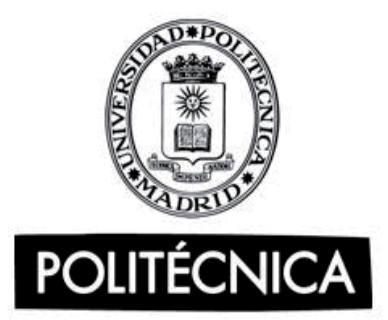

Tribunal nombrado por el Sr. Rector Magfco. de la Universidad Politécnica de Madrid, el día..... de. ..de $20 \ldots$.

Presidente:

Vocal:

Vocal:

Vocal:

Secretario:

Suplente:

Suplente:

Realizado el acto de defensa y lectura de la Tesis el día de. de $20 \ldots$. en la E.T.S./Facultad

Calificación

EL PRESIDENTE

LOS VOCALES

EL SECRETARIO 

ÍNDICE 



\section{RESUMEN.}

ABSTRaCt.

I. - INTRODUCCIÓN. 1

1.1.- Presentación. 3

1.2.- Ámbito de la investigación.

1.3.- Hipótesis de partida y objetivos del trabajo. 9

1.4.- Metodología investigadora. 13

1.5.- Agradecimientos. 33

II. - Aproximación a la Alta Edad Media en SEgovia.

III. - LA MURALLA COMO DOCUMENTO CONSTRUIDO. 91

3.1.- Descripción general de la muralla. 93

3.2.- Elementos y fábricas. $\quad 97$

3.2.1.- Zona 1. Leopoldo Moreno. 97

3.2.2.- Zona 2. Salón. 108

3.2.3.- Zona 3. Alhóndiga. 112

3.2.4.- Zona 4. Acueducto. 117

3.2.5.- Zona 5. San Juan. 124

3.2.6.- Zona 6. Santa Cruz. 126

3.2.7.- Zona 7. Misericordia. 133

3.2.8.- Zona 8. Santiago. 144

3.2.9.- Zona 9. Pozo de la nieve. 150

3.2.10.- Zona 10. Alcázar. 159

3.2.11.- Zona 11. Ronda de Juan II. 168

3.2.12.- Zona 12. Museo-Hontanilla. 173 
4.1.-Elementos desaparecidos y vestigios de discontinuidades constructivas.

4.1.1.- Casa fuerte torreada en la judería.

4.1.2.- Postigo del Sol y casa fuerte de la familia Coronel.

4.1.3.- Postigo de la Luna y la Alhóndiga.

4.1.4.- Puerta de San Martín o del Azoguejo.

4.1.5.- Torres y lienzos contiguos al acueducto .

4.1.6.- Puerta de San Juan y la actual casa del Marqués de Lozoya.

4.1.7.- Postigo de San Juan y las torres cercanas.

4.1.8.- Postigo de San Matías y muralla hasta San Cebrián.

4.1.9.- Postigo de Fuente Cercada.

4.1.10.- Un camino previo, un postigo y dos torres.

4.1.11.- Postigos del Alcázar.

4.1.12.- Casa fuerte en la Casa del Sol.

4.2.- Características arquitectónicas y constructivas de las evidencias materiales.

4.2.1.- La forma en planta de las torres de la muralla.

4.2.1.a.- Torres semicirculares.

4.2.1.b.- Torres poligonales.

4.2.1.c.- Torres rectangulares.

4.2.1.d.- Un orden lógico en una aparente aleatoriedad.

4.2.2.- Métrica de la muralla.

4.2.2.a.- Dimensiones de las torres.

4.2.2.b.- Medidas de los lienzos.

4.2.3.- Configuración de los accesos.

4.2.3.a.- Puertas.

4.2.3.b.- Postigos.

4.2.4.- La configuración de los zócalos. 
4.2.5.- Materiales constructivos y su distribución.

4.2.5.a.- Granitos. 303

4.2.5.b.- Piedra sedimentaria o carbonatada. 309

4.2.5.c.- Ladrillo. $\quad 310$

4.2.5.d.- Spolia. La reutilización de materiales. 312

4.2.6.- Sistemas constructivos y fábricas. 321

4.2.6.a.- Sillería. 327

4.2.6.b.- Mampostería. 331

4.2.6.c.- Tapia encofrada o fábrica de calicanto. 334

4.2.6.d.- Fábrica de ladrillo. 348

4.2.7.- Catalogo de aparejos. 355

4.2.7.a.- Aparejos de zócalo y parte baja de la muralla. 357

4.2.7.b.- Aparejos de la parte alta de la muralla. 377

4.2.7.c.- Relaciones estratigráficas entre aparejos. 410

4.3.- Discontinuidades constructivas y pervivencias históricas. 417

4.3.1.- Una interpretación desde la geometría y la técnica constructiva. 417

4.3.1.a.- Las torres poligonales. 424

4.3.1.b.- Las puertas y postigos. 431

4.3.1.c.- Disparidad de sistemas constructivos y aparejos. 434

4.3.2.- Una aproximación cronológica 441

V. - PALIMPSESTO CONSTRUCTIVO. LA MURALLA COMO PROCESO. 445

5.1.- Recapitulación de hallazgos y descubrimientos. 447

5.2.- Las reconstrucciones de la época contemporánea y moderna. 453

5.3.- La configuración de la muralla a finales de la Edad Media.

5.4.- La muralla de la repoblación de Alfonso VI. 461

5.5.- La muralla hispanomusulmana previa a la repoblación. 465 


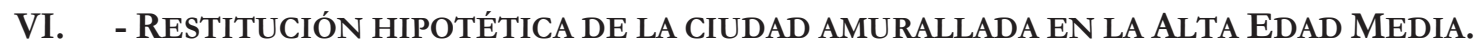

$\begin{array}{ll}\text { 6.1.- Introducción. } & 479\end{array}$

6.2.- Pervivencias arquitectónicas y urbanas de la ciudad medieval. 481

6.2.1.- Las evidencias de la ciudad de Segovia en la Alta Edad Media. 481

6.2.2.- Los edificios de la repoblación oficial. 487

6.3.- El análisis de la estructura urbana. 491

6.3.1.- El trazado de las calles y las plazas. 493

6.3.2.- La morfología de las manzanas y la tipología de las parcelas. 495

6.3.3.- El urbanismo del barrio de las canonjías. 499

6.3.4.- El efecto focalizador de las puertas de la muralla. 501

6.3.5.- Otros puntos focalizadores de la trama urbana. $\quad 507$

6.4.- Dos modelos diferenciados de estructura urbana. 513

6.4.1.- La ciudad de la repoblación de Alfonso VI. $\quad 515$

6.4.2.- La ciudad altomedieval. 518

$\begin{array}{ll}\text { 6.4.3.- Consideraciones finales. } & 521\end{array}$

VII. - FUTURAS LÍNEAS DE INVESTIGACIÓN.

VIII. - FUENTES CONSULTADAS.

8.1.- Documentación de archivo. 531

8.2.- Referencias bibliográficas. 543

IX. - ANEJOS. (SÓlO EN FORMATO DIGITAL)

Anejo I: Intervenciones en la muralla + Mapa resumen de intervenciones.

Anejo II: Fichas de toma de datos de la muralla.

Anejo III: Mapas esquemáticos de toma de datos de la muralla.

Anejo IV: Tablas de análisis comparativo de la muralla.

Anejo V: Catalogo de aparejos de la muralla.

Anejo VI: Mapas de cronología y fases constructivas de la muralla. 


\section{RESUMEN}

Según la historiografía tradicional se considera que la muralla de Segovia se construye a raíz de la repoblación de la ciudad por la iniciativa del rey Alfonso VI en 1088, tras la conquista de Toledo, considerándose terminada en 1122 según la documentación histórica disponible. Del mismo modo, los Anales Toledanos califican a la ciudad de Segovia como yerma y despoblada antes de esta repoblación.

Así pues, parece que la muralla se realiza de una sola vez, como una intervención unitaria y que la ciudad actual, que surge con esa repoblación, se asienta con un trazado de nueva planta, aparentemente exento de condicionantes y preexistencias, sobre un espacio libre, o a lo sumo, sobre un campo de ruinas, pero deshabitado.

La falta de estudios sobre la muralla en particular, y sobre la configuración de la ciudad antes del año 1088 en general, han contribuido a la aceptación de estas premisas, sin que hasta la fecha se hayan intentado demostrar otras posibilidades. La presente tesis pretende revisar estos aspectos, toda vez que creemos que existen suficientes indicios para aportar nuevas perspectivas a la difusa historia de la ciudad de Segovia durante la Alta Edad Media.

La observación minuciosa de la muralla, entendiéndola como un documento construido, leyendo e interpretando sus discontinuidades constructivas, así como la relectura de las fuentes documentales históricas existentes en busca de nuevas interpretaciones, complementado con el análisis de las fotografías, grabados y otros documentos gráficos históricos nos ha permitido redescubrir algunos elementos de la muralla como puertas perdidas, postigos tapiados, torres desaparecidas o lienzos en los que se ha modificado su trazado, a la vez que encontrar una métrica que modula de manera regular la muralla.

El estudio de la forma de las torres, de la configuración de las puertas, postigos y zócalos, de los materiales, sistemas constructivos y aparejos empleados, así como de la métrica subyacente a todo ello, ha permitido demostrar la existencia de una muralla previa de factura hispanomusulmana. 
Del mismo modo ha posibilitado diferenciar etapas constructivas posteriores a esa repoblación en que se ejecutan recrecidos, reconstrucciones, e intervenciones en las que, en algunos casos, se han podido identificar unas características comunes e invariantes gracias a las cuales se han establecido unos sectores homogéneos, proponiendo un proceso histórico constructivo para la muralla cuyas importantes transformaciones, inevitablemente, han tenido repercusión sobre la evolución de la estructura urbana.

La constatación de la existencia de una muralla previa a la repoblación cristiana, que datamos desde mediados del siglo X hasta el XI, nos hace replantearnos que ésta se efectuase realmente sobre un espacio yermo y proponernos una hipótesis alternativa de que el asentamiento se haya efectuado en el interior de un recinto amurallado, quizá incompleto, pero ya habitado al menos parcialmente, adaptándose por lo tanto, a una estructura urbana preexistente ya definida.

Conforme a esta hipótesis, el análisis de la estructura urbana, del trazado de sus calles y plazas, la morfología de sus manzanas y parcelas y la configuración de sus edificaciones históricas, especialmente la muralla y sus puertas, por su efecto focalizador sobre la red viaria urbana, evidencia la existencia en el recinto amurallado de dos tipos de tramas urbanas, una claramente vinculada a la repoblación de Alfonso VI y otra anterior, más arcaica, testigo de un asentamiento habitado previo a esa repoblación, del que, por falta de información arqueológica, no podemos aportar más que un esbozo de su estructura urbana.

La pervivencia de esa muralla hispanomusulmana nos sirve de apoyatura para creer que hemos encontrado la huella de la Segovia musulmana, un eslabón hasta ahora desconocido en la evolución de la ciudad actual. 
ABSTRACT

According to the traditional historiography, Segovia city wall was built as a result of the repopulation of the city at the initiative of King Alfonso VI, in 1088, after the conquest of Toledo, being completed in 1122, according to the available historical documentation. In the same way, the Toledo Annals qualify the city of Segovia as barren and uninhabited before this repopulation.

Thus, it appears that the wall was done at once, as one unitary intervention and that the current city, which emerges with this repopulation, is set with a new construction layout, apparently free of conditions and pre-existing structures, on a clearance, or at most, on a field of ruins, but uninhabited.

The lack of studies on the wall in particular, and the city's configuration before 1088 in general, has contributed to the acceptance of these premises, with no attempt being made to prove other possibilities so far. This thesis aims to review these issues, since we believe that there is enough evidence to bring new perspectives to the diffuse history of the city during the early Middle Ages.

The close observation at the wall, as it was a document - reading and interpreting their constructive discontinuities, as well as the re-reading of existing historical documentary sources looking for new interpretations, together with the analysis of photographs, prints and other historical graphic documents, - has allowed us to rediscover some elements of the wall such as lost doors, walled shutters, missing towers or stretches of wall whose layout has been modified, and, at the same time, to find a structured pattern that modulates the wall in a regular way.

The study of the shape of the towers, the configuration of the gates, shutters and baseboards, the materials, the construction systems and the tools used, as well as the underlying structured pattern, has served to demonstrate the existence of a previous Spanish-Muslim wall. 
In the same way, it has made it possible to differentiate subsequent constructive stages to that repopulation, when enlargements, reconstructions, and interventions were run, and in which, in some cases, some common and invariant characteristics have been identified, allowing us to establish some homogeneous parts on the historical construction process of the wall, whose important transformations have inevitably had impact on the evolution of the urban structure.

The existence of a wall prior to the Christian repopulation, dated from the mid-tenth to the eleventh centuries, makes us rethink whether this was actually set on a barren area, and propose an alternative hypothesis in which the settlement was sited inside a walled enclosure, perhaps incomplete, but at least partially inhabited, adapted to an alreadydefined and existing urban layout.

Under this scenario, the analysis of the urban structure, the layout of its streets and squares, the morphology of its blocks and plots and the configuration of its heritage buildings, especially the wall and its gates, as a focusing point on the street network, point to the existence of two types of urban grids in the enclosure, one clearly linked to the repopulation of Alfonso VI and an earlier and more archaic one, witness of an inhabited settlement prior to the repopulation, whose origin and chronology cannot be determined yet, due to the lack of archaeological information.

It could be a county repopulation, slightly before the one carried out at the initiative of the royalty, but the continued existence of that Spanish-Muslim wall supports the idea that we have found the trace of the Muslim Segovia, a missing link in the evolution of the current city.

Traducción realizada por Begoña Muñoz Herrero. 
I. INTRODUCCIÓN 



\section{1.- Presentación.}

El recinto amurallado de Segovia fue declarado Bien de Interés Cultural en la categoría de Monumento Histórico Artístico el 12 de julio de 1941. El 4 de diciembre de 1985 la Ciudad Vieja de Segovia y el Acueducto Romano fueron declarados Patrimonio Mundial por la UNESCO. En España se conservan tres ciudades con sus recintos amurallados urbanos completos, la muralla de Lugo, la muralla de Ávila y la de Segovia, estando los tres incluidos en la Lista de Patrimonio Mundial de la UNESCO. Mientras las otras dos cuentan con diversos estudios, Ávila (Gutiérrez Robledo, 2007 y 2009) (Cátedra Tomás, 2007) y Lugo (Abel Villela, 1975 y 2004) entre otros estudios y autores, la muralla de Segovia no cuenta con ninguna monografía ni estudio específico. Este hecho es muy representativo del olvido al que se ha visto sometida por los investigadores e incluso por los propios segovianos.

No existe ninguna publicación científica sobre la muralla segoviana, salvo escasos documentos técnicos destinados a la intervención restauradora, centrados en la evaluación de las lesiones y en el estado de conservación del monumento, pero no preocupados por su conocimiento. La muralla segoviana ha sido durante años la gran desconocida, en una ciudad donde posiblemente la abundancia de otras joyas del patrimonio urbano y arquitectónico, como el acueducto, la catedral, el Alcázar, la arquitectura románica, entre otros, la han relegado al ostracismo y el olvido. La muralla es uno de los monumentos más ignorados y menos estudiados con los que cuenta la ciudad de Segovia.

Siempre me ha sorprendido, que en una ciudad con más de dos mil años de Historia y distintos dominadores ocupándola, no hubiese existido más que una única muralla. Una mínima observación a sus lienzos y torres pone en evidencia que se trata de una construcción 
mucho más compleja que lo cabe esperar de la superficialidad de los datos históricos existentes y que obviamente no se trata de una construcción tan unitaria como podría interpretarse de la lectura de estas parcas referencias documentales.

He tenido la fortuna de trabajar como arquitecto municipal durante diez años en la Concejalía de Patrimonio Histórico del Ayuntamiento de Segovia. En esos años se ha elaborado el Plan director de las murallas (PH: P0035) y se han acometido una secuencia de intervenciones en las murallas y su entorno inmediato que han posibilitado la realización de un paso de inspección, que permite acceder a los pies de la muralla en muchos de sus puntos y se han efectuado algunos hallazgos, que a mi entender evidencian una mayor complejidad de la que se deduce de la historiografía tradicional, tanto para la muralla como para la ciudad.

Las murallas han sido a lo largo de la Historia uno de los elementos fundamentales de los asentamientos humanos, definitorios de la configuración urbana e incluso de la condición de ciudad $^{1}$. Ambos se condicionan mutuamente de manera significativa. Ciudad y muralla no se entienden el uno sin el otro. Así, el estudio de la muralla está íntimamente ligado al de la ciudad y la evolución histórica urbana.

Inicialmente mi intención fue documentar e inventariar esos hallazgos, antes de que, debido a la falta de mantenimiento, la naturaleza vuelva a hacerlos desaparecer de nuevo, sumidos en el desinterés, el olvido y la incomprensión, como viene sucediendo desde hace siglos. Lo que ahora observamos de la muralla es el resultado de las intervenciones realizadas en varias épocas, a lo largo de las cuales se han sucedido expolios, derrumbes, demoliciones, y reconstrucciones, reformas, reutilizaciones y construcciones de edificios encima. Un simple inventario no daba explicación a muchos de estos asuntos. Entender el significado y alcance de estos descubrimientos requería un mayor conocimiento de toda la cerca urbana.

Parto de la sospecha de que no se trata de una única muralla, no es un trazado unitario, sino la suma de varios trazados, la suma de diferentes murallas de distintas épocas, en las que se reutilizan partes de cercas preexistentes, algo que creemos apreciar con claridad en las zonas bajas de algunos lienzos y torres. Especialmente llamativo resulta la diversidad de formas en planta que presentan las torres, algo que denota con claridad la existencia de distintas fases constructivas ante las que podríamos plantearnos dos hipótesis:

- Las distintas fases constructivas son todas ellas realizadas ya bajo dominio de los reyes cristianos, sobre una muralla inicial, construida a raíz de la repoblación de la ciudad por Alfonso VI. Esto encajaría con la premisa tradicionalmente admitida de que toda la muralla es de factura cristiana (Pavón Maldonado 1999: 239).

- Se trata de distintas fases constructivas, pero las zonas inferiores de los muros pertenecen a restos de fortificaciones anteriores de cronología previa a la citada repoblación. La adscripción temporal de estas preexistencias tampoco resulta sencilla. Algunos autores las consideran romanas (Illarregui Gómez 2010: 68-87) mientras para otros es obra hispanomusulmana (Zozaya Stabel-Hansen 2005: 25) o (Zamora Canellada 2005: 1138).

\footnotetext{
1 Alfonso X definirá la ciudad como "Todo aquel lugar que es cercado de los muros con los arrauales et los edificios que se tiene con ellos". Partida VII, titulo XXXIII, ley VI.
} 
Donde no llega la documentación histórica es necesario emplear otros métodos de estudio cuya principal fuente de información debe ser la lectura del documento construido. La muralla como uno de los edificios más longevos y de mayor importancia en las ciudades medievales de la Península Ibérica a lo largo de la Historia, es una de las principales fuentes de información primaria de la que obtener datos sobre la historia de la ciudad.

Las discontinuidades constructivas pueden identificarse analizando distintos factores como es la geometría de las torres, la mutilación de elementos, los aparejos empleados, la comparación entre los distintos materiales empleados en sectores contiguos, o la disposición en fábricas más o menos homogéneas que las adyacentes, el cambio de sistema constructivo o de material, etc. Estas son algunas de las variables que vamos a manejar en el análisis de los lienzos y torres de la muralla.

Quizá por mi formación de arquitecto urbanista vinculado al mundo del Patrimonio Histórico, las vertientes que mas me han interesado sean precisamente las de la evolución urbana y la construcción histórica.

Antes de iniciar los cursos previos al doctorado, en el año 2011, publiqué un primer artículo, cuyo fin era sacar a la luz la serie de descubrimientos recién encontrados en la muralla de Segovia. Un mero inventario para documentar esos vestigios, que yo entonces no llegaba a entender completamente. Posteriormente hubo nuevos hallazgos, muchos aún inéditos, pero sobretodo, muchas horas de observación, análisis, interrogantes y la conclusión de que algo no encajaba en la historiografía que conocía de la ciudad de Segovia.

El descubrimiento de algunos estudios previos de otros autores que consideran fábrica musulmana algunos fragmentos de la muralla, es el apoyo sobre el que hemos intentado profundizar en el estudio de esta muralla como la construcción histórica que mas información puede aportarnos sobre la evolución de la estructura urbana.

De esta forma, una primera intención de documentar la serie de hallazgos inconexos descubiertos, que desde mi punto de vista, ponían en tela de juicio la unidad constructiva de la muralla a la vez que hacían imposible la adscripción cronológica de algunos de estos hallazgos como fábrica cristiana de finales del siglo XI o principios del XII, surgió una hipótesis cuyo resultado ha sido esta tesis doctoral.

El conjunto de las discontinuidades constructivas y las pervivencias históricas que integran la muralla, constituyen un proceso histórico, un palimpsesto constructivo, que ha discurrido inevitablemente en paralelo al de la transformación de la ciudad, cuyo entendimiento va ligado a la correcta interpretación de lo que vemos en la muralla.

La falta de documentación escrita en los años en que centramos nuestro ámbito de estudio, hace que el estudio de la propia muralla, como documento construido, sea la mejor, casi la única, fuente de investigación que nos permite avanzar, hasta que la arqueología aporte nuevos datos que nos posibiliten contextualizar estos vestigios, hoy por hoy bastante inconexos.

Cuando observaba la muralla de Segovia, no dejaba de preguntarme: ¿De la muralla que vemos hoy en día, que pertenece realmente a la muralla medieval? En esa muralla medieval, ¿Que hay original y que se ha modificado posteriormente a lo largo de los últimos 9 siglos?, y en este devenir de rehechos y reutilizaciones ¿que se conserva visible u oculto de otras cercas urbanas anteriores a esa fecha de 1088 ? 
La infinidad de transformaciones a que se ha visto sometida la muralla a lo largo de tantos siglos, hace difícil el entendimiento de las fábricas actuales, en que los fragmentos históricos aparecen de forma muy parcial y discontinua, separados por infinidad de reparaciones que nos ocultan las fábricas originales y las respectivas relaciones estratigráficas. Así la métrica subyacente en la muralla y la geometría de las torres adquieren una importancia excepcional para detectar sectores homogéneos que se esconden tras la heterogénea mezcla de materiales, sistemas constructivos y aparejos que muestra la epidermis de la muralla actual. La presencia de las fábricas más antiguas en los zócalos, otorga a éstos un valor incalculable, justificando la importancia de estudiar con profundidad dichos zócalos y sus técnicas constructivas, por ser la parte que se encuentra abajo, la más antigua, sobre la que apoyan todas los demás. El cruce de estos datos visibles en los zócalos con los no visibles, como la métrica, nos permite conjeturar la configuración de esta muralla previa, una muralla hispanomusulmana que hemos datado en la segunda mitad del siglo X.

La existencia de estos vestigios de una fortificación hispanomusulmana previa a la repoblación, nos faculta a plantearnos la hipótesis de que esta muralla, sin duda, defendería un asentamiento, quizá ciudad, de la que nunca se ha escrito. De hecho los Anales toledanos, califican a Segovia como "bierma y despoblada" antes de esta repoblación. ¿Existió una Segovia musulmana?

La forma actual de la ciudad está condicionada por el trazado de la muralla y por la configuración urbana del asentamiento que ya existía en el momento de la construcción de esta muralla. Lo que se plantea es una restitución hipotética de la forma urbana de la ciudad de Segovia, antes de la repoblación oficial, a finales del siglo XI, repoblación que se va a efectuar en base a unos principios de organización urbana, distintos de los que configuran el poblamiento preexistente anterior a la repoblación y que pone de manifiesto la existencia de una planificación previa del trazado de la muralla y la morfología de la trama urbana.

Como apoyo de nuestra hipótesis de la existencia de una Segovia poblada y amurallada antes de la histórica fecha de 1088 nos servimos de los datos periféricos, procedentes de otras disciplinas que contextualizan nuestro estudio. Para este fin resulta fundamental el respaldo de los estudios que concluyen que la despoblación de la meseta en la Alta Edad Media, no fue tal, al menos en la cuenca sur del Duero. La constatación de la pervivencia de nombres de raíz visigoda y musulmana, en numerosos asentamientos y otros elementos de la geografía de de la zona, gracias a los estudios de la toponimia nos han respaldado en la formulación de nuestra hipótesis.

Así nuestro empeño es arrojar luz sobre la estructura urbana de una ciudad de la que nada sabemos, la Segovia amurallada anterior a la mencionada repoblación. La vinculación de esta ciudad previa con los restos de fábricas musulmanas existentes en la muralla, nos permiten suponer que existió una Segovia musulmana. Creemos que nuestras hipótesis quedan respaldadas por un razonamiento y el apoyo de cuantos datos objetivos hemos encontrado, aportando, estadísticamente, un alto grado de probabilidad de que lo que proponemos sea verídico. En el futuro, las distintas ciencias (especialmente la arqueología) deberán contribuir con nuevos datos objetivos que permitan reforzar nuestras hipótesis. 


\section{2.- ÁMBITO DE LA INVESTIGACIÓN.}

El objeto de este trabajo es el recinto amurallado de Segovia en una etapa de su historia en el que está muy poco estudiado. Así esta tesis tiene por objeto no sólo el análisis de la muralla, como documento construido, sino que también se extiende a la escala urbana en la búsqueda de las relaciones existentes entre la configuración de las murallas y la de la trama urbana en un intento de restituir la configuración de ambos elementos en la etapa final de la Alta Edad Media. Por "etapa final de la Alta Edad Media" en el ámbito de nuestro estudio, nos referimos a un periodo indefinido durante el que suponemos la presencia musulmana controlando el poder local en la ciudad de Segovia, que de manera genérica podríamos acotar entre dos fechas históricas, el 711, en el que da comienzo la invasión musulmana de la península y el 1088 en que se produce la repoblación de la ciudad. Para la muralla el estudio abarca un periodo temporal más largo, hasta la situación actual, que es nuestro punto de partida, ya que ha sido necesario estudiar toda la evolución de la muralla, deshaciendo aquellas transformaciones posteriores para acercarnos lo máximo posible a su configuración en la Alta Edad Media.

La interpretación de la evolución urbana y su interacción con las transformaciones que se han sucedido en las murallas implica, ineludiblemente, un análisis que hemos realizado desde varios enfoques, como el constructivo, arquitectónico, urbano, arqueológico, además del histórico-documental.

Para ello se realiza un profundo análisis de la muralla, como principal fuente de información, para después relacionar los resultados obtenidos con el análisis de la estructura urbana. De esta 
forma la tesis presenta dos partes relacionadas entre sí y claramente diferenciadas. Una primera, analítica, centrada en la propia muralla, desde los aspectos constructivos, arquitectónicos y de la historia de la construcción, que estudia su evolución a lo largo de los siglos para intentar remontarse en el tiempo hacia su configuración antes de la repoblación de la ciudad. La segunda, de carácter más especulativo, en la que se acomete el análisis, eminentemente grafico, de la estructura urbana desde la perspectiva del urbanismo y la arqueología urbana, en busca de las huellas de la ciudad altomedieval que perviven en la actual.

Por último, señalar que se ha excluido del análisis principal los tramos correspondientes al sector del Alcázar, desde la 'T61' hasta la T72, si bien los hemos estudiado sectorialmente cuando se disponía de información de interés para la investigación. Aparte de su escasa visibilidad y accesibilidad, ya en la toma de datos confirmamos que sus características arquitectónicas y constructivas están más relacionadas con la evolución del Alcázar que con la del resto de la muralla urbana. La forma y dimensión de sus torres, así como las longitudes de sus lienzos, no tienen relación con el resto de la muralla. Los aparejos de los lienzos que flanquean los jardines de la Plaza de la reina Victoria Eugenia, donde abundan los sillares de piedra sedimentaria mal aparejados, evidencian la reutilización del material procedente de los desaparecidos edificios del complejo catedralicio a la vez que presentan numerosos recrecidos, tras los que se ocultan los rellenos de escombros que amortizan estas construcciones. El correcto entendimiento de estos lienzos implicaría un exhaustivo estudio de este edificio, lo cual tiene la suficiente complejidad como para ser objeto de una tesis por sí solo. Estos lienzos y torres están más vinculados a las ampliaciones del Alcázar que a la construcción de las murallas. En algunos zócalos hemos descubierto restos de torres previas, elementos en los que si encontramos similitudes con otras partes de la muralla. La torre bajo la terraza de los reyes, en la que se ha descubierto recientemente una poterna, presenta un aparejo que consideramos altomedieval. Hay otros restos altomedievales ya estudiados, pero se encuentran embutidos en el interior del edificio, no en los paramentos exteriores. Su análisis es inseparable del estudio del propio Alcázar.

Como se ha indicado, ciudad y muralla, son dos elementos complementarios, no se entienden el uno sin el otro. Resulta imposible estudiar la muralla sin conocer o entender la ciudad a la que rodea y viceversa. Este trabajo se plantea por tanto, no como un producto elaborado y acabado, sino como un estadio intermedio de un trabajo más ambicioso y de mayor recorrido. 


\section{3.- HIPÓTESIS DE PARTIDA Y OBJETIVOS DEL TRABAJO.}

Según la historiografía, la muralla y la ciudad de Segovia surgen para la historia a finales del siglo XI, con la repoblación efectuada por el rey Alfonso VI tras la toma de Toledo, sobre el solar de la antigua Segovia romana, en un yermo despoblado, durante los siglos que abarcan el reino visigodo y la conquista por los musulmanes.

Según nuestra hipótesis de partida, las murallas que se levantan con motivo de esa repoblación se efectúan, en parte, sobre el trazado de las murallas preexistentes aprovechando algunos sectores de la misma. Conforme a la tan debatida teoría de la continuidad poblacional en la Meseta al sur del Duero durante el periodo visigodo y la posterior etapa musulmana, nuestra hipótesis es que existió una Segovia amurallada antes de la repoblación, una ciudad musulmana, de la cual creemos encontrar fragmentos de su cerca embebidos en la muralla actual. Tras ella y previa a la repoblación efectuada por el rey Alfonso VI, estamos convencidos de que se sucede una repoblación condal, de modo que al ciudad, se sale de la órbita y control musulmán con bastante anterioridad a lo que indican las fuentes documentales que registran esa repoblación oficial, recogida en la Anales Toledanos.

Nuestro análisis, creemos, pone en evidencia la persistencia de una cerca previa de la que se reutilizan algunos fragmentos que reconocemos en las partes bajas de la muralla actual, vestigios que podemos relacionar con otras murallas hispanomusulmanas de los siglos IX y X. Consideramos que la muralla no se construye de una sola vez, sino que en realidad es un proceso de ampliaciones, reformas, ruinas y reconstrucciones que se han venido sucediendo durante siglos. Del mismo modo, creemos que esta "repoblación oficial" efectuada a partir de 
$1088^{2}$, no se realiza sobre un espacio vacío, como indican las Crónicas, sino que existe una ciudad previa, habitada y amurallada, al menos parcialmente. Creemos que hubo una llegada de nuevos contingentes humanos, pero que inicialmente se trata más bien de una reestructuración administrativa de un asentamiento ya establecido en la etapa hispanomusulmana y continuado con una repoblación condal previa. Creemos que en la fecha de la repoblación oficial efectuada por Alfonso VI, existía en Segovia una parte de la ciudad que ya se hallaba edificada. Así la repoblación oficial es en realidad una ampliación de esa ciudad existente, dualidad que ha conservado sus huellas en la estructura urbana actual. La lectura de la estructura urbana actual, nos permite comprobar que esta repoblación, va a generar una trama viaria y una muralla, que se adaptan a las preexistencias, asumiendo lo que ya está poblado. Las posteriores transformaciones urbanas a lo largo de los siglos, van a ir suturando estas "cicatrices urbanas" hasta el punto de hacerlas casi imperceptibles.

No disponemos de evidencias irrefutables de que parte de esa ciudad se corresponde con la ciudad hispanomusulmana y cual se debe a la repoblación condal, por lo que no podemos delimitarlas con absoluta nitidez. Simplemente aportamos hipótesis de la extensión de esa ciudad previa a la repoblación oficial, como punto de partida por donde continuar las investigaciones. Como decía Oliver Copons, “....sin más valor que mi modesta opinión. Nada más lejos de mi ánimo que en este, como en otros juicios que emita, el pretender tener razón, ni haber acertado con la verdad absoluta, sólo he procurado acercarme a ella" (Oliver Copons, [1916] 1989: 11).

\section{OBJETIVOS}

1.- Ampliar el conocimiento sobre las murallas y el urbanismo de la ciudad de Segovia a lo largo de su historia y especialmente en la Alta Edad Media.

Nos proponemos avanzar en el conocimiento y entendimiento del proceso histórico constructivo de la muralla para esbozar, hasta donde sea posible, las principales transformaciones sufridas a lo largo de los siglos y la conformación de esa muralla en la Alta Edad Media y comprender la relación de la configuración de la trama urbana actual con el trazado de esta muralla y como se han condicionado mutuamente a lo largo de la historia.

\section{2.- Verificar la existencia de un recinto amurallado previo al actual, anterior al construido tras la repoblación de la ciudad por Alfonso VI.}

Estamos convencidos de que existió una fortificación musulmana en el actual emplazamiento de la ciudad amurallada de Segovia. Creemos descubrir estas evidencias en las discontinuidades constructivas detectadas en las partes bajas de algunos tramos de la muralla, así como algunas rupturas de la trama urbana que a pesar de la sutura de las intervenciones a lo largo de los siglos permite intuir esas cicatrices. La muralla de Segovia se construye a partir de 1088 y se

\footnotetext{
${ }^{2}$ La fecha de la repoblación no deja de ser un dato, que indica la fecha en que el primer documento escrito hace referencia a ese hecho y por tanto se le asigna la fecha que indica ese documento. Evidentemente la repoblación de la ciudad, no fue un hecho puntual que ocurriese en este momento concreto, si no que se extendería en el tiempo a lo largo de varios años. Obviamente pudo haber existido población anteriormente, pero no está aceptado unánimemente por la comunidad científica por falta de documentación histórica que lo acredite. Así la fecha se ha repetido por numerosos autores, no existiendo ninguna investigación que haya intentado avanzar en el conocimiento de esta faceta de la historia de la ciudad.
} 
considera que en 1120 ya está concluida, todo ello en base a las fuentes documentales. El estudio de las fábricas nos demuestra que la construcción no es tan unitaria, rápida, ni continua como se ha señalado. El estudio de la poliorcética y la técnica constructiva nos va a permitir datar algunos de los elementos arquitectónicos desde la etapa hispanomusulmana hasta fases muy tardías de la Edad Media e incluso posteriormente.

3.- Identificar los posibles restos del trazado que perviven en la muralla actual de esa muralla altomedieval.

En la investigación vamos a detectar unos sectores homogéneos en la muralla gracias a los que reconocemos las distintas fases constructivas y las partes que se reutilizan de cercas previas, aunque el actual tratamiento de la epidermis de los paramentos los haya uniformizado dificultando su diferenciación. A pesar de las numerosas intervenciones que se han sucedido desde el siglo XII intentamos descubrir que se conserva de esa muralla altomedieval.

4.- Restituir, hasta donde sea posible, la trama urbana anterior a esa repoblación, germen de la ciudad actual.

Partimos de la hipótesis de que existe una ciudad de Segovia anterior a la repoblación de Alfonso VI, que estaba amurallada. Pretendemos profundizar en el conocimiento de la historia de la ciudad de Segovia, a través del estudio de las evidencias históricas, como elementos condicionantes de la formación y transformación urbana. La muralla es la construcción, que por su antigüedad y morfología, es capaz de haber generado mayores huellas en el desarrollo urbano. Puede aportarnos información relacionándonos distintas partes de la ciudad, frente a la escasez y dispersión de los datos arqueológicos.

Esta ciudad previa contaba con murallas y estas preexistencias de muralla y estructura urbana serán el germen de la ciudad actual y van a condicionar el trazado posterior de la ciudad de la repoblación cristiana. La ciudad actual es fruto de la superposición de tramas urbanas así como la muralla reaprovecha fragmentos de las murallas previas. La ciudad de la repoblación no se genera sobre un yermo despoblado, ni surge de un campo de ruinas. Existe una continuidad poblacional habitando en el actual recinto amurallado de Segovia, durante la Alta Edad Media. Buscamos en la configuración actual de la ciudad, los vestigios de los trazados previos así como de murallas y defensas anteriores.

\section{5.- Intentar responder a la pregunta ¿existió una Segovia musulmana?}

Hasta que las distintas disciplinas científicas, especialmente la arqueología, aporten algunos datos irrefutables, no podemos afirmarlo categóricamente. La constatación de una muralla hispanomusulmana nos da un importante respaldo, para creer que existió dicha ciudad hispanomusulmana, pero a nivel urbano aún falta mucho por investigar. Estamos convencidos de que existió dicha ciudad, al igual que también creemos que se produjo una repoblación de carácter condal, previa a la repoblación promovida por la monarquía. No disponemos de datos incontestables para poder diferenciar la Segovia hispanomusulmana, de esa ciudad intermedia anterior a la repoblación oficial de Alfonso VI. La existencia de distintos fragmentos de cerca hispanomusulmana, con diversos aparejos, que nos hacen suponer diferentes etapas constructivas, y por lo tanto una permanencia urbana en su interior. Los datos nos permiten 
concluir que preexistía una ciudad de Segovia amurallada en los años anteriores a la repoblación oficial. Con la información disponible a día de hoy, no podemos definir la entidad, dimensión, ni el carácter de ese núcleo poblacional, ni el trazado completo y exacto de la muralla que lo cercaba, pero creemos que con nuestra aportación se proporciona una razonable certeza a la hipótesis de la existencia de esa población previa, germen de la Segovia actual y de cuya existencia podemos observar sus huellas en la muralla y la estructura urbana actuales. 


\section{4.- METODOLOGÍA INVESTIGADORA}

Se plantea una metodología canónica. Establecidos los objetivos que se persiguen y las hipótesis que se pretenden demostrar, se identifican las fuentes de las que extraer la información y que representan el estado de conocimiento previo del que partimos. Se ha realizado un análisis basado en el método arqueológico de lectura estratigráfica para comprender la transformación histórica del paisaje construido. Para efectuar este tipo de análisis, establecido el estado de la cuestión, lo aportado por las fuentes documentales, se identifican las variables a analizar que caracterizan el objeto de estudio, tras lo cual se realiza la toma de datos del documento construido, la lectura histórico constructiva de los restos conservados. El posterior análisis de estos datos debe conducirnos a la obtención de las conclusiones y la verificación de las hipótesis planteadas inicialmente.

Se ha realizado una primera identificación de las fuentes, en las que se ha comprobado la existencia de información referida a nuestro objeto de estudio. Dado el carácter del tema de investigación, distinguimos tres tipos de fuentes, complementarias entre sí.

- Las documentales escritas, en las que incluimos tanto la bibliografía actual como la histórica y los documentos de archivo. Se ha elaborado una primera lista de bibliotecas y archivos en los que se realiza la búsqueda. El desarrollo de la investigación nos marca el camino por donde debemos continuar, pudiendo ampliarse o reducirse este listado. Para ello se recurre a las bibliotecas, archivos, y centros similares en los que, tras una primera indagación, se han localizado posibles documentos de interés. Se adjunta al final de la presente memoria un listado de los archivos y bibliotecas que se han seleccionado, donde se ha buscado la información existente. 
- Las fuentes documentales gráficas, tanto las planimétricas como las representaciones artísticas y fotográficas, tienen un especial interés para cotejar la transformación de nuestra zona de estudio a lo largo del tiempo. Para ello se recurre a los archivos, fototecas y publicaciones en los que, tras una búsqueda inicial, se ha identificado algunos documentos de interés. Del mismo modo se han identificado los principales fotógrafos y autores que han visitado la ciudad de Segovia. Representaciones en distintas técnicas, como las ya mencionadas de Wyngaerde, Meunier, así como Roberts, Doré, Guesdon, Avrial y Flores o Serra Basas entre otros, nos permiten observar algunos detalles a tener en consideración, si bien con las debidas precauciones sobretodo en el caso de algunos autores de representaciones poco fidedignas, pero de inestimable interés especialmente antes de la aparición de la fotografía. Especial importancia por su veracidad, respecto a la libertad creadora de los casos anteriores, adquieren las fotografías que a partir de mediados del XIX realizan Clifford, Tennison, Laurent, Hauser y Menet, Levy, Arcimis, Beer, Wunderlich, Moreno, García Mercadal y otros. Su valor documental se acrecienta por lo despejado del entorno de la muralla en su momento, dado que permite apreciar perfectamente la roca y descubrir muchos detalles que en la actualidad posiblemente existan, pero están ocultos por la vegetación. Afortunadamente Segovia ha sido una ciudad que ha despertado, desde antiguo, una elevada atracción a todo tipo de artistas y cuenta con una considerable colección de imágenes de diversos autores, técnicas y cronologías.

- La lectura constructiva de los restos arquitectónicos, la lectura del documento construido, nos aporta una información, de primerísima mano, que raramente podríamos ver recogida en las fuentes anteriores. El cotejo in situ de lo observado, o sospechado, en las fuentes documentales, puede orientar de manera muy eficaz nuestra toma de datos. Por otra parte, esta observación directa de la realidad, fuente primaria ineludible, puede señalarnos que buscar en la documentación histórica, delatándonos aspectos que podrían haber pasado desapercibidos en un primer análisis. Este sistema de retroalimentación es una potente herramienta de trabajo.

La consideración de la propia muralla como un documento a estudiar, la única fuente primaria, permite obtener una información valiosísima, complemento inevitable de la investigación documental. Sin embargo, en su construcción se emplean los materiales existentes en el entorno, abundando los materiales reutilizados procedentes del expolio de antiguos cementerios romanos o de edificios preexistentes. El sistema constructivo que predomina en la obra ha sido empleado durante siglos en la ciudad de Segovia. Esto supone una enorme dificultad de interpretación y datación del elemento construido, dado que la muralla ha sido intervenida durante todos estos siglos empleando esos mismos materiales y técnicas.

Partiendo de la planimetría del Plan Director, se ha efectuado un intenso trabajo de campo para la toma de datos sobre la muralla, fotos, planos, medición, dibujo, etc. La principal herramienta de trabajo es el estudio del elemento construido, de sus características arquitectónicas y la lectura constructiva de sus paramentos. Se ha realizado una de toma de datos pormenorizada de cada una de las torres y lienzos de la muralla, midiendo, dibujando, fotografiando los distintos elementos y recogiendo toda esta información sistematizada en dos formatos complementarios, fichas y planos esquemáticos de toma de datos. En las fichas se consignan la forma y las dimensiones de las torres y la modulación de los lienzos que las separan, mientras que tanto en las fichas como en los planos esquemáticos se reflejan los materiales, sistemas constructivos y aparejos empleados, existencia de spolia, elementos de 
carácter defensivo, la configuración de sus zócalos, etc, variables que nos han permitido establecer unos elementos de análisis y diferenciación y nos ha facilitado el comparar estos datos entre las distintas partes y con otras murallas mas estudiadas.

Para su estudio, empleamos como herramienta fundamental las lecturas de paramentos, atendiendo principalmente al estudio de las generalidades encontradas así como en las discontinuidades constructivas. Es posible que los datos tomados para elaborar esta hipótesis constructiva pertenezcan a realidades y momentos históricos distintos, a pesar de su coherencia constructiva. Por lo tanto, lo que se plantea es una suposición previa, abierta a modificaciones, sobre la que seguir trabajando. Para ello se han realizado lecturas constructivas de paramentos en 75 lienzos de los 86 que se contemplan en el plan Director, excluyendo los 11 correspondientes al Alcázar.

El análisis de la metodología empleada por otros investigadores en estudios realizados previamente en distintas ciudades amuralladas nos ha aportado las primeras variables de estudio, al igual que la toma de datos que se iba realizando simultáneamente. El avance de la investigación nos ha llevado a incluir variables que no se habían contemplado inicialmente y a descartar otras que si se habían considerado, lo que obligaba a efectuar nuevas visitas para la toma de datos. Del mismo modo, el listado de ciudades que se empleaban como casos de referencia iba aumentando al descubrir a lo largo del estudio, nuevos datos y similitudes que se desconocían inicialmente y que eran aportados por la bibliografía que se estudiaba. Así nos veíamos en la obligación de volver a ampliar la bibliografía seleccionada, lo que retroalimentaba el proceso de nuevas variables, nuevos casos de referencia y de toma de datos.

La propia investigación iba indicándonos el camino hacia el que teníamos que dirigir nuestros pasos. Inicialmente, pecando de exceso de entusiasmo y de ingenuidad, pretendía hacer el levantamiento murario y lecturas de paramentos de todos los lienzos de la muralla así como estudios arquitectónicos de todos los edificios altomedievales de la ciudad. Luego comprendí que era inabarcable e innecesario, a pesar de que implicaba renunciar a un sinfín de información. La complejidad, extensión y variedad del problema, nos disuadieron de la necesidad de reducir el nivel de la toma de datos y del análisis si no queríamos perder de vista el proceso evolutivo.

Este proceso de expansión y contracción del contenido de la investigación, también ha sido un continuo durante todo el desarrollo de la misma, una especie de cambio de escala, que permite valorar la globalidad del conjunto y los detalles antes enfocar para definir el encuadre definitivo de la foto, siendo consciente de lo que se recoge en la instantánea y de lo que se queda fuera. La búsqueda de información nos ha llevado a campos tan diversos (conceptual y geográficamente) como la toponimia, la arquitectura defensiva y las guerras en las fronteras altomedievales, la arqueología, la investigación documental, la métrica, el urbanismo, las técnicas constructivas, el estudio de otras murallas contemporáneas, etc...

Para la búsqueda de la bibliografía se ha acudido a una selección de las bibliotecas más apropiadas para el tema de investigación de entre las cercanas a mi entorno. Así se ha recurrido a las bibliotecas públicas de Valladolid y Segovia, a las de la universidad de Valladolid, tanto en su sede del Campus de Segovia como de la escuela de arquitectura de Valladolid, a la del campus de Segovia de IE Universidad, la facultad de Geografía e Historia de la Universidad Complutense de Madrid así como a las de las escuelas de arquitectura y arquitectura técnica, ambas de la Universidad Politécnica de Madrid. Se ha consultado los 
fondos de la biblioteca del Museo de Segovia, el Museo Histórico Provincial y el Archivo Municipal, todos ellos de Segovia.

Por último, se han consultado numerosas revistas especializadas y actas de congresos así como libros digitalizados de diversas bibliotecas y dominios que se encuentran accesibles en Internet. Se ha empleado préstamo interbibliotecario para acceder a algunos ejemplares de especial relevancia que no se podían conseguir en las bibliotecas referidas.

Se ha realizado un vaciado bibliográfico en orden a establecer el estado de la cuestión de forma graduada, con un acercamiento panorámico a la periferia del asunto y más exhaustivo en relación a ciudad de Segovia y sus murallas en la etapa histórica que constituye el núcleo central de la investigación. Para su listado hemos recurrido al sistema Harward. Tanto la dirección de aproximación al tema, como las necesidades de contextualización del mismo, dependen en buena medida de la formación profesional de quien investiga. En nuestro caso, mi formación de arquitecto urbanista me obligaba a un primer estudio de la metodología investigadora, especialmente la arqueológica.

Partiendo de una aproximación desde distintos enfoques temáticos, se han indagado diversos ámbitos como por ejemplo la toponimia de las proximidades de Segovia, (especialmente la vinculada con nuestra etapa histórica) publicaciones del campo de la arqueología y las excavaciones arqueológicas de ciudades romanas y musulmanas, los avatares de la reconquista y repoblación del valle del Duero, especialmente los acontecimientos militares y las razzias así como las vías de comunicación de la época, o bien las técnicas constructivas históricas de arquitectura medieval musulmana en general y omeya en particular o la metrología y la poliorcética de este momento histórico como herramientas imprescindibles para la comprensión de la muralla.

El estudio de la forma urbana es un campo muy estudiado por historiadores, pero no tanto desde el punto de vista del análisis de la configuración de la estructura urbana y su evolución en el tiempo, que es el campo que más nos ha interesado. Las transformaciones urbanas y las de su parcelario, los distintos trazados viarios y cambios de alineaciones, la superposición de edificios de distintas etapas culturales, generan una serie de cicatrices en la estructura urbana que constituyen las variables que manejaremos en nuestro estudio. Se ha buscado información relativa a la evolución histórica y urbanística tanto de Segovia como de otros ejemplos de ciudades amuralladas, buscando paralelismos con nuestra ciudad, esto es, antiguas ciudades romanas que se convirtieron en sedes episcopales visigodas y como se ha producido la transformación urbana de las ciudades musulmanas tras la conquista cristiana, esas ciudades que se han venido a llamar, ciudades mudéjares ${ }^{3}$, como Segovia.

El análisis de murallas desde el punto de vista constructivo cuenta con muy buenos ejemplos de estudios, realizados principalmente por arqueólogos. A ellos se ha recurrido como referencia. Para ello se han analizado la bibliografía técnica específica sobre cada uno de los

\footnotetext{
${ }^{3}$ El término de ciudades mudéjares, lo acuña Leopoldo Torres Balbás (1985) para referirse a las ciudades hispanomusulmanas, que tras la reconquista y a lo largo de los siglos se ven sometidas a la paulatina transformación para adecuarlas a la voluntad urbanística imperante en cada momento. Así son ciudades que nos han llegado en distintos grados de transformación, entre la ciudad netamente musulmana, en la que abundan los adarves, callejones sin salida, y calles serpenteantes, y la ciudad cristiana de repoblación trazada en forma de cuadricula regular. En palabras del propio Torres Balbás, son núcleos urbanos que participan en su morfología, disposición, combinación de elementos y estructura tanto de lo cristiano como de lo islámico.
} 
recintos amurallados que se ha considerado como referentes, intentando identificar las características y tipologías específicas de la arquitectura militar de la etapa histórica en que se sitúa nuestro trabajo.

\section{DOCUMENTACIÓN}

Se ha efectuado una búsqueda de información en los principales archivos relacionados con la ciudad en los ámbitos del estudio, así en la ciudad de Segovia se ha visitado el Archivo Municipal, el Museo de Segovia, el Archivo Provincial, el del Servicio Territorial de Cultura y el de la Concejalía de Patrimonio Histórico del Ayuntamiento, y fuera de Segovia, el Archivo General de la Administración (AGA) y el archivo del Instituto de Patrimonio Cultural Español (IPCE). Con esta información se ha realizado un listado, ordenando cronológicamente todas las intervenciones que se han realizado en la muralla de las que se han encontrado referencias. Esta tabla se ha completado con la información del mismo carácter que se ha localizado en otras fuentes. Para una mejor comprensión de dicha información se ha representado gráficamente en un plano de la ciudad para situar geográficamente todas aquellas intervenciones que ha sido posible. Ambos documentos, listado y plano, se acompañan en el anejo I.

Se ha buscado cuanta información se dispusiese relativa a la evolución urbana de la ciudad de Segovia, todos aquellos datos que constituyan indicios de la transformación urbana a lo largo de los, aproximadamente, mil años que nos separan de nuestro ámbito temporal de estudio, analizando la cartografía histórica de la ciudad, los proyectos de reforma de alineaciones, fotografías y grabados históricos, proyectos de obras (efectuadas o no) que se conservan, el plano parcelario, e incluso los estudios geotécnicos existentes para conocer la cota de la roca madre y el espesor de los estratos de rellenos en cada punto de la ciudad.

En el archivo del Servicio Territorial de Cultura de la Junta de Castilla y León se ha hecho un vaciado de todos los expedientes de arqueología existentes relativos al recinto amurallado y sus proximidades.

Se han analizado todas las imágenes históricas que se han localizado de la ciudad de Segovia, planimetrías históricas, fotografías, postales y estampas, tanto las publicadas en distintos libros como las existentes en los archivos del IPCE, el fondo fotográfico de Información y Turismo del AGA y especialmente han sido de gran utilidad, las vistas que Wyngaerde efectúa de la ciudad en 1562, de las que se conserva una copia en el Museo de Segovia.

En relación a la muralla ha resultado de elevado interés toda la documentación generada en las últimas obras efectuadas, tanto los proyectos, como los estudios previos y la documentación de final de obra. Del mismo modo la abundante documentación relativa a derrumbes, pleitos, ruinas, intervenciones y deficiencias en las murallas, que se ha localizado en el archivo municipal datada principalmente a partir del siglo XVI. Especial utilidad ha tenido la localización de cuantas fotografías históricas se dispusiesen de la ciudad de Segovia, para lo que también se ha recurrido a diversos dominios de Internet. 


\section{DETERMINACIÓN DE VARIABLES}

Tras esta investigación documental, se han determinado una serie de variables que se han considerado como las más significativas en relación al objeto de nuestro estudio. Para el estudio de la muralla, se ha considerado como factores más significativos, la configuración arquitectónica de sus torres, la métrica subyacente, los materiales constructivos y su procedencia, los sistemas constructivos, los elementos de carácter militar, la técnica y las discontinuidades constructivas, así como los hallazgos arqueológicos y la toponimia relacionada con la muralla y en menor medida la de la ciudad de Segovia y su entorno.

La comparación de los diferentes complejos defensivos adoptados en otras ciudades así como la aparición de elementos de carácter defensivo tanto en murallas urbanas como en otros tipos de fortificaciones ha sido de menor utilidad de la prevista inicialmente, dado que la limitada potencia ofensiva de la mayoría de los ejércitos de la Península Ibérica de la época, convertía en prácticamente inexpugnables a las fortificaciones cuando tenían la topografía a favor. Por ello no encontramos en el caso segoviano elementos defensivos significativos que nos permitan una datación. El mayor número de novedades poliorcéticas surgirá posteriormente, a finales de la Edad Media, al principio fundamentalmente para la defensa de las puertas, pero la aparición de artillería supondrá la alteración de las técnicas de asedio y defensa. La evolución del propio análisis nos iba indicando que variables eran significativas y cuales dejaban de serlo por excesiva dispersión de datos, por la falta de información, a la vez que permite identificar las invariantes que permanecen a lo largo del tiempo.

\section{SELECCIÓN DE CASOS DE ESTUDIO.}

Se han elegido una serie de poblaciones que presentasen similitudes históricas con Segovia en algún momento de su evolución urbana, como por ejemplo; que fueran en su momento asentamientos o ciudades romanas, preferiblemente con murallas estudiadas, ciudades que en la etapa visigoda fueron sedes episcopales, localidades en que se hayan realizado estudios de evolución y transformación urbanística desde la medina hispanomusulmana tras la reconquista medieval cristiana, ciudades o villas amuralladas en la misma área geográfica, o en condiciones topográficas similares, o cuyos recintos murados estén datados entre los siglos IX y XII.

A lo largo del proceso de investigación se han ido añadiendo progresivamente nuevos recintos amurallados no contemplados inicialmente, a la vez que acotando el estudio principalmente a la Marca Media y cronológicamente cercanos al año 1000. De este modo, se han incluido en nuestro estudio todas las murallas hispanomusulmanas de la época emiral y califal que se han identificado en la Marca Media. La reutilización de restos de posibles cercas anteriores, hecho constatado en varias de las localidades estudiadas, nos obliga a incluir otros casos adicionales para valorar esta posibilidad, que constituye una de las hipótesis de partida de nuestro estudio.

La hipótesis de la conservación de posibles restos musulmanes en la muralla de Segovia, planteaba dos alternativas, que realmente fuesen musulmanes, anteriores a la repoblación o bien que fuesen mudéjares. Se han elegido distintas murallas, mejor estudiadas y datadas que el caso segoviano, para comparar las características arquitectónicas y constructivas y relaciones o paralelismos con algún fragmento de la muralla de Segovia. Por eso se han seleccionado murallas en que se conserven restos de la época tardoromanos, murallas musulmanas anteriores al siglo XI y entre las cristianas se han incluido varias de "filiación mudéjar" para aclarar si las de Segovia son musulmanas anteriores al siglo XI o bien realizadas por alarifes 
musulmanes pero ya bajo dominio cristiano en los siglos XII y XIII. Por último se han considerado algunas construcciones en que se han identificado restos constructivos musulmanes, datables en la etapa que proponemos para el caso segoviano, si bien estos restos no sean arquitecturas militares, como el caso de Almazán, o se trate de ruinas, como Peñafora, o sean pequeñas construcciones como es el caso de Mezquetillas o las atalayas al sur de la sierra del Sistema Central.

El listado de localidades que se han empleado como referencia tanto como ejemplos de trazado urbano de recintos amurallados como por poseer restos de construcciones musulmanas y que se han visitado in situ son Agreda, Almazán, Arévalo, Atienza, Ávila, Ayllón, Bernardos, Buitrago de Lozoya, Burgos, Calatañazor, Caracena, Coca, Cuellar, Cuenca, Escalona, Fresno de Cantespino, Fuentidueña, Gormaz, León, Lugo, Maderuelo, Mansilla de las Mulas, Maqueda, Medinaceli, Medina del Campo, Mérida, Olmedo, Osma, Palma de Mallorca, Pedraza, San Esteban de Gormaz, Sepúlveda, Sintra, Talavera de la Reina, Talamanca del Jarama, Tarazona, Tiermes, Toledo, Toro, Trujillo, Turégano, Urueña, Vascos y Zamora. Adicionalmente se han estudiado a través de la bibliografía Alba de Tormes, Balaguer, Calatayud, Castrotorafe, Ciudad Real, Ciudad Rodrigo, Cogolludo, Córdoba, Coria, Guadalajara, Huesca, Huete, Ledesma, Madrid, Mezquetillas, Miranda del Castañar, Monleón, Peñafora, Recópolis, Salamanca, Sevilla, Sigüenza, Tarragona, Uclés y Zorita. A mayores, se ha realizado un viaje a los castillos omeyas del desierto en Jordania, donde se han efectuado fotogrametrías y mediciones para comparar los aparejos y sistemas constructivos allí empleados.

\section{TOMA DE DATOS Y TRABAJO DE CAMPO}

La principal fuente de información ha sido la lectura del documento construido, especialmente en el caso de la muralla, dado que en la traza urbana solo podemos identificar vestigios puntuales en algunas construcciones, debido al mayor grado de transformación de esta epidermis que son las fachadas de los edificios.

Se ha efectuado un intenso trabajo de campo para la toma de datos sobre el elemento construido, fotos, planos, medición, dibujo, lecturas constructivas de paramentos para diferenciar las fábricas originales, las zonas rehechas, restauraciones, para contrastar noticias previas, hipótesis o sospechas. En algunos casos se ha recurrido al zoom de la cámara fotográfica y a los prismáticos desde las alturas al otro lado de los valles del Clamores y Eresma, para poder estudiar los distintos sectores, debido a lo inaccesible de algunos de ellos. Esto ha impedido tomar buenas imágenes de conjunto de los lienzos, (al no disponer de drones o tecnología similar) recurriendo a las fotos de conjunto en invierno en que la vegetación permite una mayor visibilidad. Las fotos a pie de muralla presentan excesiva fuga y en algunos casos las partes altas no son visibles.

La mayor parte de la medición se ha realizado por medios propios, con cinta métrica y distanciómetro láser. En las zonas menos accesibles, a mayores de esta toma de datos in situ, se han empleado las planimetrías de diferentes proyectos de intervención, los informes arqueológicos y la documentación de final de las obras realizadas. En el resto de los casos, donde no se han realizado obras y de difícil acceso se ha recurrido al plano catastral.

Tras este trabajo se ha elaborado una planimetría propia de todo el trazado de la muralla, subsanando errores detectados en el Plan Director, tales como omisión de la existencia de 
algunas torres, el erróneo trazado en planta de otras, o incluso el inexacto trazado del los lienzos de la muralla en el sector del hospital de la Misericordia. En esta planimetría se ha conservado el criterio de numeración de las torres empleado en el Plan Director. Para la identificación de las torres se señala una letra $\mathrm{T}$ seguida del número asignado en el Plan Director (por ejemplo T1). Para la identificación de los lienzos empleamos una letra L seguida de los números de las dos torres entre las que se encuentra separados por un guión, por ejemplo L1-2, representa el lienzo entre las torres T1 y T2.

La numeración se inicia en la puerta de San Andrés, recorriendo la muralla en el sentido contrario a las agujas del reloj, finalizando en el mismo punto. En el Plan Director se cierran entre paréntesis los números de las torres desaparecidas, de forma que se indica su posición de manera aproximada e incluye algunos elementos singulares a los que nombra con letras, como son las puertas, postigos, quiebros, espolones y resaltes.

Cuando se ha identificado una torre inédita, no recogida en el Plan Director hemos optado por asignarla el mismo número que la anterior, pero con un acento, manteniendo el criterio marcado por el Plan Director, para no alterar la numeración correlativa de las demás, por ejemplo T13'.

Para una mejor organización de la información durante la fase de la toma de datos, se ha dividido la muralla en 12 zonas de trabajo, por criterios de homogeneidad tipológica y de funcionalidad para poder acceder a los pies de la muralla. Tras la elaboración de la planimetría se han realizado numerosos recorridos a lo largo de la muralla, para realizar levantamientos fotográficos y lecturas constructivas buscando elementos significativos, identificar los distintos aparejos, las discontinuidades constructivas, localizar distintas fases e intervenciones, diferentes materiales y sistemas constructivos empleados, spolia en general, lapidas y otras piezas reutilizadas así como otros elementos singulares, elementos gliptográficos, elementos de carácter militar, localizar vestigios arqueológicos, similitudes y diferencias entre elementos. Se trata de reconocer las posibles variables que hemos seleccionado para el estudio de nuestra muralla y su recopilación en las fichas y planos esquemáticos de toma de datos.

Complemento ineludible de esta toma de datos grafica se realiza la descripción exhaustiva por escrito de cada una de estas zonas de trabajo, centrándonos en esas características que vamos a analizar. Por cada zona, se plantea una presentación general en la que se exponen los datos comunes, para posteriormente proceder a la descripción elemento a elemento, torres puertas y lienzos, siguiendo el orden en el que los encontramos en la muralla, de la numeración del Plan Director. Esta información se complementa con la recogida en las fichas y planos esquemáticos de toma de datos.

\section{FICHAS DE TOMA DE DATOS.}

$\mathrm{Al}$ poco de iniciar la toma de datos, detectamos que existe una elevada heterogeneidad de aparejos en las fábricas de la muralla, por lo que optamos por realizar un catálogo de los aparejos existentes en la muralla, de forma que su análisis se puede desligar de la toma de datos general. Así en las fichas de toma de datos, se recoge exclusivamente un código de aparejos que ha sido sistematizado previamente para simplificar esta ficha de toma de datos.

El proceso de diseño de las fichas de toma de datos se ha visto sometido igualmente al proceso de continua revisión, para ajustar las variables empleadas en nuestro análisis a las mínimas imprescindibles que fuesen significativas para nuestro caso de estudio. La enorme 
extensión de la muralla, mas de tres kilómetros de trazado y 86 torres, según el Plan Director, nos obliga a reducir el nivel de la toma de datos y del análisis, para poder hacerlo abarcable. Muchas de las variables no resultan significativas, como por ejemplo la disposición del adarve, la forma del almenado, las relaciones estratigráficas entre las torres y los lienzos, que en la mayoría de los casos resulta imposible determinar que elemento se adosa a cual, debido a la multitud de rejuntados posteriores que han ocultado esa información. Otras variables que se han omitido son las gliptografía, (las marcas de cantero ocultas por los rejuntados y el deterioro de los sillares, resultaban poco esclarecedoras) así como la heráldica, exclusivamente centrada en las puertas y toda ella perteneciente a etapas posteriores a nuestra época de estudio.

En otros casos se han consignado algunos datos en las fichas de manera secundaria, debido a lo poco significativo que resulta para nuestro estudio. Así por ejemplo los adarves con sus petos y almenados, que creemos prácticamente todos completamente renovados, la posible preparación de la roca del terreno para el apoyo de la primera hilada, por el escaso número de ejemplos en que esta visible o la configuración de la torres como macizas o huecas, solución ésta ultima que sólo encontramos en dos torres vinculadas a las puertas.

Se ha realizado una ficha de toma de datos para los lienzos de la muralla y otra distinta para las torres. En este segundo tipo se han distinguido los zócalos del resto de la torre, por resultar la parte de mayor interés en nuestro estudio y haberse encontrado diferencias significativas entre estas partes inferiores respecto al resto de la torre, disparidades que no se han hallado en los lienzos, sino de forma muy excepcional.

Cuando existen estos zócalos diferenciados, algo que es mucho más frecuente y evidente en las torres que en los lienzos, se cumplimenta una segunda parte de la ficha en que se recogen la misma secuencia de datos que se han explicado hasta ahora, pero ciñéndose exclusivamente al zócalo o parte inferior de la torre, claramente diferenciada del resto. Así se consignan las dimensiones y geometría de ese zócalo, los sistemas constructivos y materiales empleados, los aparejos como se organizan, (en este caso con mayor minuciosidad, se crea una casilla específica para recoger de forma enumerativa la totalidad de aparejos existentes) y también se matiza el tipo de discontinuidad que existe entre la parte superior de la torre y esta zona inferior que hemos diferenciado, indicando en qué consisten esas diferencias, en la forma, en el tamaño, en el material empleado, en el tamaño de las piezas en el sistema constructivo o en los aparejos que los organizan, así como el tipo de discontinuidad que los separa.

Las fichas se complementan con unas imágenes del elemento estudiado y unos espacios reservados para observaciones y enumerar la documentación relacionada que se hay encontrado en cada caso, como por ejemplo, fotografías históricas, grabados o dibujos, proyectos de reparación, referencias en documentación de archivo, etc. En total se han elaborado 280 fichas que se presentan en el anejo II.

Como parte de esta toma de datos se han realizado visitas a las murallas de las poblaciones empleadas como casos de estudio que se ha listado anteriormente, dado que en numerosos casos las descripciones bibliográficas no resultan lo suficientemente claras o no entraban en los aspectos que nos interesaban para nuestro estudio, descripción y medición de aparejos, métrica, modulaciones, por lo que nos hemos visto en la necesidad de realizar esas comprobaciones in situ. Se han elegido las variables más significativas para la finalidad de nuestro estudio. 

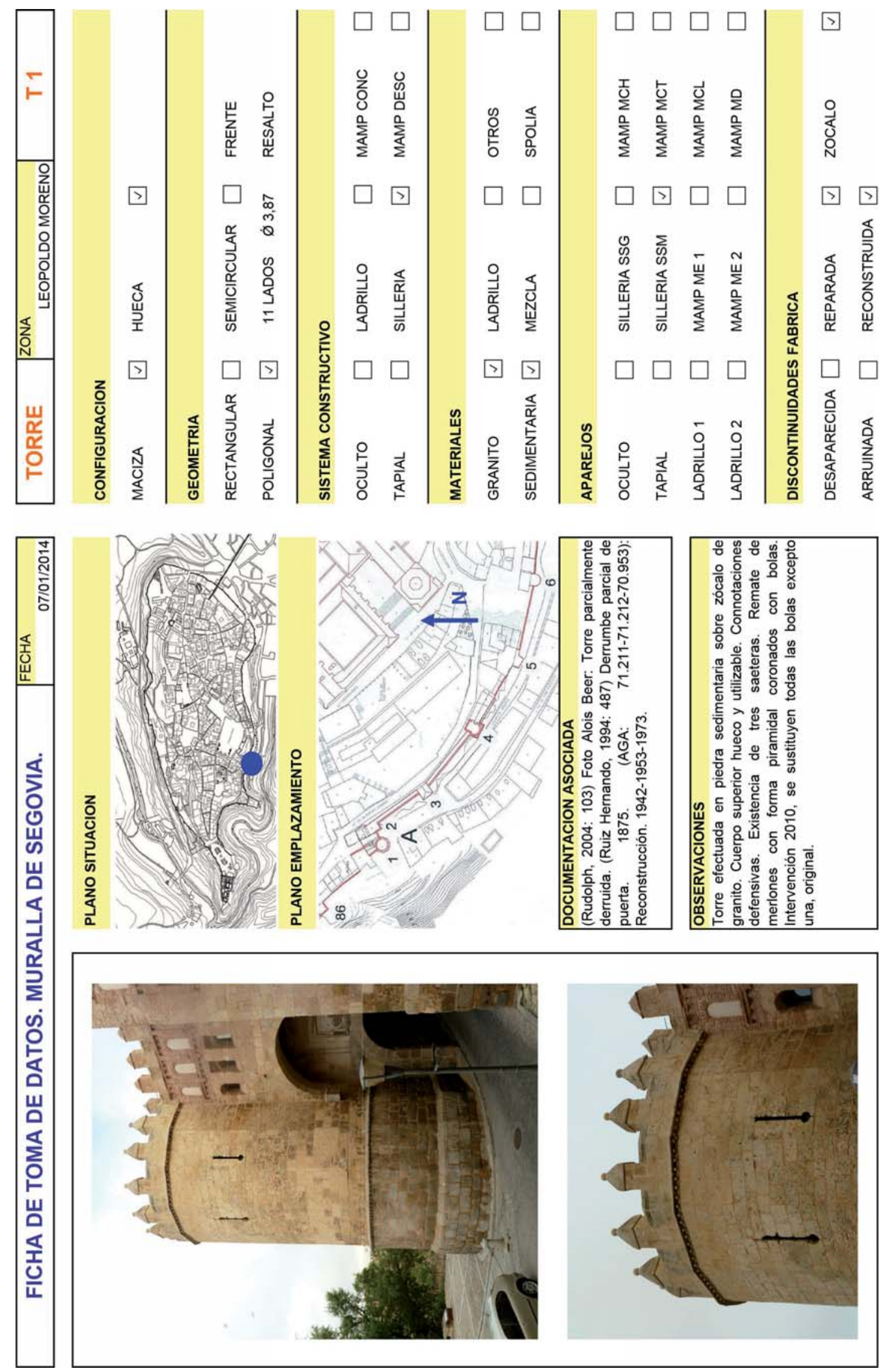

Figura 1. 1: Modelo de ficha de toma de datos para las torres, cumplimentada. 

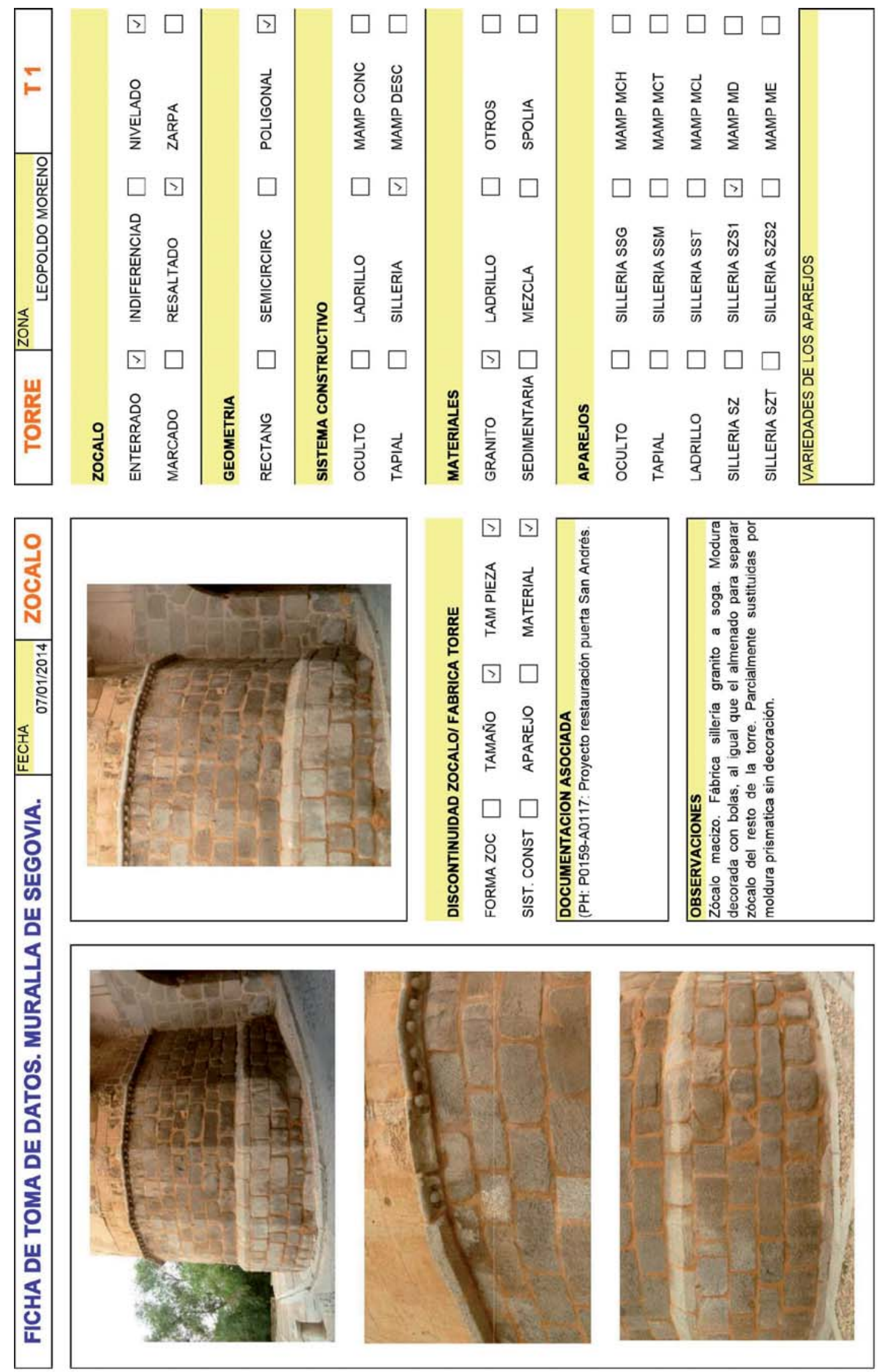

Figura 1. 2: Modelo de ficha de toma de datos para los zocalos de las torres. Cumpimentada torre T1. 


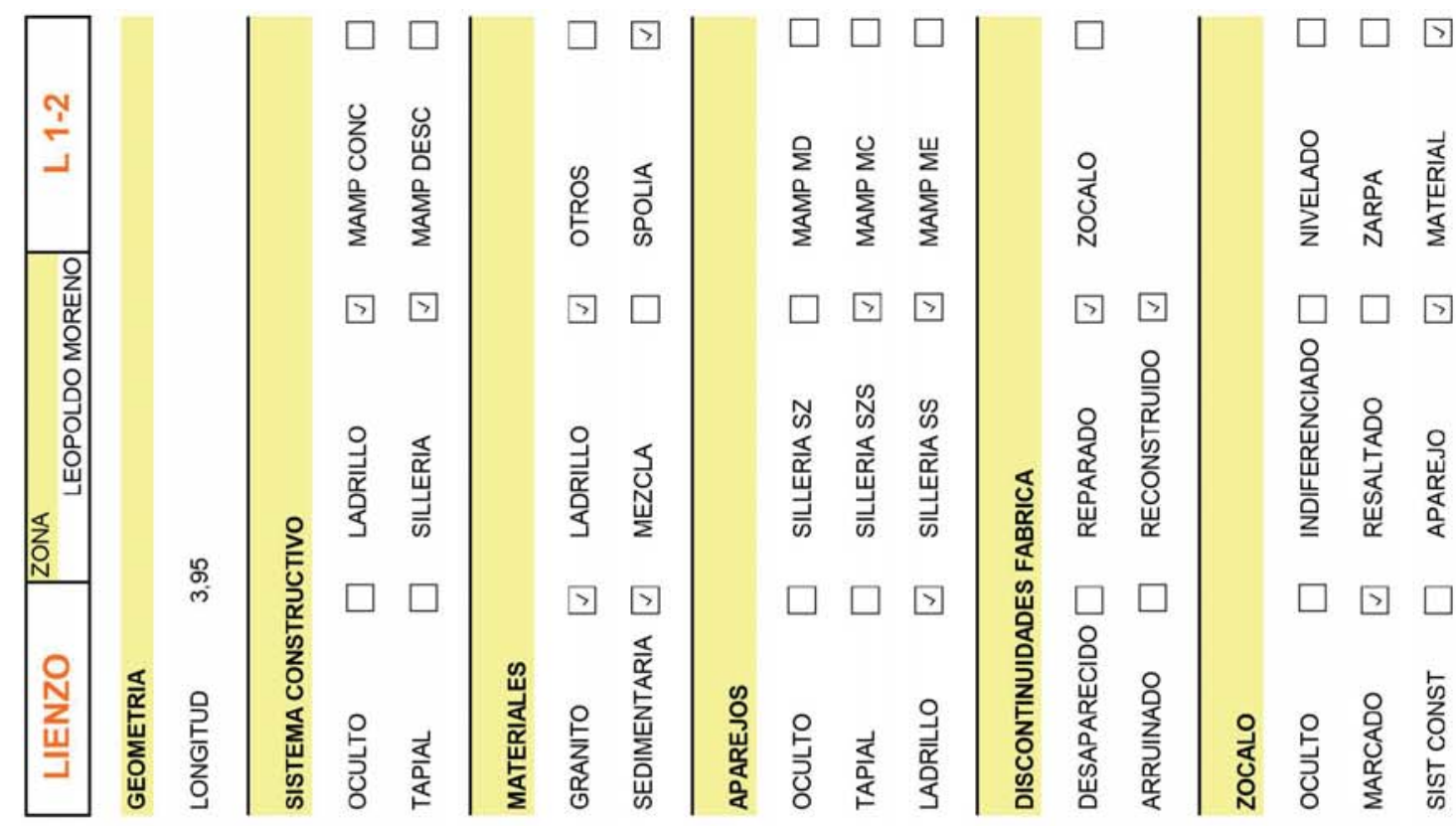

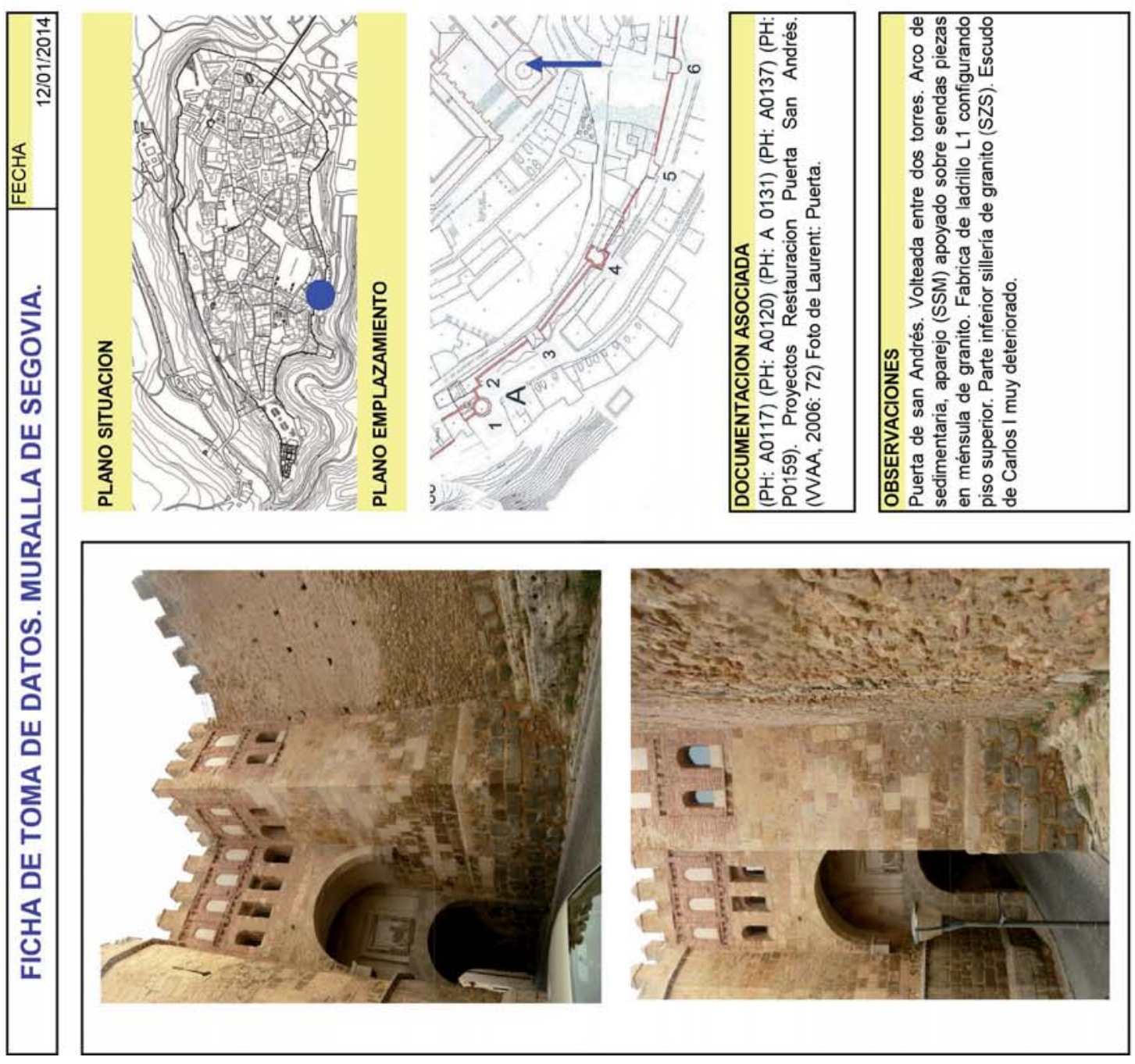

Figura 1. 3: Modelo de ficha de toma de datos para los lienzos, cumplimentada. 


\section{PLANOS ESQUEMÁTICOS DE TOMA DE DATOS.}

Los planos esquemáticos son representaciones conceptuales y adimensionales de la muralla que permiten recopilar la información y disponerla de manera que se preserva la visión de conjunto y simultáneamente aportan una mayor exactitud de la información recogida en las fichas, complementándolas.

Se representa la muralla sobre una cuadricula, de cuatro filas de alto y tres columnas de ancho, tanto las torres como los lienzos. En las torres cada columna lateral significa uno de los costados, mientras la columna central representa el frontal de la torre. En los lienzos, cada columna constituye uno de los extremos o la parte central del mismo. En vertical, la fila inferior simboliza el apoyo sobre la roca, la segunda el zócalo, la siguiente fila representa el cuerpo central y la última fila el adarve o remate.

Para diferenciar las torres de los lienzos, están se regruesan y representan más altas, con una casilla mas, en la que se indica el numero de la torre. Con franjas de colores, sobre los lienzos y torres, se indican las 12 zonas en que hemos dividido la muralla para la toma de datos.

En todos ellos se la representación de las partes de muralla desaparecidas se colorean en gris oscuro, mientras el color gris claro se reserva para las partes ocultas, ya sea por estar enterradas, en caso de zócalos, o bien tapadas por la vegetación, edificaciones adosadas por delante o revocadas.

En los planos esquemáticos representamos las mismas variables que en las fichas, con la salvedad de la forma de las torres y las dimensiones de los elementos. Obviamente se grafía sólo el elemento característico predominante de cada zona de la muralla. Por ejemplo, en el caso del mapa de aparejos, resulta imposible reflejar en una única casilla todos los aparejos o variedades que existen en varios metros cuadrados de muralla. La totalidad de aparejos se recogen en la ficha correspondiente. La variedad de significados del grafismo se recogen en la leyenda individualizada que se incluye en cada colección.

Cada colección está compuesta por dos planos, de forma que en esas dos láminas se refleja todo el alzado de la muralla, con sus torres y lienzos, excluyéndose los correspondientes a la zona 10 del Alcázar. Se han elaborado 4 colecciones de estos planos de toma de datos, uno para los sistemas constructivos, el de los materiales empleados, los aparejos existentes y el de configuración de los zócalos. Estos planos esquemáticos de toma de datos se adjuntan en el anejo III. 

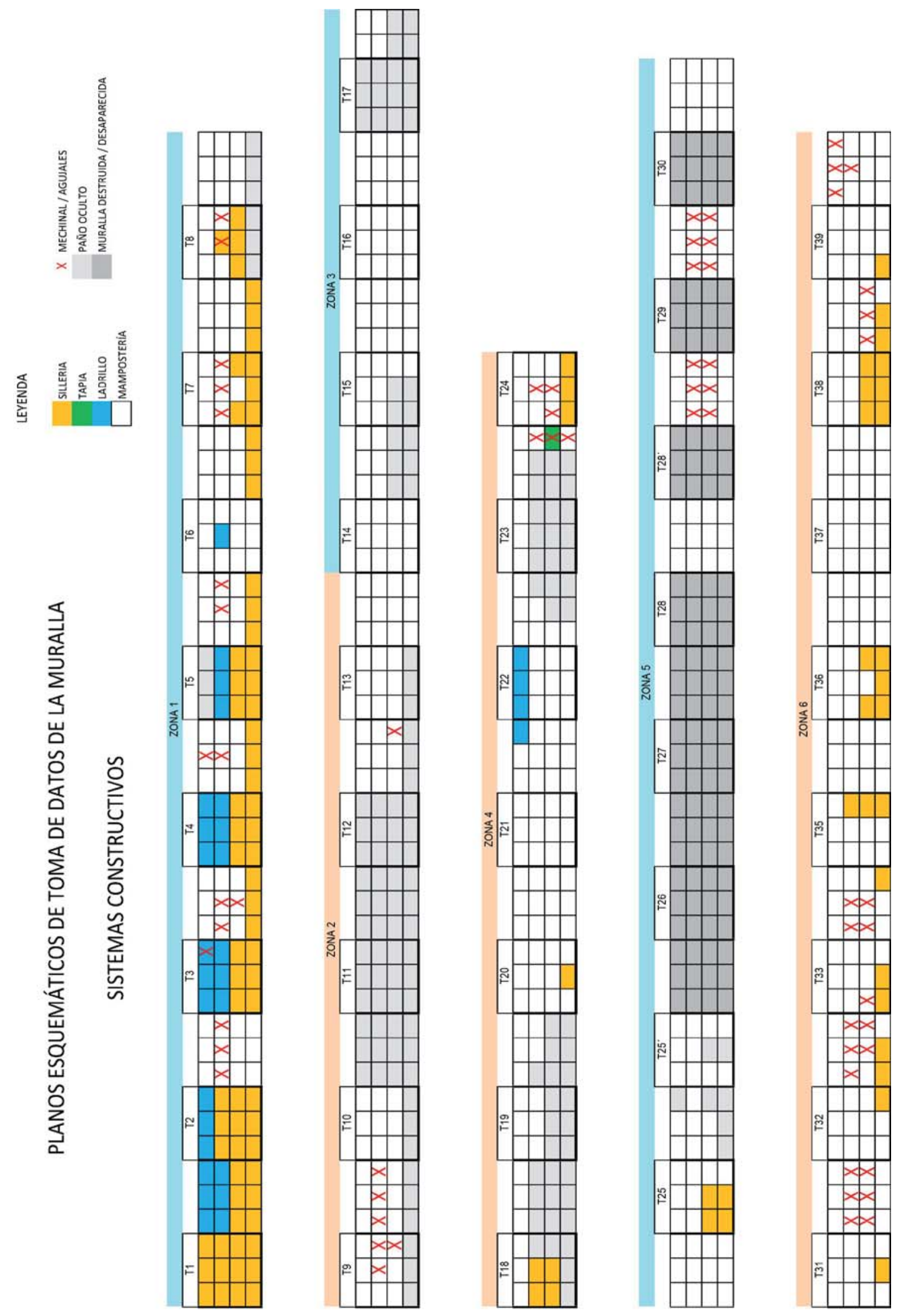

Figura 1. 4: Mapa esquemático de la muralla para la toma de datos con la disposición de los sistemas constructivos existentes, desde la torre T1 a la T39. 

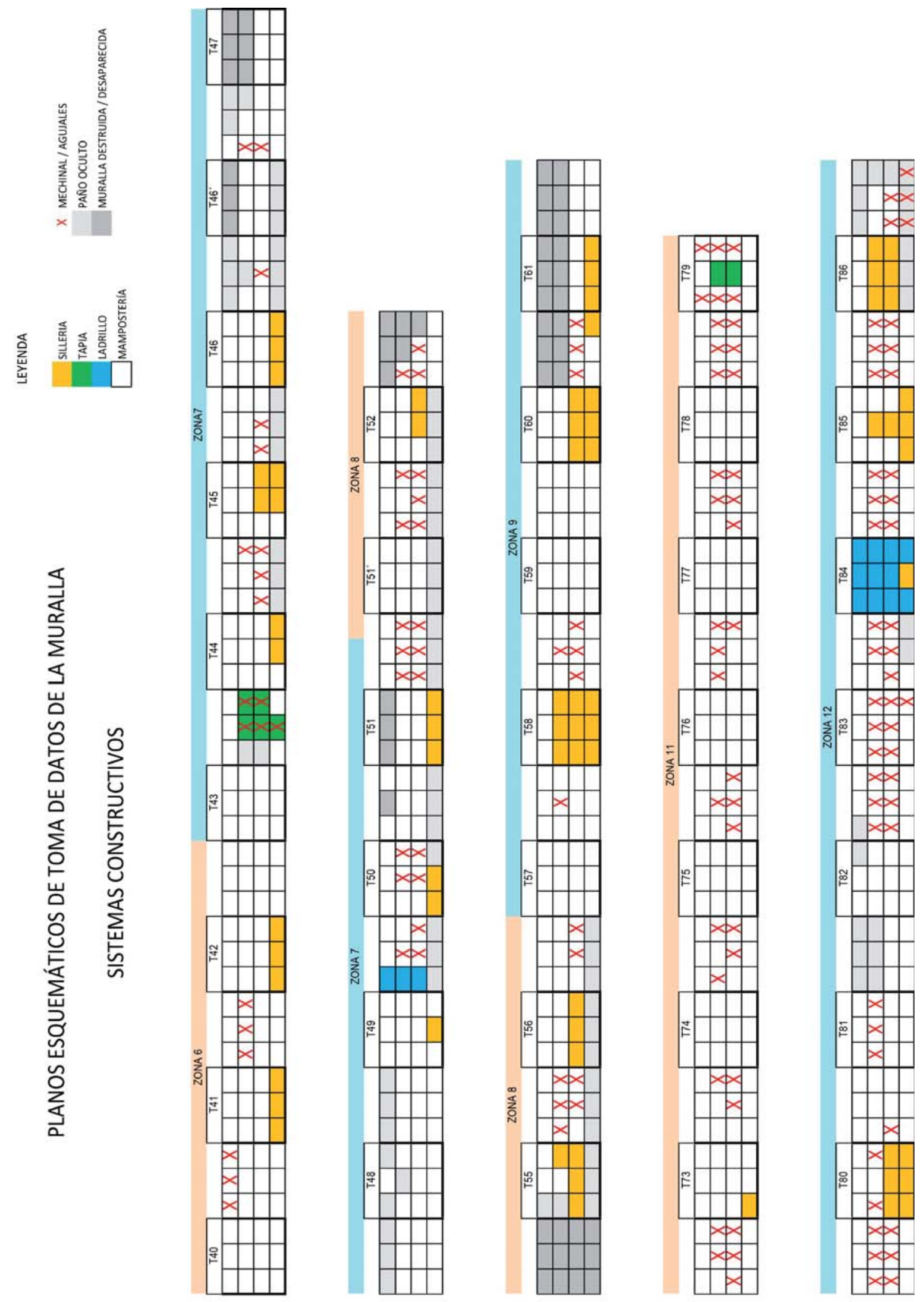

Figura 1. 5: Mapa esquemático de la muralla para la toma de datos con la disposición de los sistemas constructivos existentes, desde la torre T40 a la T86. 


\section{ANÁLISIS DE LOS DATOS}

El proceso de análisis, que constituye el capitulo IV, se ha estructurado en tres apartados.

- El primer apartado es un análisis de los hallazgos efectuados, bien en la observación de la documentación histórica gráfica, la lectura de la información archivística o por descubrimiento de alguna discontinuidad constructiva durante la toma de datos in situ, interpretando los elementos que no nos han llegado o lo han hecho muy alterados. Este primer análisis complementa la toma de datos, ya que, en algunos casos, cambia sustancialmente el punto de partida, al subsanar erratas contenidas en el plan Director o aportar una información adicional, como por ejemplo la recuperación de torres desaparecidas, algo que altera la métrica de los lienzos y los resultados del análisis que se efectúa posteriormente. Igualmente la restitución de las puertas de San Martín y San Juan o la reubicación de los desconocidos postigos de San Matías y fuente cercada alteran el entendimiento de la configuración sus entornos cercanos. Se trata por lo tanto de un primer análisis, que nos conduce a una información obtenida no de manera directa en la toma de datos, pero que resulta fundamental para la correcta interpretación y los análisis subsiguientes que se van a realizar.

- El segundo apartado consiste en un análisis temático o sectorial de cada una de las variables que se han seleccionado, esto es, la forma en planta de las torres, la métrica de las torres y lienzos, la configuración de los accesos y la de los zócalos, los materiales constructivos y su distribución por la muralla, los sistemas constructivos y los aparejos existentes. Este análisis ofrece ya algunas conclusiones parciales. Por ejemplo, la toma de datos en lo relativo a la forma en planta de las torres ha permitido descubrir algunas erratas recogidas en el plan Director y encontrar una lógica en la disposición de cada tipo de torre a lo largo de su trazado. Estas diferencias han sido refrendadas por el análisis de la modulación de los lienzos y torres de cada sector en que se ha dividido la muralla. En algunos casos, como por ejemplo los aparejos, ha permitido incluso la datación de algunos de ellos, por comparación directa con los aparejos de otras murallas empleadas como casos de referencia.

- El tercer apartado es un análisis transversal que nos permite interrelacionar todas las variables entre sí, entrecruzando los resultados de cada uno de los análisis sectoriales para llegar a unas conclusiones, asociar entre sí las distintas alternativas de cada variable y asignar cronología a prácticamente todas las características estudiadas. Para esta datación cronológica de cada una de las características analizadas se ha empleado el estudio de las relaciones estratigráficas. El análisis sectorial ha permitido ordenar de manera relativa, aunque sin datación, las distintas alternativas encontradas dentro del análisis de cada una de las variables, relacionándolas entre sí. El posterior análisis transversal nos relaciona todas estas variables y alternativas simultáneamente. Así por ejemplo, se han podido asociar una forma de torres, unos aparejos o unas tipologías de zócalos a unas métricas concretas, a la vez que constatamos que no aparecen en las otras. Este análisis transversal es el que ha permitido la relación de casi todas las variables entre sí y agruparlas por tradiciones constructivas y adscripciones estilísticas y cronológicas. Algunas excepciones quedan desconectadas, al carecer de relaciones estratigráficas, que deberá aportar la arqueología en el futuro.

Para este proceso se ha creado una herramienta informática donde se han recogido toda la información, que se dispone a modo de capas superpuestas, que podemos filtrar aislando o 
relacionando a nuestro criterio. El empleo de esta herramienta informática ha posibilitado la realización de numerosos filtros que han permitido analizar de manera individualizada cada variable, para posteriormente ir cruzando datos de los distintos elementos, variables y alternativas.

El empleo de esta herramienta informática y este método de filtrado de la información posibilita una valoración estadística y objetiva de las variables que se analizan. Así hemos podido identificar zonas homogéneas en que encontramos características muy similares, distinguir las variables subyacentes como la métrica, de las epidérmicas, como el aparejo, o incluso relacionar estratigráfica y cronológicamente unas variables con otras con las que aparentemente no existía ninguna relación.

Para su presentación, toda esta información se ha volcado en tablas Excel que se adjuntan en el anejo IV, así como de manera individualizada insertadas en el texto de cada uno de los apartados de análisis realizados en el capítulo 4.

Se han dibujado los distintos aparejos, todos a la misma escala para su mejor comparación entre sí y con los de otras fábricas de interés. Esta información se incluye en el anejo V. Se ha desistido de la realización de lecturas de paramentos de toda la muralla porque resultaba un esfuerzo desproporcionado para, en numerosos casos, no aportar datos relevantes debido a la infinidad de intervenciones indiferenciables. "Mientras mayor es la complejidad, extensión y variedad cientifica de un edificio, mas necesario se hace reducir el nivel de requerimiento a la hora de cumplimentar el registro, si se quiere acometer por un lado el estudio integral y por otro entender el proceso evolutivo de la manera más lógica" (Tabales Rodríguez, 2002: 98).

Todo este análisis de la muralla, concluye con una recopilación de las conclusiones, en que se resumen las principales aportaciones de la investigación, justificando el primer punto de los 5 propuestos en los objetivos iniciales.

A modo de restitución del proceso evolutivo de la muralla, se relatan las principales intervenciones identificadas en la muralla, que se ordenan cronológicamente en etapas histórico constructivas, de modo que se identifican las técnicas constructivas de cada etapa. Estas etapas se resumen gráficamente en los planos esquemáticos del alzado de la epidermis de la muralla en que se agrupan por cronología las intervenciones realizadas en cada una de las etapas históricas. Estos planos, titulados de cronología y etapas históricas de la muralla, se presentan en el anejo VI. Por último, también como parte de las conclusiones, se presenta en un plano del recinto amurallado de la ciudad, la extensión de la muralla musulmana, indicando los hallazgos realizados, tanto visibles a nivel de epidermis o paramentos como de posibles restos de dicha muralla hispanomusulmana ocultos por las reformas posteriores. Con dicha descripción y ambas presentaciones gráficas se da respuesta a los puntos 2 y 3 de los objetivos propuestos al comienzo de la investigación.

\section{PARTICULARIDADES DEL ANÁLISIS DE LA PARTE URBANA}

El estudio del urbanismo histórico empleando las herramientas de esta disciplina, así como el estudio de la muralla, desde el campo de la arqueología de la arquitectura, utilizando en ambos casos la ciudad y la muralla como fuente primaria, son las disciplinas en las que vamos a 
centrar nuestra investigación ${ }^{4}$. El análisis del trazado urbano, la configuración de las manzanas y las parcelas, van a ser los puntales sobre los que apoyar nuestras conclusiones. La investigación documental puede aportarnos datos para corroborar la existencia de determinadas calles, plazas o edificios con una cronología, post-quam, de manera infalible e incluso aportarnos una información muy valiosa de los hitos que jalonaban su trazado. Esto nos permite a la vista de los documentos y en base a la terminología empleada observar la evolución de la trama urbana ${ }^{5}$.

En etapas más cercanas en el tiempo los grabados, planimetrías y otras fuentes graficas pueden aportar una información muy interesante de nuestras ciudades. Grabados como los de Wyngaerde, de un elevado grado de fiabilidad, pueden permitir ubicar determinados elementos en el plano. Habida cuenta que numerosas ciudades españolas han permanecido sin importantes transformaciones estructurales en su paisaje medieval hasta mediados del siglo $\mathrm{XX}$, la fotografía histórica se convierte en una fuente de información veraz e irrefutable de un valor incalculable. Incluso la foto aérea sigue siendo muy útil en la lectura del parcelario y la evolución histórica de la estructura urbana de las ciudades.

Partiendo de esta base catastral se ha elaborado una planimetría propia del recinto amurallado de Segovia, en la que se ha retrocedido en el tiempo, "deshaciendo" todas las reformas de alineaciones que están documentadas, especialmente las reformas de la segunda mitad del XIX y principios del XX (calles Cronista Lecea, Infanta Isabel, Isabel la Católica, implantación del teatro Juan Bravo, etc). Del mismo modo se ha "repuesto" en su estado los edificios demolidos de los que se tiene constancia documental o arqueológica de su forma, ubicación o emplazamiento. Otras modificaciones de alineaciones y del parcelario de las que no disponemos información, como la construcción de la catedral y la creación de la plaza Mayor, junto con la reubicación de la iglesia de San Miguel han alterado considerablemente la trama urbana y el parcelario medieval de toda esa zona y no disponemos de ninguna información de la configuración de estos espacios en la Edad Media. Deben obviarse mentalmente ya que desconocemos su configuración en la época en que centramos nuestro estudio. Se trata de intentar restituir la forma urbana, lo más lejana en el tiempo posible, remontándonos a la Edad Media. Para este fin es de gran importancia el trabajo efectuado por Antonio Ruiz (Ruiz Hernando, 1982). Partiendo de sus planos, y dibujando sobre una planimetría propia, vamos a ir completando la información tanto arqueológica y documental, aparecida desde la publicación de su libro y tomar toda esa información como punto de partida para nuestra investigación y exponer nuestras hipótesis. Debemos tener en consideración que no disponemos de toda la información, por lo que esta restitución hipotética de la ciudad tiene las limitaciones inherentes propias de la arqueología que se efectúa en las ciudades.

\footnotetext{
${ }^{4}$ Dada mi formación técnica, el estudio de la ciudad basándonos en la lectura e interpretación del parcelario, de la trama viaria y en la propia arquitectura construida o en sus vestigios arqueológicos, es la herramienta más infalible que puedo emplear, es una fuente de información directa, primaria, que aporta datos veraces, obtenidos de la realidad construida. Las fuentes documentales pueden aportar una información complementaria valiosísima para el estudio de la ciudad y la muralla, pero a la cual sólo puedo acceder a través de la interpretación y traducción de otros autores, mejor capacitados que yo para la traducción e interpretación de los documentos históricos escritos.

${ }^{5}$ El hecho de que las calles no tengan nombre, sino que en los documentos se emplee una descripción general, confusa, sin linderos, ni enumeración de inmuebles adyacentes o próximos pone en evidencia la existencia de una morfología urbana primitiva. La evolución de la morfología a lo que podríamos calificar como de carácter urbano, implica la identificación de los inmuebles en una calle concreta, con comienzo y final, y la enumeración de los linderos o calles con los que está en contacto (Crespo Redondo 2007: 239).
} 
Sobre esta base cartográfica, se ha recopilado la información procedente de las distintas especialidades científicas que hemos considerado podían aportar luz a nuestro estudio. La toma de datos se refleja directamente sobre el plano, a veces como mera marca geográfica aproximada, como por ejemplo en el caso de las aportaciones de la toponimia, que debe considerarse con las máximas precauciones. En otras ocasiones, la pervivencia de los edificios nos posibilita conocer incluso las alineaciones históricas de la trama viaria. Así la importancia de la información depende de la fuente o disciplina de la que provenga.

La historia del arte como instrumento de estudio pormenorizado de los edificios medievales que se conservan en la ciudad, así como la arqueología en el caso de los no conservados, son complementos valiosísimos que aportan una información, si bien parcial, puntual y en muchos casos inconexa, para permitirnos realizar esta restitución hipotética de la forma urbana de nuestras ciudades en sus etapas históricas. Estos últimos estudios, que aportan datos materiales tangibles, pueden permitirnos establecer cronologías concretas a las relaciones de antero-posterioridad entre los diferentes elementos que configuran el palimpsesto urbano que constituyen nuestras ciudades históricas.

La cota del sustrato virgen, la roca madre, en el caso de ciudades asentadas sobre un peñasco rocoso como Segovia, es una referencia que nos permite conocer la entidad de los rellenos que se han sucedido a lo largo de los siglos hasta la cota de la ciudad actual, incluso aunque no se haya efectuado ningún tipo de estudio arqueológico, la realización de estudios geotécnicos nos puede aportar este tipo de datos, menos fructíferos que los arqueológicos, pero no por eso desdeñables. El análisis de los estudios geotécnicos que se han efectuado en la ciudad nos da información sobre el espesor del estrato de interés en cada ubicación. Esto nos permite conocer las pendientes de las calles históricamente o al menos la diferencia de cota existente entre diversos puntos (especialmente interesante puede resultar en las proximidades de las puertas o de las calles de acceso a través de las murallas) o establecer las líneas de pendiente del terreno o relacionar puntos que se encuentran al mismo nivel.

Generalmente las murallas se convierten en muros de contención, en cuyo interior van superponiéndose los estratos arqueológicos de las distintas "edades" de la ciudad. La habitual creación de muladares junto a la muralla, tanto intramuros como extramuros, convierten a las excavaciones que se efectúen junto a este elemento arquitectónico en un importante generador de potencial información arqueológica en la que queda depositada la secuencia estratigráfica, perfectamente relacionada con la construcción de la propia muralla. Así si los informes arqueológicos nos facilitan una información de enorme interés en el caso de efectuarse en las parcelas adyacentes a las murallas, su interés es aún mayor para los fines del estudio que nos ocupa.

En numerosos casos, la falta de mayor cantidad de información fidedigna de carácter arqueológico nos va a impedir establecer cronologías exactas o irrefutables para algunas de nuestras hipótesis, sin embargo creemos que el conjunto del discurso plantea una serie de datos contrastados, o si se prefiere coincidencias o indicios, que apuntan a la certeza de la hipótesis, convirtiéndola en probable, si bien la afirmación categórica no será posible hasta que se disponga de mayor información arqueológica. Las limitaciones de la arqueología urbana son precisamente su dependencia del número de prospecciones arqueológicas que se efectúan en la ciudad así como la discontinuidad y la restringida extensión en superficie de éstas. En estos casos la toponimia también se convierte en un importante aliado que sirve para orientar nuestras investigaciones. La toponimia urbana local es una pervivencia inmaterial, cuyo 
estudio es un recurso muy válido para orientar en las investigaciones o refrendar hipótesis u otros datos. Los nombres de las puertas, de las calles, de las plazas o de las collaciones aportan una explicación de la ciudad histórica y de su funcionamiento. El emplazamiento del mercado semanal, o del azogue, mercado diario, el emplazamiento de las distintos gremios profesionales o de las diferentes minorías étnicas, los usos y actividades desarrollados quedan constatados en los nombres de calles, plazas, etc, que han llegado hasta nuestros días, bien oralmente o a través de escritos y documentos de los archivos.

La interacción de la muralla con la estructura viaria, la forma de las manzanas, el parcelario, el trazado de las calles, la configuración de los cruces, plazas y encuentros de las calles, son las principales variables de nuestro análisis. Dado que sólo buscamos distinguir dos aéreas urbanas con características diferentes en su conformación, el menor número de variables y lo etéreo y escaso de la información disponible han hecho innecesaria la realización de herramientas informáticas, ni el empleo de filtros, ni valoraciones estadísticas. Identificadas las alternativas posibles que presenta cada variables de análisis, se sitúan geográficamente sobre el plano para determinar aéreas aproximadas en las que diferenciar las situaciones que observamos.

La principal herramienta de esta segunda parte de la investigación ha sido el análisis gráfico de la planimetría y la foto aérea, frente a la observación directa del elemento construido, que hemos empleado en la muralla. Obviamente los puntos de mayor interés se han visitado in situ, en busca de posibles vestigios que pudiesen existir visibles que confirmasen nuestras sospechas. Tal y como hemos visto en relación a la métrica de la muralla, todas las variables de este estudio de la estructura urbana subyacen bajo una epidermis de los edificios, pavimentos y escena urbana totalmente renovada, que hace muy difícil la abstracción mental, siendo muy escasos los restos originales de la Edad Media que se conservan visibles y aportan información significativa para la escala urbana de nuestro estudio.

Este método de trabajo a base de plantear secuencias de hipótesis que se reafirman mutuamente partiendo de datos reales o probables que nos va indicando los aspectos sobre los que indagar y en los lugares exactos donde hay que investigar, sobre la realidad física actual, sobre el documento construido que es nuestra ciudad, para confirmar hipótesis, que nos permiten ir completando la imagen global de la ciudad histórica. Se trata por lo tanto de un método de dos facetas. Una primera deductiva que nos indica, a la vista de los datos reales visibles, las hipótesis a confirmar y una segunda faceta, de carácter probabilístico, mediante la toma de datos guiados por esas hipótesis que nos va a permitir avanzar en la restitución hipotética de la ciudad con una probabilidad de acierto supeditada a la cuantía de vestigios constructivos históricos que se conserven.

Si bien se acompaña de una explicación escrita justificativa de las decisiones que se adoptan, el principal discurso de la investigación se apoya en las planimetrías elaboradas que muestran gráficamente los distintos análisis efectuados y en las que se concluye con un plano en que se define la posible extensión de la ciudad altomedieval y la que vendría a ocupar el crecimiento urbano propiciado por la repoblación. Con este análisis, más especulativo, de la estructura urbana, aportamos nuestra hipótesis como respuesta a los puntos 4 y 5 planteados en los objetivos iniciales de esta tesis. 


\section{5.- AGRADECIMIENTOS}

Me gustaría poder nombrar una a una a todas aquellas personas que me han ayudado de alguna manera, con su trabajo, sus comentarios o su apoyo moral. Posiblemente la lista sería mucho más larga de lo que yo mismo imagino.

Quiero empezar con dos personas que han sido fundamentales para el comienzo y finalización de este trabajo de investigación. D. Julián García Muñoz que me animó a empezar la tesis doctoral y mi director, D. Fernando Vela Cossío, quien me ha guiado a lo largo de estos 5 años y sin cuyos inestimables consejos no hubiese podido llevar a término esta bonita aventura que ha resultado para mi, elaborar la tesis doctoral.

También quiero agradecer la ayuda y dedicación que me han prestado el personal de los distintos archivos y bibliotecas que he consultado, especialmente el cariño y la paciencia que han demostrado a mis insistentes peticiones D. Andrés Llorente Arroyo, Dña. Isabel Álvarez González y D. Rafael Cantalejo San Frutos.

Del mismo modo, quiero agradecer la colaboración de mis compañeros de profesión durante la ejecución de las obras que se han efectuado en las murallas, Dña. Estefanía Herrero García, D. Pablo Beltrán Rodríguez y D. Fernando Alonso Temiño permitiéndome el acceso a las obras, donde he obtenido una información interesantísima de primera mano, así como no puedo olvidar las charlas sobre las vetustas piedras de nuestra querida muralla, con Dña. Clara Martín García, D. David Domingo Marazuela, D. Julio de las Heras Palomares, D. Luis Alberto Martín de Frutos, Dña. Pilar Barahona Tejedor y la información facilitada y los inestimables consejos de D. Alonso Zamora Canellada, D. David Gallego Valle, D. José 
Miguel Merino de Cáceres, D. Miguel Ángel Chaves Martín y D. Ubaldo Martínez-Falero del Pozo.

Tampoco quiero olvidar a mis compañeros que habiendo realizado su tesis doctoral recientemente, me han aportado sabios consejos de carácter práctico a la hora de afrontar la finalización de la tesis y cuyos comentarios y distintos puntos de vista han servido para corregir, matizar y enriquecer mis planteamientos, D. Ignacio Javier Gil Crespo, D. Luis Chamorro Bravo y D. Miguel Ángel Bru Castro.

Esta tesis tiene una infinidad de deudas, con numerosas personas que me han ayudado. Pero hay tres personas que han tenido una importante responsabilidad en que esta tesis, se haya orientado en la dirección en que lo ha hecho. En primer quiero hacer una especial mención a D. Juan Zozaya Stabel-Hansen, recientemente fallecido (17/01/2017). Es la primera persona que me hizo saber de la existencia de restos hispanomusulmanes en la muralla segoviana. Fue quien me indico, hacia donde dirigirme. En segundo lugar, D. José Miguel Remolina Seivane, cuyo artículo me abrió los ojos a interpretar la estructura urbana de Segovia desde otro punto de vista. Ambos son los que alumbraron, sin ser conscientes, el eje vertebrador de esta tesis. Dña. María Eugenia Contreras Jiménez que, con su entusiasmo, me ha espoleado continuamente a la búsqueda de nuevas posibilidades poniéndome sobre la pista de cuantos datos encontraba relacionados con el tema, dándome nuevas referencias bibliográficas y fuentes documentales en las que apoyarme para intentar ir un paso más adelante.

Y como no, a mi familia, los que están mas cerca, son los que te impulsan en el día a día. Mis hermanos Enrique y Luis, por su inestimable ayuda para el tratamiento gráfico de imágenes, planimetrías y la resolución de los inoportunos problemas informáticos. Muchas gracias por sus amplios conocimientos y estar siempre disponibles. De manera muy especial, Ana Escobar González, que me ha acompañado, literalmente, realizando ella su tesis en paralelo a la mía, impulsándonos mutuamente cuando las dudas y el cansancio hacían flaquear en el empeño. Ese apoyo intangible, que no se ve reflejado materialmente en el trabajo, pero sin él, posiblemente la tesis no existiría. Y por último a mis padres, a quienes dedico este trabajo, especialmente a mi padre, al que le hacía mucha ilusión tener un doctor en la familia. Desgraciadamente no ha llegado a ver hecho realidad su sueño. He tardado demasiado tiempo. 
II. Aproximación a la Alta EdAd Media EN SEgovia 

Una tesis que intenta indagar sobre la estructura urbana de una ciudad y la configuración arquitectónica de sus murallas remontándose en el tiempo más de diez siglos, requeriría el respaldo de una abundante información arqueológica, a falta de la cual necesita apoyarse en distintas disciplinas del conocimiento, cuya conjunción permita completar los, generalmente escasos e inconexos, datos que perviven y pueden obtenerse de la observación directa de las construcciones históricas.

Hemos organizado estas fuentes en cuatro grandes bloques temáticos, para ordenar la exposición. En cada uno de ellos distinguimos una primera parte de carácter más general, una visión de conjunto, para progresivamente centrarse en la ciudad de Segovia enfocando hacia el ámbito temporal de nuestra investigación.

En el campo de la historia, hemos orientado nuestro estudio hacia los principales textos sobre la Edad Media española, para posteriormente profundizar en la etapa medieval de la historia de la ciudad de Segovia. Se hace una especial incidencia en los viajeros y artistas que pasaron por la ciudad, atraídos por sus monumentos, que dejaron diferentes descripciones escritas, graficas y fotográficas de gran interés para el conocimiento de la ciudad.

En lo relativo al encuadre bibliográfico sobre el estudio de la estructura urbana, distinguimos tres partes, una inicial sobre el urbanismo medieval en general para después pasar al estudio más pormenorizado del urbanismo hispanomusulmán en la Península Ibérica y continuar con la transformación urbana de las ciudades hispanomusulmanas tras la reconquista cristiana.

En relación a la arquitectura y la arqueología de Segovia, los edificios medievales que han pervivido en la ciudad constituyen una fuente excepcional de información. Afortunadamente, 
Segovia cuenta con una amplia cantidad de estudios de conjunto y monografías sobre algunos de sus edificios. Por otra parte, la arqueología nos aporta un importante conocimiento sobre ese pasado, en muchos casos de los edificios de la propia ciudad y en otros gracias a los resultados de excavaciones arqueológicas o estudios sobre poblaciones cercanas. Por último se han revisado otros textos dedicados al estudio de casos de otras poblaciones, principalmente como referentes metodológicos.

La construcción de la arquitectura militar es un campo donde encontramos una amplia bibliografía. Estructuramos estos estudios en una primera parte más general, dedicada a las fortificaciones y murallas urbanas medievales, de nuevo con un importante interés por las fortificaciones hispanomusulmanas, para terminar focalizando con mayor profundidad en las existentes en las proximidades de la provincia y en la propia ciudad de Segovia. Tras este estudio panorámico, realizamos un exhaustivo repaso por la bibliografía existente sobre la propia muralla de Segovia, partiendo de las descripciones realizadas, las publicaciones centradas en extraer de los archivos y documentos históricos información sobre las intervenciones, reparaciones y demás avatares o incluso estudios más específicos sobre sus materiales y sistemas constructivos así como aquellos que se refieren a la existencia de murallas previas a la repoblación.

\section{ESTRUCTURA URBANA DE LAS CIUDADES MEDIEVALES}

El estudio del urbanismo medieval europeo es un campo ampliamente estudiado. Un primer acercamiento panorámico al asunto desde los diferentes enfoques que puede plantearse el estudio de la ciudad, lo constituyen las distintas obras sobre la historia urbana (Heers, 1978; Barel Yves, 1981; Benevolo, 1982 y 1992; Dutour, 2004; Boucheron, 2010) la sociología (Geddes, 1960), o la historia del urbanismo (Mumford, 1966; Morris, 1984; Braunfels, 1983 y 1988; Pinol, 2010; Poëte, 2011).

Varios autores extranjeros han realizado infinidad de clasificaciones de las ciudades atendiendo a numerosos criterios, pero el hecho urbano es demasiado complejo para intentar tipificarlo todo y siempre existen excepciones que ponen en tela de juicio el modelo y la clasificación adoptada (Lavedan y Hugueney, 1974; Pirenne, 1994; Piccinato, 1988). Es muy difícil, sino imposible, intentar generalizar algo tan dinámico como la ciudad. Estas excepciones son aún más patentes cuando las modelizaciones se han hecho tomando como modelos las ciudades del norte de Europa e intentamos aplicarlas a las ciudades españolas de raigambre hispanomusulmana, las denominadas ciudades mudéjares (Torres Balbás, 1985). Esas clasificaciones no se adaptan al urbanismo musulmán, ni a sus criterios compositivos. Así, los estudios realizados sobre la historia del urbanismo en España, especialmente después del impresionante trabajo de las ciudades hispanomusulmanas de Leopoldo Torres (Torres Balbás, 1985) señalan la peculiaridad del urbanismo español, diferenciando esas ciudades mudéjares de las de repoblación, que poseen unas características más acordes con el urbanismo del norte de Europa. La lista nuevamente puede llegar a ser interminable. Trabajos más tempranos y generalistas como la teoría de la ciudad de Gabriel Alomar (Alomar Esteve, 1980), Bonet Correa (1989) o la breve historia del urbanismo (Chueca Goitia, 1995) o la historia urbana (Sambricio, 1996) dan paso a otros más específicos en los que se estudia la forma urbana (Montero Vallejo, 1996), o la relación entre ésta y el trazado de las murallas como por ejemplo Seta (1991), Betrán Abadía (1992) o Gallego Roca (1996). 
También nos han interesado de manera especial, por su ámbito temporal, los trabajos de Enrico Guidoni, sobre el urbanismo en la Alta Edad Media (Guidoni, 1981 y 1991) así como los de Jean Gautier sobre el urbanismo medieval en Castilla y León (Gautier Dalché, 1989), por su coincidencia geográfica con nuestro trabajo.

El estudio de la forma urbana es un campo muy estudiado por historiadores, pero no tanto desde el punto de vista del análisis de la configuración de la estructura urbana y su evolución en el tiempo, que es el campo que más nos ha interesado. En palabras de Beatriz Arizaga, El estudio de la ciudad desde el aspecto del urbanismo histórico es una fuente de incalculable valor, que ofrece a los urbanistas una información que no se puede obtener de los textos históricos (Arizaga Bolumburu, 2002: 69).

Las transformaciones urbanas y las de su parcelario, los distintos trazados viarios y cambios de alineaciones, la superposición de edificios de distintas etapas culturales, generan una serie de cicatrices en la estructura urbana que constituyen las variables que manejaremos en nuestro estudio. Así desde el punto de vista metodológico hay que reseñar algunos trabajos sobre arqueología urbana o análisis de la evolución urbana, como por ejemplo Saverio Muratori (1960) que estudia Venecia analizando el parcelario, las tipologías edificatorias y los sistemas constructivos para comprender la evolución de la ciudad. Más cercanos temporal y geográficamente los trabajos de Avelino Gutiérrez sobre la ciudad de Zamora (Gutiérrez González 1990 y 1993) o sobre la ciudad de León (Gutiérrez González 1999), sobre Madrid (Montero Vallejo, 1992), Jaca (Yeste Navarro, 1991), Zaragoza (Yeste Navarro, 1993) y Palma de Mallorca (García-Delgado Segués, 2004).

Como ya hemos comentado, el urbanismo musulmán presenta unas características completamente distintas al urbanismo europeo, ya que ni el trazado urbano ni la edificación tenían un reglamento de control (Torres Balbás, 1985: 76), por lo que para su comprensión es necesario un estudio particularizado del mismo.

\section{URBANISMO MEDIEVAL DE LAS CIUDADES HISPANOMUSULMANAS.}

La estructuración del territorio hispanomusulmán se realiza en base a las vías de comunicación, las romanas aún en uso (García Moreno, 1987: 332-336) y las ciudades y fortificaciones que jalonan el territorio.

Esta afirmación se ve respaldada por la opinión de Juan Zozaya, que la considera acertada para los primeros años de la presencia musulmana en la península. Posteriormente la falta de mantenimiento y los daños ocasionados por las diferentes razzias y cabalgadas dejan inservible la red viaria romana en buena parte, pasando a utilizarse como vías de comunicación los cauces de los ríos (Zozaya Stabel-Hansen, 1987: 396). En los albores del año mil, las fortalezas musulmanas que defienden Madrid están dispuestas protegiendo los valles de los ríos desde los pasos de la sierra (Ladero Quesada, 1993), lo que viene a confirmar dicha hipótesis.

Así una diferente ordenación del territorio a lo largo del tiempo conlleva necesariamente una diferente tipología urbana para cada circunstancia. El estudio de Christine Mazzoli sobre las ciudades de Al-Andalus (Mazzoli-Guintard, 2000) supone una importante aportación al 
conocimiento de la estructuración del territorio en Al-Andalus y la evolución de la tipologías urbanas hispanomusulmanas a lo largo de los siglos, desde el VIII al XV.

En el siglo IX predomina la ciudad-acrópolis, encastillada, ya que la defensa es la prioridad. Estos asentamientos, generalmente en abruptos emplazamientos, son los embriones de los futuros núcleos urbanos, algunos de los cuales llegaran a serlo. En el siglo X las fundaciones de nuevos centros se multiplican (Talavera, Medinaceli, etc) ${ }^{6}$ A partir del siglo XI, con los reinos taifas, todas la capitales de los reinos taifas, se sitúan sobre centros preexistentes, no creándose ya nuevas ciudades, sino reutilizando las anteriores (Mazzoli-Guintard, 2000: 251269).

La sucesión de revueltas internas en el territorio musulmán a partir de mediados del IX va a producir un enorme debilitamiento del emirato. Abd al Rahman III (912-936) logra unificar y recuperar el control centralizado y se nombra primer califa, dando paso al Califato. El territorio de la España musulmana hasta el siglo X se organiza en torno a Córdoba, estando las partes más alejadas más desestructuradas (Mazzoli-Guintard, 2000: 380-394).

En el sureste peninsular, muy bien estudiado desde el punto de vista del urbanismo hispanomusulmán por Sonia Gutiérrez (Gutiérrez Lloret, 1993 y 1995) queda patente que se produce un proceso de desestructuración del territorio que alcanza a finales del VIII y principios del IX el momento de mayor ruralización de la sociedad. A partir de la segunda mitad del IX se produce una aparición generalizada de nuevos asentamientos, promovidos por Abd al Rahman II para hacerse con el control del territorio, acompañado por la construcción de ribats (finales del IX y principios del X) para implantación de tropas leales al estado cordobés.

En palabras de Rafael Azuar (Azuar Ruiz, 2005 b: 85) se confirma la debilidad e inexistencia de la administración emiral en esta segunda mitad del siglo IX, así como su incapacidad de controlar el territorio, en manos de los poderes locales. Con el califato, tras sucesivas campañas de Abd-al-Rahman III, se conseguirá el control definitivo por el estado omeya del territorio hacia el 940 (Azuar Ruiz, 2005 b: 87). Comparte esta opinión Manuel Acien, a lo largo de sus diferentes estudios (Acien Almansa, 1995, 1996, 2002 y 2005).

Esta hipótesis encaja con la propuesta de Juan Zozaya para la zona de la Marca Media. Un territorio muy desestructurado, controlado por débiles poderes locales, que alternativamente se alían y enfrentan unos a otros. Partiendo de esta hipótesis, efectúa un estudio de las tipologías de fortificaciones y aparejos, concluyendo que existen unos modelos cuyas características se repiten y que identifica con las construcciones oficialistas o de algún poder local apoyado por Córdoba (Zozaya Stabel-Hansen, 2005b). Sus estudios sobre los mecanismos de control del territorio y los recursos económicos (Zozaya Stabel-Hansen, 2004 y 2011 respectivamente), complementan sus análisis sobre las tipologías de asentamientos hispanomusulmanes (Zozaya Stabel-Hansen, 2005b).

Encontramos más información sobre las tipologías de los asentamientos hispanomusulmanes en Acien Almansa (2002) que posteriormente completa con otro estudio sobre los diferentes orígenes de las ciudades en Al-Andalus (Acien Almansa, 2005). Para este autor, la pervivencia de

\footnotetext{
${ }^{6}$ La autora sospecha que una mayor parte de todas estas nuevas fundaciones sean en realidad una consolidación de estructuras preexistentes.
} 
Los sillares romanos no implica la de la ciudad antigua, afirmando que la continuidad de los materiales no debe suponer la de la propia ciudad. Defiende la despoblación y ruralización de la sociedad y la desaparición del comercio en la última etapa del reino visigodo y el comienzo de la etapa musulmana. Las ciudades serían campos de ruinas (de las ciudades romanas) basándose en que no se han constatado arqueológicamente restos de los palacios en que vivirían todos esos obispos de la España visigoda que asistían a los Concilios (Acien Almansa, 2005: 22). Por lo tanto, no ve huellas de continuidad urbana, sino continuidad de campos de ruinas y yacimientos disponibles para el expolio.

Esto parece sugerir que los asentamientos pueden reutilizarse, si bien sin importantes condicionantes de trazado preexistente, dado que considera como canteras más que como ciudades preexistentes. No se conservarían trazados urbanos de las ciudades visigodas ni romanas, sino que los nuevos asentamientos musulmanes se implantarían en el mismo lugar, reutilizando los materiales, pero desarrollándose sobre un trazado nuevo. Es una curiosa opinión, que puede tener parte de cierto y que debemos considerar.

Sin duda una de las más importantes obras sobre el urbanismo hispanomusulmán es la obra de Leopoldo Torres. En 1968 publica un breve estudio sobre el urbanismo (Torres Balbás, 1968), pero sin duda la obra en la que se apoyan prácticamente todos los estudios posteriores es su libro sobre las ciudades hispanomusulmanas (Torres Balbás, 1985), que constituye un estudio pormenorizado y exhaustivo de las ciudades musulmanas, de las que analiza su tipología, morfología, la configuración del viario y el espacio público (calles, plazas, zocos, adarves), así como los edificios o construcciones singulares características, sin olvidar la transformación de las ciudades romanas. Como no podía ser de otra manera, dedica un apartado a las defensas urbanas. Otra obra de considerable envergadura es la de Basilio Pavón (Pavón Maldonado, 1992) que estudia las ciudades hispanomusulmanas, mientras en un volumen posterior, (Pavón 1999) profundiza en las ciudades y las fortificaciones.

Otros estudios sobre el urbanismo musulmán a reseñar son los de Christine Mazzoli (MazzoliGuintard, 1998), algunos de los cuales ya hemos mencionado sobre el urbanismo y la murallas hispanomusulmanas en la península ibérica (Mazzoli-Guintard, 2000), pero también hay que destacar sus estudios sobre las tipologías urbanas y su evolución (Mazzoli-Guintard, 2002). Queremos destacar una afirmación muy significativa que realiza, El callejón sin salida es el elemento base, indispensable del urbanismo musulmán tradicional (Mazzoli-Guintard, 2000:183). También se han consultado algunos textos de estudios de casos, que nos han servido de referencia como por ejemplo, el estudio de Agreda y sus murallas de Benito Martín (1995), el análisis de Sevilla de Collantes de Terán (1977) y Valor Piechotta (1989), o los de Toledo (Delgado Valero, 1987).

Frente a este urbanismo musulmán, encontramos el urbanismo europeo, del que nos va a interesar especialmente la singular simbiosis que se produce en algunas de las ciudades de la Península Ibérica por la transformación de las tramas urbanas hispanomusulmanas tras la conquista cristiana.

Como ya se ha comentado se han realizado numerosas clasificaciones, intentando organizar y sistematizar las formas urbanas. Aparte de las ya mencionados con anterioridad, podemos reseñar aquí, por proximidad geográfica, la obra de José María Medianero (Medianero Hernández, 2004) que estudia la historia de la formas urbanas y los tipos de ciudad así como los elementos representativos que le sirven para estructurarlas. El urbanismo medieval 
cristiano cuenta con numerosos estudios de carácter general, desde un enfoque de la historia, como las obras de Martínez Sopena (1990, 1991, 1992 y 2009), Ladero Quesada (1991 y 1996), Reglero de la Fuente (1994), Bonachia Hernando (1996), González Mínguez (1997) y Ladero Quesada (2008 y 2010).

Cuanta con una amplia bibliografía sobre el tema, Beatriz Arizaga, que ha estudiado el urbanismo de las villas amuralladas del norte de la península, especialmente en el País Vasco y Cantabria (Arizaga Bolumburu, 1990, 1996, 2002, 2006 y 2010). El mismo ámbito de estudio analiza la obra dirigida por Luis Azurmendi, (Azurmendi Pérez, 2001) que se centra en las ciudades cristianas del litoral Cantábrico y constituye una interesante recopilación de diversos estudios y breves análisis de diferentes villas y ciudades del norte de España, (Villaviciosa, Laredo, Bilbao, Santander, San Sebastián, etc) realizados por reconocidos autores expertos en la materia como Remolina Seivane, Arizaga Bolumburu y Pedrayes Obaya, que también se ha empleado con fines metodológicos.

Aproximándonos geográficamente hacia la meseta, Solorzano Telechea (2002), estudia el fenómeno urbano medieval entre el Cantábrico y el Duero, la recopilación de estudios sobre ciudades amuralladas (Álvarez Delgado, 2002) y la importante obra de Félix Benito sobre los asentamientos medievales en Castilla y León y la formación de la ciudad medieval (Benito Martín, 2000 y 2005). También se han consultado otras obras del ámbito aragonés, como la de Lacarra y de Miguel (1950) y Betrán Abadía (2005).

En relación con la repoblaciones que se efectúan en los nuevos territorios según los reinos cristianos avanzan hacia el sur, se han distinguido dos tipos de asentamientos repobladores, los que se trazan sobre una estructura regular, generalmente de nuevo trazado o como ampliación de asentamientos preexistentes y los que se implantan sobre trazados ya existentes, cuya evolución conlleva la adaptación al nuevo urbanismo de esa estructura urbana previa.

Los primeros se caracterizan por su trazado geométrico en retícula, la regularidad de sus manzanas y parcelas al provenir de lotificaciones predefinidas. Este reparto en lotificaciones regulares implica un poder jerárquicamente superior que efectúa la asignación por lo que se ha relacionado con la iniciativa real. A tenor del ámbito geográfico de los estudios existentes, este tipo de urbanismo parece ser más frecuente a lo largo del camino de Santiago (Passini, 1984 y 1991) y en la cuenca norte del rio Duero (Sáinz Guerra, 1990, 2010, 2011 y 2014), donde la despoblación motivada por el traslado de la población impulsada por Alfonso I, generó un mayor vacio poblacional y la desaparición de los núcleos de población preexistentes (Mañanes, 1979). Sin embargo al sur del Duero, la despoblación no llego a ser tal, existiendo asentamientos y habitantes que mantienen sus derechos y privilegios. Lo veremos más detenidamente al estudiar el apartado relativo a la continuidad poblacional en el ámbito segoviano. Así se producen dos tipos de repoblación, uno consistente en una reorganización institucional de la población ya residente y otro mediante el aporte de nuevos habitantes.

Gonzalo Martínez, encuentra un ámbito geográfico diferenciado para cada uno de estos dos tipos de repoblación y una justificación. En las comunidades más cercanas al río Duero y de menor tamaño como Coca, Cuellar, Iscar, Portillo, Medina Campo, Olmedo o Arévalo se produce una repoblación "pausada y ordenada" anterior a 1085 y otra de urgencia y apresurada tras la toma de Toledo que afecta a Salamanca, Ávila y Segovia mediante la que se colonizan miles de kilómetros cuadrados de todo el territorio que faltaba hasta la sierra e incluso al otro lado de ésta (Martínez Diez, 1983: 463). 
Para otros autores, el motivo de la existencia de estos dos tipos de repoblación tiene otra causa que encontramos mucho más ajustada a la realidad. En la primera repoblación, el reparto de tierras se efectúa por el sistema conocido como "presura", que consiste en que el primero que llegaba, ocupaba un territorio y lo defendía, era reconocido como el legítimo propietario (Sáinz y Jove, 2010: 38). Este sistema de repoblación, basado en el derecho romano, se emplea en la cuenca norte del Duero. (Mondéjar Manzanares, 2007:19)

A partir de finales del XI, la caída de Toledo obliga a acelerar la necesidad de control efectivo sobre el territorio al norte de la sierra y se emplea el sistema administrativo basado en la Comunidades de Villa y Tierra, cuyo mayor atractivo residirá en el hecho de que la propiedad de la tierra conquistada le será entregada directamente a los propios repobladores (Mondéjar Manzanares, 2007:19). Nos han interesado los estudios sobre la constitución de las comunidades de Villa y Tierra de González Herrero (1969 y 1998) como mecanismo de estructuración territorial tras la repoblación. Este diferente modelo de reparto territorial, va a producir modelos urbanos diferenciados. En esta primera repoblación, la fundación de nuevas villas se produce inicialmente utilizando formas irregulares. Las calles, las manzanas, las parcelas, la muralla, responden a criterios de oportunidad, a la forma del espacio natural al que se adaptan (Sáinz y Jove, 2010: 39). Las calles configuran una estructura lineal de caminos, de recorridos. Están jerarquizadas a partir de los elementos singulares, las iglesias y las puertas de las murallas principalmente. El elemento predominante en estas villas es el desorden en su tejido urbano (Sáinz y Jove, 2010: 40). Sin embargo para Jean Gautier, las ciudades de trazado irregular denotan un crecimiento espontáneo, en el que no hay voluntad repobladora, ni un proyecto deliberado (Gautier Dalché, 1989:17).

En Ávila la repoblación se efectuó por grupos organizados que no se fundieron, sino que siguieron siendo distintos (Gautier Dalché, 1989: 102). Esta configuración urbana de asentamientos dispersos pero cercanos, encaja perfectamente con la descripción que nos da la "Crónica de la población de Ávila" y la representación que efectúa de ella Al-Idrisi, constituida por varios puntos muy cercanos y que podemos interpretar como aldeas o barrios dispersos, si lo consideramos una ciudad discontinua o de marcado carácter rural.

Respecto a Segovia, aun disponemos de menos información aunque la configuración urbana de dispersión de los barrios que posee la ciudad y la descripción que de ella hace Al-Idrisi, nos induce a pensar que las circunstancias de la configuración de la ciudad, formada de grupos que no se fundieron, pudiesen haber sido las mismas o muy parecidas a lo que sucedió en el caso de Ávila.

De este modo, si creemos cierta nuestra hipótesis de la existencia previa de asentamientos en Segovia, tanto de una posible ciudad musulmana como la de una repoblación condal que se produce un siglo antes que la repoblación oficial de 1088, la superposición de las distintas tramas urbanas significará un proceso de transformación que nos va a resultar del máximo interés, que supondrá entre otras cosas, la apertura de plazas mayores y el cierre de adarves tras la conquista cristiana (Guidoni, 1981: 63).

La implantación de un nuevo ideal urbano, como lo define Leopoldo Torres (Torres Balbás, 1968: 151), sobre un urbanismo anterior, más arcaico, va a suponer un palimpsesto de estructuras urbanas que han llegado a nuestros días en distintos grados de transformación. Son las ciudades mudéjares, como las define Torres Balbás, ciudades de raigambre hispanomusulmana sobre las que se implanta la nueva geometría de la ciudad cristiana tras la repoblación. 
Toledo es una de las ciudades paradigmáticas al respecto. La publicación de Jean Passini (2001) supone un análisis urbano y de comprensión de la evolución urbana a través del parcelario y los hallazgos arqueológicos, de importante valor metodológico para nuestro estudio. Complemento de este último, Ruiz Taboada (2005) nos analiza la transformación cristiana del Toledo musulmán, tras la toma de la ciudad.

El elenco de ejemplos de ciudades españolas es muy numeroso, especialmente en el sur de la península, Almería, Córdoba, Granada, Jaén, Murcia, Sevilla, sin embargo cronológicamente se alejan mucho de nuestro ámbito temporal, por lo que la que más nos ha interesado ha sido la ciudad del Tajo. Estos casos, entre otros, se han estudiado a través de publicaciones más generales, en los que se analiza el urbanismo medieval, cristiano y musulmán, y la transformación de la ciudad musulmana a la cristiana, como por ejemplo Torres Balbás (1968 y 1985), Glick (1995), Jehel (1999), Aramburu Zabala (2002), Ortega Valcárcel (2002), Navarro Palazón (2007 y 2009) y Comez Ramos (2011).

Por último, mencionar el trabajo de Suleiman Shinaq (2001), que estudia la ciudad musulmana y la influencia del urbanismo occidental en su conformación, es el contrapunto a la bibliografía enumerada, al mostrar el punto de vista contrario, desde el mundo musulmán, al problema abordado.

Otros casos de estudio que se han empleado como referencia, especialmente desde el punto de vista metodológico son Corral Lafuente (1981) que estudia la evolución histórica del urbanismo de Tarazona, o la obra de Cervera Vera, de la que nos han interesado tres monografías, sobre Urueña (Cervera Vera, 1989), Arévalo (Cervera Vera, 1992) y Madrigal de las Altas Torres (Cervera Vera, 1993). También se ha consultado otras monografías, sobre Medina del Campo (Sánchez del Barrio, 1991), la ciudad de León (Álvarez Álvarez, 1992 y Gutiérrez González, 1999), Cuellar (Olmo Herguedas, 1996) y Burgos (Crespo Redondo, 2007). Estudios de gran interés metodológico para el análisis del urbanismo medieval son los trabajos de Passini (1984 y 1991) que realiza un estudio de las villas existentes a lo largo del Camino Francés a Santiago de Compostela, en que analiza el parcelario, la forma y la trama urbana, con especial interés en las retículas regulares, indicando las características que identifican a las villas de repoblación de nuevo trazado.

Otro autor que ha publicado numerosas investigaciones sobre las villas de repoblación es José Luis Sáinz. De su obra destacamos, la que fue su tesis doctoral sobre la configuración de la plaza mayor en Castilla (Sáinz Guerra, 1990), el estudio del urbanismo en Tierra de Campos (Sainz Guerra, 2010), o en los municipios de Castilla, con especial incidencia en la provincia de Valladolid (Sáinz y Sáinz, 2014) y su trabajo sobre la arquitectura y el urbanismo de las villas de nuevo trazado creadas durante la repoblación de la Tierra de Campos (Sáinz Guerra, 2011). Por último no podemos dejar de mencionar la obra de Félix Benito (Benito Martín, 2000), sobre la red urbana de Castilla y León y la formación de la ciudad medieval. En este trabajo se analizan los elementos generadores de la morfología urbana con un importante interés en las murallas como configuradoras de la forma urbana. 


\section{SEGOVIA VISTA POR LOS VIAJEROS.}

La ciudad de Segovia cuenta con numerosa bibliografía, en buena parte debida a la importancia de su patrimonio arquitectónico. El acueducto, la catedral, el alcázar y la importante muestra de arquitectura románica, tanto la religiosa como la residencial del barrio de las canonjías, así como la arquitectura civil de finales del medievo constituyen un foco de interés para la literatura divulgativa, guías de viajes, monografías sobre edificios y también para investigaciones y estudios científicos realizados por autores de las más diversas formaciones y especialidades.

Son abundantes los escritos que nos hablan de los viajeros que tras su paso por la ciudad plasmaron su admiración por Segovia, García Mercadal (1962) nos habla de los viajes de algunos extranjeros por España y Portugal, García Simón (2005) a los que recorrieron Castilla y León y Chaves Martín (2002a) se dedica a los que visitaron Segovia.

Entre las descripciones de los viajeros desde el siglo XV al XIX, nos encontramos a León de Rosmithal (1465-1467) cuyas palabras se centran en el acueducto y el Alcázar; Antonie Lalaing (1501-1503) nos describe el acueducto; Andrea Navagiero (1525-1528) también se fija principalmente en el acueducto; Enrique Cock (1592), se refiere al acueducto, la catedral, las parroquias, el Alcázar y la ceca. El Duque de Saint Simon (1721-1722) menciona el acueducto, el Alcázar y le llama la atención que las calles no son tan estrechas como en otras ciudades; Etienne de Silhouette (1729) nos describe nuevamente el acueducto, la catedral y el Alcázar al igual que Norberto Caimo (1755).

Resulta por lo tanto evidente, que ninguno de ellos presta atención a las murallas. Tan sólo Jouvin (1672) es el único que menciona las murallas, aunque tampoco les dedica una mayor consideración (...que está cerrada de simples murallas...) (García Simón, 2005: 226) para dedicarse a los mismos edificios, que ya se han repetido, el acueducto, la catedral, el Alcázar y la ceca. Moragón Agudo (1995) nos presenta unas descripciones de las puertas, de los recintos amurallados de la provincia, Ayllón, Coca, Maderuelo, Cuellar, Pedraza, Sepúlveda y Segovia.

Otros trabajos en los que encontramos menciones a Segovia que podríamos calificar como guías de viaje, más o menos eruditas, o monografías u obras generales dedicadas, total o parcialmente, a la ciudad de Segovia y sus monumentos como Gómez de Somorrostro (1820; 1861), Flórez (1860), Hernández Useros (1889), Molina y Rico (1889), Colorado y Laca (1908), Roch (1921), Grau Sanz (1947), Ponz (1947), Cabello y Dodero ( 1949), Ceballos Escalera (1953), Góngora (1963), Laínez y Ortiz de Paz (1964), Bosarte (1978), Avrial y Flores (1979), Quadrado, (2007) y por último Rodríguez Marín (2013), cuyo catálogo monumental de la provincia de Segovia nos ofrece una de las descripciones de la muralla, de las que hablaremos más adelante.

$\mathrm{Al}$ igual que hemos visto con los viajeros, muchos de ellos no prestan mayor interés por las murallas, que no se consideran como un elemento arquitectónico apreciable, por lo que su valor a los efectos de nuestro estudio es muy desigual, resultando los más valiosos aquellos cuya aportación se efectúa de manera gráfica o fotográfica, mediante vistas de la ciudad o escenas cotidianas en cuyos fondos podemos descubrir valiosa información. 


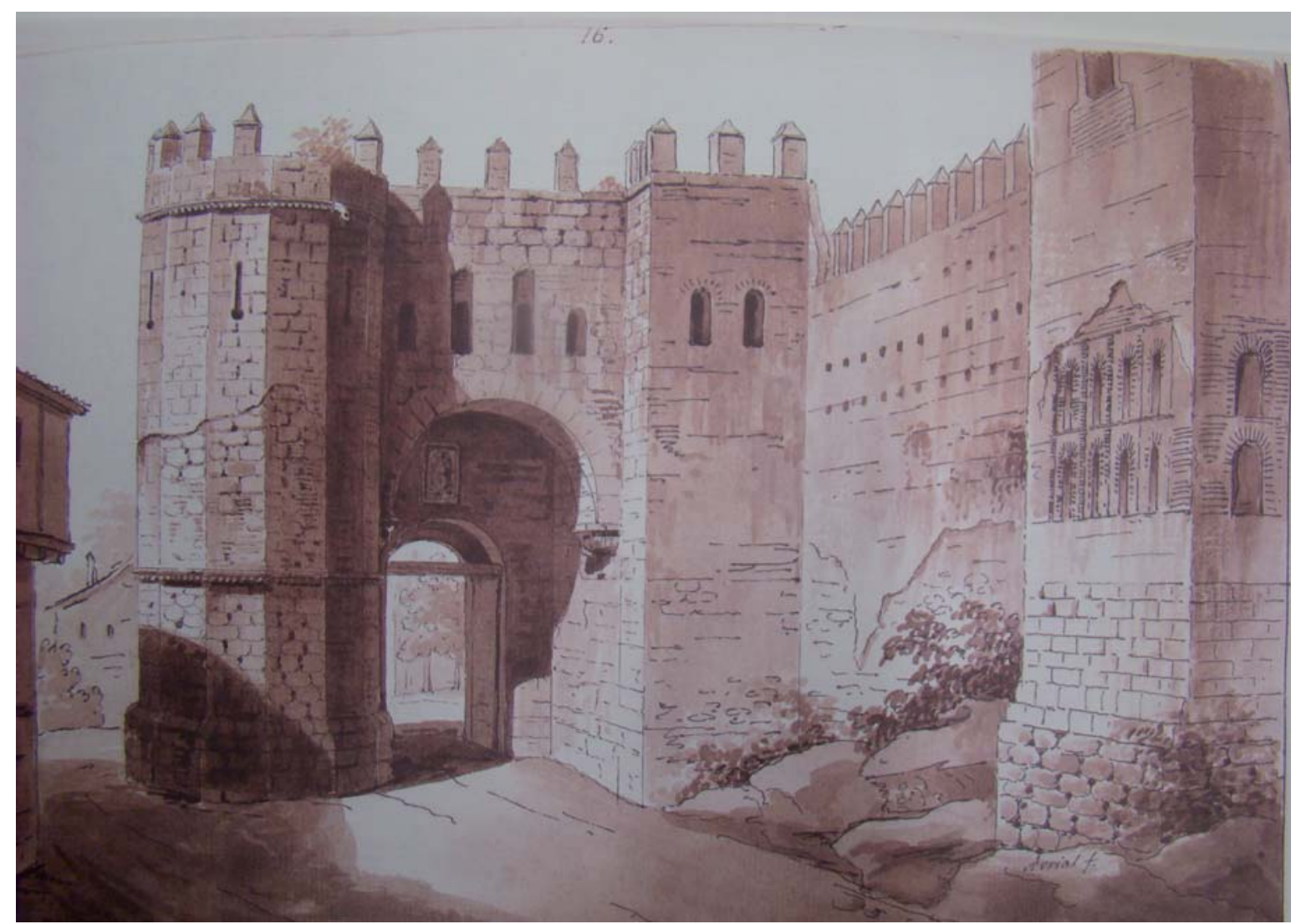

Figura 3. 1: Imagen de Avrial de la puerta de San Andrés. Se puede apreciar la limpieza y claridad del dibujo, así como lo minucioso de su grafismo, que permite identificar los sistemas constructivos, materiales y aparejos, lo que nos permite dar bastante fiabilidad a las representaciones de este autor (Avrial, 1979).

\section{SEGOVIA EN LA DOCUMENTACIÓN HISTÓRICA GRÁFICA.}

Entre la documentación gráfica que encontramos relativa a Segovia, tenemos que diferenciar tres tipos, las vistas, la cartografía y las fotografías.

Las vistas de la ciudad

Entre las vistas de la ciudad hay que destacar el papel fundamental que representan las dos vistas efectuadas por Wyngaerde en 1563, una desde el norte y otra desde el sur de la ciudad. Se trata de la primera representación que disponemos de la ciudad. La fiabilidad del dibujante nos ha permitido analizar sus dibujos escudriñando en busca de detalles que hasta la fecha habían pasado desapercibidos, como por ejemplo las torres que existían en el entorno de la Alhóndiga o el descubrimiento del postigo de fuente cercada. De ambos ejemplares se conserva copia en el Archivo Municipal de Segovia, aunque también las encontramos reproducidas en algunas publicaciones (Kagan, 1986).

Un siglo posterior, en 1666, Meunier realiza una vista de la cara sur de la ciudad (Santamaría López, 2004: 69-70), de traza menos realista, pero en la que disponemos de la primera imagen de la puerta de Santiago tras las importantes reformas acaecidas en la primera mitad de ese siglo. Aunque las estampas no son tan fidedignas como la imagen fotográfica, algunas imágenes de esta obra nos permiten acercarnos a la realidad constructiva de las murallas de aquella época, en distintos puntos de la ciudad. En esta misma obra, encontramos otras 
imágenes como la de Roberts de 1836 (Santamaría López, 2004: 39), en que se reconoce el Alcázar por la cara norte o la de Guesdon de 1854 (Santamaría López, 2004: 89), en que lo apreciamos desde la cara norte, desde las peñas grajeras, imagen que también esta publicada en Quirós Linares (1991: 162). Esta obra de Santamaría López (2004: 47), también nos ofrece la imagen de Gustavo Doré de 1874 completamente idílica del puente del piojo y el acceso al Alcázar desde la ladera sur.

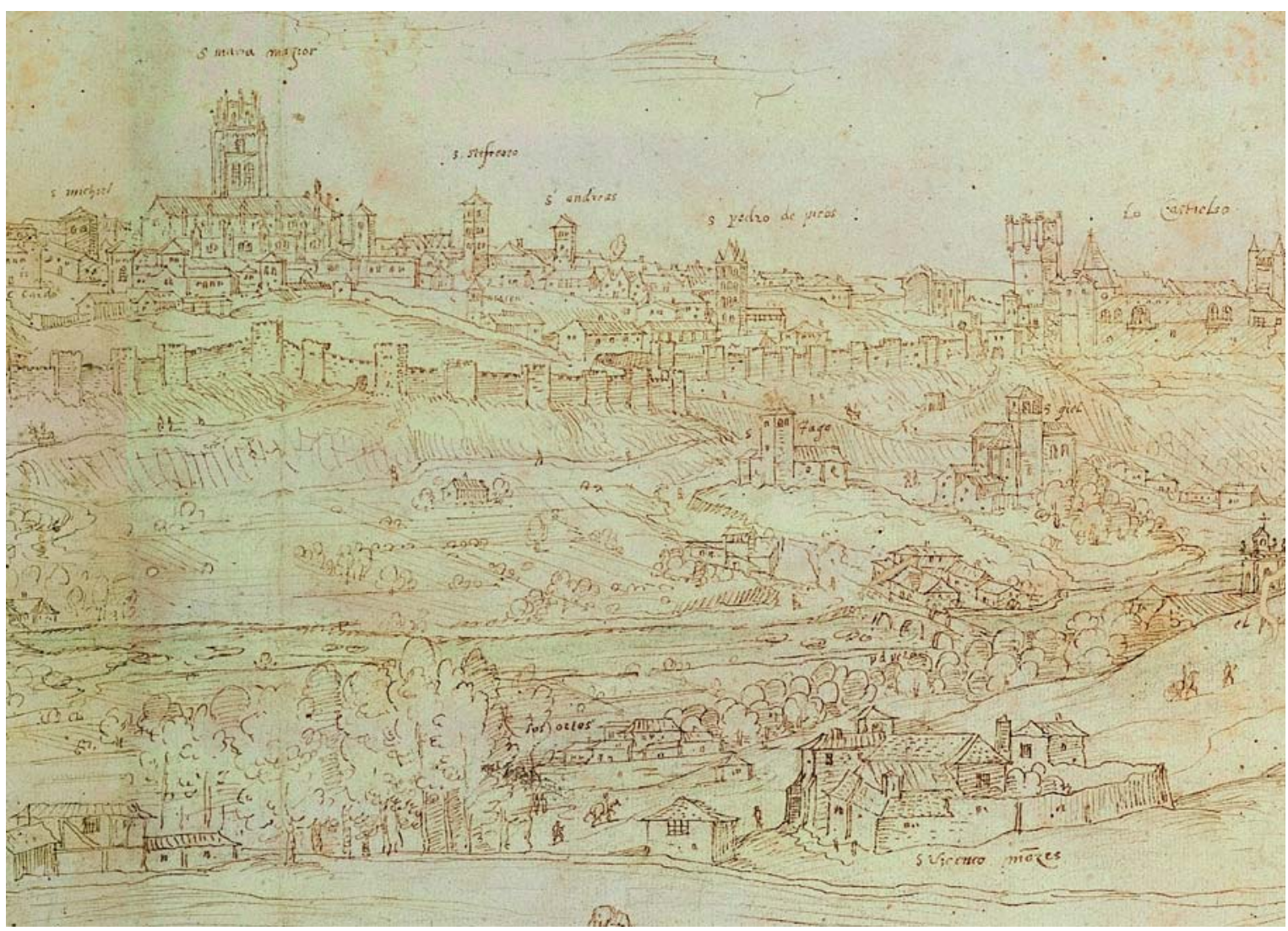

Figura 3. 2: Detalle de la vista sur de Wyngaerde. El dibujo presenta una gran abundancia de detalles lo que le convierte en un importante documento gráfico. Es la vista más antigua que disponemos de la ciudad. Fuente AMS.

Hay que reseñar el grabado que del Alcázar nos ofrece Juan Álvarez de Colmenar, datado en 1707 (Álvarez de Colmenar, 1707: 204-205). La obra de Avrial, dibujos realizados hacia 1843 (Avrial y Flores, 1979), incluye también numerosas vistas del Alcázar, así como de la ciudad desde distintas visuales, lo que permite obtener una información de gran interés como por ejemplo la vista de la zona de la puerta de San Juan que nos ha permitido restituir el entorno de dicha zona, actualmente muy alterada por los derrumbes.

Poco posterior, datada en 1870, la acuarela de Pérez de Castro, en que se representa la puerta de San Martín, pocos años antes de su demolición, nos ha sido de gran utilidad para recuperar la disposición de esta puerta. 


\section{La cartografía histórica de la ciudad}

Si en relación al número de vistas, grabados y fotografías, Segovia es una ciudad afortunada por la cantidad de ejemplos de los que dispone, en lo relativo a la cartografía, la ciudad cuenta con muy pocos planos históricos y además todos son muy recientes, por lo que su valor documental es bastante relativo, a los efectos de nuestra investigación.

Empezamos nuestra relación por el plano de Al-Idrisi, mapamundi de mediados del XII, en que se representa el mundo conocido en la época y se refleja Segovia como siete puntos muy juntos, acorde con la descripción que de ella hace. Su valor, obviamente, es más histórico que cartográfico.

El primer plano que nos ha aportado alguna información relevante ha sido el de Gómez de Mora, fechado en 1626 (Merino de Cáceres, 2010: 120), que refleja el estado del Alcázar en dicha fecha. Gracias a él, hemos identificado el acceso a la poterna descubierta bajo la terraza de los Reyes.

La primera representación urbana de Segovia se debe a Joaquín de Góngora, un plano fechado en 1820, que se conserva sólo parcialmente, recogido por Ruiz Hernando (1982: 211). De poco después, 1837, tenemos el de Antonio de la Iglesia, que es una actualización del anterior. Ambos presentan una especial atención por las murallas, posiblemente debido a que están realizados para el ejército, con motivo de las guerras carlistas. De 1845, el de Francisco Coello, publicado por Chaves Martín (1998: 153) y Quirós Linares (1999: 252). Los siguientes planos nos introducen ya en el siglo XX, en 1901 el de Odriozola, cuya copia se conserva en el archivo municipal, de 1911, el del Servicio Geográfico del Ejército (Chaves Martín, 1998), y el de Jürgens fechado en 1926 (Jürgens, [1926] 1992: 345). Todos ellos nos muestran la configuración urbana, aunque las proporciones no son correctas. Estos planos, nos permiten comprobar, dentro del recinto amurallado, las transformaciones urbanas debidas a los cambios de alineaciones llevados a cabo en estos dos últimos siglos. Es una primera aproximación a las alineaciones históricas de las calles de la ciudad.

También han resultado muy útiles los planos de los proyectos de cambios de alineaciones de calles redactados principalmente en la segunda mitad del XIX y en la primera del XX, que se conservan en el archivo municipal o recogidos en algunos libros como el dedicado al arquitecto municipal Joaquín Odriozola (García, 1987). Su proximidad en el tiempo nos ofrece una información de carácter puntual muy valiosa para algunos puntos concretos, como por ejemplo la puerta de San Martín, antes de su demolición o el cierre de callejones o de los adarves que existían a lo largo de la muralla.

La planimetría urbana que se ha empleado para esta investigación, realizada ya en base a fotografía aérea y por tanto de mayor precisión es la planimetría de catastro y las del planeamiento municipal de Segovia (PEAHIS) de 2014.

Por último, tenemos que referirnos a las planimetrías contenidas en el Levantamiento de las murallas, realizado en 1989 por Pilar Contreras Merino, Ángel Cruz Plaza, José Luis de Miguel Rodríguez y Juan Pablo Rodríguez Frade que se conserva en el archivo provincial de Segovia (MPS: SG 779) y las del Plan Director de las murallas de Segovia (PH: P0035). Ambos documentos son la mejor información planimétrica que existe de la muralla segoviana, si bien adolece de varias erratas en lo relativo a la apreciación de la forma de las torres e incluso a la 
existencia de algunas de ellas, errores motivados por la gran cantidad de vegetación existente en la ladera norte que limita la efectividad de la imagen aérea.

También de enorme interés son las planimetrías contenidas en los numerosos proyectos de intervención que se han efectuado en la muralla, principalmente a partir de los años 70 del siglo pasado, que hemos consultado en el AGA, en el IPCE y en el archivo municipal AMS.

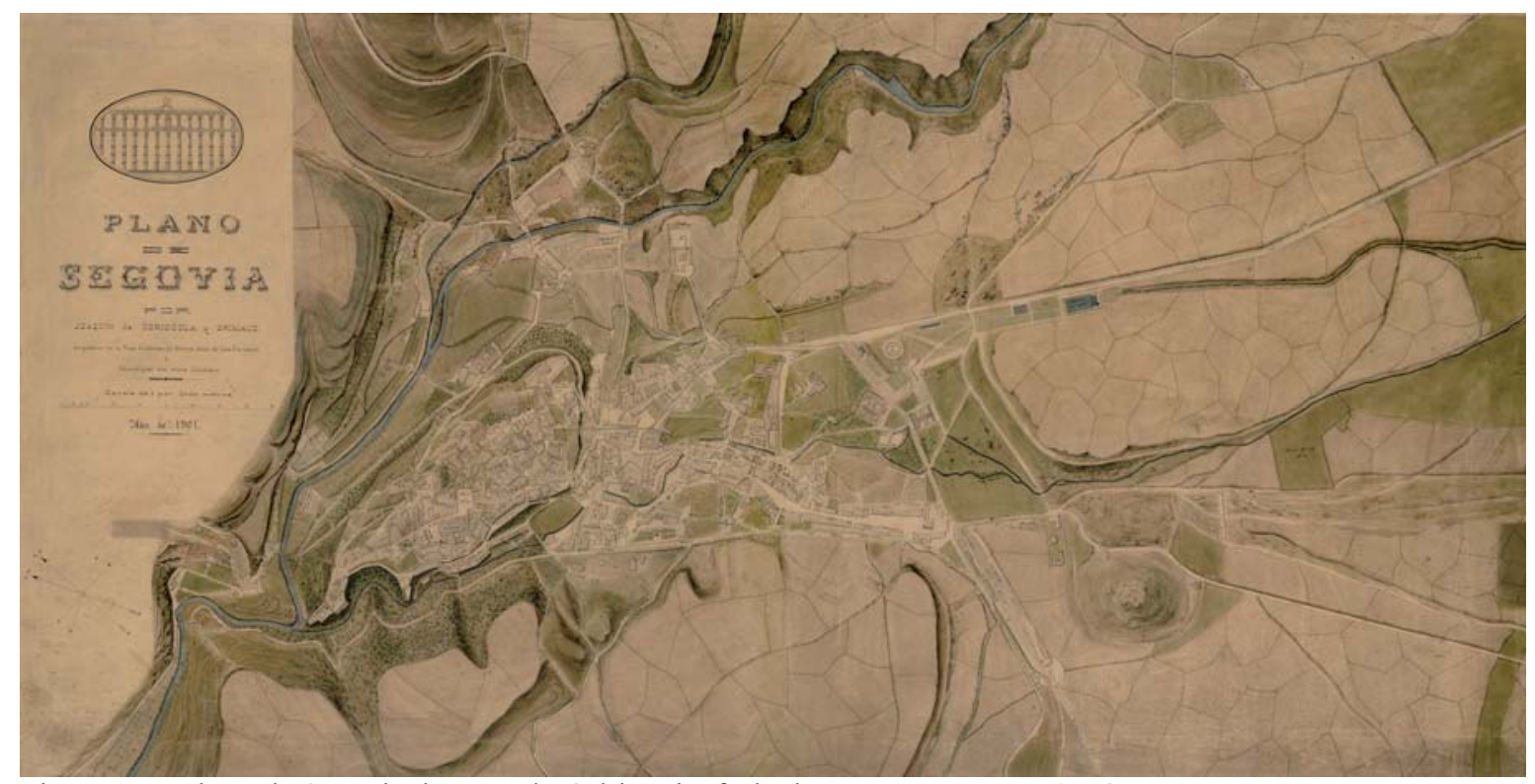

Figura 3. 3: Plano de Segovia de Joaquín Odriozola, fechado en 1901. Fuente AMS.

\section{La fotografía histórica}

Como ya se ha comentado, el extenso y ampliamente reconocido patrimonio arquitectónico segoviano atrajo a numerosos viajeros y artistas que plasmaron sus impresiones sobre esta ciudad y sus monumentos en distintos escritos y grabados. Con la aparición de la fotografía, son también numerosos los fotógrafos que nos van a dejar imágenes de la ciudad, como son las obras de Arcimis, Beer, Clifford, García Mercadal, Laurent, Levy, Loty, Moreno, Tenison, Unturbe y Wunderlich entre otros.

Las imágenes existentes, cuyo estudio nos ha permitido descubrir muchos detalles de las murallas, aportan una información novedosa, relativa al estado de conservación y la configuración de las murallas, así como las transformaciones y reparaciones que han sufrido. No podemos dejar de mencionar el conocido como "vuelo americano" realizado en 1956 que nos ofrece una imagen aérea de la ciudad de excelente calidad, que se conserva en el archivo municipal.

Son numerosas las publicaciones que se han efectuado sobre Segovia en la fotografía, tomando las imágenes que se conservan en los distintos archivos y colecciones tanto públicas como privadas como Ricardo González (1997) o Aku Estebaranz (2000 y 2008), éste último basado en las fotos de los Unturbe. En la mayoría de los casos se trata de fotos costumbristas, de escenas de época, si bien existen ejemplos de arquitectura de los edificios más singulares de la ciudad. 
La obra de Nicolás Gless, (Gless, 2004) recopila estampas y postales de época, por lo que nos muestra algunas imágenes de interés, como varias fotos de la puerta de San Andrés. Las fotografías son, en general, de reproducción en pequeño tamaño y baja calidad de imagen, pero de gran valor documental. El libro de Rudolf (2004) es claramente una recopilación fotográfica de la arquitectura monumental segoviana con fotos de Beer que nos muestra perfectamente cómo era la ciudad hace algo más de cien años. Sáez Laguna (2009) es una monografía sobre el acueducto, si bien observamos los lienzos de la muralla en su entorno en numerosas imágenes.

Por último, el libro Segovia en tres tiempos. Fotografías de Laurent, Moreno y Loty (1856-1936) (VVAA, 2006) es una recopilación de imágenes captadas por los tres fotógrafos que se enuncian en el título y nos muestra una comparativa de la ciudad en los tres momentos en que los respectivos autores pasaron por la ciudad.

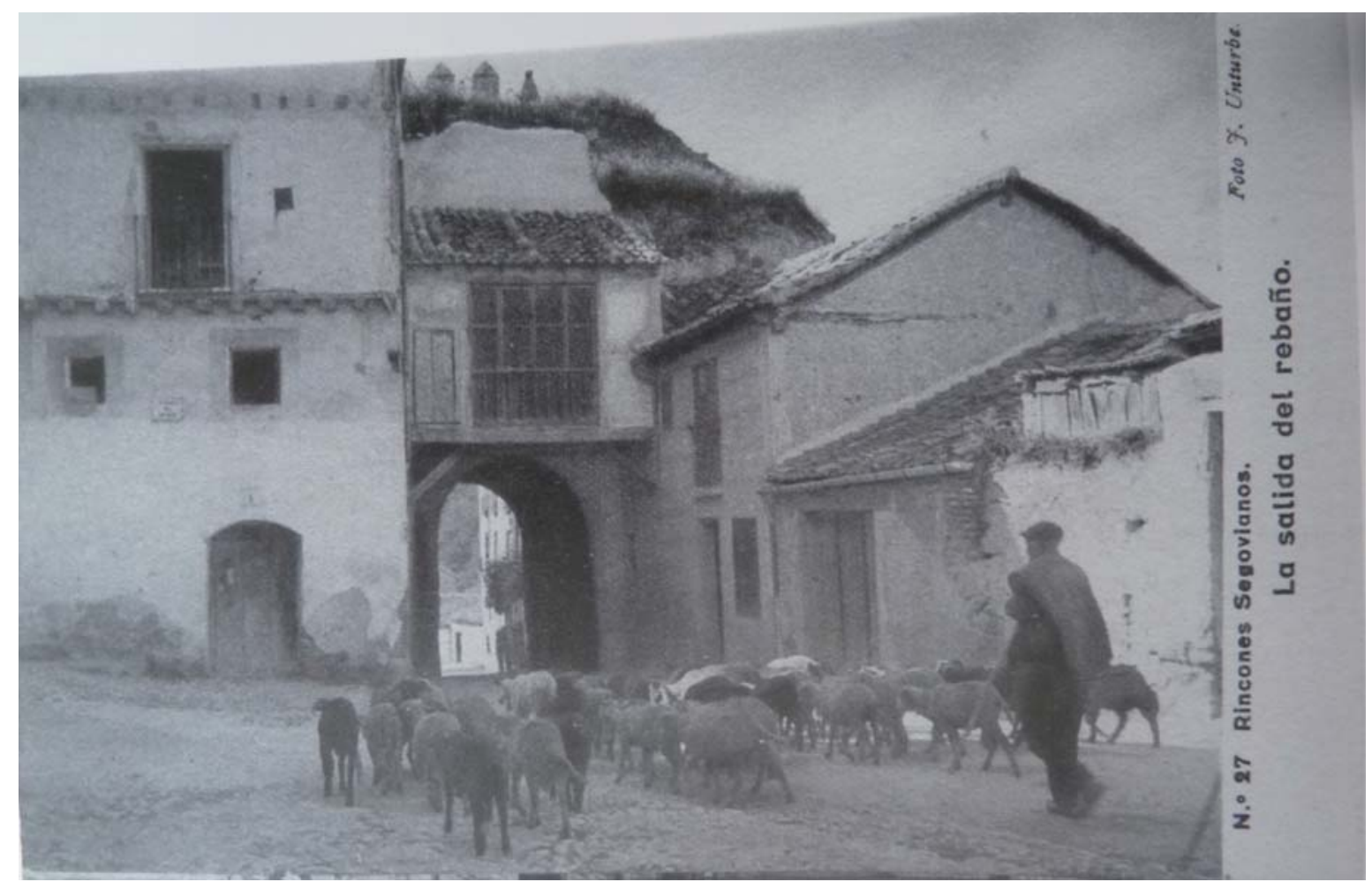

Figura 3. 4: Imagen de Unturbe que nos permite observar la configuración de la arquitectura popular, hoy desaparecida, que flanqueaba interiormente la puerta de San Andrés (Gless, 2004: 69).

LA CONTINUIDAD POBLACIONAL EN EL ÁMBITO SEGOVIANO DURANTE LA ALTA EDAD MEDIA.

La conquista de la península por los musulmanes, a principios del siglo VIII, enfatiza el vacío documental, y según algunos autores, va a suponer un nuevo agravamiento de la despoblación en la meseta norte, especialmente, tras el reinado del Alfonso I (Mañanes, 1979). Tras el largo debate sobre la despoblación de hace ya unos años (Sánchez Albornoz-Menéndez Pidal), las nuevas investigaciones defienden la tesis de que la despoblación no fue tan intensa. Se admite 
la persistencia de asentamientos de grupos de población constituidos por una mezcla de cristianos, musulmanes, judíos y extranjeros ${ }^{7}$.

Alfonso I, (739-757) conquista numerosas ciudades a los musulmanes, llevándose a la población cristiana consigo. Entre estas ciudades se incluyen Zamora, Ávila, Ledesma, Salamanca y Segovia. ${ }^{8}$ Estos datos están confirmados por las fuentes cristianas y las musulmanas (Martínez Díez, 2005: 82 y 84 respectivamente). La gran sequía y consiguiente hambruna que asola la meseta norte peninsular entre los años 748 al 753 contribuye posiblemente a que buena parte de la población, voluntariamente se trasladase al húmedo norte (Galicia, Cantabria, Asturias). Las crónicas musulmanas también dejan constancia del hecho, indicando que muchos árabes volvieron a África, en esos años de carestía (Martínez Díez, 2005: 86). Este territorio se consideraba un desierto estratégico desde las incursiones de Alfonso I, una tierra de frontera, sin someter a ningún control administrativo hasta la repoblación de Alfonso VI. Esta falta de documentación y estas interpretaciones han llevado a considerar la zona como abandonada y sin asentamientos musulmanes desde épocas muy tempranas. En la vertiente sur de la cuenca del Duero no se menciona ningún asentamiento musulmán en las fuentes documentales musulmanas medievales. Otros hallazgos y descubrimientos, principalmente de necrópolis, a falta de ciudades, (Zamora Canellada, 2006: 89-95) o el estudio de la toponimia (Zozaya- Stabel-Hansen, 1987), permiten dar mayor consistencia a la teoría de la continuidad poblacional y a la demostración de la presencia visigoda y musulmana en cada vez mayor número de ámbitos locales de buena parte de la cuenca sur del río Duero (Barrio Martín, 2010; Ruiz Hernando, 1986: 24). Entendemos que el caso de Segovia puede ser muy similar. Sólo falta que la arqueología aporte pruebas irrefutables para la constatación de nuestras hipótesis.

Julio González (1984) admite la abundancia de restos visigodos, anteriores a la dominación musulmana, pero no dentro de los siglos IX y X. Por su parte Sánchez Albornoz, tras largos años defendiendo el desierto poblacional que debió ser la meseta castellana durante la Alta Edad Media (Sánchez Albornoz, 1966), matiza en obras posteriores dicha despoblación, admitiendo la persistencia de asentamientos visigodos y bereberes (Sánchez Albornoz, 1991), acercándose a la tesis defendida por Menéndez Pidal de que, con la llamada "Repoblación", si existió un poblamiento, pero sobretodo reorganización administrativa de gentes dispersas no sometidas a ningún poder concreto.

García de Cortázar (1991: 15-40) realiza un exhaustivo análisis conjugando las dos opciones, concluyendo que en la meseta al sur del Duero la despoblación no fue tan intensa como en la cuenca norte, pudiéndose asegurar la continuidad poblacional en numerosos centros urbanos. Este mismo autor pone en relieve en un trabajo posterior (García de Cortázar, 2005), la importante presencia de asentamientos visigodos en la cuenca del Duero, apoyando la hipótesis de la continuidad poblacional en este valle, teoría que se ve reforzada por otros autores que constatan la pervivencia de las sedes episcopales visigodas (Barrio Martín, 2010: 18).

\footnotetext{
${ }^{7}$ Son numerosos los autores que respaldan este hecho, para el caso segoviano. Por citar solo algunos de los más recientes, Zamora Canellada (2010), Bartolomé Herrero (2010) y Ruiz Hernando (2010).

${ }^{8}$ Dado que su ejecito, difícilmente podría ser potente ni numeroso, podemos deducir que la presencia militar musulmana en todas esas ciudades sería mínima y las defensas escasas.
} 
Para otros autores (Montero Vallejo, 1996: 162), el valle del Duero estaba despoblado, porque las crónicas no mencionan ningún núcleo de población, ni silla episcopal en la zona. Hasta fases avanzadas de la repoblación no existen ciudades en la zona. Este autor sólo considera como tales a Burgos en Castilla y Astorga y León en el reino leonés, lo que justifica en base a las crónicas de ambos bandos que señalan la impunidad con la que las expediciones se paseaban en ambos sentidos (Montero Vallejo, 1996: 170). Este autor no defiende la existencia de población aunque no cree en la despoblación total, sino que imagina una cuenca del Duero sin ciudades, sin asentamientos con entidad económica.

Las ciudades islámicas se asientan inicialmente sobre las visigodas, reutilizando todo lo posible. Posteriormente se crean distintos tipos de fortalezas musulmanas, en torno a las cuales podrían formarse núcleos de población, alcanzando cada uno distintos grados de consagración urbana, antes de la ocupación cristiana, algunos de los cuales vieron truncada esta evolución. En esta fase se produjo la creación de nuevos centros urbanos, pero en los primeros casos se reutilizaban los centros existentes (Montero Vallejo, 1996). Muchas ciudades visigodas se rinden sin lucha, como atestigua el pacto de Teodomiro, por el que se pacta la sumisión de 7 ciudades como garantía de la paz acordada. Sin duda constituye la evidencia más palpable de una cierta continuidad urbana (Gutiérrez Lloret, 1993: 22). Según el derecho islámico, los que se sometían voluntariamente conservaban sus tierras parcial o íntegramente, pagando un tributo. En la meseta norte, la conquista musulmana se forjó por sometimiento de todas las poblaciones, por lo que los habitantes conservaron sus posesiones y no hubo reparto de tierras entre los conquistadores. Los asentamientos musulmanes eran de carácter militar y administrativo (Martínez Díez, 2005: 54).

La permanencia del emplazamiento, incluso con algo de población asentada, no presupone la continuidad de los modos de vida urbanos. La ciudad se ruraliza, llenándose de vacíos urbanos ocupados por otros actividades económicas que no le son propias, motivado por su aislamiento y la pérdida del control y explotación del ese entorno rural (Gutiérrez Lloret, 1993: 13-35).

Este largo debate sobre la posible despoblación de la meseta del Duero durante la Alta Edad Media, ha llevado en paralelo otro relativo a la configuración de la frontera entre el norte cristiano y el sur musulmán y a entender dicha frontera, no tanto como una línea, sino como un territorio con una situación jurídica especial, estructurado en torno a ciudades fortaleza como Segovia, Ávila o Sepúlveda (Glick, 1995: 115). Otros autores que han planteado posturas similares en este debate son García Fitz (2005) y Azuar Ruiz (2005 b). Aparentemente se genera un espacio de unos 250 kilómetros sin control efectivo de ninguno de los dos bandos, que a la vista de las crónicas "nadie reconoce como propio" (Martínez Díez, 2005: 93). ${ }^{9}$ Sin embargo la toponimia demuestra que el vacío poblacional fue mayor al norte del río Duero que al sur del mismo. La pervivencia de la toponimia de época visigoda

\footnotetext{
9 Este autor, incide reiteradamente en la necesaria despoblación absoluta del territorio, a salvo de eventual tránsito de pastores nómadas en las etapas de paz, "porque no se concibe cómo ni por qué esos presuntos habitantes descolgados de cualquier organización política, viviendo entre dos mundos en lucha y presa fácil de unos y otros, iban a resistir y superar los peligros de cautiverio y exterminio durante las cuatro generaciones que, al menos, duró la desertización. La supervivencia resultaba más fácil a un lado u al otro que no en tierra de nadie, expuestos a los golpes de musulmanes y cristianos". La perdida de toda la toponimia anterior, al norte del río Duero, le respalda en esta idea. Todos los topónimos son de repoblación. Al sur del Duero, la toponimia conservada tardo romana y prerrománica, avalada por el trabajo de Barrios García (1982) no le permite realizar semejante afirmación tan tajante, sino que se demuestra la continuidad poblacional en las provincias de Salamanca, Ávila y Segovia.
} 
hasta la actualidad, (de transmisión principalmente oral) refuerza la hipótesis de la continuidad poblacional (Hoz Onrubia, 2006: 60-89). ${ }^{10}$

Para otros autores, no existen datos escritos para poder defender la continuidad urbana en la península tras la ocupación musulmana (Mazzoli-Guintard, 2000: 235). Aun así estudios pormenorizados nos inducen a pensar que existían pequeños asentamientos poco desarrollados y sin estructurar, posiblemente al abrigo de una fortificación, pero fuera de las órbitas de control administrativo y político de ninguno de los reinos. Pero el que no haya "ciudades" no quiere decir que no hay población. Se ha hablado de la dispersión de la población desde la caída del imperio romano, posiblemente continuada durante el reino visigodo y acentuada tras la invasión musulmana.

Estudiando las fuentes musulmanas Maíllo Salgado (1984: 165-167) llega a la conclusión de que estos territorios no estaban despoblados, ya que en dichas crónicas se expresa que Almanzor se arrepiente de no haber despoblado las tierras reconquistadas. La misma hipótesis defiende Thierry Dutour, admitiendo que existió un abandono de ciertos lugares poblados, pero en ningún caso, de la magnitud de catástrofe que se le ha dado (Dutour, 2004: 79).

La desorganización del territorio tras las campañas de Alfonso I o Fruela hace que la zona fuera ocupada efímeramente por los musulmanes. Atendiendo a los topónimos, la frontera entre musulmanes y cristianos incluiría a la ciudad en la zona islámica, así como buena parte de la zona oriental de la provincia. Esta postura es defendida por Zozaya Stabel-Hansen (1987b), al estudiar la pervivencia de la toponimia. Esta presencia musulmana consistiría principalmente en algunos asentamientos militares, de pequeñas guarniciones probablemente bereberes, que difícilmente podríamos calificar como ciudades. Este dispositivo podría completarse con una red de torres de vigilancia visualmente conectadas que mediante señales avisaban de las incursiones procedentes de los reinos cristianos del norte, como veremos a continuación.

Esta pervivencia poblacional, en la tierra entre el Duero y la cordillera central, no sometida a ninguna autoridad, desorganizada y dispersa (posiblemente sin pagar tributo a ninguno de los bandos norte-sur), al margen de cualquier dominio político y fiscal, por lo tanto no reflejada en ninguna crónica oficial, genera un territorio sin ley, débilmente poblado, habitado por pequeños núcleos poblacionales, posiblemente autosuficientes, principalmente dedicados al pastoreo, constituidos por agrupaciones cuasi familiares, que complementan su economía con el saqueo, el pillaje (metales y vestimentas preciosas principalmente según las crónicas), robos de ganado e incluso captura de esclavos, mediante cabalgadas esporádicas por las tierras musulmanas. ${ }^{11}$

Este rápido avance hacia el sur de los reinos cristianos, obliga a Abd al-Rahman III a tomar la iniciativa e iniciar las aceifas que durante 100 años van a asolar, especialmente, la zona

\footnotetext{
${ }^{10}$ Confirma la pervivencia poblacional, aunque de escasa entidad en la toponimia y la diferente evolución de la repoblación entre las distintas zonas de la provincia de Segovia, en la cara norte de la sierra. 15 de los 195 pueblos mencionados en los documentos medievales tienen raíz árabe (Barrios García, 1991).

${ }^{11}$ En el 939, Abd al-Rahman III, tras el descalabro de Simancas, ataca las tierras del río Riaza, porque sus gentes cruzaban la sierra y realizaban correrías por tierras de Guadalajara (Martínez Díez, 2005: 348).
} 
comprendida entre el río Duero y la cordillera central ${ }^{12}$. Tras lograr la estabilidad política en sus territorios y el posterior descalabro militar en las batallas de Simancas y Alhandega en el 939, Abd al Rahman III, encarga al general Galib, la fortificación de la Marca Media. Se establece una red defensiva constituida por torres cada 4 o 5 kilómetros, pequeños castillos cada 15 y fortalezas cada 25 o $30 \mathrm{~km}$. Esto permite establecer una red de comunicaciones segura y servir como guarniciones para las tropas que defienden las fronteras y atacan periódicamente los territorios cristianos. En el fondo el sistema de control y defensa del territorio dispuesto por Galib, es muy similar al de ocupación que emplean los reinos y condados castellanos del norte en su expansión hacia el sur. Según la bibliografía existente, aparentemente este sistema defensivo se desarrolla exclusivamente al sur de la cordillera. No hay evidencias de arquitectura hispanomusulmana al norte de la misma. Al norte, entre ésta y el Duero, solo encontramos, edificios militares, de construcción más sólida, situados todos ellos en la parte oriental de la provincia, Gormaz, Noviercas, Agreda, Ayllón, y Riaza (Regueras, 1990: 13). En la ladera sur, la línea defensiva al otro lado de la sierra, está mucho más documentada con los castillos y fortificaciones dispuestos a la salida de los pasos de la sierra para proteger las vegas fértiles y el territorio, unánimemente, considerado musulmán (Sáez Lara, 1999).

Sin embargo, existe una clara línea defensiva en la cara norte de la sierra, apoyada en asentamientos con importantes fortificaciones, situados todos ellas a unos $50 \mathrm{~km}$ entre sí. Gormaz, Ayllón, Sepúlveda. A 50 kilómetros de ésta última se encuentra Segovia. ¿Por qué no podemos pensar que pudo formar parte del mismo sistema de fortificaciones? Curiosamente todas ellas se disponen a lo largo de una línea paralela al sistema central, cerca de algún paso de la sierra, sobre la vía romana que unía Segovia con Tarazona (véase Figura 3. 5) ${ }^{13}$. Así en la provincia de Segovia encontramos numerosas torres, actualmente vinculadas a iglesias, que por su configuración arquitectónica y constructiva se evidencia que son anteriores a la iglesia a la que actualmente sirven. Puede ocurrir que pertenezcan a edificios anteriores, (iglesias o incluso mezquitas) o bien tratarse de antiguas torres exentas de vigilancia y defensa del asentamiento, estructuras independientes, a las que posteriormente se adosa la iglesia, por ejemplo, Cedillo de la Torre, Fuentepelayo, Navares de la Cueva, en Segovia ciudad, San Millán, San Lorenzo, y San Andrés. En Sepúlveda, Ayllón y Turégano nos encontramos con restos de fortalezas de traza musulmana ${ }^{14}$.

Muestra de la pervivencia poblacional y de la presencia musulmana al norte del sistema central son los restos localizados en el cerro de Bernardos (Gonzalo González, 2006) y en la ciudad de Zamora (Gutiérrez González, 2011). Por otra parte Alonso Ávila (1989), documenta la existencia de importantes asentamientos visigodos en la provincia de Segovia.

Existe una gran concentración de asentamientos, confirmados por la arqueología, en la zona norte del sistema central (Burgos, Soria, Segovia) y otra menor en la ladera sur de la sierra de la actual provincia de Madrid. A pesar de su aparente escasa dimensión urbana, si nos ceñimos a

\footnotetext{
12 En el 916 realiza la primera aceifa contra Castilla, después de 23 años de paz tácita. En el año 932, Ramiro II realiza una incursión hasta Toledo, en apoyo de una revuelta contra el Califa. En el 934 se realiza una nueva aceifa que llega hasta Burgos, pero no la atacan. En el 939 se realiza la campaña de la omnipotencia y un año después una nueva aceifa asola la zona de Coca.

${ }^{13}$ Véase también el plano de vías romanas por la península en García de Cortázar (2005: 111).

14 Para más información sobre Sepúlveda, puede consultarse Martín Aymerich (1990) y en relación a Ayllón Zamora Canellada (1997).
} 
los datos arqueológicos disponibles, existían 70 sedes episcopales, entre las que destacaban, Toledo, Córdoba, Barcino, Segóbriga, Complutum, por lo que a principios del siglo VIII en Hispania podía hablarse de "ciudades" (Montero Vallejo, 1996: 107).

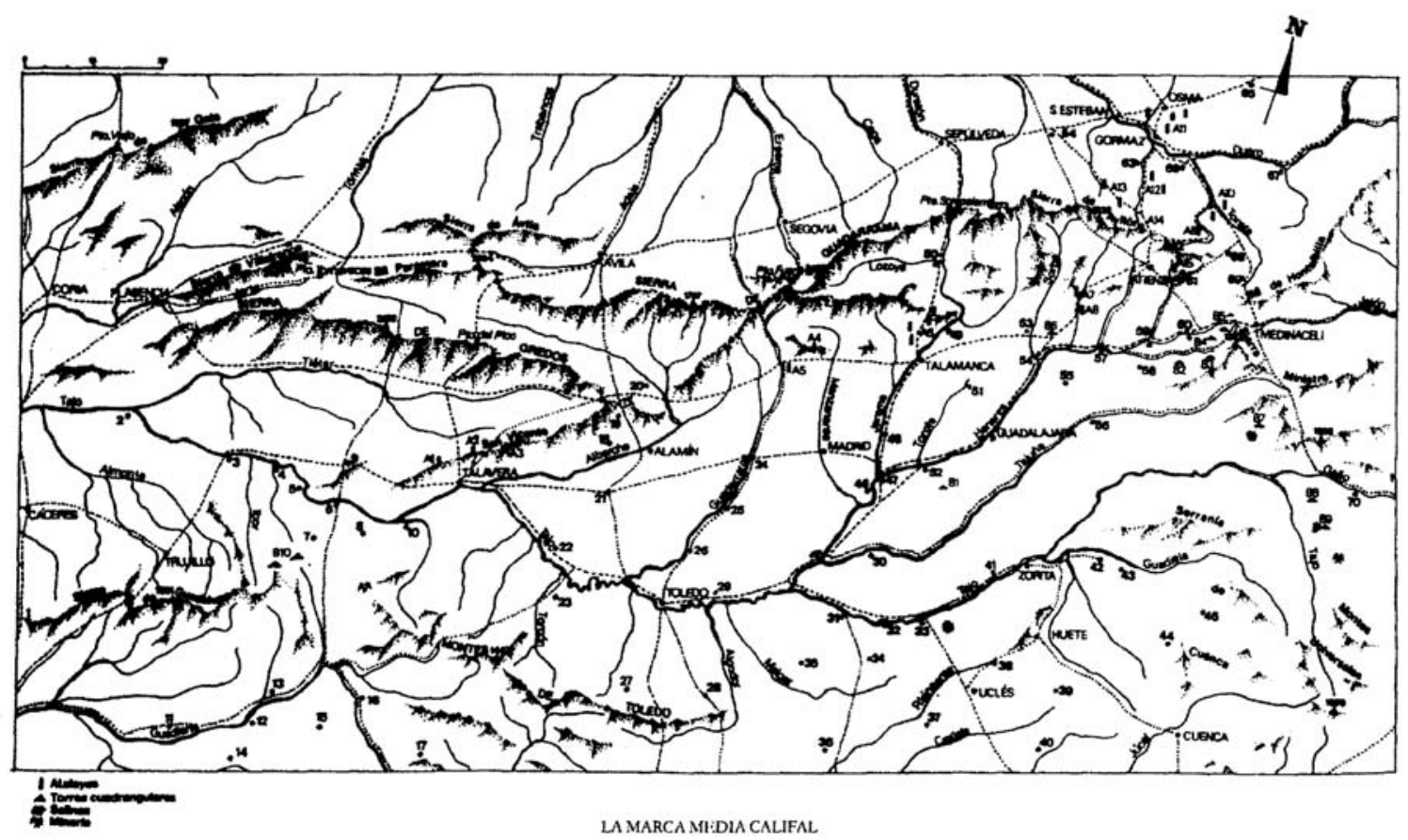

Figura 3. 5: Plano de la Marca Media con representación de la red urbana y viaria en la Alta Edad Media formada por las calzadas romana y rutas empleadas por los musulmanes, así como las principales asentamientos y fortificaciones. Publicado en Sáez Lara (1999: 539). Se observa al norte de la sierra, una ruta que conecta Ávila, pasando por Segovia y continúa hacia Sepúlveda y la actual provincia de Soria.

A partir del siglo $\mathrm{V}$, pese a la escasez de datos documentales, la continuidad de las principales ciudades, convertidas en sedes episcopales, se constata por la documentación que éste hecho genera $^{15}$ (García de Cortázar, 2005: 134-137). Existen referencias a la asistencia de obispos segovianos en los concilios toledanos (García y García-Estévez, 1998). ${ }^{16}$ Para otros autores, esto datos, sin contrastar arqueológicamente no tienen una gran validez, defendiendo el abandono de las ciudades (Acien Almansa, 2005).

Si en base a los datos documentales, sólo se puede asegurar la continuidad poblacional de las sedes episcopales, apoyándonos en la arqueología, podemos afirmar que la presencia de numerosas necrópolis en la meseta castellana (González Herrero, 1969: 54), pone en evidencia

\footnotetext{
15 Así, todavía en el Concilio XII de Toledo, celebrado el año 618, y al que asistió el Obispo de Segovia Deodato, se decreta la pena de muerte para los que adoran las fuentes, condena que no debió ser muy eficaz, ya que doce años después, en 693, se reitera en el XVI Concilio, que de nuevo revela la persistencia de los cultos paganos (González Herrero, 2000: 67-74).

${ }^{16}$ Enumera un listado de obispos segovianos que aparecen citados en distintos Concilios desde el año 527 hasta el 693. Alonso Ávila (1989: 251-255) aporta datos de los obispos procedentes de otras ciudades. El número de obispos que acuden procedentes del resto de las sedes episcopales, en torno a los 50 (generalmente más) en todos los casos de concilios nacionales, nos deja ver que existen numerosas diócesis pobladas y que envían a sus representantes con regularidad. En las proximidades de Segovia, se constatan, Uxama, Recópolis, Complutum, Ávila, y Salamanca.
} 
la importante presencia de poblamientos visigodos, frente a los escasos datos materiales que nos quedan de este periodo ${ }^{17}$ (Zamora Canellada, 1997: 416).

Siguiendo a otros autores, a pesar de la escasa existencia de arquitectura mozárabe y visigoda (Santamaría López, 1984: 86), la presencia de restos de edificios previos en numerosas iglesias románicas, (Santa María de Riaza, San Frutos de Duratón, San Martín de Fuentidueña) ${ }^{18}$ o que se encuentran vinculadas a necrópolis visigodas (Veracruz en Segovia, Madrona, Espirdo), nos sirve como argumento que refuerza la evidencia, que a pesar del vacío documental, los vestigios arqueológicos ${ }^{19}$ nos aseguran la continuidad de población en la ciudad de Segovia y aparentemente con un importante peso, al menos en la organización eclesiástica. Sin embargo prácticamente no tenemos ninguna información relativa a los aspectos urbanos de las ciudades visigodas, salvo algunos casos concretos como son Mérida, Córdoba, Sevilla, Málaga, Granada (Olaguer-Feliu, 1998: 117-130).

La arqueología nos indica que las ciudades que poseen mejores defensas naturales, no solo no sufren despoblación, sino que aumentan su población como es el caso de Segovia, Coca, Bernardos y como evidencian las necrópolis de Duratón, Espirdo, Madrona y Roda de Eresma (Blanco García, 2002: 167 y 168). Si aceptamos como cierta la afirmación de este autor, Segovia no se despuebla durante este periodo, manteniendo la continuidad poblacional e incluso aumentando su población. Parece evidente que si la ciudad aumenta de población, debido a sus mejores defensas naturales, la búsqueda de seguridad es el motivo principal de esta circunstancia. No es descabellado suponer que existiese algún tipo de defensa adicional que complementase a esas defensas naturales.

Si ponemos estos yacimientos en relación con la red viaria romana, todos ellos se encuentran situados a lo largo de rutas tardoromanas, algo que ya aprecia García Moreno (1987: 332-336). Esto nos indica que la red viaria romana sigue estando en uso hasta el momento de la invasión musulmana y que la estructuración del territorio, en lo que a Segovia se refiere, muestra una continuidad con el mundo hispano romano de la etapa imperial. Sin embargo la falta de continuidad en la información, no debe achacarse al vacío poblacional, sino a la falta de estudios. ${ }^{20}$ En la cuenca del Duero no hay grandes palacios ni edificios hispanomusulmanes como en el sur. En una sociedad culturalmente poco desarrollada y con otras preocupaciones más cotidianas como la subsistencia, es habitual que no se genere documentación escrita, pero eso no significa que no siga viviéndose en dichas tierras. A falta de documentación, la arquitectura, (también con escasos restos en estas etapas tan inestables), la arqueología (principalmente de las necrópolis, dada la escasa entidad constructiva en etapas económicamente pobres) y la toponimia, nos aportan otros datos ineludibles.

${ }^{17}$ En las proximidades de Segovia como ejemplos de necrópolis, citar las de Duratón, Madrona y la de EspirdoVeladiez. Como restos arquitectónicos, destacar el recinto amurallado del cerro del castillo en Bernardos (Zamora Canellada, 2006: 89-95).

${ }_{18}$ Otros edificios que evidencian en sus fábricas la reutilización de construcciones anteriores son las ruinas de San Julián en Castrillo de Sepúlveda y la ermita de Santa María de Cardaba en Pecharromán. (García Guinea, 2007: 474-479 y 1085-1092 respectivamente)

19 Alonso Ávila (1989: 260) incluye un plano de toda la provincia de Segovia en que representa todos los yacimientos de época visigoda. Se constata la existencia de una importante franja paralela a la sierra de yacimientos que discurre desde Madrona, Espirdo, Ventosilla, Sepúlveda, Sebúlcor, Duratón, hasta Estebanvela.

${ }^{20}$ En palabras de Municio González (2000: 73), "No existen vacíos en las secuencias culturales sino, simplemente falta o escasez de investigación." 
Zozaya Stabel-Hansen realiza un importante estudio de la toponimia en la Península Ibérica, descubriendo una elevada concentración de topónimos árabes en la cuenca del Duero, lo que unido a la existencia de evidencias arquitectónicas y arqueológicas, especialmente en el área portuguesa donde la investigación de este tema está más avanzada, le permite aseverar que la cuenca del Duero en la meseta castellana estuvo poblada, sin solución de continuidad (Zozaya Stabel-Hansen, 2012). Así afirma que "la Historia es una secuencia de hechos que ocurren en el espacio y el tiempo de manera continua y no en series inconexas de acontecimientos denominados estelares" (sic) (Zozaya Stabel-Hansen, 2007: 234). ${ }^{21}$

La toma de Toledo en 1085 es el hito por el que se estructura toda la expansión hacia el sur y la repoblación desde el Duero hasta el Tajo. A partir de esa fecha se "repuebla oficialmente" Segovia y necesariamente todos los territorios al norte de esta ciudad, debieron repoblarse antes. Esta ha sido la versión de la historiografía tradicionalmente. Así por ejemplo, Alcazaren, Mojados, Olmedo, Medina del Campo, Portillo, Iscar, y Coca, son "repobladas oficialmente" en el reinado de Alfonso VI, desde 1072 y antes de 1085. Encontramos numerosas referencias documentales que respaldan la hipótesis de que, en realidad, se produce una continuidad poblacional o bien que adelantan esta repoblación muchos años antes de las fechas que se manejaban hasta ahora.

Por ejemplo, cuando Almanzor arrasa Olmedo en el $977^{22}$ ya estaba ocupado por los cristianos que lo abandonan. La primera fecha documentada por las crónicas cristianas en que se menciona Olmedo es 1090, tras la repoblación efectuada por Raimundo de Borgoña, entre los citados años de 1072 y 1085 (Martínez Díez (1983: 518). Igualmente Medina del Campo es arrasada por Almanzor entre 977 y el 1002. La primera cita documental data del 1107 (Martínez Díez 1983: 524-528). En el caso de Coca, la villa es asediada por Abd al-Rahman III en su campaña de la omnipotencia del 939, lo que evidencia que estaba ocupada por los cristianos y contaría con unas defensas. Sin embargo su muralla actual esta datada en el siglo XIII (Val, escribano, 2004: 201-204). Del mismo otras villas enunciadas como tomadas a los cristianos por Abd al-Rahman III en su campaña de la omnipotencia del 939, como Portillo, Iscar, ya se mencionan como fortalezas ${ }^{23}$ (Martínez Díez 1983: 408). ${ }^{24}$ Estas villas están en poder cristiano, más de cien años antes de que documentalmente se repoblaran. En la parte oriental de la provincia, la diferencia de fechas arroja resultados similares. Redundando en estos aspectos, en el año 931 se produce una cesión de el Casuar al monasterio de San Pedro de Arlanza (Santamaría López, 1984: 86). Esto pone en evidencia, que los condes castellanos administran estos territorios al sur del Duero como suyos e intentan ponerlos en producción ${ }^{25}$.

\footnotetext{
${ }^{21} \mathrm{El}$ autor defiende que no toda la producción artística romana es de la época imperial y ni todo lo musulmán del califato. "No era posible admitir nada grandioso ni monumental que no correspondiera con un momento históricamente brillante. .... Se van acercando los extremos, se admiten cerámicas romanas (sic) para el siglo VII e incluso VIII así como la presencia de construcciones musulmanas del VII...(Zozaya Stabel-Hansen, 2007: 234). ${ }^{22}$ Fuentidueña y Cuellar son igualmente tomadas a los cristianos por Almanzor en el 977.

23 Señalar que de los textos se deduce que esta presencia cristiana sería militarmente débil, y las defensas de las villas poco resistentes, ya que en todos los casos, excepto en la batalla de Simancas, rehúyen defenderlas.

${ }^{24}$ Coca se menciona por primera vez en 1123 (Martínez Díez 1983: 446). Portillo aparece como atribuido a la diócesis de Palencia en 1035, con una confirmación de Fernando I en 1059.

25 Otros autores muestran otros edificios de la misma zona a los que suponen una adscripción cronología visigoda, reforzando la hipótesis de la continuidad poblacional no musulmana o una repoblación previa "oficiosa". Sáinz Saiz (1996: 31) adscribe la ermita de San Juan en Cedillo de la Torre a la cronología visigoda, aunque no lo justifica. En 1086 ya consta en los documentos la existencia de una iglesia previa, dedicada a San Millán en las proximidades de Espirdo (Barrios García, 1991: 23).
} 
Un proceso repoblador puede significar un éxodo masivo de grupos humanos hacia territorios desiertos. También puede tratarse de contingentes con pocos pobladores, pero selectivo, con la finalidad de reestructurar a la población ya existente (Montero Vallejo, 1996). Tras las incursiones de Almanzor y su hijo, que abarcan un periodo de 30 años, desde 977 hasta el 1007, en el caso de la ciudad de León, se produjo una desarticulación de las estructuras sociales y una dispersión provisional de la población, y con el fuero de León, lo que pretende Alfonso VI es restituir el orden antiguo, anterior a la desarticulación administrativa (Gautier Dalché, 1989: 50), lo que evidencia la existencia de una población previa. ${ }^{26}$ Sin embargo, los documentos oficiales reiteran la iniciativa de Alfonso VI tras la toma de la ciudad de Toledo en 1085, silenciando la evidencia u otras iniciativas condales. Entre tanto el Rey poblaba en la Extremadura las villas que eran yermas, que eran estas, Salamanca, e Ávila, e Medina del Campo, Olmedo, Coca, Yesca, Cuéllar, e Segovia, e Sepúlveda (Montero Reguera, 1999: 311).

La concesión de fueros, cartas y privilegios pone en evidencia la deliberada voluntad de la monarquía por asegurar una población estable (Gautier Dalché, 1989: 69). En numerosos casos estos fueros se otorgan a poblaciones que ya se encuentran habitadas previamente. Así ocurre en Sahagún, cuando se concede el fuero en 1085, considerado el acta oficial de nacimiento de la localidad, existiendo un documento de 1047 que atestigua la existencia de esa población (Gautier Dalché, 1989: 71-72). Idéntica situación nos encontramos en Santo Domingo de la Calzada, cuyo fuero es de principios del XIII, mientras que en 1106 se consagra la iglesia del Salvador y Santa María, que evidencia la presencia de población estable. (Gautier Dalché, 1989: 74-75). Sepúlveda es conquistada por Fernán González en el 940, tomada por Almanzor en el 984 y reconquistada definitivamente en 1011 por Sancho García. Sin embargo la repoblación oficial se documenta en el 1076 por orden de Alfonso VI. Por lo tanto, el otorgamiento del fuero confirma una comunidad urbana que ya existía (Gautier Dalché, 1989: 101). ${ }^{27}$ En el caso de Ávila, fue destruida por Almanzor en 994, lo que evidencia que ya estaba poblada y ocupada por los cristianos en esa fecha, mientras que la "fundación" de la ciudad se efectúa a finales del siglo XI, según la fecha refrendada por la documentación histórica (Gautier Dalché, 1989: 102). Si consideramos que en Segovia pudo suceder algo similar a lo acontecido en Ávila, esto supondría una evidencia más de nuestra hipótesis sobre la continuidad poblacional en la ciudad del acueducto, pero que en el caso segoviano no está respaldado por la documentación histórica.

En el caso de Segovia, tenemos citas de distintas crónicas y autores (Ballesteros Martín, 2011; Colmenares, [1637] 1922; Quintanilla, 1954b) que mencionan diversas ocupaciones y perdidas de la ciudad de Segovia (desde 740, Alfonso I, Fernán González en 923 y nuevamente en 970, perdiéndose ante Abd-al-Rahman I, Abd-al-Rahman III en 960 y Almanzor, respectivamente) y sin embargo la reinstauración episcopal se produce a principios del XII, tras la repoblación oficial de 1085.

\footnotetext{
${ }^{26}$ No se han conservado documentos anteriores al siglo XI (fueros, cartas pueblas, etc, que documenten las repoblaciones previas, o los que nos han llegado se consideran falsos o han sido profundamente alterados (Gautier Dalché, 1989: 38).

${ }^{27}$ El fuero de Sepúlveda más que un otorgamiento regio, es una confirmación de los derechos ya vigentes. El autor considera que posiblemente los supervivientes en el núcleo urbano entre las razzias de Almanzor y la Repoblación de Alfonso VI, establecieron ese ordenamiento obligados a administrarse ellos mismos debido a su aislamiento (Gautier Dalché, 198: 202).
} 
Así pues todo parece confirmar la existencia de una colonización previa a la repoblación oficial del siglo XI, similar a la ya contrastada que se produce al norte del río Duero. Esta repoblación de carácter condal se produce, para nuestro ámbito de estudio, a lo largo del siglo $\mathrm{X}$. Esta primera expansión no estaba tan organizada ni contaba con tanto respaldo regio como la que se efectúa por iniciativa del monarca a partir del siglo XI.

Según los Anales Toledanos Primeros (I: 343), La ciudad de Segovia fue muchos tiempos hierma y después pobláronla; era MCXXVI (Barrios García 2003: 105). Así, en 1088 según la historiografía tradicional parece surgir la ciudad de Segovia. Sin embargo, abundan las referencias documentales de que Segovia, siglos después, sigue presentando importantes vacíos urbanos dentro del espacio urbano intramuros. La misma expresión "estaba hierma y mal poblada" se repite en 1392, durante el reinado de Enrique III (Ruiz Hernando, 1973: 53) y Amando Represa lo reitera afirmando que también se decía de Ávila y Salamanca (Represa Rodríguez, 1949: 311). Creemos que la expresión "hierma e mal poblada", no debe interpretarse como deshabitada.

En el caso concreto de Segovia, el marqués de Lozoya defiende la continuidad de población, especialmente en los valles del Eresma y el Clamores (Contreras y López de Ayala, 1975). De la misma opinión es Antonio Ruiz (Ruiz Hernando, 1988a: 25), Barrios García (1991) y Bartolomé Herrero (2000 y 2010). García y García Estévez (1998) nos aporta el listado de obispos de Segovia en la Alta Edad Media, lo que evidencia la importancia de la ciudad y la continuidad poblacional en la misma durante esos siglos. Así los autores locales vienen a coincidir que la despoblación de la ciudad venía siendo efectiva desde Alfonso I, aunque entendiendo como tal la parte alta y amurallada, ya que en los valles subsistía una población rural diseminada (Ruiz Hernando, 1982: 21). De la misma opinión, Oliver Copons ([1916] 1989: 10) no cree que se despoblasen los arrabales, sino que la repoblación no fue total, afectando principalmente al recinto amurallado. A mediados del S. XII el geógrafo Al-Idrisi afirma que "no se trata de una ciudad, sino de un grupo de aldeas", opinión compartida por Antonio Ruiz, que afirma que cuando Alfonso VI repuebla Segovia a finales del XI, existían unos núcleos de población diseminados por los valles del Eresma y del Clamores (Ruiz Hernando, 1982: 23). La existencia de iglesias anteriores a la repoblación que sobrevivieron hasta finales de la Edad Media refuerza este punto, como ha demostrado Alonso Zamora al excavar una iglesia del siglo X bajo la traza de San Juan de los Caballeros, así como los enterramientos hallados en el atrio de San Millán (Zamora Canellada, 1979 y 1997). Puede ser que en Segovia también existiese una población, incluso con unos derechos establecidos, como en el caso documentado de Sepúlveda, que posteriormente se recogieron en el fuero tras la repoblación de Alfonso VI (Gautier Dalché, 1989: 202). Desgraciadamente, el fuero de Segovia no se ha conservado hasta nuestros días.

\section{LA PERVIVENCIA DE LA TOPONIMIA ALTO MEDIEVAL.}

Como ya hemos visto, la pervivencia de la toponimia altomedieval es uno de los puntales que refuerza la hipótesis de la continuidad poblacional en la cuenca del Duero. Al tratarse de una información de transmisión oral, su pervivencia hasta la actualidad garantiza la continuidad poblacional de forma ininterrumpida a lo largo de los siglos. 
El estudio de la toponimia con esta finalidad tiene sus raíces en los primeros estudios sobre la toponimia árabe, realizados por Asin Palacios (1944). Pocos años después, Menéndez Pidal profundizará en el tema ampliando su estudio a la toponimia prerrománica, siendo uno de los primeros defensores de la continuidad poblacional, basándose en la pervivencia de estos topónimos de transmisión básicamente oral (Menéndez Pidal, 1952).

Otro de los principales estudiosos del tema, Julio González, argumenta que la toponimia delata una muy importante presencia musulmana, con alusiones frecuentes a fortificaciones o a la riqueza forestal de la Extremadura castellana (González y González, 1974). Tras éste, Juan Zozaya, es otro de los principales continuadores de dicha línea de investigación y defensor de la hipótesis de la presencia musulmana en la meseta castellana y por ende en nuestra ciudad de estudio, Segovia.

La notable presencia de topónimos de origen árabe, y posiblemente alguno lo sea, en la zona delimitada por un eje al sur del Duero para bascular hacia sobre el Mondego hasta Coimbra, donde un resto arquitectónico atestigua la llegada del invasor a la zona. Para explicarlos indudablemente se puede aceptar la hipótesis de que sean nombres debidos a la documentada repoblación muzárabe, pero es posible pensar que algunos sean restos fósiles de una etapa anterior. Si ello fuera admisible se explicaría mejor, desde el punto de vista militar, el saliente de Coria, así como el vértice de Pedraza, Sepúlveda y castillejo de Mesleón, dominando el paso de Somosierra y el acceso occidental a Gormaz. Igualmente el dominio de las tierras altas (cotas de $1000 \mathrm{~m}$ ) hasta Calahorra-Nájera y el comienzo del curso medio del Ebro (Zozaya Stabel-Hansen, 1987 b: 399).

Sobre la toponimia en el entorno de la ciudad de Segovia contamos con algunos estudios como Hoz Onrubia (2006), que se centra especialmente en la etapa visigoda o los ya mencionados de Juan Zozaya, que centra sus estudios en distintos enfoques, como por ejemplo en la toponimia referidas a las fortificaciones, la reconquista y repoblación (Zozaya Stabel-Hansen, 2004), en la toponimia islámica en la cuenca del Duero (Zozaya StabelHansen, 2005c) o en los recursos económicos y su control (Zozaya Stabel-Hansen, 2011). Otros autores que han estudiado la toponimia en el entorno segoviano son Barrios García (1991), Menéndez de Luarca y Osorio-Navia (2000), Folgado Pascual (2009) y Sáez y Romero ([1918] 2009), estos dos últimos centrados principalmente en el significado y origen del nombre de las calles de Segovia.

Existe una importante presencia de topónimos de origen bereber, minoritario y árabe, mayoritario, entre el Duero y la sierra, que deben ser anteriores a 1086 (Zozaya Stabel-Hansen, 1987 b: 399). Defiende la tesis de la presencia musulmana entre la cuenca del Duero y la sierra, en base a la toponimia y elabora unos planos de topónimos muy reveladores (Zozaya Stabel-Hansen, 1987: 39). Y en la provincia de Segovia, se admite la presencia de tribus bereberes entre los valles de Cega y el Eresma basado igualmente en la toponimia (Ruiz Hernando, 1986: 24), como por ejemplo el río Moros, Marugán, Iscar, o Almuzara y Azoguejo en la propia ciudad de Segovia (Siguero Llorente, 1997).

Para algunos autores, (Ruiz Hernando, 1986: 12) la toponimia ya nos indica el origen celtíbero del nombre de la ciudad de Segovia, (Secovia), que ya en esa época debería ser una importante población celtíbera (Zamora Canellada, 1997: 422). La toponimia prerrománica de la ciudad queda también evidenciada en la advocación de algunas de las iglesias de Segovia, como San Briz, San Gudumian o San Millán. 


\section{PROCESO HISTÓRICO DE CONFIGURACIÓN URBANA DE SEGOVIA}

Las primeras evidencias de presencia humana, como asentamientos estables, en el actual emplazamiento de la ciudad de Segovia se remontan a la Edad del Hierro $\mathrm{II}^{28}$, (Arias Funez 1999; Municio González, 1996; Marqués Martín, 2007) hecho constatado con la aparición de varios silos, dentro del actual recinto amurallado de Segovia, así como restos de herramientas, armas, útiles de trabajo, elementos de ajuares y restos cerámicos de elementos pictóricos, en otros puntos próximos, al pie de la muralla.

Por el singular emplazamiento geográfico del recinto amurallado de Segovia, es evidente que la elección del lugar como asentamiento humano tiene una importante connotación defensiva. La aparición de restos arqueológicos deja patente que el actual recinto amurallado ya presenta ocupación humana en la Edad del Hierro II. Los restos arqueológicos, evidencian de forma fehaciente la clara vocación militar del asentamiento en la etapa celtíbera. Se ha descubierto la existencia de un foso tallado en la roca, que delimitaba un área de menor extensión que el actual recinto amurallado que aislaba la parte del alcázar del resto de la ciudad y en el que debería emplazarse el poblado inicial. (Municio González, 1996; Martínez Caballero 2008; Ruiz Hernando, 1986: 19) ${ }^{29}$.

Así tras la construcción del acueducto romano, que pone de manifiesto la existencia en esa época de un asentamiento urbano de entidad, se produce, aparentemente, un vacío documental de casi 1000 años, durante los cuales parece no existir información sobre nuestra ciudad. Independientemente de la etapa prerromana, en este milenio posterior, se produce el desmembramiento del imperio romano, la creación y posterior caída del reino visigodo, la invasión musulmana y la reconquista y repoblación de la ciudad por los cristianos, periodos durante los cuales no hay ninguna noticia sobre las murallas de Segovia. Posiblemente existan más datos, pero están pendientes de sacar a la luz, estudiar y relacionar adecuadamente. ${ }^{30}$ Este silencio documental, en buena parte se justificaba hasta hace pocos años por la despoblación de la meseta castellana, a raíz de las campañas de Alfonso I y la huida hacia el norte de los pobladores locales, huyendo de los musulmanes y la hambruna.

La Edad Media española ha suscitado el interés de numerosos autores que han estudiado la etapa que abarca desde la batalla de Guadalete en el 711d.C hasta la toma de la ciudad de Granada por los Reyes Católicos en 1492. Heers (1978, 1979, 1980), Manzano Moreno (1981) Sánchez Albornoz (1991), García de Valdeavellano (1986) Watt (1988), Monsalvo Antón (1997, 2003, 2010), García de Cortázar (2005) constituyen una breve selección del inmenso elenco de autores que han dedicado algunos de sus estudios a esta etapa de la historia española. En ellos se analizan los sucesos históricos desde diferentes enfoques, conjugando los aspectos militares, sociales, económicos, urbanos, etc.

En un contexto de casi continuos enfrentamientos militares, la fortificación se convierte en una necesidad para la vida cotidiana. Las ciudades no se conciben sin murallas, convirtiéndose éstas en importantes elementos condicionantes de la forma y el desarrollo urbano. Los nuevos

\footnotetext{
${ }^{28}$ Entre el 550/500 a.C. y el siglo II a. C.

29 Antonio Ruiz supone la existencia de defensas en la ciudad ya en el año 146 A.C. El trazado de este foso se halla interceptado por la muralla en su cara norte y en la sur, al igual que se ha identificado en la calle Velarde.

${ }^{30} \mathrm{Si}$ escasos son los vestigios documentales, aun son más exiguos los elementos materiales que permitan hacer alguna afirmación con solvencia. Respecto a los datos documentales (Ruiz Hernando, 1986: 9-22).
} 
asentamientos se implantan vinculados a fortificaciones ya existentes, o que se construyen coetáneamente. El territorio a ambos lados de las numerosas, y cambiantes, fronteras que dividen la península ibérica se estructura en torno a elementos defensivos o de carácter militar, lo que va a conferir a los asentamientos humanos, su arquitectura y estructura urbana, unos rasgos diferenciadores muy útiles para la datación de su evolución histórica.

Pérez de Urbel (1964) realiza un planteamiento de esos años de nuestra historia desde la óptica de los reinos cristianos. Frente a esto, otros autores como Levy Provenzal ([1957] 1973) o Chalmeta Gendrón $(1976 ; 1981 ; 2003)$ efectúan sus propuestas basándose en el estudio de las fuentes documentales musulmanas, lo que aporta una valiosa visión desde un punto de vista que hasta la fecha se había relegado por parte de los autores occidentales.

Con una visión muy amplia, Chalmeta Gendrón (2003) estudia la creación del estado omeya a raíz de la llegada de Abd-al-Rahman I a la Península. Su afirmación Abd al Rahman I funda una dinastía, crea ejércitos, urbaniza ciudades y organiza la administración (Chalmeta Gendrón, 2003: 349), resume perfectamente cómo se organiza la creación del nuevo estado omeya. Desde un punto de vista muy similar, Azuar Ruiz (2005 b) y Acien Almansa (2002) estudian esta nueva estructuración del territorio peninsular, que queda bajo el dominio hispanomusulmán.

Dentro de esta estructuración territorial adquieren especial importancia las ciudades y las fortificaciones. Ladero Quesada $(1993 ; 2008 ; 2010)$ centra su interés en la conformación de los asentamientos hispanomusulmanes, tanto los castillos como las ciudades fortificadas, constatando que la mayoría de estos asentamientos se construyen en los valles de los ríos, protegiendo los accesos desde los pasos de la sierra hacia la submeseta sur (Ladero Quesada, 1993: 22-23). También centrado en el estudio de las construcciones omeyas, con especial interés en las fortificaciones, a nivel de toda la península ibérica, hay que destacar la obra de Souto Lasala (2002). Posteriormente veremos estos aspectos con más detenimiento, al repasar los estudios realizados sobre el urbanismo hispanomusulmán.

Centrándose en un ámbito geográfico más acotado y próximo a nuestro estudio, Valdeón Baruque (1989) aborda el estudio del Islam en la meseta norte y Manzano Moreno (1991) las vicisitudes de la frontera de Al-Andalus en contacto con los reinos cristianos del norte peninsular durante la etapa omeya. Desde la óptica estos reinos nos va a interesar la creación de estos incipientes reinos del norte, asunto que estudia Estepa Diez (1985) y su posterior expansión hacia el sur, hasta la completa colonización de lo que se ha venido a llamar la Extremadura castellana (Villar García, 1986), donde las peculiaridades de los diferentes tipos de repoblación han generado distintos modelos de asentamiento urbano y de estructuración del territorio, constituyéndose en comunidades de Villa y Tierra (Martínez Diez, 1983; 2005). Los estudios de González y González (1943; 1951; 1974) sobre la repoblación de la Extremadura castellana evidencian como las rutas romanas aún estaban en uso durante la Alta Edad Media para el paso del Sistema Central y como los cauces de los ríos eran utilizados como vías de comunicación. El empuje de la repoblación desde los reinos del norte acaba imponiéndose y a pesar de las continuas aceifas musulmanas para frenar dicho avance repoblador, las localidades pobladas que son asaltadas por Almanzor, posteriormente vuelven a repoblarse.

La ciudad amurallada de Segovia se asienta sobre un macizo calizo, delimitado en tres de sus lados por los ríos Eresma y Clamores que confluyen bajo la proa que constituye el extremo del alcázar (AMS 4810-3: 48). Este emplazamiento de indudable carácter defensivo, se 
complementa con unos valles fértiles a su alrededor y donde de manera dispersa se sitúan los barrios históricos de San Marcos, San Lorenzo, El Salvador, San Justo y San Millán, en los que se desarrollaba las actividades agrícolas y ganaderas (Abella y Yoldi, 1993: 77). Aún en la actualidad, todos estos barrios no constituyen un continuo construido, por lo que no es difícil imaginarse la descripción y la representación en el plano que de ella hace Al-Idrisi ${ }^{31}$.

Estos arrabales se desarrollan sobre un paisaje más llano que el del recinto amurallado, lo que, unido a su menor dimensión, permite un desarrollo de la traza urbana menos condicionada por la topografía, con estructuras urbanas, sencillas y muy claras, organizadas en torno a una plaza como en San Lorenzo, o a lo largo de un camino en el caso de San Marcos. Trazados orgánicos, claramente vinculados a la actividad humana (económica y social) sin apenas condicionantes orográficos, salvo la presencia de los ríos.

El trazado de la muralla está condicionado por la topografía y su geología, con la presencia de peligrosas fallas y diaclasas, que han producido derrumbes que han ido retallando la forma del macizo rocoso, en algunos puntos llevándose consigo a la propia muralla. Este tallado de la base rocosa también se ha efectuado de manera artificial por motivos militares, para acentuar el cortado vertical, o para aprovechar los numerosos abrigos, que estuvieron habitados desde la prehistoria (AMS 4810-3).

Esta gran roca de orientación ESE - WNW es alargada y va estrechándose hacia occidente hasta acabar en la "proa" del Alcázar, confluencia del río Eresma y del arroyo Clamores. En este mismo sentido (ESE-WNW) va descendiendo en cota desde la Plaza del Seminario $(1006,5 \mathrm{~m})$ hasta la entrada del Alcázar $(976 \mathrm{~m})$, pero evidentemente todo el entorno no es, y no era en origen, acantilado, sino que existían zonas más bajas, vaguadas por las que el acceso era más fácil y en las que, al amurallarse la ciudad, se situaron las puertas (AMS 4810-3: 48).

Así el trazado de la muralla, y con él, el perímetro de la ciudad, se va ciñendo a la presencia de acantilados, descendiendo desde la cresta central hacia la muralla perimetral que se convierte en un muro de contención que permite nivelar las parcelas y calles adyacentes a dicha muralla. La forma de la roca condiciona el trazado alargado de la ciudad, si bien en numerosos puntos esta roca se ha cortado artificialmente a pico para acentuar el desnivel y su verticalidad por claros motivos defensivos y de explotación como cantera y mina para extracción de piedra y arenas. De esta forma se acentúa la percepción de aislamiento de la plataforma sobre la que se asienta el recinto amurallado. Esta plataforma tiene una pendiente longitudinal bastante uniforme hacia la confluencia de los dos ríos, hacia la punta más estrecha que es donde se emplaza el Alcázar, mientras en el sentido transversal, la trama urbana se adapta a una topografía de pronunciadas pendientes. Sobre esta plataforma existió una ciudad romana de la que nos ha quedado el famoso acueducto y algunos restos arqueológicos bastante inconexos, que no nos permiten restituir el posible trazado de dicha ciudad, aunque si estimar su extensión (Martínez, Santiago, 2010c).

Desconocemos si existió un acueducto romano subterráneo por el interior del actual recinto amurallado. Supongo que sí y que debía abastecer, por lo menos a las fuentes y edificios públicos. Solo nos ha llegado el trazado aéreo. La configuración de la plataforma sobre la que se asienta la ciudad romana condiciona el emplazamiento y trazado del acueducto romano, que

${ }^{31}$ Véase la trascripción de este texto en Ruiz Hernando (1986: 23). 
acomete a la muralla en las proximidades de la plaza del Seminario, el punto más alto, para desde allí distribuir de modo subterráneo a toda la ciudad, y posiblemente hasta el alcázar. El acueducto subterráneo que ha llegado hasta nosotros data todo ello de los siglos XV (o XIV) (Martínez Caballero, 2012: 37). De existir un acueducto subterráneo romano, es muy posible que su trazado fuese el mismo o muy parecido al que presenta el acueducto medieval, ya que las cotas topográficas no permiten una gran desviación de la cresta longitudinal para poder abastecer por gravedad a la ciudad que se emplaza a ambos lados. Lo que es cierto es que estaba en uso en 1120, aunque no se sabe si su trazado se adaptaba a las anteriores calles de la "musara" y el castrum, ambos anteriores a la repoblación (Martínez Caballero, 2012: 37).

Su trazado aéreo, el tercer río de Segovia, ha servido de eje vertebrador a lo largo de la cual se ha desarrollado el crecimiento de la ciudad desde la plaza del Azoguejo, a modo de ciudad lineal (Ruiz Hernando, 1986: 23). Del mismo modo consideramos que su recorrido subterráneo, ha condicionado el trazado de la ciudad intramuros. Es evidente que una vez en funcionamiento esta infraestructura de vital importancia para la vida de la ciudad, su trazado tuvo que ser respetado por las calles que se trazaran y los edificios que se construyeran a posteriori, condicionando de este modo el recorrido de las actuales calles por las que discurre hasta llegar al Alcázar.

Esta fortaleza está situada en la confluencia de los ríos Eresma y Clamores sobre un cortado de unos 80 metros sobre el nivel del río. Su situación, sobre una elevación rocosa recortada a modo de proa, le confiere un emplazamiento estratégico cuya defensa se complementa con un foso, que se ha seguido profundizando durante siglos y que lo separa de la ciudad. Con semejante emplazamiento, no nos extraña que haya existido una fortificación en ese punto ya en el mundo romano, e incluso con anterioridad y aunque sus primeras referencias escritas datan del siglo XII, es muy posible que existiese una fortaleza construida en madera con muro cortina y una torre previamente a la esas referencias documentales y a la repoblación de Alfonso VI (Ruiz Hernando, 1982: 29). En la documentación histórica, se le refiere con distintos apelativos, como un oppidum, castellum, castro, y por último Alcázar (Ruiz Hernando, 1973: 55), lo que nos confirma su continua transformación.

Su aspecto actual es la suma de las ampliaciones y restauraciones que ha sufrido de forma continuada, siendo principalmente visibles las obras de la dinastía de los Trastámara, la torre de Juan II, las cubiertas de pizarra de la etapa de Felipe II y la reconstrucción realizada tras el incendio del 6 de marzo de $1862^{32}$. A tenor de las construcciones visibles en las partes bajas de los muros del Alcázar, varios autores coinciden en afirmar que debió existir una fortaleza previa, si bien para unos, estos restos son romanos (Merino Cáceres, 1991) y para otros son prerrománicos, sin aventurar la posible filiación musulmana de los mismos (Ruiz Hernando, 2012: 89).

Así las murallas, que nacen y mueren en el Alcázar, definen el perímetro y el acueducto subterráneo constituye un eje vertebrador fundamental para la ciudad al proveer el abastecimiento de agua. Dentro de esta muralla, se vuelve a refundar la ciudad con la repoblación, se construyen las distintas parroquias entorno a las cuales se estructuran los barrios de los repobladores, las casas fuertes y la catedral y la existencia de sus murallas se constata por primera vez en 1120 (Ruiz Hernando, 1982: 27).

32 Sobre este aspecto puede verse Cantalejo San Frutos (1996). 
Tenemos por lo tanto una fecha que marca el inicio de la información histórica en relación con Segovia. Antes de ella, no se disponen de datos fidedignos basados en documentos escritos. A partir de esta fecha, la historia de la ciudad está mucho más estudiada, y encontramos varios autores que lo tratan.

El primer tratado data de 1551, escrito por Ruiz de Castro (1988). Si bien es lejano a nosotros en el tiempo, hay que considerar que habla sobre la repoblación de Segovia, acontecida casi 500 años de la fecha cuando él escribe su trabajo. Los datos que aporta de esas fechas son poco significativos adquiriendo el trabajo mayor valor documental en los siglos de la Baja Edad Media. Poco después, Diego de Colmenares ([1637] 1922), redacta su Historia de Segovia, que adolece de la misma escasez de información en la Alta Edad Media, centrándose en los siglos posteriores. En buena medida se basa en el trabajo de Ruiz de Castro. Esta deficiencia de información en los siglos de la Alta Edad Media es común a todos los trabajos.
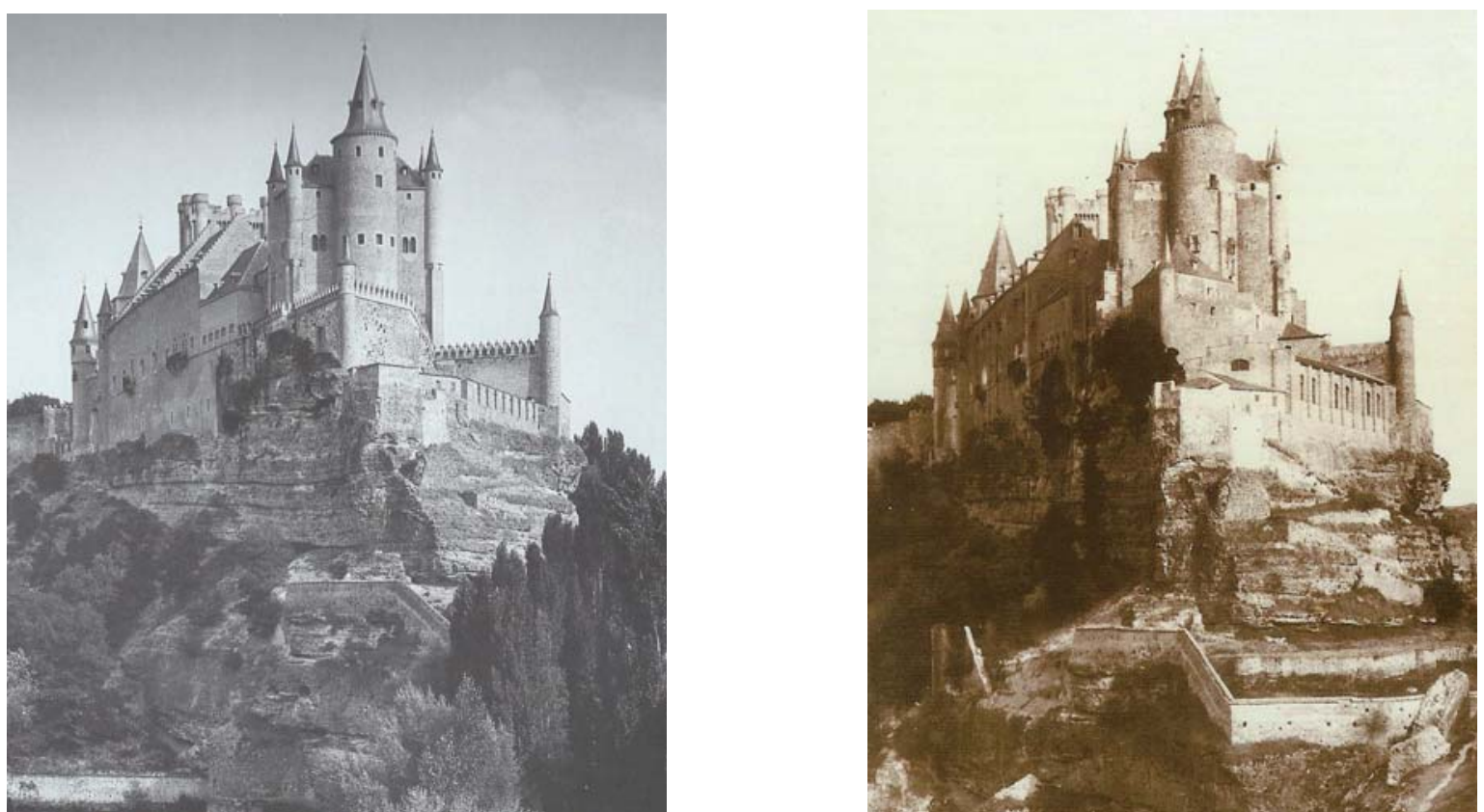

Figura 3. 6: Foto de Alois Beer, tomada en 1906, donde se hace patente lo inaccesible del Alcázar y de su ubicación y como la roca se ha ido tallando con el tiempo reforzando el aislamiento de la fortaleza. (Rudolph, 2004: 109)

Figura 3. 7: Otra imagen del Alcázar, tomada por Clifford en 1853 (VVAA, 2010: 242).

Así la mayor parte de los trabajos focalizan su interés en la Baja Edad Media o parten de ese momento. Una de las principales fuentes en la que se apoyan numerosos trabajos posteriores es el Marqués de Lozoya (1955, [1921] 2010). La Historia del urbanismo de Segovia (Ruiz Hernando, 1982), es posiblemente uno de los estudios más exhaustivos sobre el urbanismo de la ciudad de Segovia que se apoya en el análisis de los datos históricos extraídos de los archivos, abarcando el periodo desde dicha repoblación hasta la redacción del catastro de Ensenada, poniendo en evidencia que antes de dicha repoblación no existen datos históricos fidedignos y aun antes del siglo XIII estos son muy escasos. Antes de estas fechas poco sabemos. A partir de este momento, la documentación existente permite otros estudios de índole económica, geográfica, (Martínez de Pisón, 1976; Asenjo González, 1986) que indaga en los documentos existentes en los archivos, dando luz a muchos datos que estaban inéditos. Similar trabajo de vaciado documental y publicación de documentos inéditos efectúa Villar 
García (1990) en los archivos catedralicios. Otros trabajos que nos han resultado de utilidad son Represa Rodríguez (1949), (1969) y Montero Reguera (1999).

Tras la repoblación de la ciudad, en 1120, el concejo cede al Cabildo un solar delimitado, según Antonio Ruiz, entre las murallas, el Alcázar y una línea imaginaria desde la puerta de Santiago a la de San Andrés (Ruiz Hernando, 1982, 25). En este espacio se construye la catedral románica, finalizada en 1144, enfrente del Alcázar y entre ésta y el foso, se sitúa el palacio episcopal (Ruiz Hernando, 1982: 29). La catedral, con su torre enfrentada al Alcázar, constituye durante muchos años una grave amenaza para la fortaleza, motivo por el que los Reyes intentan trasladar la catedral de su emplazamiento original (Ruiz Hernando, 1982: 82). El hecho decisivo detonante de esta decisión ocurre durante la guerra de las Comunidades, en que las tropas comuneras se atrincheran en la catedral para asaltar el Alcázar en manos de las tropas fieles al rey Carlos. María López (López Diez, 2001 y 2006) nos documenta los asedios al Alcázar desde la antigua catedral románica, durante la revuelta comunera.

Tras dicho suceso y bajo pretexto de los importantes daños sufridos, la catedral se demuele. El claustro, construido pocos años antes por Juan Guas, se conserva, desmontándolo y trasladando sus piezas para reconstruirlo en su actual ubicación. Posteriormente la demolición de los restos del palacio episcopal, ya en el siglo XIX, dejan el espacio de los jardines de la Plaza de la Reina Victoria Eugenia completamente diáfano, tal y como los encontramos en la actualidad (Ruiz Hernando, 1982: 83). En la ladera que asciende hacia la iglesia de San Andrés se construyen las viviendas de los canónigos, la canonjía, primer trazado urbano no espontaneo, pero condicionado por el recorrido del acueducto y delimitado por las murallas (Ruiz Hernando, 1982: 31). Este barrio se organiza a lo largo de dos calles que confluyen en una plaza a la que se enfrentaba el ábside de la catedral. Estas calles y la plaza se cerraban al anochecer por 3 puertas, de las cuales sólo se conserva una, de modo que el barrio quedaba separado del resto de la ciudad. De la configuración de la trama urbana original de los demás barrios y colaciones muy poco se ha escrito.

Como hemos visto, las primeras noticias de la ciudad de Segovia, son a raíz de la repoblación, la cual efectúa Raimundo de Borgoña, al igual que la de Salamanca y Ávila (Montero Vallejo, 1996: 205; González y González, 1974: 298). Para asegurar los territorios recién conquistados, el rey encomienda la tarea de construir las murallas de Ávila. Se supone que también le encargaría idéntica tarea para las de Segovia (Ruiz Hernando, 1982: 25). Esta ciudad, que debería presentar un carácter predominantemente rural, estaría formada por barrios dispersos entre los que existirían importantes vacios, tal y como la representa Al-Idrisi.

La descripción de José Ortega al respecto, hipótesis compartida por Félix Benito (Benito Martín, 1996: 130) es muy esclarecedora:

Segovia, Avila, Soria, Salamanca son en pleno siglo XII grandes recintos amurallados en los que se reúnen diversas aldeas, como resaltaban las crónicas musulmanas. Amplias aéreas permanecían sin ocupar, abiertas o incluso cultivadas, como buertos o campos de cereal, según sabemos de Soria y Avila. El resto se corresponderá a un conjunto de pequeñas agrupaciones en torno a sendas iglesias parroquiales de recintos en los que se asentaban los repobladores, por puntos de origen, o por otros motivos, en una trama de caminos que relacionaban unos con otros y con las puertas que se abrian en las murallas. (Ortega Valcárcel, 2002: 314). 
Remolina Seivane (2006) también da por supuesto que el recinto amurallado de Segovia nunca ha tenido una gran población. Fue sin duda este autor, en su breve artículo (Remolina Seivane, 2006), el que me abrió los ojos para la formulación de la hipótesis que ha sido el punto de partida de esta tesis. Su acertada observación de que la mayor parte de las iglesias románicas de la ciudad se distribuyen a lo largo de un eje que discurre desde la puerta de San Juan hasta el Alcázar, me permitió empezar a ver la estructura urbana de una manera nueva.

Los siguientes siglos suponen una etapa de consolidación urbana en el proceso urbano del recinto amurallado, en su mayor parte colmatando los espacios libres y huertos que existían en su interior. Constan en la documentación histórica, numerosas citas de cierres de callejones ya que los particulares se han apropiado de ellos, o de ocupación de los adarves de la muralla por edificaciones, pleitos para que se reabran y liberen esos espacios públicos, así como solicitudes de particulares para que se les cedan dichos espacios (Ruiz Hernando, 1982, II: 333-347). La colmatación del espacio intramuros debió ser mucho mayor que en la actualidad, ya que en palabras de María Asenjo, resulta difícil de imaginar que hacia el año 1500, la ladera norte desde San Juan de los Caballeros hasta la puerta de Santiago, no estuviese poblada a tenor de la referencia a la existencia de numerosas construcciones adosadas a la muralla (Asenjo González, 1986: 62). Es significativo que en 1505, el procurador del común pidió que se mandara derribar todo lo que se ha construido sobre las murallas (Asenjo González, 1986: 6465). Las peticiones y apropiaciones de estos bienes públicos continuarán en el tiempo. En 1630, todavía se circulaba por el adarve de la muralla, en la trasera del convento del Corpus y las monjas piden que se cierre (Ruiz Hernando, 1982, II: 348-354). En 1707 el hospital de la Misericordia consigue la cesión del callejón que daba al postigo de fuente cercada, condenando definitivamente este acceso (AMS: 4810-3, I: 15).

En el plano urbanístico, el siglo XVI supone para Segovia la culminación de su morfología urbana. También, a lo largo de la centuria, la Plaza Mayor empieza a tomar forma, aprovechándose para ello diversas circunstancias. Por un lado, las monjas del Convento de Santa Clara se han trasladado al recién levantado Convento de San Antonio El Real, extramuros de la ciudad; sobre el solar que dejan se inician, en 1525, las obras de construcción de la nueva catedral, que ocupará una parte de la recientemente deshabitada judería, tras la expulsión de esta etnia. Poco después, el derrumbe y posterior reconstrucción de la iglesia de San Miguel $(1532$ - 1558) sirvió para que se trasladara de su primitiva ubicación, en el centro de la actual Plaza Mayor, al lateral que hoy ocupa. Para este hecho contamos con dos monografías específicas, de muy distinto calado. La construcción de la catedral la documenta Teresa Cortón (Cortón de las Heras, 1997) y el proceso de conformación de la plaza mayor lo estudia Miguel Ángel Chaves (Chaves Martín, 2000).

Para el conocimiento de todo este proceso urbano, desde la repoblación hasta el catastro de Ensenada, esto es desde finales del siglo XI hasta mediados del XVIII, el referente bibliográfico es la obra de Antonio Ruiz (Ruiz Hernando, 1982). Unos años más tarde, publica un nuevo trabajo sobre la ciudad de Segovia (Ruiz Hernando, 1986), en buena medida reitera lo ya dicho en su obra anterior.

Antes de esa repoblación, nada sabemos de la configuración de la posible ciudad de Segovia. Incluso en el siglo XII, como admite Antonio Ruiz en su trabajo, los datos son muy escasos, siendo más abundantes a partir del XIII. 
A partir de 1750, el estudio del urbanismo segoviano tiene su continuidad en la obra de Miguel Ángel Chaves (Chaves Martín, 1998), que se centra especialmente en las transformaciones urbanísticas de los últimos siglos. Entre ambos autores, la historia del urbanismo segoviano está bien estudiada desde el punto de vista documental. Se ha realizado una importante labor de búsqueda archivística. Sin embargo no existe ningún estudio técnico, de la ciudad antes de ese siglo XII. De la etapa anterior al trabajo de Antonio Ruiz, no tenemos ningún estudio sobre el urbanismo de la ciudad de Segovia. Se trata de un periodo de tiempo eludido en los trabajos, por la ausencia de documentación escrita.

El final de este proceso histórico, a los efectos de nuestro estudio, tiene su culminación con las reformas de alineaciones de calles emprendidas en el siglo XIX, que suponen importantes cambios en algunos puntos de la trama urbana, la desaparición de varias iglesias así como dos de las puertas de la muralla. Con la regulación del trazado viario se derribaron las puertas de San Martín (1883), de San Juan (1887) y los postigos del Sol (1864) y de la Luna (1885), además de las iglesias románicas de San Román (1866), San Pablo (1881) y de San Facundo (1884). No sólo fueron demolidas las puertas citadas, sino que otras fueron declaradas en amenaza de ruina, San Cebrián (ruina en 1825), San Andrés (1879) y Santiago (1887), si bien no llegaron a demolerse (Chaves Martín, 1998).

La posición del recinto amurallado y los inaccesibles cortados que la bordean impedían la correcta comunicación y extensión de la ciudad por sus laderas, aunque se demoliese la muralla. La demolición que en otras ciudades suponía la eliminación del corsé, que impedía o dificultaba el crecimiento continuo de las ciudades a través de los ensanches decimonónicos, no se resolvía en el caso de Segovia, con la simple demolición de la muralla. Por este motivo, el crecimiento de la ciudad se desarrolló en sus barrios ubicados extramuros, principalmente a lo largo del trazado del acueducto. Sin embargo, la mejora de la comunicación y accesibilidad, si que afectó a la conservación de las puertas de la muralla. Con esta justificación se demolieron las puertas y los tres postigos ya indicados, estos últimos recuperados en la segunda mitad del siglo XX.

Otros estudios sobre las transformaciones urbanísticas acontecidas en Segovia los encontramos en el trabajo de Luis Mariano García sobre Joaquín Odriozola (García Casas, 1987), en los trabajos de Miguel Ángel Chaves sobre la transformación urbana en el entorno del acueducto (Chaves Martín, 2001a y 2002b) o el trabajo sobre los corralillos de Mosácula María (2004).

\section{ArQuitectura Medieval en SEgovia.}

Como se ha indicado, los edificios medievales que han pervivido en la ciudad constituyen una fuente excepcional de información. Su estudio con métodos arqueológicos puede aportar importantes claves para entender el pasado de los mismos y de la propia ciudad de Segovia.

Segovia cuenta con una amplia cantidad de estudios de conjunto y monografías sobre algunos de sus edificios. Sin embargo estos estudios están hechos en su mayoría desde la perspectiva de la historia del arte, como estudios de conjunto con un planteamiento descriptivo siendo escasas las monografías con un enfoque analítico desde el campo de la arqueología de la arquitectura. Entre las primeras, es sin duda el románico segoviano, especialmente en su 
vertiente de la arquitectura religiosa el que mayor volumen de literatura ha generado. Respecto a las monografías, el más estudiado es el Alcázar.

Entre las obras generales cabe destacar la obra de Cabello y Dodero, su guía arqueológica (Cabello y Dodero, 1928), la guía de Segovia (Cabello y Dodero, 1949) y sobre la arquitectura románica de Segovia de Cabello y Dodero (1952), Ceballos (1953), Contreras y López de Ayala (1955), la obra sobre el románico segoviano del Marqués de Lozoya (1967), el estudio sobre las casas blasonadas de Vera y de la Torre (1974), la arquitectura románica de Santamaría López (1984) o la guía de arquitectura de Chaves Martín (2006).

Lojendio (1992) realiza una de las mejores monografías sobre el románico segoviano, en el que dedica un apartado a las murallas. Mención especial merece la extensa obra de Antonio Ruiz, dedicada principalmente a la ciudad de Segovia y su arquitectura, con alguna incursión por el resto de la provincia, entre las cuales destacamos, por su interés para nuestra investigación, su trabajo sobre arquitectura civil en el románico de Segovia (Ruiz Hernando, 1973), la arquitectura en ladrillo (Ruiz Hernando, 1988), la arquitectura medieval en Segovia (Ruiz Hernando, 1991), el románico civil (Ruiz Hernando, 2007), o las iglesias parroquiales de Segovia (Ruiz Hernando, 2008).

Por último, la más extensa y exhaustiva recopilación sobre el románico segoviano, la constituye la Enciclopedia del Románico (García Guinea, 2007), en cuyos tres tomos se revisa y actualiza toda la bibliografía publicada sobre la arquitectura románica de la provincia de Segovia.

Las monografías dedicadas a un único edificio, que permiten ahondar con más profundidad en el conocimiento del mismo, son más escasas, como ya se ha indicado, excepto en el caso del Alcázar, el edificio más estudiado con diferencia de toda la arquitectura segoviana. Por contra no existe ninguna monografía sobre las murallas y sólo algunas puntuales sobre otros edificios medievales.

La lista de publicaciones sobre el Alcázar es extensa, Losañez (1861), Lecea y García (1891), Oliver-Copons ([1916] 1989), Contreras y López de Ayala (1958 y 1964), Vera y de la Torre (1952), Cáceres y Blanco (1970), López Orcajo (1980), Ruiz Hernando (1994b, 2000 y 2010), Sánchez Gómez (1995), Cantalejo San Frutos (1996), Peñalosa Esteban-Drake (2001), Schnell Quiertant (2002), Martínez Falero (2011) y Merino de Cáceres (2014), por citar los más relevantes. La mayor parte de estas publicaciones son descriptivas y no entran a analizar los aspectos constructivos, ni los cronológicos. Los orígenes del Alcázar, documentalmente, hay que establecerlos en el siglo XII, como ya se ha indicado, reafirmados por la existencia de restos estilísticamente románicos en su patio de armas (Chaves 2006). Sin embargo la primera referencia a la existencia de una fortaleza previa la debemos a Antonio Ruiz quien en 1982 ya plantea la hipótesis de que en el alcázar existía antes de 1088, una pequeña fortaleza construida en madera con un muro cortina y una torre. A fines del XI comienzan las primeras construcciones en piedra y es entonces cuando nuestro castro se transforma en castillo, al tiempo que se construyen las murallas y el foso, que seguía ahondándose en el XVI (Ruiz Hernando, 1982: 29). Este mismo autor, en otra obra posterior, casi 20 años después, indica la existencia de restos de una fortificación altomedieval, absorbidos por distintas ampliaciones y reformas refiriéndose concretamente a dos torres con muro cortina que flanquearían el acceso y aventura la posibilidad de una torre albarrana con coracha (Ruiz Hernando 2010: 45-91). Resulta de especial interés para nuestro trabajo la referencia que hace a la presencia de algunos 
aparejos que podrían ser obra musulmana según Alonso Zamora (Ruiz Hernando, 2010: 55). Sin embargo esas mismas torres, José Miguel Merino las considera romanas (Merino de Cáceres, 1991: 18-19).

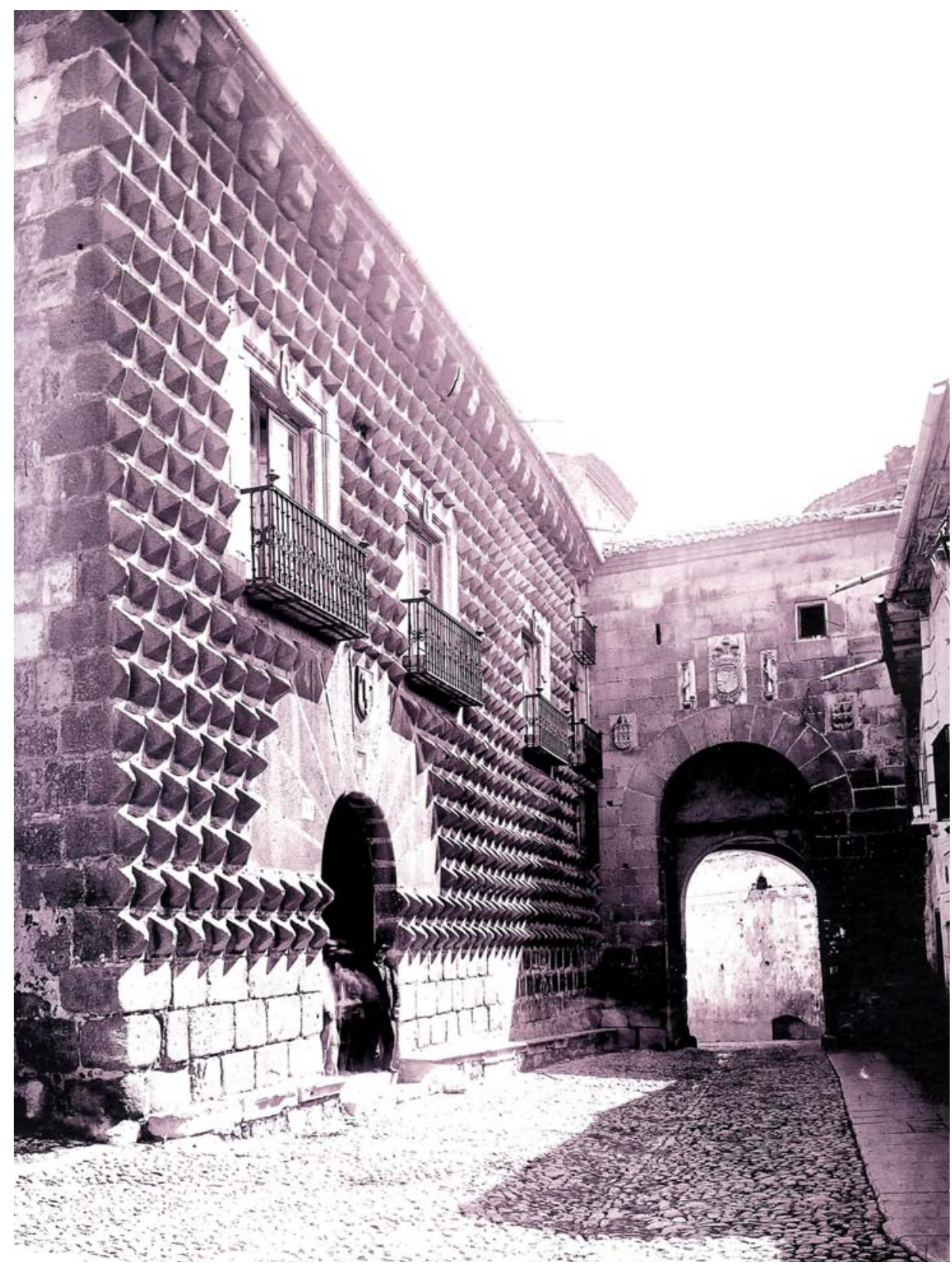

Figura 3. 8: Foto de Laurent de la desaparecida puerta de San Martín (VV.AA. 2006: 66).

Un estudio de Muñoz Jiménez (2005), nos refiere la presencia de Juan Guas en la ciudad de Segovia por sus intervenciones en el Alcázar planteando la posibilidad de atribuir a este arquitecto la autoría de la reforma de la puerta de San Andrés por las características estilísticas que presenta dicha puerta.

Otras monografías sobre algunos edificios segovianos que nos han interesado son el estudio de Cabello y Dodero (1951) sobre la iglesia de la Vera Cruz, el de Contreras y López de Ayala 
(1976), sobre la iglesia de San Martín. López Ambite (1995) publica los resultados de las excavaciones arqueológicas que lleva a cabo en la iglesia de la Santísima Trinidad, mientras Cortón de las Heras (1997) y Ruiz Hernando (2003) realizan sendos estudios sobre la catedral renacentista que nos aportan algunos datos sobre el tejido medieval sobre el que se implanta y Merino de Cáceres (2005), cuyo estudio sobre la métrica de la torre de la iglesia de San Millán le permite afirmar que tiene modulación visigoda.

Toda esta literatura nos permite conocer las 18 iglesias románicas que se conservan San Andrés, San Clemente, San Esteban, San Juan, San Justo, San Lorenzo, San Marcos, San Martín, San Miguel, San Nicolás, Santa Eulalia, Sn Salvador, Santo Sepulcro, San Sebastián, Santo Tomas, Trinidad, San Pedro y San Quirce, o de las que se conservan algunos restos como San Vicente, Santa María de los Huertos, San Blas y Santa María de Rocamador. Nos aportan información sobre las que han sido demolidas como San Pablo, San Román, San Facundo, San Mames, Santa Columba, San Antolín o de las que sólo conocemos documentalmente como San Vicente, Santiago, San Bartolomé, San Cebrián, San Benito, San Benito Nuevo, la catedral románica, San Antón, San Briz, Santa Catalina, San Gudumian, San Valero. Nuevamente el trabajo de Antonio Ruiz (Ruiz Hernando, 1982) nos resulta fundamental, situando la mayoría de ellas sobre la trama urbana actual de Segovia. La orientación sacra característica de todas las iglesias medievales que se han conservado, supone un rasgo de importancia que viene a condicionar el trazado urbano.

\section{ARQueOlogía EN LA CIUDAd DE SEgOVIA.}

Dada mi formación de arquitecto y la importante carga de análisis arqueológico que el tema de esta tesis exigía, se han consultado casos de estudios de otras ciudades, tanto como ejemplos de análisis comparativo como con fines meramente metodológicos a la hora de plantear nuestro trabajo. Así se han consultado desde trabajos generales, García y Bellido (1985), Harris (1991), Quirós Castillo (1994), Brogiolo (1995) Doglioni (1997 y 2008), Maldonado Ramos (1998), Azkarate Garai-Olaun (2001 y 2010) o Sánchez Zufiarre (2004 y 2007). Especial utilidad nos han sido los trabajos de Tabales Rodríguez (2010) sobre arqueología aplicada al estudio e interpretación de edificios históricos, para profundizar en el conocimiento de la metodología de las lecturas constructivas. Así los estudios de Caballero Zoreda (1987, 1995, 1996, 1997 y 2005) no solo desde el punto de vista metodológico, sino también como estudios de los sistemas constructivos y aparejos visigodos y omeyas.

Como importantes referentes al estudiar los sistemas constructivos hemos manejado los trabajos de Márquez Bueno (2003 y 2005) de Cáceres y Medellín respectivamente o los de Tabales Rodríguez (2002) en Sevilla o Bellido Márquez (2008) en las murallas de Marchena. Más adelante veremos otros casos de estudio cuando repasemos las obras referidas a murallas y fortificaciones hispanomusulmanas.

Entrando en la historia de la propia ciudad de Segovia, la arqueología es la que más datos nos ha aportado respecto a los siglos que nos ocupan. En los informes arqueológicos vinculados a las obras realizadas en el entorno de la muralla los principales descubrimientos efectuados se reducen a constatar la existencia de numerosos taladros y agujeros de postes tallados en la roca, algunos evidentemente anteriores a ésta, pero en los que no se encuentra ningún material asociado que permita ofrecer una datación o una finalidad de los mismos que posibilite su 
entendimiento. En casi todos ellos se hace referencia a la aparición de restos descontextualizados de cronología incierta. En otros casos encontramos los agujeros de postes perfectamente alineados y equidistantes de los lienzos de la muralla por lo que se los considera vinculados al andamiaje de construcción de la misma. Algunos de estos hallazgos se han inventariado en un trabajo anterior (Martín Blanco, 2011).

Se constata la existencia de un primer sistema defensivo urbano, identificado como celtíbero (Martínez Caballero, 2010: 143-181) ${ }^{33}$ mediante un foso tallado en la roca, que se identifica en la calle Velarde (Martín Vela, 2011) y en Ronda de Juan II y delimita un área de menor extensión que el actual recinto amurallado que aislaba la parte del alcázar del resto de la ciudad y en el que debería emplazarse el poblado inicial. De la etapa romana, si bien excede de nuestro ámbito temporal de estudio, coincidimos con Guidoni, en que el sedimento del mundo romano ha influido condicionando la evolución de la ciudad visigoda, hispanomusulmana y cristiana posterior.

Il patrimonio urbanistico romano si trasmette cosi alle eoche succesive, e, sia pure in modo discontinuo, sopravive anche al periodo islamico; basta ricordare Tarragona, Segovia, Barcellona, Saragozza, Astorga, Lugo, León, Salamanca, dove, ora il tessuto viario, ora le mura, ora grandi opere di servizio, banno profondamente influenzato le succesive transformazioni (Guidoni, 1981: 53).

Así también nos han interesado los trabajos de Municio González $(1995,2000,2002)$ buen conocedor de la arqueología segoviana así como los de Martínez Caballero (2000, 2010) además de destacar el interés de su trabajo sobre el acueducto romano (Martínez Caballero, 2012).

En los siglos IV y V la decadencia del imperio romano, conlleva la ruralización de la sociedad y la construcción de defensas en las ciudades del interior del imperio que ya no son seguras por la debilidad de los "limes", fenómeno que se repite en numerosas ciudades romanas ${ }^{34}$. Hay autores que también suponen que dicha situación ocurre en el caso de Segovia, (Illarregui Gómez, 2010: 71) pero hasta la fecha, no se han encontrado restos materiales de fortificaciones romanas que lo demuestren, a excepción de unos sillares en la cimentación de una torre previa al Alcázar. (Merino de Cáceres, 2000). Sin embargo estos mismos restos son calificados como altomedievales por Antonio Ruiz que identifica también como altomedievales otros vestigios situados en las partes bajas del Alcázar (Ruiz Hernando, 2010).

Los pueblos germanos llegados a la Península en los últimos momentos del Imperio Romano, muestran una preferencia evidente hacia la meseta norte, que a pesar de los escasos vestigios arquitectónicos que subsisten de esa época, queda suficientemente avalada por la distribución de necrópolis que se han documentado en el área comprendida entre el río Duero, el sistema ibérico y el sistema Central ${ }^{35}$ (Barrio Martín, 2010).

\footnotetext{
${ }^{33}$ Este autor se basa en los informes de intervención arqueológica realizados en los inmuebles de calle Velarde 16 (Municio González, 1996) y en calle Daoiz 13 (Moreda Blanco, 1996). De este último, no consta en el archivo del Servicio Territorial el informe de final de obras.

${ }^{34}$ En España esta constatada la existencia de murallas en época tardo romana en Lugo Itálica, Zaragoza, Barcelona, Tarragona, (García de Cortázar, 2005: 92-120) y Palma de Mallorca (García-Delgado Segués, 2004).

${ }^{35}$ Esta preferencia es aún más marcada hacia la zona de la provincia segoviana, donde las evidencias de población visigoda son más numerosas y patentes. Véase a este respecto la obra de Hoz Onrubia (2006).
} 
Existe constancia de población en Segovia, previa a la repoblación oficial, gracias a los enterramientos excavados en la iglesia de San Millán datables a partir del siglo X (Zamora Canellada, 1979: 528-535) o en los restos de una iglesia del siglo VI, transformada en el siglo X, hallados bajo la iglesia de San Juan de los Caballeros (Zamora Canellada, 1997: 423). Esto evidencia la existencia de una población visigoda, previa a la ocupación musulmana, tanto en el recinto amurallado como en los barrios extramuros, aunque no hay pruebas que demuestren que mantiene su continuidad durante la etapa musulmana (Zamora Canellada, 1991). Esta ocupación se constata con la aparición de evidencias de iglesias previas a las románicas que nos han llegado, en San Nicolás y la Trinidad (López, Barrio, 1995). Esta idea también es compartida por Antonio Ruiz. Como se ha indicado, los restos de la iglesia (e incluso las propias arquitecturas) de las iglesias de San Juan de los Caballeros, San Martín y San Millán nos hablan de una continuidad entre el prerrománico y el románico en Segovia, que en principio no se produjo en la zona de Sepúlveda (Ruiz Hernando, 1988a: 25). Algunas iglesias presentan restos claros de construcciones previas a la repoblación, como por ejemplo la torre de San Millán ${ }^{36}$ y la traza en planta de San Martín (Ruiz Hernando, 1973: 54) o presentan influencias mozárabes en el trazado de sus plantas como San Martín, San Andrés y San Lorenzo (Arias Angles, 1973). La continuidad arquitectónica nos lleva a pensar en la continuidad poblacional.

\section{MURALLAS Y FORTIFICACIONES MEDIEVALES}

El estudio de la arquitectura militar cuenta con una amplia bibliografía, si bien una buena parte de la obras son de carácter histórico descriptivo sin entrar en el ámbito de la construcción histórica y de la arqueología, que son los enfoques que más nos van a interesar.

En una primera aproximación panorámica a la arquitectura militar y las fortificaciones hemos elegido un conjunto de obras de carácter general que estudian de manera amplia el tema, o bien algunos elementos constitutivos de las fortificaciones como por ejemplo las puertas $\mathrm{u}$ otros elementos de carácter poliorcético y su evolución, sin centrarse en el análisis puntual de casos individualizados. Podemos resaltar Jiménez Esteban $(1973,1995,1997)$ que estudia los tipos de puertas, especialmente las dispuestas en recodo o flanqueadas por dos torres, Kenyon (1990) que estudia las fortificaciones europeas especialmente las de Inglaterra, Seta (1991) que analiza la relación entre la ciudad y sus murallas, Valdeón Baruque (1991), Cámara Muñoz $(1998,2005,2007,2009)$ que centra sus estudios principalmente en la fortificación abaluartada y su evolución, García Fitz (1998, 2001, 2003, 2005) que investiga el papel de los castillos y recintos amurallados y los sistemas defensivos para el control del territorio en la Edad Media, Ruibal Gil (2000), Cátedra (2007) que analiza las murallas de Ávila desde la antropología y Cains (2010).

Hemos seleccionado otro conjunto de obras que hemos empleado a modo de inventario para localizar los posibles casos de fortificaciones y murallas urbanas que podrían interesarnos a la hora de tener referencias con las que comparar las fábricas de la cerca segoviana en nuestro análisis. Jiménez Estaban (1972) efectúa un repaso somero sobre los recintos amurallados medievales de Castilla y León, al igual que Espinosa de los Monteros (1974). Casa Martínez

\footnotetext{
${ }^{36}$ Merino de Cáceres (2005) tras un estudio de la métrica y los sistemas constructivos empleados en dicha torre concluye afirmando su filiación visigoda.
} 
(1990) nos permite identificar atalayas, torres, castillos y fortificaciones en general, tanto cristianas como musulmanas y por último Martín Jiménez (2003) nos sirve para listar los principales castillos de Castilla y León.

Dado el objetivo de esta tesis en esta primera aproximación a la bibliografía nos centraremos principalmente en los casos de fortificaciones de los reinos cristianos, dado que más adelante desarrollaremos en más profundidad la arquitectura militar hispanomusulmana. Así otro de los criterios de selección bibliográfica y de análisis de la misma, ha sido la búsqueda de referencias metodológicas que hemos considerado interesantes o aplicables a nuestro caso. Por este motivo se han consultado, desde el punto de vista de su planteamiento metodológico, manuales en los que se estudiasen distintas ciudades y murallas medievales en general y cristianas en particular. Destacamos Gutiérrez González (1989, 1990, 1995) que centra su interés en las fortificaciones del reino leones, Cooper (1991 y 2014) suscribe dos interesantísimos estudios sobre los castillos con un espléndido enfoque hacia la poliorcética, Mora Figueroa (1998) presenta un interesante estudio sobre los influjos recíprocos de la fortificación islámica y cristiana, Rodríguez Almeida (2002) es un buen estudio sobre la muralla de Ávila, Amo Horga (2003) analiza las murallas de Madrid, Villafruela Arranz (2005) nos ofrece una monografía sobre la muralla de Miranda del Castañar, García Valero (2005) nos brinda otra monografía sobre la muralla de Haza y Zevi (2006).

Una aproximación progresiva hacia nuestro ámbito de estudio nos lleva a profundizar en mayor medida en la bibliografía dedicada a las murallas urbanas de Castilla y León para contextualizar nuestro trabajo en su ámbito geográfico. La obra de Pérez de Tudela y Velasco (1991) sobre la arquitectura militar castellano leonesa entre los siglos VI y XIII, o el libro de Cobos Guerra (1998) sobre las fortalezas de Castilla y León, Cardiñanos Bardeci, (2001) con su trabajo sobre la arquitectura defensiva medieval en la ribera del Duero, o Navareño Mateos (2001) que estudia los castillos medievales de la Extremadura castellana, son unos buenos ejemplos que sitúan en el tema.

Algunos manuales más recientes son el extenso inventario que realiza Nieto González (2007) sobre el patrimonio arquitectónica militar de Castilla y León, el libro de Malalana Ureña (2009) sobre los recintos amurallados de Castilla y León, González Díaz (2012) sobre las fortificaciones en la frontera del reino de León (siglos XII-XIII) o el profundo análisis sobre las murallas urbanas de la época de Alfonso VI de Paz Peralta (2014).

Se han manejado algunos manuales de estudios monográficos que consideramos pueden tener relación, en diferentes aspectos, con la cerca segoviana. La comparación que Félix Benito realiza de la muralla de Zamora con la segoviana (Benito Martín, 1996) nos ha llevado a fijarnos en la muralla de dicha ciudad y en su evolución urbana. Por este motivo hemos prestado especial atención a la cerca zamorana, basándonos en algunos de los trabajos de los trabajos que la estudian, como Ramos de Castro (1978) y Gutiérrez González (1993).

La continuas referencias a la intervención de Raimundo de Borgoña en las murallas de Ávila y posiblemente también en la segoviana, ha motivado que estudiásemos el caso abulense. Así, nos han interesado los ya mencionados de Rodríguez Almeida (1980 y 2002), Bernard Remon (1990), Barrios García (2003), la restitución del proceso urbanístico de Ávila (Olmo Rodríguez, 2004) y Gutiérrez Robledo (2007 y 2009). Por último mencionar el trabajo de Guerra Sancho (2003) sobre la muralla de Arévalo y el de Iranzo Muñio (1986) sobre las murallas de Huesca y el importante análisis de la evolución urbana de Palma de Mallorca 
durante 1000 años, analizando la traza de la ciudad romana, la configuración de la medina hispanomusulmana y la transformación tras la conquista cristiana (García-Delgado Segües, 2004) como referencia de análisis para el estudio de la evolución urbana de Segovia y la configuración de su muralla.

\section{MURALLAS Y FORTIFICACIONES HISPANOMUSULMANAS}

Tras esta aproximación a la arquitectura medieval cristiana en la Península, de la arquitectura militar medieval musulmana, la que más nos va a interesar va a ser la de la época omeya, aproximadamente hasta el año 1000, con una mayor atención a las murallas y fortificaciones situadas al norte de la sierra o en sus proximidades por la ladera sur.

Como hemos visto en la parte dedicada a la estructura urbana, los primeros asentamientos musulmanes se efectúan sobre emplazamientos elegidos con fines claramente militares y principalmente sobre asentamientos visigodos previos. Esto nos lo confirma la arqueología, que poco a poco nos va ofreciendo más datos.

Un importante numero de fortificaciones de distintos tipos y categorías (oppida, civitates, castra, castella, turres, clausuras, fortines, etc) de la etapa visigoda permanecian en pie en el 711, algunas de ellas de origen romano, como Lucus Angusti, Asturica Augusta, Legio, Bergidium, Bracara, Tiermes, Uxama, etc (Gutiérrez González, 2011: 340). Algunas de éstas son empleadas por los musulmanes, como por ejemplo Zaragoza, Pamplona, Amaya, Astorga, León, Zamora, Gijón, Bergido y Lugo. Se trata de los principales núcleos urbanos amurallados integrantes del aparato administrativo estatal del reino visigodo (Gutiérrez González, 2011: 344).

Pero hay más. Se han identificado restos de fortificaciones hispanomusulmanas en Bernardos, Tedeja, Tabara y Muelas del Pan. La arqueología nos aporta pruebas irrefutables. Han aparecido numerosos enterramientos en Pamplona, en Zamora y restos cerámicos en León (Gutiérrez González, 2011: 341). Adicionalmente se han encontrado evidencias de la ocupación musulmana en Asturias, León, Zamora, Pamplona, Pirineos y Ruscina (narbonense) (Gutiérrez González, 2011: 343). La datación de estas fortificaciones resulta complicada por la falta de documentación en muchos de los casos. Algunas referencias nos hablan de una importante campaña de fortificación de la Marca Media en la segunda mitad del IX (Herrera Casado, 1985: 9-26). Posteriormente se efectúa otra, en tiempos de Abd-al-Rahman III, hacia la mitad del X, cuando este califa ordena al general Galib el refuerzo de la Marca Media. Otras referencias nos hablan de que la repoblación cristiana no ha sido tan rápida y que la presencia musulmana en el Duero se prolongó hasta el año 1000. En 997 una incursión de Almanzor llega a Compostela. A finales del reinado de Vermudo II (poco antes del año 1000) apenas se controlaba la cuenca del Duero, pues Zamora poseía una guarnición musulmana (Estepa Diez, 1985: 31), al igual que se supone ocurrió en Salamanca (Muñoz García, 2012: 423).

Queda patente que durante la etapa omeya existieron fortificaciones al norte del sistema central. La datación de estas fortalezas de la cuenca del Duero, e incluso más al norte, todas ellas anteriores al año 1000, debe hacerse en base a la arqueología y el análisis comparativo de sus fábricas con otras que estén más documentadas y estudiadas, generalmente situadas en la mitad sur de la península. Algunas de las principales fortificaciones omeyas, en base a las fuentes documentales son Badajoz, Bobastro, Calatrava, Córdoba, Talamanca, Talavera, 
Zaragoza, Evora, Mérida, Huesca, Gormaz, Lérida, Madrid, Sevilla, Málaga, Tarifa, Baños, Peñafora, Úbeda, Tudela y Calatalifa (Souto Lasala, 2002), enumeradas en su trabajo de sistematización de la arquitectura omeya de Al-Andalus. Idéntico cometido de sistematizar la arquitectura militar de Al-Andalus se plantea Fernando Valdés (Valdés Fernández, 2003).

En una primera aproximación panorámica destacamos las publicaciones de carácter general, que estudian de manera amplia el tema, o que en su día fueron importantes aportaciones pero ahora han quedado un tanto superadas, como por ejemplo Gómez Moreno (1934), Terrasse (1954), Grabar (1985), Hoag (1989), Ettinghausen (2000) o Martín Jiménez (2003).

La variedad de tipologías de asentamientos y fortificaciones musulmanas ha sido estudiada por numerosos autores, entre los que destacamos los estudios sobre Al-Andalus de Torres Balbás (1973 y 1981), su fortificación en Bazzana (1988), Acien Almansa (1995 y 1996), o sobre la fortificación islámica en general de Cressier (1998), Creigton (2005) Félix Hernández, Guichard, , Pavón Maldonado, Ewert, Almagro Gorbea, entre otros.

Juan Zozaya ha realizado un profundo estudio de los tipos de asentamientos musulmanes para el control del territorio (Zozaya Stabel-Hansen, 1991), en el que nos muestra cómo un asentamiento militar, inicialmente, evoluciona para convertirse en ciudad. Incide en el mismo tema (Acien Almansa, 2002: 59-75). La misma línea de investigación interesa a Álvaro Soler quien realiza, junto con Juan Zozaya un estudio sugestivo sobre los castillos omeyas de planta cuadrada (Soler y Zozaya, 1992).

Desde el punto de vista de su planteamiento metodológico, nos han interesado las siguientes obras que estudian la arquitectura militar hispanomusulmana. Uno de los primeros ejemplos es el trabajo de Félix Hernández (Hernández Giménez, 1942) quien realiza una minuciosa labor de documentación y análisis de la Alcazaba de Mérida. Igualmente meritorio el estudio de Ewert (1977 y 1978) sobre la arquitectura islámica y el pacientísimo estudio sobre la decoración del salón de AAR III en Madinat al-Zahra, o sobre la muralla de Balaguer (Ewert, 1979). Otros casos reseñables de estudios de murallas lo encontramos en la ciudad de Cuenca (Almagro Gorbea, 1976 y 1980), Huesca (Escó, Senac, 1987), (Naval Más, 1997), en Ayllón (Zamora Canellada, 1993), Vascos (Izquierdo Benito, 2005), (Bru Castro, 2012) o los cubos de la muralla de Zaragoza y la aljafería (Paz Peralta, 2014). Sobre el sistema defensivo musulmán entre las marcas media y superior de Al-Andalus (siglos X-XII) contamos con el trabajo de Alejandre Alcalde (2014).

Una aproximación progresiva hacia nuestro ámbito de estudio nos lleva a profundizar en mayor medida en la bibliografía dedicada a las murallas urbanas de Castilla y León, para contextualizar en su ámbito geográfico nuestro caso. Una primera referencia es la obra Michel Terrasse sobre la fortificación omeya de Castilla (Terrasse, 1967). Avelino Gutiérrez realiza un estudio sobre las fortificaciones visigodas y su adecuación tras la conquista islámica del norte hispano (Gutiérrez González, 2011).

Sin duda una de las fortalezas más conocidas y estudiadas de Castilla y León es la califal de Gormaz, que cuenta con numerosos estudios (Gaya Nuño, 1935 y 1943; Zozaya StabelHansen, 1988; Almagro Gorbea 2008), por señalar las más destacadas. Pero en general, la provincia soriana es la más rica en muestras arquitectónicas lo que ha permitido un mayor número de estudios. Gaya Nuño (1944) estudia las atalayas de frontera para vigilar y controlar el territorio de la zona de Soria. Lorenzo Celorrio (1994) centra su atención en las torres 
refugio del califato, mientras Lázaro Carrascosa (2007) analiza el sistema defensivo musulmán en la zona de Soria entre los siglos X y XII. Félix Benito nos ofrece una monografía sobre la ciudad y murallas de Agreda (Benito Martín, 1995).

Uno de los autores que mayor número de obras dedica a las fortificaciones musulmanas es Juan Zozaya, entre las que destacamos sus tres trabajos centrados en las ciudades amuralladas de Castilla y León (Zozaya Stabel-Hansen, 1991, 1992, 1994), o sobre las murallas y fortificaciones musulmanas en general (Zozaya Stabel-Hansen, 2002, 2007 y 2009), con un monográfico especifico sobre las fortificaciones en el valle del Duero (Zozaya Stabel-Hansen, 2010). También en el valle del Duero nos ha resultado interesante el estudio sobre las murallas de Salamanca de Michel Muñoz (Muñoz García, 2012).

Basilio Pavón nos presenta un amplio estudio sobre la fortificación hispanomusulmana (Pavón Maldonado, 1999) con una importante recopilación que a modo de inventario nos permite identificar un fecundo número de casos de estudio. Del mismo autor hay que destacar su obra sobre la arquitectura hispanomusulmana en la provincia de Guadalajara (Pavón Maldonado, 1984), recopilatorio de la arquitectura militar en esta zona, al sur de la sierra pero en la que hemos encontrado numerosos paralelismos con la arquitectura de hispanomusulmana existente en la provincia de Segovia. El mismo ámbito territorial de estudio contempla la obra de Antonio Herrera (Herrera Casado, 1985) y la de María Luisa Bueno (Bueno Sánchez, 2005) que efectúa un repaso al estado de la cuestión de las fortalezas hispanomusulmanas en la cuenca del Alberche. También al sur de la sierra mencionar los diversos estudios sobre las murallas de Madrid (Montero Vallejo, 1986; Mena Muñoz, 2003; Malalana Ureña, 2011) o el intento de restitución del trazado de la muralla, pero sin efectuar un estudio constructivo, de Gea Ortigas (2008).

Otra de las ciudades ampliamente estudiada es Toledo, donde destacamos los interesantísimos estudios de Delgado Valero (1987), Carrobles Santos (2004) y Ruiz Taboada (2005) centrándose éste último en la transformación de la muralla con las reformas cristianas tras la toma de la ciudad por Alfonso VI. Más específicos, centrándose sólo en el análisis de sus puertas (Sánchez Chiquito, 1993 o Valdés Fernández, 1987), éste último sobre la puerta de la Bisagra. Muy cercana a Toledo, Talavera de la Reina, está ampliamente estudiada por Sergio Martínez (Martínez Lillo, 1987 y 1998) en la que también encontramos rasgos comunes con la cerca segoviana.

Algunos casos más de monografías dedicadas a recintos amurallados, alejándonos del entorno segoviano, son los estudios de Rosa Gomes sobre Silves (Gomes Varela, 1992 y 2002), o Badajoz (Lozano Tejada, 1983), Sevilla (Jiménez Maqueda, 1999), Mertola (Macías, 2006), Cáceres (Márquez, Gurriaran, 2003), o las murallas urbanas de Marruecos en la Alta Edad Media (Gonzalbes Cravioto, 1998).

El estudio de la construcción de la arquitectura hispanomusulmana tiene uno de sus ejemplos más relevantes en el trabajo sobre el alminar de la mezquita mayor de Córdoba (Hernández Giménez, 1975), sin duda la publicación más minuciosa sobre las técnicas constructivas omeyas, en palabras de Acien Almansa, otro de los estudiosos de la arquitectura omeya. Otros autores de trabajos destacables sobre las técnicas constructivas omeyas son Creswell (1979 y 1989), Almagro Gorbea (1976 y 1980) sobre los sistemas constructivos y aparejos musulmanes del castillo de Cuenca, Azuar Ruiz (2005) o Miranda Sánchez (1995) cuyo trabajo sobre los sistemas constructivos existentes en la ciudad de Toledo nos ha aportado un interesantísimo 
catalogo de aparejos. También queremos destacar el estudio de Amador Ruibal sobre los antecedentes bizantinos en la arquitectura militar omeya (Ruibal, 2005).

Uno de los aspectos fundamentales de las fortificaciones es su valor poliorcético, si bien en el caso de la cerca segoviana, la excelente elección del emplazamiento hace prácticamente innecesario el que se haya prestado atención a este aspecto en el diseño para su construcción. Salvo las puertas, el resto de la muralla no requiere elementos de defensa adicionales que los parapetos y merlones de sus adarves. Aun así, hemos querido indagar en este tema, que no deja de ser el principal motivo por el que se construyen las murallas urbanas y las fortificaciones. Uno de nuestros primeros objetivos era dominar un vocabulario que por específico y técnico no manejábamos correctamente. Son fundamentales para este fin los glosarios de términos sobre arquitectura defensiva (Mora Figueroa, 1996; Villena Pardo, 2005), así como comprender las armas de asedio, las técnicas de ataque medievales, los mecanismos arquitectónicos de defensa, así como su evolución a lo largo del tiempo (Cooper, 1991 y 2014; Zozaya Stabel-Hansen, 1992; Mora Figueroa, 1998; Villena Pardo, 1998; Mondéjar Manzanares, 2007 y Sáez Abad, 2009) con su estudio sobre los asedios de la antigüedad.

Como se ha indicado, las puertas de las murallas son los puntos más débiles de toda la defensa, por lo que son sobre los que suelen aplicarse los más importantes recursos poliorcéticos, y por ende, donde se centran los estudios específicos. Destacamos el estudio sobre las puertas de las fortificaciones musulmanas en España de Leopoldo Torres (Torres Balbás, 1974), sobre las puerta en recodo (Torres Balbás, 1960; Jiménez Esteban, 1973) o las puertas flanqueadas por dos torres (Jiménez Esteban, 1974).

\section{MURALLAS Y FORTIFICACIONES EN EL ENTORNO DE SEGOVIA}

Como hemos visto, muchos son los autores que han dedicado su atención a la ciudad de Segovia, pero las referencias bibliográficas a las fortificaciones de la provincia de Segovia no son tan numerosas, siendo las más abundantes las de la zona próxima a la provincia de Soria.

Encontramos referencias de interés en algunas obras de ámbito más general como el estudio comparativo sobre la fortificación islámica y la cristiana en el alto Duero (Retuerce Velasco, 2004) o el de las vías de comunicación del estado omeya (Zozaya Stabel-Hansen, 1987 o LLull Martínez de Bedoya, 1987).

Existen varias publicaciones sobre las fortificaciones de las provincia de Segovia, con breves alusiones a cada una de ellas, (Bernard Remon, 1990; Martín Jiménez, 2003), algunas de mero valor literario y poético sin contenido científico (Moragón Agudo, 1995) y otras a modo de inventario recopilatorio, de mucho mayor interés investigador (Zamora Canellada, 2008). Pocos estudios más podemos reseñar dentro de la provincia segoviana, un escueto artículo sobre el recinto murado de Coca de escaso interés para nuestro trabajo (Blanco García, 1992) y el artículo sobre los sistemas constructivos de las murallas de las comunidades de Villa y Tierra (Sáinz Esteban, 2015) que puede tener bastante relación con la muralla de repoblación de la ciudad de Segovia. De las posibles evidencias arquitectónico-arqueológicas que existen de las fortificaciones musulmanas en la provincia contamos también con pocos casos, recopilados por Alonso Zamora (Zamora Canellada, 1994 y 1997) que veremos más detenidamente en el último apartado dedicado a las evidencias de la presencia musulmana en Segovia. 


\section{LAS MURALLAS DE SEGOVIA}

La ciudad de Segovia, situada a los pies de la vertiente norte de la Sierra de Guadarrama, en una posición de control para el paso a la submeseta sur, ha tenido históricamente una importante connotación defensiva, por su situación sobre un escarpe natural casi inaccesible, perfilado por el río Eresma y el arroyo Clamores (Abella y Yoldi, 1993: 34). Como continuación de este sistema defensivo natural aparece su muralla, con un perímetro aproximado de $3,5 \mathrm{~km}$ de longitud, apoyada sobre los afloramientos de la roca madre y adoptando la forma alargada del espigón formado por la confluencia de los dos ríos, rodeando una superficie de unas 40 hectáreas.

Parece evidente que en una ciudad como Segovia, ocupada por distintos pueblos a lo largo de los siglos, deben haber existido varios recintos fortificados. Anteriores a la repoblación, encontramos documentadas construcciones defensivas de época celtíbera (Martínez Caballero 2010: 143-181; Labrador Vielva, 2015), de la etapa romana (Illarregui Gómez, 2010: 74), si bien este autor aporta pocos datos que respalden sus afirmaciones. Ya en el año 146 a.C. se cree que la ciudad contaba con defensas (Ruiz Hernando: 1986, 21). Dos autores defienden sin reservas la autoría hispanomusulmana de algunas partes de la muralla segoviana en las proximidades de la puerta de San Andrés (Zozaya Stabel-Hansen, 1987; Alonso Zamora, 1994), hipótesis con la que estamos completamente de acuerdo. Sin embargo estos mismos lienzos son considerados como fábrica mudéjar, realizada ya en la etapa cristiana, por Pavón Maldonado (1999: 239) que no debe haber observado con detenimiento la base de estos lienzos y torres.

La muralla de Segovia es un monumento muy poco estudiado. No existe ninguna monografía ni publicación específica dedicada a ella, tan solo algunos artículos puntuales o menciones parciales en publicaciones.

La primera descripción que se conserva de la muralla la ofrece en 1822 Joaquín de Góngora, coronel de artillería.

En la nominación de las Puertas se sigue el curso de la muralla principiando por la del Alcázar que mira al Oeste y continuando hacia el Sur, Este y Norte. La muralla tiene 40 estadios griegos ó 4.000 pasos de dos pies, según la Historia de Segovia; y efectivamente, produce el plano, sin el perímetro del Alcázar, 8 mil pies griegos ú 8.833 pies españoles. También se nombran como puertas los arcos que hay a los extremos N. O. y S. E. de la población y principia en ellas los caminos reales de Valladolid y de Madrid (Góngora, 1963).

Carlos de Lecea hace un somero repaso del trazado y composición de la muralla que no pasa de enumerar las puertas y postigos o el número de torres que se conservan y la longitud de su trazado.

La muralla tiene una longitud total de 4.075 varas castellanas, 12.220 pies castellanos o lo que es 10 mismo $3 \mathrm{~km}$ y $406 \mathrm{~m}$. El espesor de los lienzos alcanza los 9 pies castellanos, que equivalen a 2,50 m. La altura media de la muralla desde el pie de la roca, donde se cimenta, hasta los merlones de coronación se estima en 34 pies castellanos, es decir 9,47 m. Se conservan 86 cubos (Lecea y García, 1906: 51-54). 
Sin duda la posterior de José María Quadrado es la de mayor lirismo y una de las que mejor recoge esa indisoluble unión de ciudad y naturaleza en la que median las murallas.

Con tantos monasterios más o menos bien conservados en su mayor parte, con tantas bellas y veneradas parroquias, con tantas torres de iglesias y palacios signos de carácter tan religioso como guerrero, compone Segovia un precioso ramillete sujeto por la cinta de sus vetustas murallas, o entretegido entorno cual guirnalda, o tendido cual alfombra en su estenso arrabal. Su situación costanera, el aspecto de sus edificios y su colocación en anfiteatro, el semicírculo que aislándola describe a su alrededor el río, la asemejan a la sombría, a la magestuosa Toledo; mientras que la ribera por lo ameno, sus alamedas por lo frondoso, su horizonte por la nevada sierra en que derrama rosados y suaves tintes el sol poniente, recuerdan, al menos en verano, a la deliciosa Granada... (Quadrado, 2007: 425-428).

Según la descripción de Pascual Madoz:

Dividese la población en ciudad propiamente dicha y arrabales; la primera se halla cercada de una antigua y bien reparada muralla, que se extiende 4.075 varas lineales, cuya altura por término medio desde el pie de la cresta de la roca hasta sus almenas es de 34 pies, y su espesor 9 pies; está defendida en todo su recinto por 83 cubos, repartidos en proporcionadas distancias; 6 fuertes o baluartes sobre algunas de sus puertas.... Esta muralla tiene 5 puertas, 2 portillos y 3 postigos (Madoz, [1849] 1984).

Existen otras descripciones, como la del estudio geotécnico elaborado por José María Rodríguez (AMS: 4810-3: 7) y (AMS: 4810-3, II: 48) o la Francisco Javier Cabello en su obra sobre la arquitectura románica de Segovia (Cabello Dodero, 1952: 35) o la de catálogo monumental de la provincia de Segovia (Rodríguez Marín, 2013). Como puede verse, son textos en muchos casos meramente enumerativos, a veces incluso con más valor poético que científico, en los que no se efectúa un análisis, no se plantean preguntas. En algunos casos, se arrastran datos en los sucesivos trabajos sin verificarlos, produciéndose contradicciones, como por ejemplo la forma de las torres o el número de torres existentes, en que se aprecia falta de unanimidad entre los distintos autores. Aún mayor es la disparidad de las que se supone existieron inicialmente. Según el estudio geotécnico, elaborado en 1998 se conservan 70 de las 83 originales (AMS: 4810-3: 2), 83 es el número que da Oliver Copons de las que existen cuando redacta su texto en 1916. Sin embargo para Madoz existen 86 torres, en 1845-1850. Esto evidencia una escasa observación del documento construido y que no se han efectuado lecturas constructivas ni de interpretación de las discontinuidades, cambios de forma o de modulación de las torres y lienzos. O quizá pueda ser una demostración del ritmo al que evoluciona la ruina y destrucción de la muralla.

Las murallas de Segovia han sido mencionadas por numerosos autores, que han hablado de la ciudad, sin embargo, resulta curioso el escaso interés que muestran estos autores por las murallas de la ciudad. Ofrecen algunos datos Ruiz de Castro ([1551] 1988), Colmenares ([1637] 1922) y las descripciones de Lecea y García (1906), Oliver Copons ([1916] 1989), Joaquín de Góngora (1963), Madoz ([1849] 1984) y Quadrado (2007), pero se trata de menciones muy sucintas en la mayoría de los casos meras descripciones, si bien algunos datos poseen un alto valor documental, que vemos con más detenimiento.

Si bien el trabajo de Oliver Copons ([1916] 1989) es una monografía dedicada al Alcázar, nos sitúa los postigos del obispo y del parque, junto a la cava de esta fortaleza, afirmando que 
incluso quedaba, porque llega a verlo en 1916, una rampa de acceso al postigo del parque. Según Merino de Cáceres $^{37}$, es el postigo del obispo el paso que se ha descubierto recientemente en unas obras acometidas en el verano de 2016. De ser cierta la hipótesis de Merino de Cáceres, Oliver Copons lo debía haber ubicado erróneamente ya que el hallazgo se sitúa desplazado varias decenas de metros del foso del Alcázar. El refuerzo de la ciudad se lo confía Alfonso VI a Rodrigo Gutiérrez.", Justicia Mayor de Segovia (Oliver Copons, [1916] 1989: XLIII) aprovechando fragmentos de la muralla que se encontrarian y los materiales dispersos procedentes de las destrucciones de los últimos años (Oliver Copons, [1916] 1989: 11). Con estas afirmaciones, el autor nos está dejando claro su suposición de que existirían unas murallas previas a la repoblación y mucho material de expolio.

En la descripción de su Catálogo Monumental, el autor (Rodríguez Marín, 2013: 31) nos dice que desde el Salón hasta la puerta de San Andrés existen 7 torres de construcción y planta diversa. Su afirmación nos hace comprender que ya denota que son torres de distinta etapa constructiva, pero no lo analiza, sólo lo enumera. Y hablando de la puerta de San Andrés, nos dice: Las cornisas con bolas, almenas piramidales y saeteras en cruz determinan claramente la fecha de construcción (Rodríguez Marín, 2013: 31) adscribiendo la autoría de dicha reforma de la puerta a Juan Guas.

Nos encontramos ante una muralla que está escasamente investigada desde el punto de vista técnico, de comprensión y entendimiento de sus fábricas. Existen algunos estudios pero como señala Alonso Zamora, la muralla de Segovia está muy poco estudiada (Zamora Canellada 2008: 633). No existe ningún estudio sobre la muralla segoviana realizado por arqueólogo o arquitecto en que se analicen los sistemas constructivos, sus aparejos, los elementos defensivos o que se realice un análisis arquitectónico de sus elementos o de la métrica de sus torres y lienzos. No se han realizado investigaciones sobre su influencia e interacción en la configuración urbana, ni en la evolución histórico constructiva. No existen lecturas de sus paramentos, ni análisis en que se intenten descubrir las diferentes fases constructivas y asignarlas cronologías, ni que se analicen el origen y disposición de los materiales constructivos empleados o reaprovechados, ni nuevos planteamientos que analizando el elemento construido conciban inéditas interpretaciones que pongan en cuestión la hipótesis tradicionalmente aceptada.

Esta hipótesis atribuye la construcción de la muralla de Segovia al rey Alfonso VI, repoblador de la ciudad en 1088 según los Anales Toledanos Primeros. Así lo asume Antonio Ruiz, en su historia del urbanismo de Segovia, (Ruiz Hernando, 1982) quien vincula la construcción de la muralla a la repoblación dando por concluida su construcción en el año 1122, basándose en el documento mediante el cual el Concejo de la ciudad cede al Cabildo catedralicio los terrenos para la construcción de la catedral y el barrio de los canónigos, terrenos que se delimitan por el alcázar, las murallas, el postigo de San Andrés y la puerta de Rodrigo Ordóñez, que este autor identifica con la de Santiago.

Quizá los únicos documentos técnicos de carácter global a este respecto sean el Estudio geotécnico (AMS: 4810-3) y el Plan Director de las murallas (PH: P0035), éste último se basa en el primero, actualizando algunas de las informaciones que han quedado obsoletas por

\footnotetext{
${ }^{37}$ El Adelantado de Segovia, edición del 13 de agosto de 2016.

${ }^{38}$ Creemos que se trata de un error y que se refiere a Rodrigo Ordóñez, ya que Rodrigo Gutiérrez aparece citado 100 años más tarde, reinando Alfonso VIII. Esto encaja con el hecho de que se denomine puerta de Rodrigo Ordóñez.
} 
nuevos descubrimientos o subsanando erratas. Constituye una importante recopilación de la información existente en los archivos y bibliotecas sobre la muralla y ofrece un completo repaso al estado de conservación de la muralla, por lo que supone un buen punto de partida para nuestro estudio. Pero se centran en el estado de conservación, sin entrar en lecturas de fases constructivas, discontinuidades o cambios de forma de torres. No hay un análisis de su historia, sino sólo una enumeración de los documentos identificados en que se menciona la muralla sin un mayor análisis de los mismos, centrándose en valorar las lesiones existentes en las fábricas, la fracturas de la roca de apoyo y el estado de conservación en general.

Son innumerables los documentos que obran en el archivo municipal poniendo de manifiesto el nefasto estado de conservación en que se encuentra la muralla durante siglos, así como las numerosas contribuciones económicas que se realizan para obras de reparación y mantenimiento y en algunos casos, reconstrucciones completas de lienzos que se han arruinado.

Existen aportaciones puntuales, generalmente vinculadas a los hallazgos de alguna excavación arqueológica o de algún legajo o documento encontrado en los archivos como Larios y Bernaldo de Quirós (1972) o el artículo de Peñalosa (1949) sobre la guerra de Sucesión, que aporta algunos datos sobre el refuerzo de las murallas. Aportan numerosos datos, que permiten situar derrumbes, reparaciones y aportan una fotografía bastante aproximada del continuo problema de conservación que han supuesto a lo largo de los siglos, pero en ningún caso relacionados con la datación, los aspectos constructivos o estilísticos, o las fases constructivas de la muralla. Estos estudios específicos son escasos, siendo la mayoría de ellos centrados en la obtención de datos históricos extraídos de la documentación existente en los archivos que nos aportan datos sobre las intervenciones realizadas a lo largo de los siglos XVII y XVIII. Su procedencia, principalmente de los libros de Acuerdos, Actas y demás documentos del protocolo administrativo, motiva que su principal interés sea el monto económico de dichas reparaciones y quien debe costearlo. Estas actas, son tan genéricas que en numerosos casos resulta incluso imposible ubicar el emplazamiento de la intervención en cuestión. Si bien las descripciones de las obras no matizan en exceso, gracias a estos documentos se han podido situar aproximadamente algunas de las intervenciones e identificar los lienzos en los que más reparaciones documentadas se han realizado. Sin duda María Eugenia Contreras (Contreras Jiménez, 1986, 1989 y 1992) es la que mayor número de estudios ha publicado sobre las numerosas reparaciones que se han efectuado en la muralla a lo largo de la Historia También trata la muralla en su artículo sobre la casa de la moneda (Contreras Jiménez, 2010) en el que aporta unos datos interesantísimos para la restitución de la puerta de San Juan.

Esta evolución de la muralla a lo largo de la Historia a partir especialmente del siglo XV va a quedar registrada por los documentos existentes en los archivos, principalmente generados con motivo de los litigios entre los vecinos de la ciudad, así encontramos denuncias por el apoyo o por adosarse edificaciones particulares a la muralla, ocupando sus adarves y los caminos de ronda o privatizándolos al cercarse las parcelas adyacentes (Asenjo González, 1986: 64-65), denuncias por los desprendimientos de piedras, derrumbes y los riesgos de que estos se produzcan debido al mal estado de conservación, pleitos por aclarar a quien corresponde asumir dichas reparaciones, así como reiteradas prohibiciones de extracción de tierras de la base de la roca sobre la que se apoya. Este material es una fuente de información para la elaboración de algunos artículos que se refieren de manera específica a la muralla. 
Así por ejemplo, tenemos un brevísimo articulo de Mariano Quintanilla (Quintanilla, 1954) que saca a la luz, legajos y documentos del archivo municipal, sobre reparaciones en la muralla. Si bien su interés se centra en el valor documental del hallazgo, su descripción nos ha servido para plantear restituir la ubicación del desaparecido postigo de fuente cercada. El artículo de Chico Rello (1949) sobre el derrumbe de la roca en el que se vio afectada la casa del Marqués de Lozoya, nos aporta unos datos muy interesantes en relación a la desaparecida puerta de San Juan. Un artículo de Chaves Martín (2003) estudia las 5 puertas que existieron en la muralla segoviana en los que se efectúa una descripción de la composición de dichas puertas y de los avatares sufridos por las mismas. Describe su faceta histórica y arquitectónica, centrando un mayor interés en el proceso de demolición de las puertas de San Juan y San Martín. De los postigos existentes, tres de ello son reconstruidos en el siglo XX, los postigos del Sol, de la Luna y el del Consuelo (Chaves, 2006).

La puerta de San Juan, demolida en 1888, de la que se conserva una fotografía de Loty era una puerta datada en 1707 que sustituía a la original de la que desconocemos su composición original. El mismo destino tuvo la puerta de San Martín, demolida en 1885, a la que Antonio Ruiz también dedica un artículo (Ruiz Hernando, 1994) y de la que se conserva un grabado de Pérez de Castro y un par de fotografías de Laurent y Loty. En este caso, la demolida tampoco era la puerta medieval, dado que la data en el XVI. De las otras puertas nos indica que la de San Cebrián sufre una gran reforma en el XVIII que la da el aspecto actual mientras la de San Andrés adquiere su configuración actual en una reforma del XV-XVI. Esta puerta aparece mencionada como postigo, "Posticum" en el documento de cesión de la canonjía por parte del ayuntamiento al cabildo catedralicio (Ruiz Hernando, 1982). La puerta de Santiago también adquiere su configuración actual en una reforma del siglo XVI (PH: P0166).

Antonio Ruiz enumera las puertas y postigos que existieron y nos sitúa el postigo picado que lo descubre tapiado durante unas obras en la parcela intramuros y da la posición aproximada de los postigos de fuente cercada, obispo y del parque (Ruiz Hernando, 1973: 93).

El empleo de la metrología para la datación de las obras arquitectónicas es una técnica aprovechada con relativa frecuencia, especialmente en edificios de planta regular, como por ejemplo catedrales, iglesias, mezquitas, incluso palacios y otra arquitectura civil. El hecho de que cada país, cultura o civilización, emplearse, hasta el siglo XIX, unidades de medida diferentes basadas en el cuerpo humano, ha permitido identificar unas unidades de medida con unas arquitecturas y épocas constructivas. Si bien este sistema no lo consideramos muy adecuado para una muralla urbana, máxime cuando su trazado se ciñe a la topografía, si que hemos empleado algunos principios de metrología para distinguir en la muralla distintas modulaciones constructivas.

Sobre la muralla de Segovia no se ha empleado esta técnica de trabajo en ningún estudio previo. Existe un artículo de José Miguel Merino sobre la torre de la iglesia de San Millán de Segovia, en el que concluye que la métrica empleada es visigoda (Merino de Cáceres, 2005). Esto obviamente encaja con las hipótesis que manejamos de la existencia de población antes de la repoblación impulsada por la monarquía, especialmente en los barrios extramuros. Ante la falta de estudios específicos dedicados a Segovia y su muralla, hemos recurrido con fines metodológicos a algunos estudios referidos a la métrica de la arquitectura medieval en general (Esteban Llorente, 2007), o al empleo de las medidas de los materiales para la datación de los edificios (Naval Más, 1998), y de manera especial a la modulación en codos de la arquitectura 
musulmana (Vallvé Bermejo, 1976), y a los estudios efectuados sobre la métrica de la mezquita de Córdoba de Félix Hernández (Hernández Giménez, 1961).

A falta de documentos históricos que nos permitan datar correctamente las fábricas de la muralla segoviana, el estudio de sus aparejos y las lecturas constructivas de sus paramentos son las herramientas más eficaces que podemos emplear para avanzar en el conocimiento. Referencias metodológicas para conseguir este fin existen muchas, de las cuales hemos enumerado ya la mayor parte en fases anteriores de nuestro discurso. Podemos destacar los trabajos sobre los aparejos de la arquitectura toledana (Miranda Sánchez, 1995), los innumerables trabajos de Juan Zozaya a este respecto (Zozaya Stabel-Hansen, 1998), el estudio de los aparejos omeyas en Medellín y otras arquitecturas andalusíes (Márquez Gurriaran, 2005) o el de las fortificaciones andalusíes en sillería (León Muñoz, 2008) y (Zueco, 2012).

Sobre técnica constructiva medieval en la provincia de Segovia contamos con el ya mencionado artículo de Alicia Sáinz (Sáinz Esteban, 2015) sobre los sistemas constructivos de las murallas en las comunidades de Villa y Tierra, en que estudia los casos de Coca, Cuellar y Montejo o el artículo de Ignacio Hernández (Hernández García de la Barrera, 2007) sobre los sistemas constructivos medievales en la ciudad de Segovia. Ambos autores se centran especialmente en las fábricas de tapia encofrada.

Poco se ha escrito sobre los paramentos y aparejos de la muralla de Segovia desde el punto de vista constructivo. Juan Zozaya relaciona los aparejos existentes en los lienzos de la muralla cercanos al postigo del Sol, sobre los que apoya la sinagoga, en la zona sur, con los castillos omeyas del desierto de Siria y Jordania (Zozaya Stabel-Hansen, 2009: 117). En otra obra previa (Zozaya Stabel-Hansen, 1987) llama la atención sobre la presencia de zarpas y aparejos de sillería de raigambre hispanomusulmana, en unas pocas torres en las proximidades de la puerta de San Andrés, que relaciona con Mérida, Trujillo y Gormaz. Propositivamente sin duda se trata del primer autor en realizar una hipótesis interesante que abre numerosas vías de investigación, constituyendo un importante punto de apoyo para nuestra hipótesis de la existencia de una muralla previa a la repoblación de la ciudad.

Sobre estas zarpas y aparejos también se pronuncia Alonso Zamora, que los relaciona con Sepúlveda y algunos casos de la provincia de Guadalajara (Zamora y Vela, 2005). En un trabajo anterior (Zamora Canellada, 1994) estudia un aparejo encintado que data en el siglo XI y que localiza igualmente en el norte de la provincia de Guadalajara y en algunos pueblos de la zona oriental de la provincia segoviana. Sin embargo este aparejo no lo hemos encontrado en la muralla de Segovia. Estas son todas las alusiones bibliográficas a la existencia de una muralla previa, de origen hispanomusulmán, las referencias de Zozaya y Zamora a la existencia de zarpas en la base de algunas torres cercanas a la puerta de San Andrés y el aparejo que Zozaya relaciona con los del desierto de Siria y Jordania.

Lo más reciente son dos artículos en los que hemos colaborado (Herrero García, 2014 y 2015) sobre el sistema de tapias con que se ha construido la muralla segoviana, en los que se deducen las diferentes tipologías y modulaciones de las fábricas de tapia encofrada existentes. Para este tipo de fábricas, nos ha resultado de gran utilidad el trabajo de Fernando Cobos sobre las fortificaciones de tapia encofrada en la frontera del reino de León (Cobos Guerra, 2012). 
La existencia de piezas reutilizadas en las murallas de Segovia está documentada para aquellas más fácilmente identificables gracias a la epigrafía, las lápidas romanas procedentes del expolio de los cementerios que deberían encontrarse en las proximidades de la ciudad (Santos Yanguas et alli, 2005). En este estudio se justifica su distribución por la muralla por la proximidad al emplazamiento donde debieran encontrarse los cementerios romanos. Pero no entran a valorar su disposición en las distintas partes de la muralla o la composición de los distintos aparejos. No existe ningún estudio para las numerosas piezas, sillares, tambores de columna, molduras y restos en los que no existe epigrafía, procedentes de distintos edificios, cuya reutilización en la muralla no es fácil de datar, pero que en algunos casos nos inducen sospechas a investigar. Juan Zozaya da algunas pautas de cómo interpretar la presencia de spoliae en las fábricas, generalmente musulmanas (Zozaya Stabel-Hansen: 2013) mientras que para Cressier (2001: 311), significa la ruptura con el orden político precedente.

\section{LA PRESENCIA HISPANOMUSULMANA EN SEgOVIA}

Las evidencias arquitectónicas altomedievales son más numerosas en la zona oriental de la provincia de Segovia, hablándonos de una temprana repoblación de aquella zona por la presencia de las iglesias románicas ${ }^{39}$ (Santamaría López, 1984: 88). De las evidencias arquitectónicas musulmanas contamos con las zarpas que se conservan en las murallas de Sepúlveda, datadas entre fines del IX y principios del X (Martín Aymerich et al, 1990), Ayllón (Zamora Canellada, 1993), Fuentidueña (Zamora Canellada, 1997 y 2005: 1138) y el yacimiento del cerro del castillo de Bernardos (Gonzalo González, 2006). Antonio Ruiz, en su estudio de las fábricas de ladrillo, considera los muros de Fresno de Cantespino como muy islámico (Ruiz Hernando, 1988: 41). De todo ello, concluimos que la presencia musulmana es indiscutible en la zona oriental de la provincia, a la vez que podemos afirmar que la repoblación cristiana en dicha zona, es anterior a la fecha de 1088. ¿Pero que se ha dicho de la ciudad de Segovia?

En relación con las iglesias de la zona oriental de la provincia, la iglesia de San Martín de Segovia, presenta un mayor arcaísmo (Santamaría López, 1984: 88), los hallazgos a raíz de las excavaciones en la iglesia de San Juan de los Caballeros (Zamora Canellada, 2006), refuerzan la continuidad poblacional del recinto amurallado segoviano y la presencia de zarpas en las torres de la muralla de Segovia, hacen que podamos considerar de manera muy justificada que la supuesta falta de restos en Segovia está motivada, realmente, por la falta de estudios.

Las únicas referencias documentales encontradas desde entonces a la repoblación de Alfonso VI, nos hablan de la cesión de 200 fortalezas por Sulayman a Sancho García a cambio de su apoyo para hacerse con el califato cordobés, compromiso adquirido en 1009 y que se materializa en 1011 (Martínez Diez, 2005: 613-627), (Gautier Dalché, 1989: 58). El conde castellano apoya a la facción bereber de Sulayman frente a la eslava de Mahdi durante la fitna cordobesa. De las 200 fortalezas que dicen recuperarse, se enumeran las de San Esteban de Gormaz, Aza, Clunia, Sepúlveda y Atienza (Estepa Diez, 1985: 33).

\footnotetext{
${ }^{39}$ El ábside del Salvador de Sepúlveda esta datado en 1093, San Frutos del Duratón está consagrada en 1110 y la torre de la Virgen de la Peña, también en Sepúlveda, en 1144.
} 
Si como suponemos en nuestra hipótesis, Segovia se hallaba incluida en el listado de esas 200 fortalezas, tras cuya entrega los musulmanes se retiran a la cara sur de la Cordillera, la repoblación iniciada por este conde castellano, podría haber afectado también a Segovia ${ }^{40}$. De ser cierto, la ciudad se encuentra en poder de los reinos cristianos desde principios del siglo XI, lo que aporta lógica al ataque a Segovia ${ }^{41}$ de Al-Mamún en 1072, antes de la proclamada oficialmente repoblación de 1088, lo que, a nuestro juicio, evidencia que la ciudad estaba poblada y posiblemente defendida con murallas. Hasta ese momento, la debilidad de los reinos de taifas, hace que la frontera sea una zona relativamente tranquila, libre de ataques provenientes del sur, lo que permitiría el desarrollo de la ciudad (Ríos Mazcarelle, 1995: 250).

La historiografía tradicional ha defendido que la inestabilidad política reinante en la Península a partir de los comienzos del siglo $\mathrm{V}$, provoca la despoblación de numerosos asentamientos previos y posiblemente la desaparición de muchos de ellos. Esta despoblación se verá aun más agravada por la invasión musulmana. Sin embargo, si consideramos que Segovia, al inicio de la ocupación musulmana, era una sede episcopal visigoda situada en un estratégico y bien defendido emplazamiento, en un entorno densamente habitado (a la vista de la abundancia de necrópolis visigodas), parece creíble que la ciudad estuviese poblada y a la vez impensable que los musulmanes no la ocuparan para controlar este territorio.

Segovia es conquistada en el 755 por el caudillo cordobés Abd-al-Rahman I, recuperándola el conde Fernán González en 933, aunque no definitivamente ya que Abd-al-Rahman III, volvería a tomarla. Enterado Fernán González de la pérdida de la ciudad, acudió en su auxilio y después de no pocos esfuerzos y alardes de valentía, pudo rescatarla de nuevo (Ballesteros Martín, 2011: 17-18). Es bien sabida la multiplicidad de cercas con que contaban las ciudades hispanomusulmanas rodeando la Medina y cada uno de los distintos arrabales que la componían. ${ }^{42}$ Sin embargo, en Segovia no se han constatado hasta el momento evidencias materiales que permitan defender categóricamente la presencia musulmana.

Hemos visto que en Segovia se produce una disminución poblacional, pero no una despoblación absoluta. Un estudio del entorno cercano de la ciudad de Segovia, nos demuestra que la falta de documentos escritos, supone falta de información (o de su estudio) pero no falta de población (Alonso Ávila, 1989). En base a la toponimia se puede asegurar la continuidad poblacional a pesar de la ausencia de vestigios arqueológicos, que el tiempo y la búsqueda sistemática irán, sin duda, aportando en un futuro (Barrio Martín, 2010; González y

\footnotetext{
${ }^{40}$ Se ha constatado la repoblación de Collado Hermoso, a escasos kilómetros de Segovia, antes de 1017 (Martínez Diez, 2005: 631). También se repueblan en 1116, Sotosalbos, Pelayos, Collado Hermoso. Pozuelos en 1149 y Luguillos en el XIII. El Monasterio de Párraces y Santa María de la Sierra numerosas granjas o alquerías que se acabarían convirtiendo en pueblos (hasta 12). También se crearon numerosas villas (que recibían el nombre de sus pobladores) Víllamayor, Villaverde, Villanueva, Villagonzalo, etc (Represa Rodríguez, 1969: 229).

${ }^{41}$ La incursión contra Segovia de Al- Mamún rey de la taifa toledana en 1072, durante la que se destruyen algunos de los arcos del acueducto (Ruiz Hernando 1982: 21) se produce curiosamente durante la guerra entre Sancho II y Alfonso VI cuando aparentemente éste último se encontraba refugiado en Toledo. Esto nos induce a pensar que Segovia debía encontrarse en esas fechas en manos del rey castellano. Eso concuerda con la buenas relaciones mantenidas entre ambos soberanos, Alfonso y Al-Mamún, que de hecho actuaban como aliados, y la posterior colaboración entre Alfonso VI y Al-Qadir, nieto de Al-Mamún, su sucesor en el reino toledano a la muerte de Al-Mamún en 1075, al que Alfonso VI entrega el reino de Valencia cuando su situación en Toledo era muy complicada. También explicaría la voluntad propagandística del rey Alfonso de adjudicarse en las Crónicas Oficiales la recuperación y repoblación de la ciudad de Segovia en 1088, sin aclarar a que enemigo se la había arrebatado.

${ }^{42}$ En relación a las ciudades y murallas musulmanas, véase Pavón Maldonado (1999) y Torres Balbás (1985)
} 
González, 1974). Tanto por la continuidad poblacional, con la presencia de mozárabes y bereberes (Ruiz Hernando, 1988a: 17) ${ }^{43}$ que enlaza sin solución de continuidad el mundo visigodo con la repoblación, como por el aporte de pobladores de la repoblación de iniciativa condal que se desarrolla a lo largo del siglo X, el entorno de la ciudad de Segovia aparentemente presentaba una numerosa población (González Herrero, 1969: 80), si bien estaría dispuesta en barrios dispersos, atendiendo a la descripción de Al-Idrisi. Frente a estos barrios que a fines del $\mathrm{X}$ ya están muy poblados, a mediados del siglo XIII el casco noble permanece aún todavía escasamente habitado, hasta el punto de que Alfonso $\mathrm{X}$ tiene que estimular con privilegios especiales a los segovianos para que se incremente la población de la ciudad amurallada (Montero Reguera, 1999: 317).

La repoblación de Segovia, no partió de cero, sino de pequeños grupos de mozárabes y bereberes que vivían en aldeas dispersas- en número de siete, según el plano del geógrafo Al-Idrisi-... y ... en la que tomaron parte gentes venidas de otras tierras, ha de entenderse más como la organización de aquellas aldeas bajo un régimen común-con obispo, concejo, murallas y mercado-, que como un simple acto de asentar población foránea (Ruiz Hernando, 1988a: 17). Sin embargo, la ciudad no se cita en ninguna fuente documental, salvo la mencionada de Al-Idrisi, frente a la abundancia de referencias de otras ciudades o las extensas descripciones que Al-Idrisi hace de otras ciudades de Al-Andalus (Torres Balbás, 1985: 138-167). Debió ser una población de pequeña importancia en la red urbana hispanomusulmana de la meseta. En realidad ninguna ciudad del norte de la sierra se cita como perteneciente a la España musulmana, ni en el listado de Coras del al-Razi en el siglo X, ni entre los iqlim que enumera Al-Idrisi, ni en los textos de Ibn Said describiendo la subdivisión de los reinos de Al-Andalus, escrito entre 1135 y 1243, si bien no siempre es fácil saber a qué época hacen referencia estos textos (Mazzoli-Guintard, 2000: 352-361).

En la ciudad de Segovia no se ha encontrado ningún vestigio arqueológico consistente, salvo el hallazgo de dos capiteles califales descontextualizados, que nos permita afirmar que existió una Segovia hispanomusulmana en la Alta Edad Media. El primero de ellos, una columna y un capitel de mármol de estilo califal cuenta con una inscripción con la fecha de 960, descubierto durante unas obras en el 1868 en una casa del barrio de las canonjías, que se encuentra actualmente en el museo Arqueológico Nacional de Madrid (Ruiz Hernando, 1986: 26) ${ }^{44}$. No hay documentación que aclare las relaciones contextuales en que fue hallado. El segundo, descubierto durante las obras del antiguo convento de las Oblatas y que ahora se encuentra depositado en el Museo de Segovia, apareció en un echadizo de escombros por lo que al no ser su emplazamiento original tampoco aporta mayor información arqueológica (Zamora Canellada, 2006: 109). A mayores, sólo algunos restos cerámicos en la calle Gascos (Zamora Canellada, 1997: 420).

Hasta hace escasos años la aparición, no ya de los restos cerámicos de la calle Gascos, sino de un único capitel podría atribuirse a un hecho casual. Con la aparición de un segundo capitel creemos que esa casualidad pierde probabilidad frente a la existencia de una ciudad musulmana. Ningún autor lo ha negado, pero son muy pocos los que defienden la hipótesis de la pervivencia de restos altomedievales, entre ellos Zozaya Stabel-Hansen (1987b: 399) y

\footnotetext{
${ }^{43}$ Citando a Chalmeta, 1976.

${ }_{44}$ Algunos autores presuponen dicha presencia en base a la toponimia (Illarregui Gómez, 2010: 71.) En otros casos se afirma la influencia musulmana, pero sin embargo se asocia a una cronología mudéjar, basándose en las decoraciones de aleros, alfices, zaguanes esviados o traza de alfarjes y artesonados existentes en distintos puntos de la ciudad (Ruiz Hernando, 1973).
} 
Alonso Zamora (Zamora Canellada, 1994), y no es casualidad que ambos se apoyen en la existencia de determinados restos observados en la muralla, uno de los edificios más longevos de la ciudad. El primero aprecia la existencia de zarpas y aparejos de influencia andalusí en algunas de las torres cercanas a la puerta de San Andrés (Zozaya Stabel-Hansen, 2005c: 25) mientras el segundo encuentra ciertos parecidos en algunos aparejos de la muralla segoviana con otros de filiación hispanomusulmana que estudia con mayor detenimiento como son Ayllón, Sepúlveda, Fuentidueña (Zamora y Vela, 2005: 1138) ${ }^{45}$, que se vinculan a Almanzor y al sistema defensivo de torres para la defensa de los pasos de la sierra ${ }^{46}$ (Zamora Canellada, 1997: 419). Menos precisas estilísticamente son las afirmaciones de Antonio Ruiz sobre la existencia de una fortificación previa en el actual emplazamiento del Alcázar, quien simplemente data dicha pervivencia histórica como altomedieval, sin asignar ninguna filiación cultural ni cronología concreta (Ruiz Hernando, 2010), o las de Bonifacio Bartolomé que refiriéndose a algunos elementos de la muralla afirma cuyas formas constructivas son perfectamente compatibles con las utilizadas durante la época califal (Bartolomé Herrero, 2010: 15).

Para otros autores la pervivencia de unas murallas previas, se remonta a la época tardo romana, defendiendo la tesis de la existencia de restos constructivos que considera fábrica romana en las hiladas inferiores de la puerta de San Andrés (Illarregui Gómez, 2010).

Juan Zozaya, encuentra otro sector de muralla con fábrica de filiación musulmana, en los lienzos cercanos al postigo del Sol, sobre los que apoya la sinagoga. Se trata de un aparejo de mampostería a tizón, que se regulariza imitando los cajones de tapia encofrada, en el que encuentra paralelismos con los observados en los castillos del Desierto en Jordania (Kharrane, Qastal) datándolo en el siglo VIII (Zozaya Stabel-Hansen, 2009: 117). Sin embargo para Basilio Pavón es cristiano, similar a los de Ávila, Sigüenza, Atienza y datable en los siglos XIIIXIV (Pavón Maldonado, 1984: 62-68).

Ya José Losañez, en 1861, afirma que la variedad de formas en planta de las torres evidencia la preexistencia de unas murallas anteriores a la repoblación (Losañez, 1861, I: 13). Y también Quadrado expone sus sospechas de la preexistencia de unas murallas previas a la repoblación cuando al describir las murallas nos dice ...presenta hartas señales, sobre todo en su parte inferior en que se mezclan y confunden las obras con la peña natural; ... e incluso nos aporta un dato interesantísimo, cuando afirma Mucho se ha disputado sobre si eran estas anteriores o posteriores a aquel, y a cualquier bipótesis se presta verdaderamente la heterogeneidad de su construcción (Quadrado, 2007: 425).

Por último recordar los hallazgos en el Alcázar, algunos de cuyos aparejos podrían ser obra musulmana según Alonso Zamora (Ruiz Hernando, 2010: 55) de los que ya hemos hablado.

A modo de recapitulación podemos decir que de la muralla segoviana sabemos muy poco (Zamora y Vela, 2005: 1138). Faltan lecturas constructivas de sus fábricas y un análisis que intenten entenderlas y asignarlas una posible filiación cronológica, ordenándolas. No existe

\footnotetext{
${ }_{45}$ Admite que la muralla segoviana no está estudiada en profundidad, remitiéndose como principal fuente a Ruiz Hernando (1982).

46 Tras la primera fase de refuerzo de la Marca, los musulmanes, potencian la ruta del Jarama, en detrimento de la a ruta tradicional a lo largo de la calzada romana por Titulcia, (Torres Balbás, 1960). menos expuesta al discurrir por la cara sur de la Sierra. De esta manera, se conserva la conexión con Zaragoza, importante enclave de la España musulmana. La abundancia de restos (y nuevamente de estudios) permiten afirmar que el sector de la sierra Ayllón-Sepúlveda está fuertemente poblado desde comienzos de X (Zamora Canellada, 1997: 424).
} 
ninguna monografía sobre la muralla. Las escasas aportaciones existentes se apoyan en la recopilación de la documentación histórica (Ruiz Hernando y Contreras Jiménez principalmente) con algunas aportaciones como las ya enumeradas de Quintanilla y otros artículos meramente descriptivos de Lecea, Madoz, Quadrado y Góngora. Respeto a la presencia de restos musulmanes, tan sólo Juan Zozaya y Alonso Zamora sostienen la filiación hispanomusulmana de algunas torres cercanas a la puerta de San Andrés. Adicionalmente Zozaya atribuye esta misma filiación a un aparejo de mampostería a tizón situada en un tramo cercano al postigo del Sol. Son los únicos autores que defienden en base a evidencias materiales, la presencia musulmana en Segovia entre los siglos VIII y XI. De ellos, tan sólo Zozaya lo relaciona con la presencia de una fortificación hispanomusulmana, que no ciudad, a la que atribuye muy escasa pervivencia en el tiempo, asentamientos militares, de pequeñas guarniciones, posiblemente bereberes que difícilmente podríamos calificar como ciudades (Zozaya StabelHansen, 1987b).

Nadie ha planteado claramente nunca la existencia de una posible ciudad hispanomusulmana dentro de estas murallas. No se ha estudiado el tema, ni ha intentado demostrarse. Los trabajos generales, sobre la Edad Media y la España musulmana, no lo mencionan y no existen trabajos de alcance local que lo planteen. No hay ningún estudio del urbanismo segoviano que se centre en el periodo anterior al siglo XII, ni que se base en el análisis de su trama urbana. Es un campo inexplorado en el que no se ha aventurado nadie. 

III. LA MURALLA COMO DOCUMENTO CONSTRUIDO 



\section{1.-}

\section{DESCRIPCIÓN GENERAL DE LA MURALLA}

La muralla nace y muere en el Alcázar y cuenta con un perímetro de unos 3.760 metros $^{47}$, que se va adaptando al límite de la peña en sus costados meridional y septentrional, mientras que el oriental se abre al llano y en el occidental se sitúa el afilado vértice que supone el Alcázar. En su recorrido se disponen torres, cubos y edificios fortificados que la refuerzan y también se abrieron puertas y postigos, aunque en la actualidad no permanecen todos los que fueron, la muralla se conserva prácticamente completa.

Su trazado discurre aprovechando los escarpes naturales del terreno, provocados por la confluencia de los ríos Eresma y Clamores, que en algunos casos se han acentuado manualmente, con trabajos de tallado, o por la doble finalidad militar y de extracción de material como cantera. De esta forma el desnivel total hasta la parte alta del adarve que se consigue desde la base de los cortados rocosos llega a alcanzar hasta los 80 metros en algunos puntos, como el Alcázar, cuando la altura de los muros ronda los 9,5 metros, dimensión que concuerda con las alturas de las murallas de la época que variaba entre 8 y 10 metros (Pavón Maldonado, 1999: 245). Su espesor oscila entre los 2 y 2,5 metros, allí donde hemos podido medirlo.

Con estas dimensiones, puede entenderse que consideremos que la "verdadera muralla" es la roca completamente inaccesible, sobre la que se dispone la cerca urbana aprovechando los cortados o incluso enfatizándolos mediante el tallado realizado por la mano del hombre.

47 Dimensión obtenida según nuestras mediciones. Según el Estudio Geotécnico, la dimensión total son cien metros menos (AMS: 4810-3: 2). 
La cara intramuros no es visible en la mayor parte de los casos, al haberse colmatado con rellenos o adosarse la edificación, por lo que la muralla actúa como un muro de contención.

En la actualidad hemos considerado que se conservan 81 torres en el perímetro de la muralla, si bien algunas son meros restos o restituciones volumétricas parciales, relativamente modernas, que simplemente nos permiten conjeturar que en ese punto, quizá, existió una torre. Consideramos que en la muralla medieval original existieron 100 torres, como intentaremos demostrar a lo largo de este trabajo.

Según el estudio geotécnico se conservan 70 cubos de los 83 que se estima tuvo en origen (AMS 4810-3: 2) y según el Plan Director hay 81 torres y en principio tenía 90 (PH: P0035). Carlos Lecea dice que existieron 83 torres originales (Lecea y García, 1906: 52).

De las 81 torres, hemos contabilizado un total de 56 con planta de trazado rectangular, 17 semicirculares y 8 poligonales, aunque como se verá más adelante, tras la toma de datos y el análisis de estos datos de partida, obtendremos unos números distintos que componían la muralla primigenia.

La muralla tiene un adarve o paseo de ronda del que en algunos tramos ha sido privatizado o invadido por las edificaciones que se apoyan sobre ella, distorsionando sus elementos. Su anchura oscila alrededor del 1,20 a 1,75 metros.

Ateniéndonos a la descripción de Antonio Ruiz, se tiene constancia de la existencia de 5 puertas, de las cuales se conservan tres en la actualidad, la puerta de San Andrés o del Socorro, la puerta de San Cebrián y la puerta de Santiago. Han desaparecido las puertas de San Martín y la de San Juan.

Siguiendo al mismo autor, se cree que han existido 8 postigos, por las referencias documentales. Tres de ellos fueron demolidos y actualmente están reconstruidos, que son el postigo del Sol, (también conocido como de San Miguel, de Corpus Christi o de los Coroneles) el postigo de la Luna, (también referido como del Rastro o de San Martín) y el postigo del Consuelo o de Santa Coloma. Otros dos postigos fueron demolidos, el postigo del Alcázar y el del Obispo ambos situados en las proximidades del foso del alcázar.

De los tres postigos restantes, tan solo se conserva en uso el de San Juan, encontrándose tapiado el postigo de San Matías o Picado y el postigo de Fuente Cercada, que no ha sido identificado, pero debería encontrarse en las proximidades del Hospital de la Misericordia. (Ruiz Hernando, 1982: 25-27)

Tras unas recientes obras realizadas en octubre de 2013, se ha descubierto un nuevo acceso, nombrado como del Revellín, situado en el espigón del Alcázar en la confluencia del rio Eresma y el arroyo Clamores, del que no había referencia documental. 


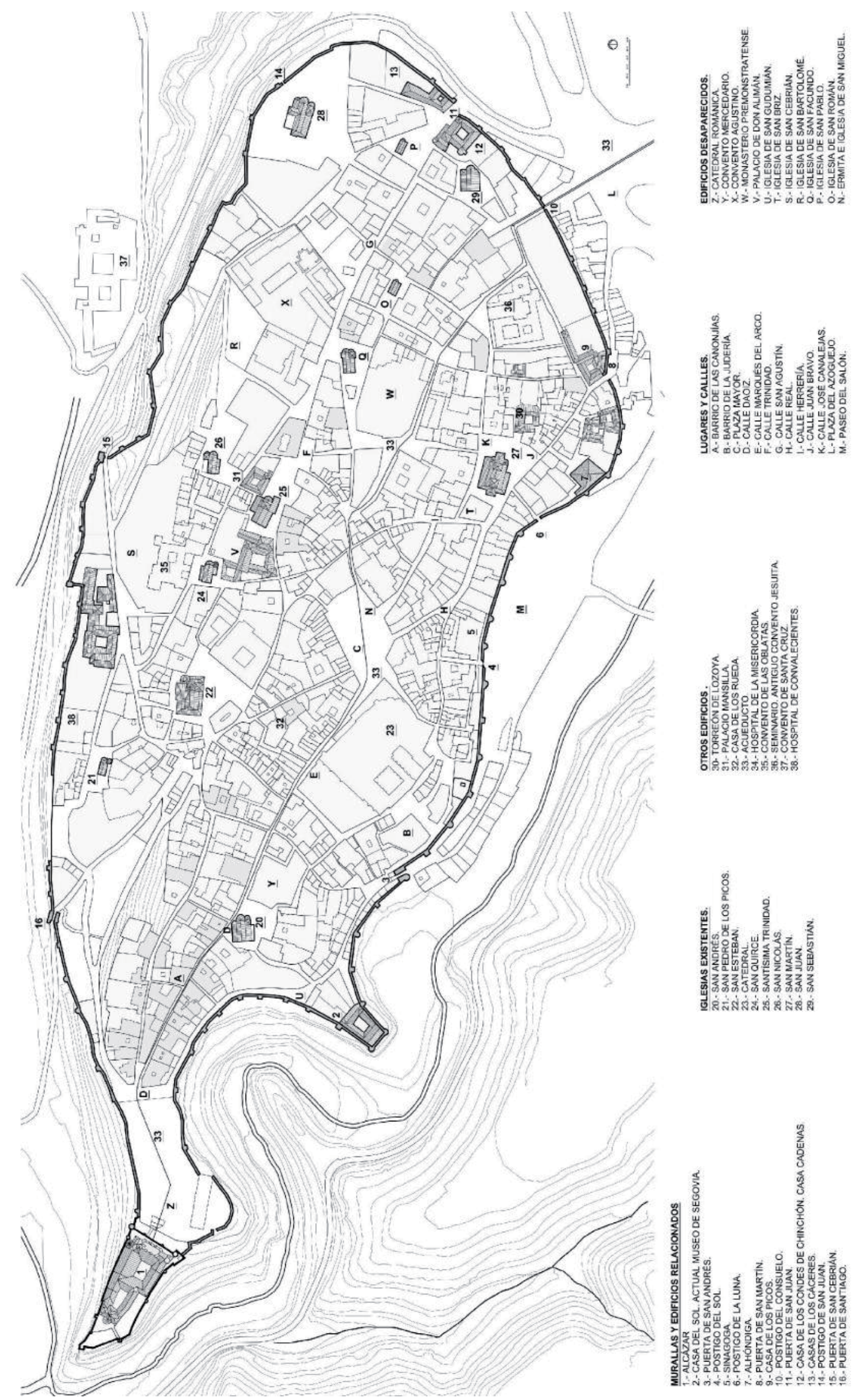

Figura 3. 1: Plano de Segovia con la leyenda e identificación de los nombres de edificios, calles y otros lugares que se mencionan en esta tesis. 


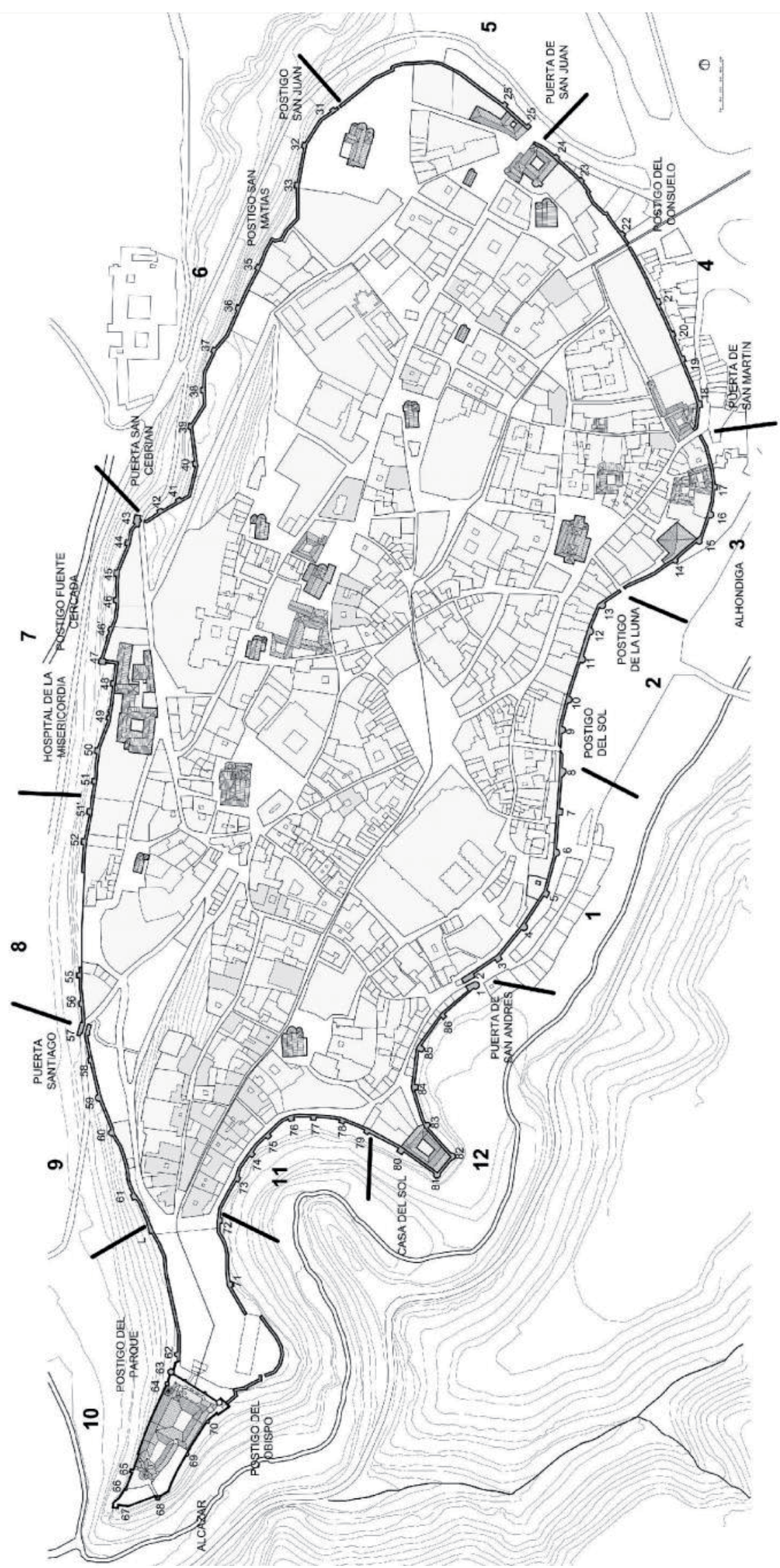

Figura 3. 2: Plano de Segovia con la numeración de las torres y las zonas en que se ha dividido la muralla para la toma de datos. 


\section{2.- $\quad$ ELEMENTOS Y FÁBRICAS.}

Para la descripción de la muralla, se ha dividido ésta en diferentes sectores y zonas, a las que iremos describiendo ordenadamente, comenzando por la que se denomina torre T1, ubicada en la puerta de San Andrés. Para identificar las torres y elementos, se ha empleado la numeración indicada en el Plan Director (PH: P0035).

En esta descripción nos centraremos en los elementos que constituyen la muralla, torres, lienzos, puertas, postigos y casas fuertes, con especial atención a sus fábricas, como están construidas, los aparejos en que se organizan y los materiales empleados. Estos datos se complementan con el anejo de fichas de toma de datos en que se ha sintetizado las principales características de las torres y lienzos.

A excepción de las puertas y las torres reformadas en que se indique expresamente, todas las torres son macizas.

\subsection{1.- ZONA 01. LEOPOLDO MORENO.}

Esta zona se extiende desde la puerta de San Andrés hasta el postigo del Sol. Tiene 270 metros de longitud en los que se reparten 8 torres y encontramos la puerta de San Andrés y el postigo del Sol. Las torres miden entre 6,00 y 6,30 metros de frente y 3,30-3,70 de resalto, mientras los lienzos que las separan fluctúan entre 34 y 35 metros, excepto el lienzo adyacente a la puerta. Las torres de este sector se caracterizan por alternar las de forma rectangular y las de planta poligonal. En sus fábricas destaca la existencia de zócalos de sillería de granito escalonados a modo de zarpas, fábricas de sillería de piedra sedimentaria 
en la parte central de las torres y un remate de fábrica de ladrillo con arquillos ciegos de connotaciones mudéjares. La estética de la fábrica así como otras características constructivas de estas torres parece indicar que están realizadas por mano de obra mudéjar y corresponderían con las reformas de Juan Guas a fines del XIV o principios del $\mathrm{XV}^{48}$.

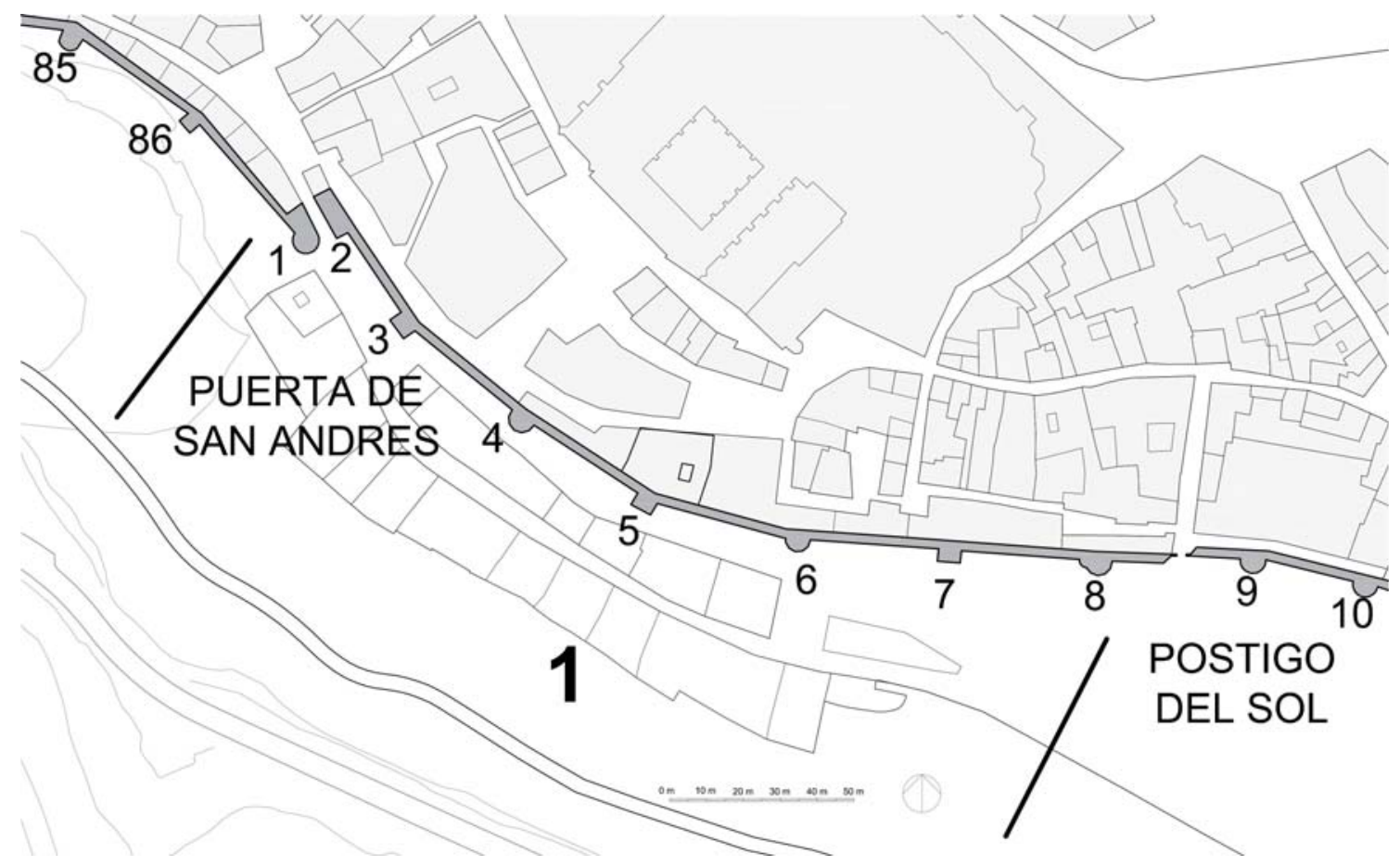

Figura 3. 3: Plano de la zona 1, que comprende desde la puerta de San Andrés hasta el postigo del Sol.

En los lienzos predominan los zócalos de sillería de granito con las piezas configurando una línea horizontal donde se apoya una mampostería desconcertada, muy reparada en la que se aprecian algunos mechinales o agujales. Se conserva igualmente amplios sectores de muro de fábrica encofrada, e incluso numerosos agujales que permiten determinar la modulación del encofrado.

Iniciaremos la descripción por la puerta de San Andrés o del Socorro que conecta la calle de San Valentín con la Plaza del Socorro, comunicando el barrio de la Judería con las tenerías y las huertas del valle del Clamores.

Es una puerta de acceso recto flanqueada por dos torres, una poligonal (torre T1) y otra de planta rectangular, torre T2. Volteando entre ambas presenta en su frontal exterior un arco de medio punto peraltado apoyado sobre unas piezas en ménsula de granito que se han encajado en la fábrica de sendas torres. Tras él se sitúa un primer cuerpo abovedado en el que se aloja una buhedera y sobre el frontal del muro interior se conserva un escudo en muy mal estado de conservación. Bajo el escudo se configura una sencilla portada compuesta por un arco de medio punto abierto en un muro de sillería de granito. El resto del muro se encuentra revocado, por lo que desconocemos la tipología de su fábrica, si bien

${ }^{48}$ En 1484, Juan Guas que se encontraba en Segovia trabajando en el monasterio del Parral, asesoró sobre la reparación de las murallas y consta la concesión de 27.000 maravedíes para las obras (Asenjo González, 1986: 64). 
aparenta que debió ser de arquillos de ladrillo ciegos por algunos fragmentos que aparecen visibles. Tras el segundo arco, el paso, profundo, cubierto por una bóveda de cañón dividida en dos partes por otro arco. En el interior del paso se situaban dos puertas en sus extremos, de las que aún se conservan los tejuelos, las quicialeras o ranguas y la huella de las gorroneras. Cada puerta abría en una dirección.

Por encima del arco exterior que voltea sobre el paso, se levanta un muro de sillería de piedra sedimentaria o carbonatada. Sobre una cornisa poco resaltada se recrece el último piso, que interiormente comunica ambas torres, ejecutado en fábrica de ladrillo en cuyo alzado se componen dos niveles de arquillos, los cuatro inferiores abiertos como huecos y los superiores ciegos. Por encima el remate almenado protege la terraza superior. Este tramo entre ambas torres lo nombramos como lienzo L1-2.

Por el lado de intradós, un camarín que guarda la imagen de la Virgen del Socorro, se adosa a la puerta, en vuelo sobre el paso. A ambos lados a lo largo de todo el paso, las torres son macizas, lo que nos hace suponer que lo que observamos en la actualidad es un forrado o un recrecido que nos está ocultando una obra previa, especialmente en el caso de la torre poligonal, T1 y que la puerta tenía antiguamente otra configuración ${ }^{49}$.
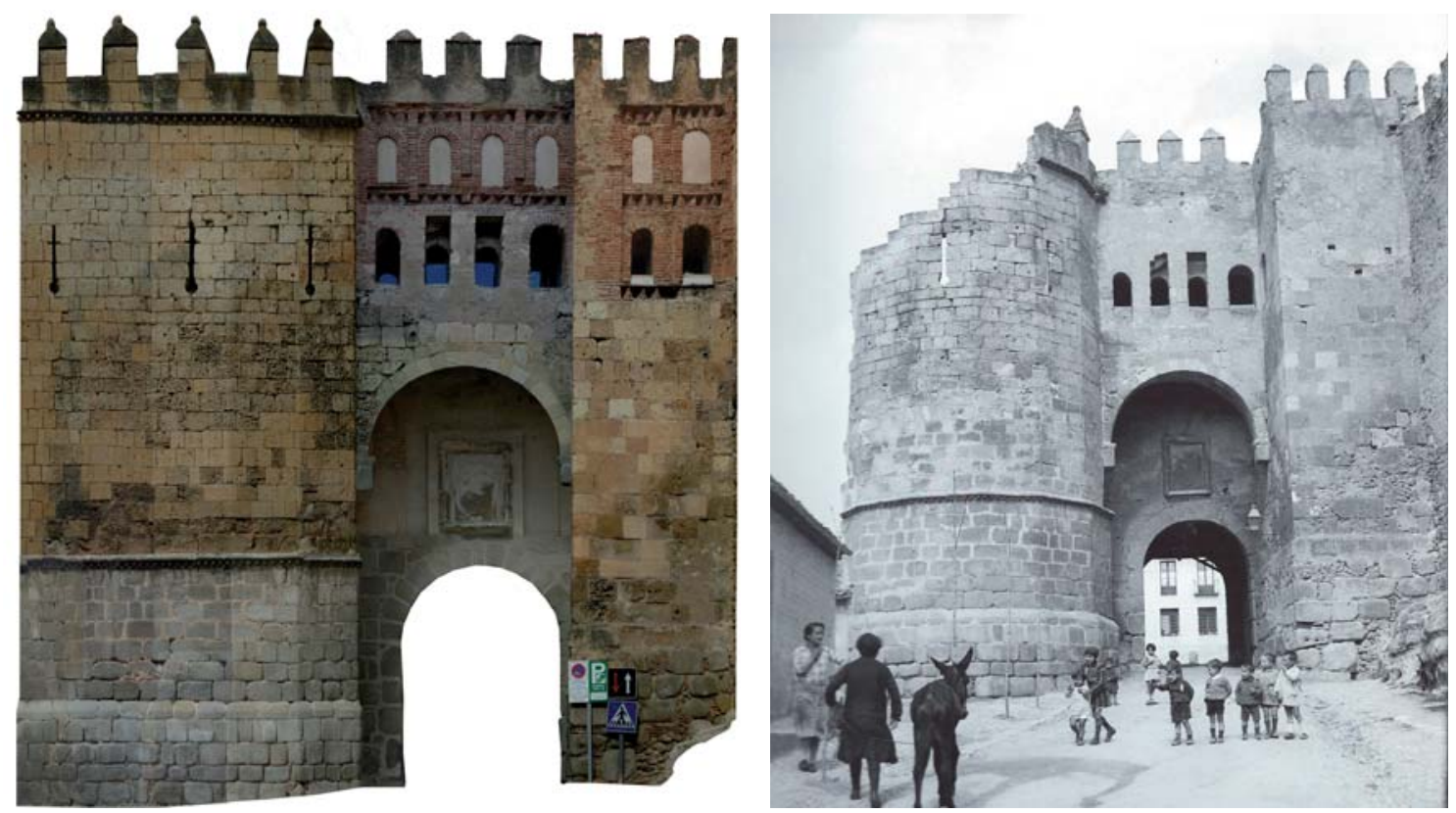

Figura 3. 4: Ortofoto. Alzado exterior de la puerta de San Andrés, extraído del proyecto de restauración (PH: P0159-A0117).

Figura 3. 5: Puerta de San Andrés. Foto de Loty fechada entre 1932-1936 (VV.AA. 2006: 127).

\footnotetext{
${ }^{49}$ La puerta original se data en el S.XII ya que es mencionada en 1120 en el documento de cesión del solar de las Canonjías por parte del Concejo al Cabildo. En estas fechas seguramente se trataría simplemente de un postigo sin función defensiva, "Posticum", pero sufrió reformas importantes a finales del s. XV o comienzos del s. XVI que le dan el aspecto actual. (Ruiz Hernando, 1973: 93). Otros autores también lo datan en esa época. "La respuesta podría estar en que, abierto en medio del barrio de la Judería, una vez expulsados éstos en 1492, los Reyes Católicos la reconstruyeron siguiendo la estética de Juan Guas, como deja entrever la decoración de bolas de la cornisa" (AMS: 4810-3).
} 
La torre T1, situada a la izquierda de la puerta, presenta forma poligonal (11 lados) con un zócalo resaltado dividido en dos niveles por un escalón. Todo el zócalo está ejecutado en sillería de granito a soga y una moldura con decoración de bolas lo separa del resto de la torre que se realiza en sillería de piedra carbonatada, a soga bien escuadrada y con una junta mínima de mortero. La torre poligonal se adosa al lienzo de muralla, como se observa en su cimentación (STCSG: OT-10/2010-11).

Presenta troneras rasgadas en tres de sus lados y en su terraza, almenado, cuyos merlones están coronados por un remate piramidal acabado en una bola. Estas características le confieren una cronología muy clara de finales del XV, asignando la autoría a Juan Guas. Las cornisas con bolas, almenas piramidales y saeteras en cruz determinan claramente la fecha de construcción (Rodríguez Marín, 2013: 31).

Presenta una clara discontinuidad constructiva en su fábrica, especialmente evidente en el tratamiento de la moldura, que muestra a las claras que buena parte de la torre, una mitad de su parte superior, es fruto de una reconstrucción del siglo $\mathrm{XX}^{50}$. La existencia de dos tipos de piedra sedimentaria, aparte de los parcheados por la reposición puntual de sillares, delimita con claridad la parte derruida que se aprecia en la foto de Loty de la década de 1930 (VV.AA. 2006: 127).

La torre T2, de planta rectangular $(6,30 \times 3.35 \mathrm{~m})$ presenta igualmente un zócalo resaltado ejecutado en sillería de granito, con numerosas piezas reutilizadas, sobre el que se realiza el resto de la torre en fábrica de sillería sedimentaria. Sobre ésta se levanta el tercer cuerpo realizado, al igual que en el cuerpo central que voltea sobre el paso, en fábrica de ladrillo en el que se componen nuevamente dos niveles de huecos rematados en arco de medio punto. La esquina presenta sillería de sedimentaria, muy deteriorada. Del mismo modo, los cuatro huecos inferiores están abiertos como ventanas y los cuatro superiores ciegos. Sobre ello el remate almenado da continuidad al ya visto anteriormente, dejando en evidencia que se trata de una intervención unitaria.

Todo el conjunto presenta una enorme similitud compositiva con la puerta del Sol de Toledo, así como un aire más simbólico y teatral que realmente defensivo, característica que observamos en los garitones que rematan la torre de Juan II del Alcázar, otra de las obras de Juan Guas en la ciudad, reafirmando la relación con este autor. Las saeteras y los remates de almenas y merlones terminan de darle el aspecto no sólo monumental sino también militar y defensivo que la caracteriza (Chaves Martín, 2003).

Ambas torres presentan la parte inferior maciza, mientras el último piso es habitable. La exacta correspondencia de niveles entre los huecos y pavimentos de las estancias interiores de ambas torres, la configuración de la torre T1, que no permite imaginar otra posibilidad de acceso en ninguna de sus caras visibles y la estética las fábricas de ambas torres, nos hace pensar en cronologías muy próximas, incluso en un único proyecto, que nuevamente vinculamos a Juan Guas y podemos datar todo ello a finales del XV o muy principios del XVI.

El lienzo L2-3, el más corto, de 25,95 metros de longitud, presenta un zócalo diferenciado de sillares de granito de colocados directamente sobre la roca, calzados con ripios. En ambos extremos parecen formar una línea superior horizontal nivelada. Sin embargo en el

${ }^{50}$ En 1879, se desploma la parte superior de la mitad que mira hacia el valle del Clamores. Fue reconstruida casi 100 años más tarde. 
centro del lienzo parecen estar removidos ya que están mal nivelados y peor asentados sobre la roca. Sobre este zócalo se ejecutan diversos aparejos entremezclados que denotan numerosas intervenciones, reparaciones y debemos entender que también, derrumbes previos. Hasta media altura del lienzo aproximadamente predomina una fábrica de mampostería desconcertada a base de piezas menudas de piedra sedimentaria, ripios y material muy mezclado entre los que se conserva algún agujal o mechinal aislado. A media altura en la parte central destaca una mampostería encintada con ladrillo mal aparejada. Ambas mamposterías son fruto de una reparación como atestigua la foto de Laurent (ver Figura 3. 8). Sobre esta mampostería se distingue una fábrica de tapial encofrada en muy buen estado de conservación en la que se aprecia perfectamente la modulación de los agujales. Esta misma fábrica es la que se observa en la cara intramuros, que en este lienzo, excepcionalmente es visible, dado que en la mayor parte de la muralla esta oculta. El remate está muy reparado aparentando nuevamente ser mampostería desconcertada, siendo los petos y merlones claramente rehechos recientemente.

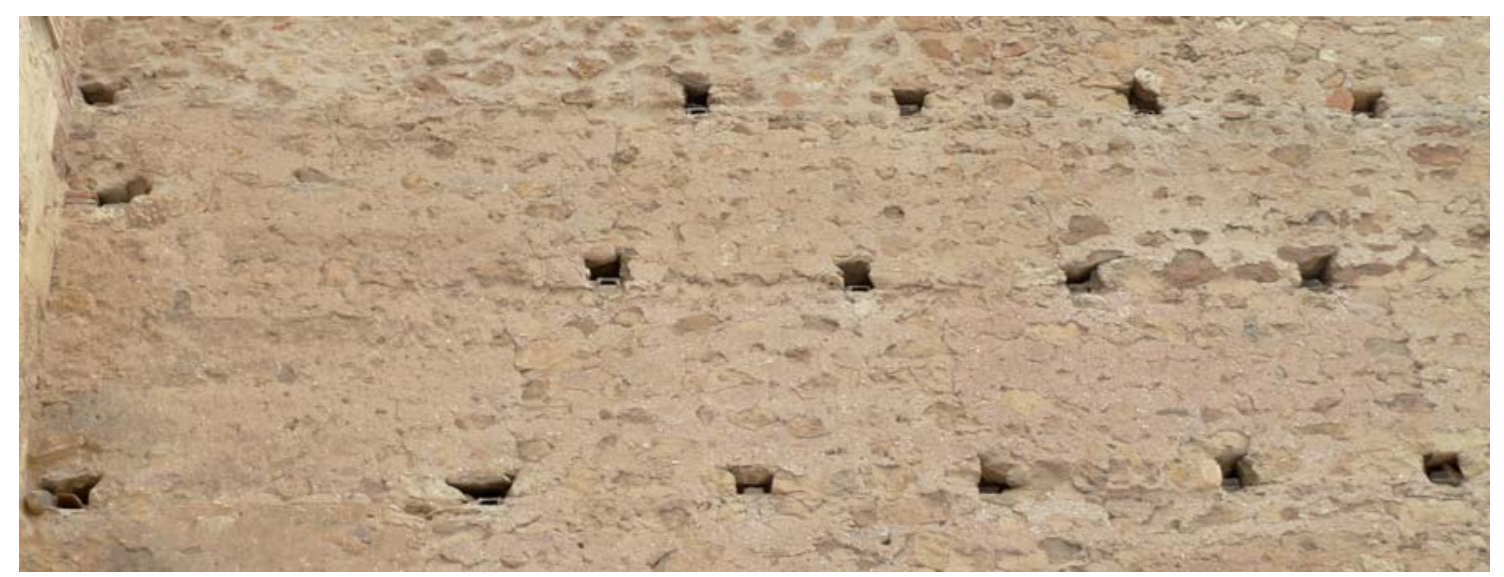

Figura 3. 6: Lienzo L2-3. Tapia encofrada en que se aprecian perfectamente los agujales, la modulación de las tapias, las juntas entre ellas y la huella de la tablazón impresa en el mortero.

En la roca se descubre una línea de agujeros de forma circular tallados en la roca, de trazado bastante paralelo a la muralla, aproximadamente a un metro de separación, que podrían corresponder a un posible andamiaje para su construcción. Su diámetro es de unos 15- 20 centímetros (STCSG: OT-30/2008-11).

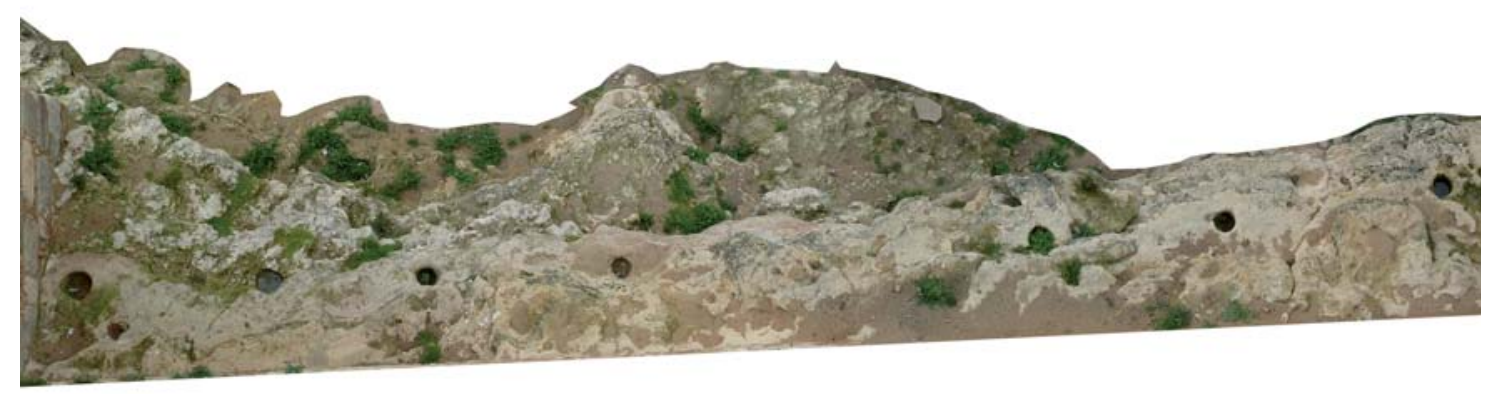

Figura 3. 7: Lienzo L2-3. Ortofoto en planta de la base del lienzo. Grupo de taladros efectuados en la roca, dispuestos en paralelo y a una distancia constante de la muralla, por lo que sospechamos su relación con la construcción de la misma, posiblemente para el apoyo de los andamios. 

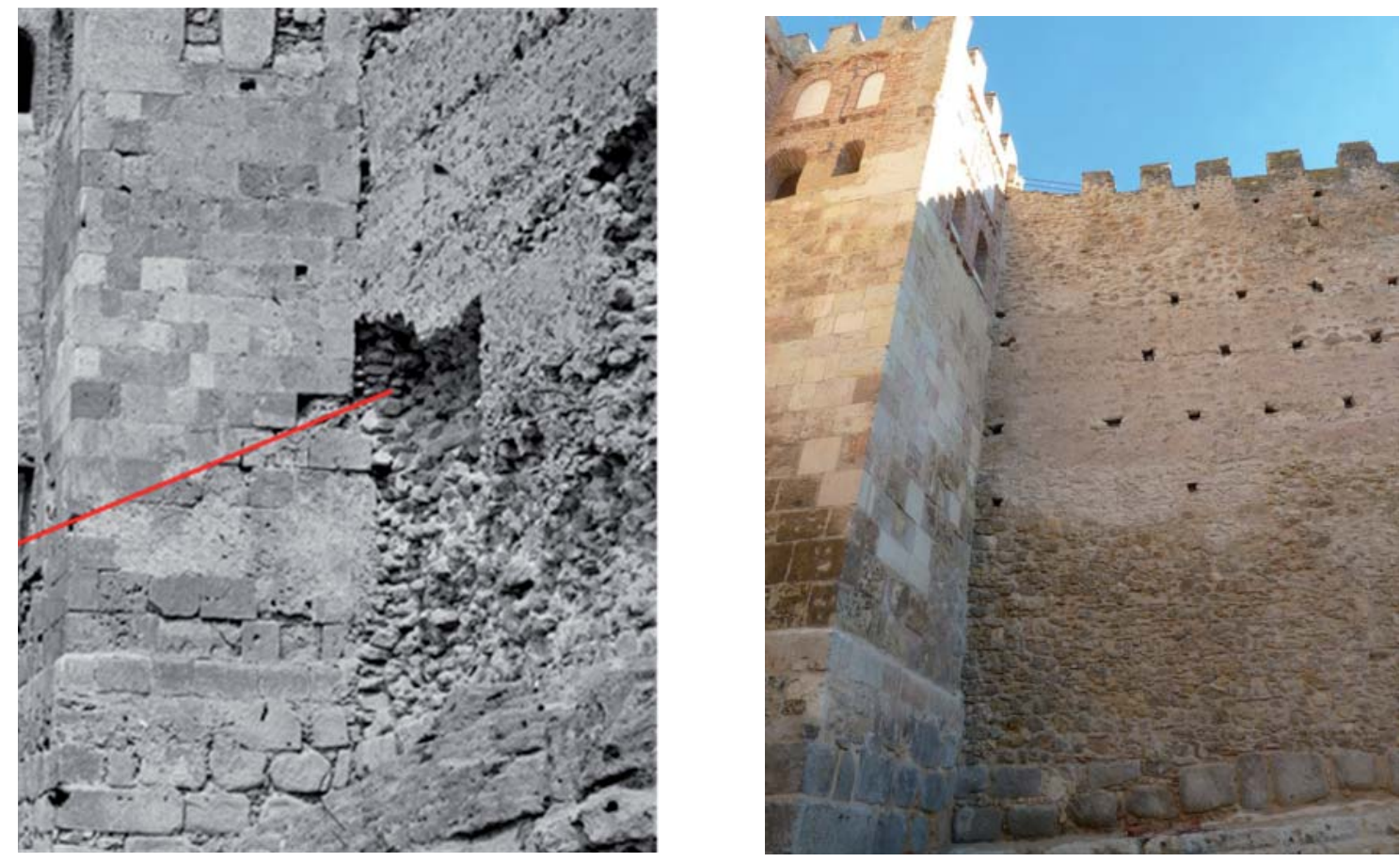

Figura 3. 8: Lienzo L2-3. Detalle de la foto de Laurent. 1868-1872 (VV.AA. 2006: 72). Se observa un importante deterioro de la muralla. En la parte inferior se aprecia como el relleno del lienzo se adosa a la sillería del zócalo de la torre. La sillería parece penetrar en el espesor del relleno del lienzo. Sin embargo, en la parte superior los sillares de la torre se adosan, manteniendo claramente lo que sería el plano de la cara exterior del lienzo. Evidencia una discontinuidad constructiva en la sillería de la torre, que acredita el plano inclinado de rotura. Esta discontinuidad se hace más palpable al observar el cambio de piedra empleado en la sillería así como la distinta dimensión de hiladas y aparejos.

Figura 3. 9: Lienzo L2-3 en su aspecto actual. Comparativa con la figura anterior para identificar una reparación del lienzo de muralla. Esta reparación ya aparece efectuada en la foto de Levy de ca. 1888, (González, 1997: 59) por lo que la reparación hay que datarla en la segunda mitad del XIX, entre 1872 y 1888.

La torre T3 presenta planta rectangular de 6,17 x 3,60 metros. Apoyada sobre la roca se observan 5 hiladas de sillería de granito dispuestas en hiladas horizontales bien organizadas, con piezas de tamaños similares y con un escalonado a modo de zarpa. Sobre esta fábrica continúan 6 hiladas de sillería de piedra sedimentaria, bien aparejada y que vuelve a presentar escalonamiento. En ambas sillerías abundan las piezas reutilizadas y se observan dos lápidas sepulcrales romanas. Sobre estas fábricas se levantan una mampostería desconcertada con las esquinas realizadas en ladrillo.

El cuerpo superior se realiza en fábrica de ladrillo decorada con 4 niveles de arquillos ciegos, muy bien conservados en la cara que se enfrenta a la puerta de San Andrés, bastante deteriorados y parcheados con mampostería en su cara frontal, mientras en el último lado, sólo existe un nivel de arquillos en ladrillo y la mampostería asciende hasta el peto, el cual se realiza en fábrica de ladrillo en la totalidad del perímetro de la torre, evidenciando el tipo de ladrillo y la interrupción de las fábricas que se trata de un recrecido posterior ${ }^{51}$.

El lienzo L3-4, de 33,95 metros, presenta un zócalo de piezas de granito, compuesto por tres hiladas junto a la torre T3 y sólo dos junto a la torre T4, constituyendo una línea

51 Tuvo un recrecido de una planta, vinculado al colegio de las Jesuitinas que se situaba en frente, que podemos observar en la foto de Unturbe de principios del siglo XX (Estebaranz, 2008: 73). 
aparentemente horizontal, pero con clara vocación de querer serlo, aunque con algún desarreglo debido a piezas claramente recolocadas. Las piezas se disponen mayoritariamente a soga, si bien en las dos primeras hiladas se observan algunas a sardinel, para resolver desniveles ocasionados por la irregularidad de la roca de apoyo. Las piezas son de tamaño grande y bastante regular, si bien no todas son sillares, podría considerarse una sillería. Aparentan ser reutilizadas, ya que presentan las esquinas muy redondeadas lo que genera anchas juntas de mortero, reforzadas con ripios.
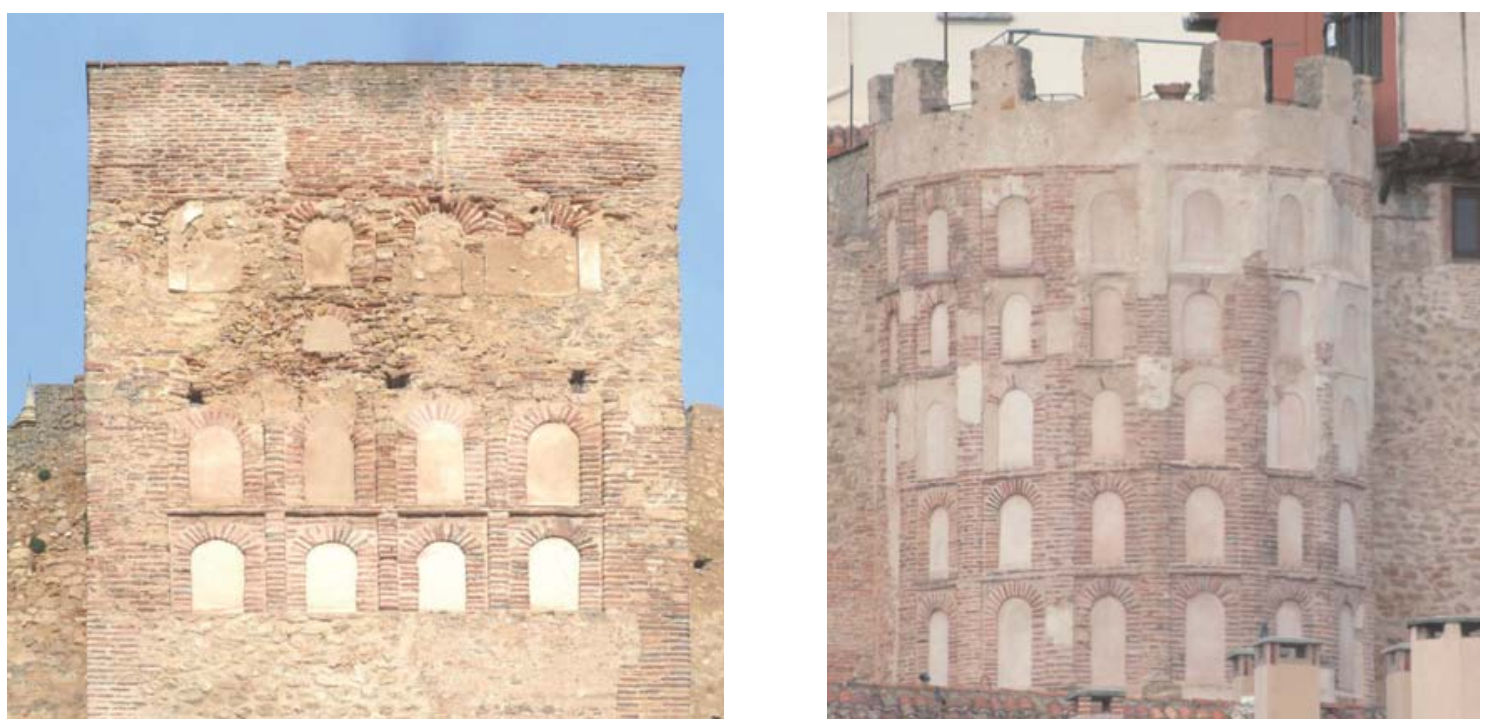

Figura 3. 10: Fábrica de ladrillo con arquillos ciegos, coronando la torre T3 de planta rectangular.

Figura 3. 11: Fábrica de ladrillo con decoración de arquillos ciegos, de influjo mudéjar, coronando la torre T4, poligonal.

Sobre este zócalo se levanta un lienzo muy reparado de mampostería desconcertada, con mucha mezcla de materiales, mampuestos, canto rodado, ripio, ladrillo y reparcheados con distintos morteros. En la cara intramuros muestra esta misma fábrica. Al igual que en el lienzo anterior, se aprecia un pequeño fragmento de mampostería encintada de características similares. En la parte alta aún se aprecia algún agujal o mechinal asilado, estando posiblemente tapados los demás por las reparaciones. Junto a la torre T4 se aprecia una importante reparación realizada en fábrica de ladrillo. En la roca, se aprecian nuevamente taladros, dispuestos de manera bastante paralela al trazado de la muralla. Numerosas partes del frontal de la roca en la base de la muralla aparecen chapadas con mampostería, por lo que es de suponer la existencia de cavidades o erosiones que debilitaban el apoyo. Peto y merlatura aparentan ser rehechos prácticamente en su totalidad como denota la discontinuidad del plano, el cambio de material y de aparejo.

La torre T4, de planta poligonal, (9 lados) apoya sobre un zócalo rectangular de dimensiones $6,10 \times 3,70$ metros, escalonado a modo de zarpa con cuatro hiladas de sillería de granito, resto indiscutible de una torre anterior de dicha traza en planta. La zarpa está incompleta y la base de roca sobre la que apoya se encuentra completamente chapada en mampostería, lo que hace sospechar de posibles descalzos y derrumbes. Sobre esta zarpa arranca un cuerpo cilíndrico de otras cuatro hiladas de altura, si bien en su encuentro con el lienzo L4-5 se ha tallado la roca con forma circular, sobre la que solo es necesario levantar las dos últimas hiladas para conseguir la horizontal que nivela el arranque sobre el que se 
inicia la construcción de la torre de trazado poligonal de 3,40 m de radio. Mientras el zócalo circular presenta una sillería con piezas mezcladas de roca carbonatada y granítica, la torre de planta poligonal se materializa con seis hiladas exclusivamente de piedra sedimentaria sobre la que encontramos 5 niveles de arquillos ciegos realizados en fábrica de ladrillo de idénticas característica a los ya comentados en las torres T2 y T3. Todo el conjunto presenta numerosas reparaciones y un elevado grado de deterioro, especialmente en las sillerías de piedra sedimentaria de trazado cilíndrico y poligonal. El remate presenta peto y merlones, todo ello revocado.
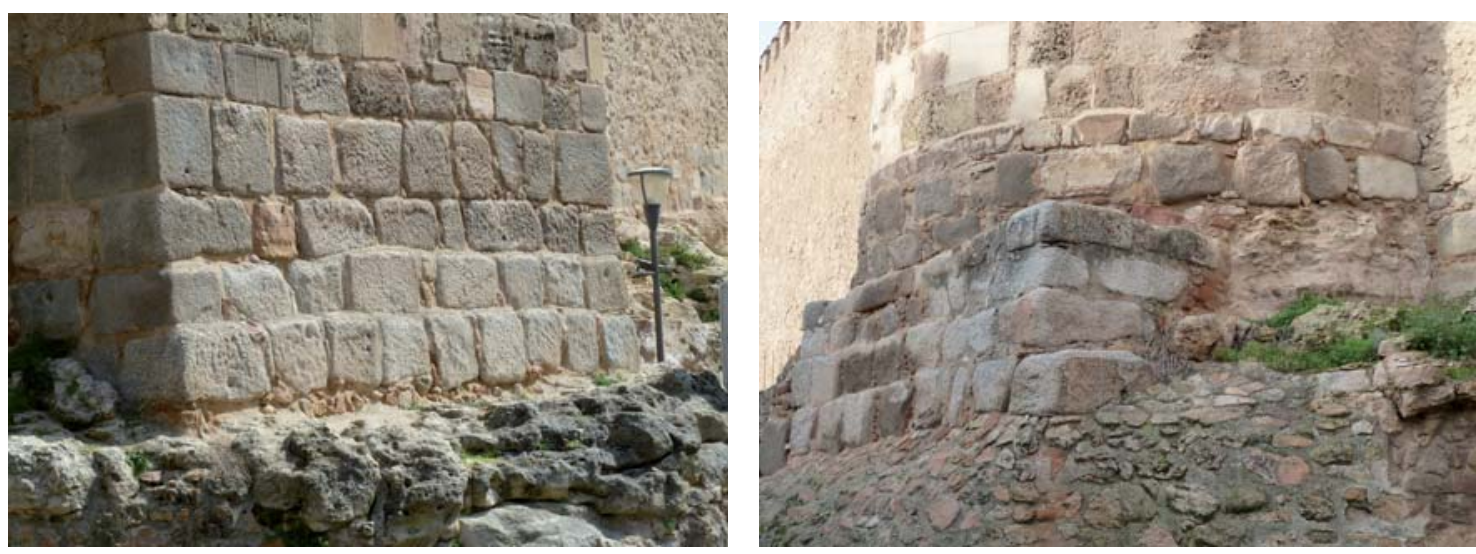

Figura 3. 12: Torre T3. Zócalos escalonados a modo de zarpa, con fábrica de sillería de granito.

Figura 3. 13: Torre T4, donde se constata que la zarpa pertenece a una torre previa de forma rectangular, sobre la que se ha apoyado una torre de trazado poligonal.
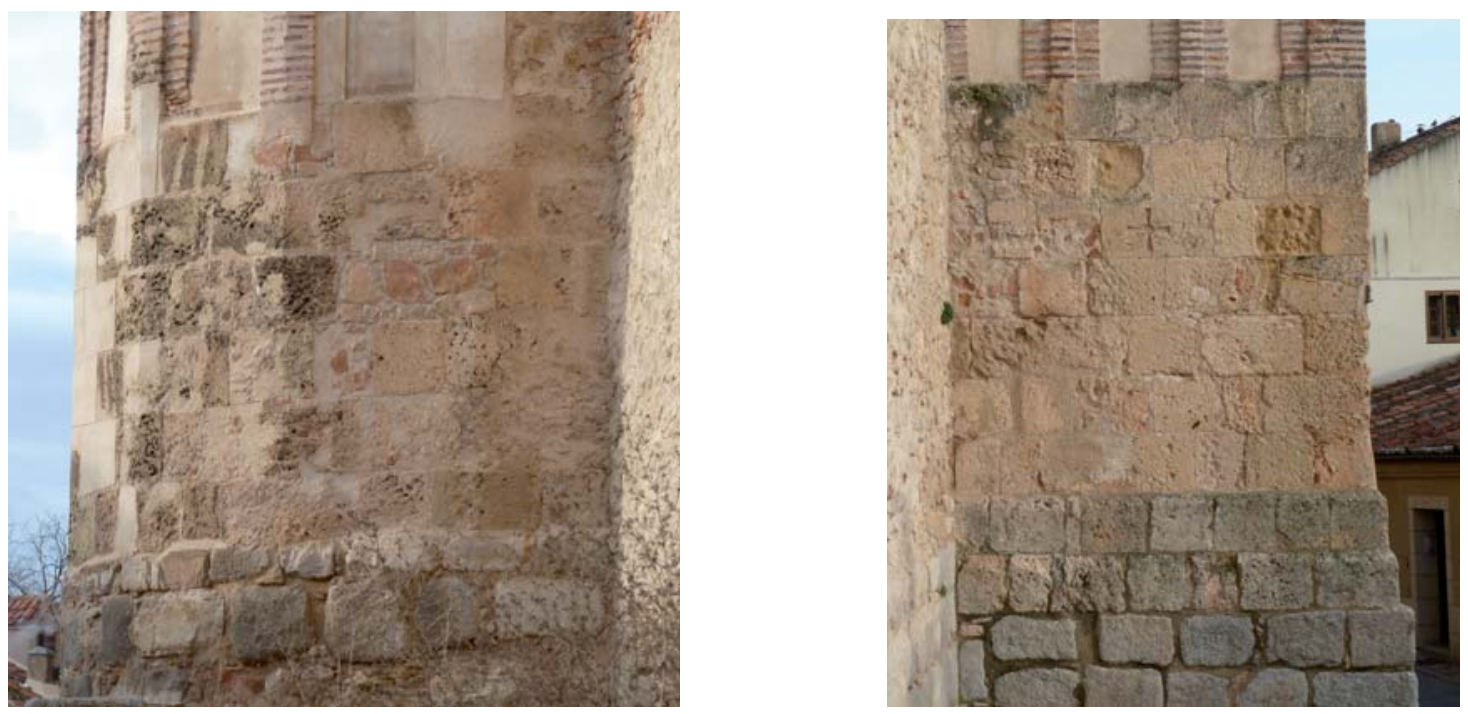

Figura 3. 14: Torre T4. Fábrica de sillería en piedra sedimentaria.

Figura 3. 15: Torre T5. Cruz tallada en uno de los sillares, evidencia de su reutilización.

El lienzo L4-5, de 35 metros de longitud, tiene un zócalo de las mismas características constructivas que el anterior. Sobre el zócalo, el lienzo es también muy similar al anterior, mampostería desconcertada, muy reparada con mucha mezcla de materiales, mampuestos, canto rodado, ripio, ladrillo y reparcheados con distintos morteros. En la parte alta aún se 
aprecia algún agujal o mechinal asilado, estando posiblemente tapados los demás por las reparaciones. Se han construido sobre parte del adarve, dos edificios. El situado junto a la torre T4, mantiene a modo de secuencia de ventanas lo que aparentemente era el almenado, volando por encima con otra planta, mientras en el resto del lienzo no existen merlones. Bajo el otro edificio junto a la torre T5, dos cuerpos semicirculares volados a modo de ladroneras, realizados en sillería carbonatada, sobre ménsulas de granito.

De nuevo encontramos en la roca, taladros alineados en paralelo al lienzo, similares a los del lienzo L2-3 y un corte tallado en la roca perpendicular a la muralla y cegado por la construcción de ésta, que aparentemente parece una conducción de desagüe.

La siguiente torre T5, vuelve a ser de planta rectangular $(6,05 \times 3,68 \mathrm{~m})$ y su configuración es prácticamente idéntica a la de la torre T3. Apoyada sobre la roca se observan 4 hiladas horizontales de sillería de granito bien organizadas y con un escalonado a modo de zarpa. Sobre esta fábrica continúan 9 hiladas de sillería de piedra sedimentaria, bien aparejada y que vuelve a presentar escalonamiento. En ambas sillerías abundan las piezas reutilizadas y se observa un sillar en el que se ha tallado una cruz rehundida, como si hubiese tenido una engastada, de gran parecido a las visigodas o asturianas. Sobre estas fábricas se levanta el cuerpo superior en fábrica de ladrillo decorada con 3 niveles de arquillos ciegos, bastante deteriorados. Por último, el remate presenta peto y merlones, todo ello revocado.
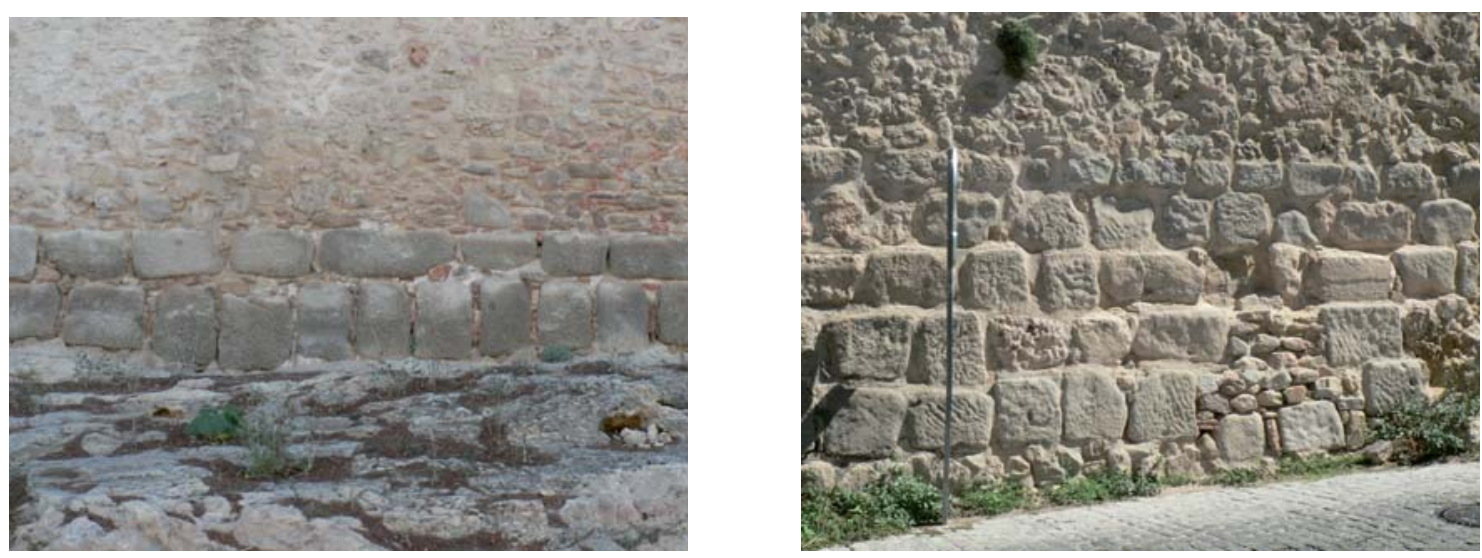

Figura 3. 16: Lienzo L4-5. Zócalo nivelado para apoyo de la fábrica de mampostería.

Figura 3. 17: Lienzo L6-7. Zócalo escalonado en zarpa. Fábrica de sillería muy reparada.

En el lienzo L5-6, de 34,86 metros de largo, encontramos nuevamente un zócalo de sillares de granito, de dos hiladas de altura junto a torre $\mathrm{T} 5$ y solo una junto a torre $\mathrm{T} 6$, con abundancia de tizones, rematado por una hilada horizontal bien nivelada. Este aparejo es idéntico al ya comentado en los lienzos L3-4 y L4-5. En algunas partes, los sillares han sido removidos por lo que se pierde la correcta nivelación, junto a torre T6 o por el empotramiento de una bajante de un edificio que utiliza el adarve como terraza privada cerca de la torre T5. En esta zona, se han abierto sendos huecos en el lienzo de mampostería para iluminación del garaje de dicho edificio.

El lienzo por lo demás, es también muy similar a los anteriores, mampostería desconcertada, muy reparada con mucha mezcla de materiales, mampuestos, canto rodado, ripio, ladrillo y reparcheados con distintos morteros. En la parte alta aún se aprecia algún 
agujal o mechinal asilado, estando posiblemente tapados los demás por las reparaciones. El peto no presenta merlones.

0En el encuentro con la torre T6, se aprecian en la parte alta del lienzo, varios mampuestos enjarjados por igual al lienzo y a la torre, fuera del plano vertical del actual lienzo. Aparentemente este lienzo es por tanto una reconstrucción y el previo debió derrumbarse tras desplomarse hacia el exterior.

La torre T6, tiene un zócalo de trazado semicircular de radio 3,40 m realizado con 3 hiladas de sillares mal escuadrados y mampuestos grandes burdamente regularizados. Se trata de un aparejo de muy baja calidad, con bastante ripio y mezcla de piezas de distintos materiales, en su mayor parte reutilizados. La tercera hilada emplea piezas más pequeñas y de proporción más alargada, cuyo remate consigue una línea horizontal nivelada sobre la que se ejecuta una fábrica de trazado poligonal (8 lados) de sillería de piedra sedimentaria de 7 hiladas de altura, muy deteriorada, que aparentemente es un chapado de un relleno interior previo. La piedra que predomina, llena de oquedades, es la misma que hemos observado en las torres poligonales anteriores.

Sobre ella se realizan dos niveles de arquillos ciegos, de similares características a los ya vistos, con la peculiaridad de que en esta torre solo existen en el frontal de la torre, evidenciando que todo es un chapado de una fábrica previa. La torre se remata hasta el almenado con una mampostería desconcertada de idénticas características a las comentadas, con mezcla de muchos materiales distintos y numerosos parcheados y reparaciones.

El lienzo L6-7, de $35 \mathrm{~m}$, presenta las mismas características constructivas que los otros lienzos de la zona 1. Zócalo de sillares de granito generando una línea horizontal de nivelación sobre la que se construye el lienzo de mampostería desconcertada. Este zócalo presenta hasta 5 hiladas en el punto más alto y en el resto solo tres, en función de la irregularidad de la roca. Presenta algunas piezas recolocadas y como es habitual, la hilada superior está compuesta de piezas más pequeñas y de proporción más alargada de forma que esa hilada es más estrecha. La singularidad es que este zócalo está escalonado a modo de zarpa, al igual que hemos visto en algunas torres. Pero este es el único caso de lienzo en el que encontramos esta característica.

Por su parte en la fábrica de mampostería desconcertada, se aprecia una zona desplomada en la parte alta central, lo que sugiere que al menos la parte alta del lienzo se ha rehecho tras un derrumbe. Sobre él, dos edificios ocupan la mayor parte del adarve, conservándose solo dos fragmentos practicables, ambos privatizados. Bajo uno de ellos se observa una gárgola y bajo el otro, se han empotrado al menos dos conducciones, posiblemente bajantes, en el espesor de la muralla. Una de estas bajantes, esta cobijada bajo un arco de ladrillo embebido en la mampostería. No existe almenado salvo en el último tramo junto torre T7.

La torre T7, es de planta rectangular $(5,97 \times 3,30 \mathrm{~m})$, aunque posteriormente se la han redondeado la esquinas por encima de zócalo, que es de sillería de granito, de similares características a lo ya visto, sobre el que continua una fábrica de sillería sedimentaria de hasta 5 hiladas escalonadas. Sin embargo ésta se encuentra ya muy deteriorada y solo es visible en los encuentros con los lienzos, mientras en el frente se ha reparado con mampostería, redondeando las esquinas, como ya se ha indicado. Esto nos hace suponer que se debió producir un derrumbe de buena parte de la torre. Incluso las piezas empleadas 
en los zócalos, están peor escuadradas que las de las torres más cercanas a la puerta de San Andrés y aparejadas con inferior calidad.

El resto de la torre se configura mediante mampostería de idénticas características a las torres anteriores. Se aprecian restos de ladrillo embebidos en el muro, los cuales son difíciles de interpretar, podría tratarse de restos de una decoración de arquillos ciegos como en las torres anteriores o bien simplemente, reparaciones puntuales. El adarve esta almenado pero su apariencia es de ser completamente rehecho nuevo hace relativamente poco tiempo.
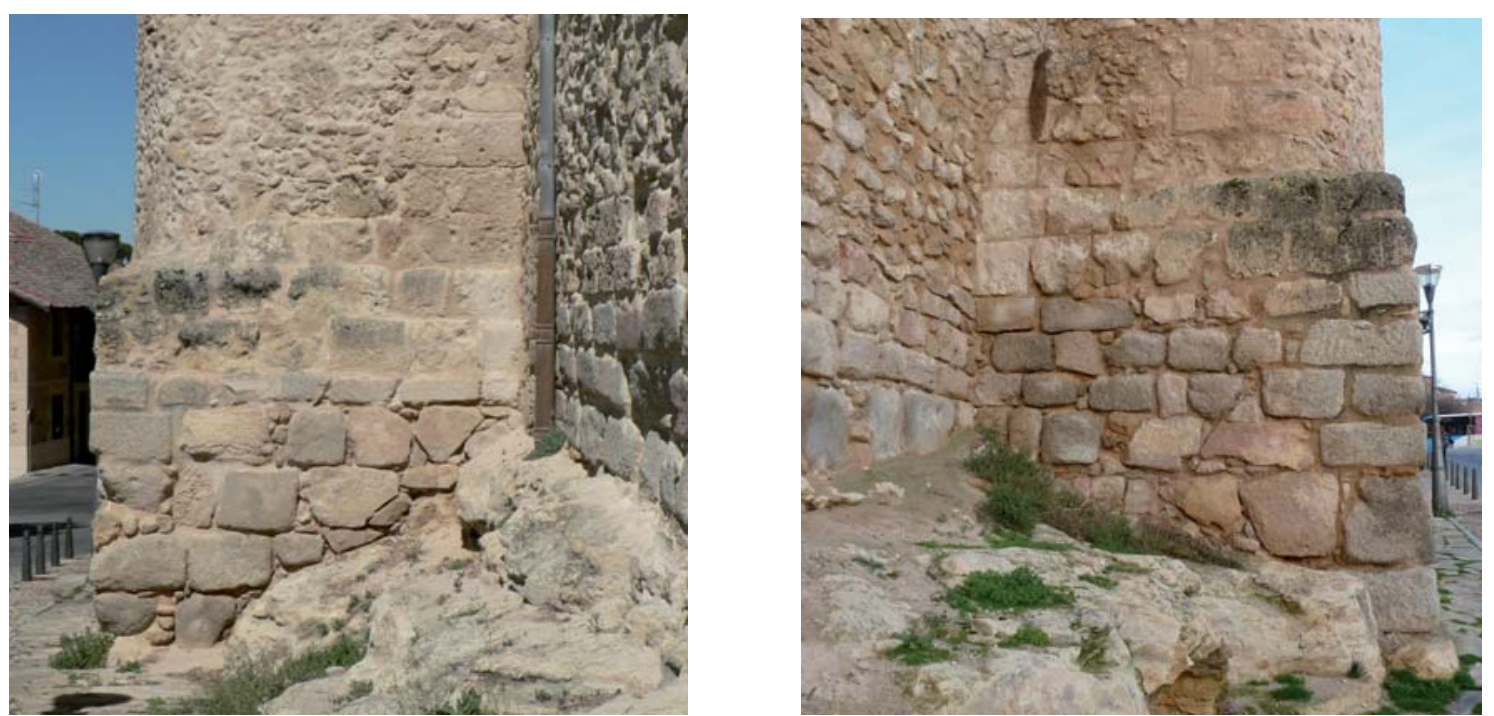

Figura 3. 18: Torre T7. Vista del lado este (uno de los dos lados cortos de la torre) en que se aprecia que la construcción continuaba en fábrica de sillería, pero se constata una interrupción de la fábrica con una línea de discontinuidad inclinada, marcando el ángulo y plano de deslizamiento. Sobre el zócalo continuaba la sillería.

Figura 3. 19: Torre T7. Vista del lado oeste en que se aprecia que la construcción continuaba en fábrica de sillería. La torre era originalmente de planta rectangular, pero en la parte de mampostería se han redondeado las esquinas.

El lienzo L7-8 $(34,27 \mathrm{~m})$ se encuentra muy alterado al estar la edificación adosada intramuros y apoyada sobre él en todo su trazado. Todo el adarve está ocupado por edificios. En sus paños se han abierto numerosas ventanas y se ha realizado un rejuntado que unifica todo el conjunto en el que sólo se puede distinguir la habitual mampostería desconcertada. Junto a la torre T8 se evidencia una reparación de cierta entidad realizada con mampostería encintada. Con aparejo muy similar, también mampostería encintada aunque de distinta modulación, se ha añadido un cuerpo de trazado curvo adosado a torre T8. Podemos asociar todo ello a la misma intervención en que se ha reconstruido esa parte de paño y abierto varios de los huecos del edificio.

El zócalo presenta tres hiladas de sillería de granito bien organizadas y niveladas, con piezas de tamaños y alturas de hiladas muy parecidas y sobre ella arrancan dos hiladas más de sillería en roca carbonatada. Todo ello constituye un zócalo perfectamente nivelado que se hace aún más patente al ir ascendiendo la rasante de la calle en pendiente que lo va ocultando paulatinamente según nos acercamos a la torre T8. 
La torre T8, de trazado poligonal (8 lados) con un radio 3,40 m, aparentemente tiene el zócalo enterrado por el recrecido de la rasante de la calle. Lo que arranca del suelo, en este caso no se ve el apoyo sobre la roca, es una sillería de piedra sedimentaria muy deteriorada, hasta 8 o 9 hiladas bien niveladas y piezas correctamente escuadradas. El resto de la torre se realiza, tendiendo a redondear las esquinas, en la característica mampostería desconcertada, toda ella muy reparada y de aspecto muy uniforme, hasta el peto almenado, que aparenta una factura reciente.

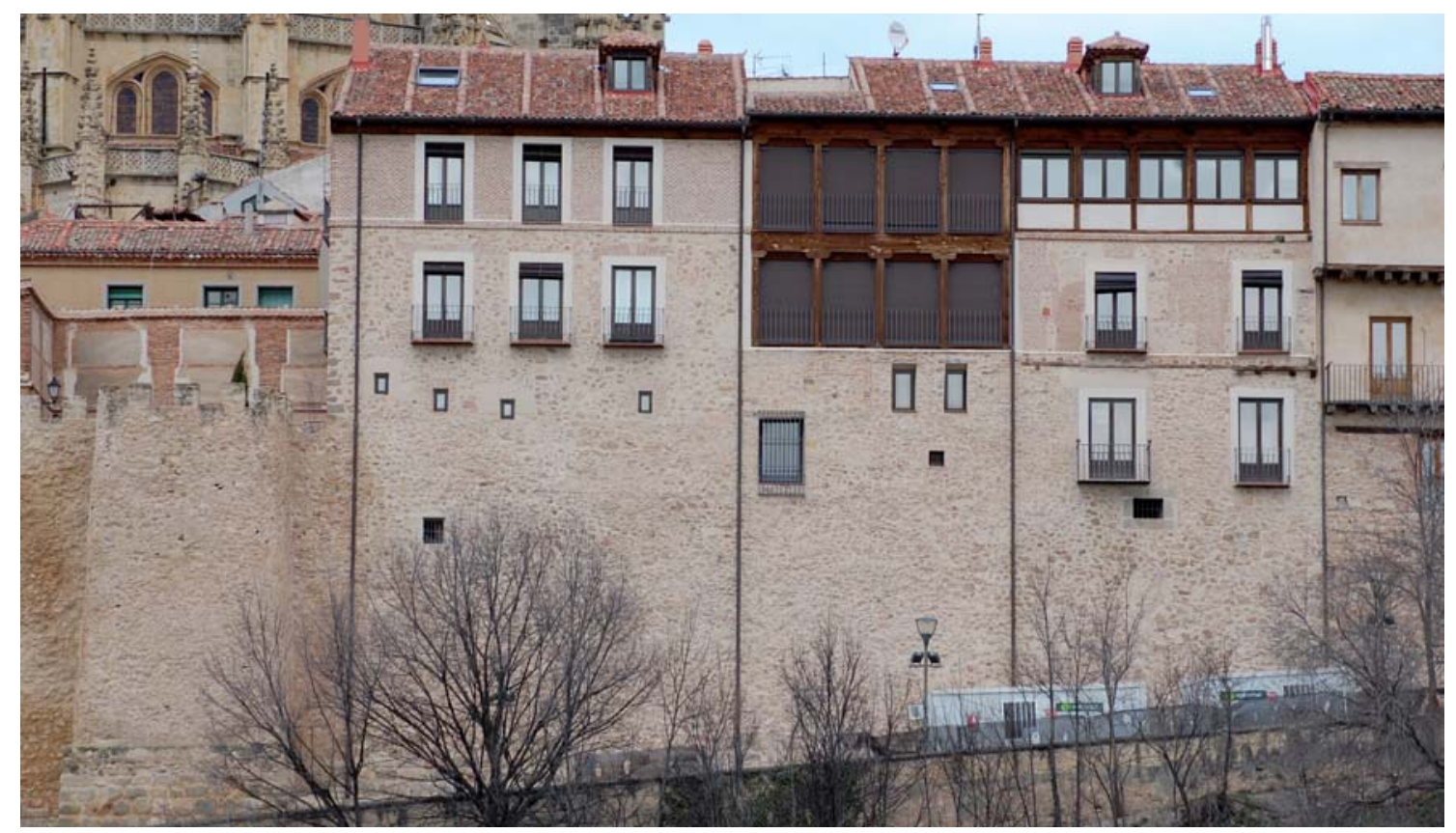

Figura 3. 20: Lienzo L7-8. Edificios construidos sobre la muralla.

El lienzo L8-9 (primera parte) hasta el postigo del Sol presenta las misma fábrica de mampostería muy reparada y homogeneizada por los rejuntados, y transformada por la apertura de varias ventanas de los edificios que se le adosan intramuros y se apoyan encima. No se aprecia ningún tipo de zócalo, sino que la mampostería arranca desde el suelo, por lo que no descartamos que pueda existir un zócalo similar a los descritos, enterrado bajo la rasante actual de la calle. No existe adarve, ya que está completamente ocupado con edificaciones construidas encima.

\subsection{2.- ZONA 2. SALÓN.}

Esta zona se extiende desde el postigo del Sol hasta el postigo de la Luna y se caracterizada por la completa colonización de la muralla por edificación. En sus 175 metros de longitud hallamos 5 torres y ambos postigos. Las torres son todas de trazado semicircular de radio entre 3,00-3,50 metros mientras los lienzos que las separan miden unos 22-25 metros. El único lienzo que no cumple este canon es el L10-11, que mide más de 36 metros. Tanto lienzos como torres se hayan recrecidos por edificios que han ocupado sus adarves y horadado los muros para abrir ventanas y puertas. Posiblemente la base de esta zona se encuentre enterrada, dado que como hemos visto la rasante actual de la calle es ascendente 
mientras el zócalo de los lienzos adyacentes mantenía perfectamente la línea horizontal. En ningún punto se ve el apoyo sobre la roca, que hasta ahora era visible en la zona previa.

Posiblemente sea la zona más vulnerable de todo el recinto amurallado, dado que la plataforma del actual salón de Isabel II, aparentemente artificial a base de rellenos que por lo que se aprecia en el grabado de Wyngaerde ya existía en el siglo XVI, reduce la altura de los lienzos a menos de 8 metros y quedan relativamente expugnables desde dicha plataforma.

La mayor parte de lienzos y torres se hayan revocados por lo que desconocemos los materiales, sistemas y técnicas constructivas empleadas. Existe una excepción, que es el aparejo que encontramos en la parte más próxima al postigo del Sol, en las torres T9 y T10 así como en el lienzo que los une L9-10 y un fragmento en el L8-9.

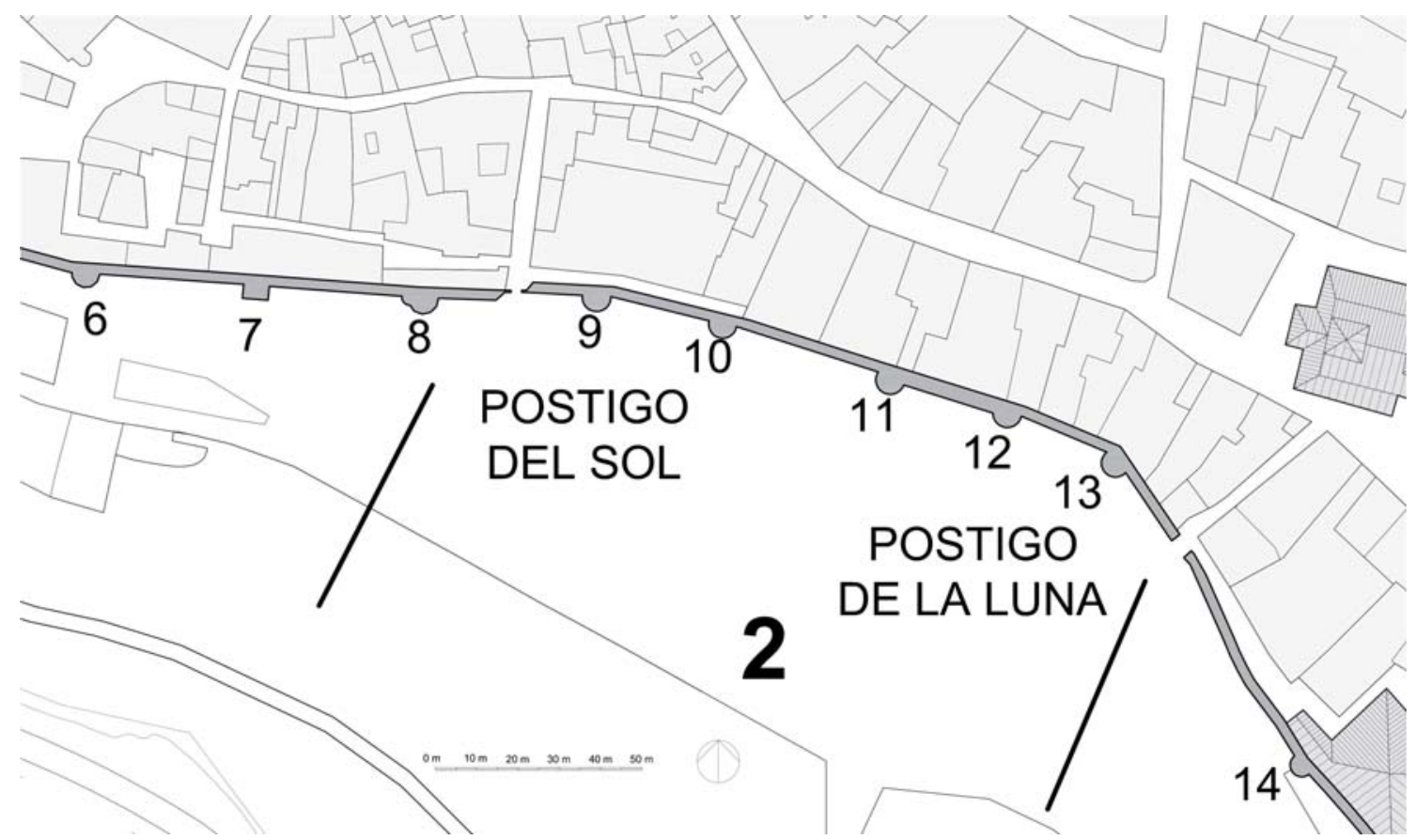

Figura 3. 21: Plano de la zona 2, que comprende desde el postigo del Sol hasta el postigo de la Luna.

El Postigo del Sol o de la Judería, tal y como se le conocía en el siglo XVI, era un doble arco de medio punto, de menor radio que el actual (AMS: 319-28), que comunicaba la Judería con la zona extramuros. Junto al Postigo, se situaba la casa de una de las familias judías conversas más influyentes del siglo XV, la de Abraham Senneor, posteriormente conocida como la familia Coronel. De ahí que se le denominara Postigo de los Coroneles. También recibe el nombre del Corpus Christi, por estar situado junto la iglesia de igual nombre, antigua Sinagoga Mayor (AMS 4810-3: 19). En 1864, a petición de un vecino, fue demolido, siendo reconstruido en 1992. (AMS: 3704-1).

La fábrica actual es un arco de medio punto volteado en ladrillo sobre dos muros de mampostería encintada, sin ningún interés documental, ni histórico constructivo para nuestro estudio. Desconocemos la configuración de este postigo en su origen, tan solo disponemos del grabado de Wyngaerde y el plano de Nicomedes Perier, pero es evidente 
que separa dos fábricas históricas de características (y posiblemente cronologías) muy distintas.

El lienzo L8-9 presenta en su base un singular cambio de técnica constructiva entre el postigo y la torre T9 respecto a lo que acabamos de ver entre el postigo y la torre T8. Se trata de un fragmento de lienzo muy corto, de aspecto muy uniforme sobre el que se apoya el muro de la sinagoga. Todo el muro tiene aspecto de haber sido muy remozado, pero en su base, prácticamente oculto por la vegetación, se ve un fragmento de aparejo de mampostería concertada en que abundan las piezas dispuestas a sardinel, idéntico al que encontramos en las torres T9 y T10 así como en el lienzo que las une.

El aparejo del resto del lienzo es muy uniforme, una mampostería desconcertada en la que aparecen numerosos bloques de granito, entremezclados y con la esquina hacia la calle del Sol ejecutada con sillares de granito de nueva factura, cortados de manera mecánica. En la parte superior del lienzo, se abren tres ventanales dobles de considerables dimensiones, pertenecientes a la sinagoga, recercados en ladrillo y rematados en arco de herradura. Una línea de ladrillo, justo por debajo de estas ventanas, parece indicar la altura de la muralla y marca el inicio del recrecido del edificio.

En la calle del Sol se rectifican las alineaciones en 1868 (AMS: 319-28), por lo que durante dichas obras se demuele el postigo y parte de la muralla para ensanchar la calle. La ampliación de la sinagoga por Odriozola en 1902 (Ruiz Hernando, 2008: 112-127) es la segunda fecha de referencia para este lienzo. Salvo el mencionado aparejo de mampostería con piezas a sardinel, el resto del lienzo debe reconstruirse prácticamente en su totalidad entre 1868 y 1902.

La torre T9, la T10 y el L9-10 presentan el mismo esquema compositivo que hemos visto en el lienzo anterior. Sobre una mampostería a sardinel se ha recrecido una muralla en mampostería desconcertada. El aparejo de mampostería a tizón, hasta 4 hiladas de 1 metro de alto cada una, es considerado musulmán por Juan Zozaya (Zozaya Stabel-Hansen, 2009: 117) con paralelismos con los castillos del Desierto en Jordania (Kharrane, Qastal) datándolo en el siglo VIII. Sin embargo para Basilio Pavón es cristiano, similar a los de Ávila, Sigüenza, Atienza y datable en los siglos XIII-XIV (Pavón Maldonado, 1984: 62-68). Este aparejo de las piezas apoyando sobre la parte estrecha y disponiéndose con predominio de la componente vertical, se le refiere en los aparejos de factura musulmana como dispuestas a tizón. Basándonos en esta filiación hispanomusulmana que efectúa Zozaya, lo denominaremos aparejo a tizón, si bien, dado que desconocemos su profundidad, sería más correcto denominarlo a sardinel, o admitir que quizá no todas sean piezas a tizón (Ewert, 1979: 26).

Actualmente en la T9, el edificio de la sinagoga se ha apoyado encima, en el que se abren tres ventanas dobles recercadas en ladrillo, mientras en la torre T10, conserva el adarve sin ocupar, pero utilizado como terraza privada por el edificio que se le adosa intramuros. 


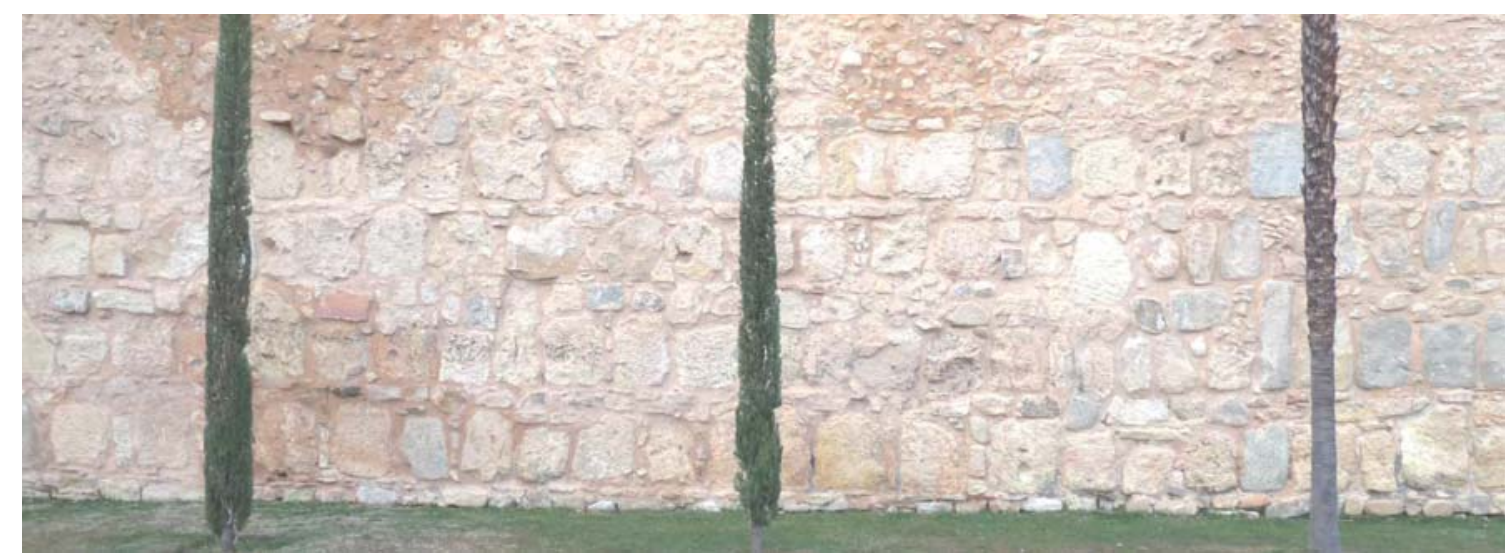

Figura 3. 22: Lienzo L9-10. Aparejo de mampostería a tizón. Zozaya lo considera fábrica musulmana del siglo VIII, relacionándolo con los castillos omeyas del desierto de Jordania (Zozaya Stabel-Hansen, 2009: 117). Sin embargo para Basilio Pavón, es aparejo cristiano datado en siglos XIII y XIV (Pavón Maldonado, 1984: 6268).

El resto de los lienzos hasta la T12 están revocados y con edificios apoyados encima, que han ocupado el adarve y abierto numerosas puertas y ventanas en los lienzos de la muralla. En el lienzo L10-11 se han abierto dos puertas en la base, mientras en el L11-12 se han abierto tres. Del mismo modo se han practicado numerosas ventanas en los paños, estando todos los adarves ocupados por edificios que apoyan en la muralla. Se han medido en estos puntos el espesor de la muralla, entre 2,10 y 2,30 metros, aunque los acabados del interior no permiten apreciar si medimos el espesor total de la muralla, o esta regruesada o repicada.
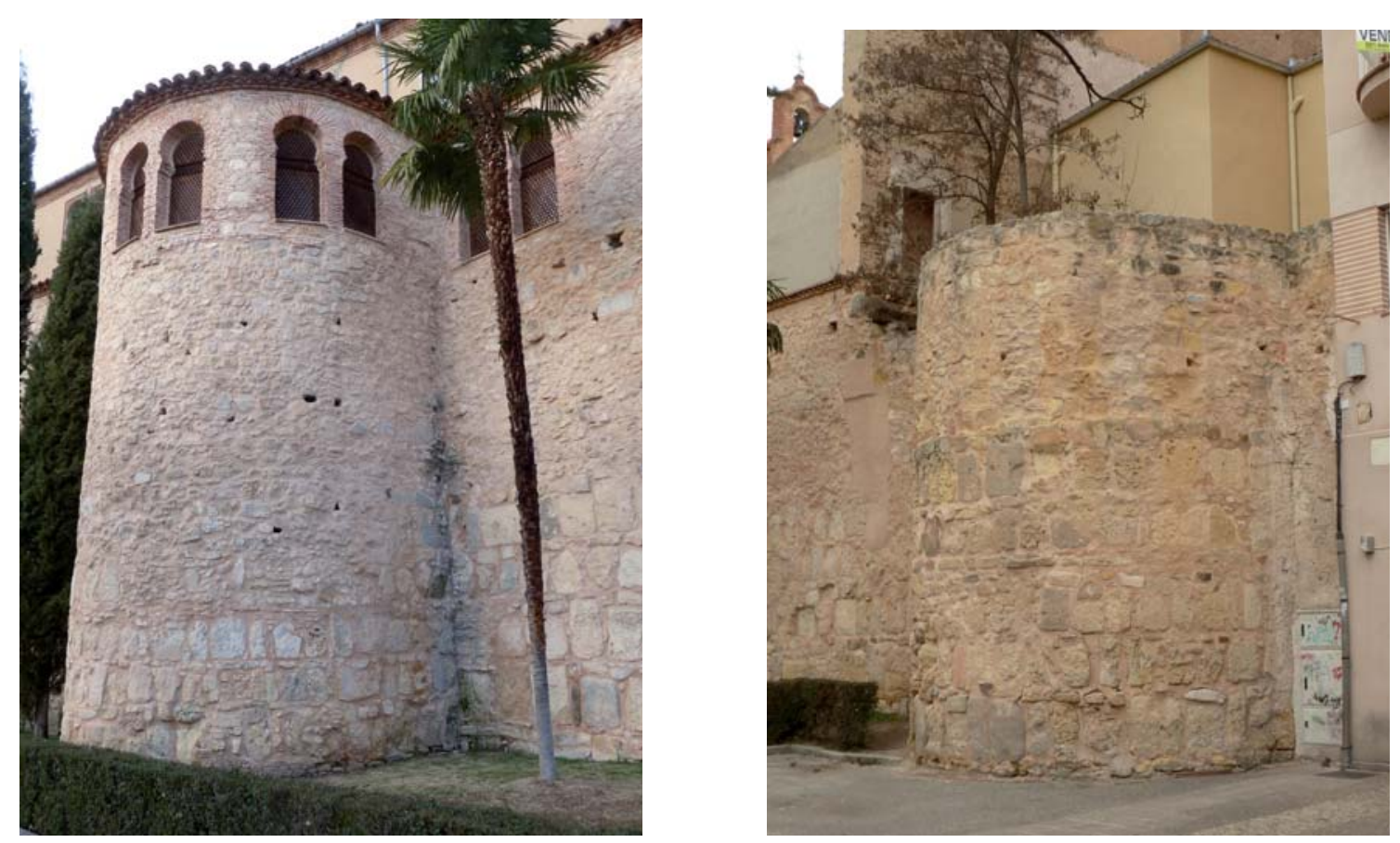

Figura 3. 23: Aparejo de mampostería a tizón en la torre T9.

Figura 3. 24: El mismo aparejo en la torre T10. 
El último lienzo el L12-13, no está revocado, sino que presenta una fábrica de mampostería desconcertada en toda su altura. Tiene un aspecto muy uniforme por las reparaciones y rejuntados. Sobre él, se apoya igualmente dos edificios cuyas fachadas están revocadas. La mitad cercana a T12 presenta indicios de desplome. La otra mitad esta aplomada, reconstruida. Se aprecia la discontinuidad en la línea de separación de ambos edificios.

Las otras tres torres T11, T12 y T13 aportan poca información adicional a la ya indicada como común a toda la zona. La T11 esta revocada y recrecida dos pisos por encima. En algunos desconchones del revoco, se aprecia una mampostería muy desordenada con abundante ripio.

La T12 está recrecida tres pisos e igualmente revocada. En el zócalo presenta piezas grandes de mampostería sedimentaria y otras casi sillares, algunas de ellas reutilizadas, organizadas en hiladas bastante ordenadas. Solo tres hiladas visibles. Por último, la T13 esta recrecida dos pisos revocados. Bajo ellos, la misma mampostería desconcertada.

El postigo de la Luna o del Rastro ${ }^{52}$ o de San Martín (por estar emplazado frente a dicha iglesia), era un simple arco de medio punto, por lo que se puede observar en el dibujo de Wyngaerde. Su utilidad quedaba reducida al tránsito de personas hacia el rastro. En 1885 el propietario de la finca colindante pidió su demolición con el fin de mejorar el aspecto exterior de su casa, petición que fue aprobada poco después (AMS 4810-3: 18). Se ha reconstruido en 1993 aunque con un trazado del arco distinto (AMS: 3714-5) por lo que no tiene ningún interés histórico-documental para nuestro estudio.

\subsection{3.- ZONA 3. AlHÓNDIGA}

En esta zona consideramos las torres y lienzos que se extienden desde el postigo de la Luna hasta el emplazamiento que ocupaba históricamente la puerta de San Martín. Se trata de una zona actualmente poco visible y bastante inaccesible, especialmente desde la Alhóndiga hasta la calle Real, ya que ha sido muy alterada con importantes zonas reconstruidas. Tanto torres como lienzos parecen estar muy transformadas, predominando el aparejo de mampostería desconcertada. Mide 230 metros. Se conservan 4 de, al menos 6, que existían. En el límite de esta zona se situaba la desparecida puerta de San Martín. Las distancias entre estas torres son muy variables, con tres lienzos centrales que varían entre los 23 y 25 metros y los dos extremos que miden 82 y 83 metros respectivamente. Falta alguna torre en ambos tramos tan largos, como veremos.

El lienzo L13-14 se haya dominado por la imponente presencia del hotel las Sirenas, construido sobre el lienzo de muralla en los años 1948-1949 y que ha abierto numerosas ventanas y unificado el aspecto de todo el paño a una mampostería desconcertada. La mayor parte del lienzo no presenta almenado, solo un peto que protege el adarve privatizado, excepto el tramo más cercano a la torre T14, ya superada la parcela del hotel. Este tramo es inusualmente largo ya que alcanza los 82 metros, lo que nos hace sospechar que falte alguna torre. Existe un arco de ladrillo embebido en la mampostería. Intervenido en 1707, aunque desconocemos el alcance de la restauración (AMS: 1162-57).

${ }^{52} \mathrm{El}$ rastro o matadero de ovejas, donde se comerciaba con los restos y desperdicios de los corderos y otros animales. Actualmente se le conoce como Paseo del Salón. 


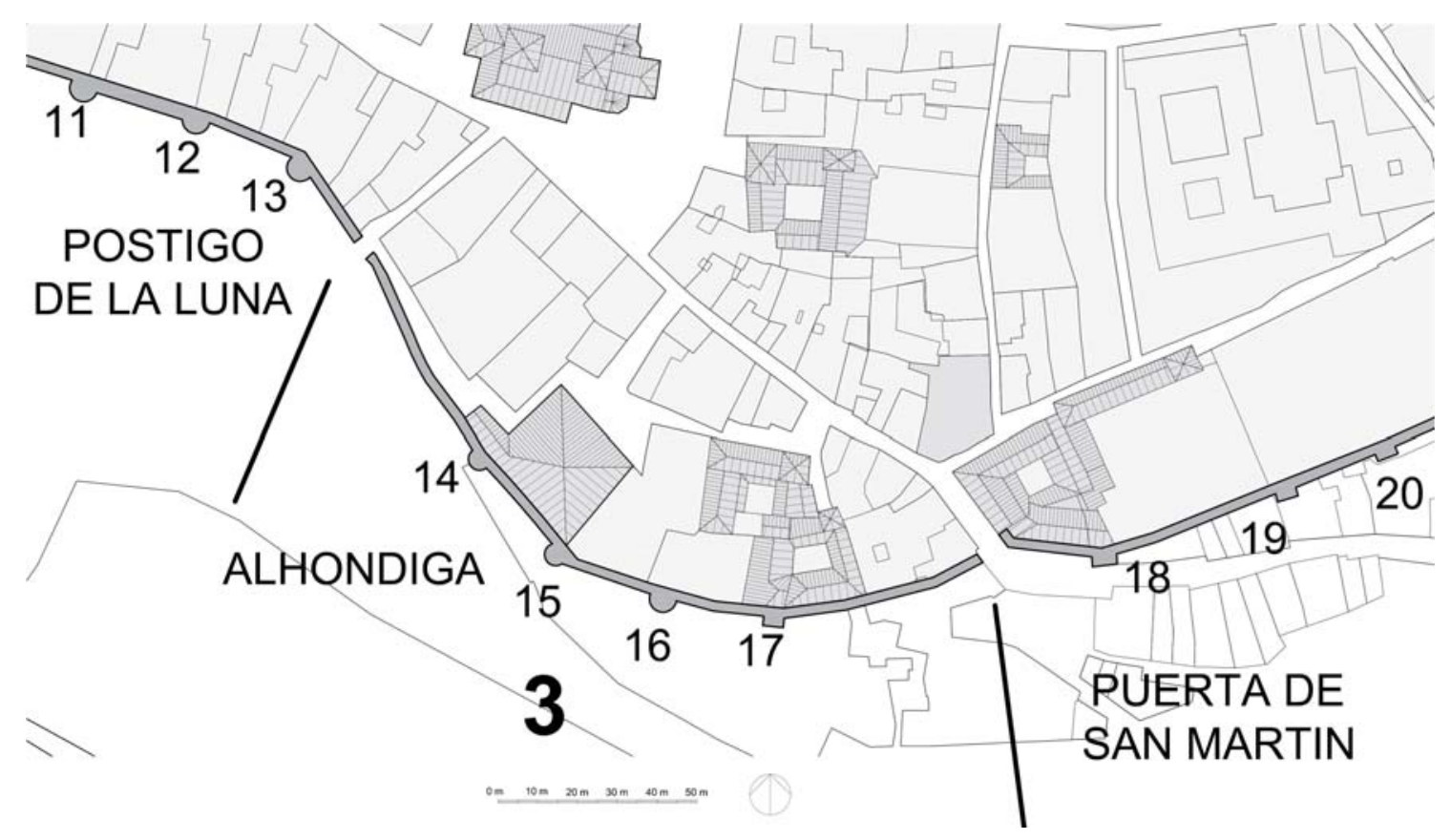

Figura 3. 25: Plano de la zona 3, que comprende desde el postigo de la Luna hasta la puerta de San Martín.

Hay que destacar un ligero quiebro que efectúa este lienzo aproximadamente en la mitad de su trazado, irregularidad poco frecuente en el trazado de la muralla, ya que lo que habitualmente observamos es que los cambios de dirección se producen en las torres, siendo los lienzos tramos rectos.

La torre T14, de trazado semicircular y 3,40 m de radio presenta un edificio adosado en su cara extramuros que nos oculta una parte de su construcción. En la base observamos un zócalo resaltado, de radio ligeramente mayor al del resto de la torre. Su aparejo es una mampostería desconcertada de piedra carbonatada en la que se distinguen algunas hiladas de sillería, una casi a la altura del adarve, que acompaña a una cornisa de talla achaflanada muy deteriorada; otra marcando el límite del zócalo, acompañando a otra hilada en talud que resuelve el cambio de dimensión entre ambas partes; y en la parte más baja de su zócalo, tapado casi totalmente por un chapado, se observan hasta tres hiladas de sillería sedimentaria. Aparentemente el zócalo evidencia una discontinuidad en relación al resto de la torre.

El lienzo L14-15, de 25 m de largo, se encuentra oculto en la mitad inferior de su alzado extramuros por una edificación adosada delante de él. Presenta la habitual mampostería desconcertada de piedra carbonatada en la que se distinguen 4 huecos. Por su cara intramuros se encuentra la Alhóndiga, desde donde se accede al adarve que tiene peto sin merlones. La Alhóndiga es una edificación de carácter público donde se almacenaba el grano del cereal para su posterior compra venta. Fue construida a principios del siglo $\mathrm{XVI}^{53}$.

\footnotetext{
${ }^{53}$ Conserva su estructura original, formada por tres crujías paralelas, con una empinada rampa de acceso a la parte superior de la central. La entrada principal tiene un gran arco con dovelas. Su fachada está decorada con el esgrafiado típico segoviano. En la actualidad es la sede del Archivo Municipal de Segovia y sala de exposiciones. (Chaves Martín, 2006: 107)
} 


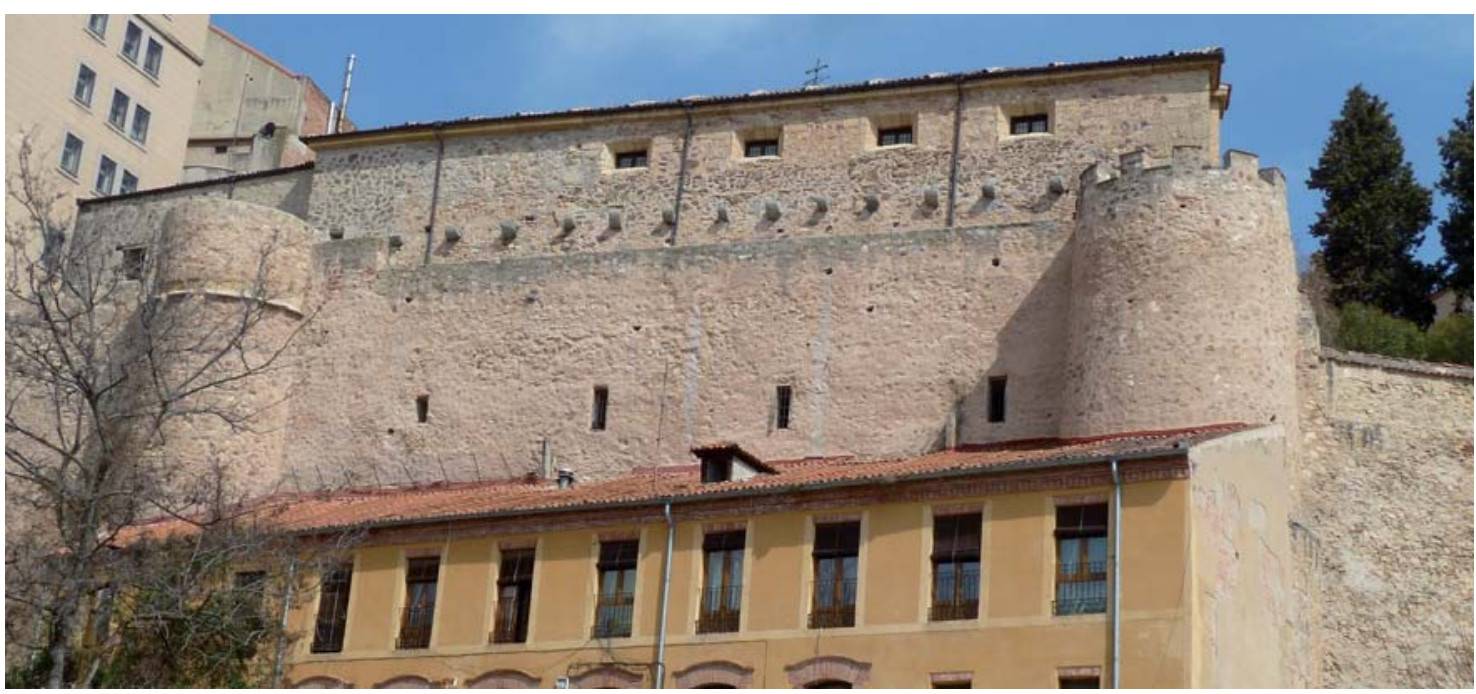

Figura 3. 26: Lienzo L14-15. Entre ambas torres, un edificio adosado delante, nos oculta la mayor parte del lienzo. Por encima de la muralla asoma la Alhóndiga. Nótese en sus muros la línea de ménsulas, donde posiblemente apoyaba un cadalso o algún tipo de cuerpo volado.

Uno de sus accesos, a intramuros, permitía la entrada y salida de mercancía a través de un callejón a la largo de la muralla, hoy desaparecido, que comunicaba con el postigo de la Luna. Hacia el exterior en la fachada que mira hacia la muralla se observan ménsulas de granito que sugiere que, aparentemente, pudo existir algún tipo de edificación o cubierta ocupando o protegiendo el adarve.

La T15 es muy similar a la anterior, trazado semicircular de 3,40 m de radio, fábrica de mampostería desconcertada de piedra carbonatada, muy reparada con rejuntados que ocultan buena parte de la piedra y actualmente está parcialmente oculta por un edificio que se le adosa por delante. Tan sólo presenta con la anterior tres diferencias significativas a los efectos de nuestro estudio, no presenta hiladas de sillería ni molduras intermedias, a diferencia de la anterior sí tiene peto almenado y la principal diferencia, su zócalo no es circular sino que parece ser de forma rectangular (es inaccesible y muy poco visible, solo de forma muy sesgada) y realizado con mampuestos y sillarejos de tamaño medio, organizados en hiladas horizontales. Aparentemente se construye sobre los restos de una torre de planta rectangular, sobre los que también se apoya el edificio que se le adosa exteriormente.

El lienzo L15-16, de $23 \mathrm{~m}$ de largo, tiene adosadas parcelas privadas en ambas caras, intramuros y extramuros, por lo que es inaccesible y relativamente poco visible desde cerca. En su cara exterior observamos una mampostería desconcertada realizada con mucho material mezclado y de procedencia muy variadas, con abundancia de ripio y cascote. Se aprecian importantes pérdidas de material en algunos desconchones. Aparentemente la mampostería está presente en toda su altura, desde el suelo hasta el remate, que no presenta almenado. No existe zócalo diferenciado con piezas de mayor tamaño. Muestra evidencias de varios derrumbes y reconstrucciones en su parte alta. Especialmente visible un escalón, prueba de que falta un trozo de lienzo, en el entronque con la torre T15, la adyacente al edificio de la Alhóndiga, coincidiendo con el fragmento que delimita la parcela de la casa fuerte de la familia Cascales-Barros ${ }^{54}$.

\footnotetext{
54 También se la conoce como casa del Conde Alpuente o casa Aspiroz.
} 

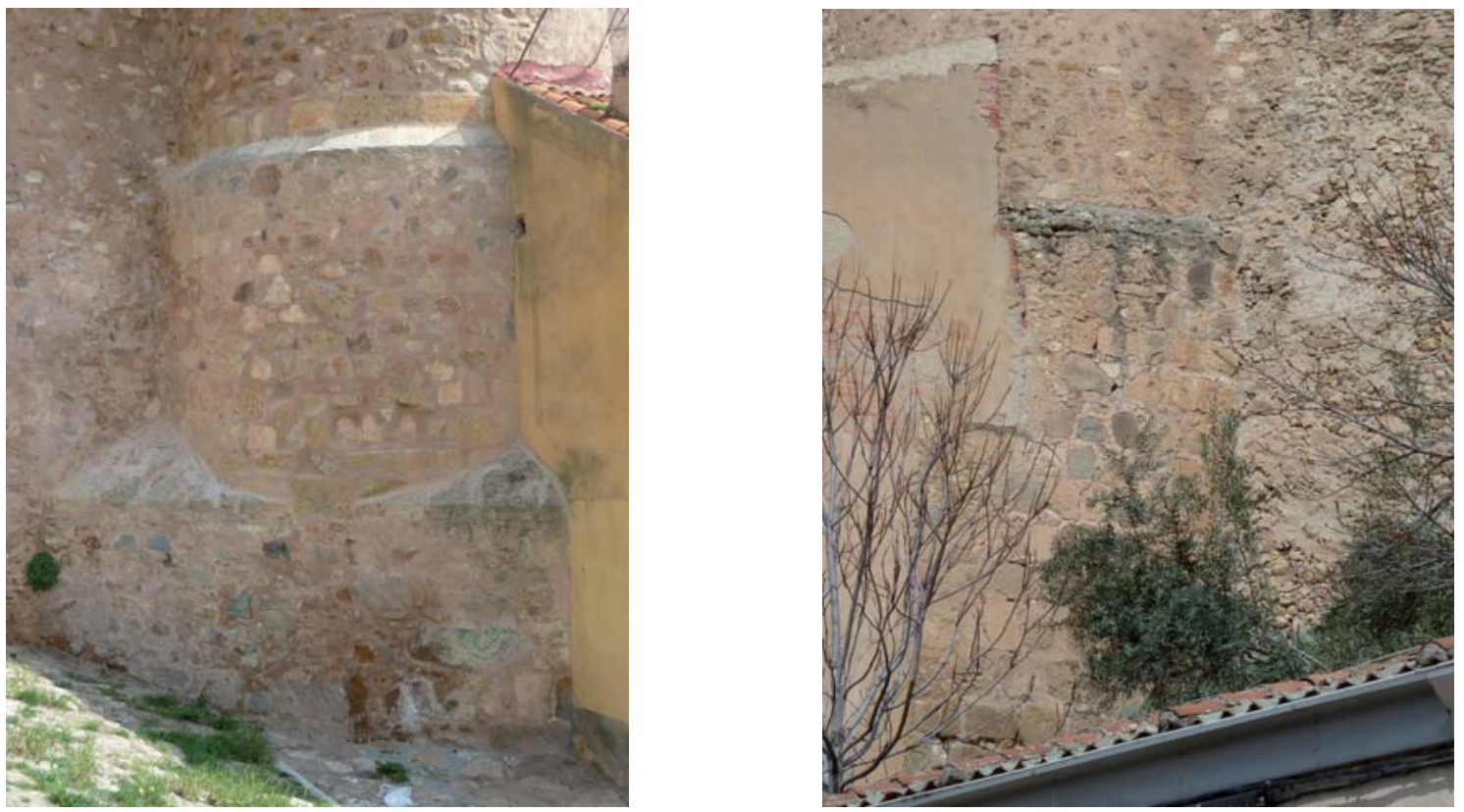

Figura 3. 27: Torre T14. Detalle del zócalo. Se observan tres hiladas de sillería de planta semicircular que continuaban por debajo del chapado que actualmente hace las funciones de zócalo.

Figura 3. 28: T15. Detalle del zócalo oculto tras el edificio. La base de la torre era originariamente rectangular. Sobre una torre originalmente de planta rectangular, se levantó una de planta semicircular.

La torre T16, de planta semicircular, aparentemente está completamente reconstruida en 1942 (STC: RH 225-1999-5). Presenta un esgrafiado historiado que oculta la construcción de sus muros, si bien en algunos desconchones se aprecia una mampostería desconcertada de piedra carbonatada y canto rodado. No existe zócalo diferenciado, llegando a mampostería hasta el arranque. Presenta unas troneras de palo y orbe recercadas en ladrillo, que hacen sospechar que su piso superior sea hueco y habitable. El remate superior a base de arquillos de ladrillos imita unos matacanes, fingidos, ya que no presentan abertura por su parte inferior, por lo que carecen de función militar o defensiva. El peto almenado con merlones rematados por una pieza prefabricada de forma piramidal.
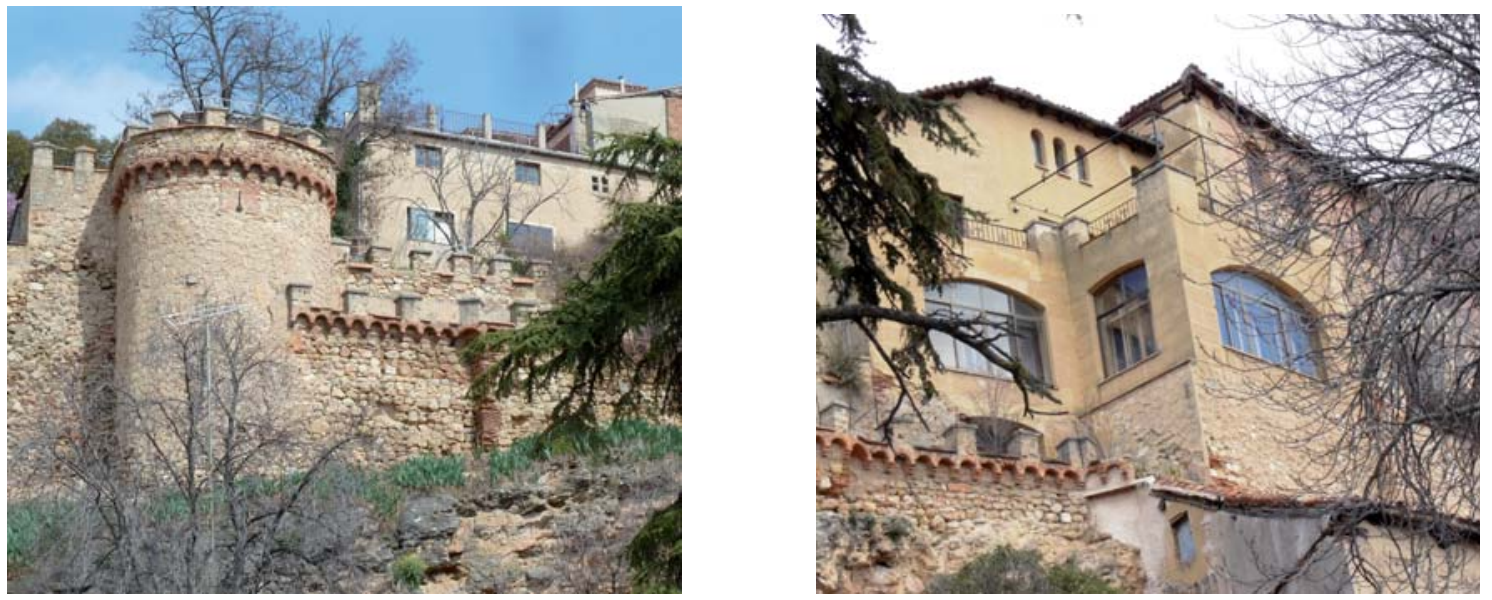

Figura 3. 29: Torre T16 y a su derecha parte del lienzo L16-17, muy rehecho con abundancia de ladrillo.

Figura 3. 30: Torre T17, recrecida como vivienda, y otra parte del lienzo L16-17. 
El lienzo L16-17 en si no es visible, oculto por una especie de falsabraga, que presenta unas características constructivas idénticas a las de la torre anterior. Matacanes de ladrillo en su remate así como en esquinas. Los merlones rematados con la misma pieza piramidal. Su fábrica es una mampostería de piezas relativamente bien organizadas en hiladas horizontales. Esta falsabraga no existe en la foto de Launay de 1852 (Sáez Laguna, 2009: 14). Todos estos datos nos hacen sospechar que se trata de una reconstrucción historicista, realizada a raíz del proyecto de 1942 (STC: RH 225-1999-5). Ambos elementos, torre y lienzo se encuentran inaccesibles y difícilmente visibles desde extramuros. Se utilizan como terraza privada del edificio situado intramuros.

La torre T17, de planta rectangular, es igualmente inaccesible y muy poco visible. Está vinculada a la parcela de la casa Fortaleza, con acceso en la actual plaza platero Oquendo $\mathrm{n}^{\circ}$ $2^{55}$. Este edificio se adosa a la muralla y se apoya sobre la torre de la cerca, que en su parte original es maciza. Se encuentra construida sobre restos de una torre maciza, (STC: RH 225-1999-5), con un edificio que se le adosa y apoya, presentando el piso superior habitable, como parte de la vivienda, con grandes ventanales y el adarve como terraza. Ya está construida en 1900 tal y como apreciamos en la foto de Mariano Moreno. (VVAA, 2006: 88) Exteriormente sus muros están revocados o con esgrafiado historiado.

El resto de lienzo desde esta torre hasta el emplazamiento donde se situaba la puerta de San Martín o no es visible desde la vía pública al estar la edificación adosada a la roca sobre la que apoyaría la muralla, o ha desaparecido por completo sustituido por edificación. En la bajada de la Canaleja, ejecutada a finales del siglo XIX, vemos numerosos sillares de piedra carbonatada reutilizados en los muros de contención, procedentes de la demolición de la iglesia de San Pablo (Ruiz Hernando, 1994: 487) y posiblemente también podrían proceder de la muralla y la puerta de San Martín. Esta puerta que desapareció en 1883 con motivo de las obras de reurbanización de la calle Juan Bravo, era el punto donde los reyes juraban respetar los fueros de Segovia, antes de entrar en la ciudad. Defendiendo la antigua puerta de San Martín, el principal acceso urbano a la ciudad, se encuentra la conocida como Casa de los Picos.

La Casa de los Picos, también llamada como casa de los de la Hoz, casa del judío o casa del verdugo, fue levantada como casa fuerte que defendía la puerta de San Martín, con la que estaba comunicada interiormente. Perteneció al linaje de los López de Ayala y Silva a quienes compró el edificio don Alonso González de la Hoz, regidor de Segovia, quien añadió a su fachada afiladas puntas de granito que cambiaron por completo el carácter de la casa (Chaves Martín, 2006: 123-124).

La vivienda se recreció, apoyándose sobre la muralla en la parte del actual teatro Cervantes y abriendo sobre las almenas, un cuerpo de ventanas geminadas de las que todavía se conserva algún vestigio, gracias al revestimiento esgrafiado que representa lo que pudieran ser los merlones de la muralla ${ }^{56}$ (Ver el apartado 4.1.4).

\footnotetext{
55 Esta casa fuerte, la casa fortaleza sita al fondo del callejón en plaza Platero Oquendo n ${ }^{\circ}$ 2, la identifica el Marqués de Lozoya, sospechando que perteneciese a algún comunero, ya que sus escudos estaban picados a principios de siglo XX. En la actualidad no se conservan dichos escudos en su fachada. (Contreras y López de Ayala, 2010: 284)

${ }^{56}$ En el año 1921 se construyó el teatro Cervantes, demoliéndose el forjado de primera planta para abrir un gran hall, donde dos grandes puertas horadadas en la muralla daban acceso a la sala principal. La torre de la muralla adyacente fue vaciada y se utilizó para instalar una escalera a la segunda planta del teatro. Posteriormente, en 1976, la casa de los Picos se adapta para albergar la Escuela de Arte y Superior de Diseño de Segovia, por lo todo que el conjunto está actualmente muy transformado.
} 


\subsection{4.- ZONA 4. ACUEDUCTO}

Esta zona abarca desde la torre T18 hasta la torre T24, esto es el espacio comprendido entre las dos puertas actualmente desaparecidas de San Martín y San Juan y en la que el acueducto acomete a la muralla y penetra en la ciudad. Son 290 metros en los que se distribuyen 7 torres y aparte de las dos puertas de los extremos encontramos el postigo del Consuelo en el entronque del acueducto con la muralla. Esta zona presenta una horquilla muy amplia de valores en lo que a dimensiones de lienzos se refiere. La mayoría de los lienzos oscilan entre los 22 y los 27 metros. Sin embargo encontramos lienzos de 47 y 63 metros. La existencia de unos quiebros en el trazado de la muralla coincidiendo con estos lienzos tan largos nos hace sospechar que pueda faltar alguna torre. Como ya hemos visto en las anteriores puertas, el lienzo L24-25, contiguo previo a la puerta de San Juan, es más corto de lo habitual. Las dimensiones de las torres van desde los 5,30 a los 5,70 metros de ancho mientras el resalto varía de 2,00 a 2,40 metros.

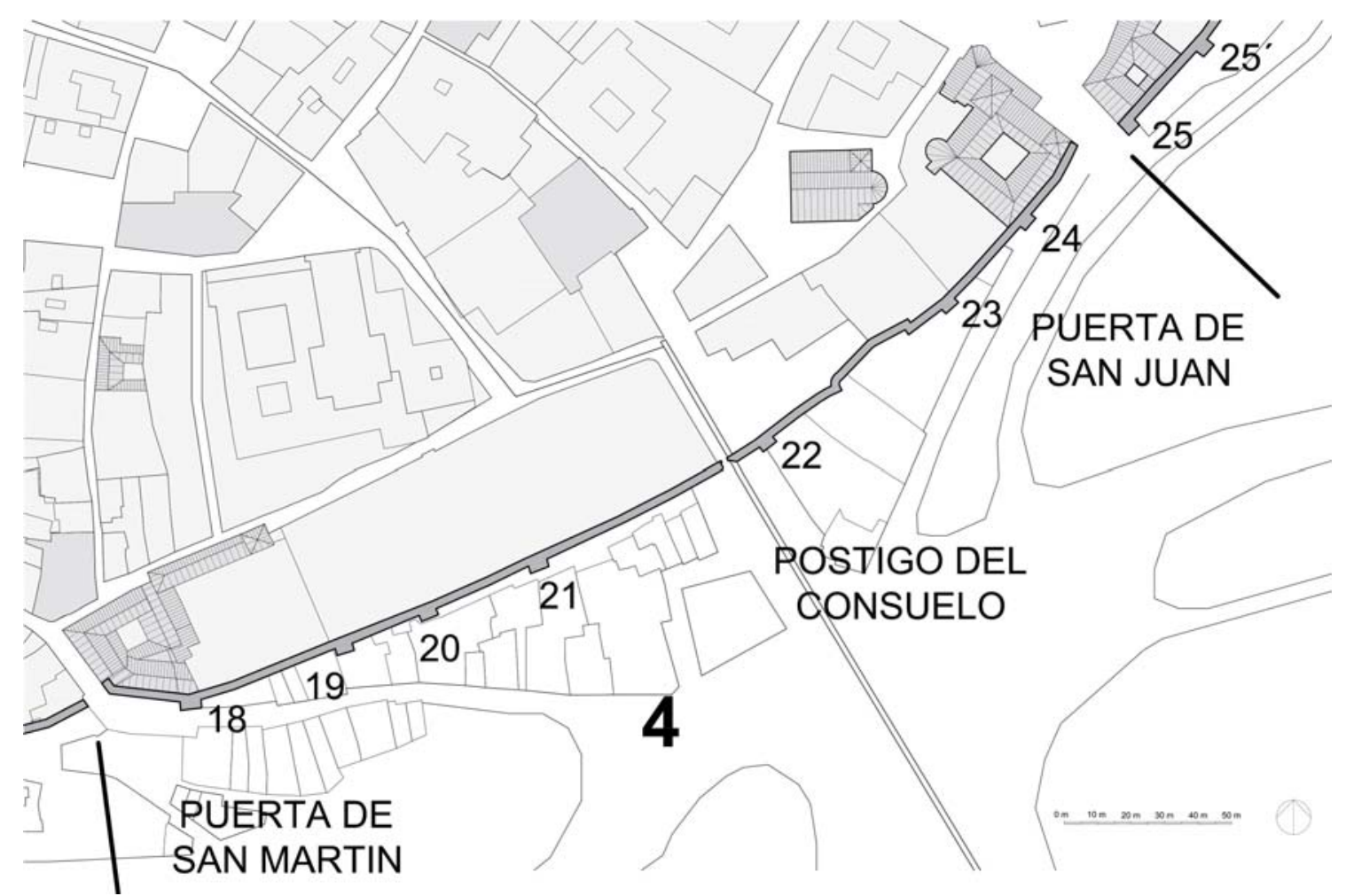

Figura 3. 31: Plano de la zona 4, que comprende desde la puerta de San Martín hasta la puerta de San Juan.

Esta zona se caracteriza por constituir el alzado del recinto amurallado hacia el resto de la ciudad, donde se situaban dos de las principales puertas de la cerca urbana que conectaban con el Azoguejo. A consecuencia de ello, a todo lo largo del tramo encontramos edificios adosados a la roca y la muralla, ocultándolas y haciéndolas inaccesibles en muchos puntos. Los lienzos que son visibles desde el exterior presentan una mampostería desconcertada de piedra sedimentaria muy oculta por el rejuntado, sin piezas de refuerzo en el zócalo. En algunos puntos se aprecia aflorar la roca, sobre la que apoya directamente la mampostería. Las torres son todas rectangulares, mostrando en su arranque, las que son visibles, una fábrica de sillería o mampuestos grandes someramente aparejados en hiladas, a base de piedras mezcladas, aunque predomina el granito. Sobre este zócalo, se eleva una mampostería desconcertada similar a la de los lienzos, con distintos tipos de solución en las esquinas. 

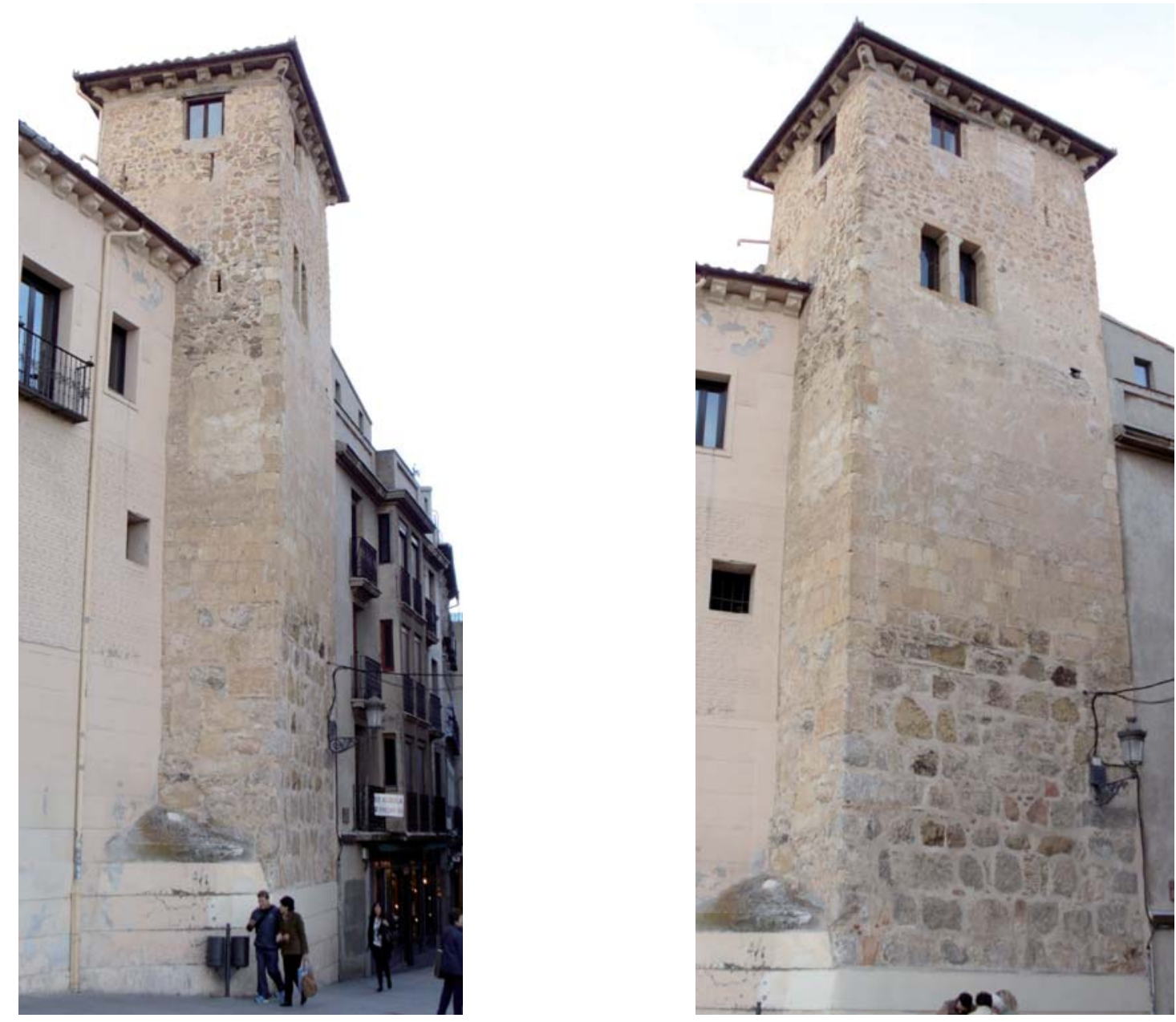

Figura 3. 32: Torre T18. Vista de la torre desde la posición donde se encontraba la puerta de San Martín, que ayudaba a defender.

Figura 3. 33: Torre T18. Otra vista más frontal de la misma torre. Nótese el cambio de material y aparejo que denota la mitad inferior de la torre, respecto a la parte superior.

La torre T18, vinculada en otros tiempos a la casa fuerte que defendía la puerta de San Martín, manifiesta planta rectangular con fábrica de sillería en su parte inferior, diferenciando dos tipos. Sobre un zócalo revocado arranca una sillería de piedra mezclada de tamaño medio grande con numerosas piezas graníticas y aparentemente reutilizadas a tenor de lo redondeado de sus formas que obliga a ejecutar amplias juntas de mortero con calzos de ripios. Por encima de este aparejo descubrimos 4 hiladas de una sillería de piedra carbonatada de tamaño mediano pequeño, perfectamente tallada que se coloca con muy poca junta. El resto de la torre esta revocada imitando un torpe despiece de sillares, aunque las esquinas siguen manteniendo sillares, aparentemente de la misma cantera que las 4 hiladas de sillería comentada. La torre se remata con dos pisos recrecidos en mampostería desconcertada, utilizándose mampuestos ligeramente más grandes para las esquinas. Estos son habitables, con una ventana doble el piso inferior y el superior con una ventana y una saetera en cada una de las dos caras visibles, si bien se perciben señales de otros huecos tabicados. Se trata por lo tanto de un recrecido del edificio adyacente sobre la torre maciza de la muralla inicial. 
El lienzo L18-19 coincide con el actual teatro Cervantes, que se apoya sobre la muralla, antigua parte de la Casas de los Picos. Con 42 metros, supone una separación entre torres inusualmente larga. Este lienzo no es visible desde el exterior al estar adosada la edificación. La única parte visible, donde se adosa el teatro, es la cara interior, de gran interés por ser uno de los pocos lienzos en que se observa el intradós de la muralla, muy poco alterada, al haber estado protegida en el interior de un edificio. Se observa que es una fábrica encofrada de cal y canto, con tres agujales por tapia, desde el arranque en la roca y con algunos parches y recrecidos de ladrillo para apoyar la cubierta del teatro. No presenta ningún tipo de zócalo diferenciado ni la existencia de piezas más grandes o mayor resistencia.

La torre T19 (5,30 x 2,16 m) está prácticamente embebida por la edificación adosada y solo es visible su remate. Presenta un almenado de ladrillo, con una parte de su terraza cerrada por el recrecido de los muros y cubierta por un tejadillo piramidal, a modo de garita, mientras el peto y la parte de fábrica apreciable es una mampostería desconcertada. Actualmente está privatizada y sólo es accesible desde la huerta del seminario, al igual que los siguientes lienzos y torres, hasta el acueducto.

El lienzo L19-20, de 22 m de largo, posee edificación adosada en su cara extramuros, si bien puede observarse de cerca desde una plataforma de la roca que hace las funciones de liza y que se utiliza como terraza privada por los edificios. Exhibe mampostería desconcertada en todo su extensión, desde el arranque en la roca, visible en algunos puntos, hasta el almenado, todo ello con numerosos rejuntados, parcheados y reparaciones. Se aprecia una discontinuidad en la proximidad de la torre T20 que prueba que se ha producido una reconstrucción.

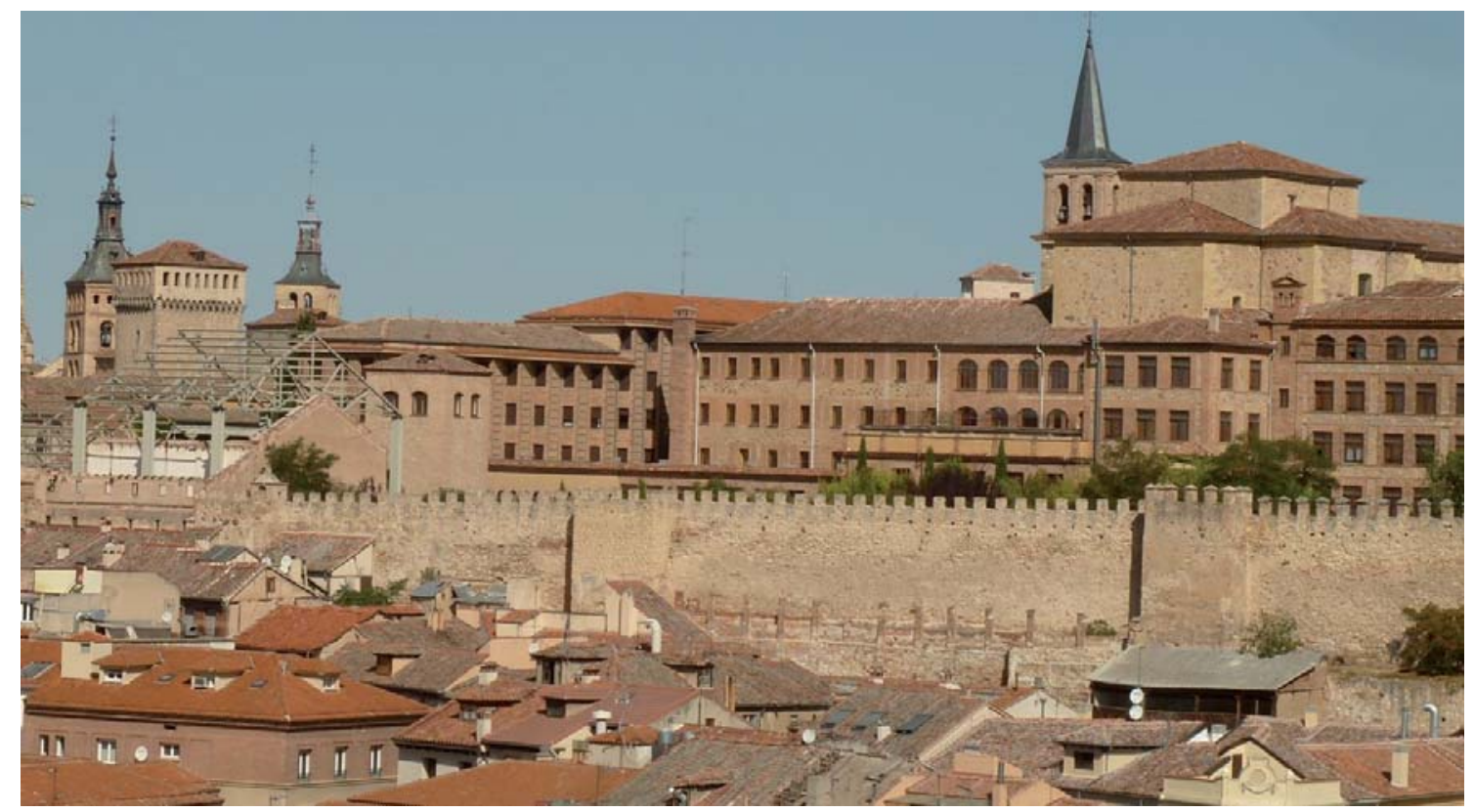

Figura 3. 34: Zona 4, vista desde lo alto del acueducto. Se observan las torres T19, T20 y T21.

La torre T20, muestra en la parte inferior una fábrica de sillería muy mal aparejada, con distintos tipos de piedra mezclada, sin criterio claro de organizar en aparejo. A partir de una nítida línea horizontal enseña una mampostería desconcertada de factura muy uniforme 
hasta el almenado, todo ello a base de piedra carbonatada. Esta fábrica se relaciona con la discontinuidad detectada en el lienzo L19-20 comentado y con otra apreciable en el lienzo siguiente L20-21, en el encuentro con esta torre. Se puede concluir que se produjo un derrumbe de esta torre y parte de los lienzos adyacentes, reconstruyéndose todo ello en el siglo XX. Esto se confirma con la foto de Alois Beer de principios del siglo XX (Rudolph, 2004: 53).

El lienzo L20-21, posee las mismas características constructivas de los lienzos de esta zona, mampostería desconcertada desde el suelo hasta el almenado. Aparece la roca en algún punto donde se apoya directamente la mampostería.

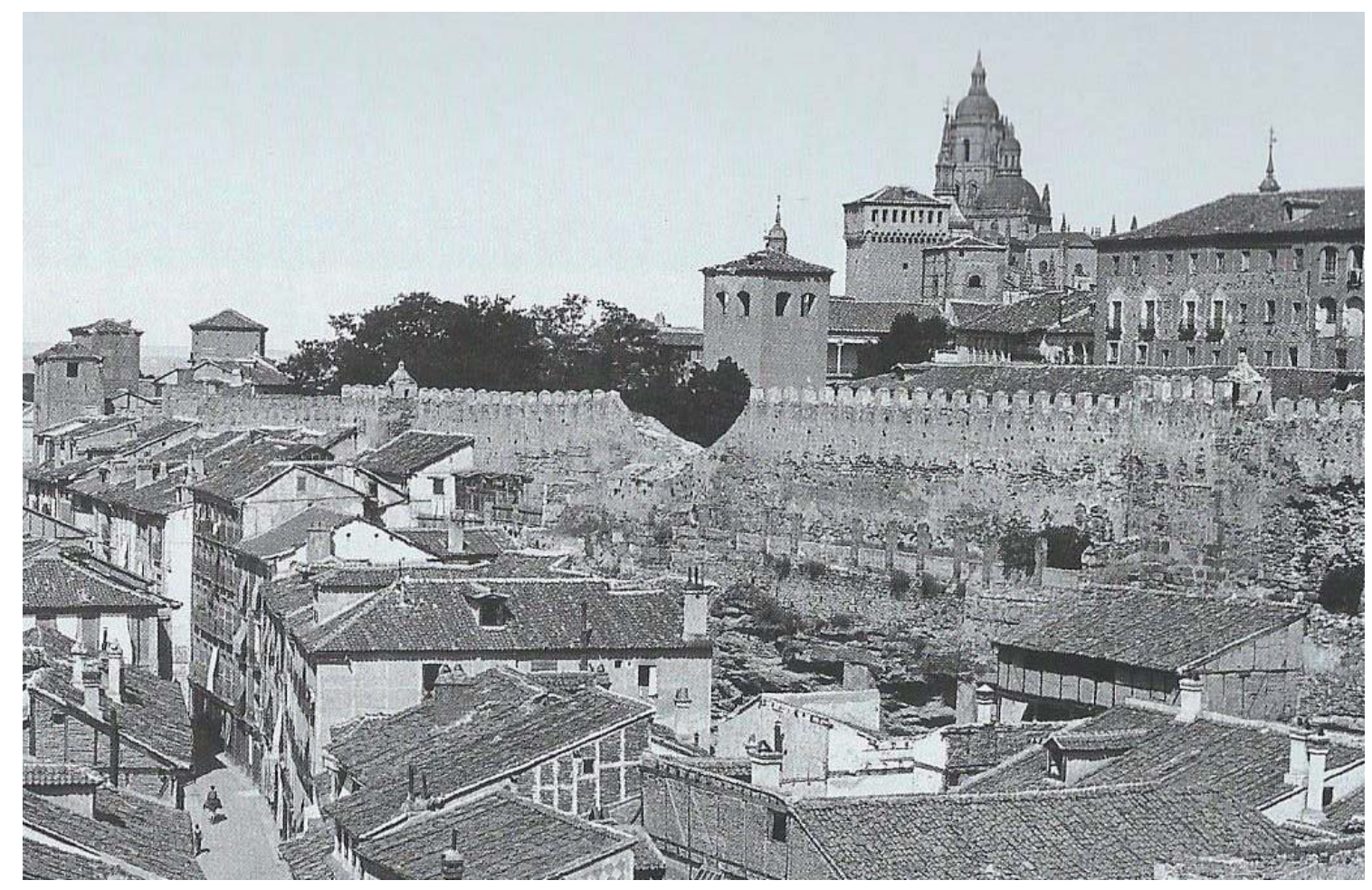

Figura 3. 35: Foto de Alois Beer. Se observa en el centro de la imagen la torre T20 arruinada, así como parte de los lienzos adyacentes (Rudolph, 2004: 53).

La torre T21, sigue la misma tónica descrita, fábrica de piezas de granito mal aparejada en el zócalo y sobre ello, mampostería desconcertada muy tapada por los rejuntados con sillares en las esquina y en la parte alta, las esquinas se resuelven en ladrillo. Tuvo otra garita como la que se conserva en T19 (Ver Figura 3. 35).

El lienzo, desde la torre T21 hasta el postigo del Consuelo posee las mismas características constructivas de los lienzos de esta zona, si bien no es visible desde cerca ni accesible. Exhibe algunos sillares como hilada de arranque, si bien aparentemente no componen ningún aparejo ordenado. Muestra un resalto en vertical, en el límite de la escalera de subida al postigo que se realiza con sillares de piedra sedimentaria, tipo de piedra que abunda en la parte alta del lienzo y la merlatura. Su longitud, 47 metros, está completamente fuera de las medidas habituales en la muralla segoviana (Véase el punto 4.1.5). Otra singularidad que observamos, precisamente en la vertical de la escalera de subida al postigo, de una serie de fusileras recercadas en ladrillo claramente resultado de 
una reforma, evidente no solo por la tipología del elemento defensivo, sino además por el cambio de piedra empleada en la construcción de ese trozo de lienzo. El almenado está realizado con un aplacado de piedra carbonatada de escaso espesor cortado mecánicamente. Se trata por tanto de una reconstrucción del siglo XX.

El postigo del Consuelo o de Santa Coloma, obtiene su nombre de la desaparecida ermita que se encontraba a escasos metros de éste. Era tan solo un hueco abierto en la muralla para el paso de personas. Fue derribado en el siglo XIX y reconstruido en 1947 colocando la portada de una edificación desmontada de la calle Real (AMS 4810-3: 47). Anteriormente, a finales del XIX, el arquitecto Odriozola, ya había ejecutado las escalinatas que aun hoy comunican la plaza del Azoguejo con la ciudad intramuros (AMS 4810-3: 17).

La torre T22 está construida sobre un peñasco rocoso, al borde de un cortado vertical, sobre el que se apoya una fábrica de grandes piezas de granito reutilizadas, burdamente regularizadas o muy deterioradas, que se organizan alcanzando hasta tres hiladas en el punto en que la roca está más baja y constituyendo un zócalo horizontal bastante nivelado sobre el que se construye el resto de la torre en mampostería desconcertada de piedra sedimentaria, bastante menuda, reforzándose las esquinas con sillares del mismo material. La primera hilada de granito del zócalo está resaltada, a modo de zarpa, respecto a las sucesivas. Los merlones se ejecutan en ladrillo con inclusión de algún sillar del mismo tipo de piedra carbonatada, fruto de una reparación relativamente reciente, posterior a la década 1930-1940, como apreciamos en la foto anónima (Sáez Laguna, 2009: 100).

El lienzo L22-23 traza dos quiebros produciendo un remetido, al pie del cortado de la roca. Es un lienzo inusualmente largo, alcanzando los 63 metros entre ambas torres. Todo el lienzo presenta un aparejo de mampostería desconcertada con un rejuntado que oculta una parte importante de las piezas. En el quiebro más cercano al acueducto, se aprecia en la hilada de zócalo un sillar que se sale de la alineación de la muralla actual. Así mientras la muralla traza el quiebro remetiéndose, el sillar de zócalo se dispone en continuidad con la dirección que presenta el lienzo previo a ese quiebro. De este modo, ese sillar de zócalo, parece que nos está indicando el trazado original de la muralla, que continuaba recto sin quiebro. En el otro extremo de este quiebro, la base del lienzo esta oculta por la edificación. En algunos puntos se aprecia el afloramiento de la roca y en otros observamos algunos sillares de granito reutilizados dispuestos a modo de zócalo, en un punto relativamente bien colocados, mientras en otro transmiten toda la impresión de estar recolocados, ya que no constituyen aparejo, sino simplemente una primera hilada de separación del terreno, sin intención de nivelar el arranque. Nuevamente encontramos un cambio brusco de dirección en mitad de un lienzo de la muralla, que resulta ser atípicamente más largo que la medida de los adyacentes.

En el primer tramo, se abre una ventana con arco de descarga de ladrillo. El almenado se realiza todo en ladrillo, muy uniforme con una clara discontinuidad en la piedra empleada para rematar la mampostería y nivelar el arranque de los merlones. En el intradós de este lienzo se encontraba, hasta 1681, la antigua casa de la Moneda instalada por Enrique IV en $1455^{57}$ (Contreras Jiménez, 2010: 6-20).

\footnotetext{
57 La casa vieja de la Moneda deja de funcionar como tal entre 1681 y 1714. El rastro de dicha casa desaparece entre 1776 y 1806. En 1826 la encontramos ya sustituida por una vivienda privada (Contreras Jiménez, 2010:20-22).
} 


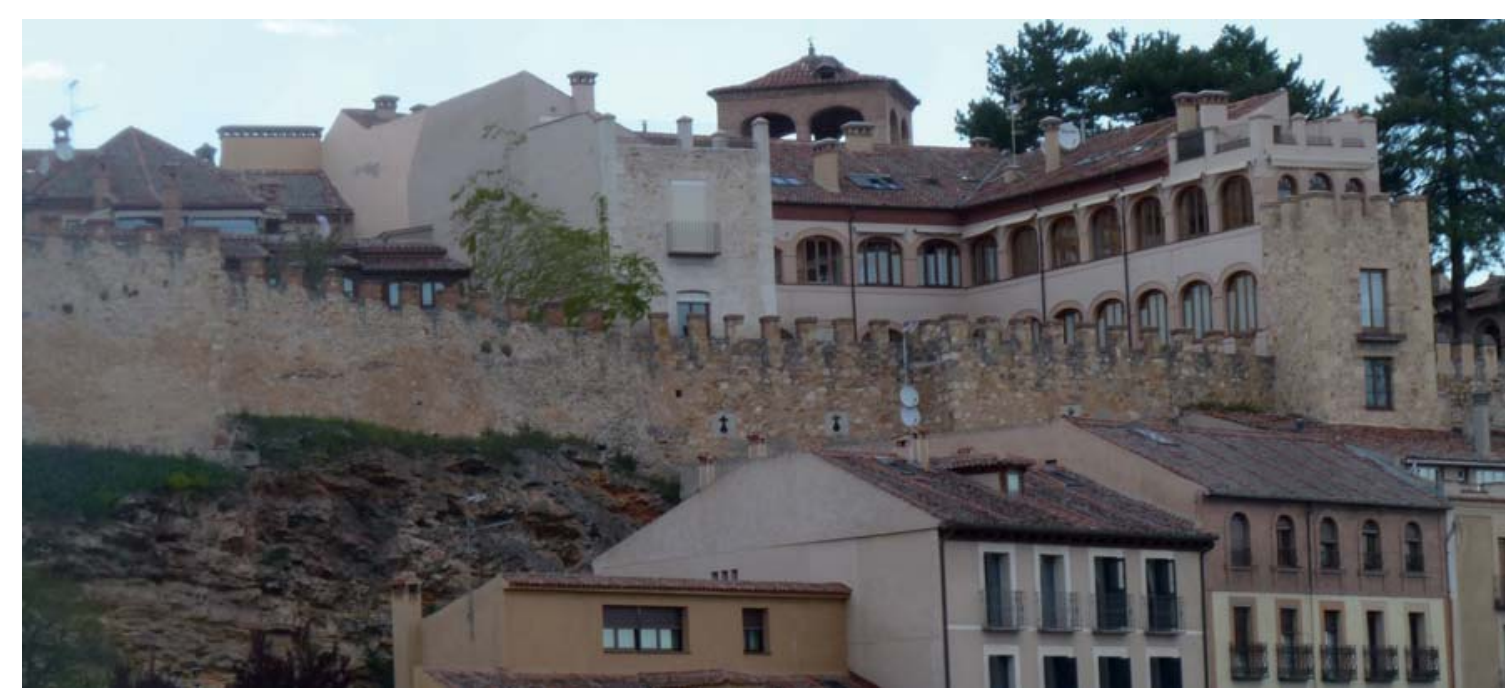

Figura 3. 36: Lienzo L22-23. Se observan los dos quiebros que generan un remetido del trazado de la muralla al pie del cortado rocoso. Se aprecia el cambio de material en los lienzos de la muralla, coincidiendo con la línea de separación de la parcelas intramuros.

En el segundo tramo se cambia el tipo de piedra con el que se ejecuta la mampostería, siendo todo él, de nuevo, muy uniforme incluso hasta los merlones, realizados en esta ocasión también con la misma mampostería. Abundan las piezas de granito entremezcladas, incluso en la parte alta del lienzo. Además encontramos unas cañoneras de cruz y orbe dos en el lienzo remetido y otra más en el segundo tramo recto tras el quiebro. Se trata de piezas en granito, y aunque sólo visibles desde muy lejos, aparentan estar cortadas a sierra por lo que redundan en el convencimiento de que todo este lienzo es una reconstrucción muy reciente, produciéndose el cambio de materiales en la división entre las parcelas de los edificios que se sitúan intramuros (Ver apartado 4.1.5).

La torre T23, es solo visible desde la distancia. En lo que se ve se trata de una torre reconstruida completamente, nueva, hueca y habitable. Sus dimensiones, con un resalto de 2,80 metros, exceden a lo habitual en las torres de esta zona. Se aprecia un primer nivel habitable ligeramente por debajo del adarve, otro ya por encima de dicho nivel y por detrás, retranqueado, se levanta otro piso más, todos ellos con ventanas y balcones abiertos en el frontal de la torre. Construida con aparejo de mampostería careada de piedra carbonatada, con piezas de sillería en las esquinas y jambas, algunos sustituidas por ladrillos. Toda la obra muestra un aspecto uniforme hasta los merlones que rematan el peto de la terraza a la que se accede desde el último piso retranqueado.

El lienzo L23-24 está oculto detrás de los edificios que se le adosan delante. Sólo es visible desde lejos su parte superior y el encuentro con la torre T24 en toda su altura. En el remate se aprecia una mampostería desconcertada, con diversas reparaciones, siendo la más reconocible una que nivela la parte superior para construir el peto almenado. Se caracteriza por mezclar una variedad de tipos de piedra, entre los que abundan numerosos sillares reutilizados organizados en hiladas que tienden a la horizontalidad, a pesar de partir de un nivel inclinado. Los merlones están completamente revocados, en una misma intervención.

En el entronque con la torre T24, se muestra un fábrica de mampostería desconcertada apoyada sobre la roca, y sobre ella dos niveles de lienzo revocado, y otros de una mampostería con las piezas muy cubiertas por el mortero, apreciándose algunos mechinales 
y fisuras, que parecen la separación entre los diferentes cajones, por lo que sospechamos que se trata de una fábrica encofrada. En el encuentro con la torre, se abre un balcón perteneciente a la casa de los Condes de Chinchón que se le adosa intramuros.

La torre T24, vinculada a la casa fuerte de los Condes de Chichón se halla muy próxima a la ubicación de la desaparecida puerta de San Juan. Presenta un zócalo resaltado en el que, a pesar de estar revocado, se observan en los desconchones de su frontal y en el lateral, algunas piezas de sillería carbonatada muy deterioradas y reparadas con cascote y ladrillo. Sobre este arranque, el cuerpo de la torre revocado con un esgrafiado nos oculta su sistema constructivo. Sobre la torre se apoya la casa, recreciendo su fábrica, en la que aun es posible ver los merlones originales y el tapiado de las almenas. A la altura del peto del adarve adyacente, apreciamos la discontinuidad constructiva con el cambio de materiales, evidenciando el recrecido posterior de la torre. Mientras en la parte inferior presenta sillares en las esquinas, a partir de este punto se emplean ladrillos para el refuerzo de las esquinas. La torre continua ascendiendo, dos pisos más, ahora con mampostería desconcertada y ladrillo en esquinas, jambas de ventanas e incluso cruzando algún encintado. Abunda el material mezclado y el granito careando las piezas, todo ello de ejecución muy uniforme hasta el almenado, que se ejecuta del mismo modo. Se aprecian algunos mechinales e incluso especie de saeteras. Todo ello obra de mediados del siglo XX, aparentemente fruto de las reformas de Pedro Escorial en 1960 (Chaves Martín, 2006: 149).

La casa de los Condes de Chinchón y Marqueses de Moya fue construida entre los siglos XIII y XV (Chaves Martín, 2006: 149). También se la denomina Casa de Segovia o de Cabrera (Lecea y García, 1906), casa de las Cadenas o Alcázar Viejo. Disponía de un muro de cierre exterior, del cual quedan restos en la calle de San Sebastián, auténtico muro cortina provisto de saeteras, que antecede el patio, detrás del cual se eleva la segunda línea defensiva (Ruiz Hernando, 2005: 93). El edificio es de planta cuadrada en torno a un patio central, adosándose a la muralla. Presenta tres torres defensivas en tres de sus esquinas, una de ellas perteneciente a la muralla, la T24 de la que ya se ha hablado, y en la cuarta se adosaba a la puerta de San Juan a cuya defensa contribuía. La puerta se demolió en 1888 al ensanchar la calle (Ruiz Hernando, 2005: 93), si bien tampoco era la medieval ${ }^{58}$ (Véase el apartado 4.1.6 dedicado a esta puerta).

$\mathrm{Al}$ igual que en la torre anterior, en el edificio se aprecia un recrecido de dos plantas sobre el nivel del adarve de la muralla, por debajo de los cuales se han abierto otros dos niveles de ventanas horadando el lienzo de la muralla. En la cuarta esquina, se aprecian en su base una suerte de jambas de granito e incluso un arranque de arco que podrían indicar la posición de la puerta de San Juan. El lienzo se encuentra lleno de reparaciones, parcheados y rejuntados que ocultan mucha información. Se aprecia un portillo que podría ser la comunicación entre la galería de la casa o el antiguo adarve de la muralla y la puerta de San Juan desde donde se descendía por una escalera que ahora no conduce a ninguna parte.

Entre esta casa y la actual casa del marqués de Lozoya, situada al otro lado de la calle, se encontraba la puerta de San Juan, la cual defendían entre ambas casas fuertes (Chaves Martín, 2003: 17).

58 La puerta que se demuele es la que construye Juan de Ferreras, ya que la puerta medieval había desaparecido previamente. 


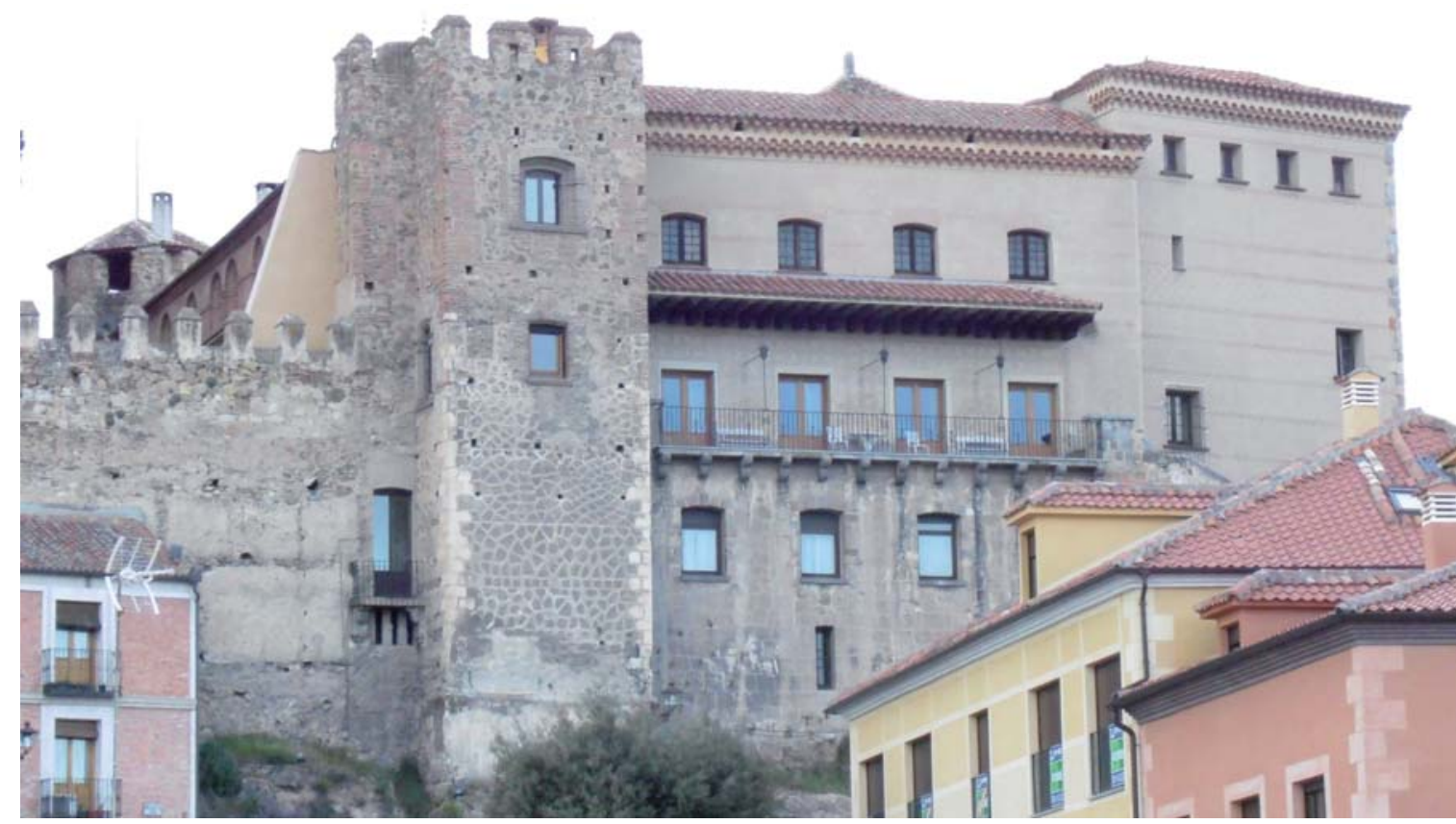

Figura 3. 37: Torre T24 y la casa de los Condes de Chinchón. Se aprecia la altura original de la torre, coincidente con la del adarve de la muralla, marcado por el cambio de material. A ambos lados de la ventana, se aprecia el almenado original de la torre. La parte original, la inferior, presenta sillería en las esquinas, mientras en el recrecido se emplean ladrillos.

\subsection{5.- ZONA 5. SAN JUAN}

Esta zona se extiende desde la antigua puerta de San Juan hasta el postigo del mismo nombre, correspondiéndose la mayor parte del trazado con la parcela de la actual casa del Marqués de Lozoya. Son 258 metros en los que sólo se conservan 2 torres y el mencionado postigo. La mayor parte del trazado y los elementos de la muralla de en esta zona han desaparecido debido a diversos derrumbes de la roca. Incluso, parte de la casa del Marqués de Lozoya se ha visto afectada por estos desplomes. No se conserva ninguna torre medieval, tan solo dos reconstruidas y los lienzos existentes son simples tapias de cerramiento, en el caso de la parcela de la casa de Lozoya y el resto, lienzos prácticamente reconstruidos en su totalidad.

La casa del Marqués de Lozoya es una casa-palacio construida entre los siglos XIII y XV que conserva su portada románica y que perteneció al Mayorazgo de los Cáceres. (Chaves Martín, 2006: 152). Es un edifico de estilo románico como muestra su fachada principal, que a pesar de haber sufrido una restauración completa en el primer tercio del siglo XX, aún deja ver la magnífica portada de arcos de medio punto. Hay que destacar las dos saeteras que la flanquean. (Chico Rello, 1949: 594)

La casa del Marqués de Lozoya, también estaba relacionada con la puerta de San Juan. En el frente hacia la derribada puerta de San Juan, existe un muro de mampostería almenado donde podemos ver una hornacina con una virgen y un escudo, ambos recuperados de la puerta original (Chaves Martín, 2006: 153). En 1887 se derrumba la roca y con ella la muralla, dos torreones y gran parte de la crujía posterior de esta casa (Chico Rello, 1949: 594). Según consta en los archivos municipales la muralla fue reparada y demolida en parte, ya que había sufrido continuos desplomes. Tenía una torre al mediodía que entestaba con la puerta de San Juan (Ruiz Hernando, 2005: 94). 

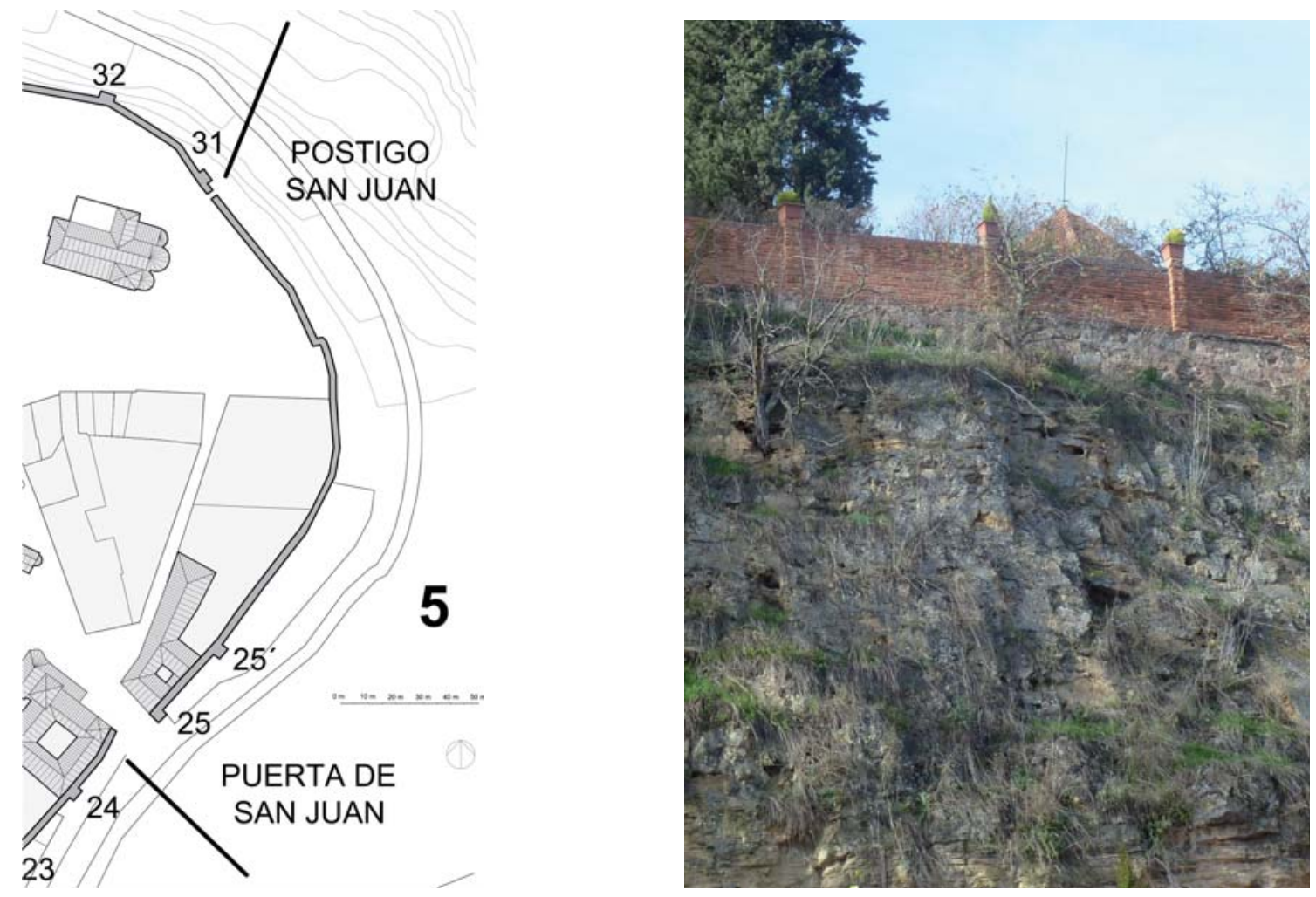

Figura 3. 38: Plano de la zona 5, que comprende desde la puerta de San Juan hasta el postigo del mismo nombre.

Figura 3. 39: Imagen de la tapia que cierra la parcela de la actual casa del Marqués de Lozoya, en sustitución de la muralla derrumbada.

Las torres T25, al igual que la T25', son reconstrucciones realizadas en la parte baja de la roca, posiblemente con finalidad de refuerzo y contención de ésta. No presentan peto en el remate superior, sino parecen incompletas, como si estuviesen desmochadas. Muestran una fábrica de mampostería con sillares en las esquinas y con muchos más reutilizados entre los mampuestos, mezclando distintos tipos de piedra y ladrillo. Destaca la abundancia de piezas de granito incluso en las partes altas, algunos cortados a sierra. En los zócalos no existe mezcla de material, siendo todo sillares de granito, colocados a soga.

En los diferentes tramos de la zona 5 se han reconstruido numerosas fábricas, pero ni siquiera en la alineación de la muralla, ya que el desprendimiento de la roca ha obligado a remeter el cerramiento de la parcela superior. Así se observa un peto de mampostería, otra zona completamente oculta por la vegetación, una tapia de ladrillo, un edificio adosado a la muralla sobre un lienzo reconstruido en el que abundan los sillares de granito reutilizados en la parte alta. Se constata la presencia de varias spolia romanas. El peto no presenta almenado.

En el Paseo de Colmenares se ha reconstruido el lienzo con mampostería entre la que abunda mucho granito serrado, piedra mezclada y sillares utilizados como mampuesto. Se advierte la presencia de numerosos mechinales ordenados y varios escalonamientos disminuyendo la sección del muro. En este punto advertimos la existencia de un resalto de la muralla, cuya fábrica no está trabada con el lienzo y en la que abunda numeroso material cerámico, lo que nos hace suponer que se trate de una reconstrucción. 
Se aprecian varias discontinuidades en vertical, que podrían indicar la posible presencia de las torres en 'T28', 'T29 y T30 y en el último lienzo se nota una parte desplomada cercana al postigo de San Juan y la otra rehecha aplomada. La no rehecha, cercana al postigo presenta una mampostería desconcertada a base de piezas muy menudas, en la línea con lo visto en el resto de la muralla.

El postigo de San Juan, situado a espaldas de la iglesia de San Juan de los Caballeros, se compone por un arco apuntado de dovelas de ladrillo y en la parte interna un arco de medio punto conforma la plataforma del adarve. Se constata la presencia de varias spolia en las jambas.

\subsection{6.- ZONA 6. SANTA CRUZ}

Esta zona abarca desde el postigo de San Juan hasta la puerta de San Cebrián. Son aproximadamente 500 metros en los que se distribuyen 12 torres y encontramos el postigo de San Matías. Todas las torres son de planta rectangular y dimensiones muy similares, variando entre 5,20-5,50 metros de frente y 2,00-2,30 metros de resalto, separadas por unos lienzos relativamente largos, en torno a los 34 metros, si bien las distancias son un tanto irregulares. Existen algunos quiebros en los lienzos, en puntos donde no existe ninguna torre, lo cual es bastante atípico, dado que los cambios de dirección se producen en puntos en los que se colocan las torres. En estos casos, los quiebros aparentemente están motivados por desplomes de la roca que obligan a la reconstrucción remetiéndose para buscar apoyo como por ejemplo en el L34-35, o bien para aprovechar restos de construcciones previas, como en el caso del lienzo L38-39. Así los lienzos miden desde 32 hasta 40 metros mientras los tres últimos, cercanos a la puerta de San Cebrián, miden tan solo entre 16-19 metros.

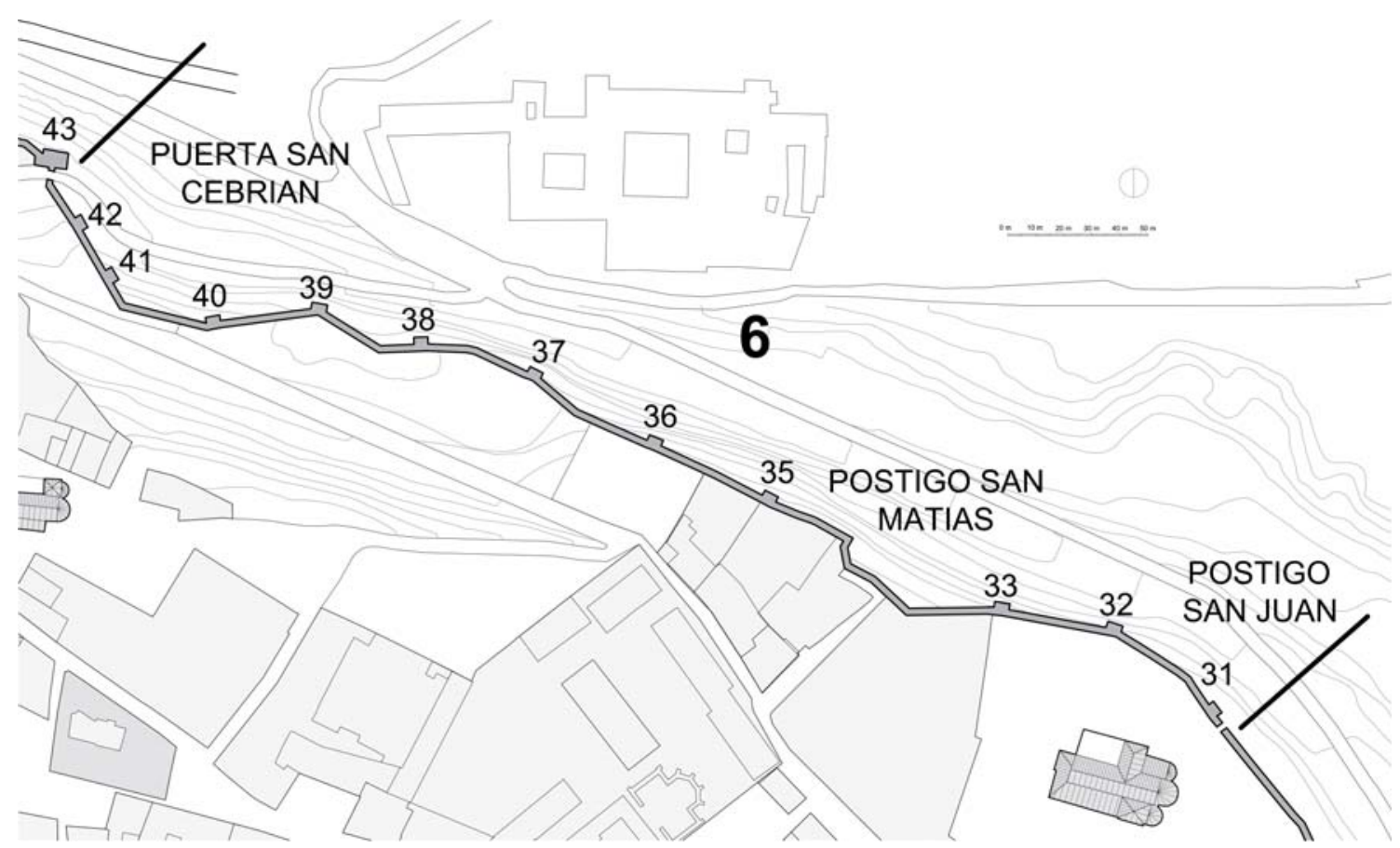

Figura 3. 40: Plano de la zona 6, que comprende desde el postigo de San Juan hasta la puerta de San Cebrián. 
Constructivamente son todos muy similares, mostrando algunas hiladas de arranque con piezas más grandes y regulares o bien sillares reutilizados, pero que se aparejan como mampostería, no como sillería. Sobre ello, la mayor parte del lienzo se muestra una mampostería desconcertada, en la que aparecen algunos agujales o mechinales, en unos lienzos con mayor orden que en otros, excepto en el tramo entre T35-T38 y en el lienzo L40-41 que no se aprecia ninguno. En la mayor parte de los trazados de los lienzos, el zócalo está parcialmente enterrado y la roca de apoyo no está visible, ni el posible zócalo, por lo que vemos la mampostería ascender desde el suelo.

Las torres denotan igualmente la existencia de numerosos derrumbes, como el caso de la T31 o la T40, estando todas ellas reconstruidas, al menos, la parte superior. En algunas se conserva fragmentos de fábricas de sillería con cierta calidad, especialmente en los zócalos o en uno de sus lados cortos, como por ejemplo la T35 y T41, mientras el resto de la torre se ejecuta en mampostería desconcertada, en la que se emplean algunos sillares dispersos, como si de una mampostería se tratase. En las demás torres vemos una mampostería desconcertada con predominio de sillares y piezas de tamaño medio bastante regulares pero muy mezcladas, principalmente en el zócalo y en las esquinas, reduciéndose el granito, la regularidad y el tamaño de las piezas según se asciende. Todo parece indicar que han sido fruto de un derrumbe y posterior reconstrucción. Todos los remates y petos son rehechos, algunos despliegan almenado.

La T31 la consideramos reconstruida y remetida respecto a la posición original (Ver el apartado 4.1.7). Presenta piezas más grandes y más regulares entremezcladas en la base y en las esquinas. El resto de la fábrica, es conforme al tipo genérico descrito, mampostería desconcertada.

El lienzo L31-32 es inusualmente largo, 41,20 metros. En una zona existen sillares de granito como hilada de contacto con la roca y en el resto, la mampostería apoya directamente en el terreno. Muestra almenado. Presenta evidencias de desplomes y partes rehechas nuevamente aplomadas, indicio de derrumbes. Se aprecian incluso adoquines modernos para perfilar los nuevos mechinales.

La torre T32 muestra las mismas características que T31. Mampostería desconcertada con piezas más regulares y más grandes en las partes bajas y en las esquinas. Presenta hasta tres resaltos escalonados reduciendo dimensión, coincidiendo con cambios de material, aparejo o técnica constructiva, lo que denota su reconstrucción o sucesivos recrecidos. El lienzo L32-33 constructivamente tiene la misma apariencia que el anterior. Reseñar que en este caso se aprecian algunos agujales.

La T33 muestra en su zócalo frontal dos hiladas de sillares granito y sobre ellas otras tres de sillares de piedra sedimentaria. El resto de la torre se ejecuta en mampostería con sillares en las esquinas, si bien faltan estos refuerzos esquineros en las últimas hiladas. Se observan algunos agujales, aunque no hay orden claro. Presenta una discontinuidad en el aparejo del zócalo, lo que nos hace suponer que una de las mitades de la torre se derrumbó y ha sido reconstruida. Al ser visible solo desde lejos, no poder acceder y estar parcialmente cubierta por vegetación, no están claras las relaciones estratigráficas.

En este punto la muralla realiza un marcado quiebro remetiéndose hacia el interior, pero completamente al borde del acantilado. El lienzo L33-35 no es accesible por encontrarse apoyado sobre una roca en voladizo, con un desnivel considerable. Aparte de la 
información documental relativa al derrumbe que inhabilitó el postigo picado, la construcción también evidencia que existe una parte arruinada y posteriormente reconstruida. Se observa el material mezclado con piezas de granito en la parte alta. Tan solo, en la zona situada bajo el postigo se conserva la lógica constructiva predominante en los zócalos de la muralla, con numerosos sillares granito reutilizados (spolia romanas) en el zócalo y por encima varias hiladas de sillares de piedra sedimentaria. Es la única parte que no aparenta ser reconstruida.
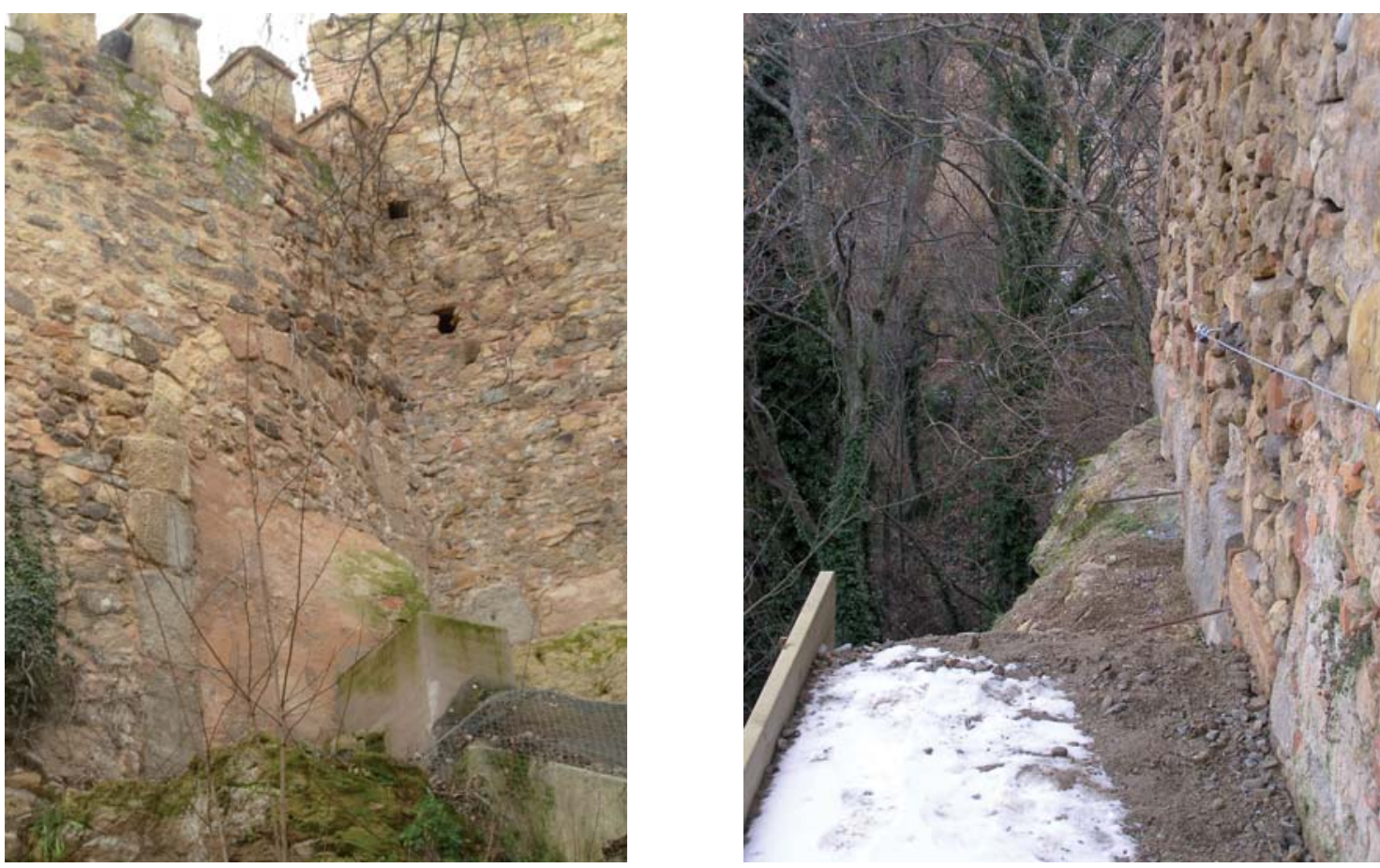

Figura 3. 41: Postigo de San Matías o picado visto desde el exterior. Tapiado e inaccesible, se ha desconocido su ubicación durante años.

Figura 3. 42: L33-35 evidencia el derrumbe que inutilizó el postigo picado y motivó la reconstrucción de la mayor parte de este lienzo.

El resto del lienzo aparenta estar reconstruido, mostrando los sillares de granito en el zócalo pero sin vocación de nivelar el arranque y la mampostería desconcertada, con abundantes agujales aunque sin un orden claro, en la que aparecen algunos sillares y distintos tipos de piedra entremezclados.

El postigo de San Matías, asi denominado por la cercana ermita de San Matías. El desplome de la roca le hace hoy inaccesible, aunque nunca tuvo fácil acceso, de abi su otro nombre de postigo Picado (AMS 4810-3: 16). Actualmente tapiado, aparece inaccesible en lo alto del cortado, prácticamente invisible desde el exterior, formado por un arco de medio punto con dovelas de piedra carbonatada sobre jambas con sillares de granito. Durante mucho tiempo permaneció ignorado y perdida su memoria, pero con motivo de estarse realizando obras en una finca de la calle del Taray apareció. Se trata de un sencillo arco apuntado que puede fecharse en el siglo XIII (Ruiz Hernando, 1982, I: 55). Su uso estuvo casi reservado en exclusiva a los frailes dominicos de Santa Cruz que protestaron en varias ocasiones a causa de su cierre (AMS 4810-3: 16). 
La torre T35 evidencia una clara discontinuidad constructiva. En lado oeste presenta sillería sedimentaria bien aparejada, casi hasta adarve. Por el otro lado y en su frontal posee peor aparejo, piedra mezclada y algunos sillares pero sin organizarse como sillería. Ambas caras son reconstruidas. Peto y almenado de mampostería muy menuda mal aparejada.

El lienzo L35-36 de 40 metros es inusualmente largo. Como contacto con el terreno (no se ve la roca) observamos una doble hilada de sillares de piedra mezclada entre la que aparece una caliza con gasterópodos y en el resto del lienzo, la habitual mampostería desconcertada hasta al adarve, en este caso almenado que se ejecuta con un menor espesor, a modo de tapia de cierre de las parcelas intramuros adyacentes. Esta caliza blanca con gasterópodos es algo extraño. Es un tipo de piedra que no existe en Segovia (PH: P0178: 137-153). Aparece exclusivamente en los lienzos desde T35 hasta T39.

La torre T36 es una torre recrecida. Presenta tres resaltos escalonados reduciendo dimensión, coincidiendo con cambios de material, aparejo o técnica constructiva. Nos hace sospechar, de nuevo, en un derrumbe parcial en que la parte superior de la torre parece haber deslizado. En el zócalo se observan tres hiladas de sillería de granito seguidas por tres de sedimentaria. Tras el primer resalto encontramos otras tres hiladas de sillería de piedra carbonatada. Tras el segundo escalón se continúa la mampostería desconcertada con sillares en las esquinas.
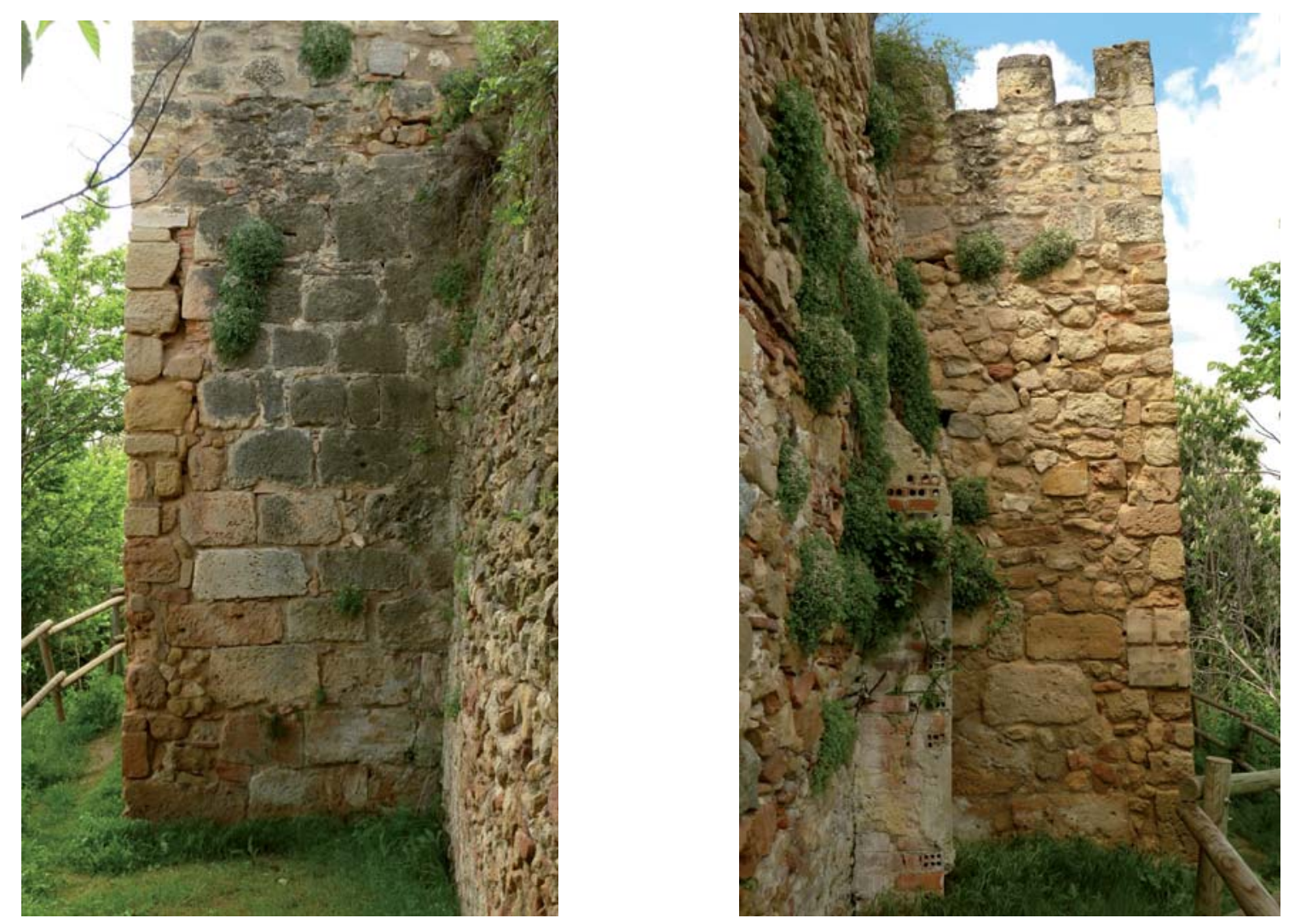

Figura 3. 43: Torre T35. Alzado oeste. Conserva el aparejo de sillería original. Se observa la discontinuidad debida a un posible derrumbe de la cara frontal y la lateral occidental.

Figura 3. 44: Torre T35. Alzado este. Aparejo idéntico al que vemos en el frontal de la torre, pero completamente distinto del existente en el otro lado corto da la misma. La cara frontal y lateral presentan las mismas características constructivas. Ambas son reconstruidas. 
El lienzo L36-37 y el L37-38 son idénticos constructivamente al anterior, con una longitud también superior a la media, 44 metros y 37 metros respectivamente.

La torre T37 muestra las características típicas ya comentadas. Mampostería desconcertada con sillares de piedra carbonatada en las esquinas. Aparece la caliza blanca con gasterópodos vista en los lienzos adyacentes, pero esta es la única torre en que aparece. Se aprecia asimetría en la distribución de los sillares, aunque están mal aparejados, empleados como si fuese mampostería, solo existen en uno de los laterales de la torre. Posiblemente esta reconstruida, junto con los lienzos donde encontramos el mismo tipo de piedra sedimentaria con gasterópodos.

La T38 manifiesta una fábrica de mampostería desconcertada con abundancia de sillares y piezas de tamaño medio bastante regulares. Mezcla de distintos tipos de piedra, con abundancia de granito en zócalo y en esquinas, mientras en parte alta las esquinas son de ladrillo.

El L38-39 constructivamente es idéntico a los anteriores. Largo 35 metros. Aparecen algunos mechinales. El trazado de muralla marca un quiebro muy forzado en el lienzo para apoyarse parcialmente sobre unos restos de fábrica de sillería preexistentes, compuestos por 2 hiladas de sillares de granito reutilizados colocados a soga sobre los que se asientan una hilada de sillares de roca sedimentaria colocados a tizón y algunos intercalados entre los de granito. Fábrica de aparejo musulmán con total certeza, reaprovechando sillares romanos. Algunos de estos sillares están tallados en la piedra caliza blanca con gasterópodos. Este es el último punto de la muralla donde aparece este tipo de piedra, por lo que suponemos que debe proceder de algún edificio en ruinas que estuviese por esta zona, sino proceden directamente de esta construcción de trazado curvo.
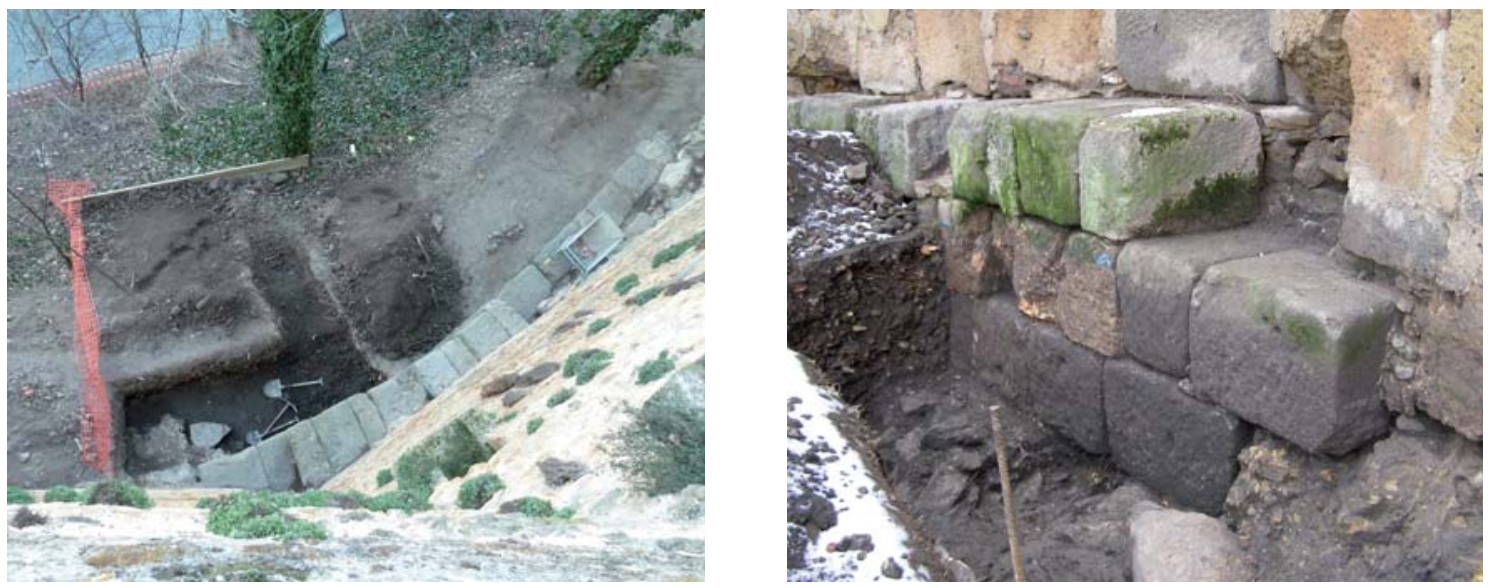

Figura 3. 45: Lienzo L38-39. La muralla realiza un quiebro muy brusco y se apoya parcialmente sobre una fábrica de sillería preexistente. Se trata de sillares alternando granitos y dolomías.

Figura 3. 46: Detalle del mismo lienzo L38-39. Ambos tipos de piedras tienen marcas de garras, en disposición que evidencia que no se emplearon dichas garras para su colocación en este punto por lo que son reutilizados y provienen de una construcción previa. Están colocados en posición secundaria.

La existencia de marcas de garras para su elevación en uno de estos sillares de caliza blanca con gasterópodos evidencia que este tipo de piedra lo trajeron a Segovia los romanos. Su disposición con las marcas de las garras para su izado en la cara superior, muestra que se 
encuentran en posición secundaria a la vez que su colocación en aparejo de tizones, de claro influjo califal, parece indicar que formaron parte de un edificio hispanomusulmán, sobre el que posteriormente se apoyó la muralla, pero no deja de plantear algunas dudas. ${ }^{59}$

La torre T39 muestra una fábrica de mampostería con abundancia de piezas regulares reutilizadas y mal aparejadas en el zócalo. En la parte superior estas piezas desaparecen y las esquinas se realizan en ladrillo. El peto no tiene merlones.

El lienzo L39-40 se ejecuta con la habitual mampostería desconcertada. Todo muy uniforme. Se aprecian algunos agujales, mientras el zócalo supuestamente está enterrado. No se ve en ningún punto la roca de apoyo.

La torre T40 es una torre totalmente reconstruida, ya que se aprecian los restos de la torre previa, a modo de masa informe, caídos en la ladera casi ocultos por la maleza. Aparentemente la torre se arruinó por deslizamiento. La fábrica actual está completamente realizada en mampostería desconcertada con piezas muy pequeñas, rematada en un peto almenado.

El aspecto externo del L40-41 es idéntico al anterior, salvo que no aparecen agujales. Aflora la roca en distintos puntos del lienzo a 3 y 4 metros de altura del suelo, por lo que la roca debe encontrarse en ménsula, formando grandes cavidades debajo, que han sido tapiadas por la muralla. Aparentemente la muralla está chapando la roca en los 4 primeros metros. En dos puntos, se observa que se ha realizado un arco de descarga bajo la roca en ménsula, embebido en la mampostería. No hay agujales, ya que creemos que seguramente sea mampostería. Lo más llamativo es el quiebro que realiza la muralla en su trazado, girando hacia el exterior, con un cambio de dirección que dispone el lienzo en paralelo a la carretera de acceso a la puerta de San Cebrián. Se trata del cambio de dirección más marcado de todo el recorrido de la muralla, que se produce en un punto donde no existe torre.

La torre T41 presenta las características comunes. Como contacto con el terreno (no se ve la roca) observamos una triple hilada de sillares de piedra mezclada y en el resto del lienzo, la habitual mampostería desconcertada, hasta al adarve, sin almenado.

El lienzo L41-42 es excepcionalmente corto, cercano a la puerta de San Cebrián. Constructivamente es idéntico a los anteriores, aunque aquí vemos agujales pero sin orden claro. El zócalo está enterrado, ya que no se ve la roca en ningún punto, por lo que observamos la mampostería desconcertada desde el suelo hasta el peto almenado.

La torre T42 vuelve a mostrar abundancia de sillares en la parte baja, dispuestos asimétricamente en sus caras laterales, evidenciando un derrumbe. Hasta 6 hiladas, aparejadas como sillería, con predominio de granito, especialmente en la cara que mira hacia la puerta de San Cebrián y el frontal de la torre, mientras en la tercera cara los sillares son de piedra sedimentaria y se emplean como mampostería con piezas regulares. $\mathrm{Al}$ ascender dejan de emplearse sillares y vemos sólo mampostería desconcertada.

\footnotetext{
${ }^{59} \mathrm{La}$ alternancia de distintos tipos de piedra y colores es una característica empleada en las dovelas de los arcos de la arquitectura califal, pero resulta excepcional y extraño encontrarlo en un muro. Agradezco esta observación a Alonso Zamora.
} 
El lienzo L42-43 es en el que se ubica la puerta de San Cebrián. Su fábrica es la característica mampostería desconcertada hasta el peto, por ambas caras, ya que en este lienzo es también visible la cara intramuros. Los merlones son de ladrillo en la cara exterior mientras al interior muestra un peto de mampostería. En este lienzo la muralla realiza un nuevo quiebro, disponiéndose perpendicular al camino de acceso, en el corto tramo en el que se sitúa la puerta. Al interior, el lienzo de la muralla presenta un machón trabado con el lienzo cuya finalidad nos resulta difícil de entender. Este machón no alcanza la altura del adarve, sino que asciende hasta aproximadamente la mitad de la altura del lienzo. A partir de ese punto desaparece (Véase el apartado 4.2.3.a).

La puerta de San Cebrián recibe el nombre de una ermita que se levantaba en las inmediaciones (Ruiz Hernando, 1982: 26). Comunica la ciudad con el valle del Eresma a la altura del Convento de Santa Cruz y por tanto es la entrada a la ciudad desde el barrio de San Lorenzo. Desde el punto de vista poliorcético no cuenta con ninguna singularidad reseñable, siendo la más sencilla de las puertas conservadas. Carece de cualquier valor estratégico, pues se trata de una simple abertura en el muro protegida en su flanco derecho por una torre cuadrada (AMS: 4810-3: 16). Situada en disposición muy cercana al cortado, el saliente de la torre que la flanquea hacia el exterior protege eficazmente costado de la puerta, a la vez que el lienzo de la muralla efectúa un giro para disponerse perpendicular al camino de acceso. La proximidad de las torres T41 y T42 flanqueando el camino de acceso complementan su equipamiento defensivo.
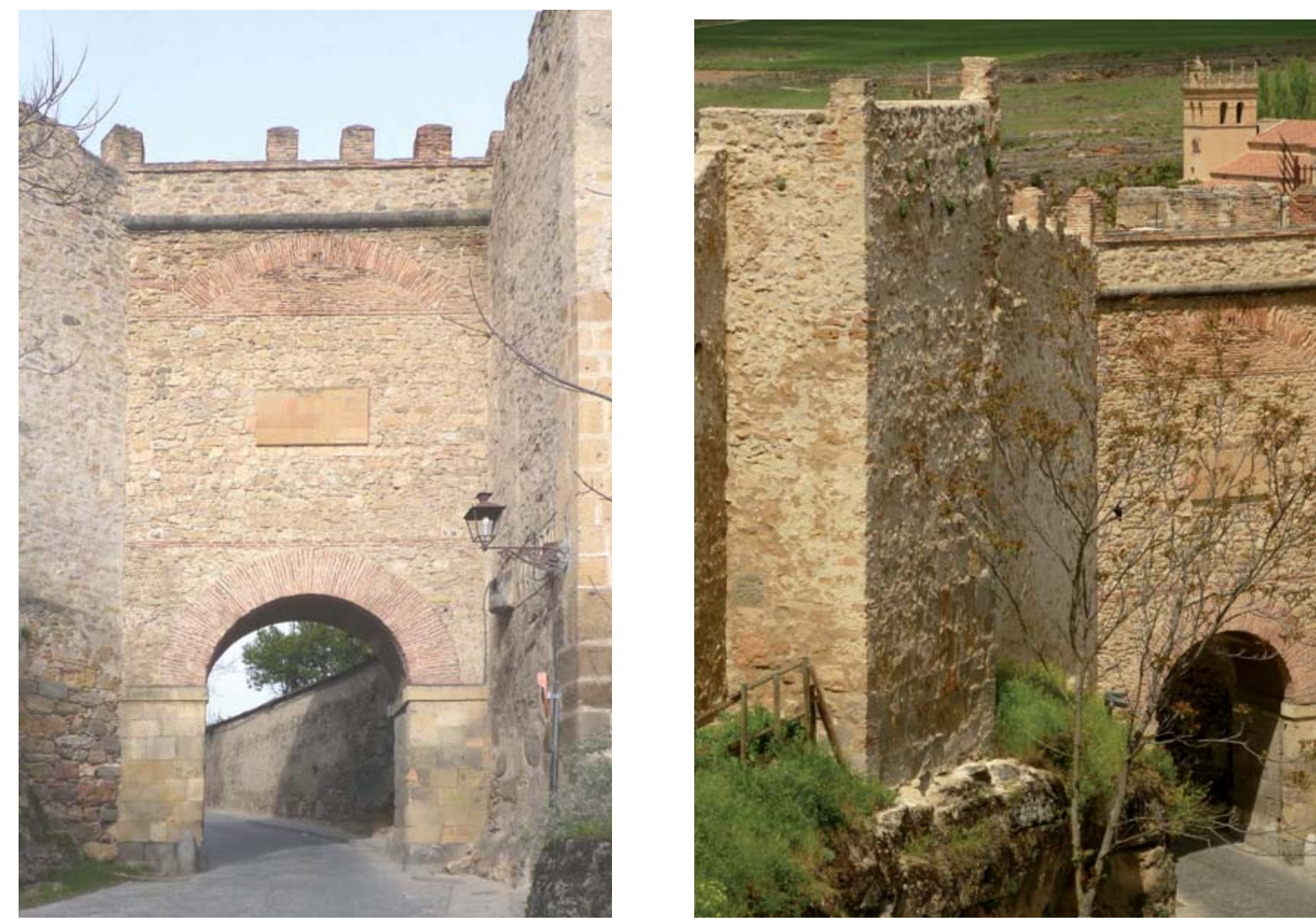

Figura 3. 47: Puerta de San Cebrián. Aspecto exterior. Nótese el arco de ladrillo en la parte alta de la puerta, justo bajo la cornisa.

Figura 3. 48: Los lienzos adyacentes a la puerta son más cortos de lo habitual, por lo que las torre T41 y T42 se encuentran mucho más cerca de la puerta, flanqueando el camino de acceso para contribuir a la defensa. 
De traza más sencilla que las otras, abre su arco de medio punto en medio del paño de la muralla, con mezcla de material, caliza y ladrillo, éste último bien visible en los arcos de descarga de las dos caras, interna y externa de la puerta ${ }^{60}$ (Chaves Martín, 2003: 12). La presencia de estos arcos de ladrillo ha llamado la atención de otros autores (Moragón Aguado, 1995; Basilio Pavón, 1999: 245).

\subsection{7.- ZONA 7. MISERICORDIA}

La zona 7 incluye, posiblemente, la parte en peor estado de conservación de la muralla, que va desde la puerta de San Cebrián hasta el final de la parcela del hospital de la Misericordia. Tiene una longitud de 270 metros y en ella encontramos 9 torres y se situaba históricamente el desaparecido postigo de fuente cercada. Sus torres presentan un frontal de entre 5,10 y 5,50 metros mientras los resaltos oscilan desde 1,70 a 2,20. Cuatro torres salen de estas medidas, la T45, T46, T46' y la T47. Los lienzos oscilan entre un largo de 25 y 30 metros excepto el adyacente a la puerta de San Cebrián, el L45-46 y el L47-48. Existe un quiebro en el trazado de la muralla, remarcado por una torre más grande de lo habitual, la T47, resolviendo la esquina.

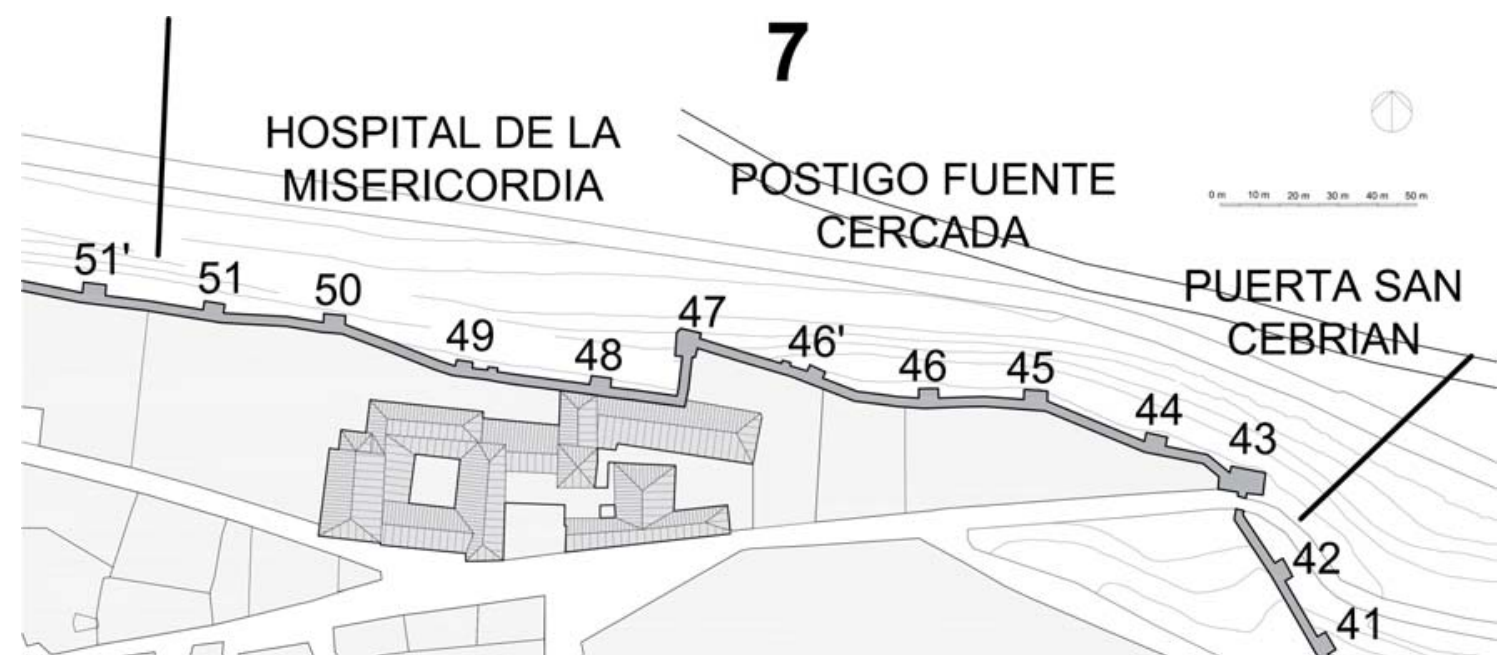

Figura 3. 49: Plano de la zona 7, que comprende desde la puerta de San Cebrián hasta el final de la parcela del hospital de la Misericordia.

Se aprecian evidencias de numerosas reparaciones, derrumbes y discontinuidades de dirección tanto vertical como horizontal. Se observan en los paramentos numerosos escalonados en horizontal en que el recrecido reduce el espesor y también lienzos desplomados junto a partes aplomadas, que evidentemente han sido reconstruidas tras derrumbarse.

El tipo característico de fábrica de los lienzos es la mampostería desconcertada de piedra muy menuda y mezclada desde el arranque, ya que en varios casos, no se ve la roca de

\footnotetext{
${ }^{60}$ La puerta medieval fue completamente transformada, sino reconstruida totalmente, en 1689 por Juan de Remis y Santiago García. (Chaves Martín: 2003: 12). La traza actual, completamente barroca y mucho más humilde se debe a las reformas llevadas a cabo en 1712 (Contreras Jiménez, 1986: 5) y 1812 (AMS: 4813-3, I: 9). En 1825 fue declarada en ruina (AMS: 4813-3, I: 12), y restaurada en 1946.) Restaurada en el primer cuarto del siglo XX o posiblemente finales del XIX (Rodríguez Marín, 2013: 31).
} 
apoyo. Quizá exista zócalo diferenciado enterrado. En los puntos donde se ve el apoyo en la roca, no hay zócalo diferenciado, pero si se ha constatado que la roca esta tallada en vertical. Las partes altas, se rematan con petos, sin almenado y abunda el empleo de piedra de granito, tal y como hemos visto que ocurre habitualmente en los lienzos, cuando se trataba de reconstrucciones.

Como se ha indicado, es una zona en que la muralla se encuentra en muy mal estado de conservación, por lo que localizamos numerosos lienzos donde se ha desprendido parcialmente la hoja exterior y lo que se ve es el relleno interior y en cuyo seno se aprecian los agujales y las tongadas de nivelación del mortero, lo que demuestra que se trata de tapia encofrada, pero las reparaciones lo han desfigurado. En un caso, L43-44, se aprecian perfectamente conservados los agujales y se distinguen dos modulaciones de tapia.

Respecto a las torres, son todas de planta cuadrada. Podemos afirmar casi con total certeza que todas han sufrido ruina por desplomes de la roca base o derrumbes por deslizamiento y posteriores reconstrucciones totales o parciales. En todas se aprecian discontinuidades y reconstrucciones. La fábrica que predomina es la mampostería desconcertada con refuerzo de sillares en las esquinas que tienden a desaparecer al ascender. Impera la mezcla de materiales y abundan las reparaciones con ladrillo, especialmente en esquinas o como enripiados. Excepcionalmente aparece un zócalo completo de sillería bien aparejada, pero lo más frecuente es que la mampostería desconcertada arranque desde el apoyo, aunque con una mayor presencia de piezas regulares y sillares embutidos en ella. En la mayor parte de los casos, la roca no es visible y cuando se ve, está tallada en vertical en la base. No hay almenado en ningún caso y a veces ni siquiera peto, debido al mal estado conservación.
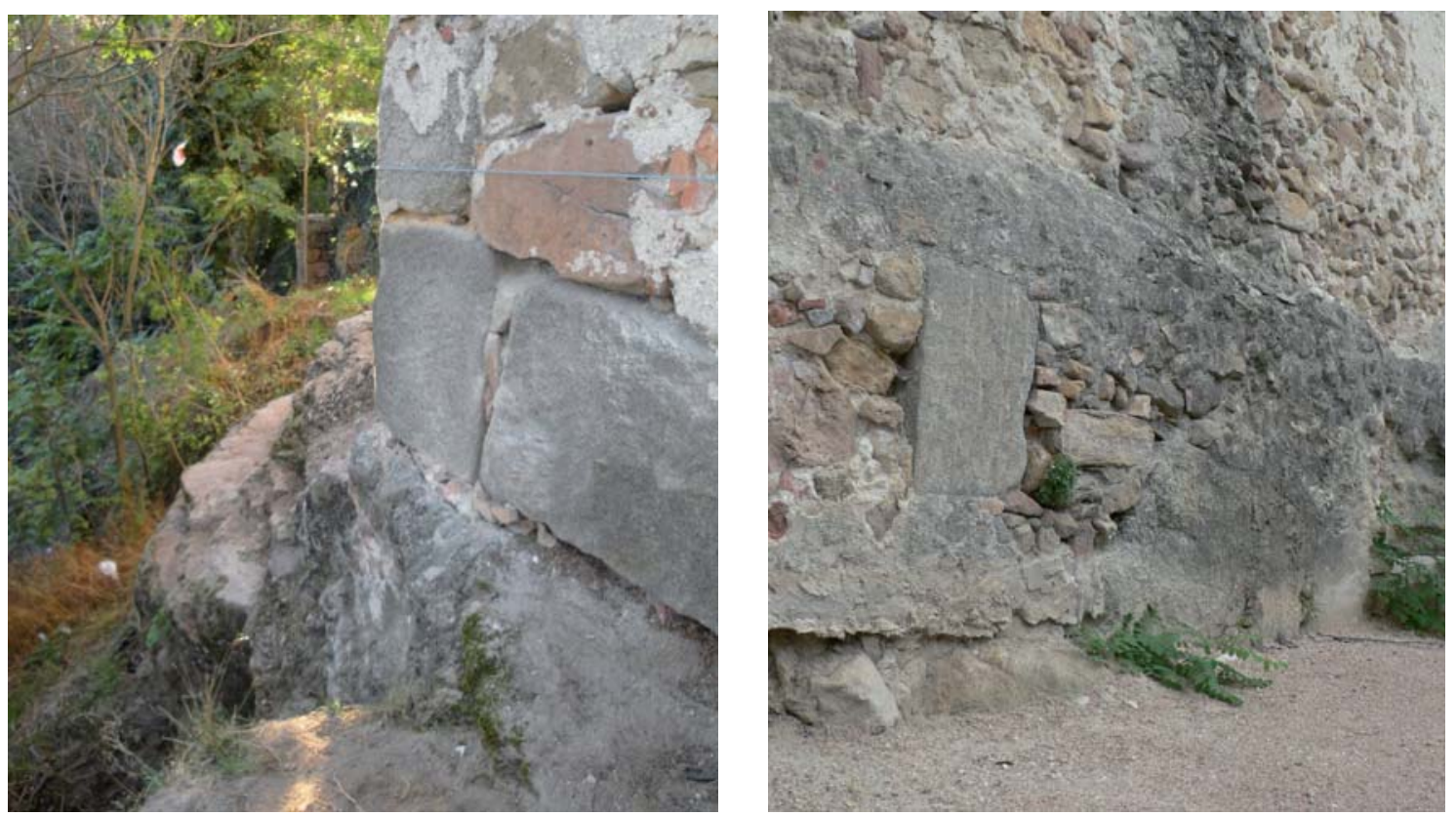

Figura 3. 50: La torre T43 flanquea la puerta de San Cebrián y se construye completamente al borde del cortado de la roca.

Figura 3. 51: Lienzo L43-44. Roca cortada en vertical al pie de la muralla. La mampostería baja hasta apoyar sobre la roca, sin ningún tipo de zócalo de separación. 
La torre T43 tiene el apoyo visible sobre la roca. Exhibe algunos sillares de granito en el zócalo, especialmente en las esquinas. Muestra la referida mampostería desconcertada con sillares de piedra carbonatada en las esquinas, que desaparecen a partir de la mitad de la torre. Por la cara posterior a la puerta aparecen unos sillares esquineros de granito a media altura, pero tampoco llegan al adarve. Presenta almenado realizado con mampostería y un rejuntado que tapa mucho la piedra.

En la parte baja de la cara interior, vemos numerosos sillares de granito reutilizados y spolia romanas, pero no están aparejados para constituir un zócalo sino que están dispersos por la fábrica, como si fuesen mampuestos.

El lienzo L 43-44 es inusualmente corto, sólo $18 \mathrm{~m}$. El apoyo en roca es visible. La roca esta tallada en vertical y calzada mediante mampostería en la base. En algunas zonas el revoco cubre completamente la fábrica, que aparenta ser la típica mampostería desconcertada, pero en el centro del lienzo se aprecian los agujales muy ordenados, lo que nos hace sospechar que es una fábrica encofrada en buen estado de conservación. Sin embargo observamos dos modulaciones de agujales, distintas, una de 3 agujales en horizontal por tapial y otra de sólo 2 que se sitúa directamente por encima de la primera.
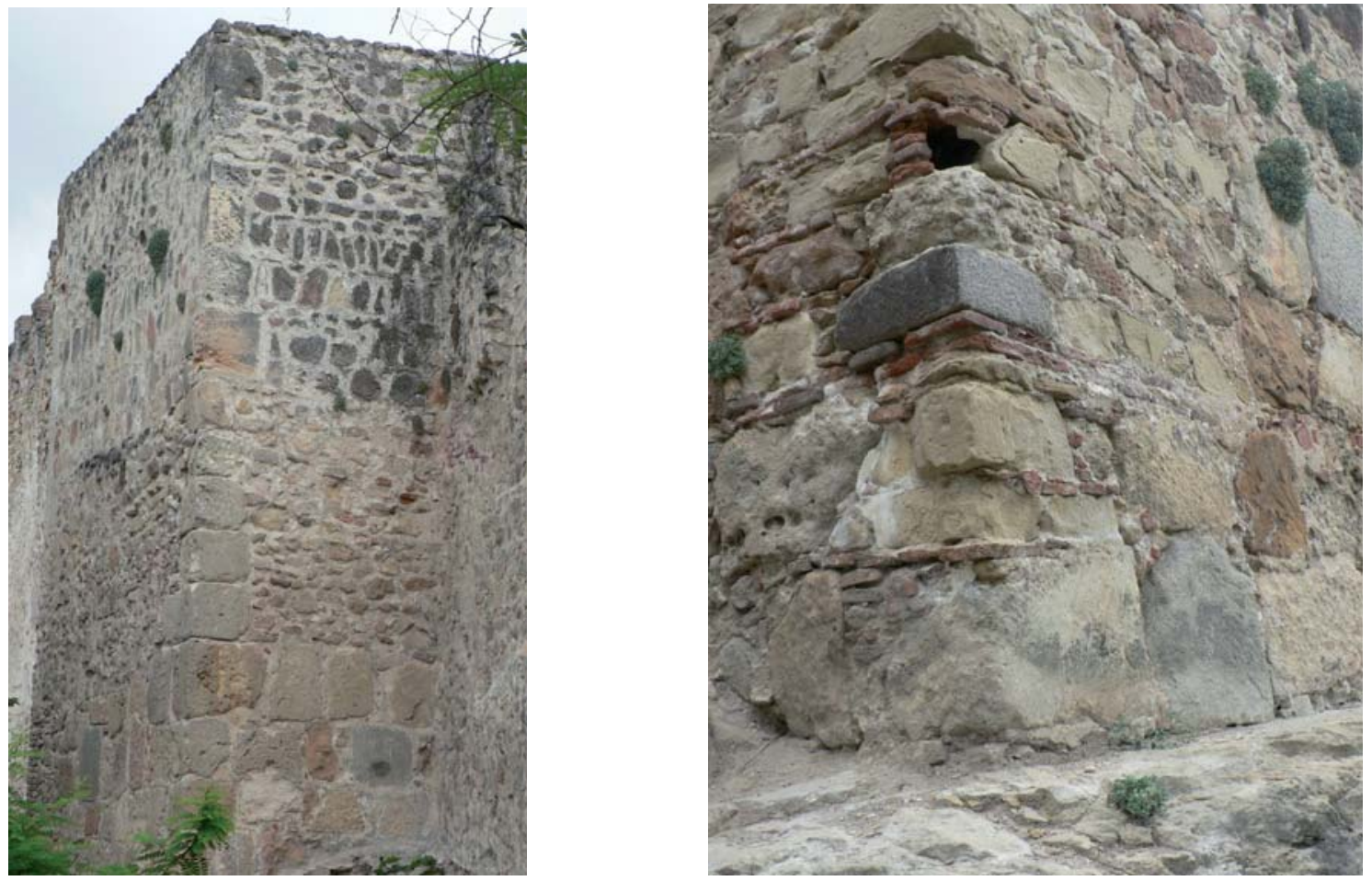

Figura 3. 52: Torre T44. Imagen representativa del tipo de torre característico de esta zona. Zócalo de sillería sobre el que se levantan varias mamposterías en distintos aparejos o sin aparejar, con las esquinas reforzadas por sillares.

Figura 3. 53: Torre T45. Desde el zócalo se aprecian los sillares calzados con numeroso ripio de ladrillo y las piezas dispuestas sin nivelar sobre la roca, sin tallar. No es hasta la tercera hilada que los tendeles son horizontales.

En la T44 apreciamos que está parcialmente derruida y reconstruida. En su cara frontal y en la oeste observamos en su zócalo 5 hiladas de sillería de roca sedimentaria con material 
mezclado y proliferación de spolia, algunas de ellas lápidas romanas, pero todo ello aparejado con cierta corrección. Sin embargo, el tercer lado se ejecuta exclusivamente con mampostería desconcertada con material mezclado y en el zócalo, la esquina en ladrillo. Encontramos claras evidencias de reparaciones en ladrillo en las esquinas y distintas etapas constructivas. No se ve el apoyo en la roca. La torre se realiza en mampostería hasta el peto.

En el lienzo L44-45 distinguimos unas claras líneas de discontinuidad en horizontal. Existen varios recrecidos, disminuyendo el espesor. También se diferencia una discontinuidad en vertical junto T44, en el que una parte está muy desplomada y la otra reconstruida aplomada, indicio inequívoco de derrumbe. Mampostería desconcertada muy parcheada, en la parte alta con abundancia de sillares y piezas regulares de distintos materiales mezclados, concertadas en hiladas. Remate en peto sin almenado. No se ve el apoyo en la roca, por lo que podría existir un zócalo enterrado. Vemos algunos agujales, pero sin orden claro.
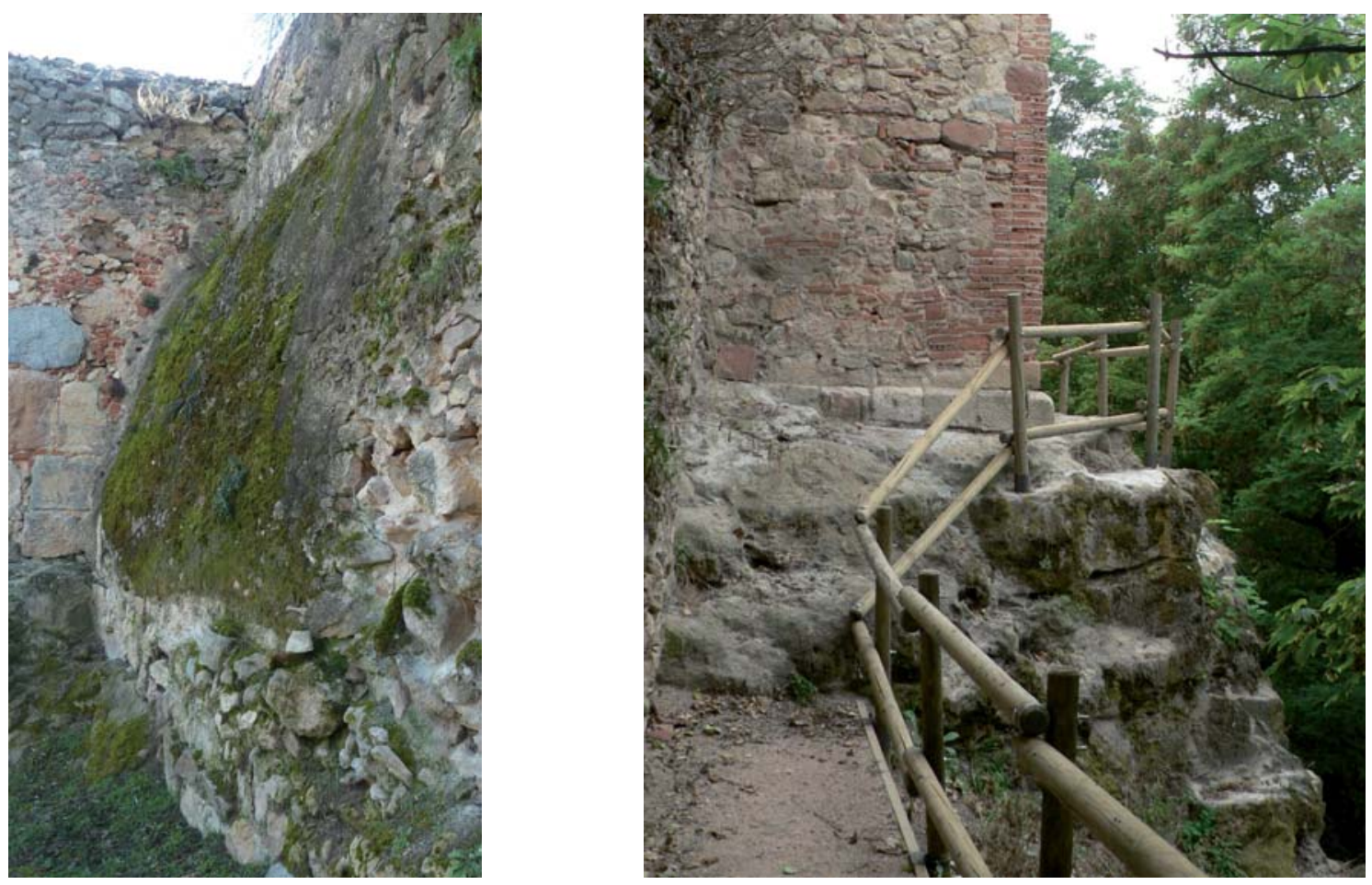

Figura 3. 54: Lienzo L45-46. Lienzo derruido por deslizamiento y que se ha reconstruido con muy poca altura y reduciendo el espesor dejando en evidencia el plano inclinado de rotura.

Figura 3. 55: Torre T46. La planta de la torre se ciñe a la plataforma del saliente rocoso, resultando una torre más estrecha de lo habitual, pero con mayor resalto.

La torre T45 tiene extrañas proporciones, 6,00 x 1,95 metros. Es muy ancha, pero con poco resalte y muy poca altura. También está reconstruida, al menos parcialmente. Vemos una discontinuidad muy evidente en su aparejo. Un lateral presenta varias hiladas de sillares de piedra sedimentaria, que vuelven por la cara frontal, pero sin llegar a la otra esquina que se realiza con mampostería encintada en ladrillo. En esta torre distinguimos en el zócalo sillares calzados con ripio y diversos aparejos que se entremezclan, así como los materiales con que se ejecutan, como por ejemplo, mampostería encintada, mampostería con sillares y 
piezas regulares, mampostería desconcertada. Predomina la piedra carbonatada pero hay también granito y alguna spolia. Las piezas regulares son más abundantes en el zócalo y las esquinas. Aparentemente podría tratarse de una reconstrucción con un posible forrado de la preexistente regruesando por estabilidad. Apoya directamente sobre la roca que se encuentra tallada verticalmente en uno de sus lados.

El L45-46 muestra una clara discontinuidad en horizontal. Vemos dos recrecidos disminuyendo el espesor. Fábrica ejecutada con la habitual mampostería desconcertada muy parcheada, con mezcla de distintos tipos de piedras y en proceso de ruina. En diversas zonas se ha perdido hoja exterior y vemos el relleno interior del muro. No se ve el apoyo en la roca. Puede existir un zócalo enterrado porque el lienzo visible tiene una altura de escasos 5 metros. Se remata en peto sin almenado. Su longitud, 21,50 metros, algo más corto de lo que predomina en la zona, puede ser motivado por la posición de la torre siguiente, sobre un peñasco que condiciona su posición y la longitud de este lienzo.

La torre T45 tiene extrañas proporciones, $6,00 \times 1,95$ metros. Es muy ancha, pero con poco resalte y muy poca altura. También está reconstruida, al menos parcialmente. Vemos una discontinuidad muy evidente en su aparejo. Un lateral presenta varias hiladas de sillares de piedra sedimentaria, que vuelven por la cara frontal, pero sin llegar a la otra esquina que se realiza con mampostería encintada en ladrillo. En esta torre distinguimos en el zócalo sillares calzados con ripio y diversos aparejos que se entremezclan, así como los materiales con que se ejecutan, como por ejemplo, mampostería encintada, mampostería con sillares y piezas regulares, mampostería desconcertada. Predomina la piedra carbonatada pero hay también granito y alguna spolia. Las piezas regulares son más abundantes en el zócalo y las esquinas. Aparentemente podría tratarse de una reconstrucción con un posible forrado de la preexistente regruesando por estabilidad. Apoya directamente sobre la roca que se encuentra tallada verticalmente en uno de sus lados.

El L45-46 muestra una clara discontinuidad en horizontal. Vemos dos recrecidos disminuyendo el espesor. Fábrica ejecutada con la habitual mampostería desconcertada muy parcheada, con mezcla de distintos tipos de piedras y en proceso de ruina. En diversas zonas se ha perdido hoja exterior y vemos el relleno interior del muro. No se ve el apoyo en la roca. Puede existir un zócalo enterrado porque el lienzo visible tiene una altura de escasos 5 metros. Se remata en peto sin almenado. Su longitud, 21,50 metros, algo más corto de lo que predomina en la zona, puede ser motivado por la posición de la torre siguiente, sobre un peñasco que condiciona su posición y la longitud de este lienzo.

La torre T46 está sobre un peñasco aislado, ya que se apoya sobre una roca tallada en vertical en la base, aparentemente escalonada, mientras ambos lienzos adyacentes tienen su arranque a una coita inferior y en ellos la roca está enterrada. Sus dimensiones, 4,35 x 2,40, ligeramente distintas a las de las demás torres de la zona posiblemente estén motivadas por adecuarse a la roca de apoyo disponible. El zócalo arranca sobre una hilada de sillería con corte en chaflán, claramente reutilizada y presenta abundancia de spolia bajomedievales, piezas de molduras, jambas con bocel, etc. Sobre esto, la ya comentada mampostería con abundancia de ladrillo enripiando y esquinas de ladrillo, excepto en parte alta en la que desaparecen y sólo se emplea mampostería hasta el peto.

En el lienzo L46-46' se reitera la fábrica de mampostería desconcertada, aunque en este caso se aprecian algunos agujales. De nuevo vemos una discontinuidad vertical con una de las partes desplomada. La mitad cercana a T46' esta reconstruida aplomada y presenta 
abundancia de piezas de granito especialmente en las partes altas, lo que indica que está reconstruida completamente desde el suelo hasta el peto. Se observa en la mitad del lienzo unos restos, dos jambas de ladrillo y un arranque de, posiblemente, un arco embebido en la fábrica, muy deteriorado todo ello. Podría tratarse de una antigua ventana tabicada. En unas partes la mampostería arranca directamente en la roca y en el resto no se ve apoyo. Puede existir un zócalo enterrado, pues la roca presenta importantes desniveles.
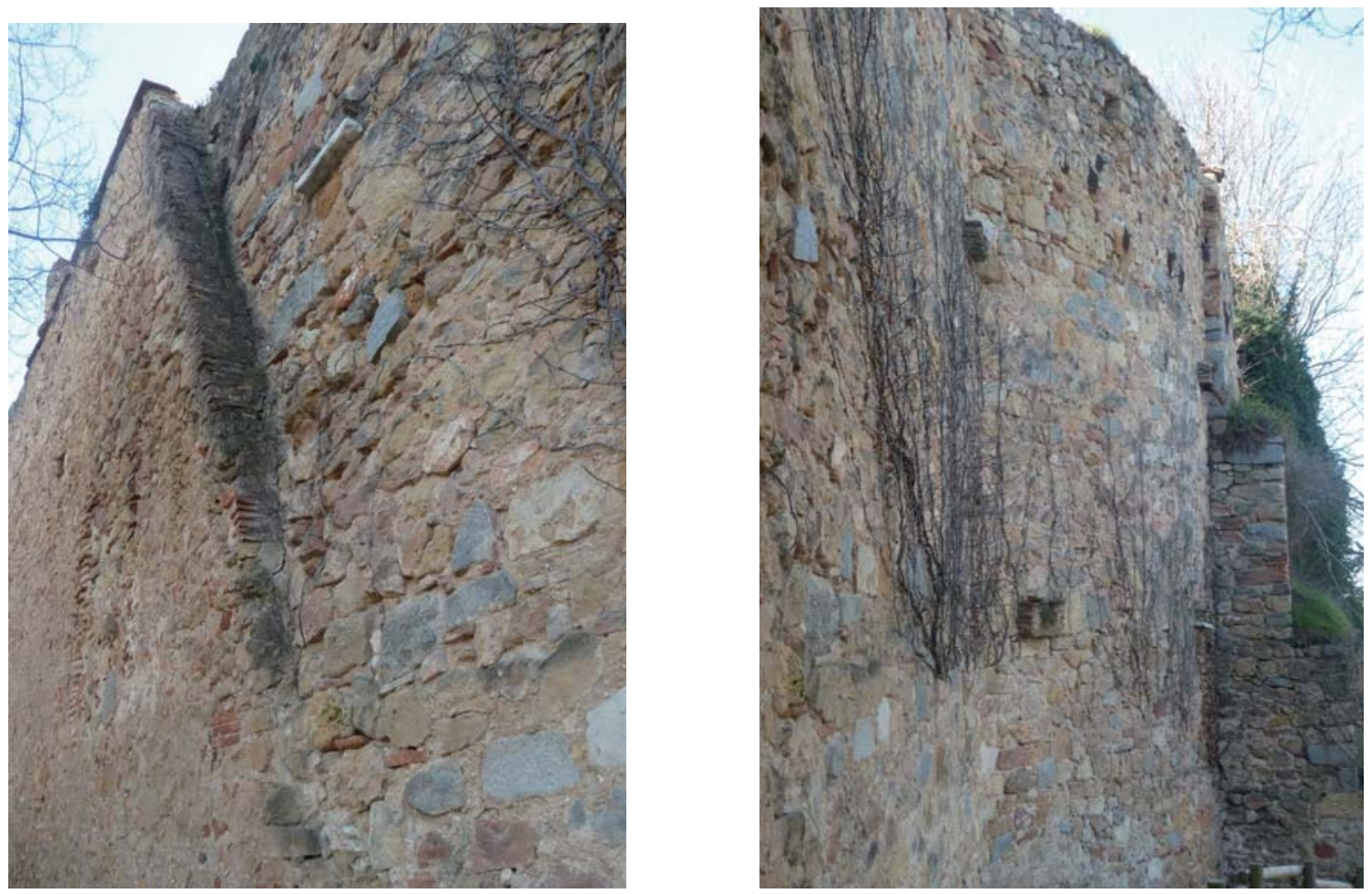

Figura 3. 56: Lienzo L46-46'. Muro desplomado y reconstruido parcialmente evidenciado por la línea de discontinuidad casi vertical que divide el lienzo en dos partes.

Figura 3. 57: Lienzo L46-46'. Vista de la parte de lienzo reconstruida aplomada, donde se aprecia la fábrica de mampostería desconcertada, sin agujales, con mezcla de distintos tipos de piedra y abundancia de granito hasta las partes altas, entre ellos algún granito gris azulado. El otro extremo de la parte reconstruida, se evidencia con otro quiebro en el trazado del lienzo.

La torre T46'no está contemplada en el plan Director. Se trata de una torre reconstruida, aunque sin recuperar totalmente la volumetría inicial, sino más bien una especie de consolidación de lo conservado, rematándolo en forma escalonada. Quizá esta recuperación volumétrica haya alterado sus proporciones ya que presenta unas dimensiones muy escasas, 4,35 x 1,73 metros, en comparación al resto de las torres de la zona. Presenta una fábrica completamente uniforme, sin reparaciones, claramente ejecutada de una sola vez, mediante la habitual mampostería desconcertada en la que se mezclan distintos tipos de materiales con abundancia de granito distribuido homogéneamente hasta la parte superior.

El L46'-47 muestra varios fragmentos de fábricas, separadas por líneas de ruptura, discontinuidades y distintas reconstrucciones. Vemos abundancia de piezas de granito entremezcladas en la mampostería desconcertada sin criterio, con varios escalonamientos y cambios de material. Abunda el ladrillo diferenciando las reparaciones al emplearlo como calzo y ripio. 

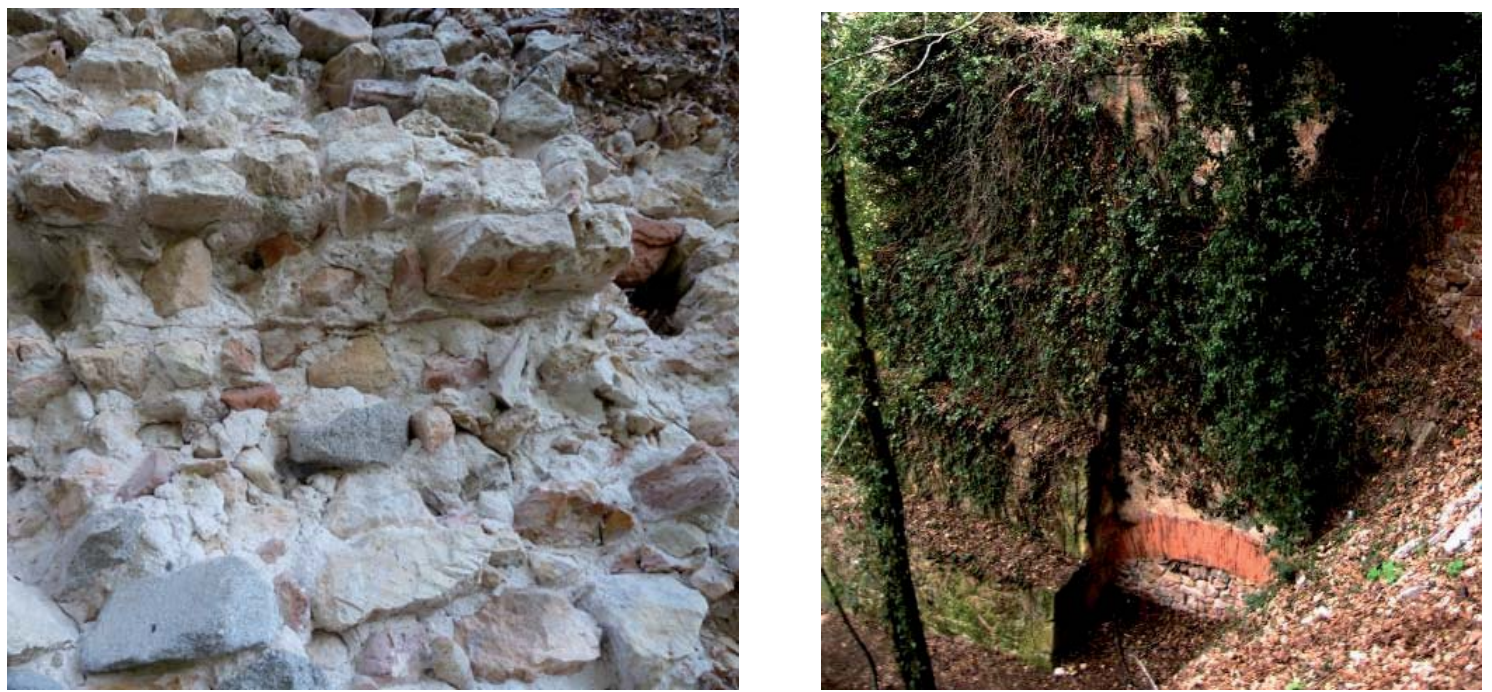

Figura 3. 58: Lienzo L46'-47. El desprendimiento de las piezas que componen la cara exterior nos permite observar el interior del relleno de este lienzo en el que apreciamos la línea de agujales y la tongada de nivelación del mortero. Es una fábrica de tapia encofrada.

Figura 3. 59: Vista de la torre T47, prácticamente oculta por la vegetación, y el arco de ladrillo que existe en el quiebro del lienzo L47-48, de características similares al arco de ladrillo de la puerta de San Cebrián.

Importantes fragmentos del lienzo están ocultos por la vegetación. Aparecen numerosos agujeros dejados en la fábrica, que creemos en su mayoría son agujales, otros posibles mechinales y algunos parecen desagües o drenajes hechos en las reconstrucciones. En una zona se ha desprendido parcialmente la hoja exterior y lo que se ve es el relleno interior, en cuyo seno se aprecian los agujales y las tongadas de nivelación del mortero, lo que demuestra que se trata de tapia encofrada, pero las reparaciones lo han desfigurado.

En unas partes la mampostería apoya directamente en la roca y en otras no se ve el apoyo. Puede existir un zócalo enterrado, pues aparentemente la roca presenta importantes desniveles.

La T47 es difícilmente accesible y se encuentra derruida, posiblemente por el desplome de la roca en su esquina exterior. Aparentemente era más grande de lo que ahora vemos. Se trata de una reconstrucción parcial, escalonada, tal y como hemos visto en la T46', posiblemente chapando los restos conservados. Presenta una mampostería con material mezclado, granito, piedra carbonatada, ladrillo, material reutilizado, constituyendo un aparejo uniforme, aunque muy oculto por la vegetación. Sus dimensiones resultan sorprendentemente grandes, 5,80 x 5,60 metros y podría ser incluso mayor, dado que se encuentra al borde de un precipicio que impide medir con facilidad y podría haberse visto afectada por un derrumbe, como se ha indicado.

La muralla realiza un quiebro muy significativo en el L47-48 que es inusualmente corto, $17,70 \mathrm{~m}$. Tiene trazado en $\mathrm{L}$ con un lado muy corto, en el que hay que destacar la existencia de un arco ladrillo de dos pies y medio de rosca. Aparentemente parece ladrillo de la fábrica Carretero, por lo que debe tratarse de una reparación que datamos entre mediados del XIX hasta mediados del XX. Este arco nos resulta en cierto modo parecido al que existe en la parte alta de la puerta de San Cebrián, aunque en este caso tiene menos peralte y media rosca más. Desconocemos lo que hay debajo, ni que profundidad de lienzo se encuentra enterrada. 


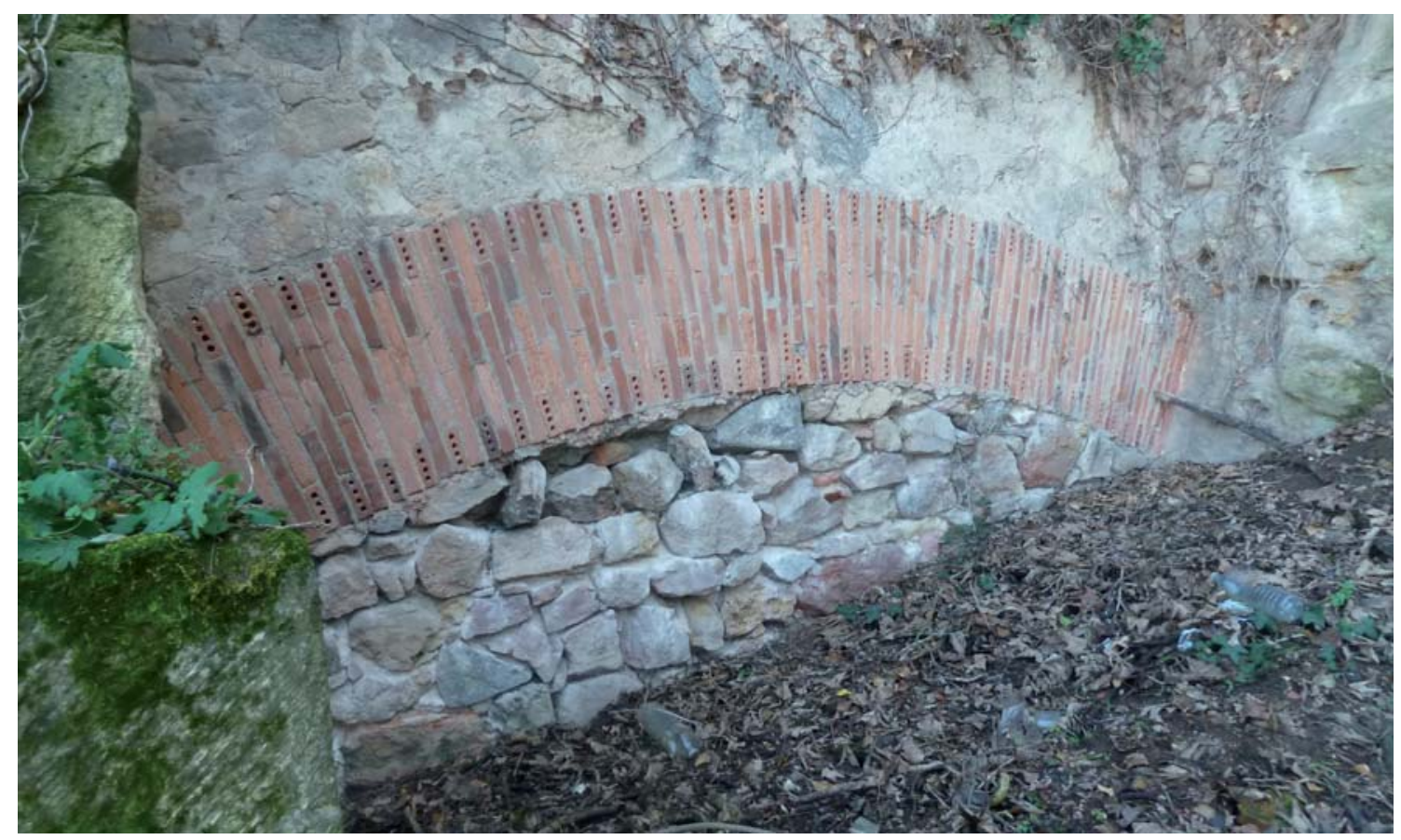

Figura 3. 60: Lienzo L47-48. Arco en ladrillo, de similares características al que existe en la parte alta de la puerta de San Cebrián.

Las dimensiones de la torre T47 bastante mayores que de las de sus homónimas, la disposición en quiebro de la muralla en este punto, con el siguiente lienzo L47-48 en forma de L donde vemos el arco de descarga en ladrillo y la proximidad de la siguiente torre T48, nos hacen sospechar que este pudiese ser el emplazamiento del desaparecido postigo de la fuente cercada (Véase 4.1.9).

El resto del lienzo se ejecuta en la consabida mampostería desconcertada. En él apreciamos un hueco, que aunque presenta restos de lo que debió ser un recercado, aparenta ser un desagüe, más que una ventana. La topografía y la vegetación no permiten acercarse. Sobre el adarve se apoya el edificio de hospital de la Misericordia.

Esta parte del lienzo apoya directamente sobre la roca, con un gran desnivel sobre la cota a la que se encuentra el otro trozo de lienzo donde se halla el arco. Aparentemente se trata de un corte, prácticamente vertical, aunque no se puede indagar si esta tallado de forma intencionada o es un desnivel natural. Está muy tapado por la vegetación que descuelga desde arriba.

La T48 está reconstruida y el edificio del hospital de la Misericordia apoya sobre su adarve a la vez que se han abierto ventanas sobre los paños recrecidos. Apreciamos la mampostería desconcertada que arranca desde el suelo con refuerzo de sillares en las esquinas, algunos de granito en la parte más baja. No se aprecia el apoyo en la roca y buena parte de la fábrica se encuentra prácticamente revocada en su totalidad, en la parte inferior y oculta por la vegetación en la parte superior. En la parte alta, predomina el ladrillo en el recercado de los huecos y en una reparación tras la apertura de una ventana en la cara frontal. Algunos sillares esquineros han desaparecido y han sido sustituidos por ladrillo del mismo tipo. 
El lienzo L48-49 presenta la singularidad de mostrar la roca tallada en vertical en el apoyo de la mampostería desconcertada con la que se ejecuta todo el lienzo desde la base. Existen algunos posibles agujales, pero no presentan un orden claro. Se aprecia un rejuntado que uniformiza el tratamiento del lienzo, que por otra parte se halla bastante oculto por la vegetación.

El edificio del hospital de la Misericordia apoya sobre el adarve recreciendo en fábrica de ladrillo en la que se han abierto ventanas. Una de las ventanas en un piso inferior, aparentemente está abierta en el espesor del lienzo de la muralla, habiéndose recercado en ladrillo.
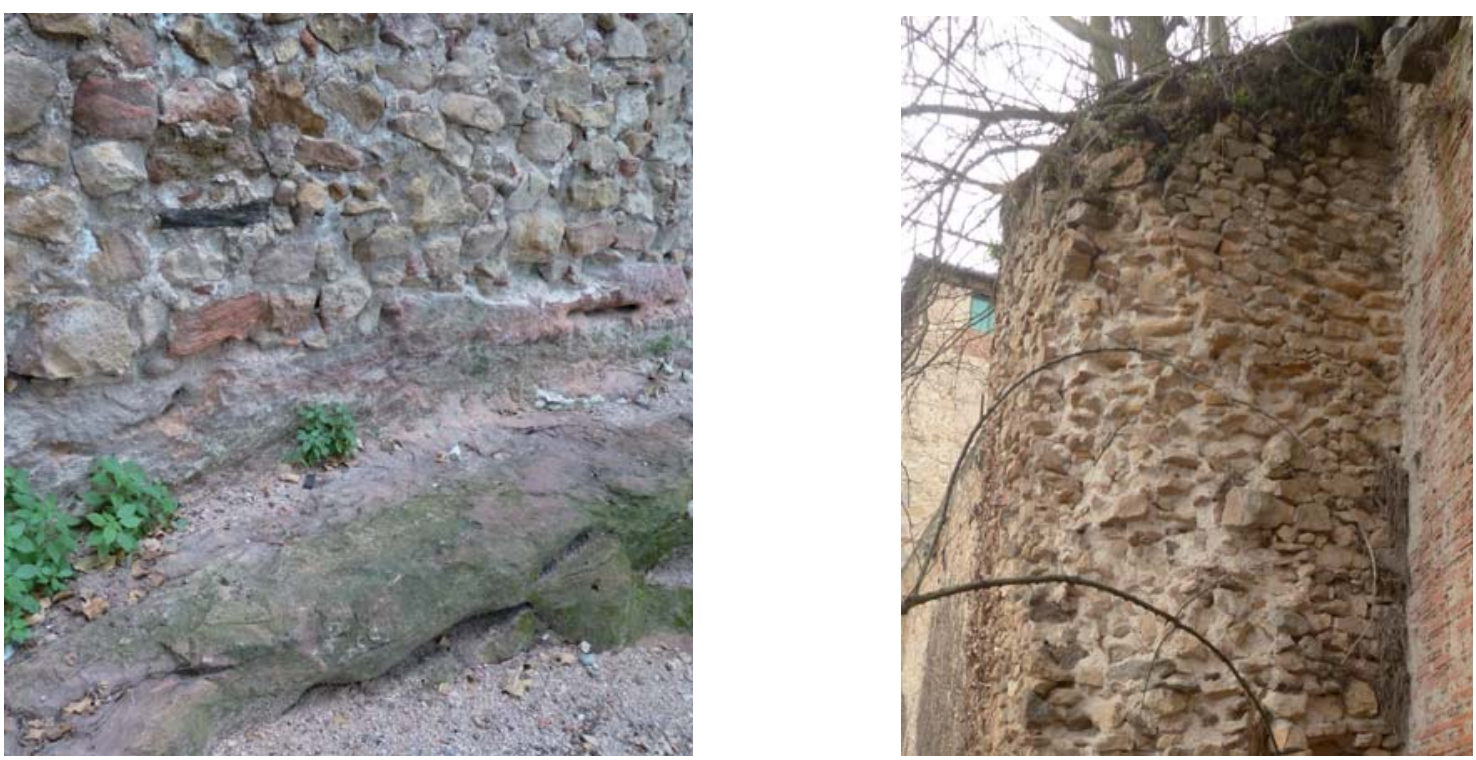

Figura 3. 61: Lienzo L48-49. Roca cortada en vertical para apoyar la muralla y tallada horizontal dejando un resalto o escalón delante del apoyo del lienzo.

Figura 3. 62: Torre T49, donde se han perdido los sillares esquineros, pero se observa que tanto la cara lateral como la frontal son rectas y configuran una forma rectangular.

La T49 es una torre en que se han perdido los sillares esquineros, por lo que aparenta forma circular y de hecho en su parte superior se ha reparado configurándola con dicho trazado. Sin embargo la planicie de sus caras y la disposición de los sillares de piedra carbonatada en la cara frontal de su zócalo corroboran este hecho. Sobre esta sillería de piedra sedimentaria de tamaño medio y grande que apoya en la roca se ejecuta la torre en mampostería desconcertada. Buena parte de lo ahora visible en las esquinas es el relleno interior de la mampostería, mientras la reparación de la parte superior evidencia una mezcla de material con abundancia de granitos. La parte alta se haya derruida en plano inclinado hacia el exterior, lo que evidencia el desplome por deslizamiento. No hay adarve ni peto, sino unos árboles enraizados sobre el plano inclinado que están reventando la fábrica, de por sí ya muy deteriorada. Sobre ella existió un edificio construido, ocupando su adarve, del que asomaban dos voladizos a modo de ladroneras, posiblemente retretes, tal y como apreciamos en la foto de 1864 (González, 1997: 105), por lo que el derrumbe de la torre es posterior a esa fecha. 
El L49-50 es otro lienzo representativo de la norma en esta zona, en el que vemos ejemplos de casi todos los casos ya mencionados. Se encuentra en estado ruinoso, parcialmente derruido y a punto de derrumbarse, reventado por las raíces de los árboles que lo colonizan. Exhibe la conocida mampostería desconcertada, con un sinfín de reparaciones, parches y la evidencia de varias discontinuidades, con zonas reconstruidas, quiebros que separan una parte desplomada y otra parte aplomada y reconstruida en ladrillo, o zona reconstruida con mampostería encintada que genera un resalto vertical que altera la línea exterior del lienzo. Exteriormente existen algunos agujales pero sin ningún orden, pero vemos zonas en que se ha perdido la hoja exterior del muro y se descubre el relleno interior con los agujales tapados por las restauraciones volviendo a demostrar que en origen se ejecutó como una tapia encofrada. Mientras en la hoja exterior observamos numerosos mampuestos de granito entremezclados con la piedra sedimentaria, en el relleno interior no se aprecian piezas de granito. No se ve la roca de apoyo, pero en la parte que sí se ve, la mampostería apoya sobre roca, directamente, sin zócalo diferenciado.
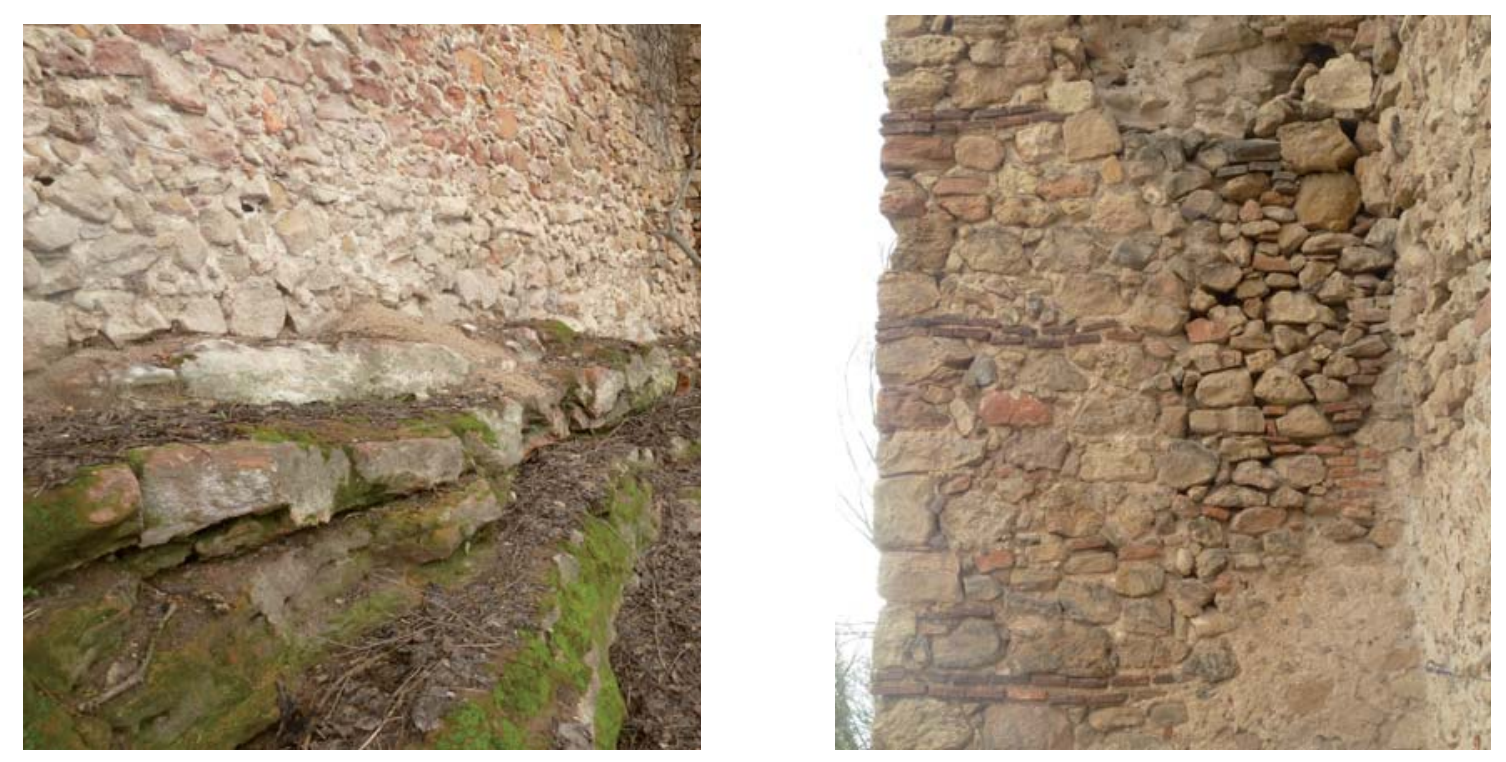

Figura 3. 63: Lienzo L49-50. La mampostería apoya en la roca directamente, sin existencia de piezas de mayor tamaño que generen un zócalo diferenciado.

Figura 3. 64: Torre T50. Mampostería encintada, muy mal aparejada, que no llega hasta el encuentro con el lienzo, lo que denota que se trata de una reparación en que se ha rehecho de la hoja exterior de la cara frontal de la torre.

La T50 muestra claramente como su frontal se ha derruido y ha sido reconstruido. Se aprecian las discontinuidades de su aparejo visibles en ambos laterales. En la base se ven algunos sillares de granito, con marcas de las garras de elevación y que no llegan a constituir hilada como tal, sobre los que apoya la mampostería desconcertada característica. En ambas esquinas vemos algunas verdugadas de ladrillo que en uno de sus lados cortos no llegan hasta el lienzo, lo que indica que es una reconstrucción con distinto aparejo, no el original de la torre. La existencia de estas verdugadas de ladrillo en la reconstrucción le confiere el aspecto de una mampostería encintada. Carece de almenado. No se ve la roca en el apoyo.

El lienzo L50-51 es otro ejemplo de multitud de derrumbes evidenciados por varias discontinuidades, con la fábrica ejecutada con la habitual mampostería desconcertada muy 
parcheada, con mezcla de distintos tipos de piedras y en proceso de ruina. Existe una línea de discontinuidad evidente por desplome separando dos partes, en un tramo apreciamos que después de arruinarse parcialmente fue reconstruido, mientras en el otro está a punto de derrumbarse, reventado por raíces de los árboles que crecen en su remate, que carece de adarve. En su base apreciamos la roca tallada en vertical y como es habitual se conservan algunos agujales en el lienzo, pero sin orden.

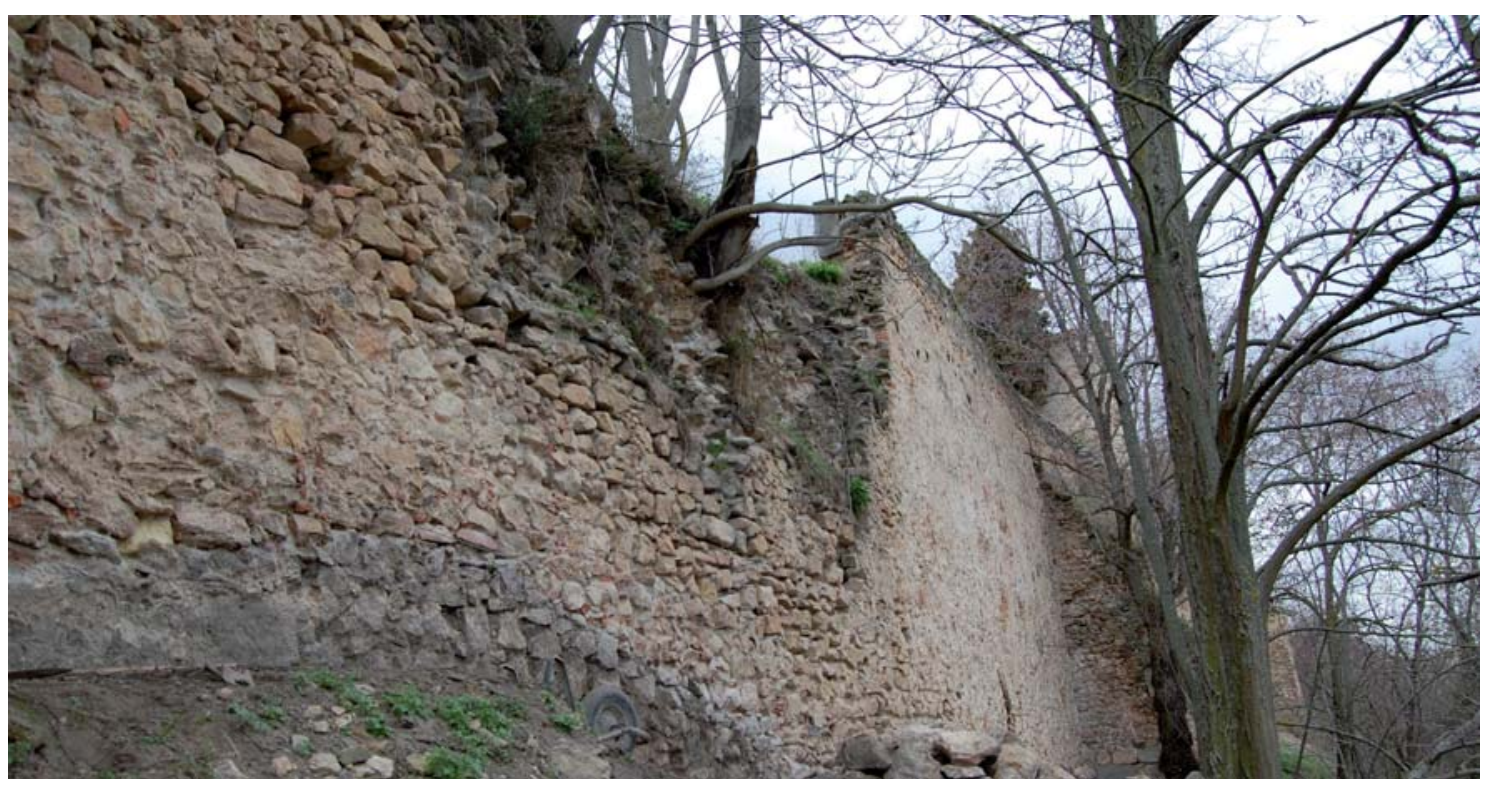

Figura 3. 65: Lienzo L50-51. Imagen del lienzo en que se percibe su estado de ruina y derrumbe parcial con los arboles enraizando en el propio lienzo.
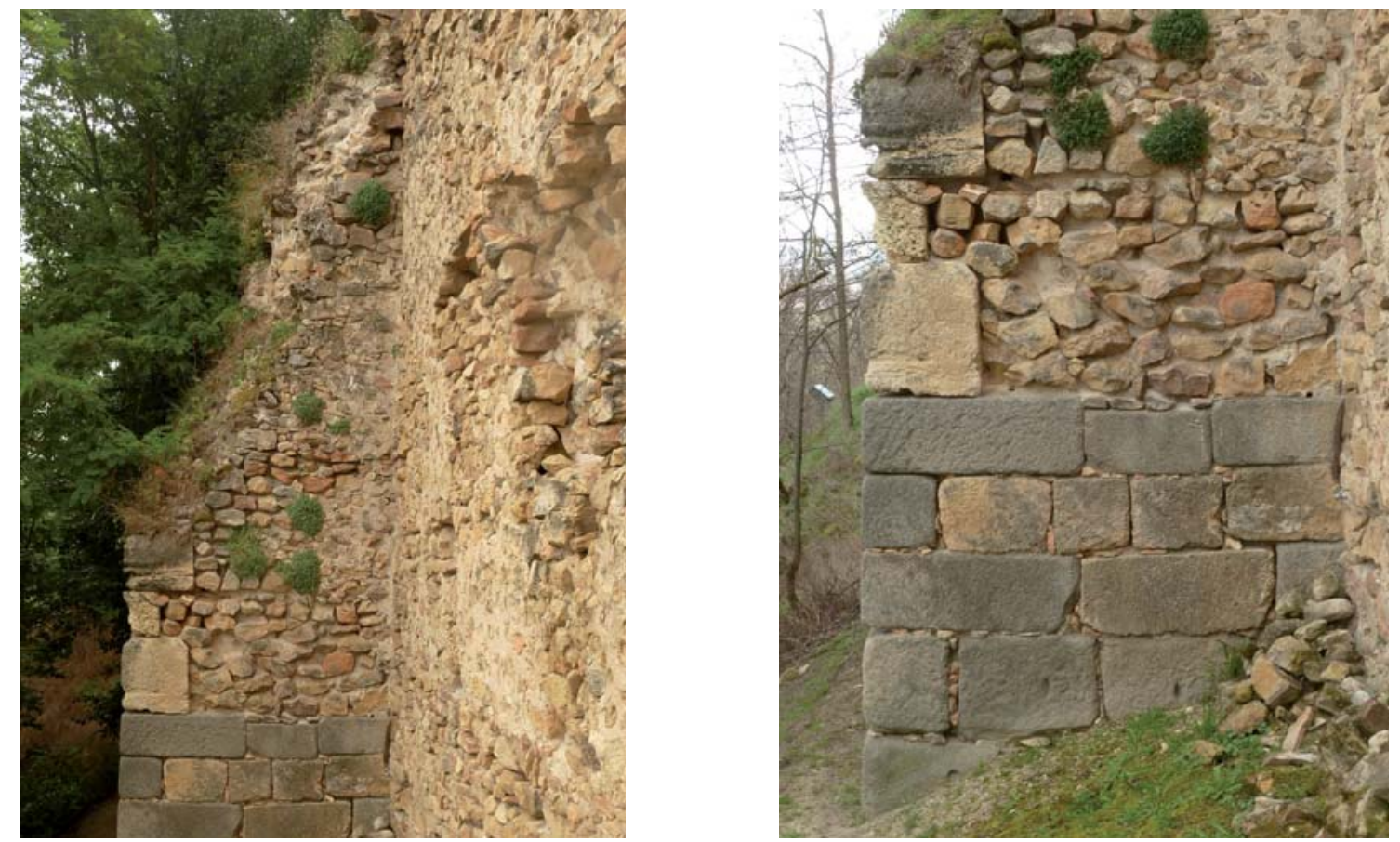

Figura 3. 66: Torre T51. Torre derrumbada por deslizamiento en que se aprecia claramente el ángulo de rotura y la línea del plano de deslizamiento de la parte superior de la torre.

Figura 3. 67: Torre T51. Detalle del zócalo de sillería de la misma torre ejecutado en sillería de granito, con abundantes piezas reutilizadas. 
La torre T51 coincide con el límite de la parcela del hospital de la Misericordia. Esta derruido parcialmente ya que denota en su remate el plano inclinado con el ángulo de rotura por deslizamiento, igual que hemos visto en otras torres anteriores.

Sobre un zócalo diferenciado, relativamente bien aparejado, de sillería de tamaño medio, en que predomina el granito pero mezclado con rocas carbonatas, se ejecuta la torre en mampostería desconcertada, conservando algunos sillares de piedra carbonatada en sus esquinas. Algunos sillares del zócalo presentan las marcas de las garras para el izado, lo que corrobora que están dispuestos en posición secundaria. No se ve la roca en la que apoya.

\subsection{8.- ZONA 8. SANTIAGO}

Si bien esta zona se ha diferenciado de la anterior, aprovechando el límite de la parcela del hospital de la Misericordia por motivos prácticos a la hora de la toma de datos, constructivamente nos encontramos con la misma tipología de torres y de lienzos ${ }^{61}$.

Abarca desde el límite de la parcela del hospital de la Misericordia hasta la puerta de Santiago. Totaliza una longitud de 248 metros, en los que se conservan 5 torres y se encuentra la ya mencionada puerta de Santiago. Han desaparecido tres torres y los lienzos que las unían. Las medidas de las torres oscilan entre 5,10-5,30 metros de frente y 2,00-2,20 metros de resalto con una separación de entre 24 y 28 metros de longitud de lienzo. Tan solo la torre T57 correspondiente a la puerta de Santiago y el lienzo adyacente incumplen esta pauta.

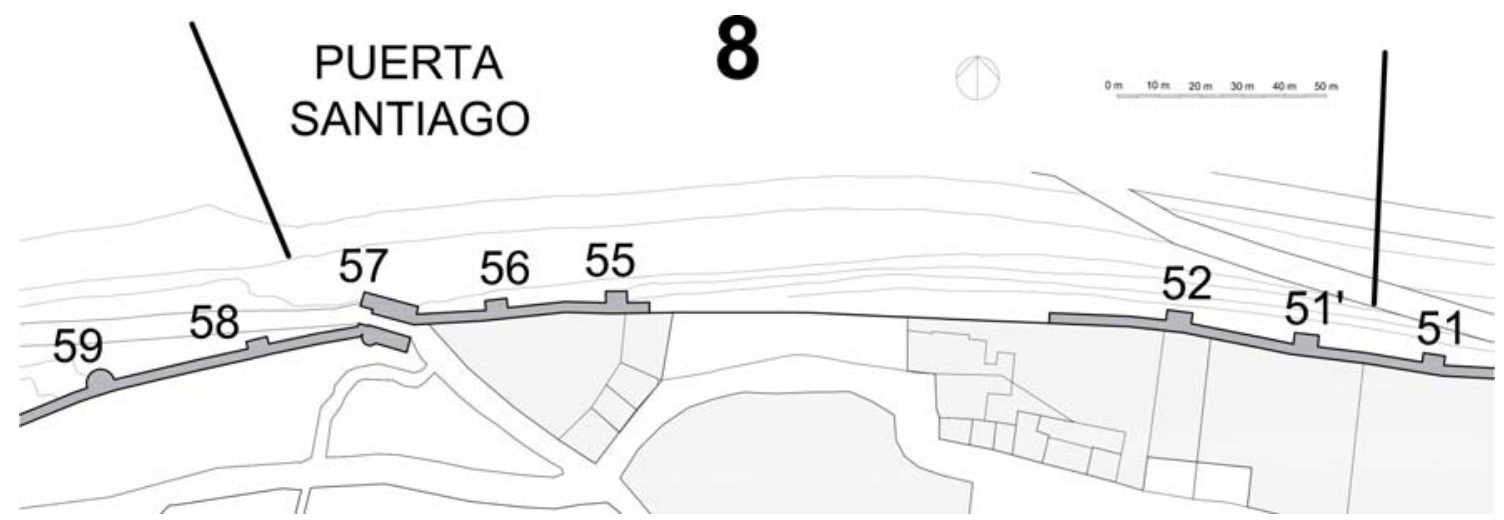

Figura 3. 68: Plano de la zona 8, que comprende desde la parcela del hospital de la Misericordia hasta la puerta de Santiago.

Los lienzos se ejecutan en mampostería desconcertada con distintos tipos de materiales entremezclados, si bien nuevamente, en los que se ha perdido la hoja exterior, se aprecia que en origen se ejecutaron como fábrica encofrada, quedándose en evidencia los agujales en el interior del relleno. La lectura constructiva vuelve a distorsionarse con las reparaciones y reconstrucciones. El estado ruinoso de buena parte de los lienzos deja

\footnotetext{
${ }^{61}$ La falta de accesibilidad a esta parte de la muralla, impide la continuidad en la toma de datos desde levante, debiendo llegar a este tramo desde la puerta de Santiago. La falta de referencias en este trecho de la muralla nos hizo optar por utilizar el limite parcelario del hospital para tener una referencia reconocible entre la espesura de la vegetación.
} 
entrever numerosas discontinuidades e infinidad de reparaciones en las que abunda de manera palpable el ladrillo. No existe almenado en ningún punto.

Las torres de esta zona son de planta cuadrada. Vemos las mismas discontinuidades ya comentadas en la zona anterior. Todas presentan huellas de haberse arruinado en algún momento y han sido reconstruidas parcialmente. La fábrica predominante es la mampostería desconcertada con presencia de sillares en zócalos y esquinas. Aparece mucho ladrillo como ripio, o incluso en reparaciones completas. Varias de las torres han desaparecido y las que existen están en estado ruinoso, por lo que no llegan a tener ni adarve, ni peto, ni almenado.
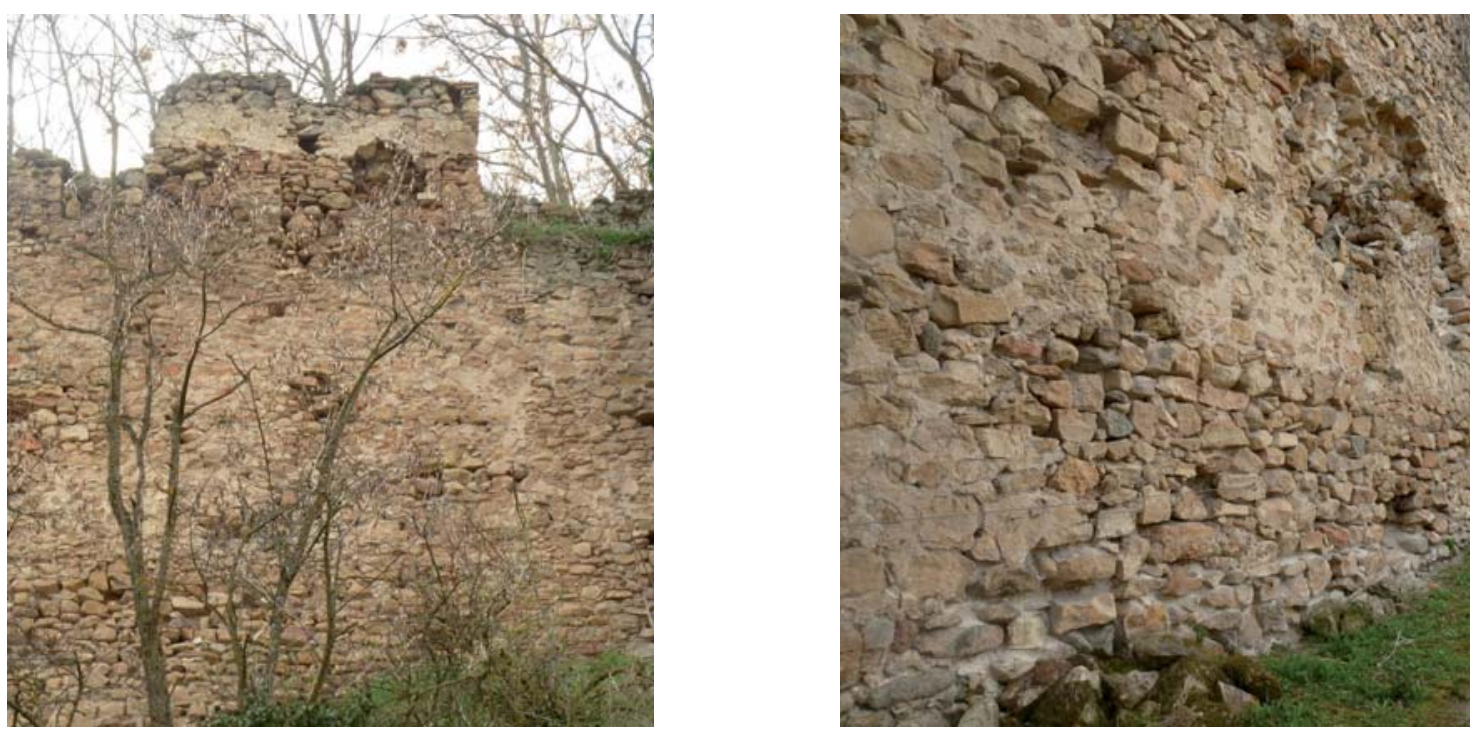

Figura 3. 69: Lienzo L51-51'. Lienzo en estado ruinoso, con restos del recrecido del edificio encima.

Figura 3. 70: Lienzo L51-51'. Perdida de la hoja exterior. En el relleno se observan agujales ordenados, testigos de la realidad constructiva de la ejecución del lienzo mediante tapiales.

El lienzo L51-51' presenta un estado ruinoso, que ya se observa en la imagen de 1864 (González, 1997: 105). Se observan zonas derruidas y otras que han sido reconstruidas así como innumerables reparaciones parciales. El aparejo empleado es el de mampostería desconcertada con mezcla de distintos tipos piedra, abundante ripio y ladrillo calzando mampuestos. En un derrumbe parcial en que se ha perdido la hoja exterior, se deja en evidencia que esa hoja exterior es una reparación de chapado de un lienzo que originariamente era tapial, con los agujales ordenados.

Sobre el lienzo vemos restos del muro de un edificio, ahora en ruinas, que apoyaba encima, en donde todavía se distingue lo que podría ser un almenado tabicado o una sucesión de ventanas, que aprovechaban ese almenado. No se aprecia el apoyo sobre la roca, ascendiendo la mampostería desde el suelo hasta el remate superior.

La 'T51' se ha arruinado parcialmente y se ha vuelto a reconstruir. En su aparejo se evidencia las discontinuidades de las distintas fases de recrecidos y reconstrucciones. Una muy clara recorre verticalmente la cara frontal de la torre por su punto medio. La mampostería desconcertada arranca desde el terreno con sillares esquineros que 
desaparecen al ascender. En algunos casos se han repuesto con ladrillo. No se ve apoyo en roca. No presenta peto, ni adarve.

El L51'-52 presenta los restos de un edificio en ruinas encima, con dos niveles de ventanas en cuya apertura y posterior recercado se emplea numeroso ladillo ${ }^{62}$. En su entorno abundan los sillares y piedras más grandes y regulares. Se lee perfectamente la que sería la esquina del edificio, reforzada con sillares. Como todos los lienzos, esta derruido y parcialmente rehecho, mediante la mampostería desconcertada que trasdosa una fábrica preexistente en la que se aprecian los agujales ordenados. No se ve el apoyo sobre la roca.
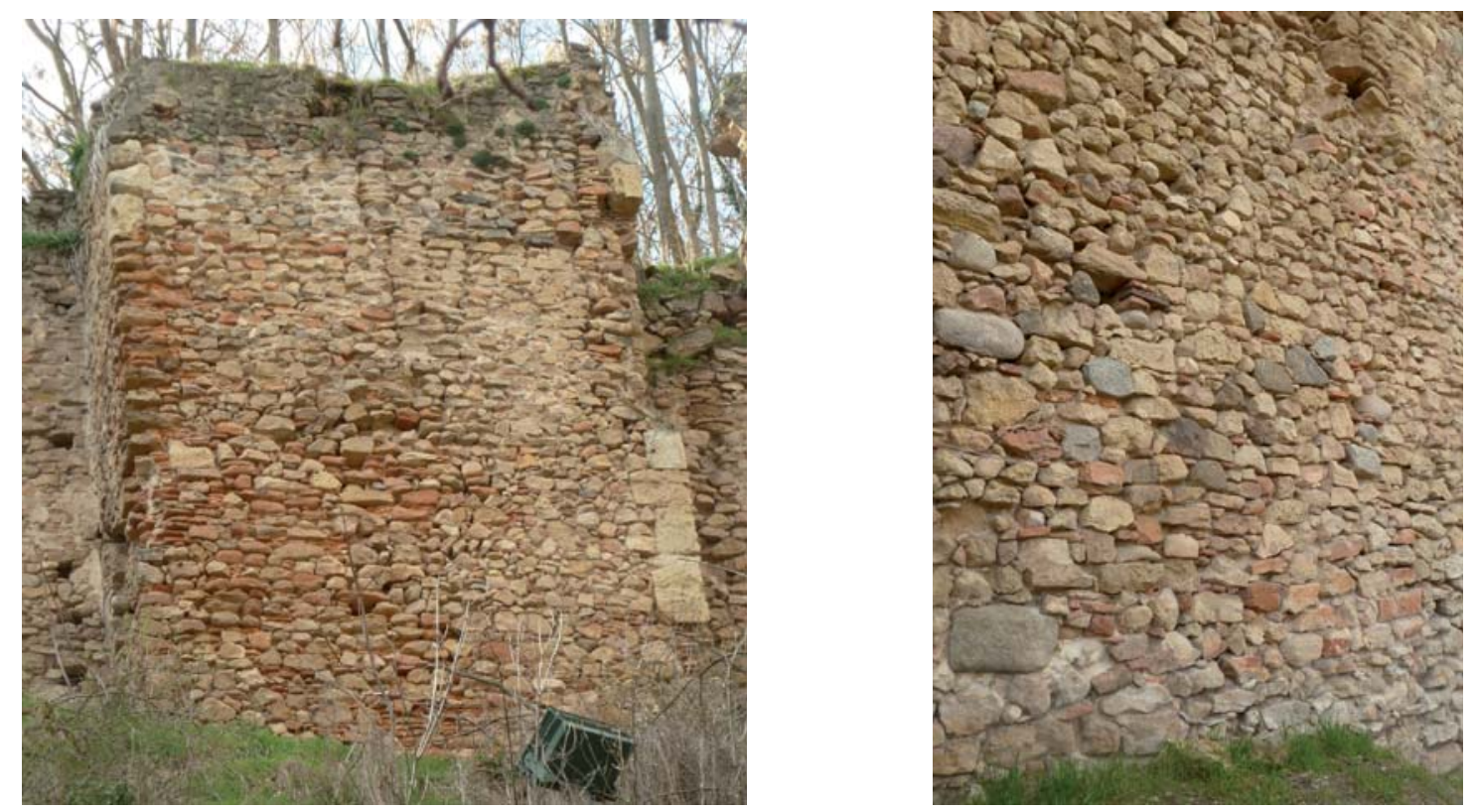

Figura 3. 71: Torre T51'. Nótese la abundancia de ladrillo entremezclado que aparece a modo de calzos y ripios en la mitad izquierda de la torre. Se aprecia una línea vertical de discontinuidad en la fábrica bastante nítida.

Figura 3. 72: Lienzo L51'-52. Fábrica de mampostería desconcertada característica. Aparecen piezas de granito hasta alturas medias y altas del lienzo mezcladas con las piedras carbonatadas. Se observan algunos agujales, pero sin una continuidad que permita relacionarlos o establecer una modulación constructiva.

La T52 no se ve el apoyo sobre la roca, y evidencia la discontinuidad de un derrumbe y posterior reconstrucción. En uno de sus lados cortos se observa una sillería de piedra carbonatada en zócalo, mientras en el otro lado corto, la mampostería desconcertada arranca desde el terreno. Presenta algunos refuerzos de sillares y ladrillos en las esquinas.

El lienzo L52-52' está incompleto, parcialmente desaparecido. Presenta mampostería desconcertada muy descarnada. Buena parte de lo actualmente visible es el relleno interior, al haberse perdido la hoja exterior.

Desde aquí encontramos unos tramos, el correspondiente a las torres T53 y T54, así como a los lienzos L52'-53, L53-54 y L54-55 que han desaparecido y sus restos se encuentran

${ }^{62}$ En el año 1864, tal y como podemos ver en la foto de Marcos y Saavedra, este edificio presenta tres alturas, otra adicional a las que ahora vemos y en la parte más próxima a la T51', un cuerpo volado y jabalconado sobre el lienzo de la muralla. (González, 1997: 105) 
inaccesibles. De este último lienzo se conserva un pequeño bulto amorfo, prácticamente oculto por la vegetación, visible desde la T55.

Los lienzos desde T55 hasta T57 y las propias torres T55 y T56 están todos completamente reconstruidas. El aparejo es la consabida mampostería desconcertada en la que se entremezcla el material disponible, distintos tipos de piedras, se aprecia alguna spolia y presentan un tratamiento muy homogéneo, resultado de una intervención muy reciente, datada en 1972, que aún no ha sido reparada por encima. (AMS 4810-3, III: 47) En ambas torres, aparentemente se conservan algunas hiladas de sillería en sus partes bajas que debieron subsistir al derrumbe.

La T57 es la que alberga la puerta de Santiago que se abre a la carretera que une Segovia con Medina del Campo, el antiguo Camino Real por el que llevaba a los puertos del Norte.
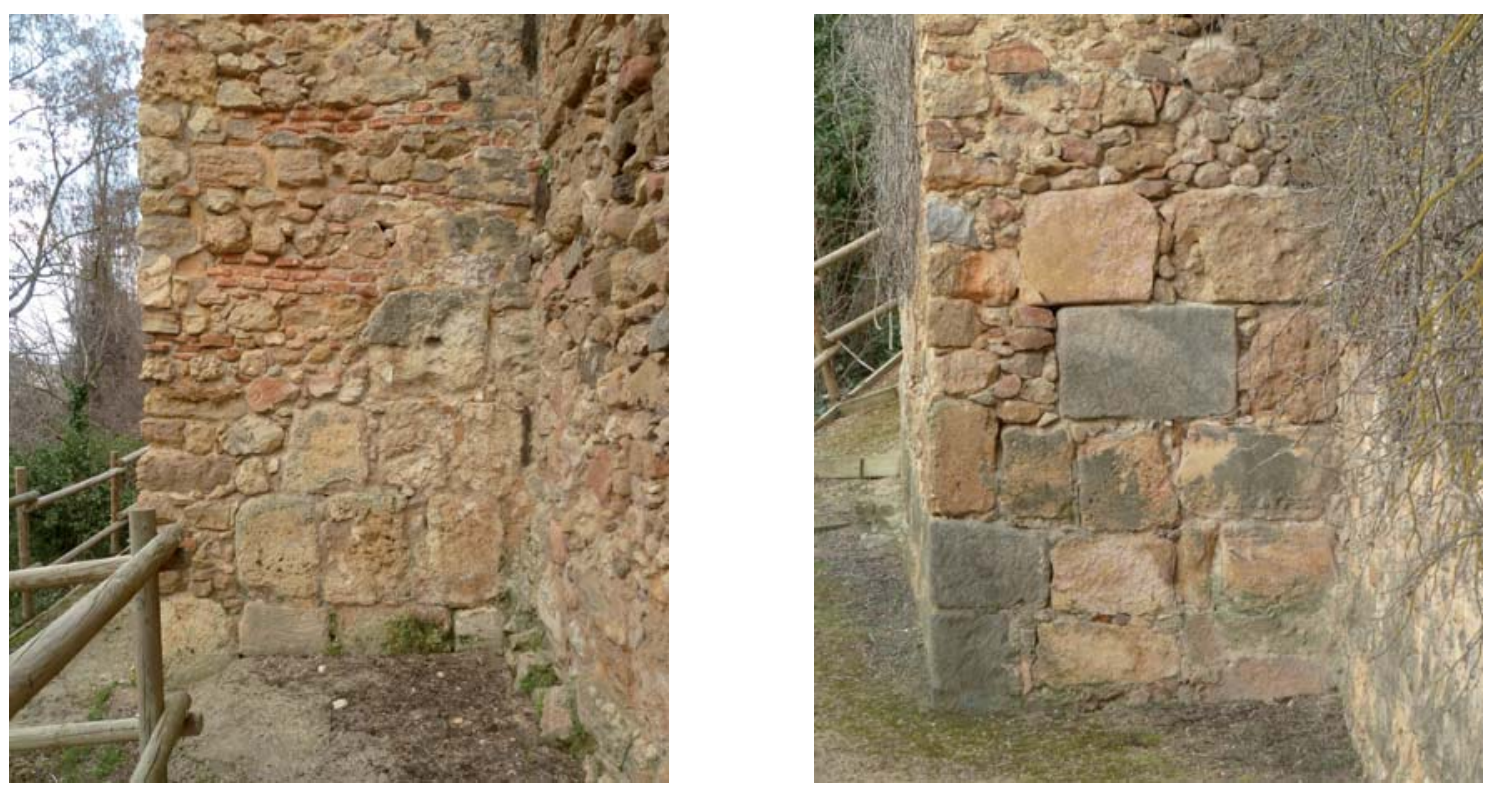

Figura 3. 73: Torre T55. Se aprecian restos de hasta 4 hiladas de sillería de piedra carbonatada, la inferior medio enterrada, que parecen ser vestigios de la torre primigenia que han subsistido al derrumbe. Se aprecia la línea de rotura en plano inclinado, marcando el ángulo de deslizamiento. El resto de la torre procede de una reconstrucción del año 1972.

Figura 3. 74: Torre T56. Se aprecian tres hiladas de sillería que podrían ser originales, sobre las que se han recolocado en la reconstrucción algunos sillares reaprovechados, ya sin lógica constructiva, ya que no se reservan para la esquina y peor aparejados.

La construcción de la Puerta se considera posterior al resto de la muralla, datándose en el siglo XIII; inicialmente llamada de Rodrigo Ordóñez, pasó posteriormente a denominarse Puerta de Santiago, tomando el nombre de una parroquia de extramuros situada muy cerca de la misma y derribada en 1836. (Ruiz Hernando: 1982, I: 31)

Respecto a la muralla, se sitúa realizando un quiebro, en el trazado de los lienzos. Actualmente tiene dos plantas cerradas y cubierta a cuatro aguas. En el piso superior, inmediatamente bajo el alero, la secuencia de pequeñas ventana muy próximas, sugiere la configuración de un antiguo almenado, que desapareció al hacer habitable la terraza superior. 

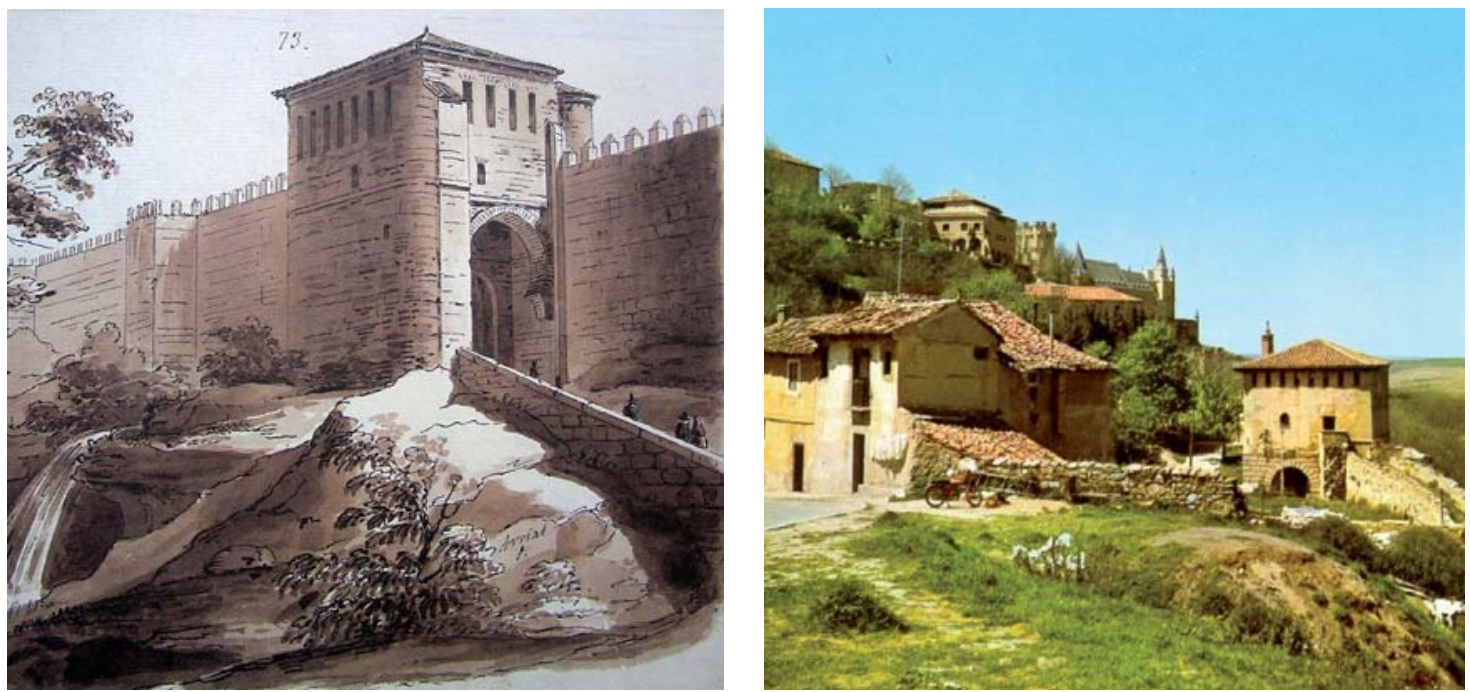

Figura 3. 75: La Puerta de Santiago con la cascada que formaba el arroyo Vallejo. Dibujo de José María Avrial (1843) publicado en Avrial y Flores (1979) lámina 73.

Figura 3. 76: Interior de la puerta y adarve de la muralla hacia 1960. Fotografía cedida por gentileza de Rafael Cantalejo San Frutos.
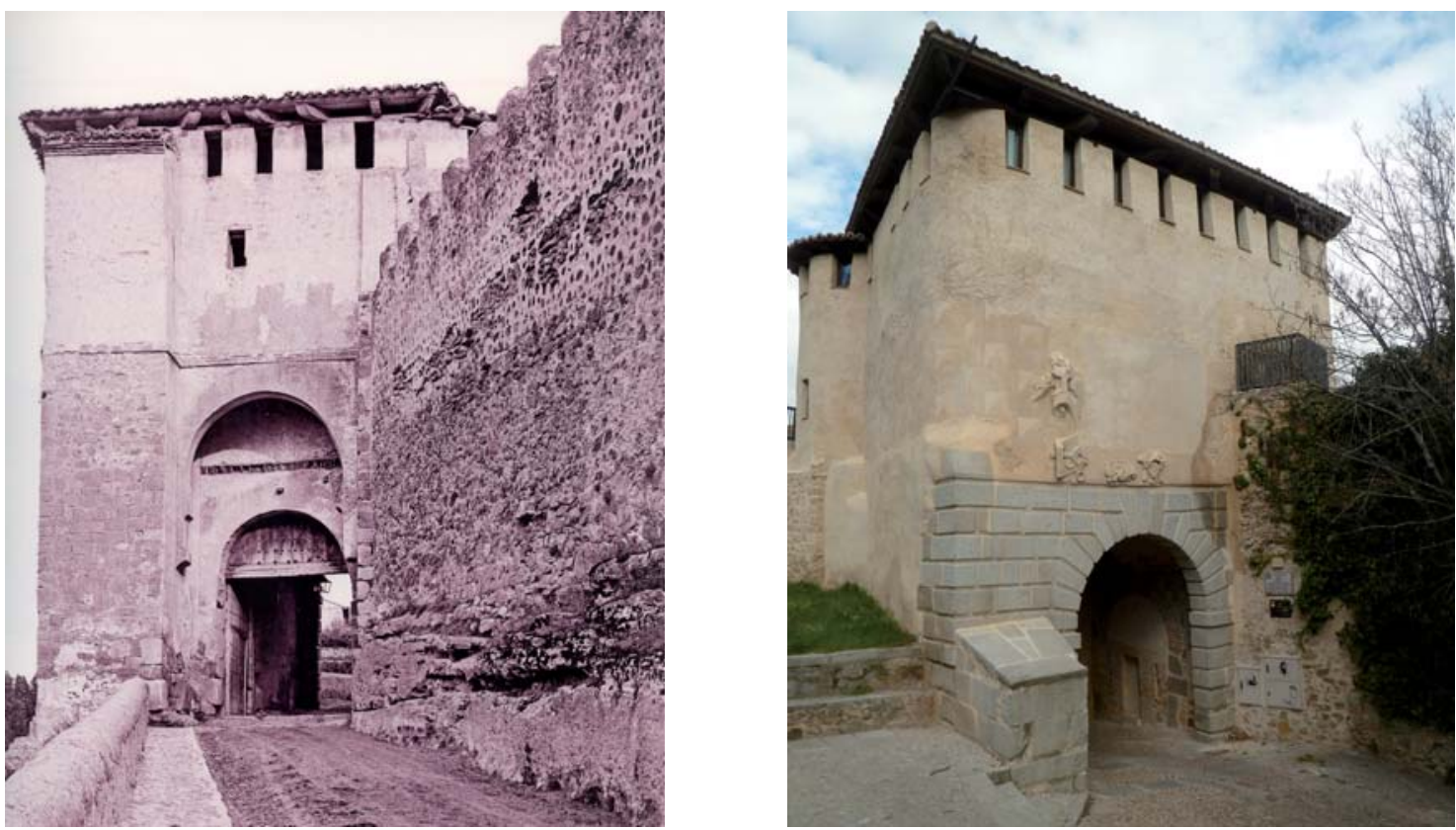

Figura 3. 77: Foto de Laurent (1868-1872). Vista en la que aún se aprecia en el revoco los merlones sobre el arco de herradura que señalan la altura original de la puerta antes de su recrecido (VVAA, 2006: 73).

Figura 3. 78: Derecha: Vista del interior de la puerta. Sillería almohadillada de granito enmarcando el arco y el resto de la torre revocada. La secuencia de ventanas bajo el alero, vuelve a remitir a la reconversión del almenado, cuando el recrecido de la torre hace habitable el piso superior al implantar la cubierta. Restos de un escudo muy deteriorado

En sus muros exteriores de primera planta, parcialmente oculto por revocos posteriores, todavía se intuye el antiguo almenado del adarve original, tabicado en el recrecido posterior de la primera planta, así como la presencia de saeteras, imagen mucho más perceptible en las fotografías históricas, de finales del siglo XIX que tras la reciente restauración. 
En origen era una simple puerta situada en una torre de la muralla. Este cuerpo original, parece que disponía la misma altura de almenado que los lienzos adyacentes. En la primera mitad del siglo XVII se le recrece una planta y se le adhiere un volumen circular donde se situaba la escalera de acceso al cuerpo de guardia. Posteriormente, aun en el siglo XVII se le incorporaron una techumbre ${ }^{63}(\mathrm{PH}:$ P0165). Así la vemos en el grabado de Louis Meunier de 1666 (Santamaría López, 2004: 68-69), que representa la puerta con la segunda altura elevándose por encima de los lienzos de la muralla y con una cubierta a cuatro aguas.

La fachada exterior presenta un arco de herradura realizado en ladrillo, volado sobre ménsulas de granito, tras el cual se sitúa la buhedera. El cuerpo interior abovedado está delimitado por dos arcos de medio punto. En el interior del paso se situaban dos puertas en sus extremos, de las que aún se conservan las quicialeras o ranguas y los tejuelos. Cada puerta abría en una dirección. En su parte intermedia, más cerca de la puerta exterior que de la interior, se situaba el rastrillo. Al lado izquierdo según se entra, una vez superado el rastrillo, se ha descubierto recientemente un arco de ladrillo apoyado sobre jambas de sillería que cobija una puerta protegida lateralmente por dos saeteras. Esta puerta es el antiguo acceso al cuerpo de guardia, cuyas jambas, recercados y dintel se realiza todo ello en ladrillo. Encima de la puerta existe una tercera saetera en mitad de un lienzo revocado, desde el dintel de la puerta hasta la cara intradós del arco que cobija al conjunto.
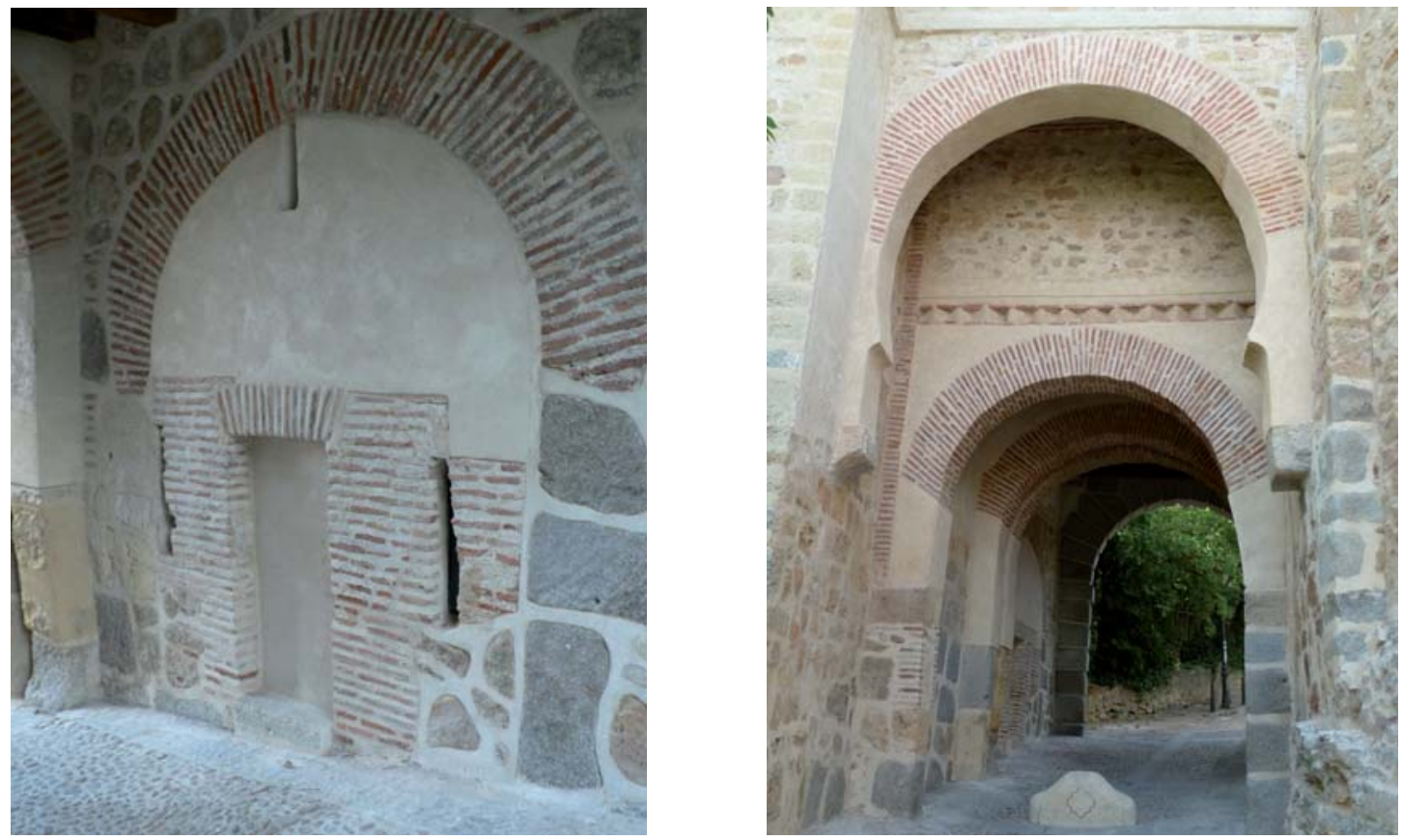

Figura 3. 79: Puerta de Santiago. En el interior de la puerta se ha descubierto un arco que cobija acceso al cuerpo de guardia, protegido por tres saeteras.

Figura 3. 80: Puerta de Santiago. Secuencia de arcos en los que se ubican los diferentes elementos defensivos de la puerta. Tras el primero, la buhedera, en el segundo, la primera puerta, Entre los dos arcos interiores se situaba el rastrillo. Por último en el arco posterior, la segunda puerta.

\footnotetext{
${ }^{63}$ Desde entonces ha experimentado gran cantidad de intervenciones debido al estado de ruina que tuvo en distintas épocas; en 1668 se reteja la cubrición por primera vez, en 1750 se informa del estado ruinosos de la cubrición del tejado debiéndose demoler por el excesivo peso que suponía, en 1872 se entrega la Puerta al Ayuntamiento (hasta ahora propiedad del ramo de la guerra) que en 1887 lo remodela como refugio para pobres hasta 1929. Se salvó, con bastante fortuna, de una demolición. (PH: P0165).
} 
La fachada intramuros muestra un zócalo de sillares almohadillados de los que arranca un arco de medio punto, todo ello en granito, fruto de la reforma barroca llevada a cabo a finales del siglo XVII. Sobre ello se elevan el resto de la planta baja y la primera completamente revocadas, conservándose restos de una decoración fingida de puntas de diamante y un escudo.

Mariano Sáenz en las primeras décadas del siglo XX, nos aclaraba Estos arcos se cerraban de noche con fuertes planchas de hierro que subian por una escotadura, y por puertas gruesas de madera, $y$ defendida por saeteras y matacanes (Chaves Martín, 2003: 13).

Desde el punto de vista poliorcético, es muy similar a la puerta de San Andrés. Es una puerta de acceso recto flanqueada por una torre. Por la parte exterior, por encima del paso voltea un arco de herradura apoyado sobre unas piezas en ménsula de granito. Tras él se sitúa un primer cuerpo abovedado en el que se aloja una buhedera. Al igual que en San Andrés, en el interior del paso se situaban dos puertas en sus extremos, de las que aún se conservan las quicialeras. Cada puerta abría en una dirección. Sin embargo en este caso observamos entre ambas puertas, los dos arcos entre los que descendía el rastrillo, única puerta de la muralla donde encontramos este elemento.

\subsection{9.- Z Zona 9. Pozo de NIEVE}

Esta zona se extiende desde la puerta de Santiago hasta la verja de los jardines del Alcázar. Tiene una longitud de 196 metros y en ella encontramos 4 torres, un foso celtíbero cegado por la muralla en L58-59 y un posible antiguo camino o postigo tapiado en el lienzo L5960. Las torres son de forma rectangular, excepto la T59, reconstruida a finales del XX, pero que dispone de zócalo rectangular y la T60, en la que también se han descubierto restos de una forma rectangular bajo su actual trazado. Sus dimensiones fluctúan desde los 5,10 a los 5,50 metros de ancho y el resalto alrededor de los 2 metros. Los zócalos rectangulares de las dos torres circulares, incumplen estas dimensiones, al ser mayores. Los lienzos oscilan entre 28 y 30 metros de largo, excepto los dos de los extremos, que miden entre 21 y 22.

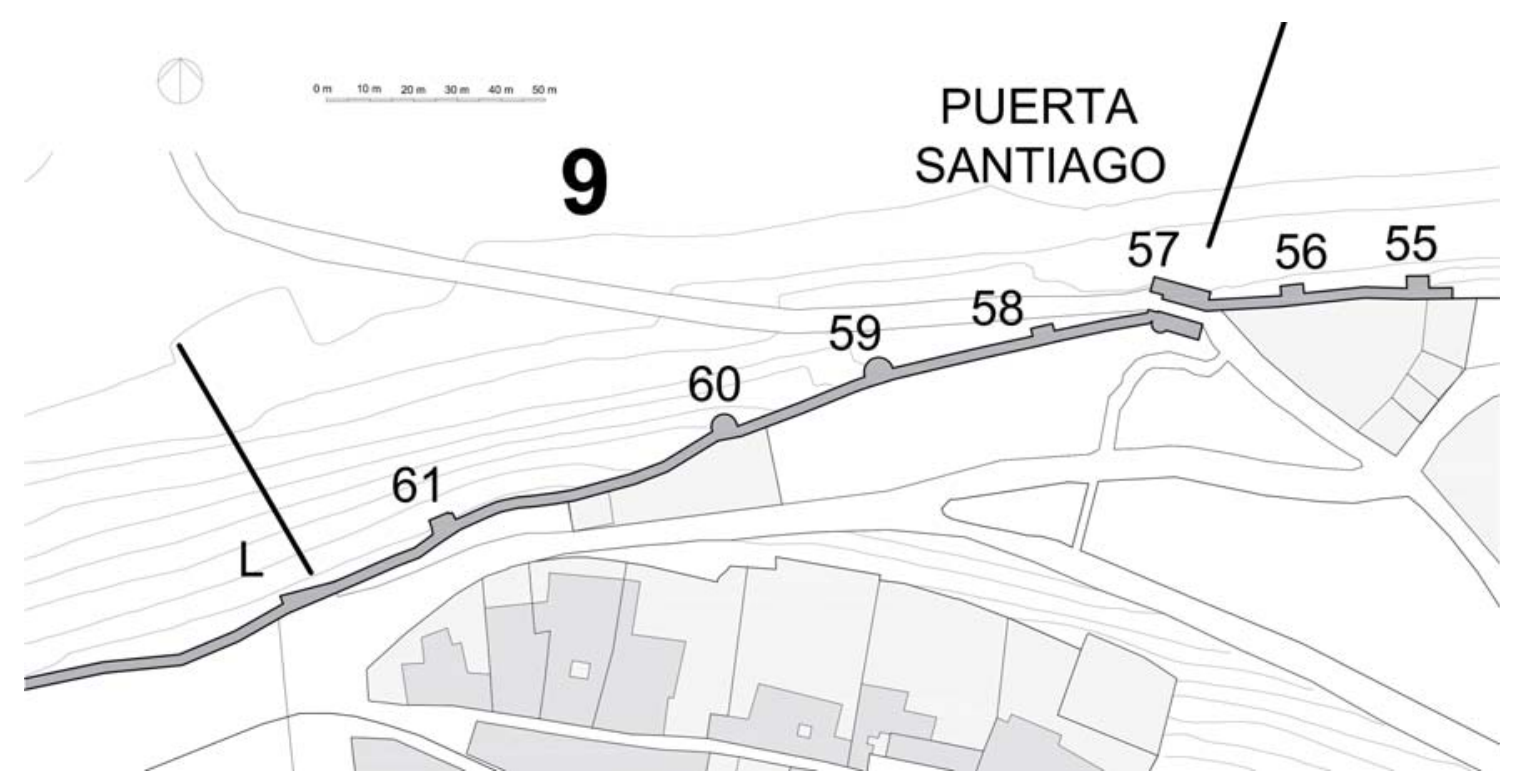

Figura 3. 81: Plano de la zona 9, que comprende desde la puerta de Santiago hasta la verja del Alcázar. 
Todos los lienzos y torres están reconstruidos casi en su totalidad o se encuentran arruinados. Presentan la característica fábrica de mampostería desconcertada, en la que se mezclan distintos tipos de piedras, con abundancia de ladrillos e incluso sillares reutilizados en las partes altas de los lienzos. Esta fábrica arranca desde el apoyo en la roca hasta los petos que no suelen disponer almenado. En algunos de los lienzos se observan varios agujales o mechinales, pero no muestran un orden claro y en otros puntos vemos algunos sillares de granito en los zócalos, todo ello de modo muy parcial o fragmentado.

El L57-58 es el lienzo adyacente a la puerta de Santiago de longitud en torno a los 21,50 metros, por lo que es más corto de lo habitual. Observamos la roca tallada verticalmente en la base, a todo lo largo de su extensión, posiblemente para abrir el camino a la puerta.

Sobre este basamento de roca apoya inmediatamente una fábrica de mampostería desconcertada que resuelve todo el paño hasta el adarve almenado. Vemos piezas de escaso tamaño, mezclando distintos materiales, incluso granito azulado y ladrillo de la fábrica Carretero, con abundancia de ladrillo mezclado con mampuestos, especialmente en las partes altas, reparando pequeñas oquedades. Infinidad de parcheados de mortero y rejuntados dificultan la lectura constructiva del lienzo, pero también muestran a las claras que está muy retocado y reconstruido, posiblemente en su totalidad, en época muy reciente.

La T58 presenta un zócalo con dos hiladas de sillería de granito de tamaño medio grande y numerosas spolia, entre las que destacan varias lápidas romanas. Sobre ello se disponen 5 hiladas de sillería sedimentaria de tamaño grande, también de material reutilizado seguidas de otras 6 hiladas de sillería del mismo tipo de piedra, pero de tamaño mediano. Sin embargo a pesar de la presencia de tanta sillería, vemos que no es un aparejo continuo. Todo ello está enripiado con demasiado ladrillo. Se detectan discontinuidades en las hiladas, en las esquinas de la torres. En el lateral izquierdo vemos una clara discontinuidad en el enjarje con el lienzo, donde existía una fábrica de sillería de piezas de mayor dimensión que la que resuelve la esquina y continúa en cara frontal, no encajando las hiladas. Por otra parte, en el encuentro con el lienzo en el lateral derecho, se aprecia que la sillería se adosa a la mampostería del lienzo y el remate de varias hiladas de sillería se resuelve con mampuestos. Incluso se reconoce un fragmento de una pieza tallada, como una flor, muy deteriorada pero que por sus características podría remitirnos a los siglos XII o XIII incluso posteriores. Los últimos metros de la torre se elevan en mampostería desconcertada con las esquinas en ladrillo y algún sillar, rematando el conjunto en un peto sin merlones, salvo unos resaltes en las esquinas, restos procedentes de una garita de vigilancia que existió sobre el adarve (PH: P0170).

Aparentemente da la impresión de haberse derruido casi totalmente, y se ha reconstruido sobre los restos de una torre preexistente, tal y como vemos en el zócalo del lado izquierdo y en la abundancia de enripiado en la sillería empleando el mismo tipo de ladrillo que el que se utiliza para las esquinas del recrecido en mampostería.

El lienzo L58-59 presenta varios recrecidos, diferenciándose claramente tres grandes fases constructivas con dos discontinuidades entre ellas. La primera se delimita con un escalón horizontal recto que asciende hacia el adarve junto a la torre T58 ${ }^{64}$. Por encima se reconoce un nivel de almenado tabicado, justo por debajo del actual. El lienzo está, por lo tanto,

\footnotetext{
${ }^{64}$ Este corte ya se aprecia en la foto de Levy de 1888, (González, 1997: 58) por lo que el desplome y reconstrucción de este primer escalón es anterior al siglo XX. Sin embargo en dicha imagen, el lienzo no posee almenado, por lo que esta parte se recrece después de la fecha indicada.
} 
derruido y reconstruido. En la documentación histórica hemos identificado dos derrumbes comprobados, en 1882 y 1987. Podrían coincidir con los dos recrecidos que observamos sobre el lienzo original, que indudablemente también está muy reparado. Lo apreciamos en la mezcla de piedra, con abundancia de sillares reutilizados, que aportan cierta apariencia de regularidad al aparejo, pero que nos evidencian que se trata de una reconstrucción de época moderna por la abundancia de granito gris azulado, procedente de las canteras de San Lorenzo-Sotillo (PH: P0178) en las partes altas de este primer tramo de muralla. Ambos recrecidos son exclusivamente de mampostería desconcertada con piezas muy menudas. Tenemos dos valiosos documentos gráficos en que se aprecia el lienzo derruido, falta la parte alta del mismo, en la foto de Loty de mediados de la década de 1930 (VVAA, 2006: 115) y seguía en el mismo estado el año 1953 (Ceballos Escalera, 1953: 147).
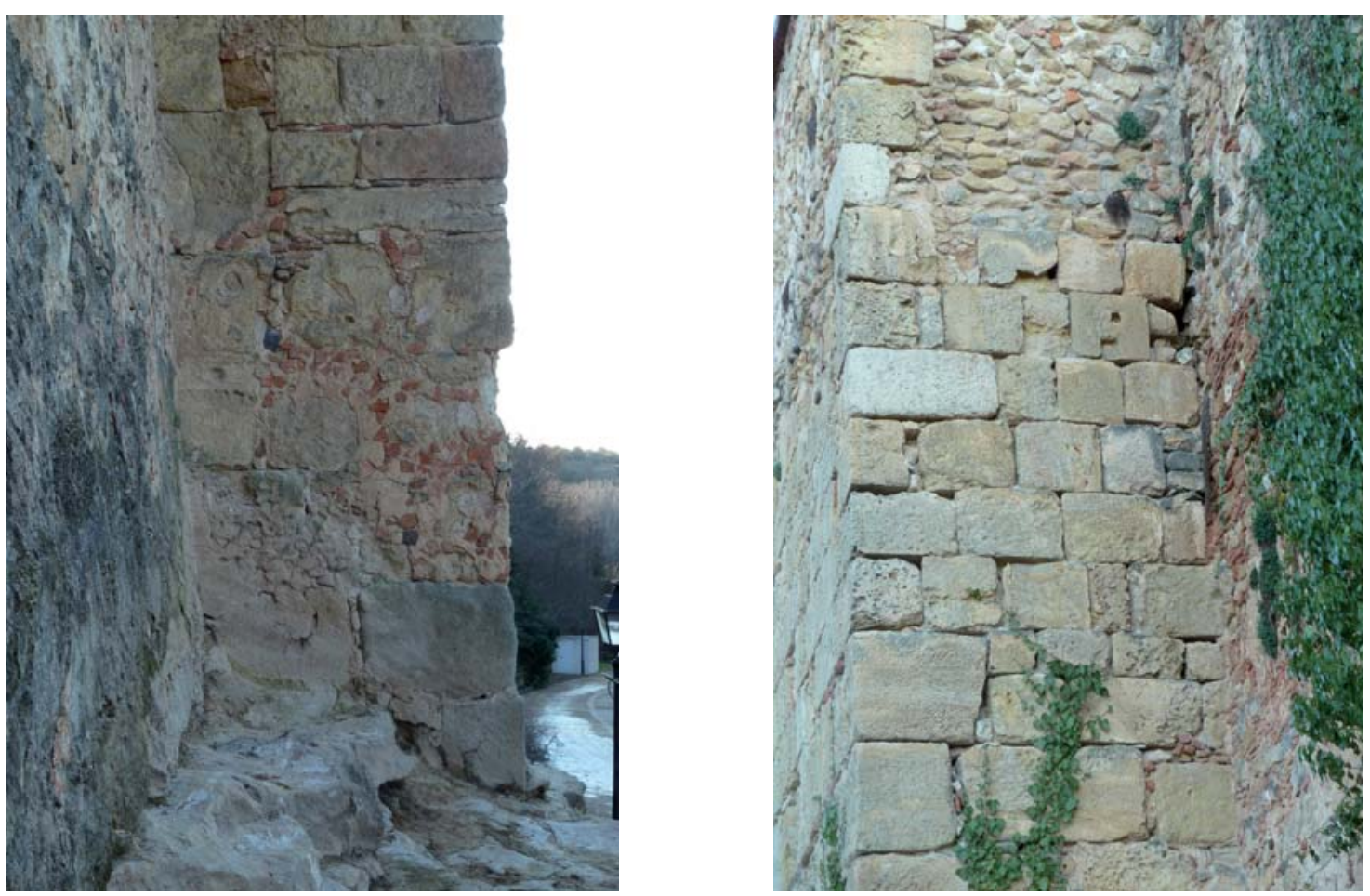

Figura 3. 82: Torre T58. Se aprecia la discontinuidad de los sillares más grandes junto al lienzo y los más pequeños, que completan la torre dando la vuelta a la esquina. Las hiladas no coinciden.

Figura 3. 83: Torre T58. La sillería se adosa al lienzo que en algunos tramos está ejecutado en ladrillo, empleándose mampuestos en lugar de sillares para completar la hilada. Este lateral es una reconstrucción.

Esta fábrica de mampostería muestra numerosos agujales en la primera fase constructiva aunque no presentan un orden claro. En los dos recrecidos posteriores, no vemos ninguno. El zócalo conserva dos hiladas de sillares de granito de grandes dimensiones colocados a soga, pero sin voluntad de aparejar como sillería.

Hay que reseñar, si bien no tiene relación con la construcción de la muralla, la existencia de un corte en la roca de trazado aproximadamente perpendicular al de ésta. Se ha identificado como un foso de 1,80 $\mathrm{m}$ de ancho asociado a cronología celtibera, (Martínez Caballero, 2010: 143-181) y que la muralla intercepta y tabica para lo que se emplean sillares romanos. 


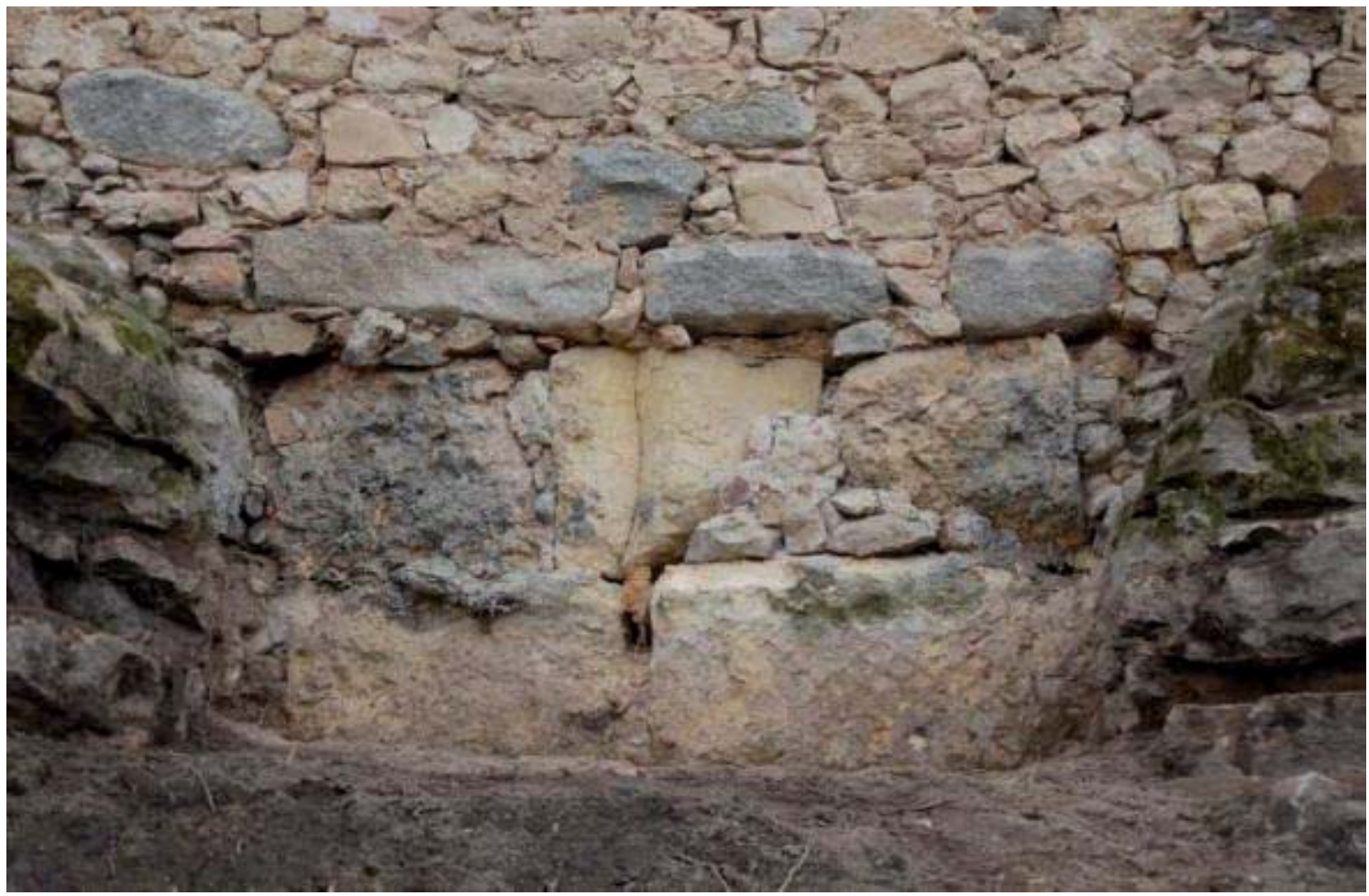

Figura 3. 84: Lienzo L58-59. Tapiado del corte identificado como foso celtibero mediante el empleo de grandes sillares de piedra sedimentaria procedentes de algún edificio de origen romano. En el sillar de la esquina inferior derecha, a pesar del deterioro, aún se aprecian restos de un talado a modo de cesteado.
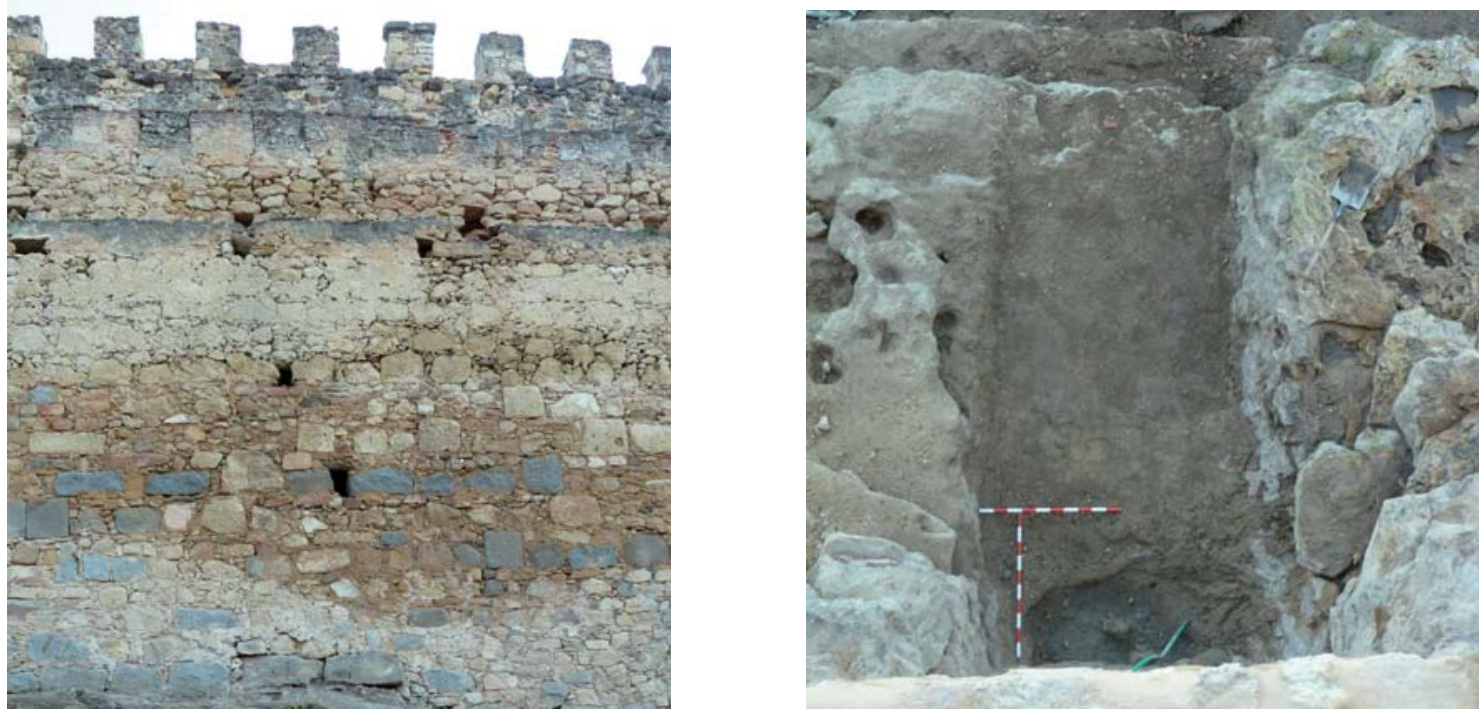

Figura 3. 85: Lienzo L58-59: Lienzo en que se observan los 3 recrecidos y los dos niveles de almenado. La abundancia de sillares entremezclados con la mampostería demuestra que se trata de una reconstrucción aprovechando el material disponible.

Figura 3. 86: Lienzo L58-59. Corte tallado en la roca, visto desde el adarve, que se ha identificado como un foso celtíbero. 


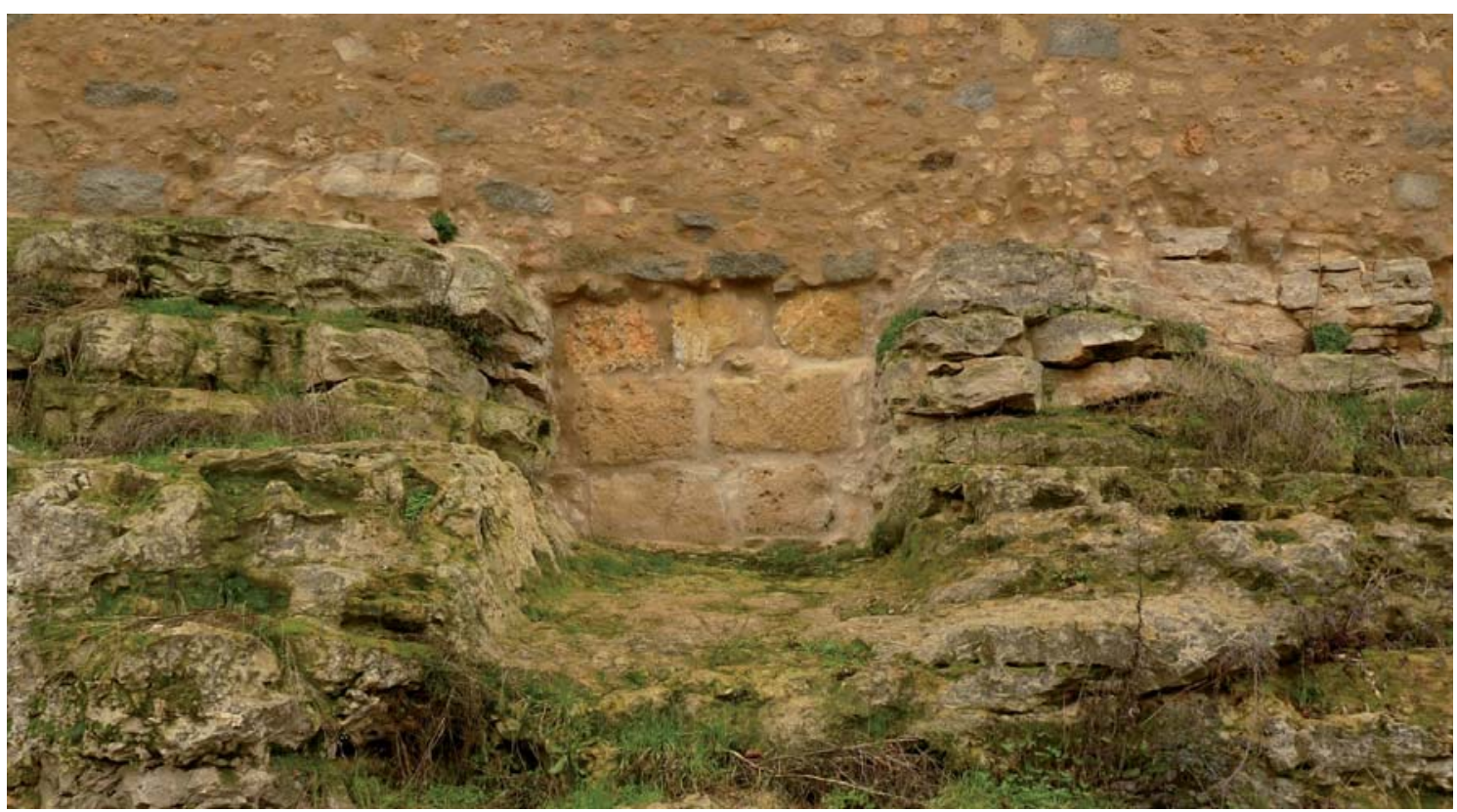

Figura 3. 87: Lienzo L58-59. Corte tallado en la roca, que se ha identificado como un foso celtíbero, visto de frente. El tapiado se efectúa con sillares de grandes dimensiones, mientras el resto del lienzo se construye con mampostería de tamaño pequeño.

La torre T59 está completamente reconstruida en el año 2000, ya que se derrumbó en 1998 (AMS 5132-5). ${ }^{65}$ Tiene un zócalo rectangular, sobre el que se levanta una torre de planta semicircular. Observamos la típica mampostería desconcertada en el que se ven algunas hiladas más ordenadas por el empleo de piezas regulares. Las dimensiones de la torre son excepcionalmente grandes, 6,90 x 4,00 metros. La forma con que se ha reconstruido recupera la preexistente (Avrial y Flores, 1953: lamina 51).

El lienzo L59-60 esta reconstruido en su mayor parte. Se evidencia un corte vertical oblicuo en la fábrica con desplome de la zona adyacente a la torre T60, mientras el resto está aplomado. Todo realizado en mampostería desconcertada, desde la roca hasta el peto, que no tiene almenado, aunque existen algunos sillares de granito en el zócalo.

Hay que destacar, junto a la torre T60, la existencia de una rampa escalonada, posiblemente un antiguo camino tallado en la roca, que se encuentra interceptado por la construcción de la muralla. Sin embargo, la alineación de sillares de granito que se disponen a modo de zócalo diferenciado, se interrumpen, como si inicialmente se hubiese previsto respetar ese acceso, un posible postigo. Este paso no ha podido adscribirse a ninguna cronología dado que no se ha localizado material arqueológico asociado en relación directa, aunque se plantea incluso remontarlo a época celtibera o romana (STCSG: OT-189/2013-11: 95). El paso tiene una anchura máxima de 1,40 metros y consta de cuatro peldaños (STCSG: OT189/2013-11: 45).

La torre T60 tiene forma semicircular, pero también se ha descubierto que apoya sobre un zócalo de base rectangular, cuya cara parece llevar una alineación ligeramente distinta a la

${ }^{65}$ En el informe arqueológico, se hace constar que aparecen rellenos del Hierro II desde la superficie. El hecho de que en un depósito antrópico los restos más antiguos sean los superficiales puede implicar que los más modernos sean los más profundos. Esto puede haberse producido porque son echadizos transportados desde algún otro punto, posiblemente no muy lejano (Harris, 1990: 71). 
de la torre actual. El zócalo actual presenta gran abundancia de piezas de granito regulares que ascienden hasta casi la mitad de la altura de la torre, pero muy mal aparejadas. Aún así, esto le confiere al aparejo regularidad y orden a las hiladas. En el informe arqueológico se postula que la torre se construyó con trazado semicircular desde el arranque, aunque para mejor asiento se colocó por delante los sillares de la base rectangular (STCSG: OT189/2013-11: 47) pero las evidencias de la mezcla de materiales y el empleo de granito hasta una altura considerable nos reafirma en la creencia de que la torre actual es fruto de una reconstrucción, sobre una torre previa.

Las dimensiones de esta preexistencia son 5,35 x 3,50, lo que supone mucho resalto para las medidas habituales. Está compuesto por dos hiladas de sillares de granito que presentan escalonamiento. Podría tratarse de una zarpa o que la segunda hilada ha sido desplazada hacia el interior, al construir la torre de planta semicircular, ya que sólo queda un único sillar de la segunda hilada que sigue el trazado rectangular, estando los demás dispuestos ya conforme al trazado semicircular.
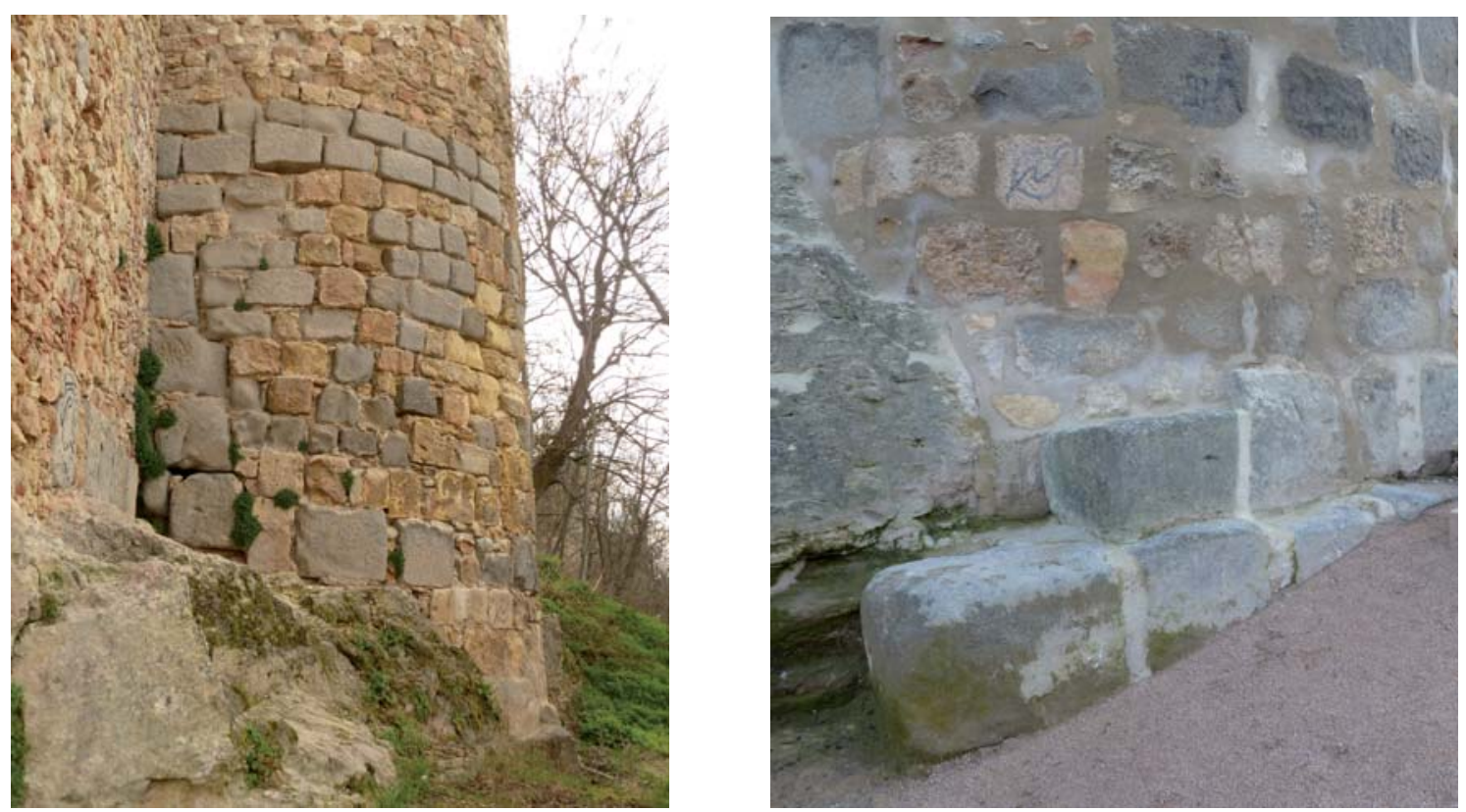

Figura 3. 88: Torre T60. El número de sillares empleados en la construcción de esta torre parecen confirmar que los constructores medievales expoliaron las ruinas celtiberas y romanas adyacentes (en el lienzo siguiente L60-61). Obsérvese el material mezclado y la abundancia de granito hasta una altura considerable. Por otra parte, la existencia de cuatro sillares de mayores dimensiones dispuestos de manera vertical en el encuentro con el lienzo, uno de ellos presenta engatillado para resolver el aparejo de los nuevos sillares más pequeños.

Figura 3. 89: Torre T60. Imagen del zócalo descubierto en la base de la torre, de traza rectangular.

Existen cuatro sillares de granito de grandes dimensiones, mayores que todos los demás con que se construye esta torre, que se conservan en el encuentro con el lienzo de la muralla. Su discontinuidad con el resto del aparejo parecen indicar que fuese una preexistencia de una torre previa. No hay relación directa entre estos sillares y los de trazado rectangular dispuestos en el zócalo, por lo que no podemos relacionarlos cronológicamente con garantías. 
En el lienzo L60-61 distinguimos tres tramos. El más cercano a la torre T60 es una mampostería desconcertada en la que se aprecian algunos agujales, pero sin ningún orden. Esta apoya directamente en la roca, arranque que ha sido excavado recientemente constatando que se hallaba inalterado, al estar enterrado desde el momento de la construcción en la Edad Media. Así los agujales empiezan por encima de la cota que estaba enterrada.

La muralla efectúa un ligero cambio de trazado, en el punto donde consideramos que empieza el segundo tramo, coincidiendo con un desnivel significativo de la roca. En esta parte encontramos una mampostería desconcertada con piezas de granito entremezclado de manera bastante uniforme hasta en las partes altas, que apoya sobre unos grandes sillares de roca carbonatada, sin aparejar, simplemente como zócalo diferenciado que lo separa del terreno. Se encuentra en muy mal estado de conservación y muestra varias reparaciones en ladrillo. Completamente inaccesible solo puede observarse desde lejos.

El tercer tramo, que comienza coincidiendo con la tapia de la parcela adosada a la muralla, se halla completamente derruido y en la última intervención se han repuesto por anastilosis dos hiladas de sillares que se encontraban derrumbadas (PH: P0205). Ya aparece hundido en la litografía de Guesdon de 1854 (Santamaría López, 2004: 83). ${ }^{66}$ Presenta una reconstrucción provisional para contener tierra, pero no con el espesor de la muralla.

Un dato singular a tener en consideración es que en el primer tramo de esta zona para construir la muralla se tuvo que excavar en la tierra para llegar a la roca y se ha encontrado una pequeña zanja cajeando ésta, preparando la base de apoyo de la muralla (STCSG: OT189/2013-11: 56) Es el primer punto donde la roca esta tallada a lo largo del trazado de la muralla para crear una zanja de nivelación. No lo hemos visto en otro sitio.

Otro hallazgo reseñable en este tramo de muralla es el descubrimiento de un trozo de muralla adscrito a cronología celtíbera y que se reutiliza como cimiento posteriormente por un edificio romano. Ambos yacimientos hayan sido posiblemente expoliados por los constructores medievales al levantar la muralla (STCSG: OT-189/2013-11). En la parte central del lienzo abundan los sillares de granito romanos reutilizados en el zócalo de la muralla, posiblemente provenientes de este edificio.

Delante del lienzo se han encontrado una cantera en la que se conservan algunos sillares a medio extraer, que en el informe arqueológico se considera que pudo estar en funcionamiento para la construcción del barrio de las Canonjías, estando ya en desuso en el siglo XVI (OT- 189/2013-11: 76). Seria coetánea a la construcción de la muralla de Repoblación. Al final de este tramo debería encontrarse la T61, según el Plan Director, pero en las obras recientes no se han encontrado restos de su existencia, ni su ubicación (PH: P0205).

Del lienzo L61-61' no quedan más que unos escasos restos, sillares graníticos y sedimentarios constituyendo un zócalo, muy desordenados, sin organizar en hiladas, aparentemente recolocados entre los que destaca una lápida romana. Junto a la posición donde se encontraría la T61 existe una escalera tallada en la roca, no datada (OT189/2013-11), que ha sido parcialmente mutilada por la actual escalera.

${ }^{66}$ Según el informe arqueológico, el derrumbe podría datarse en el siglo XIX o XX (STCSG: OT-189/201311: 80). 
La torre T61' esta arruinada y aparece consignada como semicircular en el Plan Director. Originariamente tuvo planta de forma rectangular, tal y como se ha descubierto con el desbroce efectuado durante las obras. No se aprecia su aparejo exterior. Solo se conservan dos hiladas de zócalo, realizadas en sillería de piedra sedimentaria y del resto de la torre sólo se ve una pequeña parte de la mampostería del relleno interior.
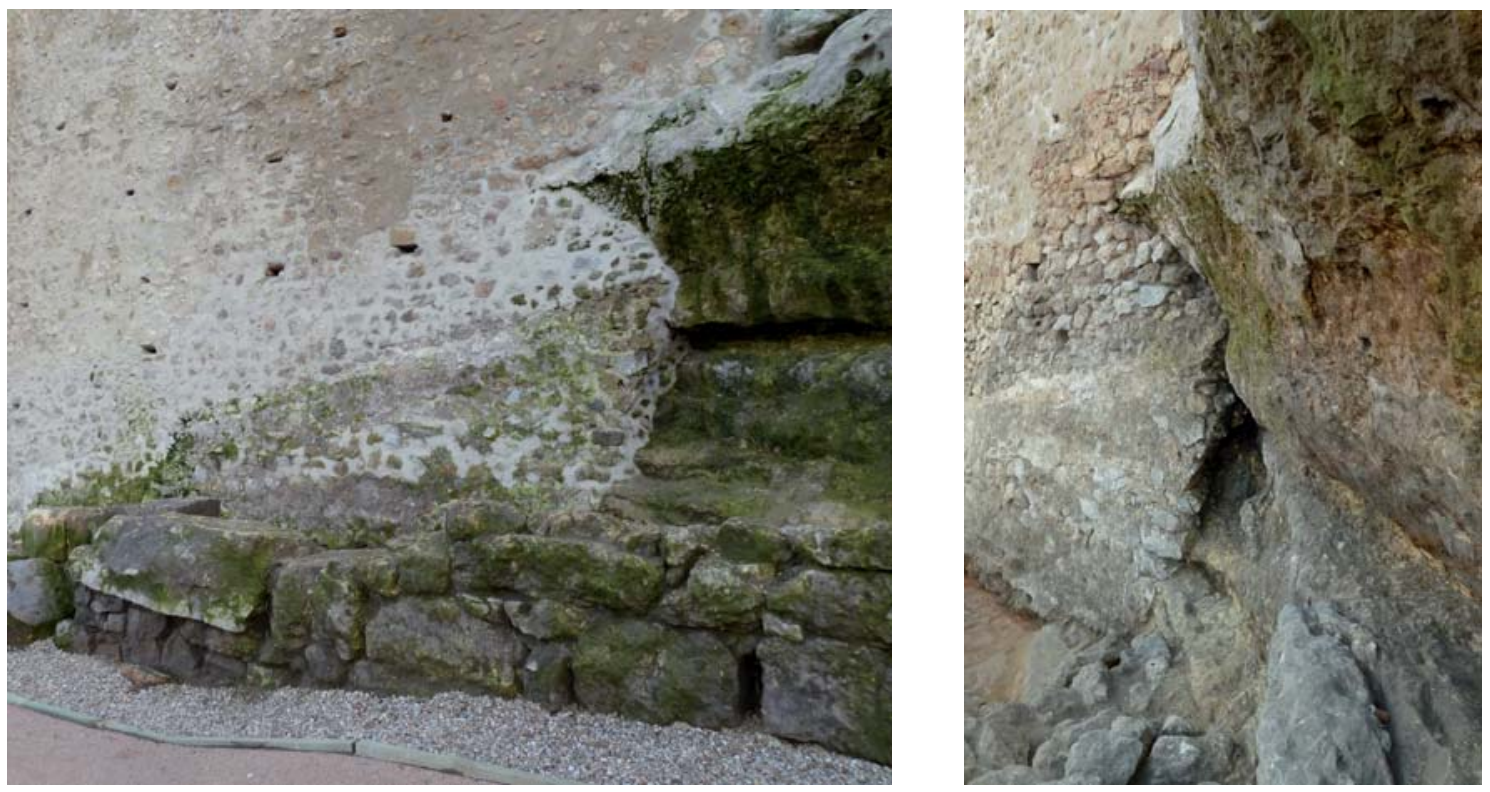

Figura 3. 90: Lienzo L60-61. Muralla celtibera en primer plano. Detrás vemos la muralla medieval, en la que se aprecia la parte que estaba enterrada y como los agujales aparecen a partir de ese nivel que quedó enterrado.

Figura 3. 91: Lienzo L60-61. Detalle en que se aprecia que la muralla está trasdosando la roca natural.

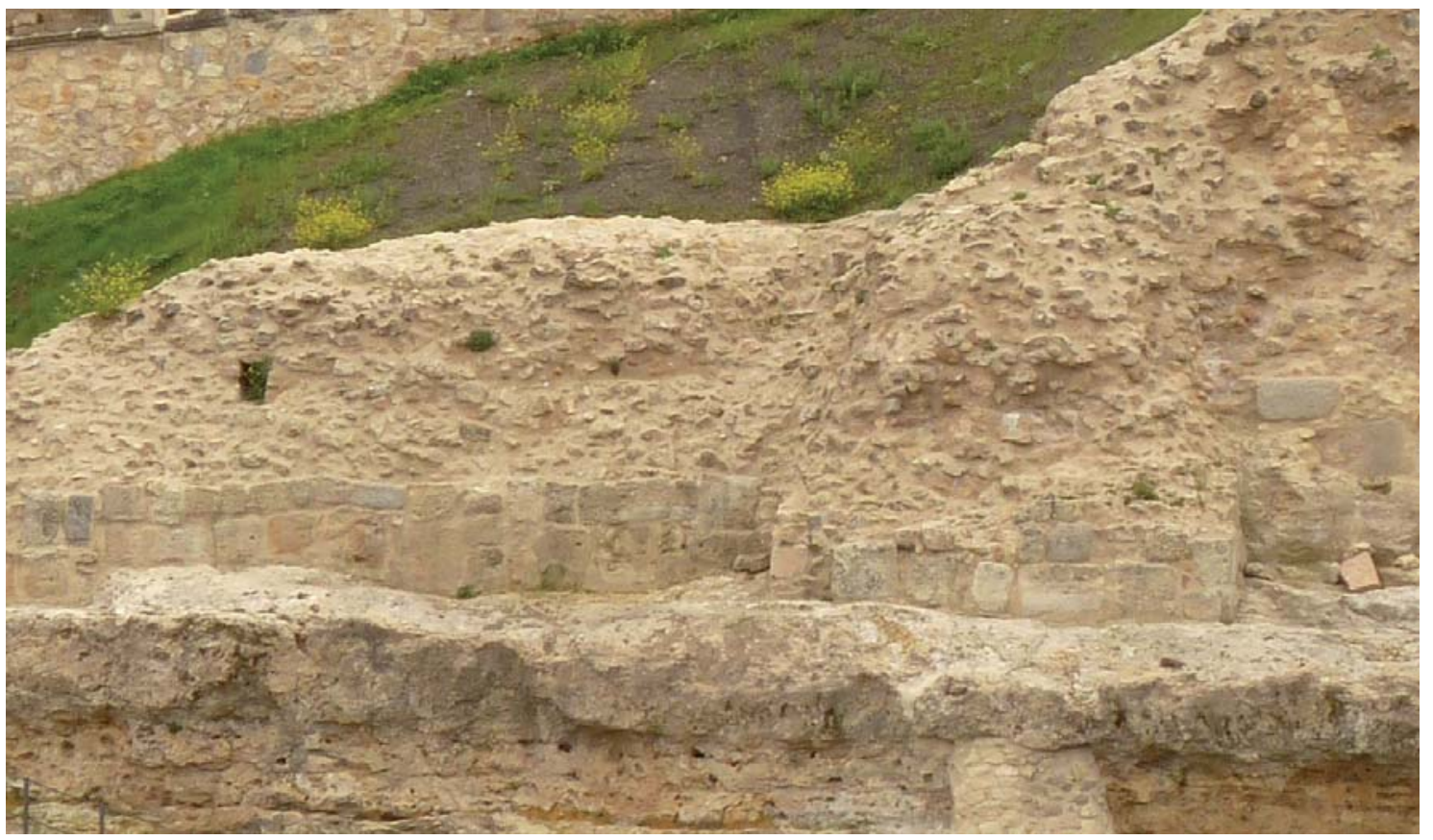

Figura 3. 92: Lienzo L61-61'. Vista del lienzo arruinado. La torre T61' se aprecia en el extremo derecho de la foto. El aparejo del zócalo, realizado a base de sillares, no presenta ningún orden claro. Por encima, el paño arruinado nos permite ver el relleno interior de lo que fue el lienzo de la muralla. 


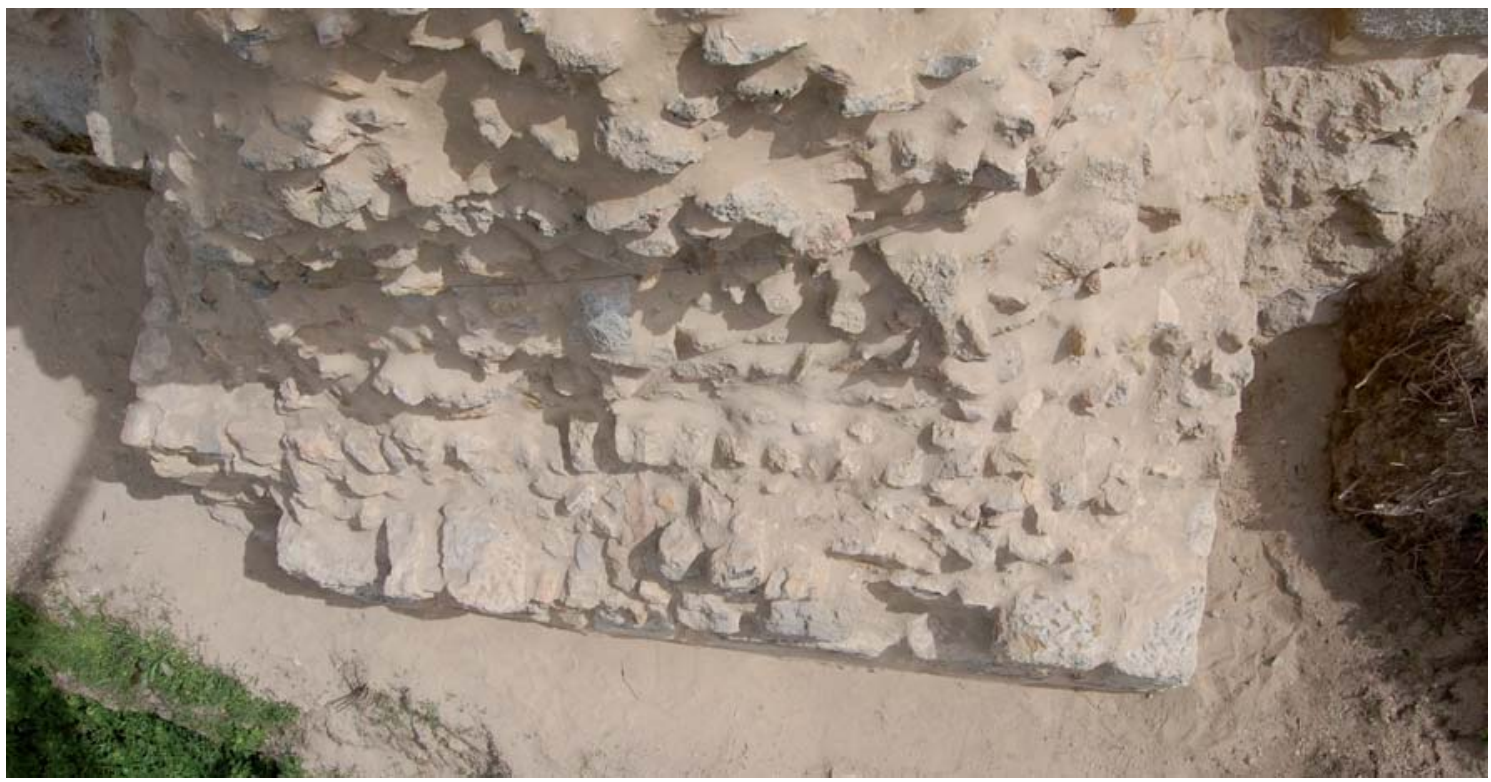

Figura 3. 93: Torre T61. En la vista en planta se aprecia la forma rectangular original. Antes del desbroce, lo que se veía era la masa informe del relleno interior medio oculta por la vegetación que le hacía parecer de trazado semicircular, que es como se señala en el Plan Director. Foto cedida por Estefanía Herrero García.

El lienzo L61' - $\lambda$ es más corto de lo habitual, ya que mide 22 metros. Al igual que el lienzo anterior se halla derruido totalmente, habiéndose perdido buena parte del paramento exterior. Lo que se observa es una mampostería, relleno interior del lienzo y en la parte inferior, que se conserva la hoja exterior, se observa un aparejo de mampostería muy desordenado, con abundancia de sillares de piedra carbonatada en el zócalo.

El saliente $\lambda$, actualmente es un mirador junto a la verja de los jardines del Alcázar. Sus dimensiones son mayores de las de las torres de la muralla. El aparejo que observamos, es difícilmente interpretable desde la lejanía y muy oculto por la vegetación. Piedra muy mezclada aunque vemos una sillería de granito bien aparejada en su lateral derecho. En su base existe un escalonado, solo visible desde la parte superior, por lo que es difícil interpretar si se trata de una zarpa o una reconstrucción escalonada como hemos visto en otros puntos de la muralla.

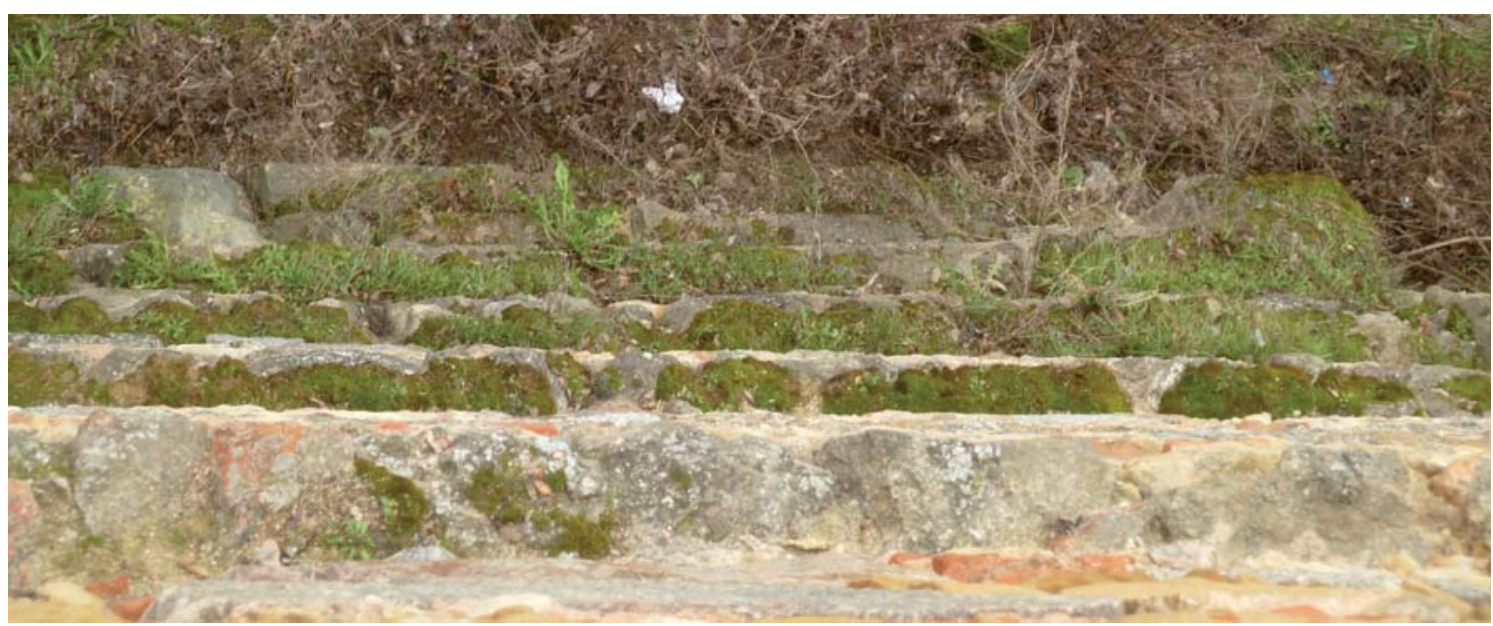

Figura 3. 94: Lienzo L61-62’. Escalonamiento en el zócalo. Al no poder ver la fábrica de cerca y frontalmente es imposible apreciar si se trata de una zarpa o de una reconstrucción escalonada moderna. 


\subsubsection{0.- ZONA 10. AlCÁZAR}

En esta zona incluimos todo el trazado que se sitúa dentro de los actuales límites del Alcázar, lo que supone 725 metros lineales, 10 torres y dos postigos históricamente situados a ambos lados del foso, el postigo del obispo y el postigo del parque, actualmente ambos desaparecidos. Hay que añadir el postigo del revellín, recientemente descubierto, que no ha sido mencionado en ninguna documentación histórica. Todo este perímetro es prácticamente inaccesible por el cortado existente a los pies, con un desnivel cercano a los 80 metros en su punto máximo. Por otra parte la presencia de importantes masas de vegetación las hace muy poco visibles desde la distancia, por lo que su estudio va a tener un carácter secundario en este trabajo.

La zona podría dividirse tipológicamente en dos sectores, siendo la charnela de separación el foso del Alcázar. La primera zona sería la correspondiente a ambos lados del jardín, actual plaza de la reina Victoria Eugenia, desde la verja exterior hasta el foso a los pies el propio Alcázar.

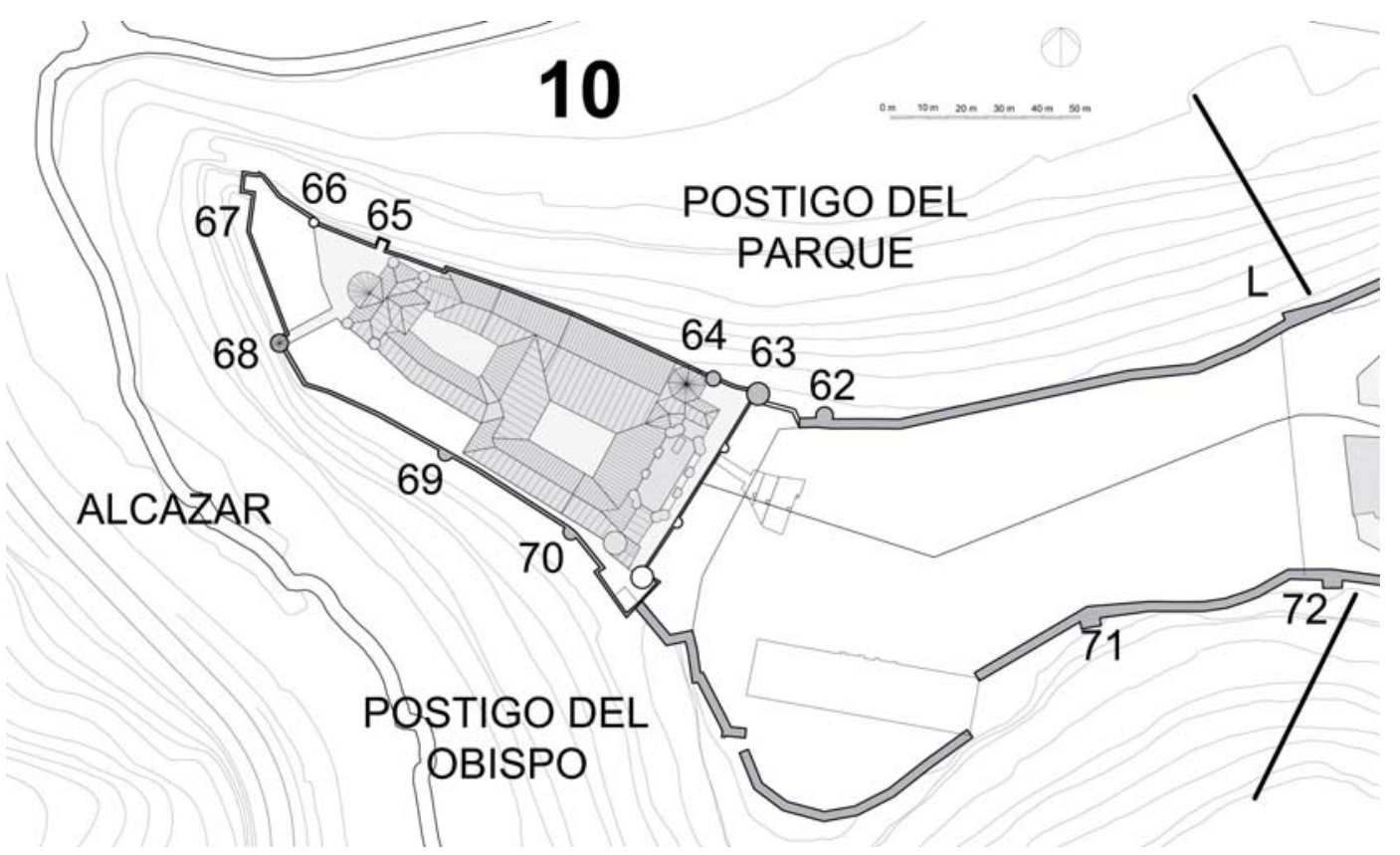

Figura 3. 95: Plano de la zona 10, que comprende todo el ámbito del Alcázar.

Esta primera parte se halla muy deteriorada, de hecho solo se conservan dos torres en sus más de 400 metros de longitud, una de ellas, la T71, arruinada y la T62 reconstruida. Presenta numerosos recrecidos, con abundancia de sillares mezclados en la fábrica, pero sin organizarse como sillería ${ }^{67}$. La inaccesibilidad de la zona y vegetación impiden su observación directa. La segunda zona, desde la torre T63 hasta un poco más allá de la T70, donde se situaría el postigo del obispo, presenta unas características que en su mayor parte se corresponden con las del Alcázar, ya que el propio edificio apoya sobre lo que debería ser la muralla, por lo que podemos asociarlas a las respectivas fases de esta fortaleza y sus

\footnotetext{
${ }^{67}$ Posiblemente procedan de la demolición de la antigua catedral y demás dependencias religiosas, al igual que lo sucesivos recrecidos podemos achacarlos a los rellenos generados por los escombros de la demolición de estos edificios que finalizaron en el XIX.
} 
características tienen muy poco que ver con lo que estamos viendo en el resto de los lienzos y torres de la muralla.

Este primer lienzo hasta la T62 es muy poco visible, oculto por la vegetación. Solo se tiene una visión parcial de un par de fragmentos de lienzo. En la primera no se observa el zócalo con claridad, aunque aparentemente es diferenciado por la existencia de numerosos sillares, algunos de ellos de granito, pero constituir un sin aparejo de sillería. En la segunda zona vemos un zócalo nivelado de fábrica de sillería, mezclando distintos tipos de piedra, aunque el aparejo no es de calidad excepcional. Sobre ello se levanta un paramento de mampostería desconcertada en la que distinguimos una línea horizontal a medio lienzo, probable indicio de un recrecido. En su coronación distinguimos un almenado tabicado por otro añadido realizado con sillares de piedra sedimentaria ${ }^{68}$. Toda la obra presenta varios recrecidos.
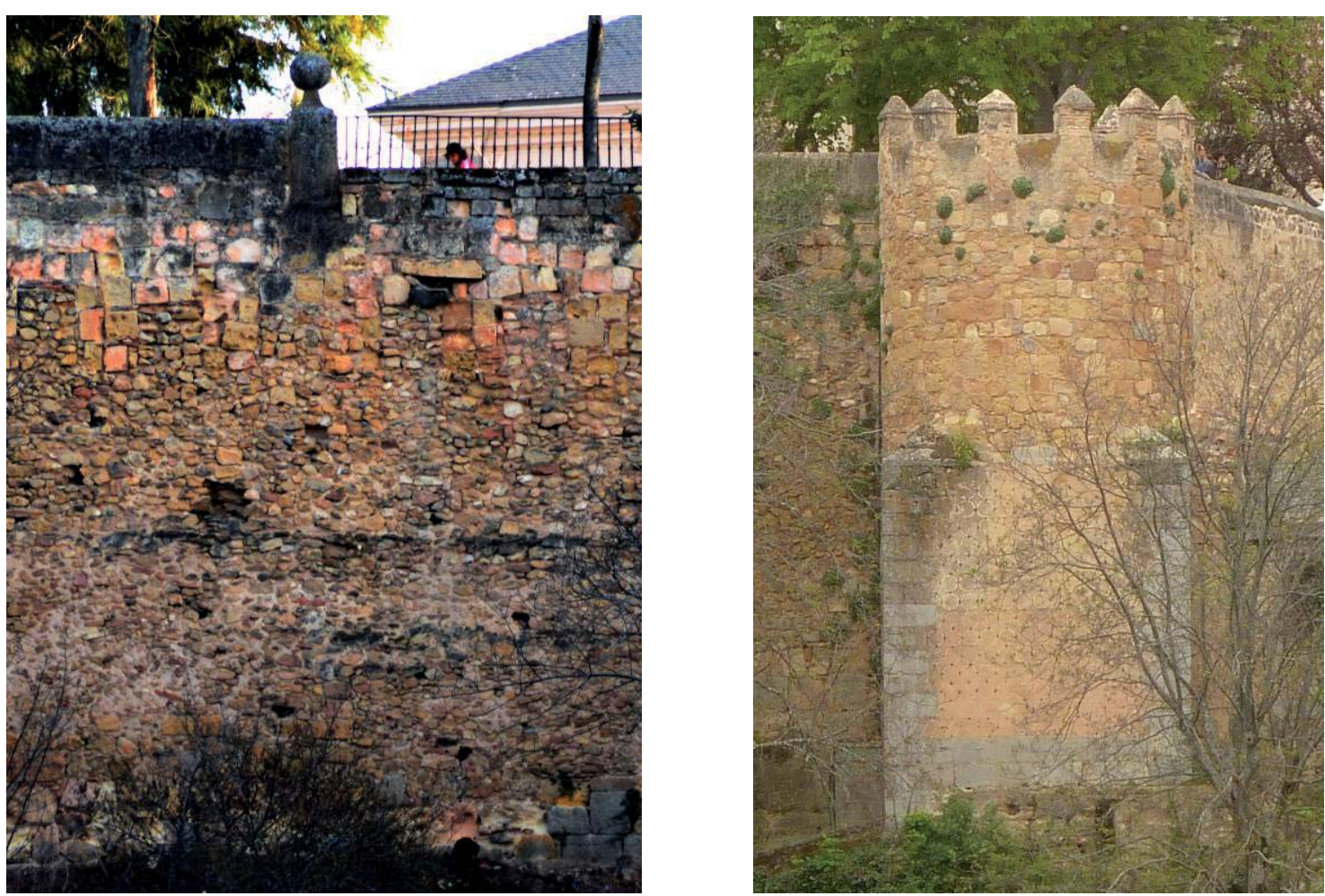

Figura 3. 96: Lienzo L61'-62. Lienzo en el que apreciamos el almenado tabicado con sillares al efectuar el recrecido posterior de la muralla.

Figura 3. 97: Torre T62 de trazado semicircular, pero construida sobre un potente zócalo de traza rectangular hasta la mitad de la altura.

La T62 es una torre de planta semicircular construida sobre un zócalo de planta rectangular, cuya altura es aproximadamente la mitad de la total de la torre, apoyado directamente sobre la roca. Este zócalo se conforma por unas primeras hiladas de sillería de granito sobre las que se levanta un cuerpo totalmente revocado, por lo que desconocemos su hechura, de la que sólo apreciamos unos sillares de granito en las esquinas. Sobre el

${ }^{68}$ No debemos olvidar que en la ubicación de estos jardines estuvo en su día la catedral, el palacio del obispado y otras dependencias del cabildo. La catedral fue demolida en el siglo XVI y las demás dependencias se mantuvieron hasta la demolición de los últimos edificios, ya en el siglo XIX. Todas estas demoliciones generarían abundante material de escombro para su reutilización. 
zócalo se levanta el cuerpo semicircular de la torre, realizado prácticamente en su totalidad por sillería de piedra sedimentaria, con mezcla de piedras procedentes de distintas canteras y algún sillar de granito. El almenado actual se ejecuta en mampostería desconcertada y ladrillo aparentando ser un recrecido sobre otro que se insinúa inmediatamente debajo. Su adarve esta libre, a modo de mirador sobre el Eresma.

El L62-63 equivale al foso del Alcázar. A su otro lado se levanta la torre T63, torre hueca, ya perteneciente al propio Alcázar, de trazado semicircular, se caracteriza por las cubiertas de pizarra que identifican al monumento. Está completamente revocada, pero lo más significativo es la existencia en su base de lo que parece ser los restos de una torre de planta rectangular de la que se aprecian dos hiladas de sillares de granito.
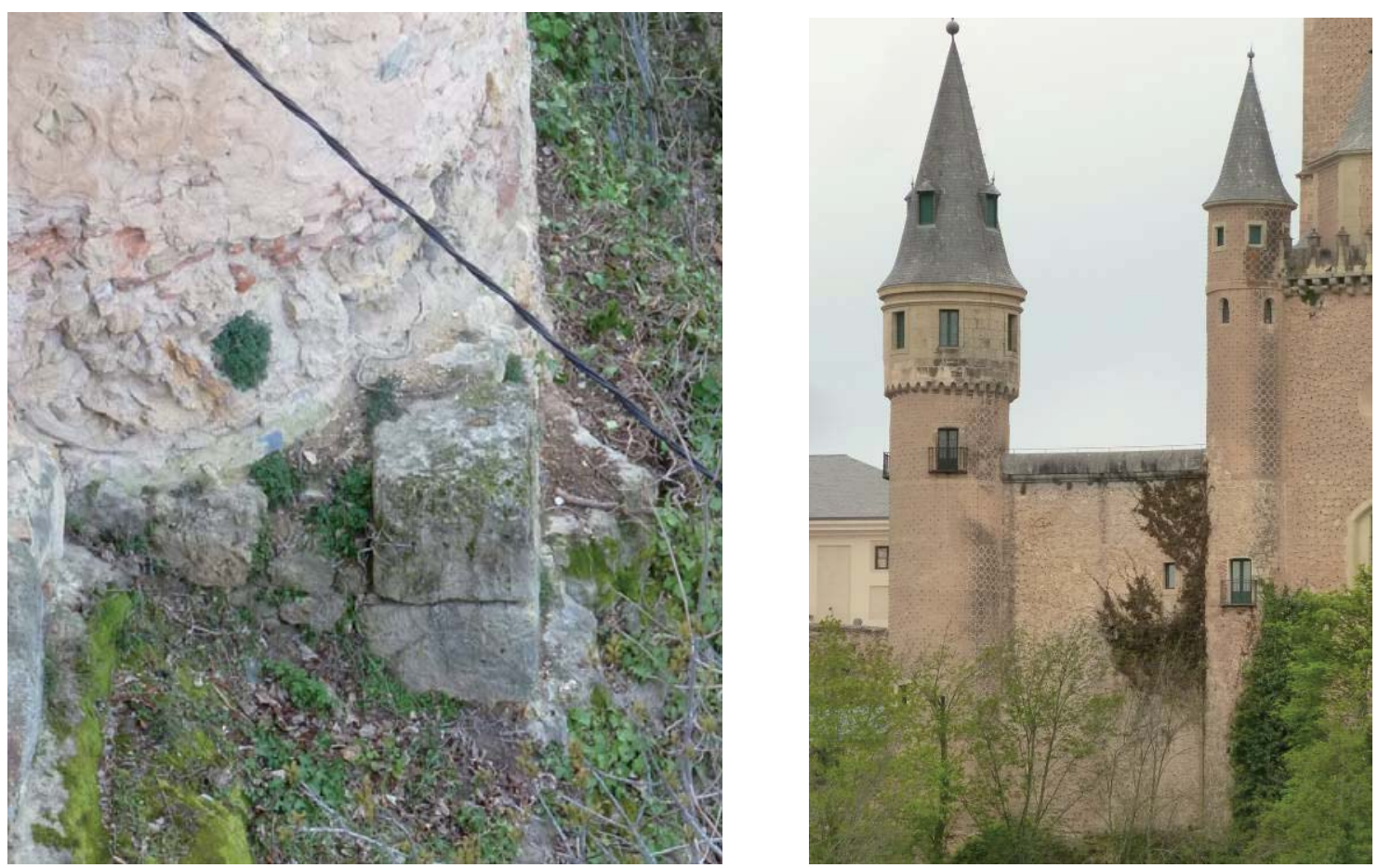

Figura 3. 98: Detalle de la Torre T63. Restos de una posible torre de sillería de granito de planta rectangular sobre los que se construyó la torre actual.

Figura 3. 99: Imagen de las torre T63 y T64 y del lienzo que las une. Los zócalos son inaccesibles y están ocultos por la vegetación, mientras el resto de la construcción se encuentra completamente revocada mediante esgrafiado que nos oculta el aparejo.

A partir de este punto, hasta la T65, las fábricas no son propiamente las de la muralla, sino las del Alcázar, que en sus sucesivas ampliaciones ha ido ocupando los adarves y lizas ${ }^{69}$. Sus fachadas se hayan completamente revocadas con esgrafiado historiado con aperturas de

${ }^{69}$ Para el estudio de este interesantísimo edificio, que por sí solo sería objeto de una tesis completa, remitimos a la bibliografía de este trabajo. Puede consultarse, por ser la recopilación más reciente, la monografía publicada en 2010 por el Patronato del Alcázar (VVAA, 2010) en la que encontramos recogida la historia del edificio en varios artículos escritos por diversos autores. Además puede examinarse Madrazo (1987), OliverCopons ([1916] 1989), Merino de Cáceres (1991), Cantalejo San Frutos (1996), Merino de Cáceres (1999), Merino de Cáceres (2000) y Chaves Martín (2001b) por mencionar sólo algunas de las últimas publicaciones dedicadas al Alcázar. 
varias ventanas y balcones, por lo que poco podemos aportar de interés a los efectos de este estudio de su configuración constructiva. En al menos uno de sus pisos son huecas ya que alojan estancias del edificio.

A partir de la torre T65, el edificio se retranquea, separándose del lienzo exterior, que se mantiene ceñido al precipicio, generando una terraza exterior. Sin embargo a los efectos de nuestro estudio, estos lienzos y torres siguen presentando la misma disposición constructiva, apoyado directamente sobre la roca, una mampostería con un esgrafiado historiado que desdibuja la forma del aparejo, en la que distinguimos algunas piezas de granito en la parte alta. Todo ello, lienzos y torres, muestran un tratamiento muy similar y uniforme. Indicar que las dimensiones de las torres son comparativamente muy pequeñas, pero el imponente desnivel sobre el que se elevan respecto al río las hace completamente innecesarias desde el punto de vista defensivo.

En este acantilado se descubren diversas oquedades, que infunden la sospecha de que han sido realizadas, agrandadas y utilizadas por el hombre, lo que nos induce a sospechar todo un mundo interior subterráneo comunicado con los sótanos de la fortificación. Todo ello se prolonga hasta una torrecita, T66, en que el muro gira hacia el interior, constituyendo el final en proa de remate del conjunto.

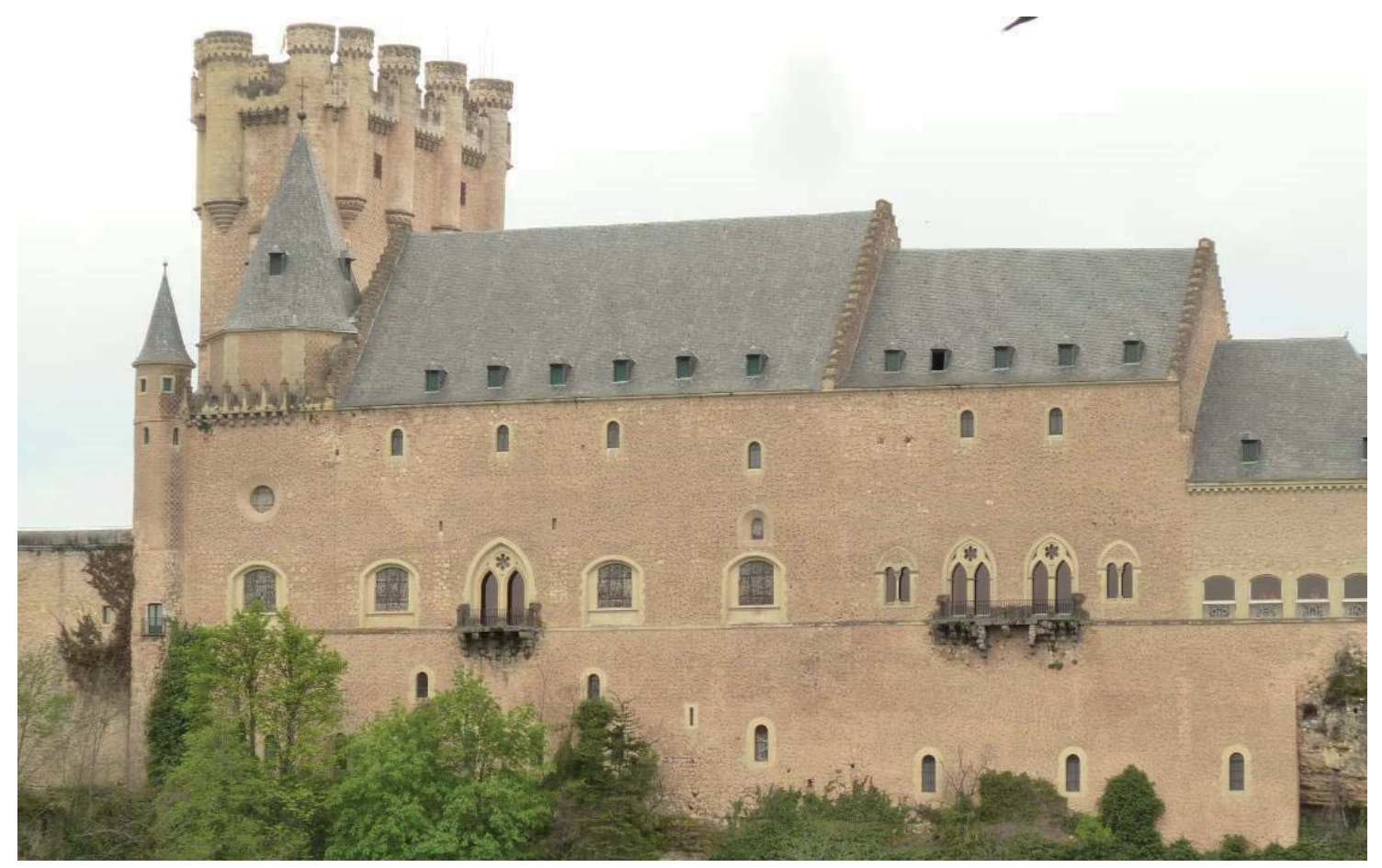

Figura 3. 100: Lienzo L64-65. Imagen de la fachada norte del Alcázar desde la iglesia de la Veracruz. Todo el edificio se construye al borde de un abrupto cortado de gran desnivel que lo hace inexpugnable.

A partir de este punto, se genera un recinto superior y otro por debajo, a modo de terraza previa. En el nivel inferior, avanzando aún más hacia el espigón de la confluencia de los ríos Eresma y el arroyo Clamores, asoma una construcción, la T67, recientemente intervenida, en la que se ha descubierto un postigo. Le referimos como Postigo del 
Revellín, siguiendo la denominación del personal del patronato y no se encuentra citado en ningún momento en la documentación histórica.

El muro esta tratado con un rejuntado que oculta buena parte de la piedra, aunque la fábrica original parece ser una mampostería desconcertada compuesta por piezas de poco tamaño. Presenta sendas líneas horizontales en las que se reduce el espesor del muro, lo que nos hace sospechar que ha sufrido diversos recrecidos o reconstrucciones. Interiormente confirmamos estos añadidos al observar un almenado en ladrillo, tabicado por otro suplemento que eleva el muro hasta la cota actual.

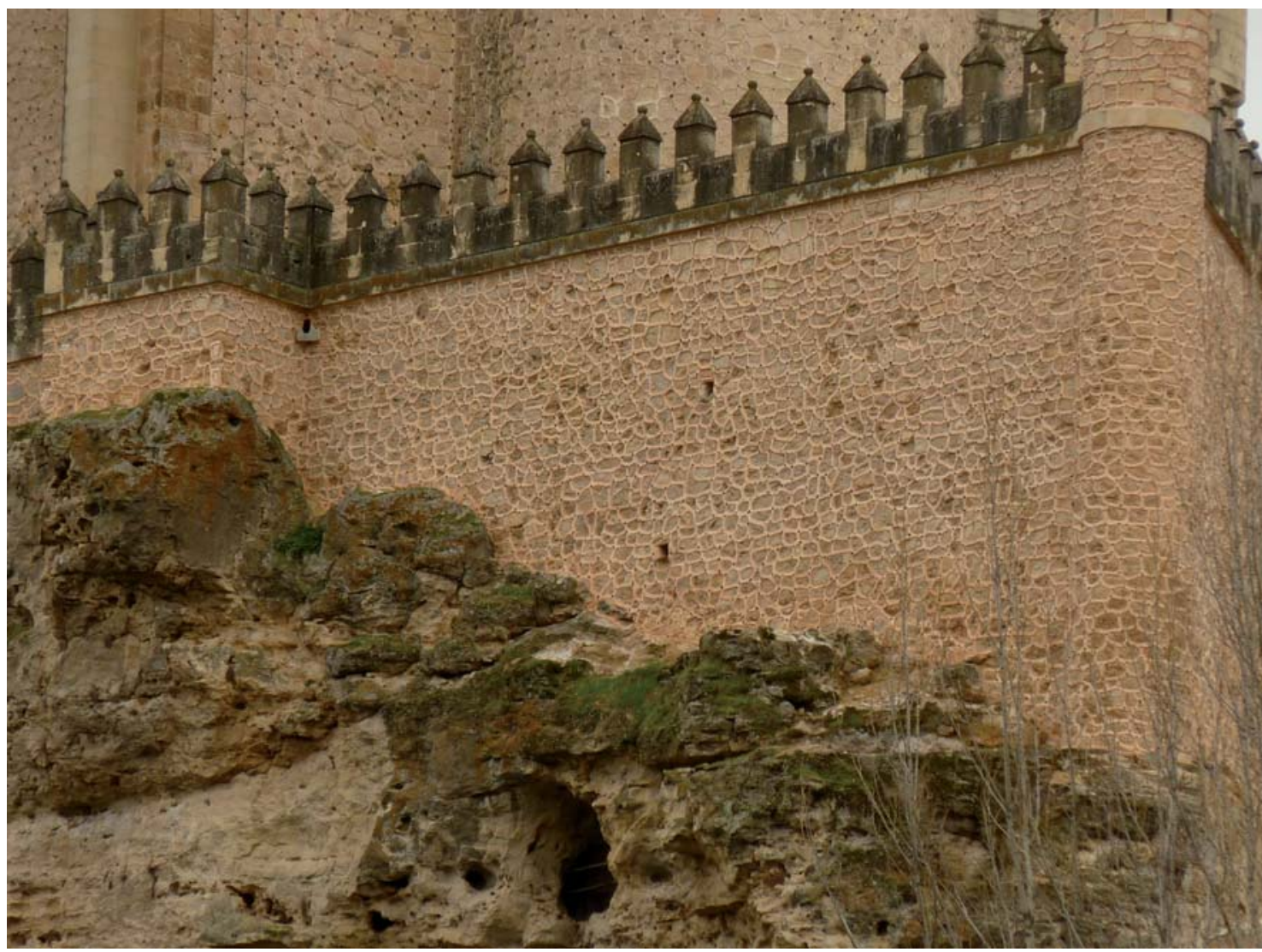

Figura 3. 101: Lienzo L65-66. Obsérvese la uniformidad del aparejo de todos los elementos. Debajo notamos la apertura de una importante cavidad en la roca, inaccesible desde el exterior.

Resulta curiosa la existencia en este lienzo de una puerta abierta sobre el acantilado que no conduce a ningún sitio a día de hoy, actualmente protegida por una reja. Volviendo la esquina, en la cara frontal de la torre, aparecen unas fusileras en la parte alta del lienzo, por encima de un escalón horizontal, en la que se reduce el espesor del muro, marcando un añadido. El postigo, que se encuentra en la cara de resalto que mira hacia el sur, queda oculto por un muro que prolonga el frontal de la torre. Está precedido por un estrecho foso tallado en la roca, que se salvaría por un pequeño puente levadizo. El postigo en sí, se nos presenta en la actualidad como una pequeña puerta adintelada de escasas dimensiones. Por debajo vemos restos de otras construcciones, muros de contención generando las rampas de acceso y una posible torre de flanqueo de esas rampas. 


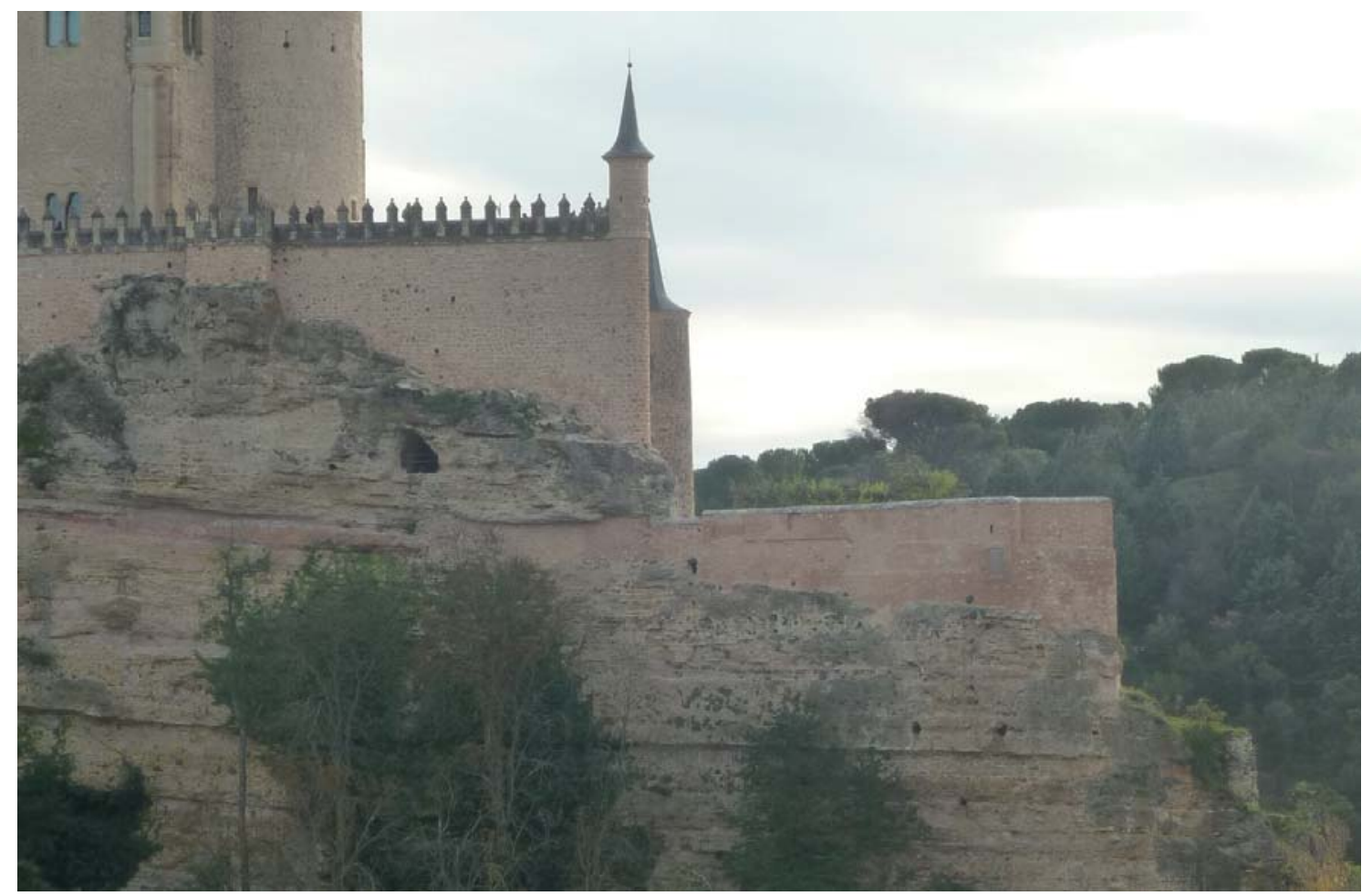

Figura 3. 102: Vemos a la izquierda la torre T65, en el centro la torre T66, rematada en una garita y en medio el lienzo L65-66. En un nivel inferior, la torre T67, rematando el conjunto del Alcázar, en la confluencia del Eresma y el Clamores.
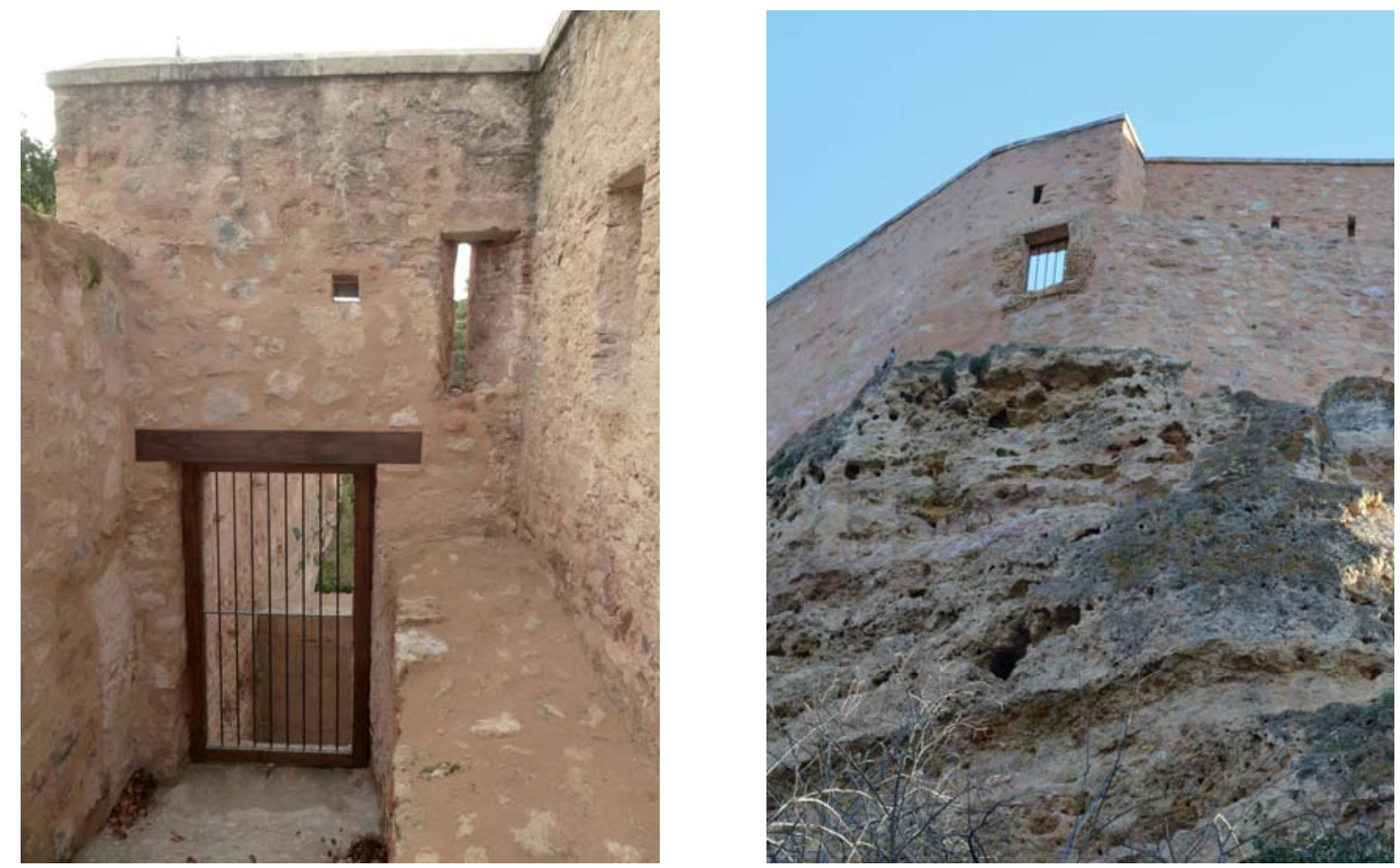

Figura 3. 103: Torre T67. Imagen actual del postigo, tras la restauración, visto desde el interior.

Figura 3. 104: Torre T67. En el lado contrario a la del postigo se observa una puerta abierta en la torre inexplicablemente abierta hacia el vacío del acantilado. Evidentemente esta torre T67 presentaba en origen una composición muy distinta complejidad mayor que la que nos ha llegado. Es evidente que de esta torre y postigo se han perdido importantes fragmento que nos impiden interpretarla correctamente. 
Se trata de una importante primicia que requiere un estudio más detallado. El conjunto posee una complejidad mayor de lo que inicialmente pudiera parecer y requiere un análisis pormenorizado más exhaustivo. La actual disposición del postigo no se comprende correctamente sin un estudio de las rampas de accesos y la casi segura conexión con el puente del piojo (Véase el apartado 4.1.11).

El lienzo L67-68 continúa por detrás de este saliente, a modo de torre en el que se ubica el postigo, en cuyo parte superior vemos que se repite el recrecido, reduciendo espesor del muro, en el que se abren tres fusileras flanqueando el postigo. Presenta un rejuntado que tapa mucho la piedra, dando continuidad al tratamiento visto en la torre T67. A lo largo del lienzo, por encima del mismo resalto, ahora claramente marcado, vemos unos machones de sillería sobresaliendo en el muro de mampostería, restos de una construcción anterior ${ }^{70}$. En todo ello se mezclan algunos mampuestos de granito.

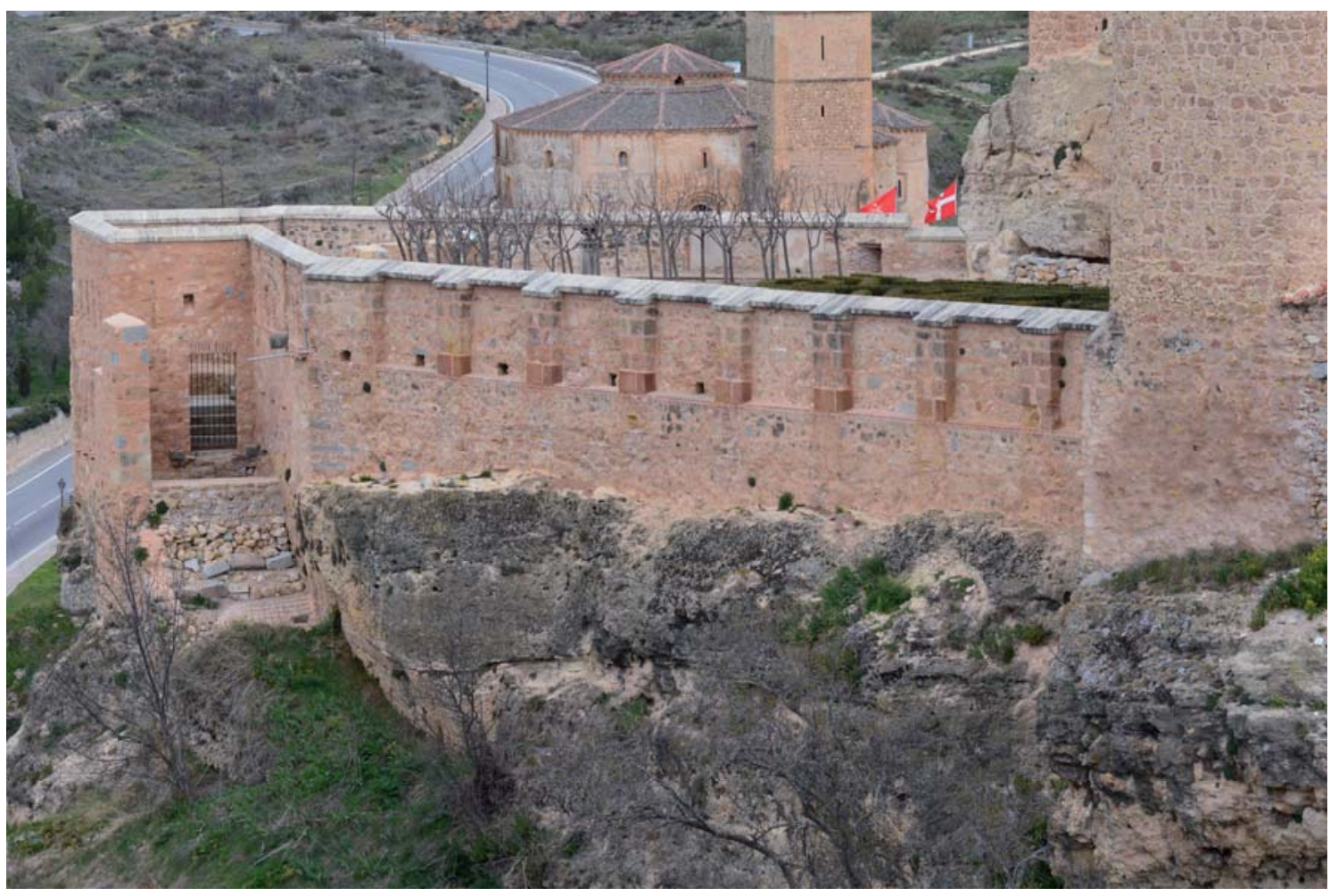

Figura 3. 105: Lienzo L67-68. Se observa el postigo del revellín, oculto hacia el exterior por el muro que rebasa el frontal de la torre T67 y el quiebro que efectúa el lienzo T67-68, donde es evidente el escalonamiento, reduciendo el espesor y la secuencia de machones en sillería que modula el paramento.

La torre T68, tiene una curiosa forma en planta proveniente de un rectángulo, claramente conservado en su zócalo, que se le han redondeado las esquinas, lo que muestra a las claras que se trata de una reconstrucción, prácticamente completa. El zócalo presenta una mampostería menuda, donde el rejuntado actual vuelve a tapar la mayor parte de la piedra, mientras la parte superior, con las esquinas redondeadas, exterioriza una mampostería de piezas más grandes ordenadas en hilares horizontales, hasta un nivel en que el aparejo vuelve a desorganizarse y las piezas no son tan regulares en el que se abren dos saeteras,

70 Son restos de una construcción que existía en 1868, según vemos en la foto de Laurent (VVAA, 2006: 61) y que en 1932, en la vista de la foto de Loty, ya había desaparecido (VVAA, 2006: 116) 
recercadas en ladrillo, por lo que intuimos que al menos esos dos pisos son habitables. La torre se remata con una cubierta de pizarra. Esta torre es considerablemente más alta que los lienzos, ya que podría considerarse como una torre albarrana del recinto superior, con el que está comunicado por el adarve.

El denominado L68-69 es más bien una tapia con un remate de tejas a dos aguas que propiamente una muralla. Tras dicho cierre, en su interior, se genera una plataforma horizontal a la que limita en el lado opuesto, la roca cortada prácticamente en vertical. Sobre dicho acantilado se apoya el edificio del Alcázar. Posiblemente ese fuese el emplazamiento original de la muralla, ocupado en alguna ampliación del edificio.

Esta tapia presenta muy mal estado de conservación y está muy oculta por la vegetación, que tan sólo permite ver un par de fragmentos. Es un muro de mampostería desconcertada que arranca desde la roca, sin ningún tipo de zócalo diferenciado, con un nivel sobre elevado que se delata por el cambio de material, constatándose una mayor regularidad de las piezas, la aparición algunos mampuestos de granito y de numerosos ladrillos entremezclados. En algunos segmentos, puede considerarse como mampostería encintada. Se aprecian algunas gárgolas y dos aberturas del tamaño de pequeñas puertas, que no conducen a ningún sitio, dado que el muro está construido al pie del acantilado.

En las proximidades de la T69, existen, 4 saeteras recercadas en ladrillo, claramente relacionadas con la elevación del muro indicada, pudiendo existir muchas más ocultas entre la vegetación, tal y como refleja Avrial en sus láminas del Alcázar desde este lado del Clamores (Avrial y Flores, 1953: lámina 52).
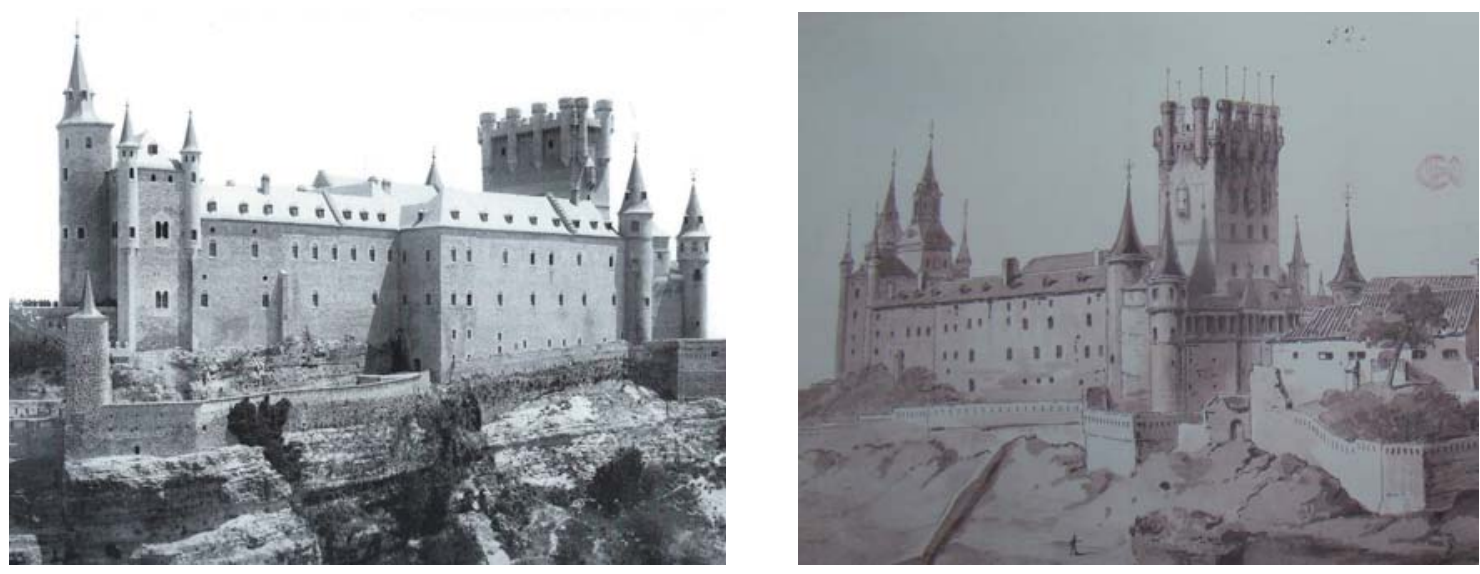

Figura 3. 106: Vista del Alcázar desde la cuesta de los Hoyos. Se aprecian los lienzos desde la T68 en el extremo izquierdo de la fotografía hasta el saliente que limita con el foso en el acceso principal al Alcázar. No existe ninguna de las torres actuales. Foto Moreno datada entre 1897-1900 (VVAA, 2006: 33).

Figura 3. 107: Detalle del dibujo de Avrial en el que se aprecia el postigo del Obispo hacia el centro de la imagen y los lienzos hacia la T68 (Avrial y Flores, 1979: Lámina 52).

La torre T69 no es visible. Tanto ésta como la siguiente T70 son de planta semicircular. Esta última tiene un cuerpo volado sobre unos falsos matacanes ciegos, que recorren todo el perímetro, sobre los que se apoya el cuerpo superior hueco y habitable, rematado con cubierta de pizarra y en el que se abren varias fusileras, todo ello en el mismo aparejo de mampostería desconcertada realizada, casi exclusivamente, en la misma piedra granítica que 
los lienzos desde la T69 hasta el quiebro con resalto en que se sitúa el foso del acceso frontal al Alcázar, superada ya la T70. En estos lienzos observamos numerosas piezas de granito gris azulado, entremezcladas de manera uniforme por todo el lienzo. Se trata de una intervención unitaria, en la que posiblemente se reconstruyesen todos los lienzos y ambas torres, ya en el siglo XX, puesto que ninguna de las dos torres existe en una foto de principios del siglo pasado (VVAA, 2006: 33).

En este punto se creía ${ }^{71}$ hasta la fecha, que se encontraba el postigo del obispo, tal y como vemos en la lamina de Avrial (Figura 3. 107), del que solo tenemos constancia por citas documentales y los grabados de Avrial, Roberts y una foto de Oliver-Copons, ([1916] 1989: 379) (Véase el capítulo 4.1.11). A él se llegaba desde el, también desaparecido, puente del Piojo. Actualmente existe una pequeña puerta formada por dos jambas y un dintel adovelado, todo ello en sillería mezclando piedra reutilizada, granítica y sedimentaria, de configuración muy reciente.

Superado el postigo, el lienzo L70-71 está muy deteriorado, solo se conservan fragmentos, con muchas zonas derruidas y trozos perdidos. En varios tramos lo que ahora vemos es una reconstrucción de una tapia, de nula calidad constructiva, realizada en mampostería carbonatada de tamaño pequeña con ladrillo mezclado, todo ello al borde del cortado de la roca, apoyando directamente sobre ella. Son fragmentos muy parciales, muy dañado por la vegetación y los empujes de los rellenos por el intradós que han ocasionado no pocos derrumbes. En muchos puntos lo que se ve es el relleno interior. Cuando se conserva el paramento exterior, tiene la apariencia de ser una reconstrucción moderna, por la mezcla de material y los aparejos de muy poca calidad que muestran. El peto superior evidencia los recrecidos y rellenos aportados para nivelar la plataforma donde antiguamente se ubicaba la catedral (Ruiz Hernando, 2010: 51).
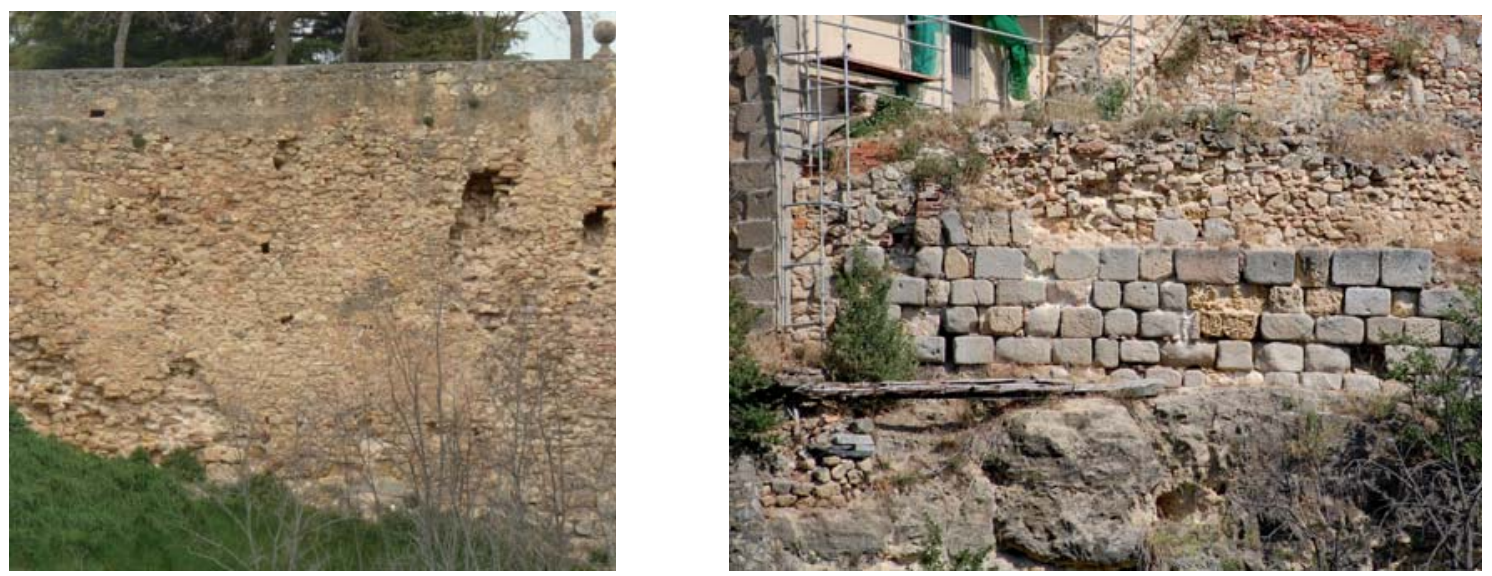

Figura 3. 108: Lienzo L70-71. La mayor parte del lienzo se realiza con la habitual mampostería desconcertada, que se encuentra muy deteriorada.

Figura 3. 109: Lienzo L70-71. Junto a la Casa de la Química vemos los restos de una fábrica de sillería de granito en el zócalo.

\footnotetext{
${ }^{71}$ Unas obras recientemente acometidas en los lienzos de la muralla del Alcázar en esta ladera sur han dejado al descubierto lo que, según José Miguel Merino de Cáceres, arquitecto director de dichas obras, sería el postigo del obispo. Se le ubica un poco más al este de donde lo situaba Oliver Copons, concretamente junto a la torre T71. (noticia aparecida en el Día de Segovia de 12 de Junio de 2016 y en el Adelantado de Segovia del 13 de agosto de 2016).
} 
Junto a la casa de la Química, destaca un trozo en que hay varias hiladas de sillares de granito reutilizados a modo de zócalo, en el punto más alto, 5 hiladas. Se trata de un fragmento mutilado, ya que el resto aparentemente se cayó o derribó al construir la casa de la Química, ya que la esquina del edificio invade el trazado de dicha sillería (Figura 3. 109).

La T71 también se haya arruinada, de la cual solo se aprecia un pequeño muñón prácticamente amorfo y de escasa altura. Actualmente sólo se conserva una mampostería desconcertada, que constituiría el relleno interior. Desconocemos las demás características constructivas. Por lo restos conservados, creemos que su trazado era de planta rectangular. Junto a esta torre se ha descubierto recientemente un postigo, que el arquitecto Merino de Cáceres, identifica con el postigo del obispo, cuya construcción data entre los siglos XIII y XIV (Adelantado de Segovia 13/08/2016).
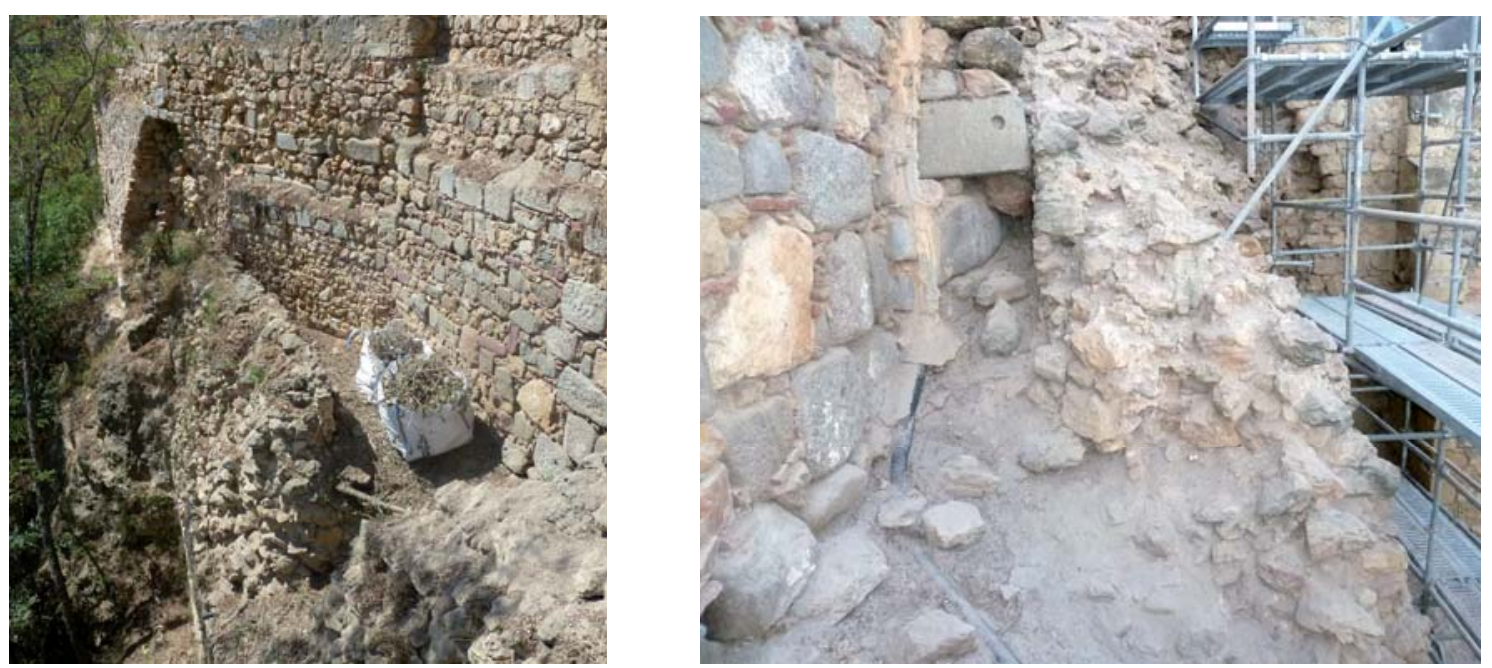

Figura 3. 110: Lienzo L71-72. El lienzo L71-72 es inaccesible y está oculto por la vegetación en la mayor parte de su trazado.

Figura 3. 111: Junto a la torre T72 observamos una parte derruida de la muralla y una tapia, que se ha construido remetida, la sustituye, haciendo las funciones de peto a los jardines del Alcázar.

El lienzo L71-72 también esta derruido junto a T72 y lo que vemos es una tapia remetida respecto al trazado original de la muralla, que hace las funciones de peto a los actuales jardines. Cerca de la torre T72 descubrimos la ruina de la muralla original que nos permite conocer estos escasos datos de que disponemos en relación a esta parte de la muralla. El plano de rotura inclinado nos evidencia la ruina por deslizamiento de la parte superior del lienzo. El resto de lienzo es inaccesible y está oculto por la vegetación.

\subsubsection{1.- ZONA 11. RONDA JUAN II}

La zona mide 220 metros en los que se sitúan 8 torres de medidas entre 5,22 y 5,38 metros de frente y 2,55 y 2,70 de resalto. Todas ellas presentan, por lo tanto, unas dimensiones muy similares, al igual que una común configuración constructiva. Esta zona ha sido muy reparada en la década de los 70, especialmente las partes altas, los petos y almenados, siendo todos reconstruidos ya que tanto torres como lienzos los habían perdido, estaban desmochados como apreciamos en las fotos anteriores a estas intervenciones. El paramento ofrece un aspecto muy uniforme y en buena parte de su trazado presenta un 
zócalo diferenciado de piezas de granito dispuestas sin voluntad de constituir un aparejo, sólo como un zócalo de separación con el terreno, sobre el que apoya una mampostería desconcertada en la que distinguimos numerosos agujales, claramente ordenados y donde es posible descifrar la modulación. En las torres se distinguen un zócalo resaltado con un pequeño escalón, excepto T73, T76 y T77. Sillares de piedra sedimentaria refuerzan las esquinas hasta el peto, la mayor parte de ellos, repuestos en las intervenciones de los 70's. (IPCE: PI 611.03; PI611.04; PI611.05; PI611.06; PI612.01). De reparaciones anteriores dan testimonio algunos parches en ladrillo o ripios del mismo material.

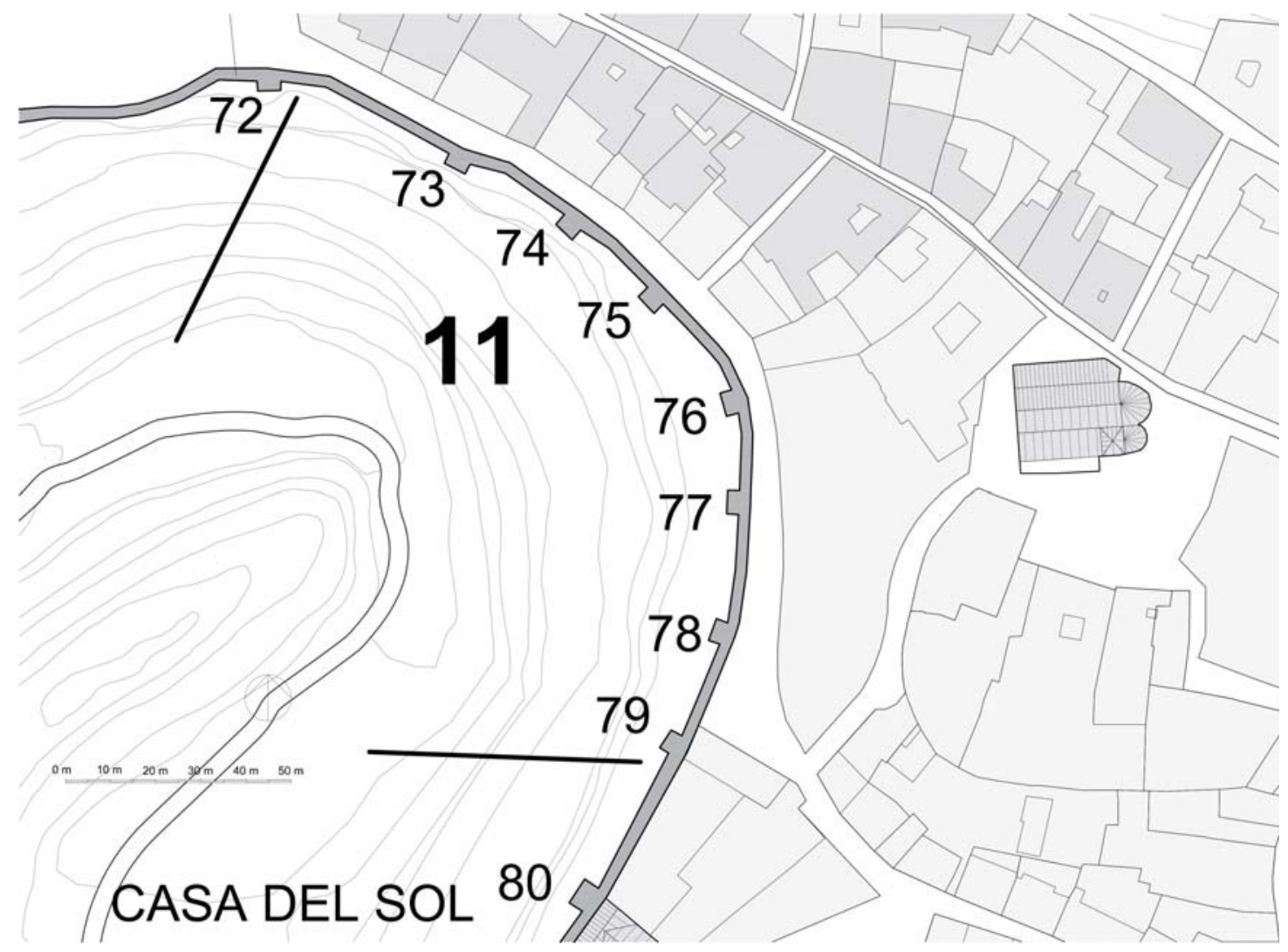

Figura 3. 112: Plano de la zona 11, que comprende desde la verja del Alcázar hasta la casa del Sol.

Quizá la conservación de estos elementos sea debida a que han estado enterrados, ya que el extradós se ha utilizado como vertedero al que se arrojaban todo tipo de echadizos y que llegaron a constituir unos taludes que colmataban toda la altura del lienzo y permitían descender desde el adarve hasta el arroyo Clamores, como se aprecia en una foto de Wunderlich (FPH: W-01706; Gutkind, 1967: 369)

Toda la muralla presenta al menos un recrecido, ya que en varios lienzos vemos uno y hasta dos niveles de gárgolas, posiblemente al reurbanizar la calle Ronda de Juan II y es probable que la cota original del amuralla sea más cercana a la de la T72 que a la que presenta el resto de la zona. En esa parte alta, en los lienzos, abundan las piezas de granito. En varios tramos de toda esta zona descubrimos al pie de la muralla numerosos taladros de forma circular realizados en la roca, que denotan la actividad humana en esta ladera. Algunos son claramente anteriores a la muralla, que los sella parcialmente y en otros casos es imposible pronunciarse. Encontramos el extremo sur del foso celtíbero tallado en la roca que ya hemos mencionado al hablar de la ladera norte. 
Esta zona presenta una modulación de lienzos un tanto extraña ya que los dos últimos son más largos que los demás, presentando ambos grupos unas medidas muy parecidas entre sí. Los primeros miden entre 34 y 35 metros, mientras los demás rondan los 20-24 metros excepto el L76-77 que solo mide 17 metros. Además en todos ellos, excepto el L79-80 la muralla cambia de dirección en mitad del lienzo, en lugar de efectuar ese cambio en las torres. Los lienzos presentan peto sin merlones.

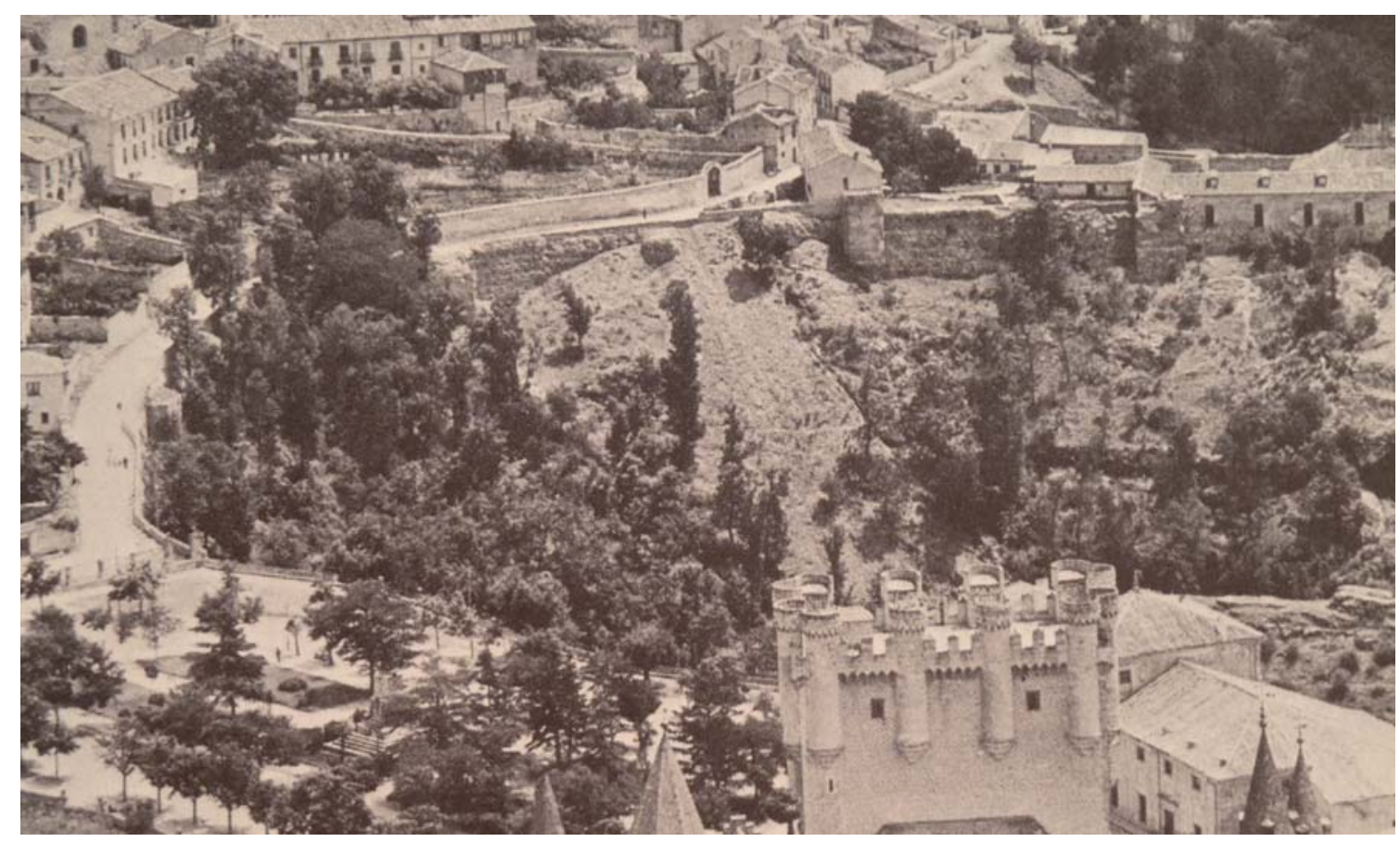

Figura 3. 113: Detalle de la foto en que se aprecia la entidad de los echadizos, enterrando por completo algunas torres, como la T78 y los lienzos L77-78 y L78-79. No existían merlones, ni en los lienzos, ni en las torres. Foto publicada por Gutkind (1967: 369).

La T72 tiene aparentemente un resalto mayor de lo habitual pero es debido a la pérdida del trazado original por el derrumbe del lienzo L71-72 y estar remetida la cara exterior del nuevo trazado lo que aumenta el resalto de la torre en ese lado. Tiene un arco de ladrillo embutido en la mampostería en su cara frontal y presenta contrafuertes laterales en ambas esquinas reconstruidos recientemente en sillería de piedra sedimentaria, lo que nos hace sospechar de posibles derrumbes que han alterado sus dimensiones. Ni siquiera tiene peto y su adarve actual se encuentra más de 3 metros por debajo de la cota del resto de la muralla.

Los lienzos se adaptan perfectamente a la descripción de las características generales comunes que se ha hecho, lo que denota la uniformidad del tratamiento actual. Tan solo encontramos algunos matices o excepciones puntuales, como el caso del L73-74 en el que vemos piezas talladas, (molduras, dovelas) de granito en la parte alta, procedentes de un edificio posterior a Edad Media o en el L74-75 cuyo quiebro es especialmente visible ya que separa dos zócalos claramente diferenciados, a un lado el zócalo se compone de tres hiladas de mampuestos grandes y al otro lado sólo una, lo que evidencia una clara discontinuidad constructiva. La parte alta del lienzo presenta un trazado ligeramente curvo, continuo, lo que denota que se trata de una reconstrucción, ignorando el ligero quiebro del trazado original. 
Respecto a las formas talladas en la roca, encontramos dos singularidades, en el L75-76, un corte en la roca que tapa muralla, difícil de interpretar y en el L76-77 volvemos a toparnos con el foso celtibero tapiado por la muralla (Martínez Caballero, 2010b: 149-151). En el primer caso, no vemos la roca de apoyo, enterrada, por lo que desconocemos la profundidad de dicho corte. Actualmente vemos un pequeño hueco, de unos 60 centímetros de ancho, cubierto por un dintel de granito y que se encuentra tabicado poco más al interior por el lienzo de muralla. Sin embargo a algo más de un metro y medio, encontramos la roca que aflora nuevamente creando un desnivel de más de dos metros, aparentemente también tallada en vertical, ligeramente ataludada, delimitando lo que podría ser un pequeño paso abierto en la roca. Todo ello se encuentra tapiado por el lienzo de muralla que se construye después y en el que se interrumpe la habitual disposición de piezas de granito en el zócalo, que vemos a ambos lados. En el segundo caso, la talla en la roca es más evidente, al quedar parte de la roca tallada perfectamente visible. La torre T76 se acerca al borde del talud artificialmente tallado en la roca.

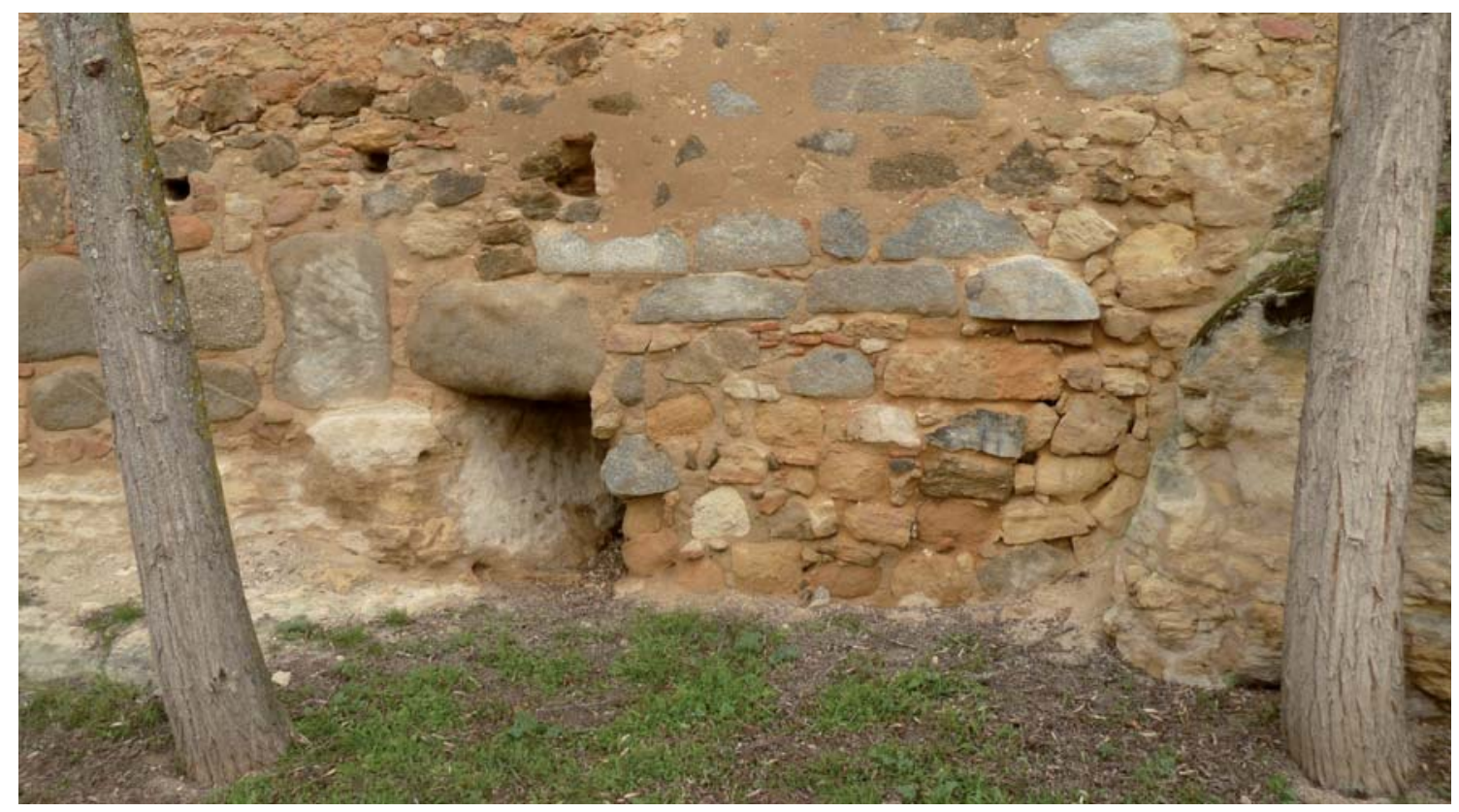

Figura 3. 114: Lienzo L75-76. Roca tallada en vertical tapiada por la muralla, en cuyo zócalo se interrumpe la disposición de piezas de granito.

Las torres T73, T74, T75 y T76 conservan una o dos hiladas de sillares o mampuestos de mayor tamaño, mayoritariamente de granito, dispuestos a modo de zócalo, a veces a sogas y otras a tizón, aunque no nivelan el arranque de apoyo de la mampostería desconcertada, de piezas muy menudas, que asciende hasta el peto con las esquinas reforzadas con sillares de piedra sedimentaria, repuestos en la última intervención. En la T77 se evidencia el trazado de una torre previa ligeramente distinto del de la torre actual, ya que en la primera hilada del zócalo, dos sillares se salen de la alineación de la torre, un claro testimonio del reaprovechamiento de los cimentos de una construcción anterior. Entre ambos, queda visible el hueco de uno o dos que faltan, gracias a ello es posible observar el interior de la construcción de la torre, comprobando que estos sillares constituyen un forro exterior que se rellena con mampostería. 


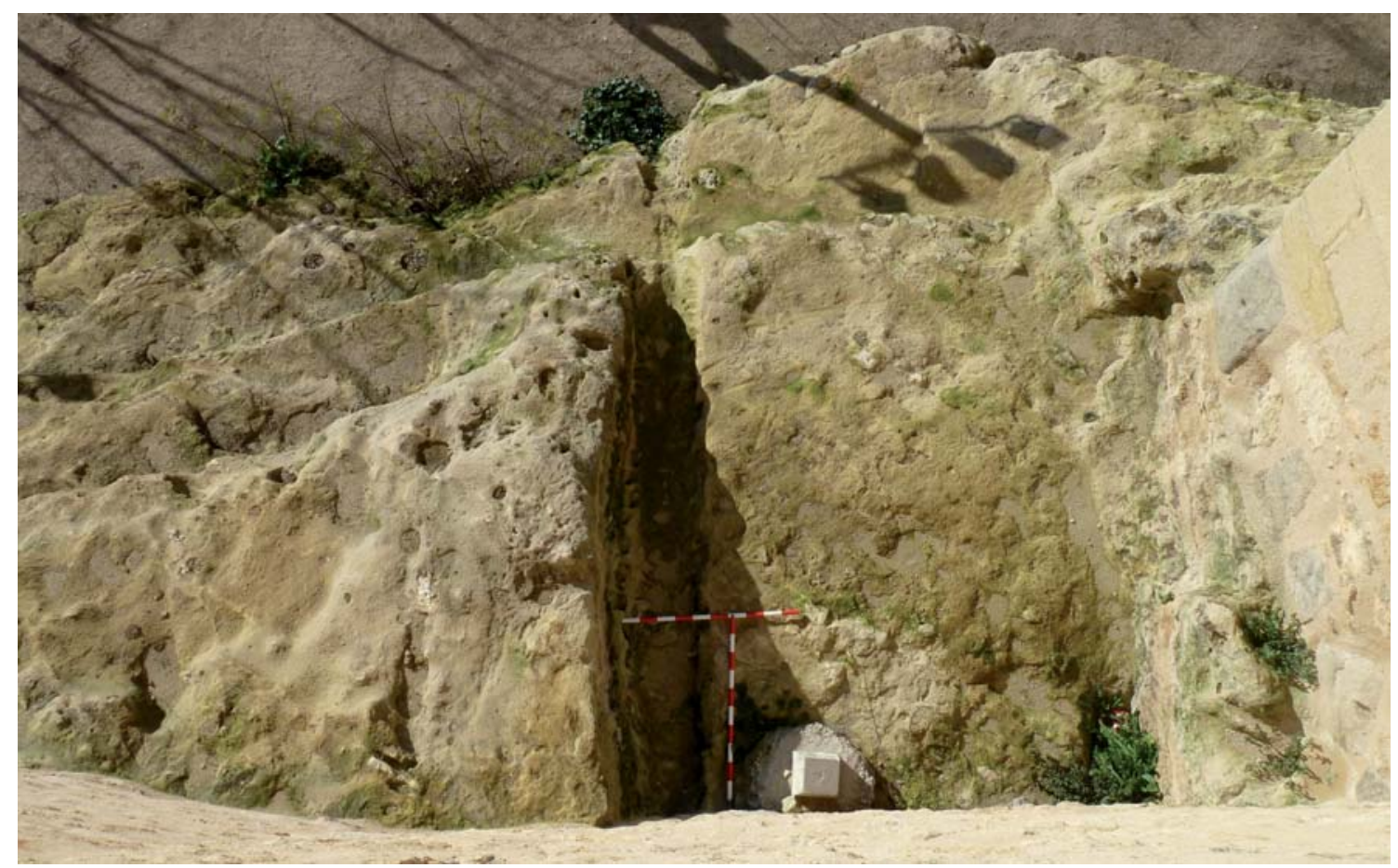

Figura 3. 115: Lienzo L76-77. Corte vertical tallado en la roca visto desde el adarve y que se asocia con el foso celtíbero localizado en otros puntos de la ciudad.

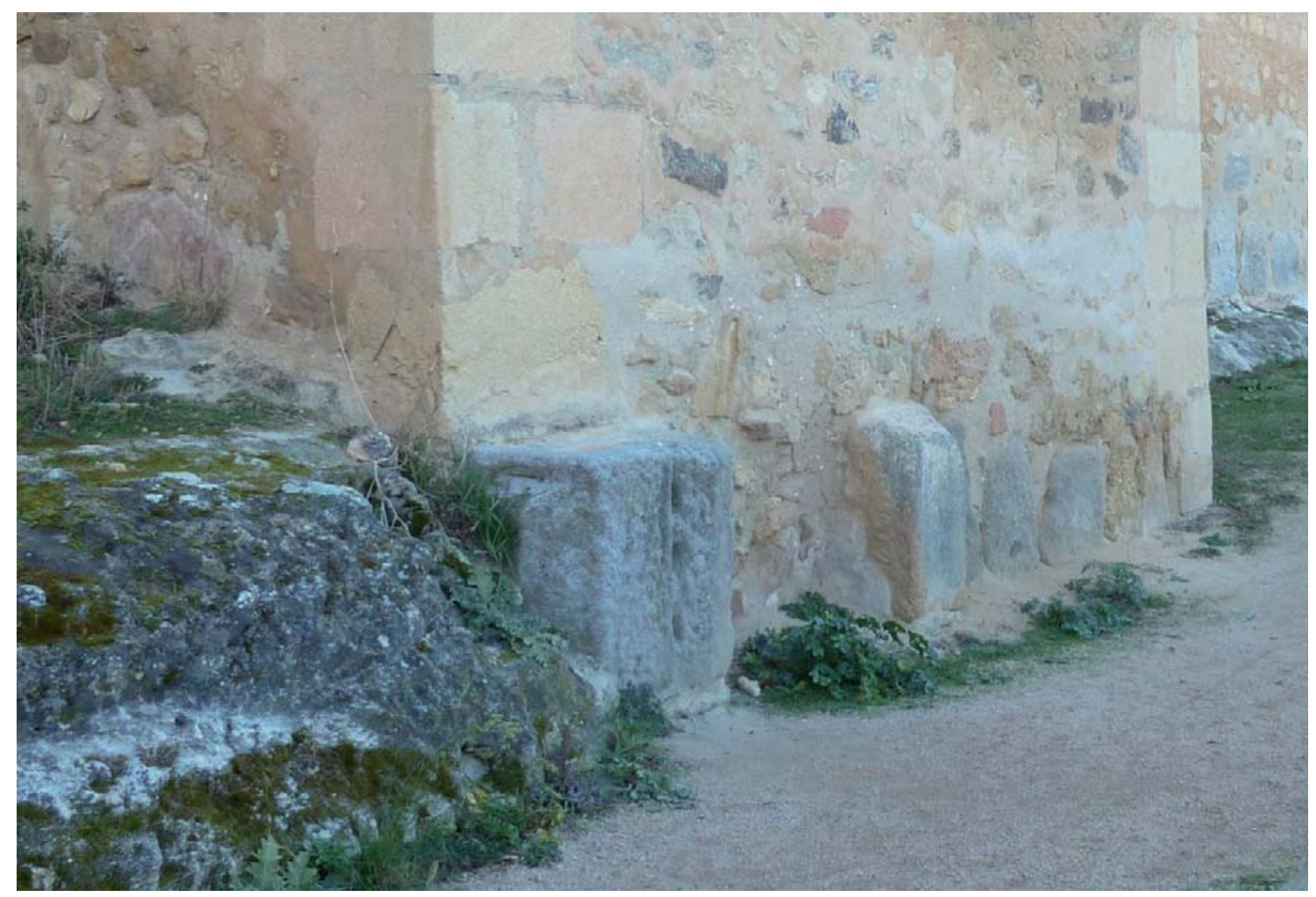

Figura 3. 116: Torre T77. Dos sillares que se salen de la alineación actual de la torre, evidencian el reaprovechamiento de unos cimientos previos. Se observa la existencia de cuñas en la cara del sillar, prueba de que intentaron partirlo en dos. 
La T79 conserva evidencias de estar ejecutada mediante mampostería encofrada al leerse aún la impronta de la tablazón en su cara frontal y las tongadas de nivelación de los cajones, pero sólo se aprecian dos agujales dispuestos en vertical, uno encima de otro en su cara frontal, sin ser posible adivinar la modulación de las tapias. También conserva tres agujales en una cara lateral junto al lienzo y dos en la otra, muy próximos a la esquina exterior, lo que nos permite, en este caso, intuir la disposición de los encofrados conjugando la información de ambos alzados.
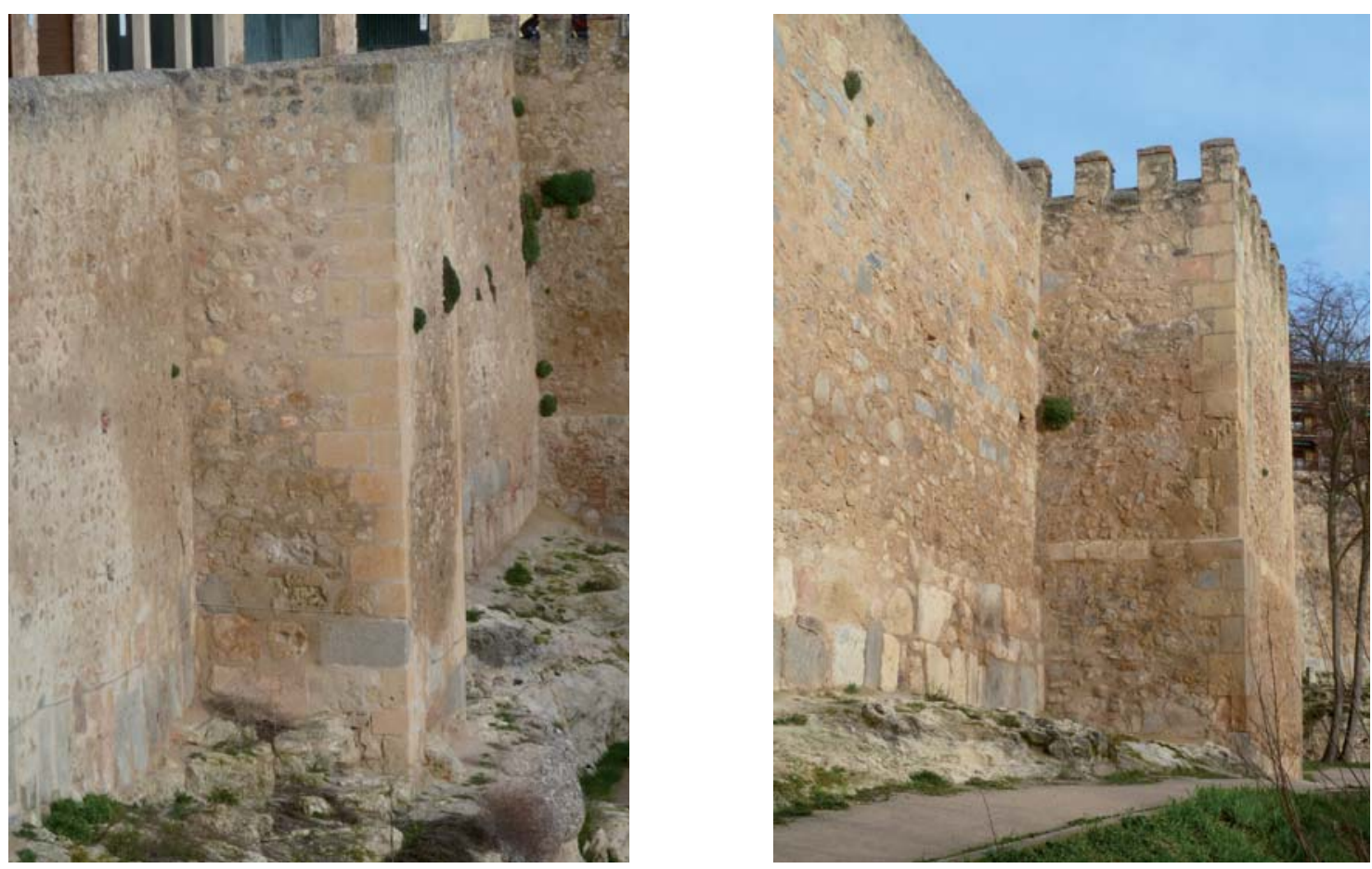

Figura 3. 117: Torre T73. Zona de aspecto muy uniforme. Zócalo con piezas de mayor tamaño, sin llegar a nivelar el arranque de la mampostería, en la que se aprecian mezcladas piezas de granito en las partes altas.

Figura 3. 118: Torre T75 y lienzo L74-75. Fragmento de muralla con zócalo diferenciado en el lienzo y resaltado en la torre, que se realiza con mampostería con sillares de piedra sedimentaria en las esquinas. Peto con y sin almenado.

\subsubsection{2.- ZONA 12. MUSEO-HoNTANILLA}

Esta zona abarca desde el actual Museo de Segovia, Casa del Sol, hasta la puerta de San Andrés. Alcanza los 300 metros de longitud en los que se reparten 7 torres, 3 de planta rectangular y 4 poligonales. De las tres torres rectangulares, dos son completamente rehechas en el siglo XX, si bien sus medidas son bastante uniformes ${ }^{72}$. Los lienzos oscilan entre los 33 y 36 metros, excepto el que constituye el alzado frontal del Museo hacia el valle, que se adapta a la forma de la roca sobre la que se asienta la Casa del Sol.

\footnotetext{
${ }^{72}$ La zona ha sido objeto de numerosos proyectos de intervención en la década de los años 70 , habiendo localizado en el AGA varios expedientes, como por ejemplo, AGA: 70.735, AGA: 70.736, AGA: 70.737, AGA: 70.792, AGA: 71.019, entre otros. Adicionalmente se han localizado otros proyectos en el IPCE, IPCE: PI 611.03, IPCE: PI 611.04, IPCE: PI 611.05, IPCE: PI 611.06, IPCE: PI 612.01, IPCE: PI 612.02. Algunos son copias de lo existente en el AGA,
} 
El actual Museo de Segovia, antiguo Matadero Municipal, uso al que se dedica desde tiempos de Enrique $I^{73}$, posee un marcado carácter de fortificación por su forma y emplazamiento sobre una escarpada y saliente roca en el conocido como "Espolón" situado entre los lienzos de la muralla, parece poseer una finalidad estratégica, como antes han reconocido otros autores (Vera y de la Torre) ${ }^{74}$ e incluso durante las guerra carlistas, 1834-1836, que lo fortifican (AMS: 4810-3, I: 57).

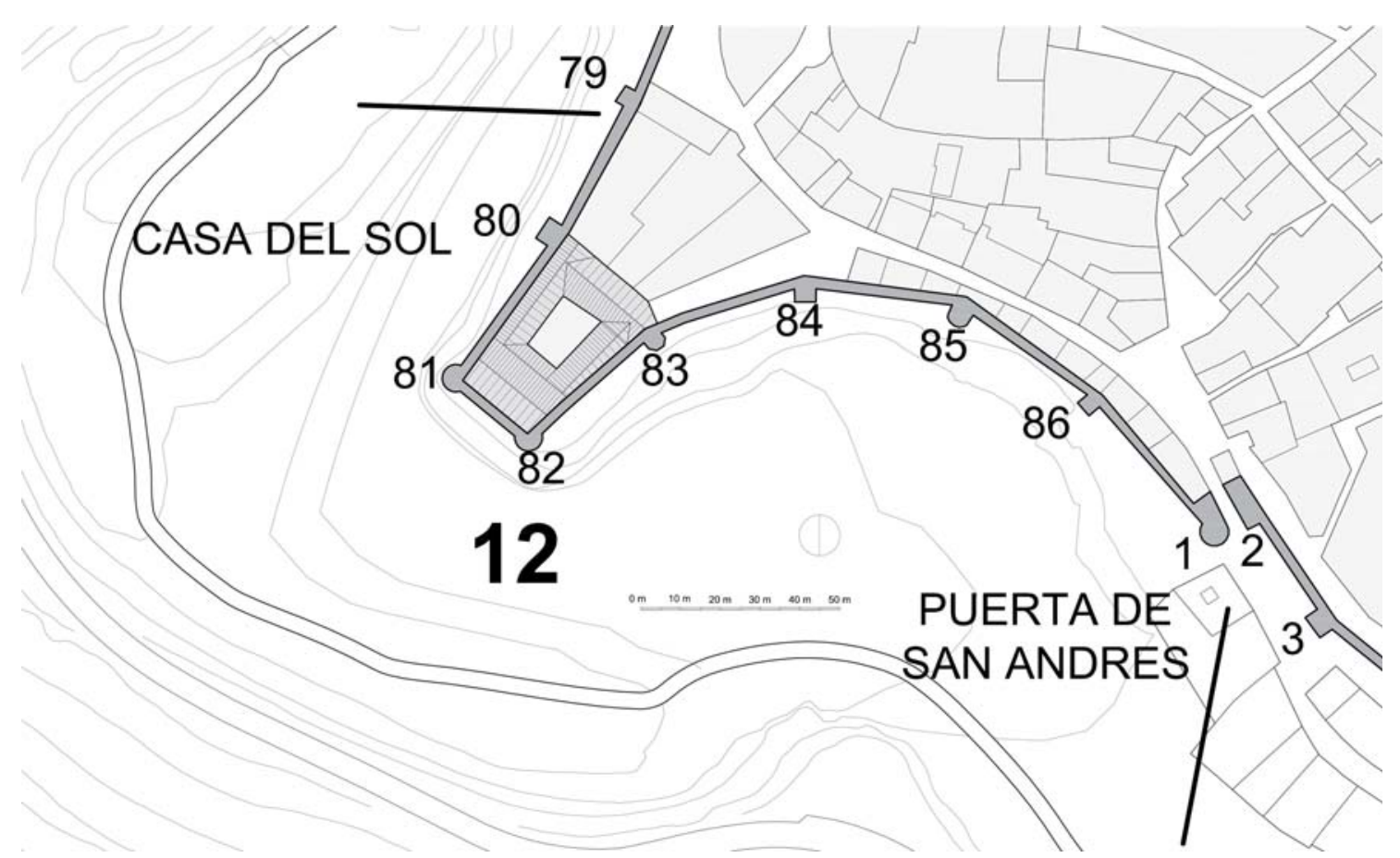

Figura 3. 119: Plano de la zona 12, que comprende desde la casa del Sol hasta la puerta de San Martín.

Sus torres poligonales presentan una curiosa disposición afacetada que las diferencia del resto de los casos de la muralla. Tan solo hemos encontrado algo parecido en una torre de la muralla de Coca, que esta datada en el XIII. En sus aparejos diferenciamos una sillería en el zócalo, con abundancia de piezas de granito, entremezclado con piedra sedimentaria, sobre la que se dispone una sillería de piedra sedimentaria bien tallada.

En todo el entorno de esta zona existen numerosas muestras de la actividad humana, reflejado en diversas formas talladas en la roca, tanto extramuros visibles como intramuros, documentadas en los expedientes administrativos (OT-100/2001-11; OT-116/95-8; OT 174/2012-11), entre otros.

\footnotetext{
${ }^{73}$ Las primeras noticias documentales, del siglo XV, ya lo mencionan como sede de las carnicerías. Tras dejar de ser matadero municipal, se convirtió en destartalado almacén municipal y finalmente sede del museo de Segovia (Chaves Martín, 2006: 39-40).

74 “...la capilla de San Gregorio, aneja en tiempos pretéritos al edificio-fortaleza, que sobre un espolón rocoso se alzaba como avanzada inexpugnable de la muralla. Solar de los Ibáñez de Segovia, convento después y años ha transformado en Matadero municipal" (Vera y de la Torre, 1950: 461).
} 
Los lienzos están muy transformados por la apertura de numerosos huecos para su adaptación, primero a matadero municipal, (AMS: 811-8) luego la restauración realizada en 1974 (IPCE: PI 611-06) y por último su conversión a museo (AGA: 26/01830). ${ }^{75}$

La T80 tiene un escalón resaltando el zócalo que se realiza en sillería, la cual también continua, por encima de dicho escalón, hasta 12 hiladas de piezas bastante regulares de 40 centímetros de altura. Se ejecuta todo ello en piedra sedimentaria aunque apreciamos algún sillar granítico en la primera hilada, que está prácticamente enterrada, por lo que no se ve el apoyo en la roca. Sobre esta sillería se eleva el resto de la torre en mampostería desconcertada, reforzando con sillares las esquinas. Actualmente el adarve se emplea como terraza privada. Dispone de peto sin almenado.

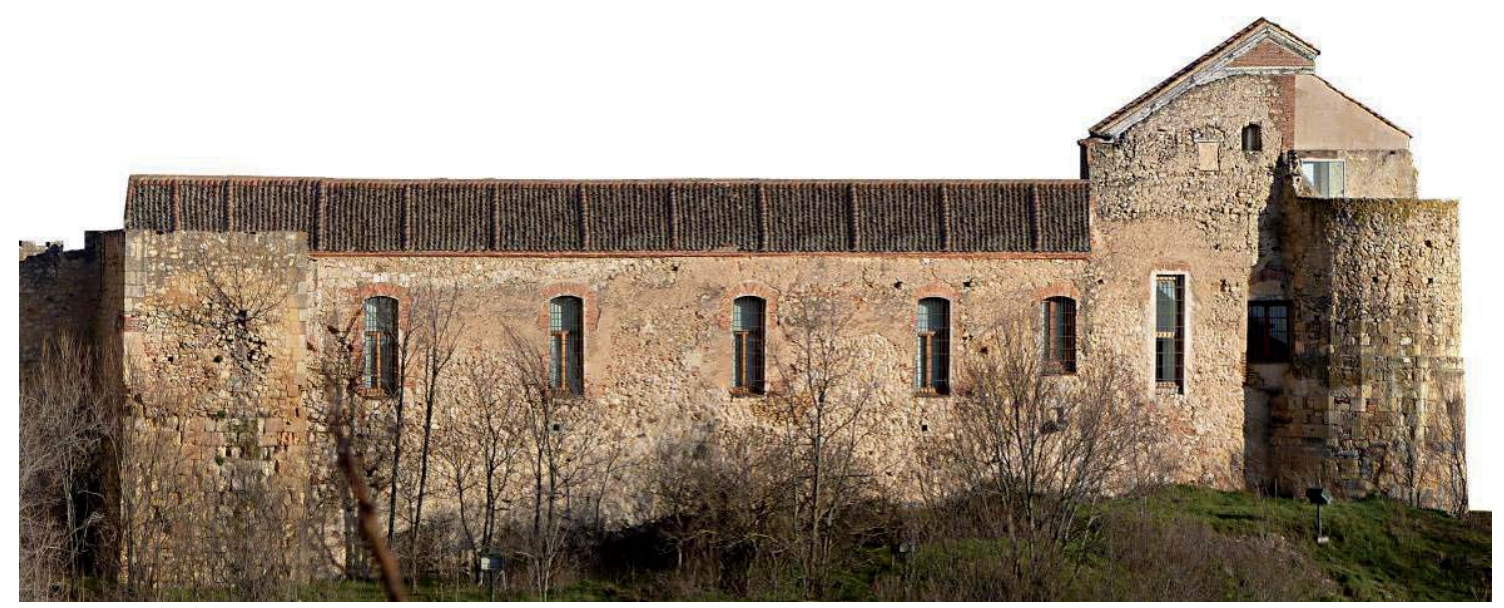

Figura 3. 120: Lienzo L80-81. Alzado oeste hacia el Alcázar del actual museo de Segovia.

En el L80-81, el edificio del museo se ha elevado sobre el lienzo de la muralla. Con la ampliación se han abierto varias ventanas recercadas en ladrillo. Todo ello da la impresión de estar muy reparado, detectando mucha mezcla de distintos tipos de piedra, especialmente en partes altas, canto rodado, granitos, sedimentarias e incluso ladrillo. Abundan los parcheados, rejuntados y reparaciones con distintos morteros. El zócalo está nivelado por una de una hilada de piezas de granito, que en algunos puntos se disponen intencionadamente a tizón. En los paramentos encontramos algunos agujales ordenados, pero nos faltan muchos para poder modular el lienzo por completo.

Por el interior del Museo, observamos en algunas de las aberturas para las ventanas, el espesor de los muros, confirmándonos que se trata de la muralla original. Medimos alrededor de 2 metros de espesor.

Hay que destacar la existencia de unos extraños huecos, compuestos por dos tejas, aparentemente mirillas de vigilancia, aparentemente realizadas simultáneamente con el muro en el que están ubicadas, en cuyo análisis profundizaremos en el apartado 4.1.12.

\footnotetext{
75 Además del proyecto inicial de Manuel Manzano-Monis también se conservan los numerosos modificados que se redactaron durante el proceso de las obras (AGA: 26/01700; 26/01828; 26/01829; 26/01731 y 26/01832).
} 


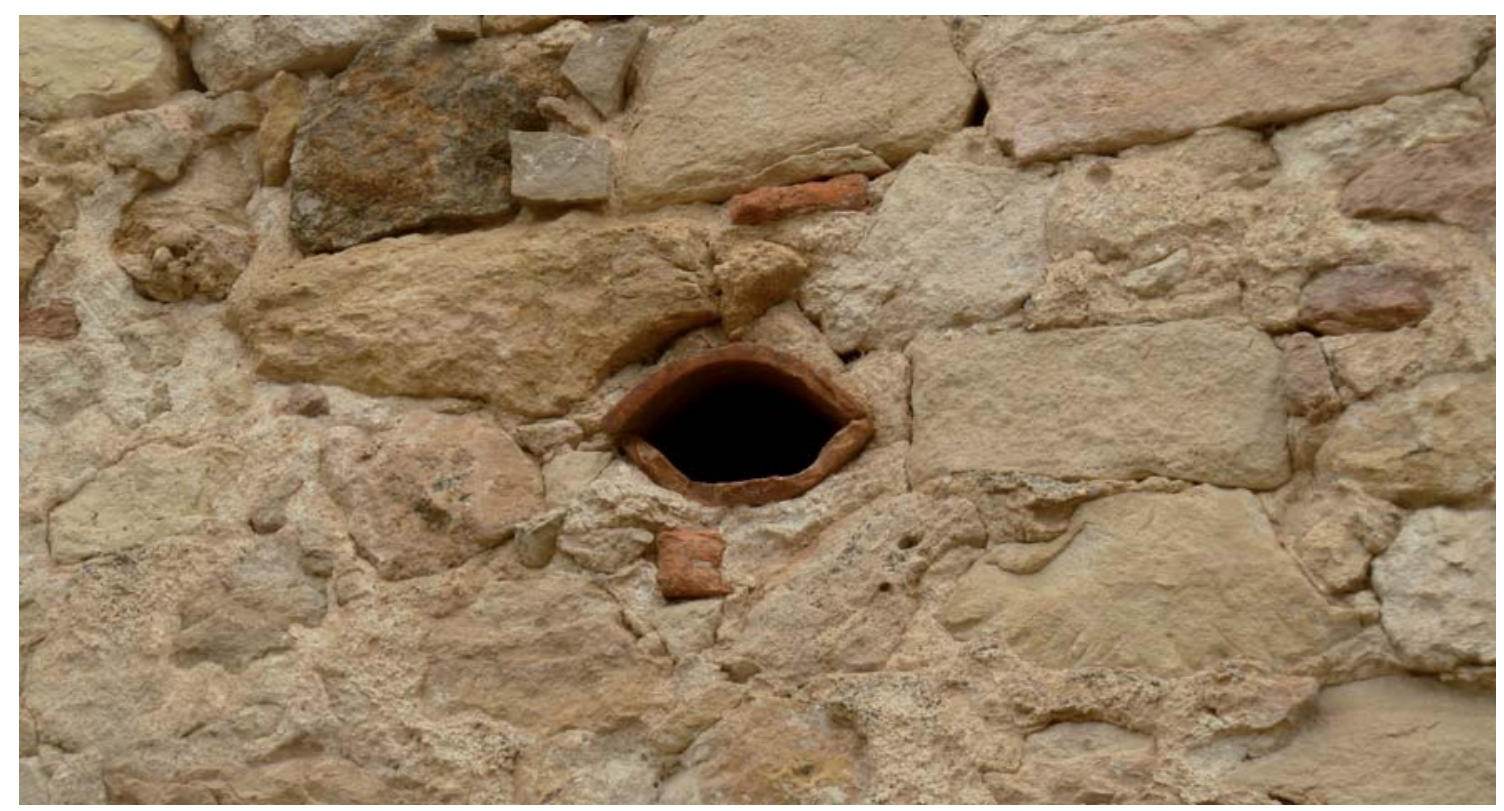

Figura 3. 121: Lienzo L80-81. Extraño elemento, posible mirilla realizada con dos tejas, cuya función original desconocemos. Este elemento sólo lo hemos encontrado en otros dos edificios de la ciudad, la Casa Cadenas y el antiguo Palacio de Don Alimán, ambas reconocidas casas fuertes.

La T81 presenta un zócalo semicircular en contacto con el terreno realizado con grandes piezas de granito, bastante regulares, que en algún caso podría calificarse como sillería. Consta de hasta cuatro hiladas, más estrechas las dos últimas, generando una línea de nivelación, donde cambia la forma y el aparejo de la torre. Sobre ello apoya una torre de planta poligonal, con aparejo organizado en hiladas perfectamente regulares, que resuelven las esquinas con sillares tallados expresamente y el paño plano de las caras se cuaja con mampostería, adaptándose a las hiladas definidas por los sillares esquineros. Tras un escalón, continúan cuatro nuevas hiladas con el mismo aparejo, si bien estas hiladas son de menor altura. La parte superior se corona con una fábrica de mampostería desconcertada muy menuda, en la que aparecen algunos mechinales o agujales, hasta el peto, que no tiene almenado. El adarve se emplea como terraza vinculada al museo.

El L81-82 está protagonizado por el edificio del museo que se aloja dentro del saliente de muralla que ocupa el espolón rocoso. Caracterizado por la puerta y las dos ventanas en planta baja y otras tres bajo el alero que se han abierto en él para adaptarlo a edificio, su zócalo, a base de piezas de tamaño medio de granito, esta aparejado sin voluntad de nivelar una línea de apoyo de la mampostería.

En la mampostería desconcertada apreciamos numerosos retoques y rejuntados, piedra muy menuda, mayoritariamente sedimentaria y con abundante ladrillo, recercando todos los huecos y parcheando desperfectos. En el lateral junto a la T80, vemos una tongada de mortero de nivelación, lo que nos hace pensar que podría tratarse de una fábrica encofrada. La parte superior, queda oculta por el revoco. En planta baja, junto a la torre T80, descubrimos la existencia de otra pequeña ventana recercada en ladrillo que se ha tabicado posteriormente, para abrir la ventana actual, ligeramente desplazada. 

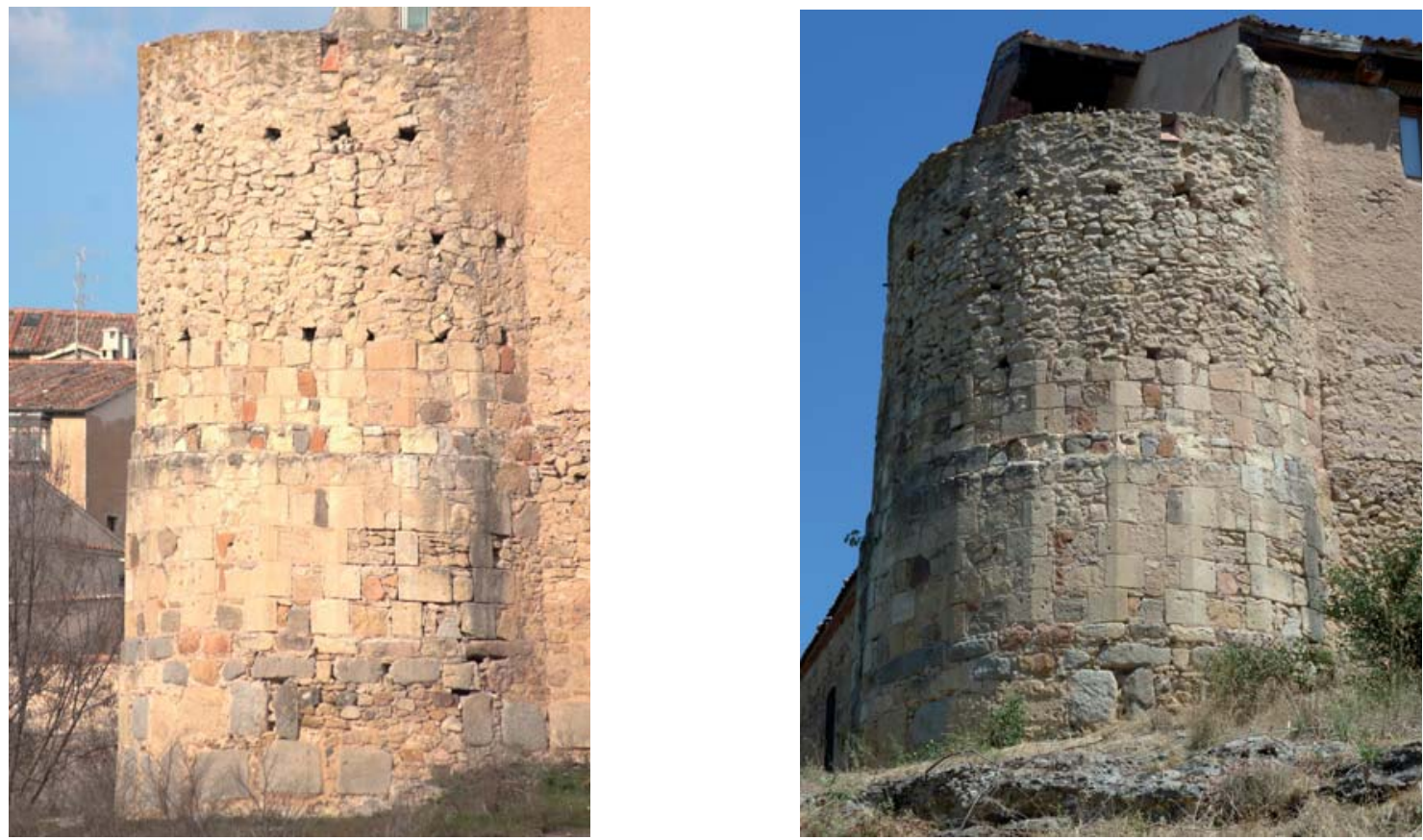

Figura 3. 122: Torre T81. Superposición de sistemas constructivos y aparejos, que evidencian diferentes recrecidos de la torre.

Figura 3. 123: Torre T81. Se aprecia el zócalo semicircular, el cuerpo de trazado poligonal con las esquinas de sillares y en la parte superior rematado por una mampostería en la que distinguimos tres líneas de posibles agujales.

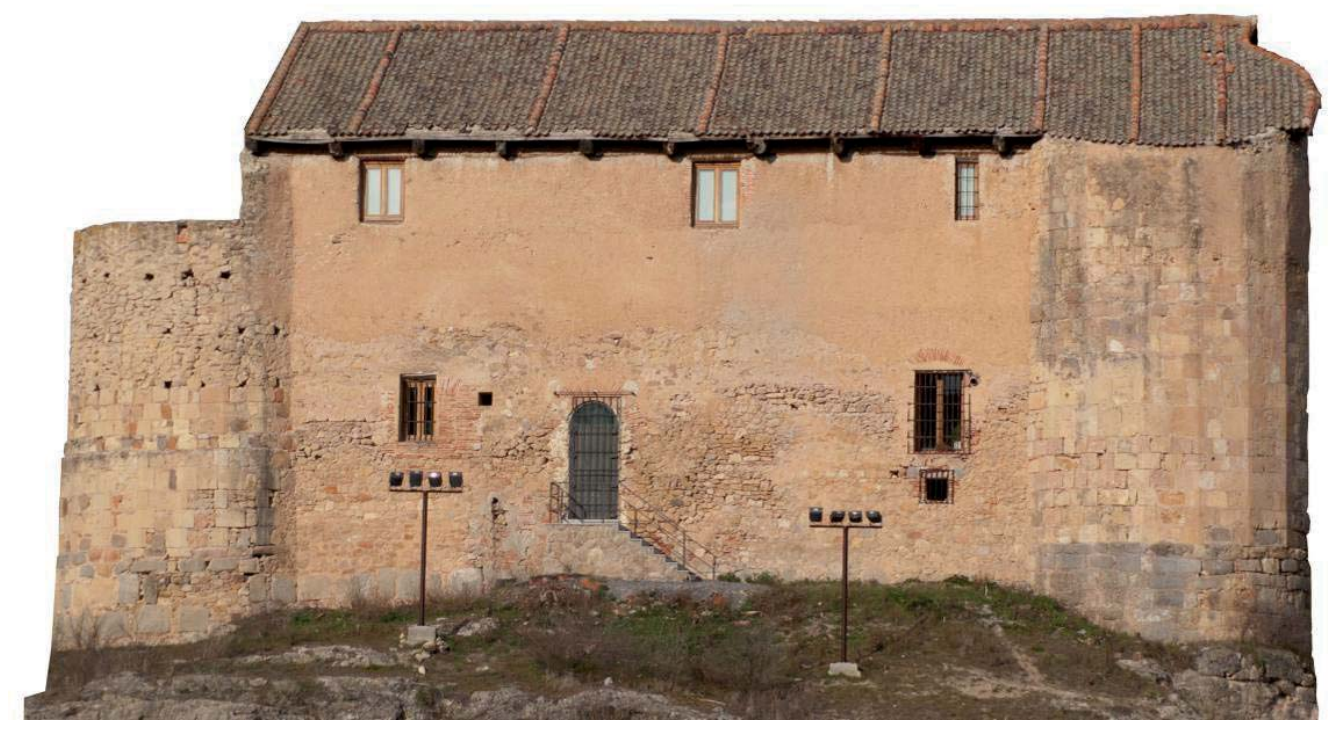

Figura 3. 124: Lienzo 81-82. Alzado sur del actual museo hacia el Pinarillo.

La T82 presenta un zócalo de forma semicircular realizado con sillería a soga mayoritariamente de granito, organizada en hiladas niveladas. Ambos extremos de la torre están bien aparejados mientras en el centro resalta la mezcla de materiales y de piezas calzadas con abundante ripio. La última hilada, más estrecha, resuelve la transición hacia el resto de la torre, ya de trazado poligonal, en la que conviven varios aparejos. El primero consta de seis hiladas de sillería sedimentaria de tamaño pequeño medio, bien aparejadas, 
aunque abundan los ripios de pequeño tamaño para ajustar las piezas. A continuación tres hiladas de mayor altura, a base de sillares resolviendo las esquinas del polígono, mientras el relleno de los paños entre sillares se efectúa con mampostería, que se adapta a las hiladas definidas por los sillares esquineros. Sobre ello, otra vez sillería, de tamaño medio-pequeño, casi hasta la cubierta en uno de los lados y el resto revocado. Hay que destacar que la sillería de las torres se adosa al lienzo, por lo que su aparejo en posterior al de los lienzos.

La cubierta da continuidad al faldón del edificio, por lo que la torre presenta un alzado lateral rematado por un paño inclinado, teniendo un recrecido hacia el interior para alcanzar la altura del edificio.

En todo el conjunto distinguimos numerosas piezas reutilizadas, tanto en el zócalo de granito como entre los sillares de sedimentaria. Sin embargo los sillares que resuelven las esquinas de la parte poligonal, aparentemente están tallados ex profeso.

En el L82-83 el edificio del museo asoma por encima del lienzo en la zona más cercana a la T82, donde se ha abierto una ventana en la planta baja y tres en la parte alta que parecen aprovechar el almenado, disponiéndose muy seguidas rítmicamente. En esta parte, el recrecido se realiza con ladrillo y mampostería muy menuda, mientras el lienzo sobre el que apoya se haya revocado, ocultándonos su técnica constructiva. En el resto del lienzo, sobre una hilada de piezas de granito, a modo de zócalo diferenciado, distinguimos una fábrica encofrada con 6 líneas de agujales muy ordenados, que nos permite obtener la modulación de las tapias. En la parte alta, se distingue un recrecido, claramente diferenciable por el cambio de piedra, utilizándose una más blanca. Todo el remate almenado esta reconstruido en las restauraciones de los años 70 (AGA: 70.792).

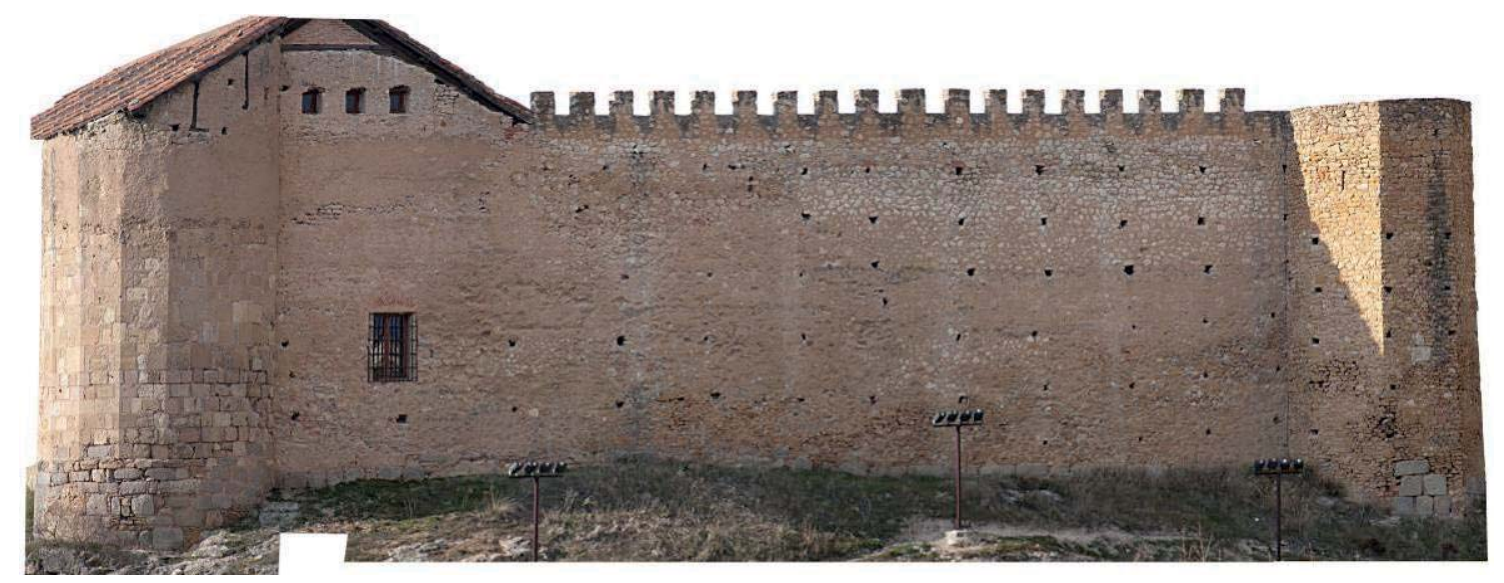

Figura 3. 125: Lienzo 82-83. Alzado este del actual museo hacia la Hontanilla.

La T83 posee un curioso trazado pentagonal, que es un caso único en la muralla segoviana, tanto por el número de lados como por el aparejo de mampostería concertada en lajas. Aparecen agujales modulando los paños en todas las caras, separados aproximadamente 1,50 metros en vertical. Toda la torre muestra una gran uniformidad en sus paramentos, evidencia de que se ha efectuado en una única intervención, a la vez que se encuentra muy bien conservada, en la que no se han realizado reparaciones, haciéndonos sospechar que pueda tratarse de una reconstrucción total relativamente reciente. En la base de sus 3 caras frontales se conservan algunos sillares reutilizados de lo que debió ser la torre original. En el resto de la torre la mampostería de lajas apoya en el suelo. 
El L83-84 presenta las mismas evidencias de haber sido restaurado recientemente. Todo el lienzo presenta un tratamiento muy uniforme y junto a la torre T83 la reparación deja visto un hueco en el que no se ha repuesto la hoja exterior del lienzo, por lo que se aprecia el relleno interior de la muralla, posiblemente el estado en que se encontraba este paño antes de la restauración. En el límite de ese hueco, la muralla hace un pequeño quiebro en que el lienzo cambia de plano, remetiéndose y disminuyendo el espesor. Se conservan algunos agujales muy ordenados, que denotan la realidad constructiva de la fábrica primigenia.

La T84 es una torre de planta rectangular en que se conserva un zócalo de sillería sedimentaria en la parte inferior de su frontal. Sobre ella se ha efectuado la reconstrucción de la volumetría mediante una fábrica de ladrillo que está marcando, aparentemente, la modulación de la sillería pretérita, al menos las alturas de hilada, de la que se conservan algunos sillares muy deteriorados. El zócalo se diferencia mediante un escalonado, transición que se remarca con el cambio de material. Así el conjunto está completamente renovado, salvo los sillares que se han preservado envueltos por la fábrica de ladrillo. Zócalo de sillería y cuerpo de la torre en ladrillo, creemos que recubren los restos de la torre anterior.

El L84-85, presenta la habitual mampostería desconcertada y a pesar de tener partes que parecen reconstruidas y con muchas reparaciones se conservan numerosos agujales con un orden muy claro, que nos permiten interpretar la modulación de la fábrica encofrada. Sobre el lienzo se apoyan los edificios de viviendas, utilizando el adarve no construido como terraza privada. En el lienzo detectamos un quiebro vertical que posiblemente indica distintas reconstrucciones o fases de reparación.
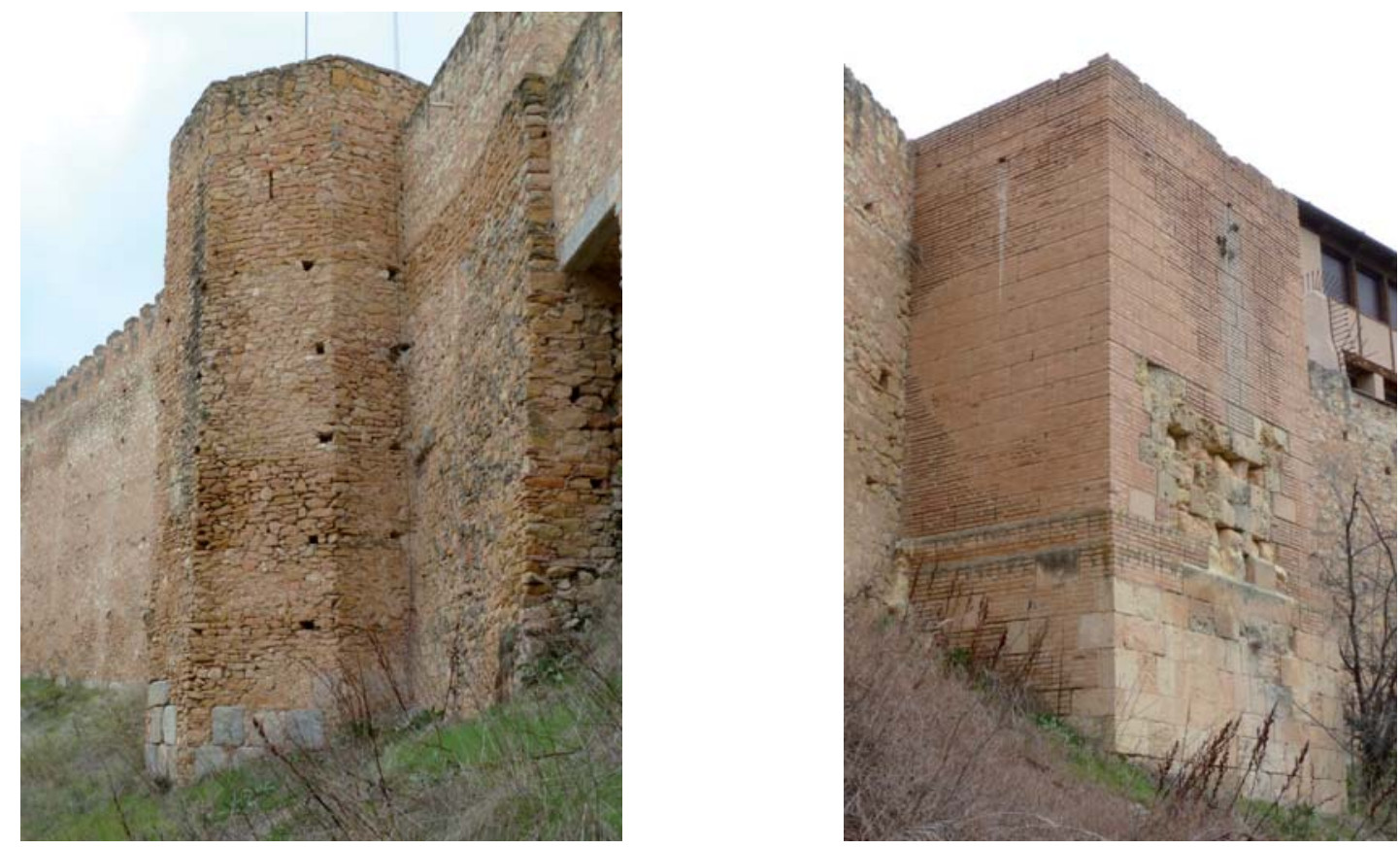

Figura 3. 126: Torre T83. Fábrica de mampostería concertada en lajas, en una torre pentagonal. Dos singularidades, excepciones que no se repiten en la muralla segoviana.

Figura 3. 127: La torre T84, sobre un zócalo de sillería sedimentaria, ha sido reconstruida en ladrillo, conservando lo que aparentemente sería las alturas de hilada de la sillería original. 
La T85 es una torre de planta poligonal, sobre un zócalo de trazado semicircular. En su frontal, a media altura, presenta un aparejo de sillería sedimentaria que no continua en los laterales y que denominamos aparejo colgado. En parte superior, el diámetro de la torre se reduce, adquiriendo una especie de forma troncocónica, que muestra una mampostería desconcertada. El aparejo de sillería lo consideramos una reconstrucción devolviendo la cara exterior a una torre derruida, mediante un chapado de sillería. En su frontal y en sus proximidades detectamos la roca tallada en corte vertical. En su apoyo la roca se ha tallado, dándola la forma semicircular del zócalo. La roca se adapta al trazado del zócalo de la torre que se ejecuta a base de sillares de granito reutilizados, que en algunos tramos presenta hasta tres hiladas bien concertadas, generando una rasante horizontal de nivelación. La última hilada de este zócalo es más estrecha que las anteriores. Parte del zócalo está enterrado, porque la primera hilada que vemos, está parcialmente oculta, por lo que puede existir otra por debajo.

El L85-86 está parcialmente reconstruido junto con la torre T86 en el siglo XX. Todo el lienzo presenta un tratamiento muy uniforme. Presenta muchos agujales con un orden muy claro. El adarve actualmente está utilizado como terraza de la vivienda intramuros. La roca se halla tallada verticalmente delante, en continuidad con lo visto en la T85.

La T86 está reconstruida, conjuntamente con las mitades de los lienzos adyacentes, correspondientes a la parcela intramuros. Vemos un aparejo de sillería sedimentaria, cortada a sierra, en el zócalo que se resalta con dos escalones. La sillería aún continúa 9 hiladas más por encima del segundo resalto. En la parte superior se realiza una mampostería desconcertada con sillares esquineros de la misma piedra que la sillería. El adarve esta privatizado como terraza. Se observa una hilada de sillares de granito reutilizados en contacto con terreno, parcialmente enterada.

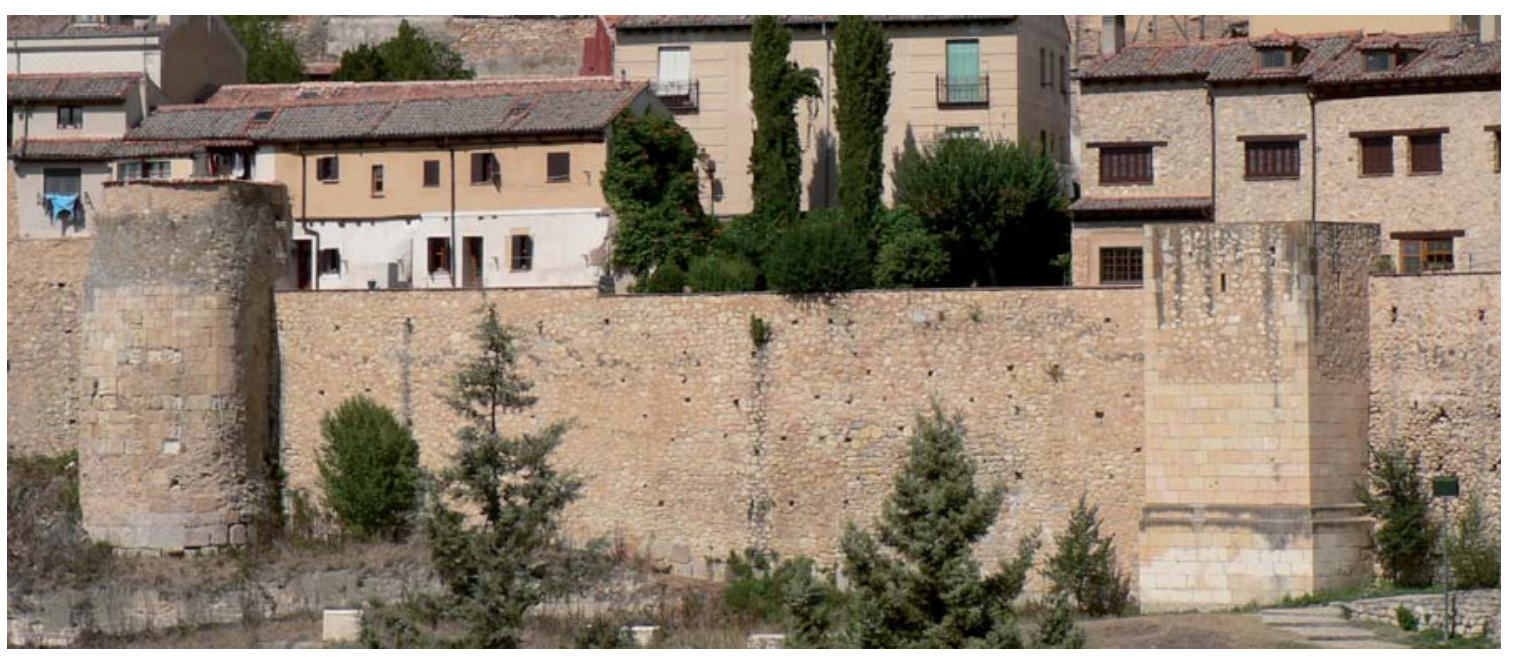

Figura 3. 128: Lienzo L85-86. A la izquierda vemos la T85, con la parte inferior en sillería, chapando resto de la torre previa. Es característico su remate troncocónico. A la derecha la T86, completamente reconstruida desde el zócalo. El lienzo intermedio denota la ejecución como fábrica encofrada por la pervivencia de numerosos agujales bastante ordenados.

El lienzo L85-86 es un lienzo completamente reconstruido en la primera década del XXI (PH: A0160). Como en otros casos, lo que aparentemente era una mampostería desconcertada, durante las obras quedó en evidencia que se trataba de una fábrica encofrada al descubrir varios agujales ordenados, con tongadas de nivelación distanciadas 
una altura de $120 \mathrm{~cm}$. En la parte central del lienzo se ha dejado abierto un hueco, posiblemente un antiguo desagüe, a través del cual se ve el relleno interior. En la base se detectó una hilada de sillares de granito de tamaño medio grande dispuestos a modo de zócalo diferenciado que separa la tapia encofrada del terreno y que actualmente ha vuelto a quedar enterrada.

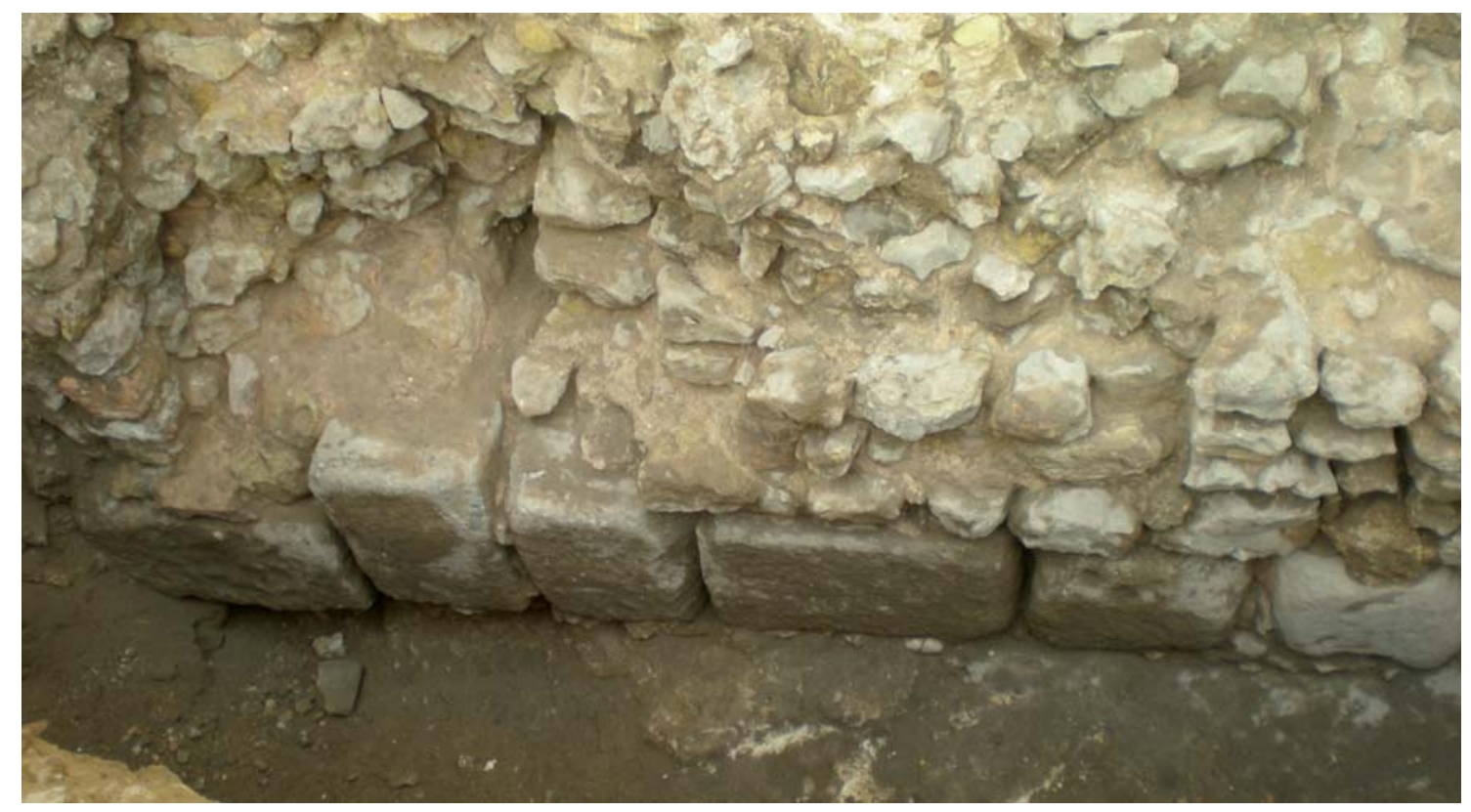

Figura 3. 129: Lienzo L85-86. Imagen del apoyo del lienzo sobre la roca, actualmente enterrado. Observamos la hilada de sillares de granito procedentes de expolio empleados para separar el muro de mampostería del contacto con el terreno. 

IV. ANÁLISIS ARQUITECTÓNICO Y CONSTRUCTIVO DE LAS MURALLAS 



\section{1. - ELEMENTOS DESAPARECIDOS Y VESTIGIOS DE DISCONTINUIDADES CONSTRUCTIVAS.}

Las discontinuidades materiales nos indican la interrupción por un corto lapso temporal del proceso de obra o bien la superposición de distintas etapas constructivas, generalmente separadas por una fase destructiva. La diferenciación de estos dos casos no siempre es clara y nos genera interrogantes. Los quiebros, cambios de dirección, líneas de rotura, en general las discontinuidades materiales en la fábrica, son pruebas patentes de un hito repentino en el devenir cotidiano o del proceso constructivo. Sin embargo, no todos los hitos históricos, no todas las evidencias materiales quedan reflejadas en forma de discontinuidad tan palpable, hay casos menos palmarios, como por ejemplo la métrica constructiva, la forma de distribución y la proporción en que los materiales se disponen a lo largo de la muralla.

La descripción exhaustiva del elemento a estudiar es el primer paso para volcar, de forma ordenada, la información del estado actual recogida en la toma de datos. No obstante este esfuerzo narrativo, en principio meramente objetivo, es consustancial con el planteamiento de diversos interrogantes, dudas y preguntas que surgen, cuando algo se sale de la lógica, de la síntesis mental que ineludiblemente va generándose a lo largo del proceso narrativo que se hace de la lectura del documento construido.

El cuestionarse dichas preguntas es sólo el primer paso del análisis con el que intentamos comprender la realidad y completar una información que la toma de datos nos ha aportado de forma fragmentada. La descripción deja de ser narrativa y comienza a ser analítica. 
En estos casos recurrir al análisis de la documentación histórica contenida en los archivos, tanto escrita como planimétrica, el estudio de las fotografías y grabados en que aparezca reflejado nuestro objeto de estudio, puede aportarnos una información valiosísima para el entendimiento de esa realidad parcial.

A la inversa, la observación de estos documentos en que se recoge la configuración de nuestra muralla en sus etapas pasadas nos aporta nuevas sospechas así como puntos clave, donde reiterar las visitas de toma de datos e indagar con mayor profundidad. La concatenación de datos obtenidos en una y otra dirección, de lo material a lo documental y a la inversa, es lo que nos permite avanzar en nuestro análisis. Nos va indicando por donde debe o puede continuar la investigación. Saber lo que se busca y donde puedo encontrarlo facilita enormemente el desarrollo de la misma.

No deja de ser un método heurístico, abandonando la mera descripción objetiva, ya que nos adentramos en el campo de la probabilidad y de las hipótesis, una continuación de la toma de datos, más intuitiva y subjetiva, podríamos decir descripción interpretativa, que nos permite completar de manera significativa los datos disponibles de nuestro punto de partida. La certeza nunca será absoluta, pero el cúmulo de indicios, sólidamente argumentados, al menos permitirá aumentar la probabilidad de que nuestras hipótesis sean ciertas.

\section{EVIDENCIAS DOCUMENTALES Y MATERIALES.}

Sin ninguna duda el primer documento gráfico de gran interés con que contamos para nuestro trabajo, son las dos vistas de Segovia que Wyngaerde realiza en 1562, que nos permiten ver un buen porcentaje del trazado de la muralla, con una exactitud y definición muy aceptables ${ }^{76}$.

Unos cien años más tarde, Meunier en 1666, si bien su definición no aporta tanta fiabilidad en los detalles, nos aporta la primera imagen de la puerta de Santiago con el piso superior construido y con la imagen actual de puerta torre con cubierta de teja. En otra imagen, nos facilita una vista de la proa del Alcázar.

El siguiente documento de interés es el plano que en 1837 elabora Antonio de la Iglesia con motivo de las guerras Carlistas, en el que parece realizar un inventario del estado de las defensas de la ciudad, dibujando expresamente las murallas, con sus torres. Sin embargo, hemos detectado varios errores ${ }^{77}$, por lo que a pesar de su indiscutible finalidad militar e

\footnotetext{
${ }^{76}$ Hay que aclarar que se toma algunas licencias gráficas, como es aumentar la altura de las torres urbanas, civiles y campanarios, son desproporcionadamente altas y dibuja todas las torres de la muralla más altas que los lienzos, lo cual puede ser otra licencia gráfica para distinguirlas o que realmente en origen, esto era así. Consideramos el plano totalmente fiable en la disposición y número de torres existentes en las distintas zonas, ya que cuando encontramos una contradicción entre lo dibujado y la realidad actual, al identificar el punto correctamente, una nueva visita nos permitía localizar las evidencias materiales que certifican la exactitud del dibujo. Por lo representado, vemos que en tiempos de Wyngaerde la vegetación era bastante escasa a los pies de la muralla y su observación debería ser mucho más nítida que en la actualidad. Aparentemente la forma de las torres reflejada en el dibujo es también fiable, por lo que hemos podido apreciar, en lo lienzos más próximos y frontales del dibujo. En los más lejanos, donde las torres se ven en escorzo, el dibujo esta necesariamente simplificado y no se diferencia entre torres semicirculares y rectangulares.

${ }^{77}$ Entre la puerta de San Martín y el postigo del Sol, dibuja una torre más de las que existen. Dibuja 7 torres, sin contar las dos de la puerta, cuando en la actualidad solo hay 6. En esa zona parece bastante improbable que se haya perdido una torre sin tener ninguna noticia al respecto. Tampoco encajan con la realidad actual el número de las torres que se representan entre el postigo de la luna y la puerta de San Martín, ni entre esta puerta y el acueducto. En el primer caso representa 7 y en el segundo 6, dos más de los que existen en la actualidad en cada
} 
interés por los elementos defensivos de la ciudad, creemos que debió elaborase con mucha urgencia y poca exactitud ${ }^{78}$. Aún así, nos aporta una planta de cómo se configuraba la puerta de San Juan y pruebas de la existencia de algunas torres que actualmente han desaparecido.

Otros planos, como el de Coello (1845) o el de Odriozola (1901), prestan poco interés por la muralla, siendo muy genéricos y a la vez, ya demasiado cercanos en el tiempo para aportarnos alguna revelación de interés. Gómez de Mora nos ofrece un detalladísimo plano de la planta del Alcázar en 1620. Por último, se conserva sólo una parte del plano atribuido a Góngora y datado hacia 1820, en el que apreciamos la mitad occidental del recinto amurallado, si bien su definición y calidad lo hacen poco fiable ${ }^{79}$.

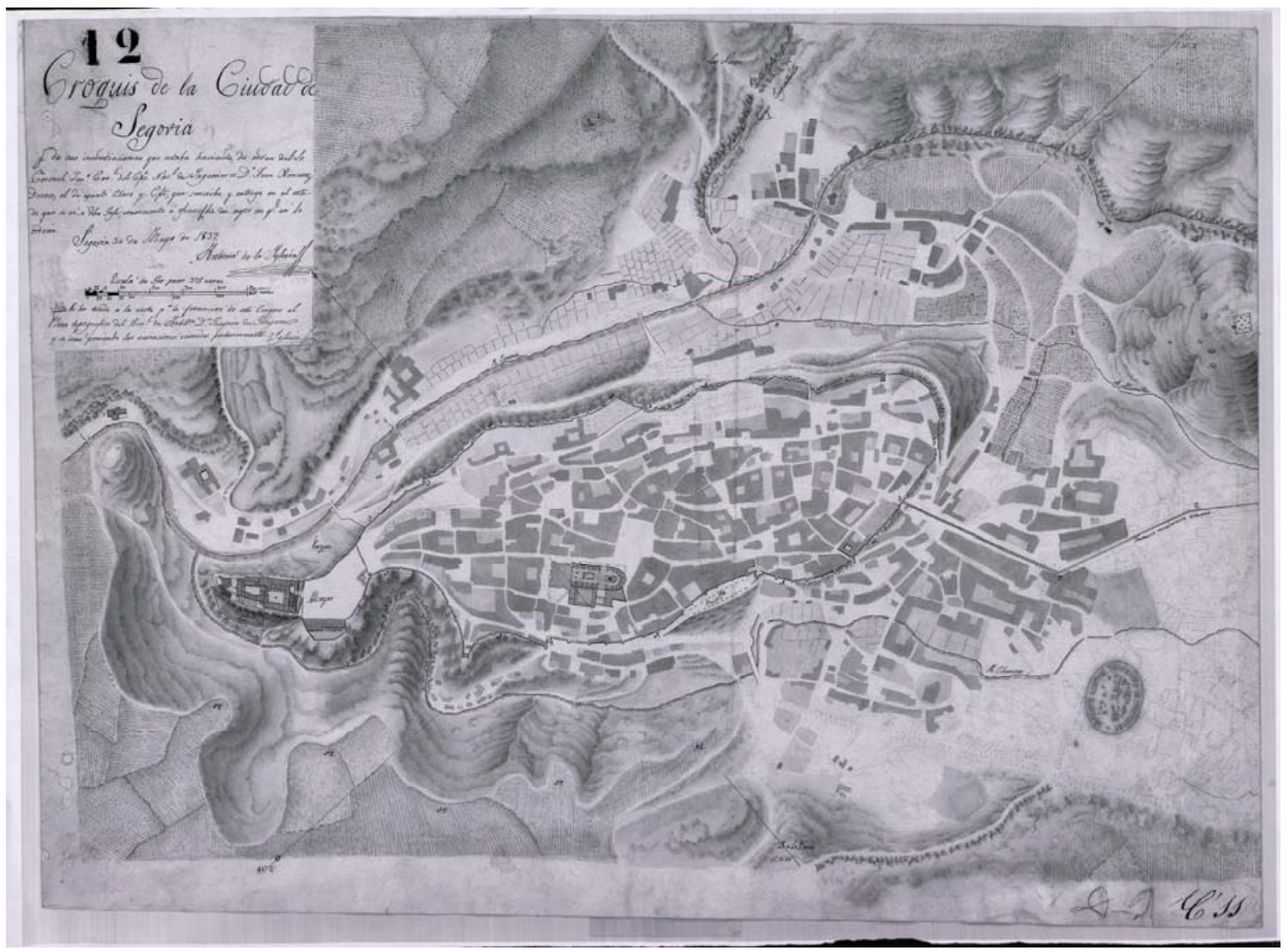

Figura 4.1.1: Plano de Antonio de la Iglesia, fechado en mayo de 1837. Fuente AMS.

uno de los tramos. Veremos que en estos casos, la diferencia tan abultada no es por un error del dibujante, sino que es correcto que han desaparecido torres en estos lienzos.

${ }^{78}$ Los errores son tan de bulto, que casi parezca que el plano se ha hecho desde el despacho, "de memoria" sin comprobar sobre el terreno la veracidad de los datos o que realmente pensase que la información (y la exactitud), era irrelevante para el armamento de la época.

${ }^{79} \mathrm{Al}$ igual que el plano de Antonio de la Iglesia, representa 7 torres entre la puerta de San Andrés y el postigo del Sol, una más de las que existen en la actualidad. Entre la verja del Alcázar y la casa del Sol aparecen grafiadas las mismas que hay en realidad, mientras entre este edificio y la puerta de San Andrés, no representa ninguna de las tres existentes actualmente y que sí se recogen en el plano de 1837. Por contra, entre el Alcázar y la puerta de Santiago vemos 4 torres conforme a la realidad, mientras en el plano de 1837 sólo figuran tres. 
Los grabados, imágenes y demás estampas que los distintos artistas y viajeros han dejado de la ciudad poseen una fiabilidad científica muy variable. A algunos como así como, Doré, Vivian, Guesdon, Roberts o Serra Basas, no podemos concederlos una gran credibilidad científica, aunque si muestran importantes detalles. Otros casos, como los dibujos de Avrial (1979) ${ }^{80}$ o la acuarela de Pérez de Castro de la puerta de San Martín nos aportan una imagen que consideramos bastante fidedigna de la realidad.

Por último, ya en los últimos 150 años, la fotografía nos da una información mucho más fidedigna, al ser una imagen no interpretada por el cartógrafo o el dibujante. Afortunadamente Segovia ha sido objeto de visita por numerosos fotógrafos, gracias al renombre de sus principales monumentos. Clifford, Tennison, Laurent, Hauser y Menet, Levy, Arcimis, Beer, Wunderlich, Moreno, García Mercadal, Loty, los Unturbe, entre otros, nos han sido de gran utilidad. El análisis de sus imágenes nos ha permitido comprobar apariciones, alteraciones y desapariciones de elementos. La comprobación in situ, tras el estudio de la documentación gráfica, ha orientado nuestra lectura del documento construido, para corroborar sospechas y ha contribuido a advertir detalles que en inspecciones previas no habíamos percibido o entendido; nos han ayudado a identificar los elementos desaparecidos y otras transformaciones que se han producido.

De esta manera hemos descubierto un total de 18 torres que actualmente están desaparecidas, 10 demostrado de manera fehaciente, que son la T13', 'T17', T21', T22', T24', T25, T25', T29, T30, T61 mientras que las otras 8, si bien no podemos demostrarlo de manera categórica si podemos considerar su posible existencia de manera hipotética. Estas son la T13', T26, T27, T28, T34, T52', T53, T54,

Del mismo modo hemos localizado varios postigos que estaban desaparecidos, como son el postigo picado y el de fuente cercada. El primero de ellos, ya identificado por Antonio Ruiz, hemos conseguido fotografiarlo, si bien creemos haber descubierto su ubicación original. Esta disposición es tan solo una hipótesis, al igual que el emplazamiento del postigo de fuente cercada. Estos hallazgos modifican la métrica de la muralla, lo que nos permite entender mucho mejor su lógica constructiva original, como veremos más adelante.

\section{ELEMENTOS DESAPARECIDOS Y DISCONTINUIDADES DE TRAZADO.}

Uno de los aspectos que van a interesarnos, son los quiebros y cambios de trazado de los lienzos, hechos excepcionales, ya que los cambios de dirección se efectúan de forma mayoritaria coincidiendo con la disposición de las torres. Es por ello que estas discontinuidades en el trazado de la muralla, que en numerosos casos hemos comprobado que constituyen cicatrices de antiguos derrumbes, evidencian la desaparición de torres y tramos de lienzos.

Normalmente los lienzos entre torres son rectos, ejecutándose los cambios de dirección en las torres. Esto es lógico si consideramos que la mayor parte de la muralla se ha ejecutado como tapia de calicanto encofrada ${ }^{81}$, por lo que la realización de cambios de dirección en mitad de un lienzo resulta una complicación innecesaria. Por otra parte, la métrica de la muralla,

\footnotetext{
${ }^{80}$ Las imágenes las realiza entre 1837, año en que llega a Segovia y 1840. El cuaderno de "Segovia Pintoresca" está fechado en 1843.

${ }^{81}$ Este aspecto lo trataremos más adelante, en el punto 5.2.5. Sistemas constructivos y fábricas.
} 
también ha resultado un importante aliado a la hora de identificar estas irregularidades geométricas y constructivas.

Cuando en un lienzo aparece un cambio de dirección, en los casos en que hemos encontrado pruebas, hemos identificado tres posibles causas que lo han motivado:

- Reaprovechamiento de restos previos, ya sea como cimiento (no visible) o como zócalo, visible.

- Derrumbe de la torre que ocultaba el cambio de dirección, tras el que se reconstruye el lienzo, pero no la torre.

- Adaptación estricta a la topografía del terreno. Aparentemente parece deberse a un derrumbe previo de la roca que obliga a reconstruir el lienzo sin margen de movimiento para poder plantear otro trazado.

Así encontramos quiebros en los lienzos, L8-9, junto al postigo del Sol; entre las torres T21, T22 y T23; en el L34-35, en el L38-39; en el L40-41, entre la T41 y la T44 coincidiendo con el entorno de la puerta de San Cebrián y en el L60-61.

Sintetizando, hemos identificado y localizado dos postigos que estaban desaparecidos, el de San Matías y el de la fuente cercada, tres probables casas fuertes, dos en la judería y la casa del Sol y hemos descubierto 21 posibles torres actualmente destruidas, cuya existencia está demostrada fehacientemente en 9 casos (T13'”, T17'”, T21', T22', T24', T29, T30, T34, T46') de los cuales sólo tres se reflejan en el plan Director, mientras en las otras 12 torres propuestas son sólo posibles hallazgos que no hemos podido demostrar de manera categórica (T13', T17', T18', T26, T27, T28, T28', T36', T52', T53, T54, T61) pero avanzamos algunas pistas tendentes a verificar la posibilidad de su existencia. De estas 21 torres, 11 ya se recogen en el Plan Director, siendo las otras 10 una aportación completamente novedosa, de las cuales 7 hemos podido demostrar de forma segura y 3 como propuestas posibles.

A continuación se muestran dos planos esquemáticos de la muralla en los que se representan todos estos elementos desaparecidos y de los cuales hemos descubierto algún indicio de su posible existencia previa y que vamos a exponer en los siguientes puntos. 


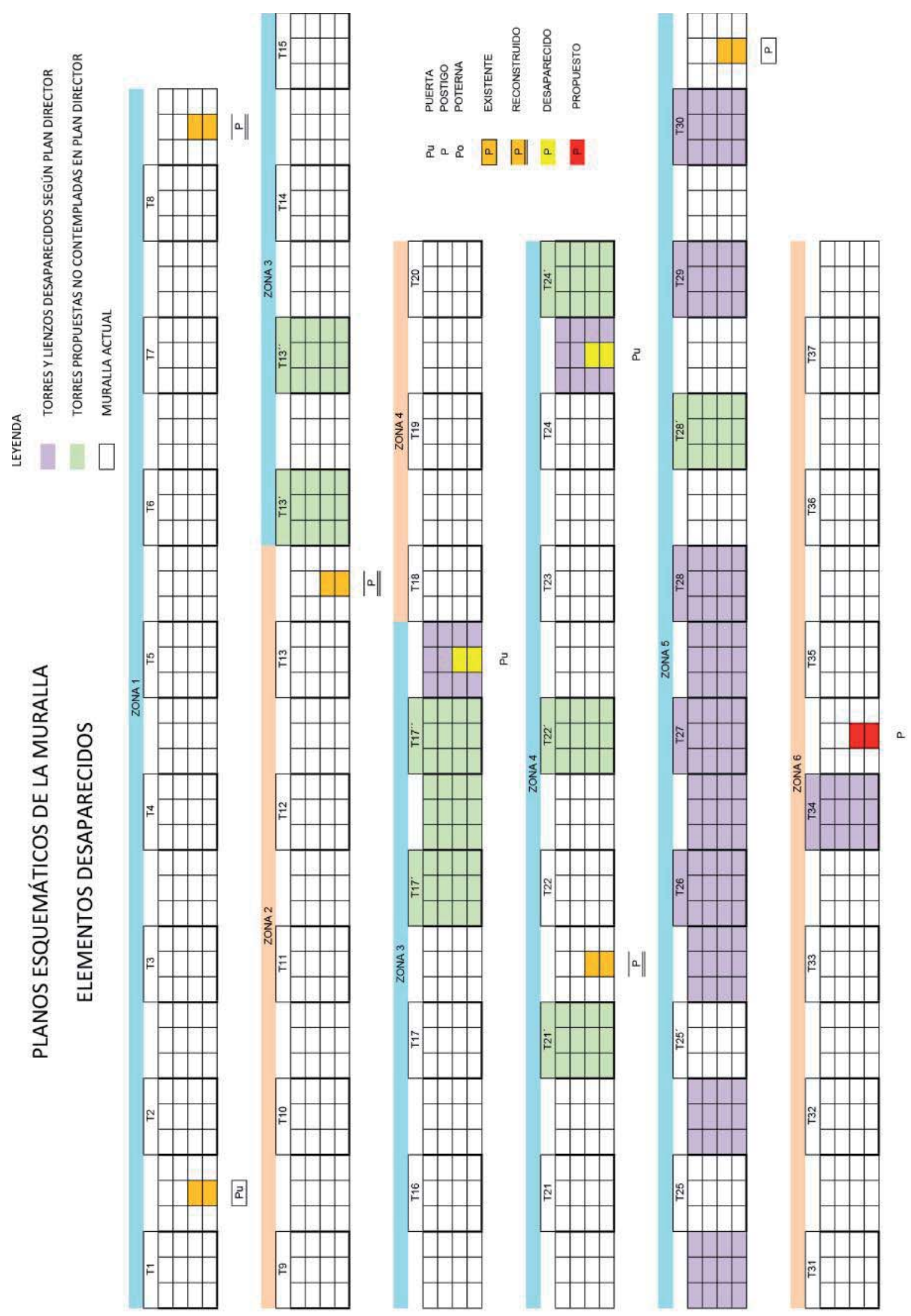

Figura 4.1. 2: Mapa esquemático de la muralla en que se señalan los elementos desaparecidos redescubiertos en esta tesis. 


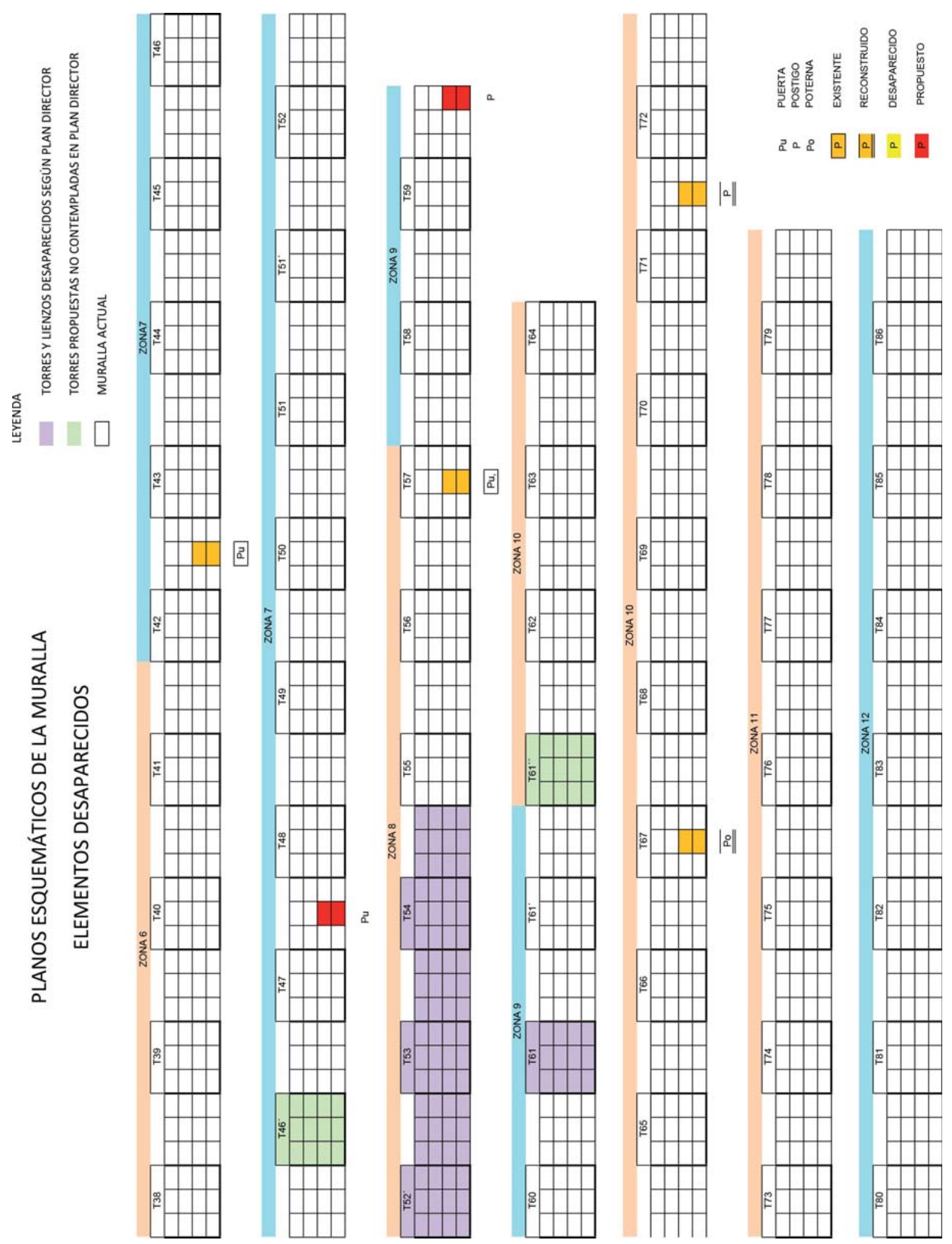

Figura 4.1. 3: Mapa esquemático de la muralla en que se señalan los elementos desaparecidos redescubiertos en esta tesis. 
Veamos estos elementos desaparecidos y estas discontinuidades constructivas de manera más pormenorizada que hemos identificado en cada tramo de muralla. En nuestra planimetría hemos corregido los errores que presentan las existentes, tanto del plan director de las murallas como del planeamiento municipal.

\subsubsection{CASA FUERTE TORREADA EN LA JUDERÍA.}

En el grabado de la vista sur de Wyngaerde apreciamos una torre elevada sobre la T5 que se adosa a una construcción apoyada en la muralla, sobre la que parece volar un cuerpo al otro lado de la torre y a cuyo margen grafía "Comendador de Segovia". Esto nos infunde la sospecha de que podría tratarse de una antigua casa fuerte, que se vincula o apoya en la muralla, en plena judería. Actualmente en ese espacio se sitúa la conocida como Casa de Castellarnau, cuya fachada a la muralla se haya completamente revocada ${ }^{82}$ y no nos quedan indicios materiales visibles de dicha posible casa fuerte.

\subsubsection{El Postigo del Sol y la CASA Fuerte de la FAMilia Coronel.}

Si observamos el postigo del sol $^{83}$ y su entorno en la vista del lado sur de Wyngaerde, hay tres detalles significativos que nos llaman la atención.

El más visible, es que la T8, presenta una altura mucho mayor que en la actualidad y se encuentra rematada por un cuerpo volado sobre un matacán corrido a lo largo de todo su perímetro, claramente poligonal. La torre está perfectamente dibujada de forma poligonal, tal y como la encontramos en la actualidad. La imagen tiene un marcado carácter militar. Esta torre ciertamente desmesurada para vigilar o reforzar un postigo, nos hace pensar que la configuración de la torre está motivada más por la casa que se encuentra adyacente que por la propia muralla. La casa era la de la familia Coronel, antigua Casa de Abraham Senneor, judío, uno de los personajes más influyentes en la Corte a finales de la Edad Media. La existencia de una fusilera en la esquina de la calle Sol con Judería Vieja, perteneciente al mismo edificio, evidencia la existencia de una casa fuerte vinculada a la muralla, propiedad del que fuera regidor en Segovia a finales del $\mathrm{XV}^{84}$.

El segundo hecho llamativo es el quiebro dibujado junto al postigo. De hecho, en el grabado se marca claramente la línea vertical y en la actualidad pasa desapercibido por el tratamiento dado a los lienzos a ambos lados, con un chaflán que absorbe esa discontinuidad, además de la completa reconstrucción del postigo.

En el postigo del Sol se produce una importante discontinuidad en el trazado de la muralla. La dirección que llevan los lienzos a un lado y otro de dicho postigo es diferente. El desfase es de aproximadamente un metro. La muralla hace un quiebro, la alineación no es continua.

\footnotetext{
82 En la fachada intramuros, apreciamos una fábrica de ladrillo con cajones de calicanto y dos escudos flanqueando la portada principal que está realizada con jambas y dintel de granito. La regularidad y dimensión de los huecos nos indican una importante transformación de la fachada.

83 También conocido como de los Coroneles o de la Judería, como ya se ha indicado.

${ }^{84}$ El Marqués de Lozoya incluye este edificio en su apartado de las casas fuertes torreadas de su obra dedicada a la casa segoviana. (Contreras y López de Ayala, 2010: 276)
} 

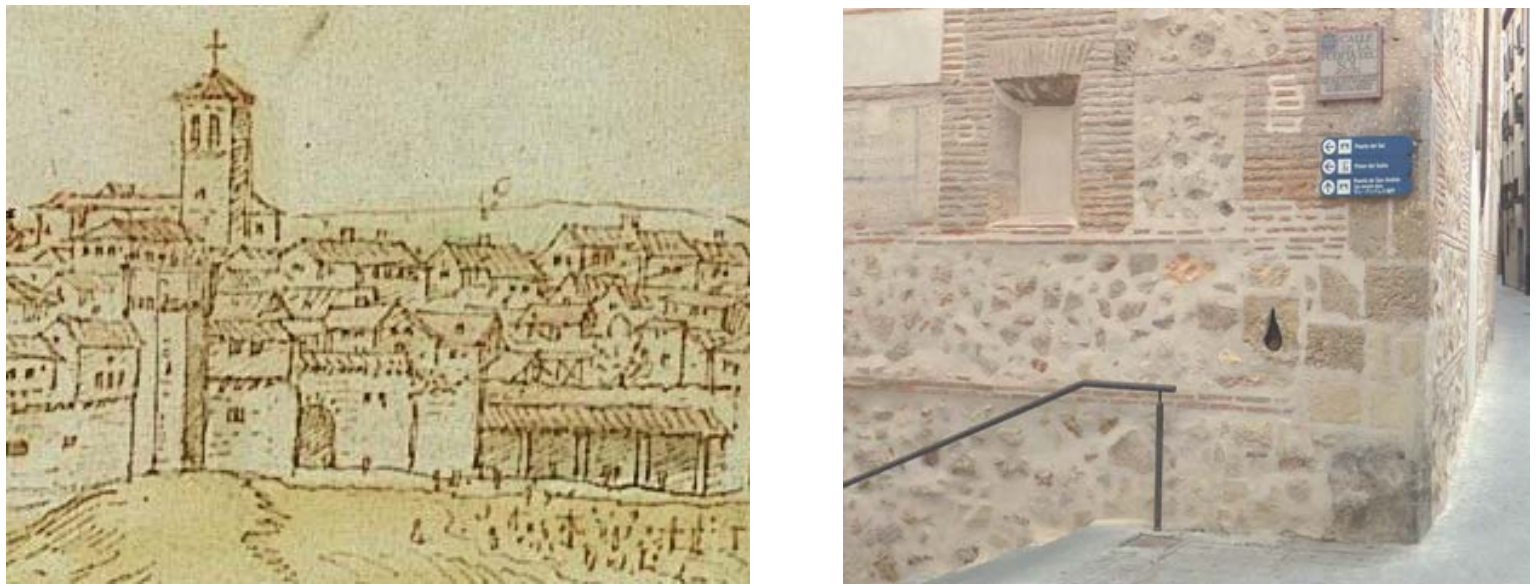

Figura 4.1. 4: A la izquierda., detalle de la vista sur de Wyngaerde donde se aprecia el postigo del sol, con la torre con matacán volado y el quiebro en el lienzo de la muralla justo enrasado con el postigo que separa las dos fábricas de técnica constructiva y modulaciones diferentes. Fuente: AMS.

Figura 4.1.5: A la derecha, fusilera en la esquina de las calles del Sol y Judería Vieja en el edificio, casa fuerte, que perteneció a la familia Coronel.

Nos parece bastante extraño para que esté justificado poliorcéticamente por la presencia del postigo, no ocurre nada similar en ningún postigo, ya que son simples arcos abiertos en el lienzo de la muralla. Tampoco podemos pensar en la alteración de los paños de la muralla con posterioridad por los edificios adyacentes, como queda demostrado en el siguiente párrafo. Pensamos que el quiebro nos denota una discontinuidad constructiva en la ejecución y comparando los paramentos a ambos lados, curiosamente separa dos frentes con técnicas constructivas completamente distintas y dos modulaciones diferentes (ver capítulo 4.2.5). Creemos que el postigo del Sol esconde una charnela donde se produce el encuentro entre dos murallas históricamente independientes.

El tercer detalle lo observamos al otro lado del postigo, en el L9-10. En la foto fechada en $1870^{85}$ (Sáez Laguna, 2009: 23), apreciamos una alineación de huecos en la parte alta, que inicialmente interpretamos como una especie de matacán corrido a lo largo del lienzo y de la torre T9, como si un cuerpo volado hubiese apoyado encima. Sin embargo en Wyngaerde observamos un tejadillo adosado delante de la muralla, que nos explica el significado de esa alineación de mechinales ${ }^{86}$. Esto nos confirma que el lienzo que vemos en la actualidad es el mismo que existía en 1870 y el del siglo XVI, por lo que no se ha producido un derrumbe y reconstrucción del mismo, al menos desde el siglo XVI. La torre T9 parece estar desmochada o parcialmente arruinada y el lienzo sin almenado. Las alineaciones de la muralla deben ser las originales.

\footnotetext{
${ }^{85}$ La conocida foto de la Sociedad Artístico Fotográfico se ha datado en torno al año 1870. Sin embargo, en ella observamos que ya está ejecutada la Bajada de la Canaleja y que ya no existe la puerta de San Martín, por lo que hay que retrasar su datación unos años, por lo menos posterior a 1883.

${ }^{86}$ Este tejadillo aún existe en 1789 “...porque arrimado a la muralla había un soportal para matadero del ganado lanar, que de allí se trasladó al edificio que hay junto al puente de Sancti Spíritus” (Laínez y Ortiz de Paz, 1964 : 324)
} 


\subsubsection{El Postigo de la Luna y la Alhóndiga}

Como ya se ha visto en la descripción del estado actual, en la fachada de la Alhóndiga que mira hacia la muralla se observa una alineación de ménsulas de granito que sugiere que, aparentemente, pudieron dar sustento a un cadahalso de madera que volaría sobre el adarve, lo que le confiere un carácter defensivo militar, al menos parcial, en algún momento de su historia, quizá anterior a ser la alhóndiga ${ }^{87}$.

Esta imagen nos la confirma la vista sur de Wyngaerde si identificamos como la Alhóndiga el edificio donde se produce el cambio de dirección en el trazado de la muralla y en cuyos lienzos vemos sendas secuencias de sombras, lo que parece ser, ventanas o matacanes de cuerpos edificados apoyados o volados sobre los lienzos a ambos lados.

El alzado de la muralla ha cambiado bastante en más de cuatro siglos, pero si identificamos con la T15, la torre que hace la esquina, donde se produce el giro de la muralla, observamos varios detalles. Ambos lienzos con construcciones encima serían el L14-15 y el L15-16. En el primero tenemos las ménsulas de granito sobre el muro de la alhóndiga que serían la pervivencia de esa construcción y en el segundo vemos en el lienzo actual un hueco, con una forma similar a la del antiguo edificio. Esa parte de lienzo ha desaparecido. Por otra parte, existiría una torre entre el postigo de la Luna y la primera torre vinculada a la Alhóndiga. Existiría una torre T13", algo que tampoco nos extraña ya que ese lienzo es atípicamente largo. En este momento está muy alterado con la construcción del hotel las Sirenas, todo el lienzo rejuntado tapando mucho la piedra con un tratamiento muy uniforme, por lo que en los paramentos no es posible intuir si esa torre existió y donde se encontraría ${ }^{88}$. Sin embargo, comparando la imagen de Wyngaerde con la actual, (Ver Figura 4.1.6) aunque el punto desde el que se ha hecho la foto actual no coincide exactamente con el punto de vista usado en el dibujo de Wyngaerde ${ }^{89}$, en éste la torre T13" se sitúa en la vertical de la casa Eraso, debajo del torreón de Lozoya, por lo que en la imagen actual se encontraría aproximadamente casi en la vertical del extremo del actual hotel Las Sirenas.

Junto al Postigo de la Luna, observamos nuevamente una marcada línea vertical, no tan repasada como en el postigo del Sol, que parece querer marcarnos una discontinuidad. Sin embargo en este caso no encontramos ese diferente trazado en los lienzos actuales a ambos lados de dicha línea, tampoco los aparejos clarifican nada, al estar muy transformados. El espesor que se aprecia en los huecos abiertos en la parte baja del hotel, hacia las escaleras del Salón, parecen confirmar que observamos el espesor completo de la muralla completo. El lienzo aparentemente se conserva en todo su espesor, por lo que tampoco se ha producido un desfase o escalón en el trazado de la muralla, como hemos visto que ocurre en el postigo del Sol, aunque si se aprecia un ligero cambio de dirección en dos puntos. Uno parece coincidir

\footnotetext{
${ }^{87}$ Como se ha indicado, la alhóndiga se construye en el siglo XVI. Sin embargo este tipo de elementos defensivos son más habituales de cronologías más tempranas, hasta el siglo XIII-XIV y posteriormente se fueron sustituyendo por obras de piedra, si bien existen casos tan tardíos como la Calahorra en 1509 (Mora-Figueroa, 1996: 59-60). El caso segoviano podría ser otro ejemplo excepcionalmente tardío o quizá debemos considerar la posibilidad de que el muro en cuestión sea una preexistencia de un edificio de carácter militar anterior en el que tendría más sentido la construcción de un cadahalso que en una alhóndiga, en el siglo XVI.

${ }^{88}$ Como veremos más adelante, en el trazado de la muralla si es posible intuir la posición de esa torre.

${ }^{89}$ Hoy en día la vista desde la posición que está hecho el dibujo de Wyngaerde es imposible por la construcción del colegio de los Maristas. La foto se ha realizado desde el punto más próximo posible para minimizar la diferencia.
} 
con la posición de la torre detectada en el grabado de Wyngaerde. El otro es más cercano al postigo.

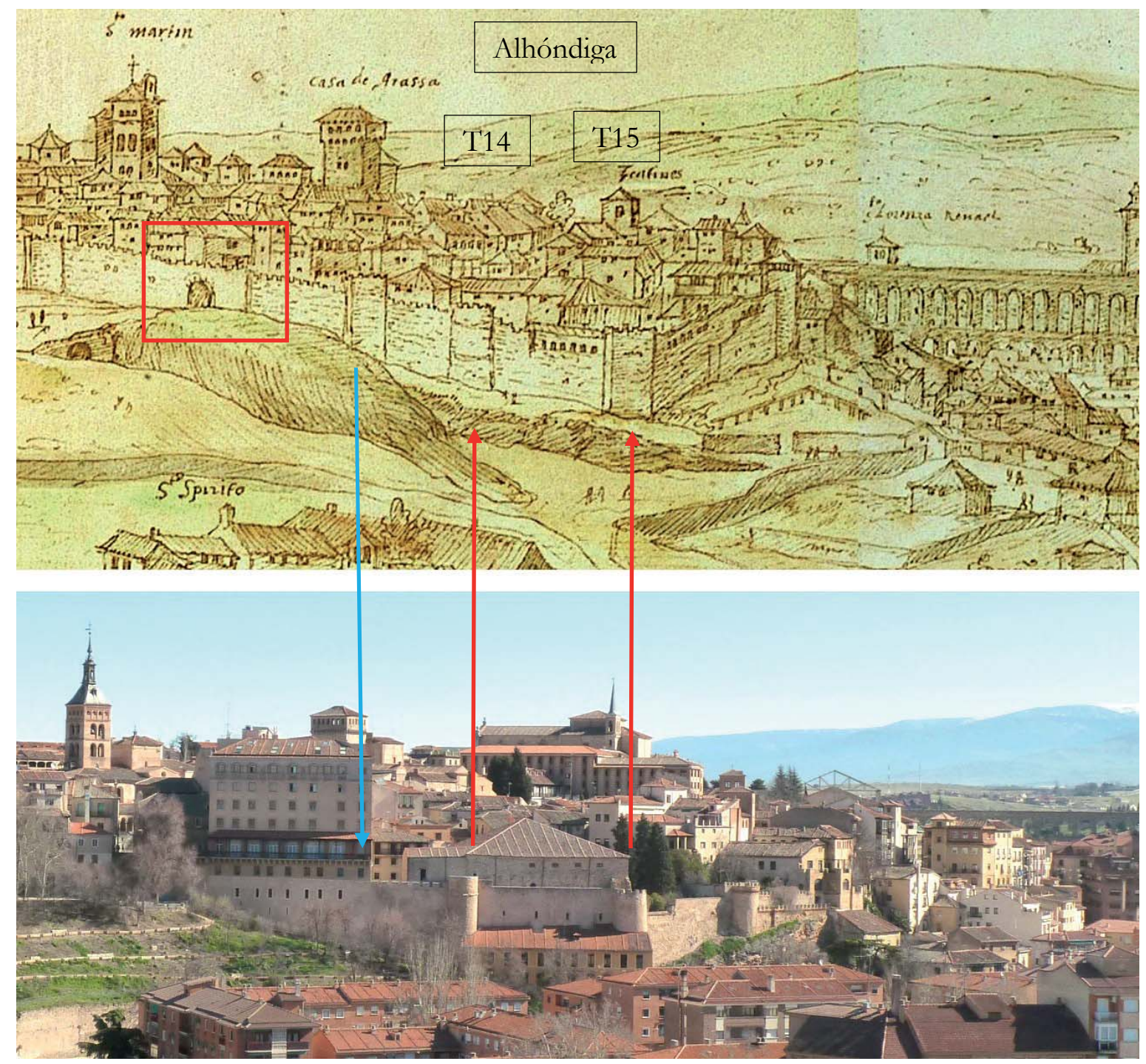

Figura 4.1.6: Comparativa en detalle entre la vista sur de Wyngaerde (Fuente: AMS) y el estado actual. Arriba: Apreciamos a la izquierda, dentro del recuadro rojo, una torre adyacente al postigo de la Luna, el edificio de la Alhóndiga entre las dos torres T14 y T15, el cambio de dirección de la muralla en esta última torre y la sucesión de elementos alineados en la parte alta de los lienzos a ambos lados de la T15. Comprobamos que existía otra torre adicional delante del actual emplazamiento del hotel las Sirenas, marcada con una flecha azul, y también ha desaparecido la torre adyacente al postigo, que se encuentra oculto por los arboles. La torre T15, donde se efectúa el giro de la muralla esta dibujada rectangular, mientras la otra torre que flanquea la Alhóndiga esta dibujada semicircular, levantada aparentemente sobre un zócalo rectangular. La torre T16, no existe en la imagen de Wyngaerde.

Si la línea que se aprecia en el grabado de Wyngaerde no era un resalto, otra alternativa quizá más factible, es pensar que falta un trazo en el dibujo y puede tratarse de la existencia de una segunda torre desaparecida, que estaría contigua al postigo, hipótesis que por métrica encaja perfectamente. Nos parece más verosímil la opción de que en el dibujo falta una línea y en ese 
punto existía una torre, la T13', que pensar que en ese punto hubo un quiebro que parece contradecir el trazado de la muralla que nos ha llegado. En este caso consideramos que esta torre T13', por el grafismo empleado, sería de trazado semicircular, ya que no representa el resalto en su lado derecho, que es donde debería verse por perspectiva, al igual que en las torres rectangulares próximas. Lo que representa es más bien una sombra, como en la T14, en la cual el grafismo es más evidente dado que refleja con forma redondeada los dos encintados de sillería que presenta la torre actualmente, indicando la voluntad de querer reflejar ese trazado circular.

Somos conscientes que en este caso, el dibujo de Wyngaerde no es una prueba tan irrefutable como en la T13". Entramos en el campo de la especulación, pero creemos que existieron dos torres, actualmente desaparecidas, entre la Alhóndiga y el postigo de la Luna, la T13'y la T13". No podemos demostrarlo de manera incontestable, pero es una posibilidad que tampoco hay que descartar. Sus posiciones vienen a coincidir con los dos puntos en los que en la actualidad observamos un ligero cambio de dirección en el lienzo atípicamente largo. Este cambio de dirección se hace patente en la cornisa que se genera para el balcón volado sobre la muralla del hotel las sirenas (Véase Figura 4.1.7). En ese punto aproximadamente, estimamos que se situaría la torre desaparecida T13“'. La T13'se situaría adyacente al postigo de la Luna, flanqueándolo, algo que como veremos en el apartado 4.2.7 es la disposición común en todos los postigos.

La torre T15, Wyngaerde la dibuja de planta rectangular, evidencia que aún pervive en su zócalo, prácticamente oculto actualmente por la edificación adosada delante y la vegetación. Se trata de una torre reconstruida en trazado semicircular, sobre los restos de la anterior que era rectangular. También podemos interpretar que en la torre T14, aparentemente marca un zócalo diferenciado, lo que parece sugerir que la parte de trazado semicircular apoya sobre los restos de otra torre previa de planta rectangular. Es una posibilidad que tampoco podemos pasar por alto.

En dirección contraria, hacia la puerta de San Martín, nos faltaría una torre, la T16, que es circular y hueca, lo que nos induce a pensar que es una reconstrucción posterior como ya vimos (STC: RH 225-1999-5) ${ }^{90}$ y que no existía en 1562. Puede que la forma que muestra en la actualidad, semicircular, no fuese la original, si es que llego a existir, que también podríamos dudarlo, aunque por métrica parece razonable la existencia de una torre en ese punto. Al fondo vemos la T17 con su adarve construido, ocupado al igual que hoy en día por una casa fuerte, la casa Fortaleza. Ya la vemos así en la foto de Moreno de 1900 (VVAA, 2006: 88).

Desde esta torre T17 hasta la posición que ocupaba la puerta de San Martín y la siguiente torre que se conserva, la T18, estimamos que hay unos 83 metros, distancia bastante considerable que nos induce a pensar que podría haber existido una torre T17'entre ambas, de la que no hemos encontrado ninguna huella. No hay manera de saber si existió. Quizá existan restos embebidos en la edificación, algún espacio macizo dentro de las viviendas. Es tan solo una posibilidad, que aquí apuntamos, que sólo un estudio en profundidad de los inmuebles afectados podría aclararnos.

\footnotetext{
${ }^{90}$ En una de las fotos del expediente se observa una puerta en la parte inferior de la torre, lo que nos induce a pensar que ésta es hueca y se utilizaba como escalera de comunicación entre el jardín superior en el adarve y la terraza inferior en la falsabraga. Dado que la falsabraga no existe en 1852, hay que pensar que todo el conjunto es una reconstrucción, posiblemente inventada.
} 


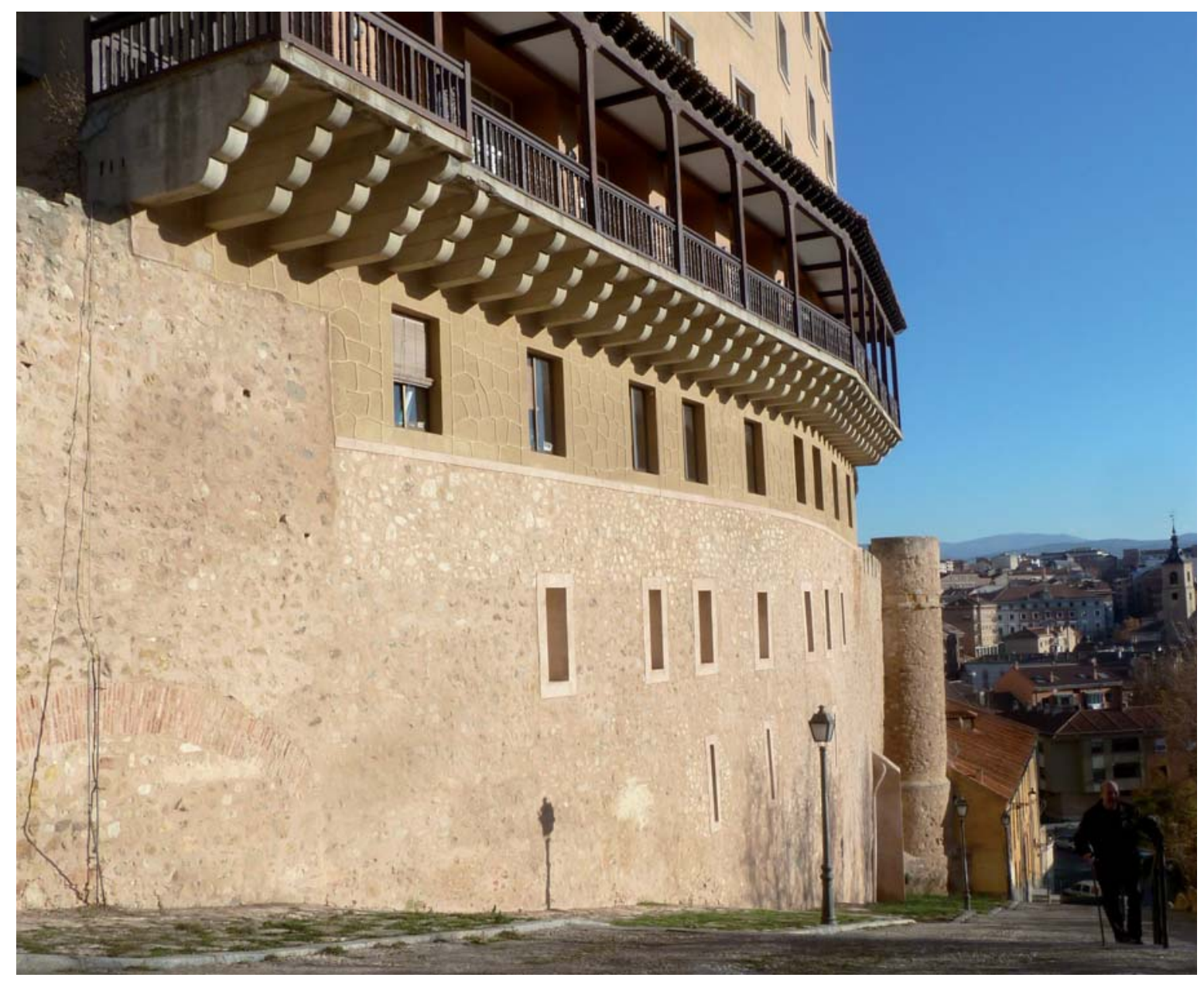

Figura 4.1.7: Imagen del lienzo entre el postigo de la luna y la torre T14, junto a la Alhóndiga. Obsérvese como el lienzo se curva ligeramente, algo que se evidencia con total claridad en la cornisa volada del hotel que apoya sobre la muralla. En ese punto aproximadamente, estimamos que se situaría la torre desaparecida T13". La otra torre, T13' se encontraría aproximadamente en el borde izquierdo de la imagen.

Así pues, recapitulando, ésta nos parece la hipótesis más probable. Teníamos sendas construcciones, ambas desaparecidas en la actualidad, una sobre el lienzo L14-15, vinculada a la Alhóndiga y otra en el L15-16 vinculada a la casa fuerte de la familia Cascales-Barros, o casa palacio del conde Alpuente. Por otra parte han desaparecido dos torres entre la Alhóndiga y el postigo de la Luna, que por métrica nos resulta razonable suponer su existencia, cuyo emplazamiento en el lienzo podemos estimar con bastante certeza, la T13' de planta semicircular y la T13" de planta rectangular. La T13'se situaba adyacente al postigo de la Luna, flanqueándolo, mientras la T13" la emplazamos en el punto en el que apreciamos el cambio de dirección del lienzo, evidenciado en la cornisa del hotel las Sirenas. La torre T15 actualmente semicircular, es una reconstrucción de una torre que originalmente era rectangular, tal y como vemos en su zócalo prácticamente oculto por la edificación adosada delante de él. En la T14, podría haber sucedido lo mismo, por lo que en origen podría haber sido también una torre de planta rectangular. La T16 es una reconstrucción y creemos que pudo existir una torre más, la T17', entre la T17 y la puerta de San Martín. 

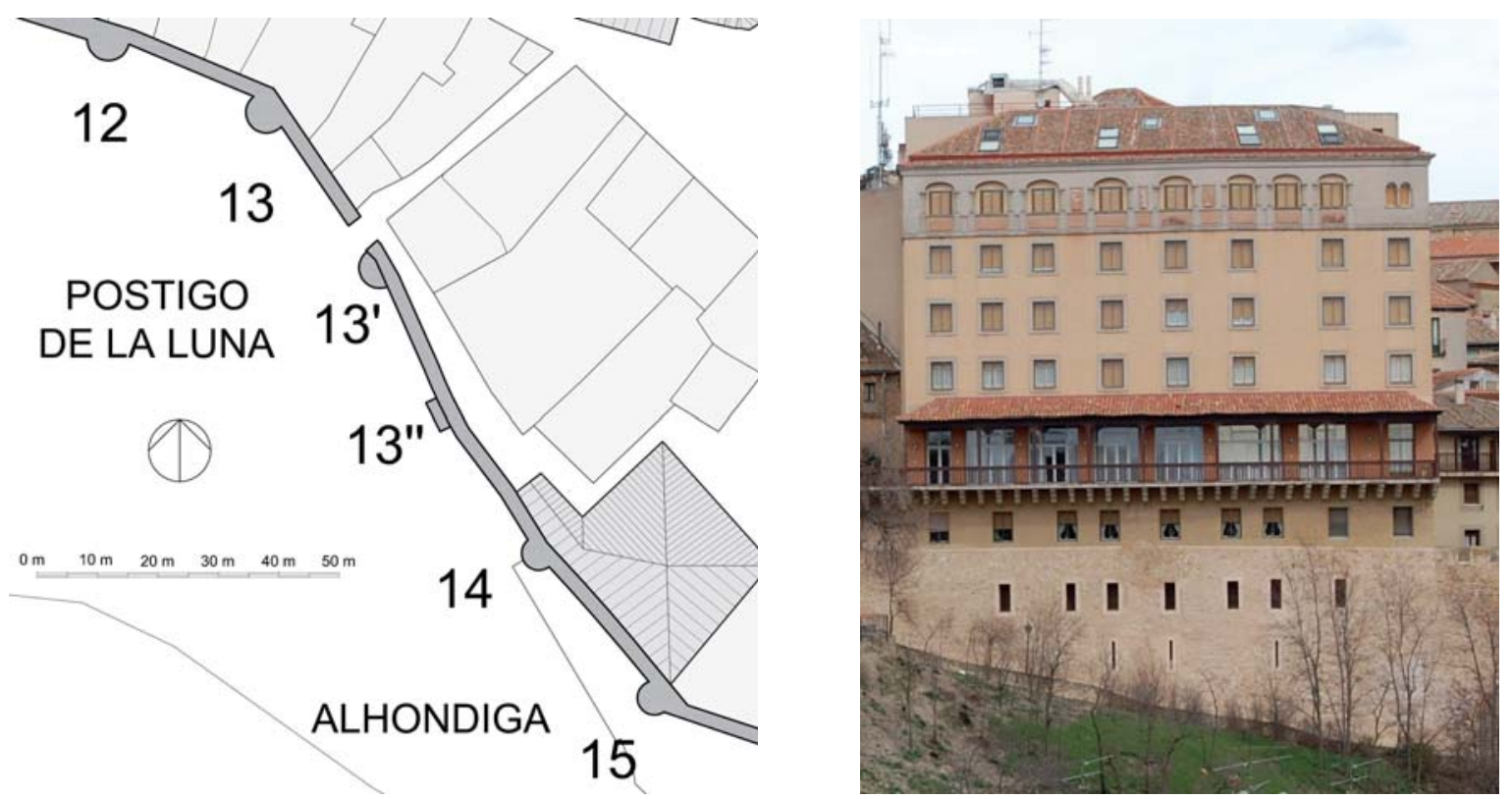

Figura 4.1.8: Plano de los lienzos cercanos al postigo de la Luna en los que se sitúan las dos torres, actualmente desaparecidas, T13' y T13" en su emplazamiento original.

Figura 4.1.9: Vista actual del lienzo sobre el que se apoya el hotel las Sirenas, donde se encontraban las torres desaparecidas, T13' y T13"'.

\subsubsection{La Puerta de San Martín o del azoguejo.}

La puerta de San Martín ${ }^{91}$ se demolió en 1883. Era una puerta de acceso directo, al igual que la de San Andrés, con la que tiene en común el mismo diseño defensivo, perpendicular a la línea de la muralla, con una torre poligonal adelantada, que hemos denominado T17". Un pasadizo elevado permitía cruzar por encima de la calle conectando la torre con la Casa de los Picos $^{92}$. En el pasadizo se ubicaba el cuerpo de guardia que comunicaba directamente con la Casa Fuerte que la reforzaba (AMS: 4810-3, I: 18). También alojó la llamada Cárcel de

\footnotetext{
${ }^{91}$ La puerta de San Martín se denominaba así por la cercana iglesia de San Martín. Era la puerta principal de la ciudad, por ella pasaba la Calle Real, muy transitada debido a que unía el Mercado Mayor con el Mercado Chico (Azoguejo), así como con los arrabales del lado sur, los más poblados y dinámicos. Por ella no sólo accedía la mayor parte de la población sino que también era paso obligado de reyes, nobles y cuantas visitas oficiales llegaban a la ciudad, siendo la puerta donde los monarcas de Castilla prestaban juramento antes de entrar en la ciudad. Estaba defendida al lado derecho por la casa fortificada de los Picos. Concebida como obstáculo para el progreso fue derribada a mediados del siglo XIX para ensanchar la calle de Juan Bravo. De ella sólo se conservan los Escudos que la decoraban. Había sobrevivido al devenir de los años a pesar de una amenaza de ruina en 1543, a un incendio que provocó grandes destrozos en una torre en 1701 y a continuos desprendimientos y remociones, en especial en el cuerpo alto o Cárcel de Caballeros. Finalmente, fue demolida en el siglo XIX, en el seno del movimiento "Abajo las murallas". Una de las causas de la demolición se remonta a la necesidad de realizar una alineación en la calle Cervantes (calle Real), que fue ensanchada y acondicionada, aprovechándose también para adecentar la cercana bajada de la Canaleja, un pasadizo lúgubre y oscuro, que había suscitado innumerables denuncias por parte de la prensa y la opinión pública por ser un espacio nocivo, insalubre y pestilente. A estas necesidades se le unió la propuesta de Joaquín Odriozola de conectar la estación de ferrocarril con el centro urbano, mediante la construcción de un viaducto de pilares de hormigón y estructura metálica, si bien finalmente nunca se llevaría a cabo. A pesar de que se encontrara cierta oposición a la demolición de la puerta, como por ejemplo por parte de Ezequiel González, la puerta desaparece, como consecuencia del proyecto de alineación de Odriozola para la calle Cervantes.

${ }_{2}$ Para mayor información sobre esta casa fuerte, Contreras y López de Ayala (2010: 275-276), Chaves Martín (2006: 123-124)
} 
Caballeros (Ruiz Hernando, 1994) ${ }^{93}$. Por la disposición de la calle, la subida se efectuaba a lo largo del lienzo de la muralla, que flanquea todo el recorrido con el refuerzo de que la última torre, la anterior a la puerta, está más próxima, por lo que ese lienzo T17-18 es más corto de lo habitual, sólo 21 metros, como en todos las puertas de la muralla. Así, el acceso, el espacio frente a la puerta quedaba flanqueado por el lienzo de muralla, la casa fuerte y la torre T18.

Exteriormente existían otras construcciones que completaban el conjunto defensivo de la puerta, además de la Casa de los Picos y la torre poligonal, un arco exterior almenado con otra puerta, de forma que entre ambos arcos se generaba una especie de patio intermedio similar a la puerta de Bisagra de Toledo (Ruiz Hernando, 1994: 473), en el que se situaba un fortín. Arco, fortín, torre poligonal y puerta de San Martín se demolieron en 1883.
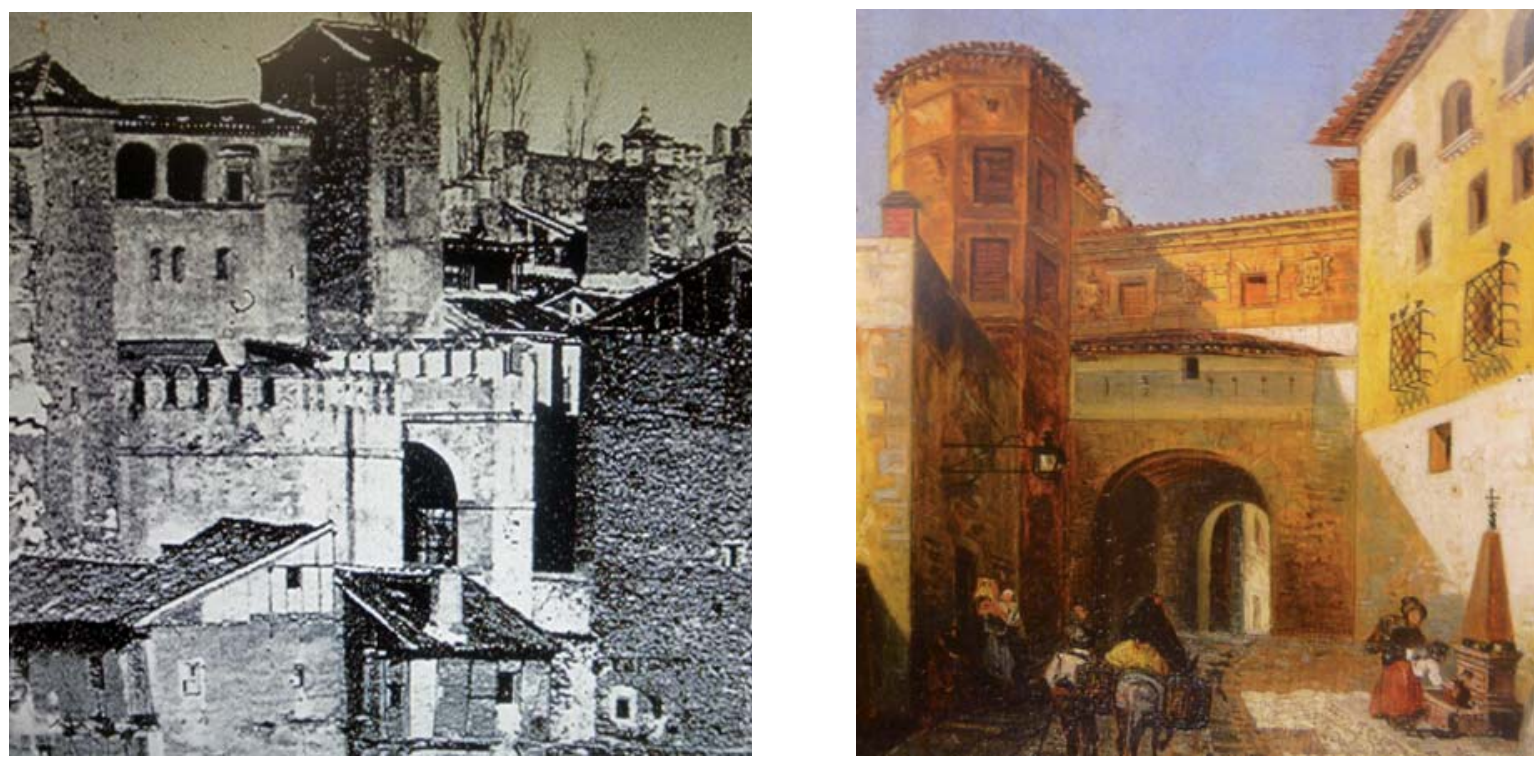

Figura 4.1.10: Foto de Alphonse de Launay ca. 1854, publicada por Sáez Laguna (2009: 14). Imagen de la puerta de San Martín antes de su demolición. Se observa el arco externo que constituía parte del conjunto defensivo de la puerta de San Martín. A la izquierda vemos parte de la torre poligonal, el almenado del fortín y la cara interior del arco que se encontraba unos metros más abajo de la puerta. Por encima, la Casa de los Picos y la torre T18.

Figura 4.1.11: Acuarela de Pérez de Castro (Fuente AMS). Imagen exterior de la puerta de San Martín, datada en 1862. Apreciamos a la izquierda, adelantada, la torre poligonal, en la puerta, el primer cuerpo más bajo con las fusileras, girado respecto a la puerta y asomando por detrás, el paso de la puerta con el pasadizo de la Cárcel de Caballeros cruzando por encima de la calle.

Desconocemos las características constructivas de dicha torre poligonal y su cronología. Lo único que podemos asegurar es que existía dicha torre, que no se contempla en el Plan Director. En la acuarela de Pérez de Castro intuimos unos resaltos rectangulares modulando sus caras pero no podemos adivinar, materiales, ni aparejos, ni dimensiones. Lo mismo nos sucede con los demás elementos defensivos, arco y fortín. Sin embargo la puerta ya se encontraba en ruina y en 1543 se manda derribar (AMS: 4810-3, I: 1). En 1571, se la está tejando por lo que las obras de reconstrucción debieron terminar en esa fecha (AMS: 4810-3, I: 2). Así, desconocemos el aspecto que tendría la puerta medieval ya que las imágenes que

93 Disponemos de una buena descripción del conjunto defensivo de la puerta en el artículo de Antonio Ruiz (Ruiz Hernando, 1994), quien remite a Quadrado (1993) y algunos datos provenientes de Quintanilla (1954). Otras descripciones de la puerta las encontramos en Moragón Agudo (1995) y Chaves Martín (2003). 
tenemos de la puerta anteriores a su demolición, la acuarela de Pérez de Castro de 1862 (Sáez Laguna, 2009: 23) y algunas fotografías de finales del XIX, son de la puerta de mediados del siglo XVI, que sustituía a la puerta medieval original.

Toda la fachada interior de la puerta era de sillería de granito (Ruiz Hernando, 1994: 472) al igual que el tratamiento de la fachada de la Casa de los Picos, que creemos que sólo es un "forrado" que recubre el muro original de la casa fuerte medieval que defendía la puerta de San Martín. Este forrado presenta un grosor considerable, superior a los 50 centímetros, e incluso adarajas, como puede apreciarse en la esquina de la calle Obispo Gandásegui. En la foto de Laurent, de 1868-1872 (VVAA, 2006: 71), apreciamos que existe un perfecto acuerdo entre las hiladas de la sillería de la puerta y las de la fachada de puntas de diamante que adornan la Casa de los $\operatorname{Picos}^{94}$, por lo, dado que la casa fuerte existía con anterioridad al siglo XVI, nos parece muy probable que el "chapado" de su fachada, se realizara simultáneamente con la reconstrucción de la puerta a mediados de dicho siglo ${ }^{95}$. Así la reforma de todo el conjunto defensivo, puerta y casa fuerte, se efectúa dentro de un mismo proyecto y sin ninguna duda, creando una unitaria impronta en la imagen urbana.
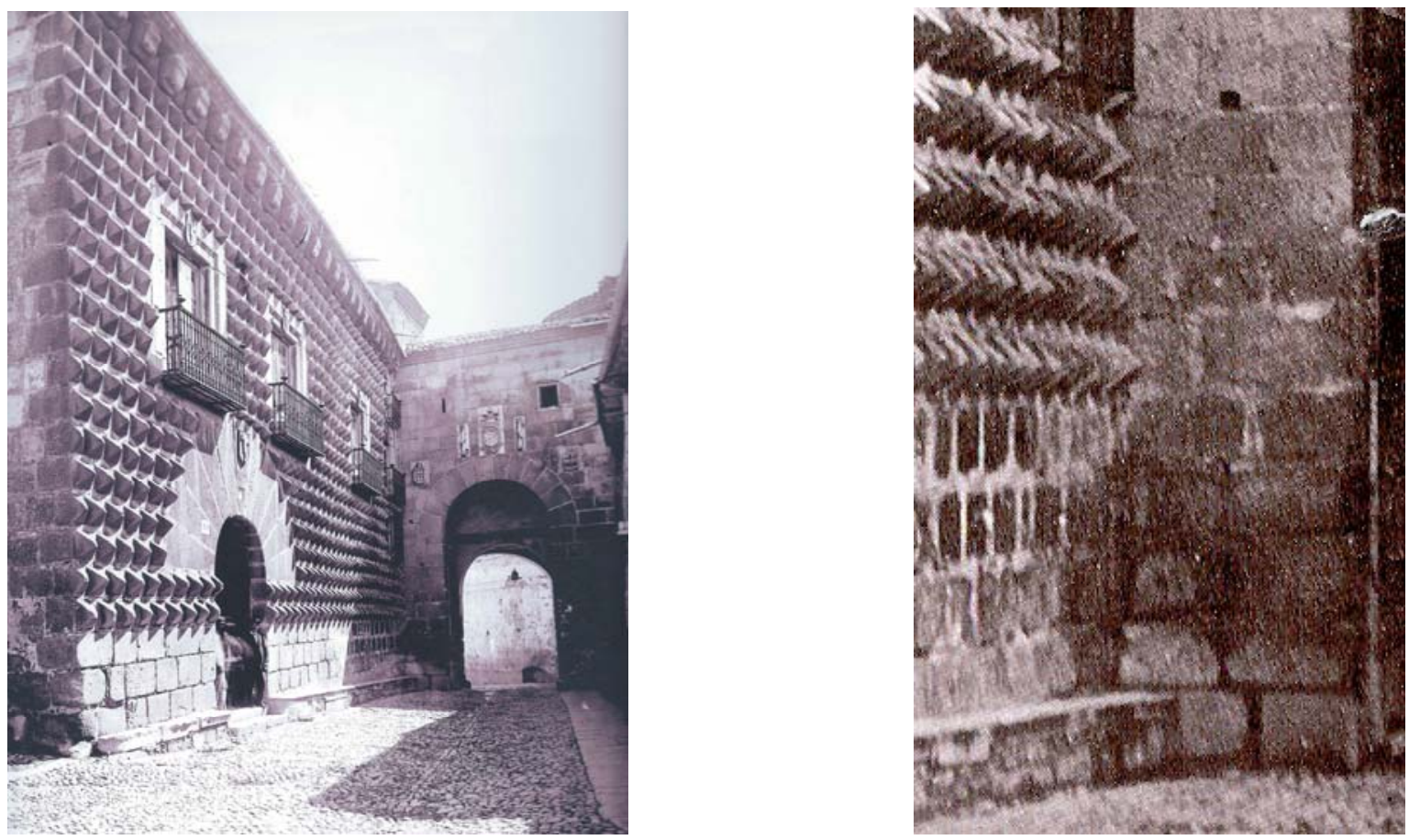

Figura 4.1.12: Imagen del interior de la puerta antes de su demolición tomada por Laurent en 1873 (VVAA, 2006: 71).

Figura 4.1.13: Detalle de la foto de Laurent. Se aprecia una perfecta correlación entre las hiladas de la sillería de granito de la puerta y las de la fachada de picos de la casa, correspondencia que llega hasta el nivel de la cornisa.

\footnotetext{
${ }^{94}$ En 1555 ya se la conoce como Casa de los Picos (Lampérez y Romea, 2012: I: 345), por lo que, al menos, la fachada estaría acabada. Como las obras de retejo en la puerta se realizan en 1571, nos parece que transcurren muchos años desde que está acabada la fachada de la Casa de los Picos hasta terminar las cubiertas de la puerta, lo que nos induce a pensar que posiblemente la cita de 1571 se refiera a una reparación de las cubiertas y no a la finalización de las obra de construcción de la puerta.

${ }^{95} \mathrm{La}$ fachada de la casa denota una clara discontinuidad en la disposición de los sillares tallados con las puntas de diamante, que la recorre prácticamente de arriba a abajo. La reconstrucción de la puerta de la muralla debió conllevar una importante reforma de la casa, incluyendo la apertura de ventanas e incluso de la puerta de paso que, a través del pasadizo elevado, cruzaba por encima de la calle.
} 
De su aspecto antes de la demolición, no podemos concluir la configuración que poseía la puerta medieval que existiría antes de la importante reforma del XVI. Por las descripciones de Quadrado que recoge Antonio Ruiz (1994: 472) podemos deducir que la existencia de los dos arcos con un patio intermedio es anterior al XVI, pero no sabemos si era original. Coincidimos con Antonio Ruiz en que la puerta medieval posiblemente fuese como la de Santiago antes de la reforma del XVII (PH: P0165) y San Cebrián, con sólo planta baja y una terraza abierta encima, sin el piso superior. Tampoco sabemos si la torre poligonal exterior era un elemento añadido o por el contrario pervivencia de la defensa original de la puerta, como en la puerta de San Andrés. Suponemos que sí, en San Martín, existía una torre adelantada, flanqueando la puerta, al igual que en la puerta de San Andrés y en la de San Juan, como veremos más adelante. Son meras suposiciones. Nada sabemos de sus dimensiones ${ }^{96}$, fábricas, aparejos y la técnica constructiva que pudo tener la puerta medieval.

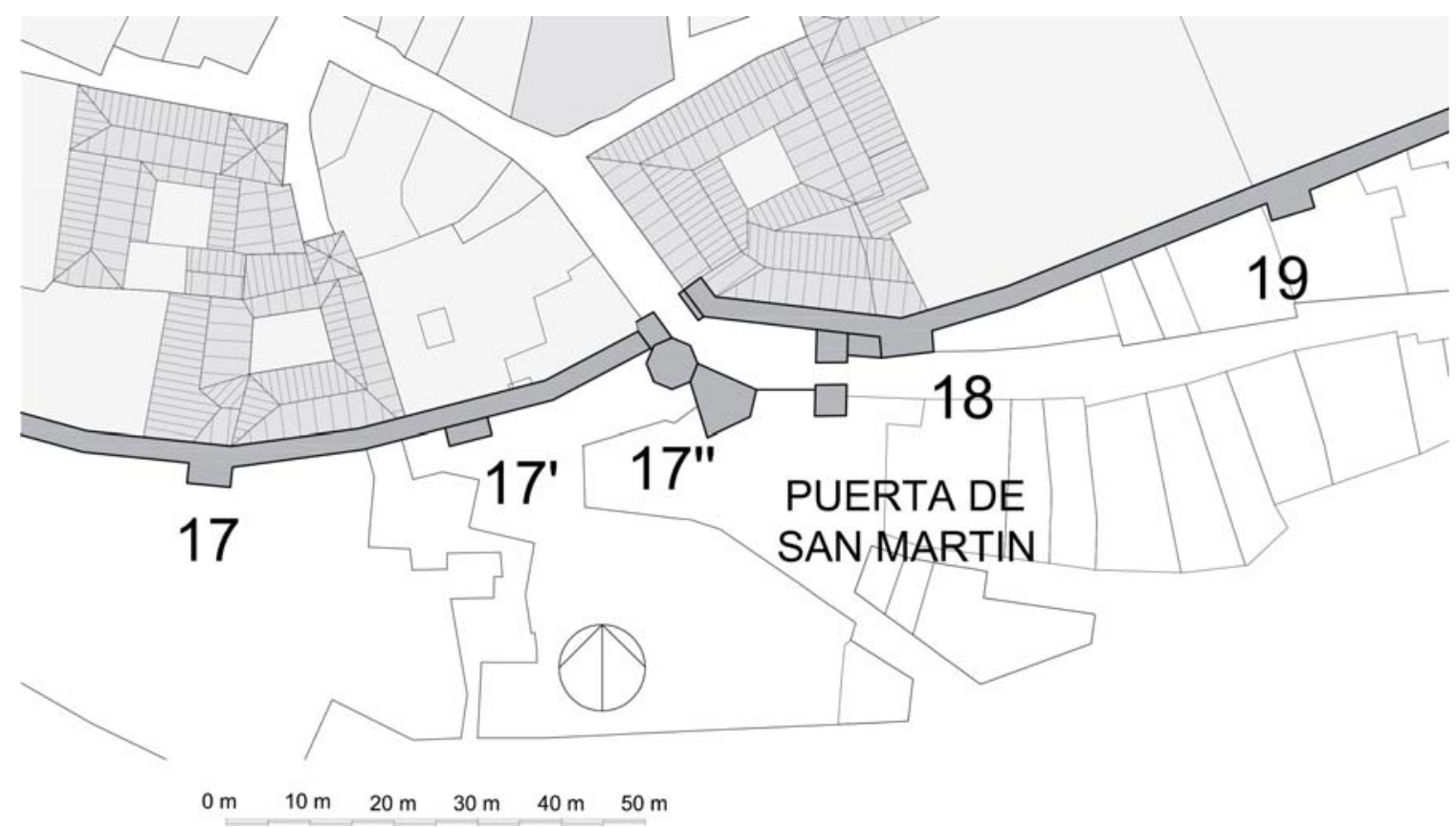

Figura 4.1.14: Planta de restitución de la puerta de San Martín, sobre la trama actual de la ciudad antes de su demolición. La disposición de la puerta en planta la obtenemos del plano de alineaciones para la calle Real de José Santiago Ortiz (AMS: 811-9), del "Proyecto de alineación de la calle Real del Carmen y Bajada de la Canaleja” que realiza Joaquín Odriozola entre 1882 y $1888^{97}$ (AMS: 5376-10), las fotos históricas y de las mediciones realizadas por el autor sobre la calle actual.

\subsubsection{TORRES Y LIENZOS CONTIGUOS AL ACUEDUCTO.}

A ambos lados del acueducto encontramos dos irregularidades en la muralla que nos llaman la atención. Tenemos un lienzo, a cada lado, más largo de lo habitual y con un quiebro en su trazado. La mayoría de los lienzos oscilan entre los 22 y los 27 metros. Sin embargo estos miden 47 y 63 metros respectivamente. La existencia de esos quiebros en estos lienzos tan largos, creando un retranqueo en la muralla, que se adapta al borde del acantilado, nos hace

\footnotetext{
${ }^{96}$ Estimamos que el paso mediría entre 4,90 metros en el punto más estrecho, el paso del arco interior. En el arco exterior, trazado en oblicuo respecto a la dirección de la calle, hemos calculado un máximo de seis metros. ${ }^{97}$ Más datos sobre la reforma de alineaciones de esta calle en García Casas (1987) y Chaves Martín (1998).
} 
pensar que se ha producido un derrumbe de estos tramos y sospechamos que pueda faltar alguna torre.

En el primer caso, entre el acueducto y la puerta de San Martín, la fotografía de la Sociedad Artístico Fotográfica (Sáez Laguna, 2009: 23) muestra bien claro cinco torres, cuatro completas y la del medio parcialmente arruinada. Por lo tanto, existía una torre, la T21', muy próxima al acueducto, justo donde hoy vemos el quiebro, contra el que entesta la escalera que sube al postigo del Consuelo. En el plano de Antonio de la Iglesia se dibujan seis torres en este tramo, si bien nos confirma la existencia de esta quinta torre, creemos que es un error. La existencia de una sexta torre quizá puede justificarnos la irregularidad de la longitud de los lienzos de esta zona. En el plano de 1837 parecen adivinarse 4 torres en la huerta del seminario y otras dos en la parcela del teatro, lo que significaría que el actual lienzo de 42 metros se dividiría en dos de entorno a los 20 metros, medida más cercana a la métrica del resto de los lienzos de la zona. Este dato no nos parece suficiente apoyatura para confirmar en la existencia de esta torre, a la que llamamos T18', teniendo en cuenta la fiabilidad del plano de Antonio de la Iglesia. No la hemos encontrado. Debería encontrarse entre la T18 y la T19, embebida entre el caserío adosado a la base de la muralla extramuros. El estudio de estos inmuebles en un futuro quizá puede ayudar a confirmar o descartar esta hipótesis.

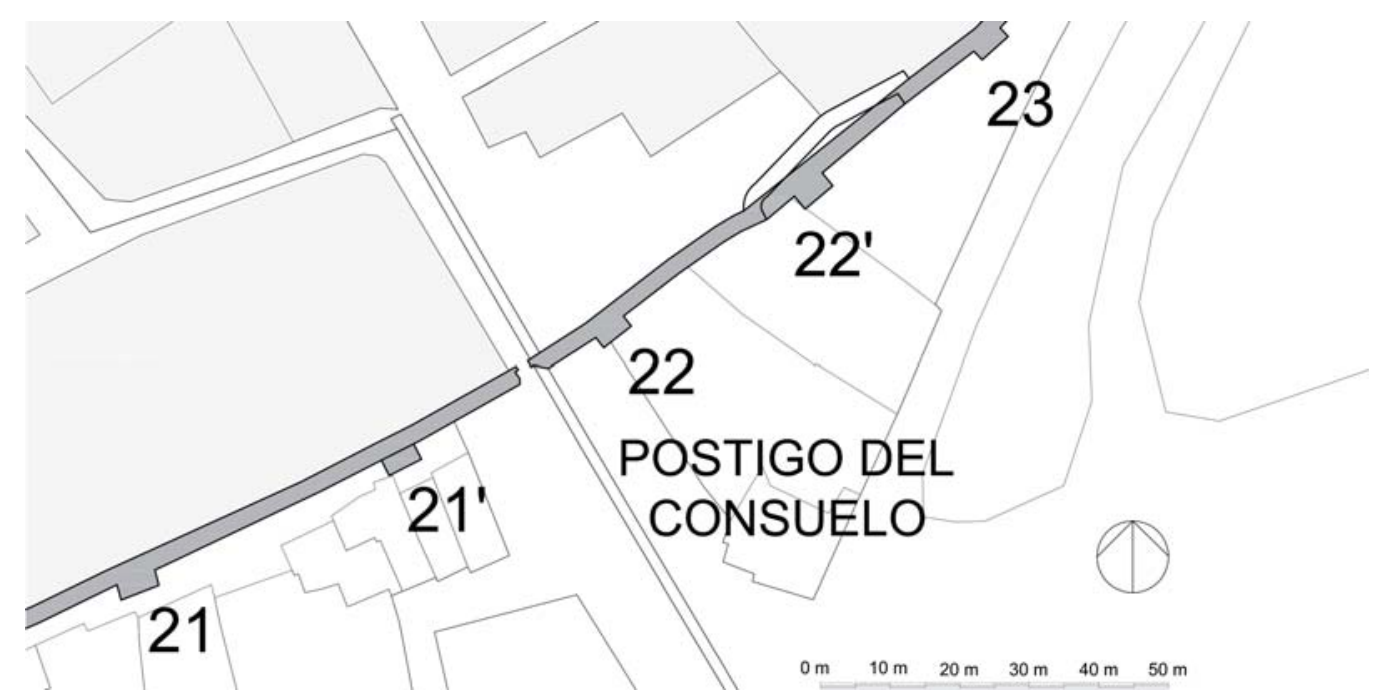

Figura 4.1.15: Plano de los lienzos cercanos al postigo del Consuelo en los que se sitúan las dos torres, actualmente desaparecidas, T21' y T22'en su emplazamiento original.

En el segundo caso, entre el acueducto y la puerta de San Juan, encontramos una pronunciada concavidad en el trazado de la muralla, entre las dos torres, que están separadas 63 metros, algo muy por encima de la media. En el plano de Antonio de la Iglesia esta zona se representa recta, sin el remetido actual y vemos sólo dos torres y dos resaltos que modulan una métrica muy similar a la que proponemos. Nuestra hipótesis es que existiría una torre adicional, la T22', originariamente eran 4 torres, en lugar de las 3 actuales. Confirma nuestras sospechas la existencia de un sillar en la primera hilada cuya disposición da continuidad al lienzo, en vez de generar la esquina, lo que denota que ese quiebro se debe posiblemente a un derrumbe y que el lienzo continuaría recto. Por detrás de él vemos mampostería muy menuda, posiblemente el relleno interior que continuaría, y por debajo la roca que está hundida, perdiéndose la línea que llevaría la hoja exterior de la muralla. 


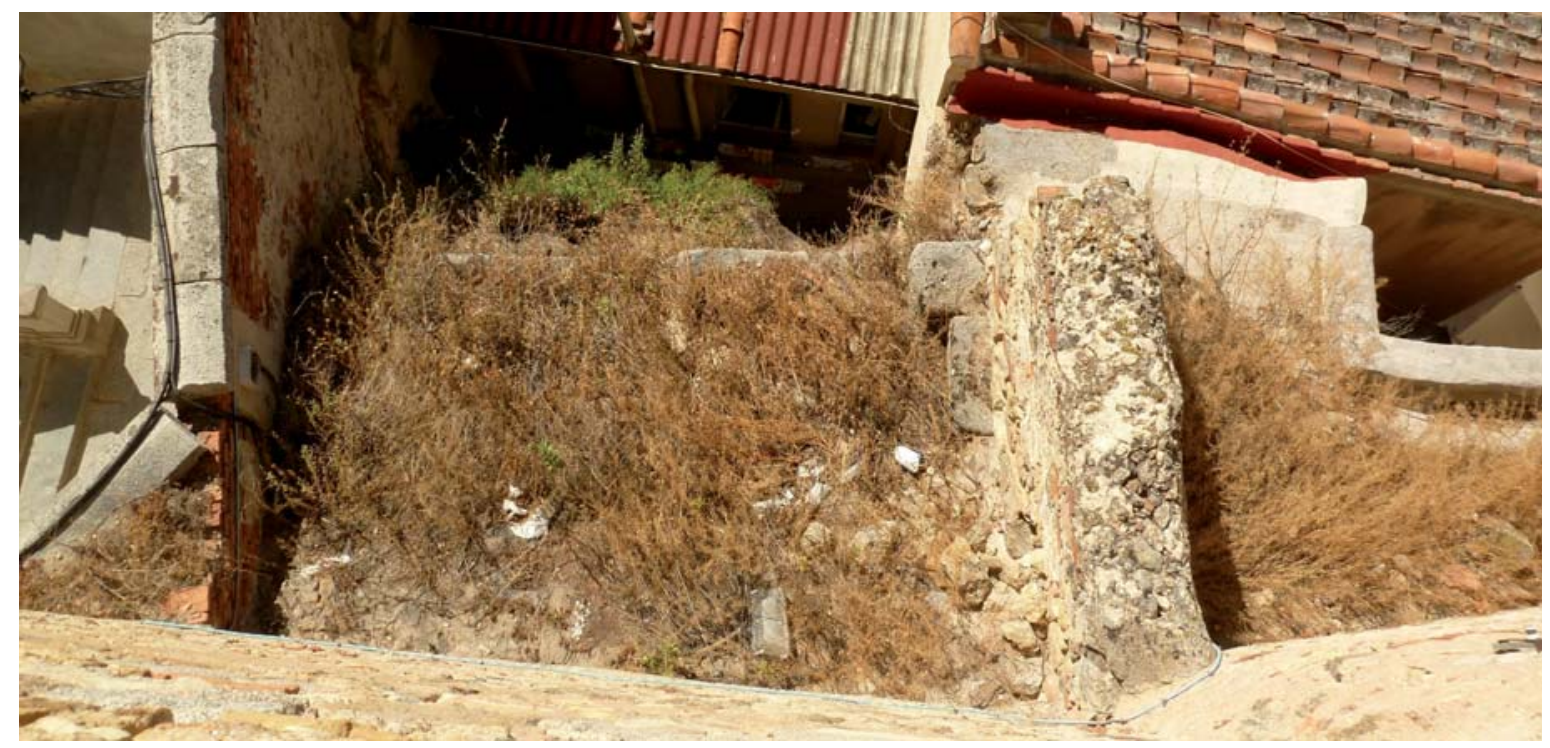

Figura 4.1.16: Torre T21'. Foto de la base de la muralla vista desde el adarve en la actual parcela del seminario. Los restos de la torre sirven de testero a la escalera de subida al postigo del consuelo reformada por Odriozola.
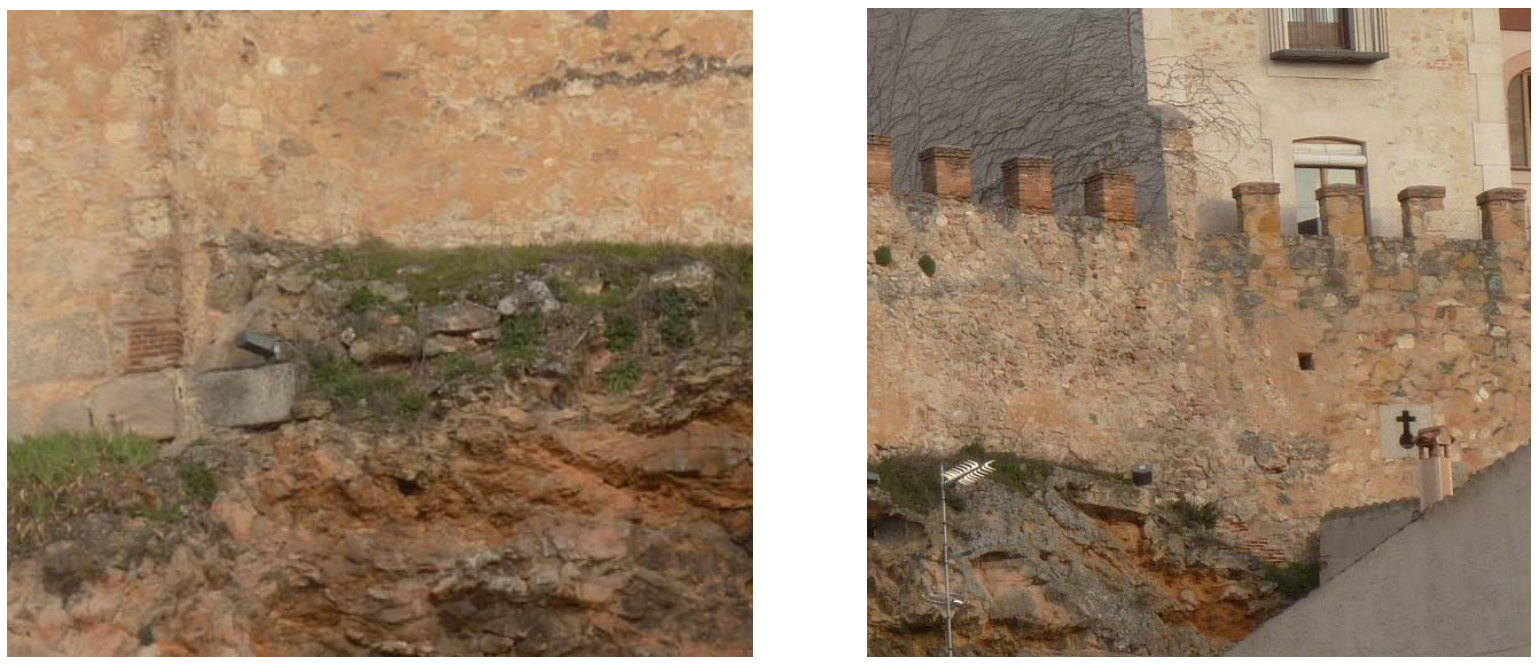

Figura 4.1.17: Lienzo L22-23. Detalle del quiebro en que se observa un sillar de granito del zócalo que indica que el trazado original de la muralla continuaba recto. Parcialmente enterrado se ve el relleno del intradós derruido delante del actual lienzo reconstruido.

Figura 4.1.18: Detalle del lienzo L22-23. Se observa el cambio de material y de solución constructiva (merlones) coincidiendo con la separación entre las parcelas de los edificios que se sitúan adosados a la muralla por el intradós.

Este derrumbe creemos identificarlo con el que tiene lugar el 28 de julio de 1713, en que se desmoronan unos lienzos cercanos a la antigua casa de la Moneda y se destruyen cinco casas situadas debajo $^{98}$. (Laínez y Ortiz de Paz, 1964: 166-167)

${ }^{98} \mathrm{El}$ texto se centra en la desgracia que supuso la destrucción de esas viviendas y la muerte de nueve personas que quedaron sepultadas en los escombros y no entra a valorar los elementos destruidos, hablando genéricamente de la roca y la muralla. No matiza si se destruyó una torre o no. 
La reconstrucción ${ }^{99}$ retranqueada de los nuevos lienzos denota una realización con distinto tipo de piedra, desigualdad que coincide con la división entre parcelas de los edificios que se sitúan intramuros. El trazado cóncavo de la muralla y la descripción constructiva de estos paños nos reafirma en nuestra hipótesis de que se trata de una reconstrucción muy reciente. La mampostería es muy uniforme hasta los merlones, no hay reparaciones. Abundan las piezas de granito entremezcladas, incluso en la parte alta del lienzo. Además encontramos unas cañoneras de cruz y orbe, dos en el lienzo remetido y otra más en el segundo tramo recto tras el quiebro. Se trata de piezas en granito, y aunque sólo visibles desde muy lejos, aparentan estar en muy buen estado de conservación, con las aristas muy vivas, como cortadas a sierra.

\subsubsection{La Puerta de San Juan y la actual Casa del Marqués de lozoya.}

La puerta original, medieval, era uno de los principales puntos defensivos del recinto amurallado al ser la zona de más fácil acceso a la ciudad, la zona nororiental de la muralla. Estaba protegida por dos casas fuertes: la Casa de los Cáceres (actual casa del Marqués de Lozoya) ${ }^{100}$ y la de los Marqueses de Moya (conocida como la Casa de las Cadenas) ${ }^{101}$.

Es de suponer que en este punto de la muralla, existía una puerta medieval. De dicha puerta no se tienen datos, aunque hemos encontrado una cita que nos puede ayudar a datar su desaparición. En 1661, el Regimiento de Segovia efectúa un pago a un vecino, Agustín de la Fuente, por el perjuicio que de la Fuente habia recibido en una casa que tenía por bajo de dicha puerta de la muralla (de San Juan) cuando ésta se arruinó (Contreras Jiménez, 2010: 7) Entendemos que se ha desplomado la parte exterior de la puerta, si bien hay noticias anteriores de la ruina de la puerta, en 1648 (AMS: AC-1039: 799). Tenemos por tanto evidencias de una puerta que a mediados del XVII estaba aquejada por un grave deterioro y sufrió algún derrumbe.

Esta primera puerta es reemplazada, según unos autores, en 1705 por otra mucho más simple y sin el carácter militar de la anterior ${ }^{102}$, más acorde con los criterios estéticos del momento ${ }^{103}$, diseñada por Juan de Ferreras (Chaves Martín, 2003: 14). Otros autores entienden que la nueva puerta aún no se ha construido en esa fecha y que las obras acometidas por Ferreras en 1705 son de reparación de la puerta anterior, que aún se conserva (Contreras Jiménez, 2010: 89). No hay un criterio claro respecto a la fecha de construcción de la puerta de San Juan que conocemos por las fotografías y que se atribuye a Ferreras.

\footnotetext{
${ }^{99}$ Los avatares posteriores para la reconstrucción son largos, llegando a pedirse dinero al Rey Felipe V, bajo pretexto de verse afectada la Casa Vieja de la Moneda, ante la falta de medios económicos y de no saber quién debería hacerse cargo del coste de las reparaciones. Para más información sobre estos sucesos puede verse el trabajo de Contreras Jiménez (2010).

100 Para mayor información sobre esta casa fuerte, Contreras y López de Ayala (2010: 265) y Chaves Martín (2006: 152-153)

101 Para mayor información sobre esta casa fuerte, Contreras y López de Ayala (2010: 274-275) y Chaves Martín (2006: 149-151)

102 "Tanto el exterior como el interior presentan el mismo diseño. Arco de medio punto en el que se marca la traza de las dovelas, con una leve moldura lisa en las enjutas que da paso al cuerpo superior de remate mediante coronamiento de bolas sobre pedestales y escudos reales entre pilastras cajeadas, representando a la ciudad interior, y con los cuarteles de Castilla y León, toisón de oro y corona real, el exterior, actualmente reubicado en el muro de la Casa del Marqués de Lozoya sobre la hornacina que alberga la estatua sedente de la virgen de los Remedios, copia de la original románica." (Chaves Martín, 2003: 14)

${ }^{103}$ Los criterios artísticos y compositivos son muy parecidos a los que, él mismo, estaba ejecutando en las puertas de la Fuencisla y de Madrid, en la misma Segovia, más cercanas a un arco triunfal que a una puerta de muralla.
} 
Sin embargo hay un dato que puede ser relevante para nuestra investigación. En 1705 se remite un escrito al Conde de Chinchón en el que se habla de que la Ciudad está reparando el arco de piedra y puerta de San Juan, que servía de estribo a la casa de dicho conde. (Contreras Jiménez, 2010: 8) $)^{104}$

Sr. Don lucas pastor. Escribano de Cama del Consejo de Ytalia y governador General del estado de chinchon

Haviendo la ziudad puesto en execucion el reparar el arco de piedra que haze puerta a la calle prinzipal que llaman de san Juan y sirve destribo a la casa del exmo. Señor Conde de Chinchon pues esta unida a la muralla esterior de ella, la qual se a recorrido y metido algunas piedras que nezesitava para la seguridad desta obra, ermosiandola con una portada y pareziendo preciso para el paso de los coches el escrarpar un qubo mal reparado que se alla contiguo a la puerta que por obra desunida de la prinzipal fabrica solo sirve de ympedimento al paso y ermosura de dicha casa, como se podra reconozer por las personas que fueren de la confiança de Vm., a quien suplicamos atento a estas razones se sirva de conzeder permiso para que un pie o dos que sovresale pa punta de la nariz del cubo antiguo, se excarpe yguale para que se logre el paso que dificulta este ympedimento por cuio veneficio ara la riudad en lo demas que quedare el reparo para que quede con la seguridad Nezesaria y a ractificacion de los maestros que Vm. Elijiere y esta ziudad, con el reconozimiento devido para servir a Vm. En quanto ocurriere de su maior agrado y sactisfazion. Cuia vida guarde Dios muchos años. Segovia y Julio 8 de $1705 .^{105}$

A la vista de la descripción entendemos que la portada que "han hermoseado" se refiere a la construcción de la puerta de Ferreras, pero también se dice que sirve de estribo a la casa del conde, por lo que estaría pegado a ella y a un cubo mal reparado contiguo a la puerta desunido de la fábrica principal. Por ello interpretamos que lo que puede haber sucedido es que el paso abovedado de la puerta se ha hundido. Hacia el acantilado, la puerta tendría un importante contrarresto, para estabilizar los empujes de la bóveda, que sería una torre, de la que dicen que está mal reparada. Esta torre es lo que consideran restos de la puerta anterior, posiblemente dañada por el hundimiento del arco y los empujes de la bóveda.

Lo que hace el arco de Ferreras es unir los restos de esta torre con la casa de los condes de Chinchón, donde queda un machón, que se aprecia en la foto de la puerta desde el interior. (Ver Figura 4.1.22). En la foto por el exterior vemos que la portada esta adosada a un muro, resto anterior de gran espesor, que no existe al interior, que creemos son los restos de la muralla medieval y una torre. (Ver Figura 4.1.23). La confirmación de la existencia de esa torre exterior que haría de contrarresto a los empujes de la bóveda la obtenemos en la lámina de Avrial fechada en 1843 (Ver Figura 4.1.19).

En 1887 se produce un nuevo derrumbe, en el que caen una parte importante de la casa del Marqués de Lozoya y en el que, dejando dañada la puerta de Ferreras, se hundiría la torre exterior y el lienzo de muralla, que ya no aparecen representados en el plano del "proyecto de alineación para las calles de San Agustín, Plazuela de San Pablo, calle de San Juan y Plaza del

\footnotetext{
104 Esta autora también referencia a los siguientes documentos (AMS: AC-1060 sesión 5 Septiembre de 1705) y (AMS: Leg 318). Esta última referencia contiene una errata, al haber omitido "Leg".

105 Debo la trascripción y traducción de este texto a Isabel Álvarez, del Archivo Municipal de Segovia, que localizó el texto original (AMS: Leg 318) referenciado por Contreras Jiménez (2010: 8) para poder reinterpretar la descripción que se hace de la puerta.
} 
Azoguejo" de Joaquín Odriozola, redactado poco después en base al cual se la puerta es demolida definitivamente en $1888^{106}$ (Chaves Martín, 2003: 17).

En el basamento de la Casa de las Cadenas aún se observan los restos de una fábrica de trazado perpendicular al de la muralla. Por su posición y atendiendo al plano de alineaciones que realiza Odriozola, esos restos no pueden ser los de la puerta diseñada por Ferreras, que sólo era un arco, prácticamente sin fondo.

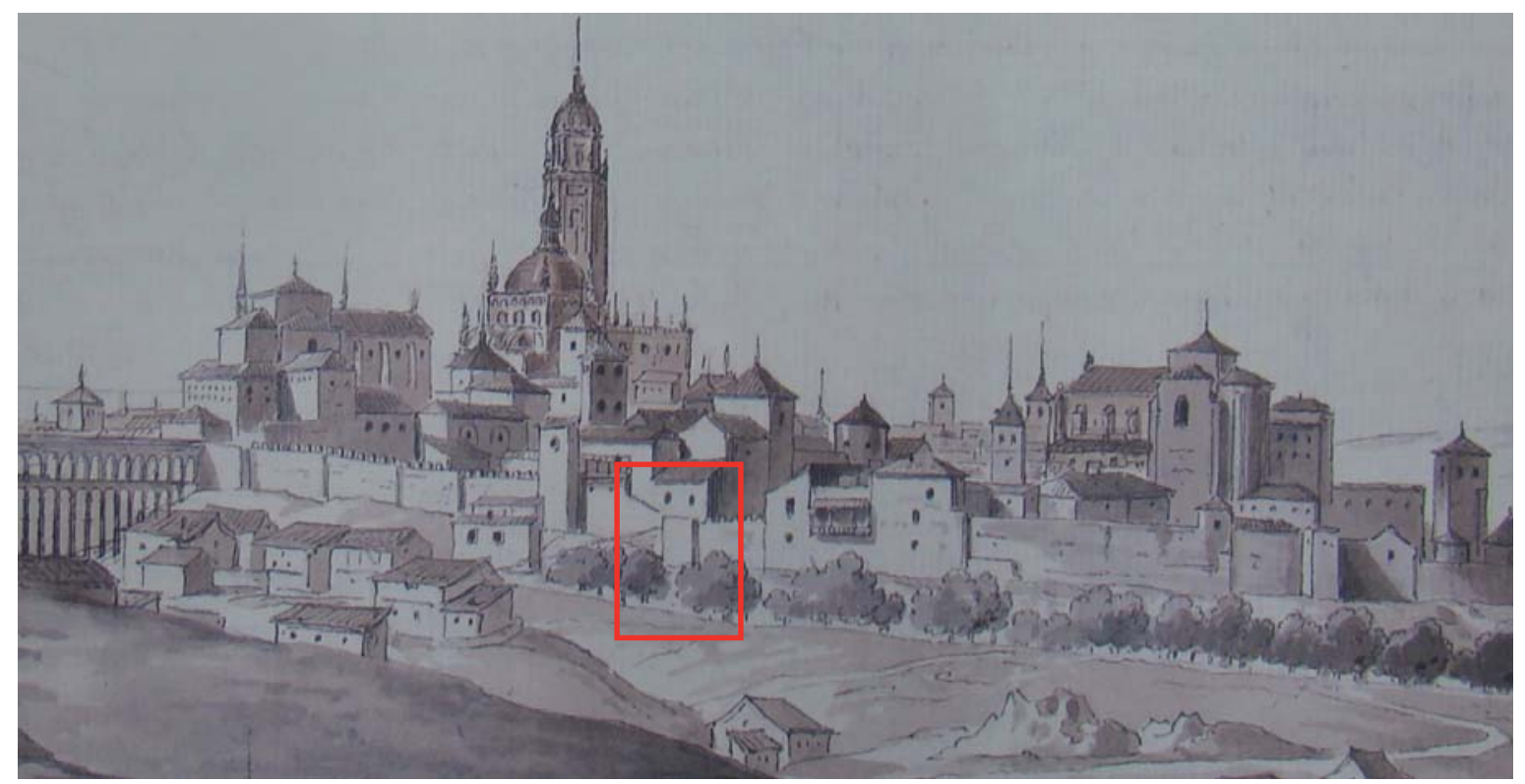

Figura 4.1.19: Dibujo de Avrial (1843). Se observa que existe una torre frente a la casa de las Cadenas, prolongando la muralla desde la actual casa del Marqués de Lozoya antes del derrumbe de ésta en febrero de 1887 (Avrial y Flores, 1979: Lámina 1).

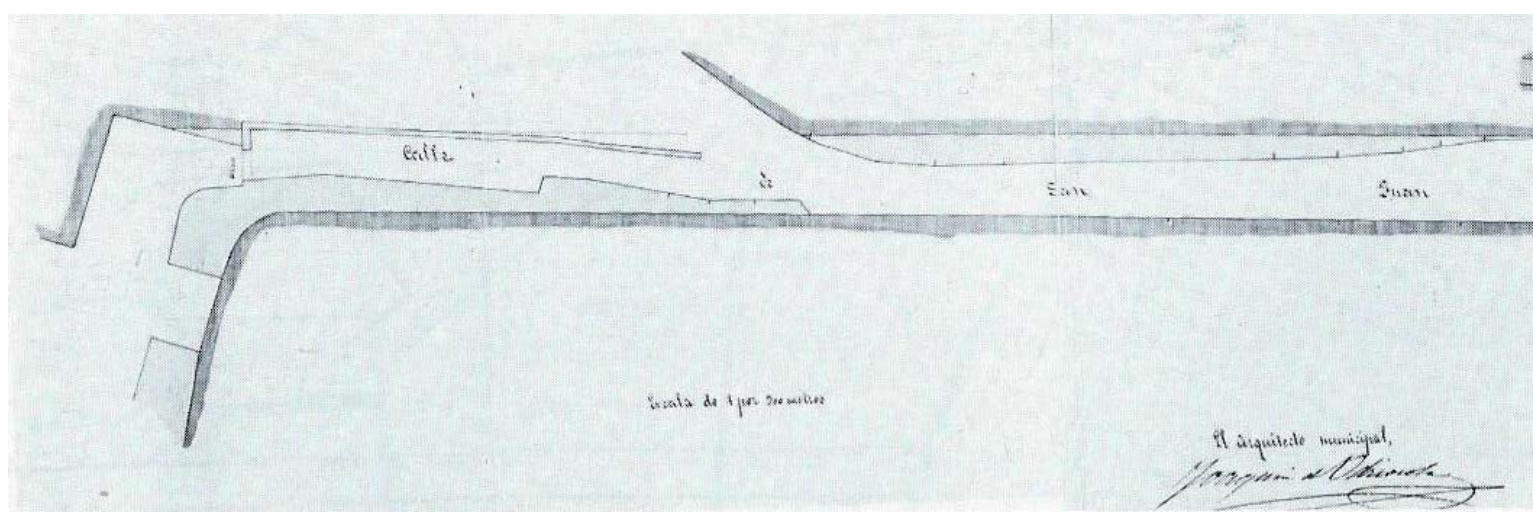

Figura 4.1.20: Plano de alineación de la Calle San Juan del proyecto de Odriozola en que se aprecia en el extremo izquierdo la disposición de la puerta y la propuesta de rectificación de alineaciones que se plantea hacia el lado interior de la puerta (García, García, 1987: 50).

${ }^{106}$ La razón de su definitiva desaparición fue la necesidad de conectar el centro de la ciudad con la nueva estación de ferrocarril mediante un tranvía que realmente nunca existió. Según el libro de acuerdos municipales de la época, su demolición fue incluida en el programa anual que promulgaba el ayuntamiento para atenuar el paro obrero. Más datos sobre la reforma de alineaciones de esta calle en García Casas (1987) y Chaves Martín (1998). 
Según nuestra hipótesis estos restos, jambas, arranques de arco, enjarjes de muros pertenecen a la puerta medieval. Por encima vemos la escalera que descendería a la terraza de la puerta de la muralla y que serviría para salvar el desnivel entre los adarves a ambos lados de la puerta, comunicándolos entre sí y con la casa fuerte. Nos queda la duda de saber si esta puerta tenía dos pisos cerrados con cubierta, como tuvieron la puerta de San Martín y aún conservan las de San Andrés y Santiago, o bien nunca llegaron a añadírselo y contaba solo una terraza descubierta como la que muestra la puerta de San Cebrián y en su día tuvo la de Santiago.

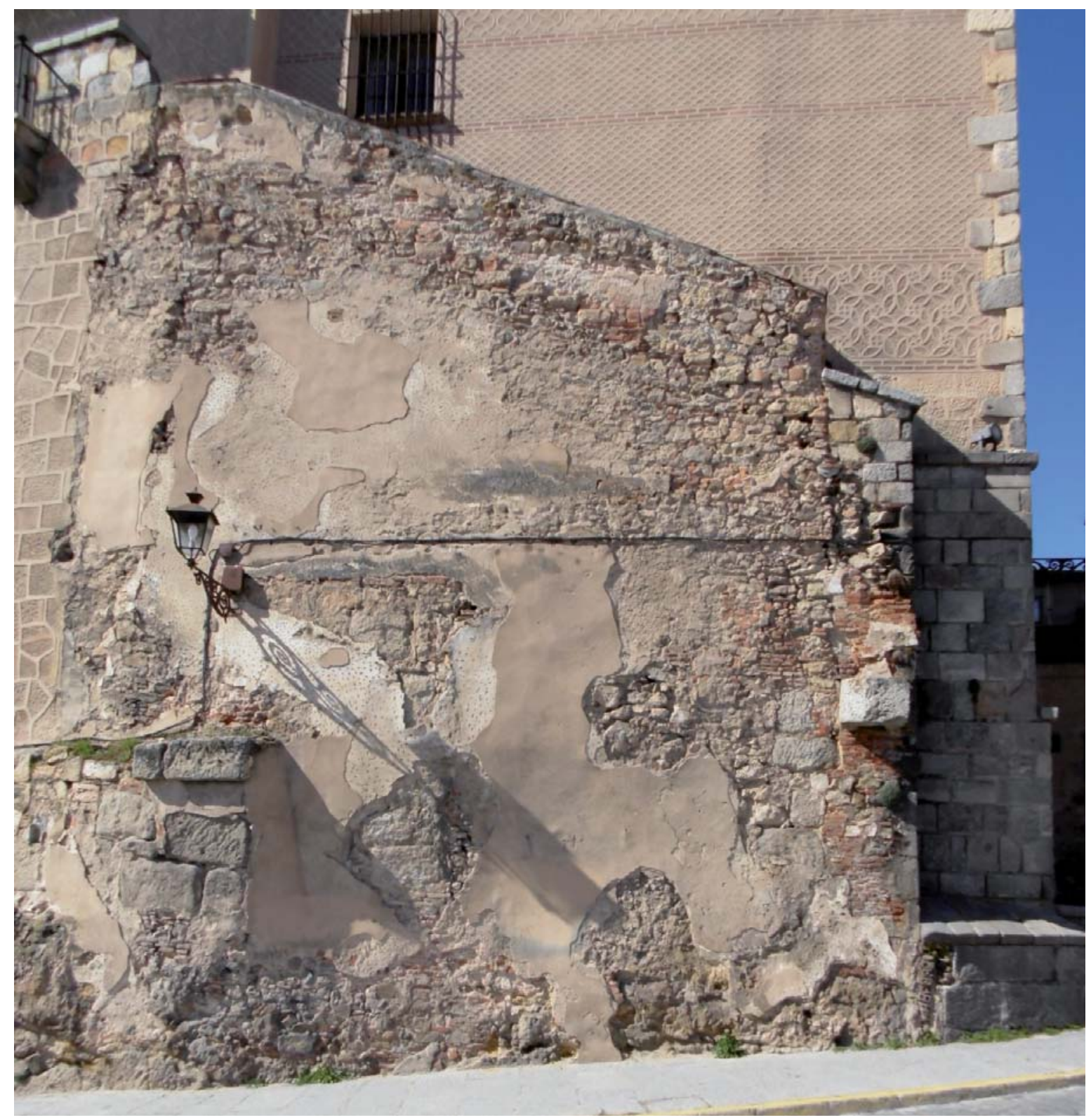

Figura 4.1.21: Lienzo L24-25. Fragmento de muro que creemos no se vio alterado en exceso por el ensanchamiento de la calle, salvo el picado de los elementos salientes de la parte baja. Según nuestra hipótesis, en este punto entestaría la puerta medieval vinculada con la Casa de las Cadenas. Vemos restos de dos ménsulas. Una de granito sobre jamba de sillería también de granito. A la derecha, ménsula de piedra sedimentaria sobre jamba muy reparada en ladrillo. En el medio aún se adivina un tercer machón de sillería. La escalera, que actualmente no conduce a ningún punto, descendería desde la cota del adarve de la muralla a la terraza o piso superior de la puerta. 
No se conoce ninguna descripción, ni disponemos de ninguna imagen de la puerta medieval. Respecto a su configuración, creemos que era muy similar a lo ya visto en San Martín. Nos confirma esta hipótesis la descripción realizada de la puerta en 1508 que estaba comenzado a hacer un atrio grande para que la dicha puerta se pueda morar (AGS: CRC, Legajo 679, folio 5). La aproximación se realiza desplazándose longitudinalmente a lo largo de la muralla, en el lado en que se le adosa la casa fuerte y con la torre T24 flanqueando al asaltante desde muy cerca de la puerta. El paso de la puerta mediría unos 7,5 metros de fondo. San Andrés mide 6,5 metros, más 2,5 de vuelo para la buhedera, por lo que, por dimensiones, podría ser muy similar. El acceso posiblemente sería directo. Como hemos comprobado, también existía una torre adosada a la puerta en la cara extramuros, donde ahora se sitúa el muro de contención, al igual que existían las torres poligonales en la puerta de San Andrés y San Martín.

Es muy posible que la puerta medieval estuviese en el XVII en muy malas condiciones o desplomada por deslizamiento o derrumbe de la ladera, ya que la roca en esa zona ha demostrado ser muy poco fiable con los numerosos desprendimientos y derrumbes que se han producido. Si el paso se cubría con bóveda, los empujes laterales que generaría dicha bóveda en una construcción situada en una ladera, apoyando en una roca tan fisurada e inestable, posiblemente hicieran que se cayera ladera abajo.
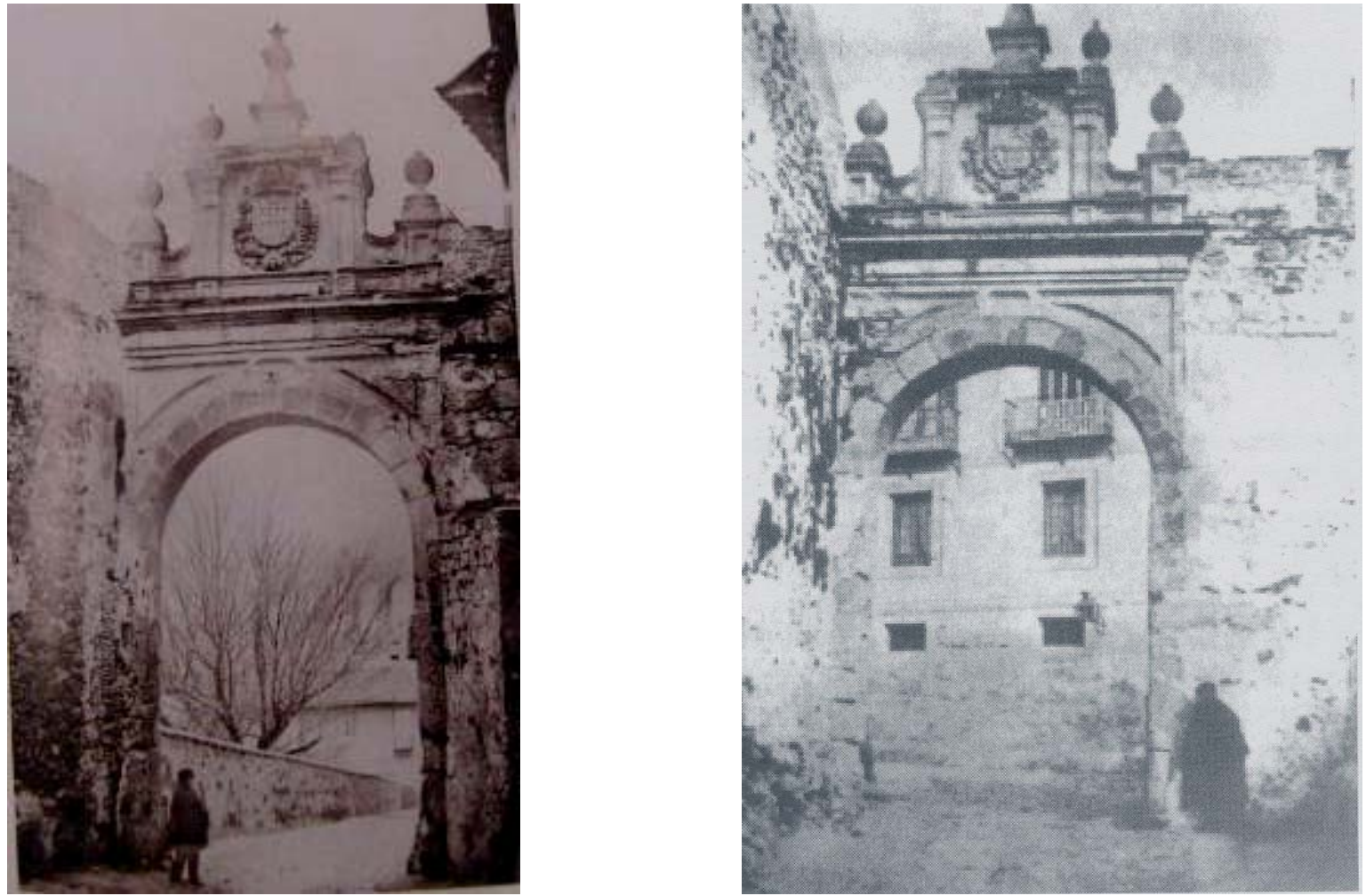

Figura 4.1.22: Vista interior de la puerta de San Juan. Apreciamos a la izquierda junto al arco de la puerta, una jamba resaltada en el lienzo de la muralla. Posiblemente pertenezca a la puerta medieval. La puerta de Ferreras se adosa a la muralla, sin más resalto que una jamba. A la derecha se ve un trozo de machón en sillería y lo que parece una primera dovela. Creemos que es el arranque del arco interior de la puerta. Foto publicada por Chaves Martín (2003: 15).

Figura 4.1.23: Imagen del exterior de la puerta de San Juan. En el lado izquierdo vemos que el arco está prácticamente pegado a la pared. El único resalto es la dimensión de la jamba. A la derecha apreciamos el espesor, incompleto, de la muralla a la que se adosa la puerta de Juan de Ferreras. Sólo las jambas pertenecen a ésta. El muro visible desde el exterior es mucho mayor que el que vemos en la foto desde el interior. Creemos que debe ser el grueso de la muralla medieval. Foto publicada por Chaves Martín (2003: 14). 


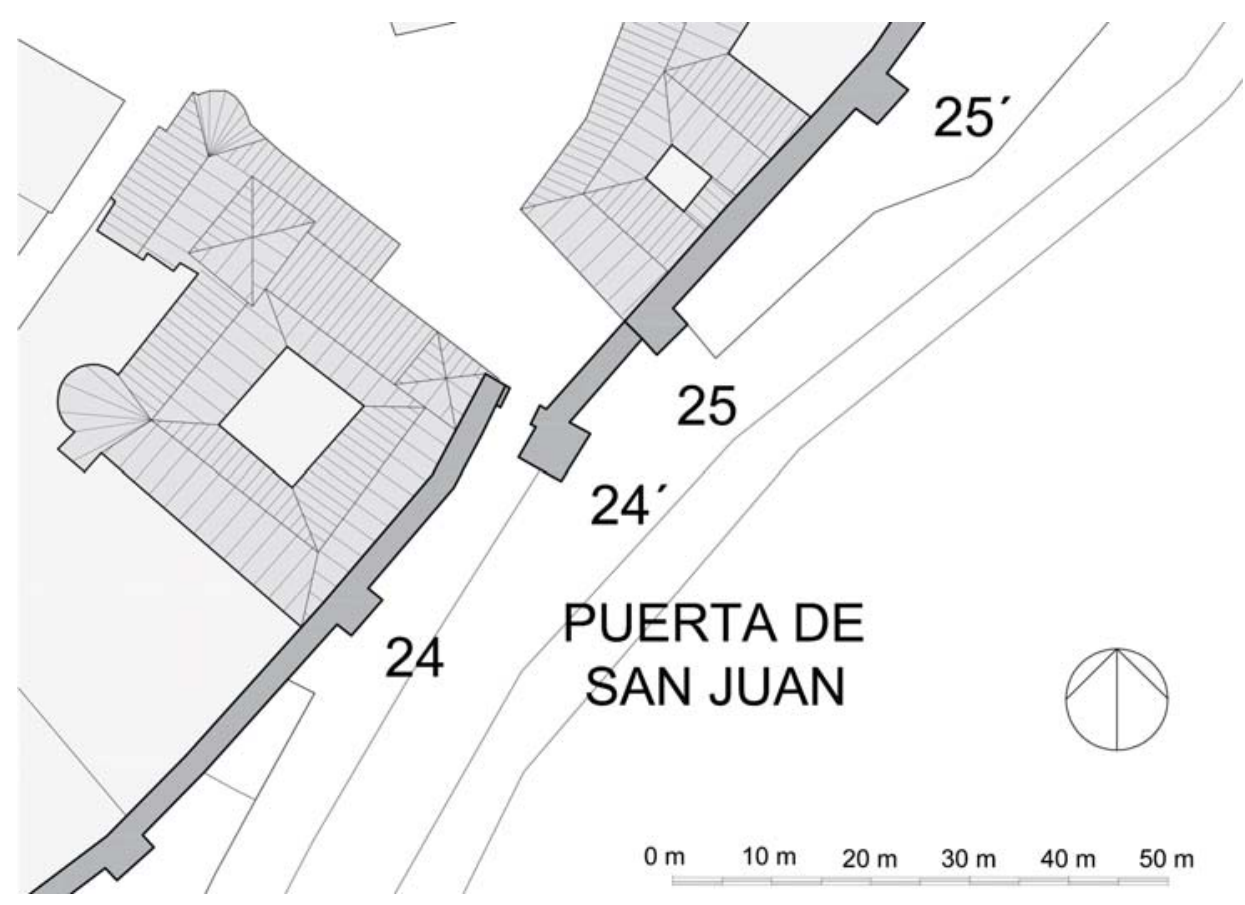

Figura 4.1.24: Restitución hipotética de la puerta medieval de San Juan con la torre T24' y el fragmento de lienzo desaparecido que enlazaba con la torre T25.

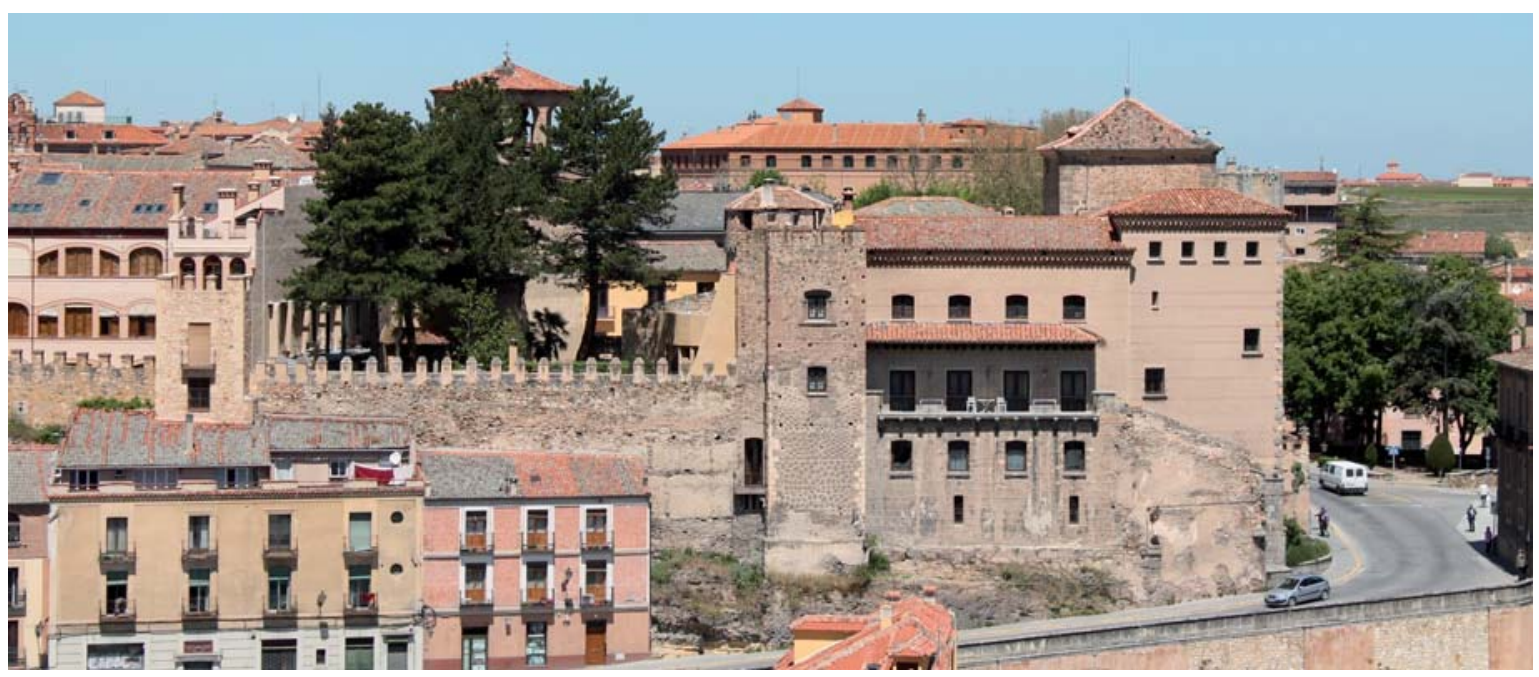

Figura 4.1.25: Imagen de conjunto de la casa fuerte de los Condes de Chinchón. A la izquierda vemos la muralla que entesta con la torre vinculada a la casa fuerte, mucho más alta que la muralla y en el extremo derecho de la casa, vemos el muro donde se situaría la puerta medieval, en el que se aprecia la línea inclinada que nos rememora el trazado de la escalera que unía los adarves y la puerta.

Precisamente uno de estos derrumbes de la roca reciente, que está bien documentado, el 8 de Febrero de 1887(AMS: 4810-3, I: 20) ${ }^{107}$, arrastró consigo un tramo considerable de muralla,

${ }^{107}$ En el archivo municipal hemos encontrado documentados en esta zona de la muralla, 4 derrumbes de la roca desde 1824 (AMS: 4810-3, I: 12), varios en 1887 (AMS: 4810-3, I: 20-21), en 1910 (AMS: 1466-118) y en 1927 (AMS: 1366-3). 
dos torres y gran parte de la crujía posterior de la casa del Marqués de Lozoya (Chico Rello, 1949: 594). Respecto al resto de las torres hasta el Paseo de Colmenares debieron desaparecer en algún momento, del que no tenemos información. Viendo el dibujo de Avrial ${ }^{108}$, parece que en 1843 ya había desaparecido alguna de esas torres y lienzos (Ver Figura 4.1.19) por lo que tampoco podemos corroborar si fueron realmente 6 como indica el plan Director que existían en ese tramo (las torres T25, T25', T26, T27, T28 y T28'). En el plano de Antonio de la Iglesia sólo vemos 4 torres. No hemos encontrado ningún otro documento grafico anterior, que nos permita confirmar esta información.

\subsubsection{El POSTIgo de SAN Juan. TorRes CERCANAS.}

Las torres T29 y T30, han desaparecido, pero en su entorno detectamos varias pruebas que nos señalan el lugar en que estuvieron. En el caso de la T29, el lienzo de muralla realiza un ligero cambio de dirección. La morfología del terreno en ladera con forma de cono también es una evidencia de que se ha producido un derrumbe (Martín de Frutos 2012: 117). Los restos de la torre se encuentran a media ladera, cubiertos por material echadizo y vegetación.
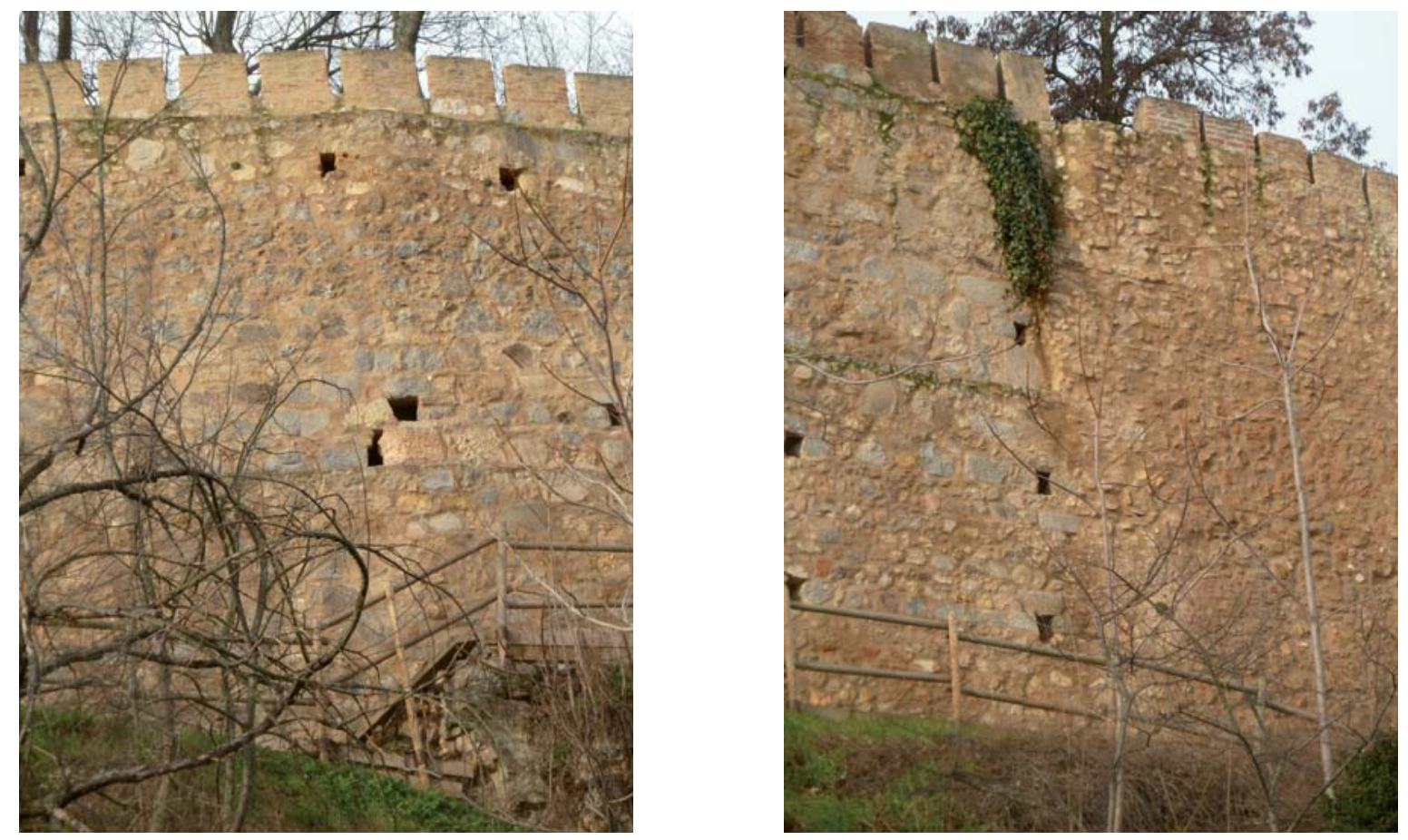

Figura 4.1.26: Lienzo L29-30. El lienzo L29-30 realiza un cambio de dirección en el punto en que se situaba la torre T29. La morfología del terreno en ladera con forma de cono indica que se ha producido un derrumbe en ese punto (Martín de Frutos, 2012: 117).

Figura 4.1.27: Lienzo L29-30. El cambio de material, aparejo y hasta de configuración del almenado denotan el punto donde se situaba la torre T30 por la discontinuidad que se produce en la fábrica.

${ }^{108}$ El dibujo de Avrial es poco definido en la representación de este tramo de muralla. Parecen intuirse 4 torres, pero los volúmenes no se reflejan con la claridad que muestra en otros dibujos. Las aristas no se ven nítidas. Quizá estuviesen ya muy arruinadas. 
En el caso de la torre T30, la discontinuidad del aparejo, el cambio de material empleado e incluso del tratamiento del almenado denotan, la posición en la que se encontraba la torre. A la izquierda se observa un lienzo con abundancia de mechinales y piezas de granito entre mezcladas en la mampostería. Al lado derecho el aparejo es una mampostería mucho más menuda, sin piezas de granito y sin la presencia de mechinales. Los petos presentan un almenado distinto a uno y otro lado del punto donde se encontraba la torre y a su izquierda los merlones se encuentran remetidos respecto a la vertical del lienzo, mientras a la derecha existe continuidad entre ambos elementos.

Al otro lado del postigo de San Juan, delante de la T31, encontramos tres sillares, supuestamente hay un cuarto sillar cubierto, prácticamente enterrados que se han descubierto al realizar unas labores de desbroce.
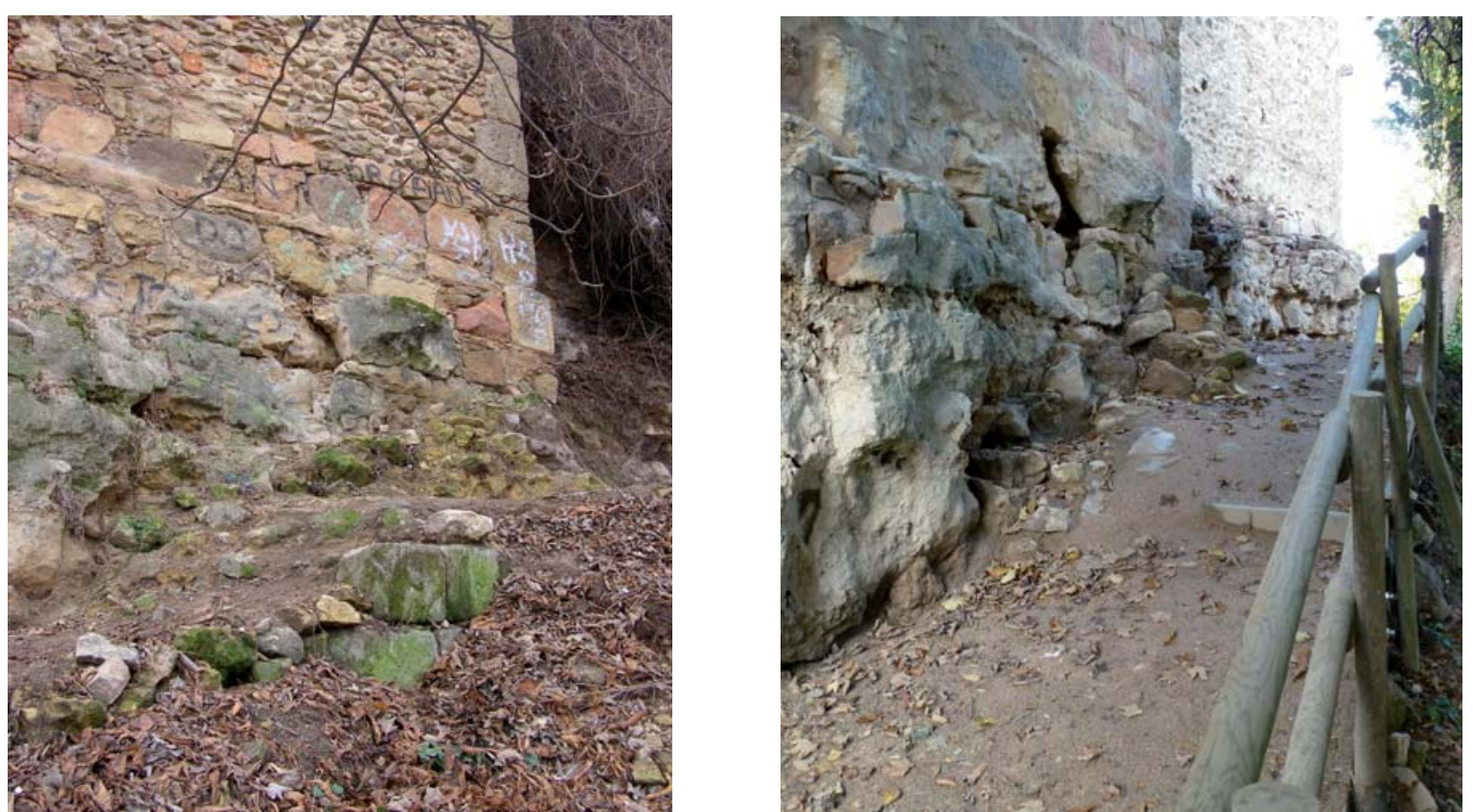

Figura 4.1.28: Torre T31. En el centro de la imagen se observan 3 sillares de granito que aparecieron en esa disposición al desbrozar y observamos por detrás de ellos una especie de mampostería que consideramos es el relleno del interior de la torre. La torre forraría la roca, como hemos visto que hace en otros puntos de la muralla. Figura 4.1. 29: La torre Actual se ha reconstruido nuevamente retranqueada, apoyada sobre la roca sana.

Creemos que esos sillares están dispuestos en su posición original. Lo que vemos detrás de ellos es una mampostería arruinada que creemos es el relleno interior de la torre, actualmente prácticamente tapada por el jabre aportado para la capa superior del camino. Esta torre forraría la roca, como hemos visto en otros puntos de la muralla y el colapso de ésta, produciría el derrumbe de la torre, que fue reconstruida en una posición más retrasada, apoyando sobre la roca sana.

Si estas piezas están en su posición correcta, como sospechamos, la torre T31, tendría un resalte mayor, su cara exterior se encontraría más adelantada de donde se encuentra actualmente. Al estar adyacente al postigo de San Juan, el mayor resalto redundaría en una mejor defensa del postigo, ya que posiblemente el camino de acceso subiría hacia el postigo zigzagueando por la ladera, obligando a pasar a los pies de la torre que flanquearía el acceso. 
La T31, presenta todas las características de ser un aparejo de nueva factura, fruto de una reconstrucción. Una intervención realizada recientemente en el entorno de esta torre ha desvirtuado estos restos, enterrándolos casi totalmente.
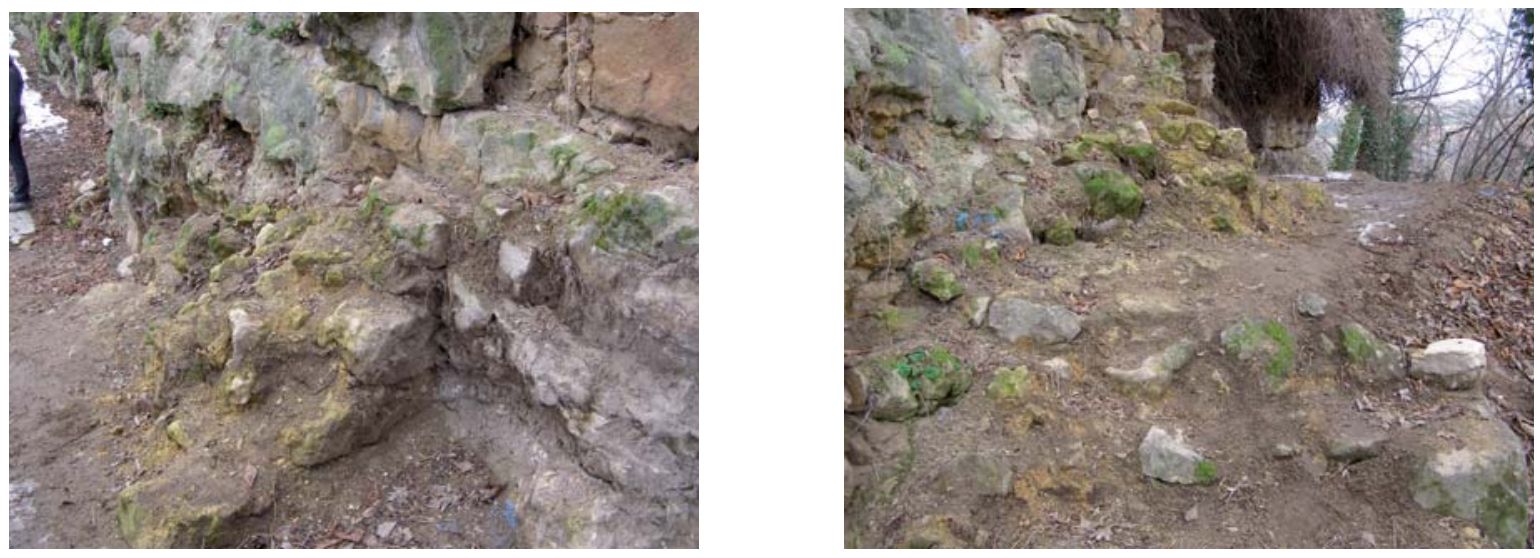

Figura 4.1.30: Otras evidencias del distinto trazado de la torre T31 que a día de hoy han quedado ocultos por la intervención.

Figura 4.1.31: Otras alineaciones sobre una roca tallada verticalmente y el relleno interior de mampostería mezclado con otro material procedente, casi con total certeza, del derrumbe de la torre.

\subsubsection{Postigo San Matías y muralla hasta San Cebrián}

El postigo de San Matías, se conocía por las fuentes documentales, pero no se había localizado, hasta que tras unas obras en la parcela adosada a la muralla, calle Taray $\mathrm{n}^{\circ} 2$, se descubrió. Sin embargo la vegetación volvió a ocultarlo ${ }^{109}$ (Ruiz Hernando, 1982, I: 55).

En la actualidad, el postigo está inaccesible motivado por el derrumbe de la roca que lo ha dejado suspendido al pie de un acantilado, destruyéndose la rampa de acceso al mismo. Es posible que en dicho hundimiento se cayese alguna parte de la muralla dado que el lienzo hasta la torre T35 está totalmente reconstruido y realiza unos quiebros muy bruscos, remetido a la nueva vertical de la roca tras el derrumbe. Intramuros, el callejón que daba acceso se cerró incorporando lo a la propiedad privada, cediéndolo el ayuntamiento en 1888 (AMS: 931-24). ${ }^{110}$

En el plan Director se plantea que el lienzo de muralla discurría más recto, sin trazar la concavidad actual para adaptarse al perfil del cortado de la roca, existiendo una torre, a la que denominan T34, en ese nuevo trazado entre la T33 y el postigo, que atendiendo a dicha propuesta, lo que contemplamos hoy en día, sería una reconstrucción.

No hemos encontrado ninguna evidencia que respalde dicha afirmación. En el dibujo de Wyngaerde, ya vemos la muralla con un trazado muy similar al actual, realizando un quiebro que se remete.

\footnotetext{
109 Aprovechando unas nuevas obras con motivo de la consolidación de una zona cercana de la muralla, hemos conseguido fotografiarlo.

${ }^{110}$ En el expediente se incluye un plano con el trazado del callejón en esa fecha.
} 

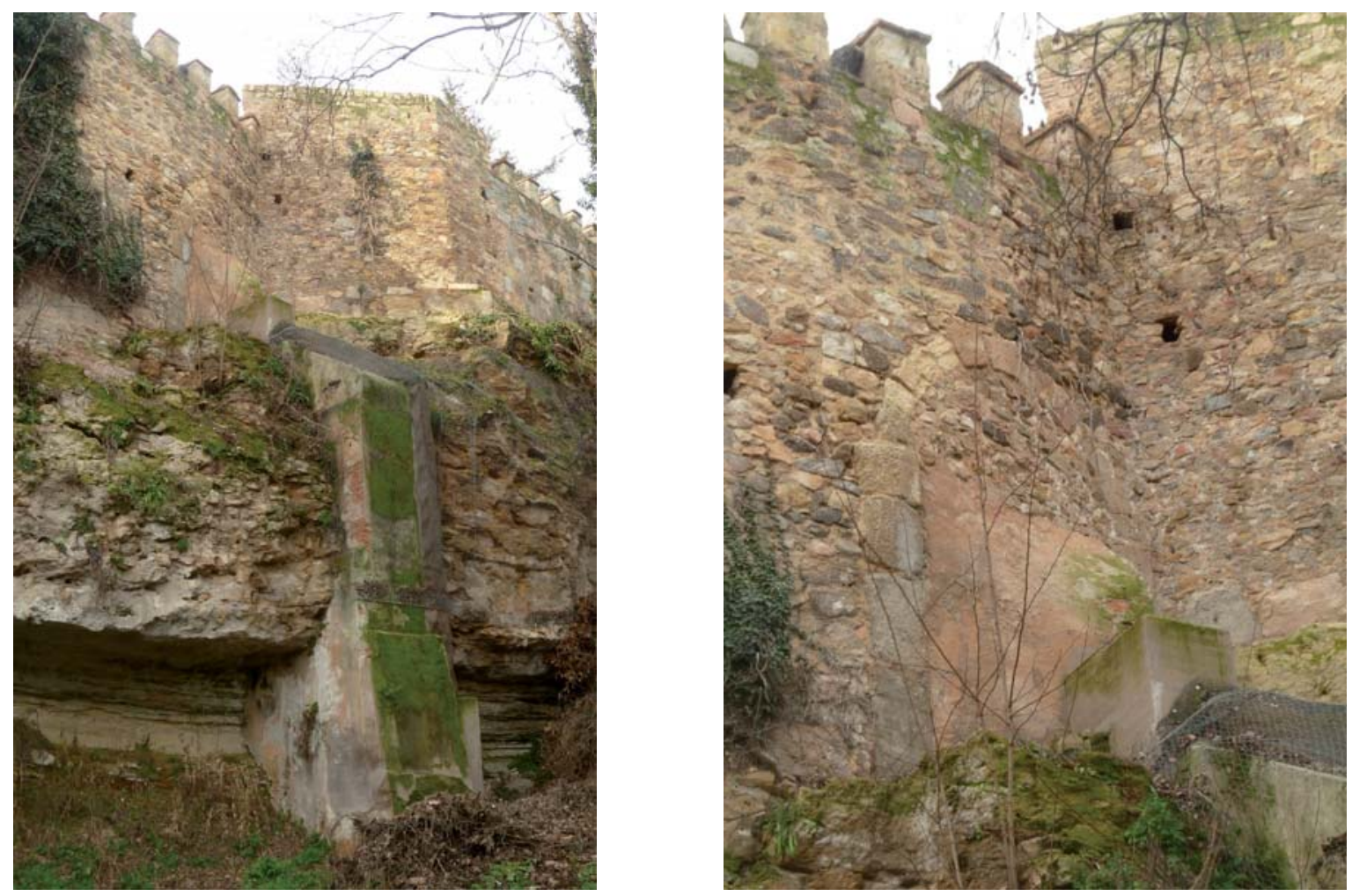

Figura 4.1.32: Imagen del postigo picado o de San Matías, suspendido al borde del cortado de la roca, completamente inaccesible en la actualidad. Se ha construido una bajante adosada a la roca justo delante de él.

Figura 4.1. 33: Detalle del mismo postigo tapiado. Se trata de un sencillo arco apuntado de pequeñas dovelas que parece ser obra de mediados del siglo XIII (Ruiz Hernando, 1982, I: 55). Ver Figura 4.1.36.

Observando el dibujo de Wyngaerde descubrimos que entre el postigo de San Juan y el de San Matías, existen tres torres ${ }^{111}$, por lo que lo tenemos perfectamente situado, donde se encuentra en la actualidad. Estaba en la zona del quiebro, tras el cual, la muralla recupera la alineación.

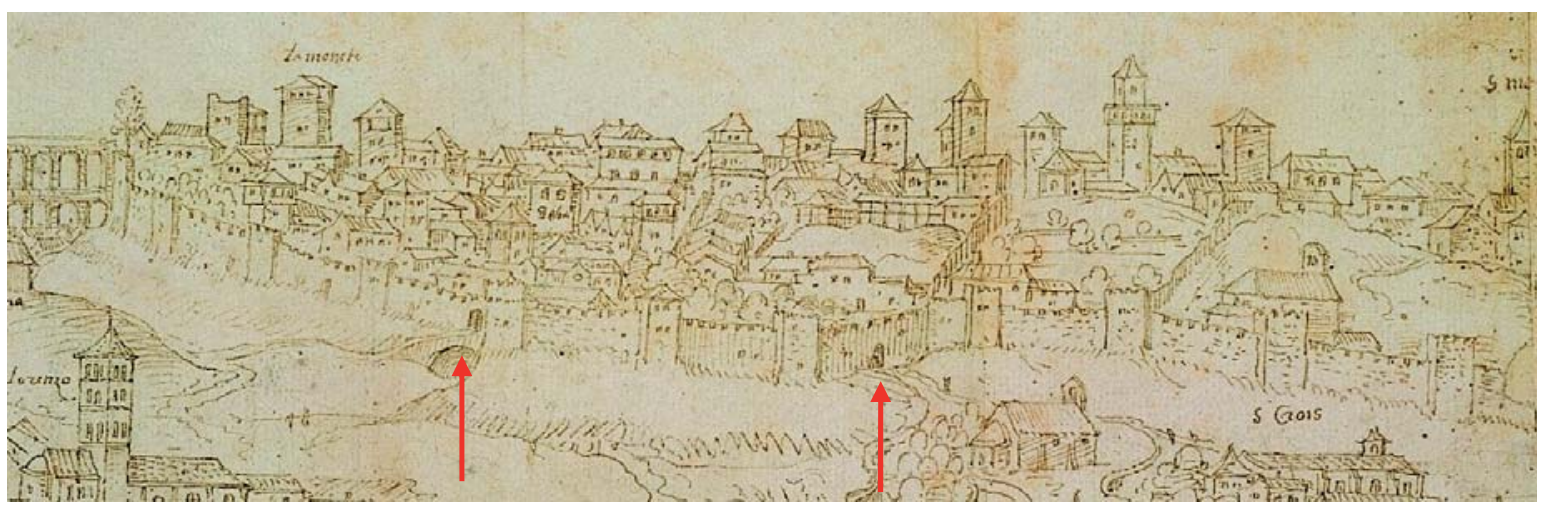

Figura 4.1.34: Detalle del dibujo de la cara norte de Wyngaerde (Fuente: AMS). Marcados con sendas flechas rojas, observamos los dos postigos, el de San Juan a la izquierda y el de San Matías, en el centro de la imagen. Entre ambos contamos 3 torres. También se aprecia que el trazado de la muralla hace una concavidad en esa zona en que se sitúa este segundo postigo.

${ }^{111}$ Curiosamente, la T32 presentaba en 1562 una cubierta a 4 aguas, como si tuviese una construcción habitable encima. 
En el plano de Antonio de la Iglesia, se representa perfectamente la muralla, también con tres torres en ese tramo y vemos una torre, que coincidiría con la T34, en la esquina que genera la muralla al final del trazado cóncavo que presenta en la actualidad y por el lado intramuros distinguimos la calle que conducía al postigo. Dado que el postigo se cierra en $1811^{112}$ (AMS: 864-7), se reabre en 1826 (AMS: 4810-3, I: 35-36), el derrumbe que inutiliza ese postigo se produce en 1831 (AMS: 4810-3, I: 57), el tapido definitivo en 1834 (AMS: 4810-3, I: 13) y el plano de Antonio de la Iglesia es de 1837, en el que representa el postigo cerrado ${ }^{113}$ y la muralla en un trazado muy similar al actual, deducimos que esa parte de muralla no se hundió en el XIX, por lo que el trazado actual era el que tenía antes del tapiado.

Esto no contraviene que el postigo cegado que actualmente vemos en el lienzo de muralla sea una reconstrucción anterior al XIX motivada por algún derrumbe de la roca y que el postigo y lienzos medievales pudieron situarse en otro trazado más recto como propone el Plan Director, dado que la existencia de quiebros tan bruscos en puntos donde no existe una torre es algo excepcional en el trazado de la muralla. Si bien Antonio Ruiz lo data en el siglo XIII, creemos que bien podría tratarse de una reconstrucción, reubicándolo en su nueva posición y reaprovechando las jamabas y dovelas, realizada en una de las reparaciones tras alguno de los numerosos derrumbes que han afectado la zona, 1811, 1725, 1647 o incluso antes de $1608^{114}$.

Así según nuestra hipótesis, el postigo medieval de San Matías, para cuyo paso se perfila la roca, queda arruinado e inaccesible por un derrumbe del peñasco. La reparación de 1648, para azer el postigo y camino que se cayo en la puerta de san mathias (AMS: AC-1039: 475), consiste en la reconstrucción de los lienzos arruinados y un nuevo postigo en las proximidades, con acceso a la calle interior preexistente y para el que se prepara un nuevo camino de acceso por el farallón, de marcada pendiente, como su sobrenombre de postigo picado indica, posiblemente condicionado por la disposición del caserío y el camino de acceso desde el interior que no permitía alejar de ese punto su nuevo emplazamiento.

Nos hace pensar así la existencia de un corte tallado en la roca, (Ver Figura 4.1. 37) adyacente a la situación del actual postigo tapiado, en el que creemos se emplazaba originalmente el postigo, pero que el derrumbe de la roca, dejo inaccesible, obligando a la construcción de un nuevo postigo en las proximidades, que es el que se tapia en el siglo XIX. Así el que actualmente se considera postigo picado, sería una reconstrucción, que podríamos relacionar con cualquiera de las dos intervenciones más importantes que hemos documentado, la de 1648 (AMS: AC-1039: 475) o la de 1725 (Larios Bernaldo de Quirós, 1972: 328), o incluso

112 Este postigo ha sufrido numerosos avatares como demuestra otras referencias que también hemos encontrado, en la que se dice que el postigo de San Matías está cerrado en 1608, pero había estado "abierto basta tiempos cercanos" (Quintanilla, 1954: 348). En 1625, el prior de San Agustín pide a la ciudad que se cierre dicho callejón (AMS: AC-1029: 644-646), posiblemente porque el postigo seguía tapiado o bien porque no tenía mucho tránsito. En 1647, se paga a Manuel Ximilio, escribano del número de la ciudad, 1.300 rs. por la cerca y sitio que dio para azer el postigo y camino que se cayo en la puerta de san mathias. (AMS: AC-1039: 475). En 1707 hay una solicitud de la comunidad de religiosos de Santa Cruz para que se reabra el postigo (Ruiz Hernando, 1982, II: 352), lo que nos demuestra que tras la intervención de 1647 se ha vuelto a tapiar por algún motivo. En 1725 tenemos una nueva intervención, en que se consolida postigo y roca, y que algún autor relaciona con el derrumbe que deja sin acceso al postigo (Larios Bernaldo de Quirós, 1972: 328).

113 En el resto de los casos, las puertas y postigos se representan claramente marcando el paso abierto. Es significativo que en este caso vemos perfectamente dibujada la calle de llegada al postigo, pero la muralla no se grafía abierta.

114 Curiosamente constatamos que transcurren unos 80 años entre las distintas intervenciones que tenemos documentadas para recuperar el postigo tras alguna ruina. Esto nos da una idea de la periodicidad con que se han producido los derrumbes en la zona. 
pudo haber ocurrido en otra intención previa que no tenemos documentada. Creemos que este postigo es fruto de la intervención de época moderna en que se reutilizó el material, jambas, dovelas y sillares con que se ejecuta el actual postigo tapiado, que sustituiría a otro previo, quizá el original de la muralla. No encontramos otro sentido a ese tallado perfectamente cajeado de la roca en una altura considerable, con las dimensiones muy acordes a las de un paso peatonal.
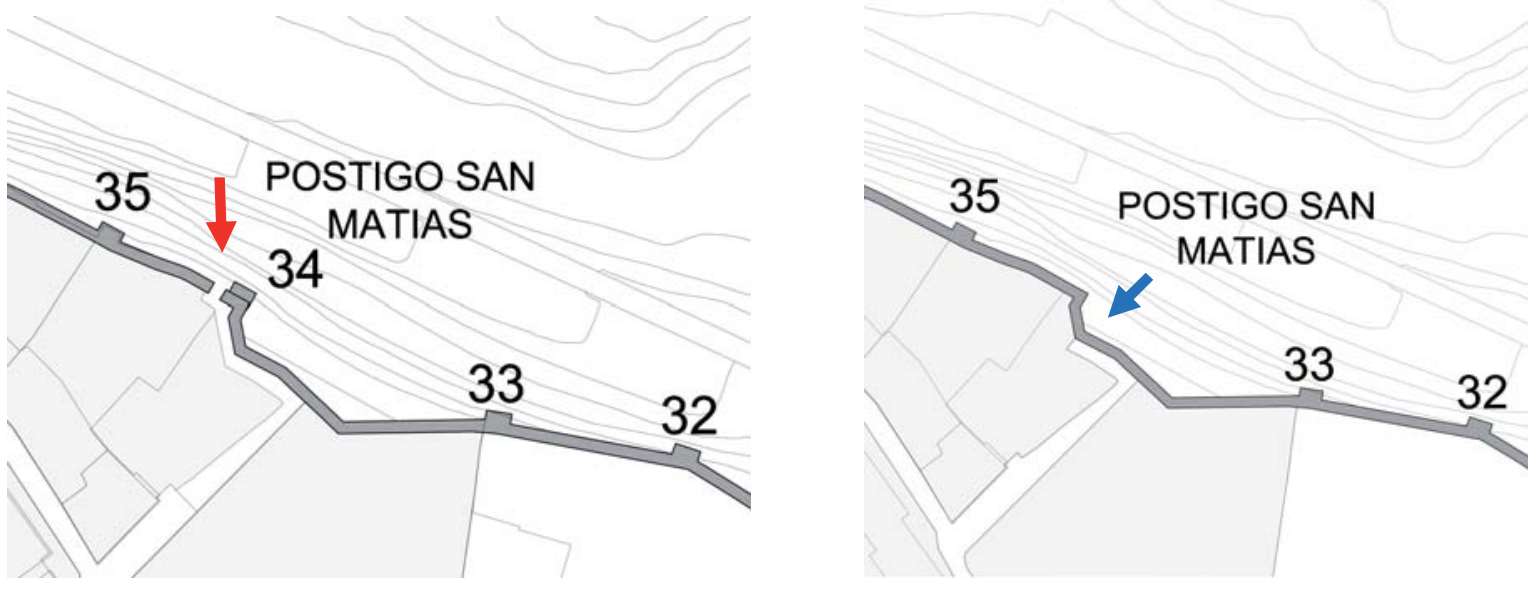

Figura 4.1.35: Plano de la restitución de la torre T34 y el postigo picado o de San Matías en su posición original. La torre se encontraba en el quiebro que actualmente traza la muralla. A su derecha, se encuentra el actualmente tapiado postigo. Creemos que el postigo originalmente se situaba más hacia el oeste, superado ya el actual quiebro, al otro lado de la torre T34 que lo flanqueaba, donde marca la flecha roja. El callejón de acceso era más largo que cuando se desplaza el postigo a su última posición, donde marca la flecha azul en la Figura 4.1.36. Véase la posición de este postigo desaparecido en la Figura 4.1. 37.

Figura 4.1.36: Plano de restitución del postigo picado o de San Matías hacia 1831, en el momento en que se clausuró definitivamente el postigo de medidos del siglo XIII. Posteriormente se privatiza el callejón que conducía hacia él, al quedar sin uso. La disposición es muy similar a la representada por Wyngaerde en 1562.

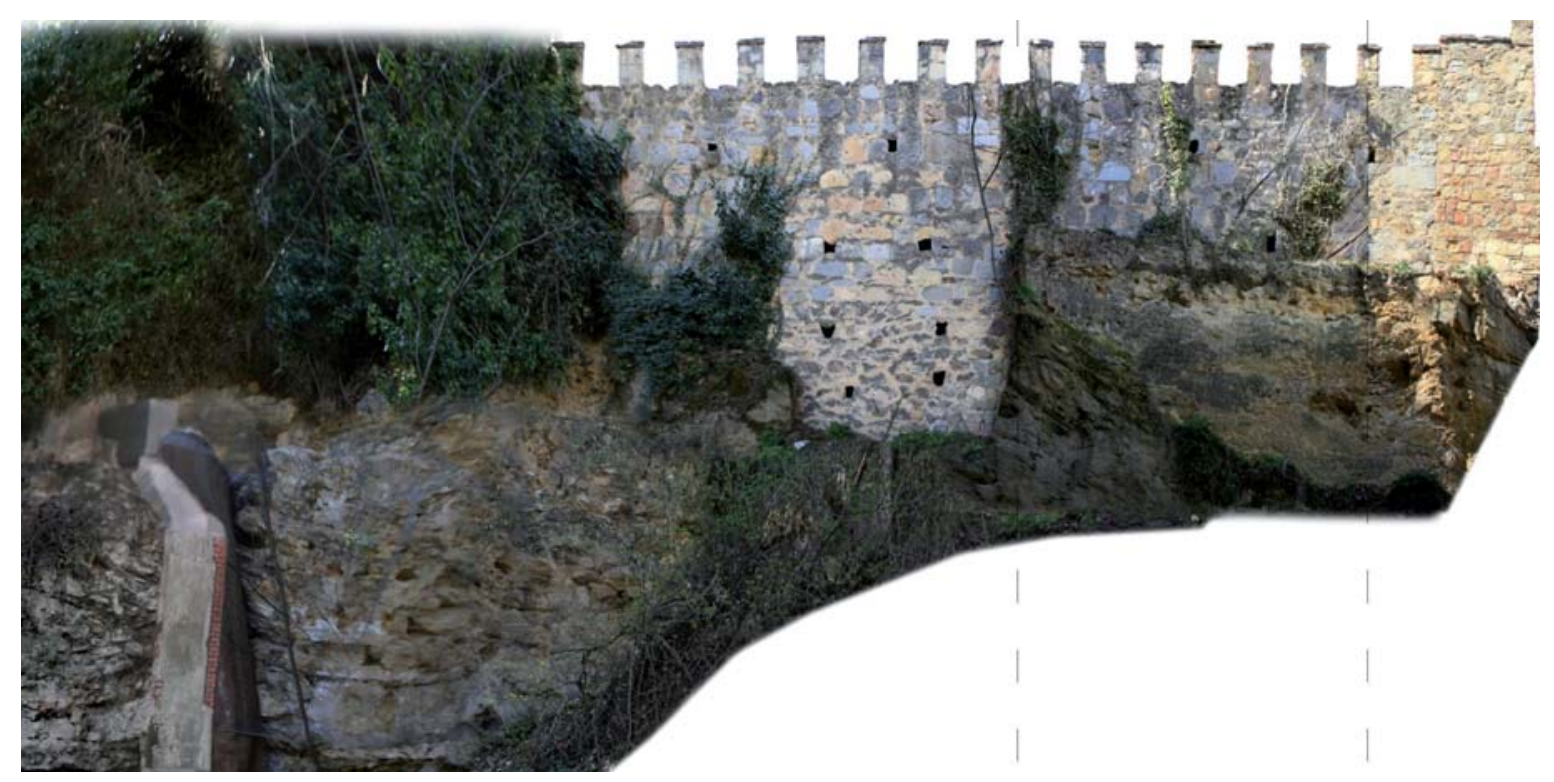

Figura 4.1. 37: Ortofoto del lienzo L33-L35, junto al postigo picado. Se observa un corte tallado en la roca que sospechamos sería el paso inicial del postigo, tapiado por una fábrica de mampostería en la que distinguimos tres pares de mechinales a distintos niveles. A su izquierda, la actual situación del postigo picado, tapiado y oculto por la vegetación. Su emplazamiento se identifica por la bajante que se ha construido adosada a la roca (PH: P0170) y que vemos en la parte inferior a la izquierda de la imagen. Su ubicación puede verse en la Figura 4.1.35. 
Así además del postigo picado en un emplazamiento distinto, existía una torre T34, en la esquina que se genera en la concavidad cercana al postigo, la cual sospechamos que podría haberse desplomado, con posterioridad al derrumbe de la roca de 1831, ya que dicha torre aún aparece grafiada en el plano de 1837. La regularidad en las dimensiones de las torres, y la desproporcionada distancia ente la T33 y la T35 que se sitúan a ambos lados del postigo de San Matías, coincidiendo con un extraño quiebro del trazado de la muralla nos hacen convencernos de la existencia de esa torre adicional, T34. Esto coincidiría en posición con lo reflejado en el plano de Antonio de la Iglesia.

En esta zona, todas las torres son de planta rectangular y dimensiones muy similares, variando entre 5,20-5,50 metros de frente y 2,00-2,30 metros de resalto, separadas por unos lienzos relativamente largos y de longitudes un tanto irregulares. Existen algunos quiebros en los lienzos aparentemente motivados por desplomes de la roca que obligan a la reconstrucción remetiéndose para buscar apoyo en la roca nuevamente o bien para aprovechar restos de construcciones previas, como en el caso del lienzo L38-39.

Desde ese punto hasta la puerta de San Cebrián, esto es desde la T34 hasta la T40, contamos 10 torres, mientras en la actualidad encontramos 8. En el plano de Antonio de la Iglesia figuran 9. Si consideramos que existía una junto a San Matías, en nuestro recuento tendríamos que existen las mismas que en el plano de 1837, por lo que solo diferiría el grabado de Wyngaerde, induciéndonos a pensar que faltaría otra más, que desapareció entre 1562 y 1837. Eso explicaría que la métrica de esta zona sea tan elevada, mucho mayor que en el resto de la muralla y las longitudes de los lienzos tan variables.

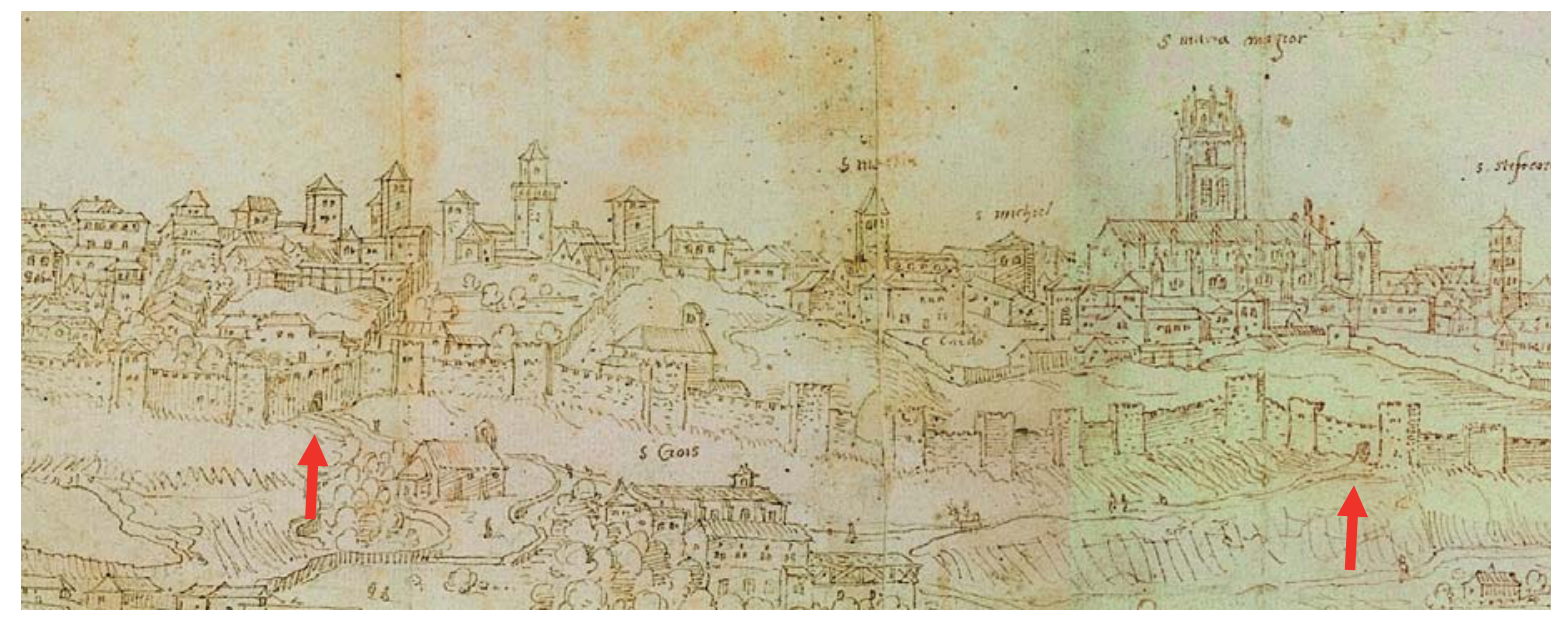

Figura 4.1.38: Detalle del grabado de la parte norte de Wyngaerde (Fuente: AMS). Observamos el postigo de San Matías a la izquierda y la puerta de San Cebrián a la derecha. Entre ambos contamos 10 torres. También se aprecia que el trazado de la muralla hace un quiebro para acometer a la puerta de San Cebrián, representándose muy juntas las torre T41 y T42, tal y como sucede en la actualidad.

En el grabado de 1562, se reconocen perfectamente el cambio de dirección que realiza la muralla en las proximidades de la puerta de San Cebrián, así como las torres T41 y T42, muy cercanas entre si y a la puerta. De faltar una torre, no sería entre estas. Los lienzos más largos son L35-36, L36-37, de 40 y 44 metros respectivamente, siendo las torres T36 у T37, aparentemente reconstruidas en su totalidad, no así la T35. 
Si creemos el número de torres que se reflejan en el grabado de Wyngaerde, supondría asumir la hipótesis de que en algún momento se derrumbaron dos torres y el lienzo que las unía y en la reconstrucción solo se recuperó una de las torres. De ser así, la torre T36, sería la opción más creíble y en origen deberían existir dos torres entre la T35 y la T37. En el plano de Antonio de la Iglesia en ese punto la muralla hace un quiebro muy acusado y se simula una discontinuidad ya que se modifica el grafismo. Esto no deja de ser una hipótesis con el único sustento del grabado de Wyngaerde. Sin embargo, con lo frontal que está hecho el grabado en esta parte de la muralla, creemos que puede ser factible. Otra cosa muy distinta sería en zonas donde las torres se ven más en escorzo ocultándose unas a otras, como por ejemplo hacia la puerta de Santiago y el Alcázar. Es sólo una posibilidad a considerar, pero que no nos atrevemos a computar como torre real en el computo de torres existentes inicialmente en la muralla.

\subsubsection{Postigo de Fuente Cercada.}

Del postigo de Fuente Cercada sólo se sabe que estaba cercano a la puerta de San Cebrián en la huerta del Hospital de la Misericordia. (Ruiz Hernando, 1982: 54). Estaba incluido dentro de la buerta del Hospital de la Misericordia, entre éste y la puerta de San Cebrián, pero se ha perdido todo rastro. Nunca debió de tener un gran uso, lo que motivó que el Ayuntamiento lo cediera al Hospital en el siglo XVII. Las referencias documentales son minimas (AMS: 4810-3, I: 15)

Si observamos la planimetría de la muralla en la parcela del Hospital de la Misericordia ${ }^{115}$, lo primero que nos llama la atención es el significativo desvío, un giro de $90^{\circ}$ que realiza la muralla a la altura del edificio de Hospital. Un giro de $90^{\circ}$ con una torre de grandes dimensiones en la esquina exterior. La misma disposición que encontramos en la puerta de San Andrés y muy similar a las de la puerta de San Martín y San Juan, según la configuración que hemos planteado para ellas en nuestra hipótesis.

En el grabado de Wyngaerde se reconoce perfectamente el quiebro de la muralla, las edificaciones del Hospital de la Misericordia (únicas cercanas a la muralla en esta zona) que facilitan la identificación del punto y se aprecia un camino de acceso hacia dicho punto, que evidencia que allí hay una puerta. El acceso está muy cerca de San Cebrián, y situado en la actual huerta del Hospital. Más al fondo se ve otro camino que asciende por la ladera con otra puerta de entrada a la ciudad, pero ya muy cercano al alcázar. Ese postigo lo identificamos con el postigo del Alcázar o del parque que se verá más adelante.

Sin embargo, ente San Cebrián y el Alcázar solo se reconoce ese acceso, a cuyos pies se sitúa la iglesia de Santiago, por lo que habitualmente este postigo se ha interpretado como la puerta de Santiago. Sin embargo esa puerta está demasiado cerca de San Cebrián y claramente situada junto al Hospital de la Misericordia, algo que confirma la presencia de la iglesia de San Pedro de los Picos detrás de ella. Este acceso se sitúa por delante de la iglesia de San Pedro de los Picos, algo que no encaja si esa fuese la puerta de Santiago ${ }^{116}$. Si contamos las torres

\footnotetext{
115 En este punto hemos localizado que existe una torre adicional, que no se refleja en el Plan Director. La hemos nombrado como T46’ y existe un lienzo más, el L46’-47. Véase el capítulo III, de descripción de la muralla.

116 Hay que recordar que cuando Wyngaerde realiza este grabado, la puerta de Santiago aún no presentaba la imagen actual, con dos plantas y con cubierta, sino que era una torre muy similar a las demás de la muralla, rematada con una terraza descubierta. No se aprecia ningún otro camino de subida hacia la muralla, pero también hay que destacar que en esa parte, el grabado pierde definición y detalle. La muralla empieza a verse en escorzo y posiblemente las torres se tapasen unas a otras, ya que el número de torres representadas tampoco encaja con la
} 
representadas en el grabado desde la puerta de San Cebrián, incluyendo la T43, completamente adosada a la puerta, hasta el quiebro, hay seis. Son exactamente las que existen en la realidad hasta la T47 que es la que se sitúa en la esquina, considerando la T46'que hemos descubierto y que no se refleja en la planimetría del Plan Director.

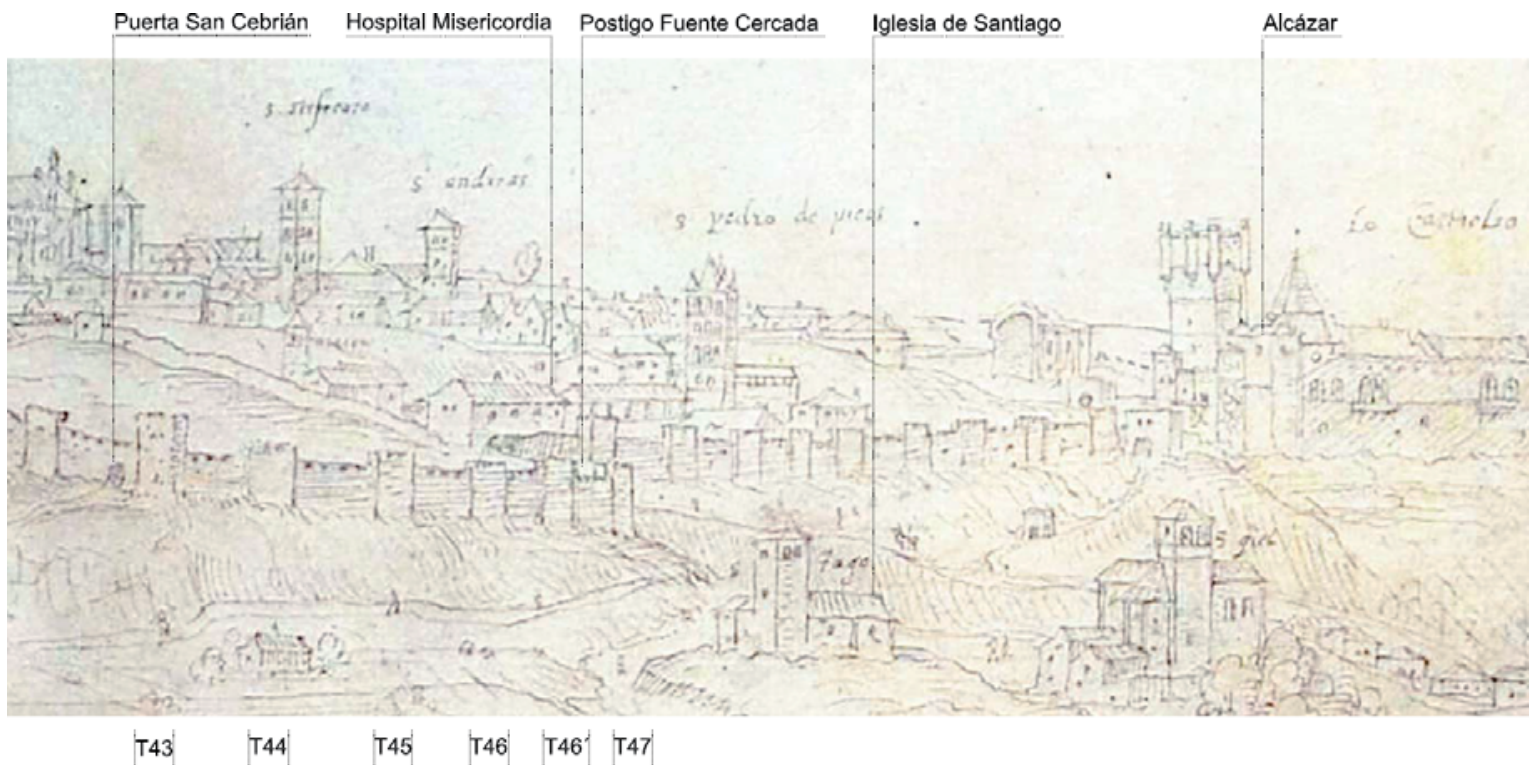

Figura 4.1.39: Detalle del dibujo de Wyngaerde de la parte norte de la ciudad (Fuente: AMS). A la izquierda vemos la puerta de San Cebrián. No lejos de ella se encontraba el postigo de la Fuente Cercada. Se observa el camino de subida hacia el postigo. Se identifica perfectamente el quiebro de la muralla, a la altura del edificio del Hospital de la Misericordia. La iglesia de San Pedro de los Picos se representa por detrás.

Así según nuestra hipótesis, en ese quiebro de la muralla hacia el que se dirige el camino se encuentra el desaparecido postigo de Fuente Cercada. ${ }^{117}$

En 1623 se cita a un tal Francalin, como propietario de la parcela, en la que tiene una casa, colindante al Hospital de la Misericordia, parcela que hoy en día es la huerta del Hospital (Quintanilla, 1954: 349). En 1663 consta una petición del Hospital para que se le ceda la calleja que va al postigo de Fuente Cercada (AMS: 1158-83 (41-2)). Debemos suponer que en ese momento el postigo tendría poco uso y posiblemente el Hospital ya era propietario de la parcela de Francalin, de modo que pretende agrupar sus dos propiedades, hospital y huerta, que estarían separadas por el callejón de acceso al postigo. En 1707, el 19 de Septiembre, el ayuntamiento acuerda cerrar el postigo y ceder al hospital el terreno del callejón (Ruiz Hernando, 1982; II: 352).

realidad. La puerta de Santiago podría ser cualquiera de las torres que se representan entre San Pedro de los Picos y la torre-puerta cercana al Alcázar.

117 De esta afirmación se puede también obtener otra conclusión. La puerta de Santiago se llamaba así por la cercana iglesia, desaparecida, de la misma advocación, que hasta la fecha se ha ubicado debajo de la citada puerta, en las proximidades de la Casa de la Moneda. Si ese quiebro y ese camino no pueden ser la puerta de Santiago, sino el postigo de la Fuente Cercada, observando con detenimiento el grabado de Wyngaerde vemos que la iglesia de Santiago se encuentra debajo del postigo de Fuente Cercada, sobre una pequeña loma, no junto a la Casa de la Moneda, donde se la ha buscado hasta ahora. Quizá si se busca en esta ubicación, aparezcan sus posibles restos. 
Pero este testimonio nos aporta aun más datos interesantísimos para confirmar nuestra hipótesis. Se trata de la descripción de unas obras que se compromete a realizar el maestro Jusepe Riero, en la muralla de Segovia, documento del que extraemos el fragmento en que se habla del postigo de la fuente cercada. Por su interés, lo trascribimos literalmente:

El 13 de febrero de 1623 el maestro Jusepe Riero, de la parroquia de San Miguel, se obligó, ante el mismo escribano, a reparar los muros y puertas, por 5.700 reales. Habría que recubrir de piedra y cal y revocar tres lienzos de muralla y tres cubos cuadrados, desde el que hace esquina hacia la fuente cercada hasta pasar el huerto de la casa de Francalin, levantar la muralla por dentro desde esta casa hasta el postigo de la fuente cercada, en el que arreglaría el arco y las almenas; desde aqui hasta el tercer cubo bajo el Hospital de la Misericordia se rehenchirian los tres lienzos de muralla con buena piedra y cal y se repararían con piedra franca bien labrada las esquinas de los dos cubos cuadrados;

(Quintanilla, 1954: 349)

Siguiendo el orden de las intervenciones en la muralla establecemos perfectamente los elementos. La descripción tiene que empezar desde el lado de la puerta de San Cebrián, dado que primero encontramos la huerta de Francalin, luego la casa de Francalin, el cubo que hace esquina hacia la fuente, luego el postigo y por último el edificio del Hospital. No puede ser en orden inverso porque al otro lado del Hospital de la Misericordia se encuentra desde 1579 el Hospital de Convalecientes. Por lo tanto, la huerta de Francalin tiene que ser necesariamente, una parte, o completa, de la parcela sensiblemente triangular que abarca desde el Hospital hasta la puerta de San Cebrián, la actual huerta del Hospital. La casa de Francalin, se sitúa en el extremo de esta parcela, entre su propia huerta y el Hospital, posiblemente haciendo pared, sino fachada hacia el callejón del postigo.

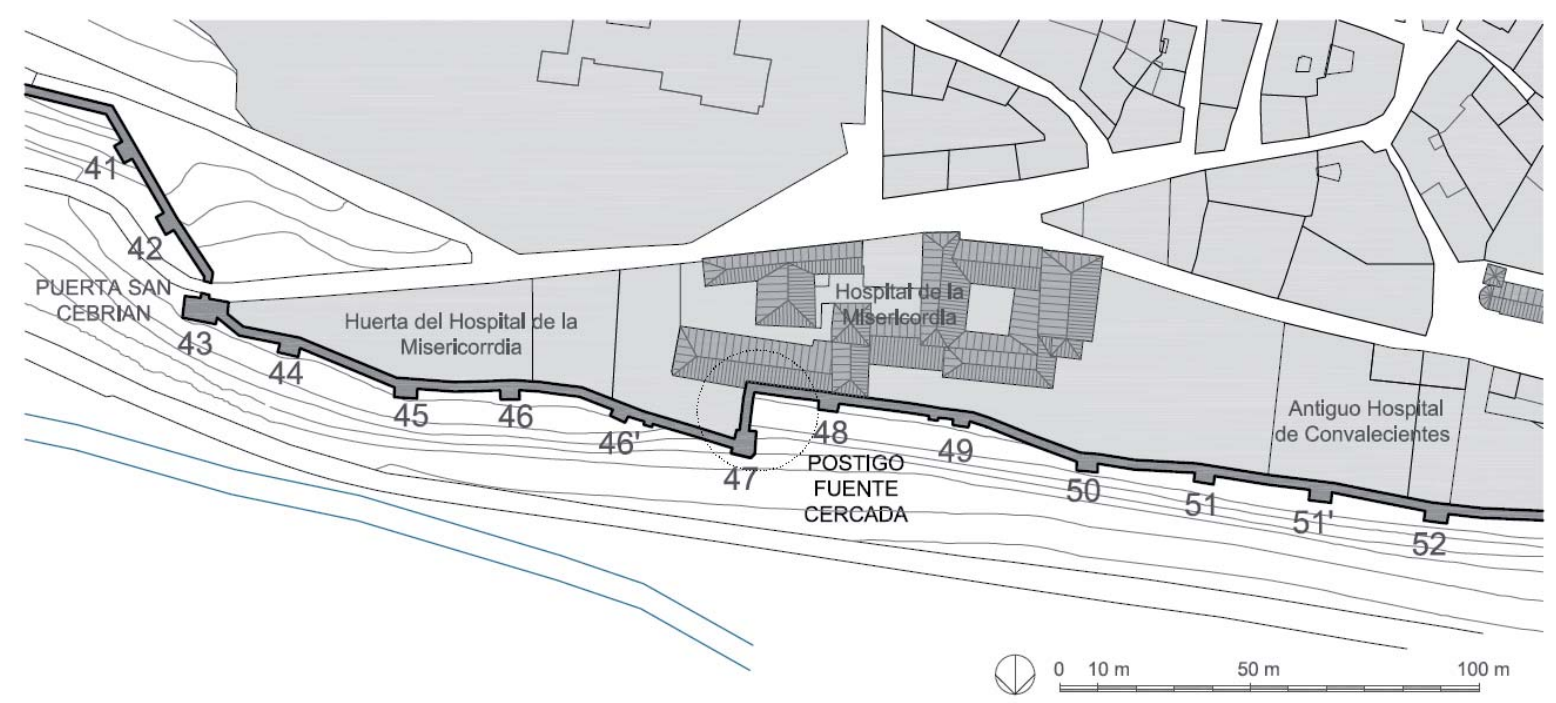

Figura 4.1.40: Plano de la muralla entre la puerta de San Cebrián y el Hospital de la Misericordia, representando los elementos que se describen en el documento estudiado por Quintanilla e indicando nuestra hipótesis de la existencia del postigo de fuente cercada y el camino de acceso. Se ha dispuesto orientado al sur para comparar con el grabado de Wyngaerde.

En esta parte se arreglarían tres cubos y tres lienzos, desde el que hace la esquina. Esto es, los lienzos desde la torre T45, sin incluir ésta última, hasta la T47 (Figura 4.1.41). Al otro lado de la esquina y el postigo, bajo el Hospital de la Misericordia, otros tres lienzos, con sus tres cubos, de 
los cuales dos son cuadrados, esto es hasta la T50. Es anecdótica pero importante la aclaración, dado que como ya hemos visto en el capítulo IV, la torre T49 decíamos que era una torre rectangular en la que se habían perdido los sillares esquineros y que se había reparado dándola forma semicircular. De esta forma se representa en la planimetría del Plan Director y comprobamos que el "engaño" en la forma de la torre, por la reparación redondeando las esquinas, se repite ${ }^{118}$. En las otras dos torres se conservan algunos sillares esquineros, si bien están deteriorados, algunos sustituidos por ladrillo y en la T48 ocultos por el revoco. En la T50 identificamos una reparación de las esquinas con mampostería encintada, quizá esa sea la reparación del maestro Jusepe en 1623.

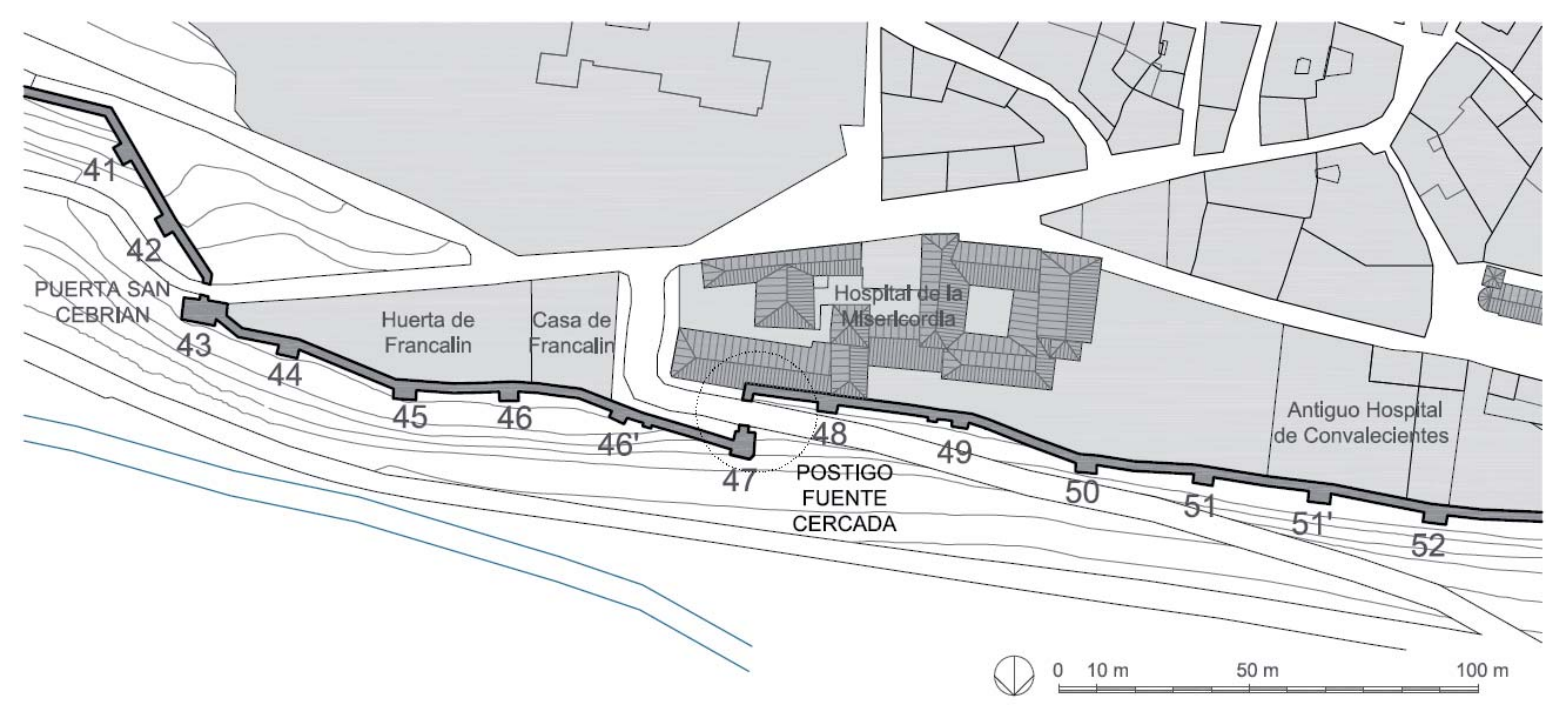

Figura 4.1.41: Plano de la muralla entre la puerta de San Cebrián y el Hospital de la Misericordia, representando nuestra hipótesis de la existencia del postigo de fuente cercada, el camino de acceso y el resto de elementos mencionados en el documento publicado por Quintanilla.

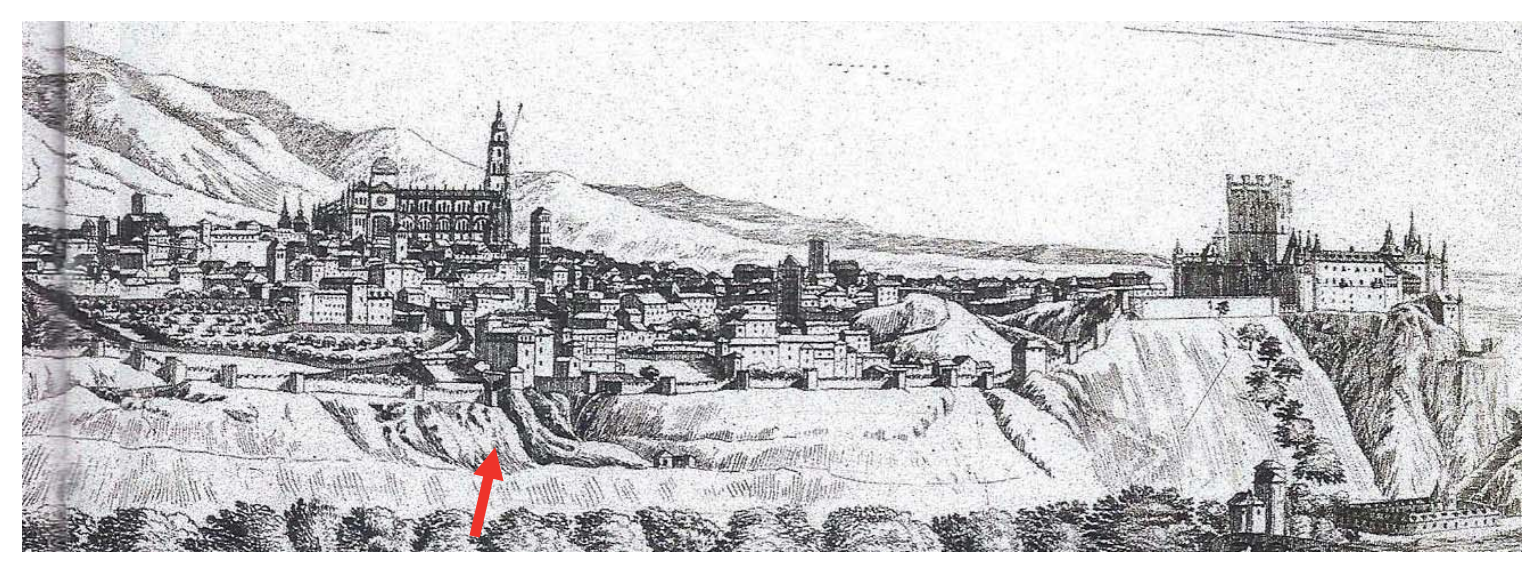

Figura 4.1.42: Profil de la ville de Segovie, en Espagne de Louis Meunier, ca. 1666. Aproximadamente en el centro de la imagen, se aprecia el vallejo que constituiría el desagüe de la fuente cercada, que lo representa como lo más abrupto de toda la ladera norte. Aún se distingue la tapia que separa el Hospital de la Misericordia de la huerta de Francalin, aunque no hay definición para percibir el callejón de acceso al postigo entre ambas (Santamaría López, 2004: 69).

118 Este dato nos sirve para asignar una fecha ante-quam a la perdida de esos sillares esquineros y la reparación redondeando las esquinas de la torre, que podemos afirmar es anterior a 1623. 
La descripción de las obras encaja perfectamente con la ubicación. Creemos que esta concatenación de datos, dan bastante probabilidad para ser verídica la hipótesis de que en ese quiebro se encontraba el desaparecido postigo de la fuente cercada, sobre el que además nos dan otro dato; sobre el postigo existían almenas.

La T47 es una torre de dimensiones mayores de las habituales en la muralla. En la actualidad está arruinada, posiblemente por un desprendimiento de la roca sobre la que apoya, ya que su esquina exterior está al borde de un acantilado, pero creemos que está incompleta. La fábrica que vemos hoy en día es una reconstrucción parcial escalonada, posiblemente chapando los restos preexistentes, como ya se ha comentado. Tras la torre, se produce el quiebro, desarrollándose el lienzo L47-48 en forma de L. El paso de entrada debe situarse entre esta torre adelantada y la continuación del lienzo hacia la torre T48, de modo que el acceso se realiza avanzando en paralelo a lo largo de la muralla exactamente igual que en las demás puertas. Además el lienzo adyacente, L47-48, es más corto de lo habitual por lo que la siguiente torre, la T48, está más cerca, como en todos los casos de puertas que hemos visto.
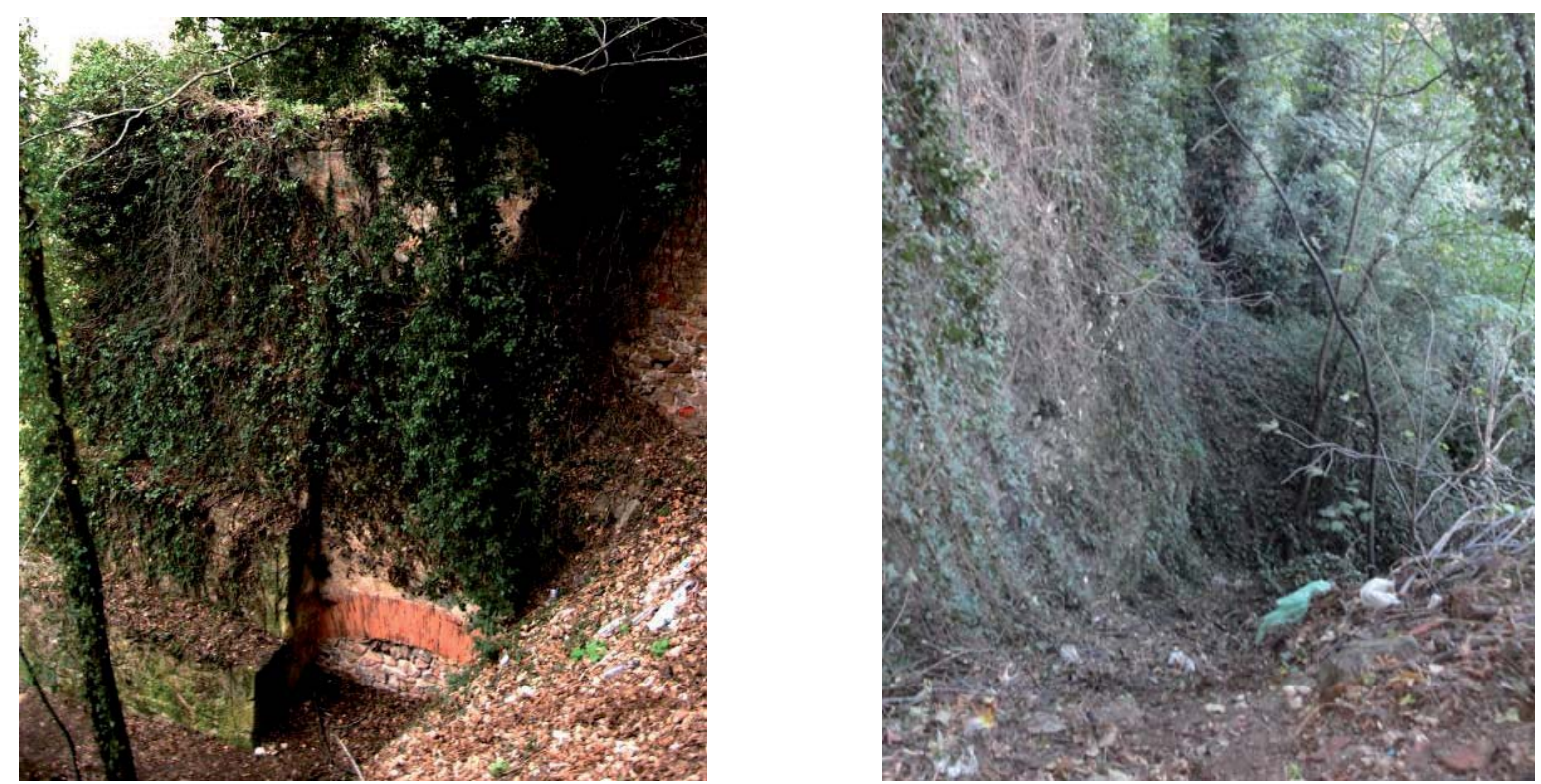

Figura 4.1.43: Imagen de la torre T47. Observamos el arco de ladrillo de características similares al de la puerta de San Cebrián. La configuración de gran torre flanqueando una entrada, que se cobija en un quiebro de la muralla, posee todas las probabilidades de tratarse del desaparecido postigo. Si la disposición del arco en esta hipotética puerta se encuentra a la misma altura que en el caso de la puerta de San Cebrián, podemos hacernos una idea de la profundidad de lienzo que hay enterrado.

Figura 4.1.44: Posible sendero de acceso al postigo. Si el postigo está tan enterrado como parece sugerir la posición del arco de ladrillo de la figura anterior, la rasante original estaría mucho más baja y la pendiente de la subida no sería tan pronunciada. El marcado desnivel lateral de la roca que vemos a la izquierda de la imagen, actualmente tapada por la vegetación, aparentemente cae en vertical lo que favorece la defensa del acceso por flanqueo.

Del lado corto de la L, donde se debe situar el paso, sólo vemos en la actualidad un arco de ladrillo de dos pies y medio de rosca. Este arco es similar al que existe en la parte alta de la puerta de San Cebrián. Esta realizado con ladrillo perforado, por lo que debe tratarse de una reparación de la segunda mitad del XIX, como muy temprano. Desconocemos lo que hay debajo, ni que profundidad de lienzo se encuentra enterrado. El posible camino de subida 
presenta a día de hoy una pendiente intransitable, pero si descontamos los rellenos que entierran la puerta en la actualidad y recuperamos la cota del paso original, la pendiente sería mucho más razonable, prolongándose la subida en el recorrido intramuros, donde también se ha rellenado para nivelar la parcela del Hospital.

Aún podemos encontrar algunos vestigios más que pueden complementar nuestra hipótesis. En la tapia de cerramiento del Hospital hacia la calle Doctor Velasco existe una jamba de sillería, evidencia de que hubo una esquina, hacia un espacio no construido, que podemos asociar con la esquina original que indica donde estaría el callejón de acceso al postigo y que separaba la huerta de Francalin del Hospital de la Misericordia. Este último trozo de tapia, hasta el actual portón del Hospital que se aprecia al fondo de la foto en la Figura 4.1.45, se levantaría cuando definitivamente se cerró el callejón, cediéndolo al Hospital, en 1707. En el interior de la parcela del Hospital, partiendo desde el punto donde se sitúa esa jamba y en dirección hacia la muralla, se conservan los restos de una tapia bastante arruinada, prácticamente oculta por la vegetación, que sospechamos era el cerramiento de la parcela de Francalin hacia el callejón de acceso al postigo. Resulta imposible determinar la altura que conservan estos muros, pero es posible que en sus fábricas, si se despojasen de vegetación, podamos descubrir restos de jambas y huecos, que serian las puertas y ventanas de esta casa.

Un poco más abajo por la calle Doctor Velasco, superada la jamba de sillería, encontramos otra puerta de menor entidad y calidad constructiva tapiada, se observan dos jambas de ladrillo y un dintel de madera, lo que nos indica una propiedad distinta. Debe ser la entrada a la huerta de Francalin. Todas estas evidencias constructivas nos dan suficientes pistas para restituir el trazado viario y parcelario de esta zona, antes del cierre del postigo.
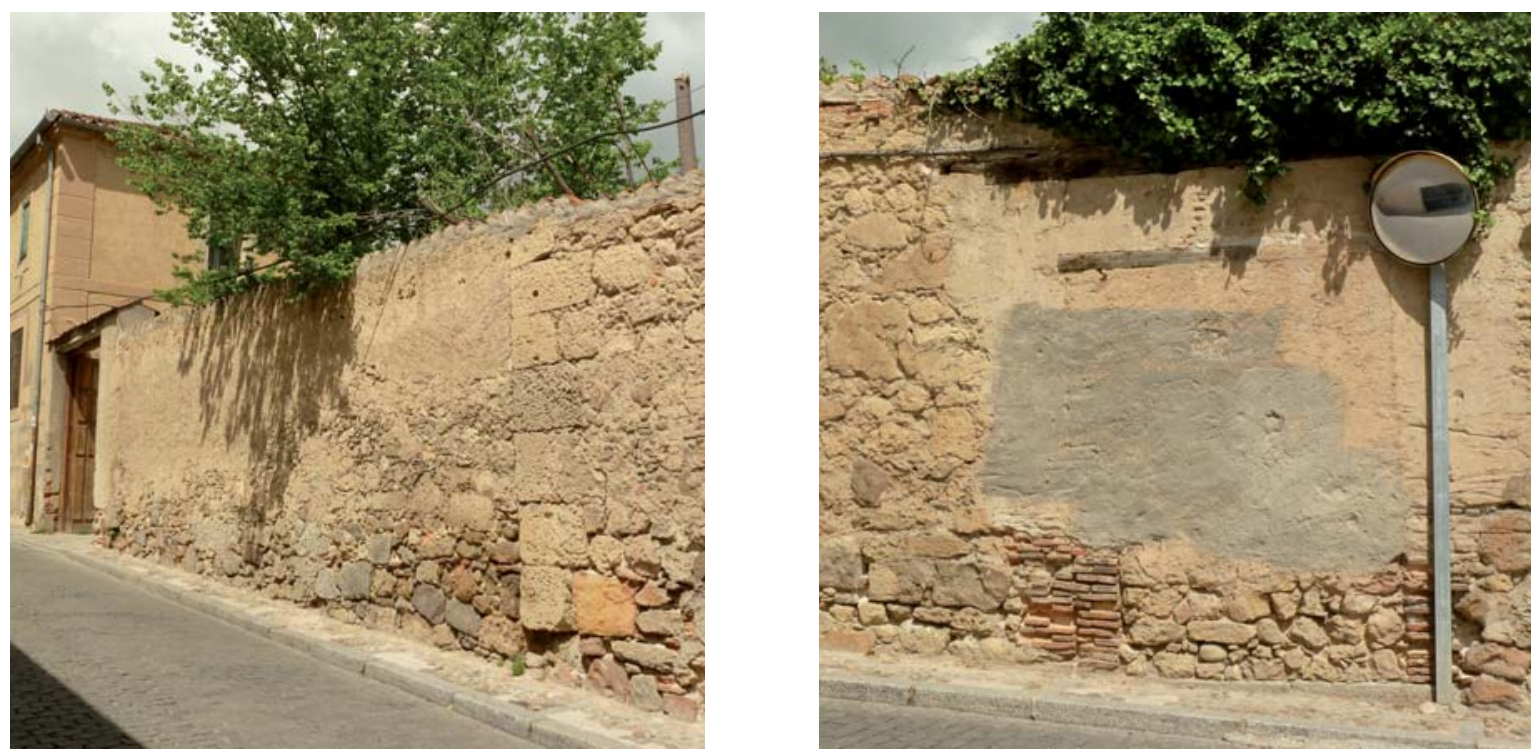

Figura 4.1.45: Imagen de la actual tapia de la huerta del Hospital de la Misericordia. A la izquierda, en la parte alta de la calle, asoma el primer edificio del Hospital. Vemos la esquina de sillería que denota donde finalizaba la tapia y donde se encontraría el callejón de acceso al postigo de la fuente cercada.

Figura 4.1.46: Unos metros más abajo, en la misma tapia, descubrimos un antiguo acceso tapiado, con dos jambas de ladrillo y un dintel de madera, que suponemos pertenecía a otra parcela. Tiene que ser la entrada a la huerta de Francalin. 
Y por último la fuente, que daba su nombre a este postigo, con la curiosa denominación de cercada, que no hemos encontrado explicación a este topónimo, bien podría referirse a que se encontraba cercada por un pretil ${ }^{119}$ o bien sospechamos que se trataba de un manantial que brotaba en ese punto y quedó embutido en la cerca de la ciudad al construirse la muralla.

Según la descripción de las obras de Jusepe Riero, la fuente se encontraba más allá de la torre que hacía la esquina de la muralla, esto es, superado el quiebro en el que situamos el postigo. Y en esa parte de lienzo, al descubrir un hueco en la muralla, bastante deteriorado y que denota numerosas derrumbes y reparaciones, con jambas en ladrillo, dinteles de piedra, e incluso precercos de madera, como si hubiese tenido anclado algún tipo de elemento delante, pretil o aplacado, no podemos dejar de pensar que quizá sea el manantial donde brotaba la fuente "cercada".
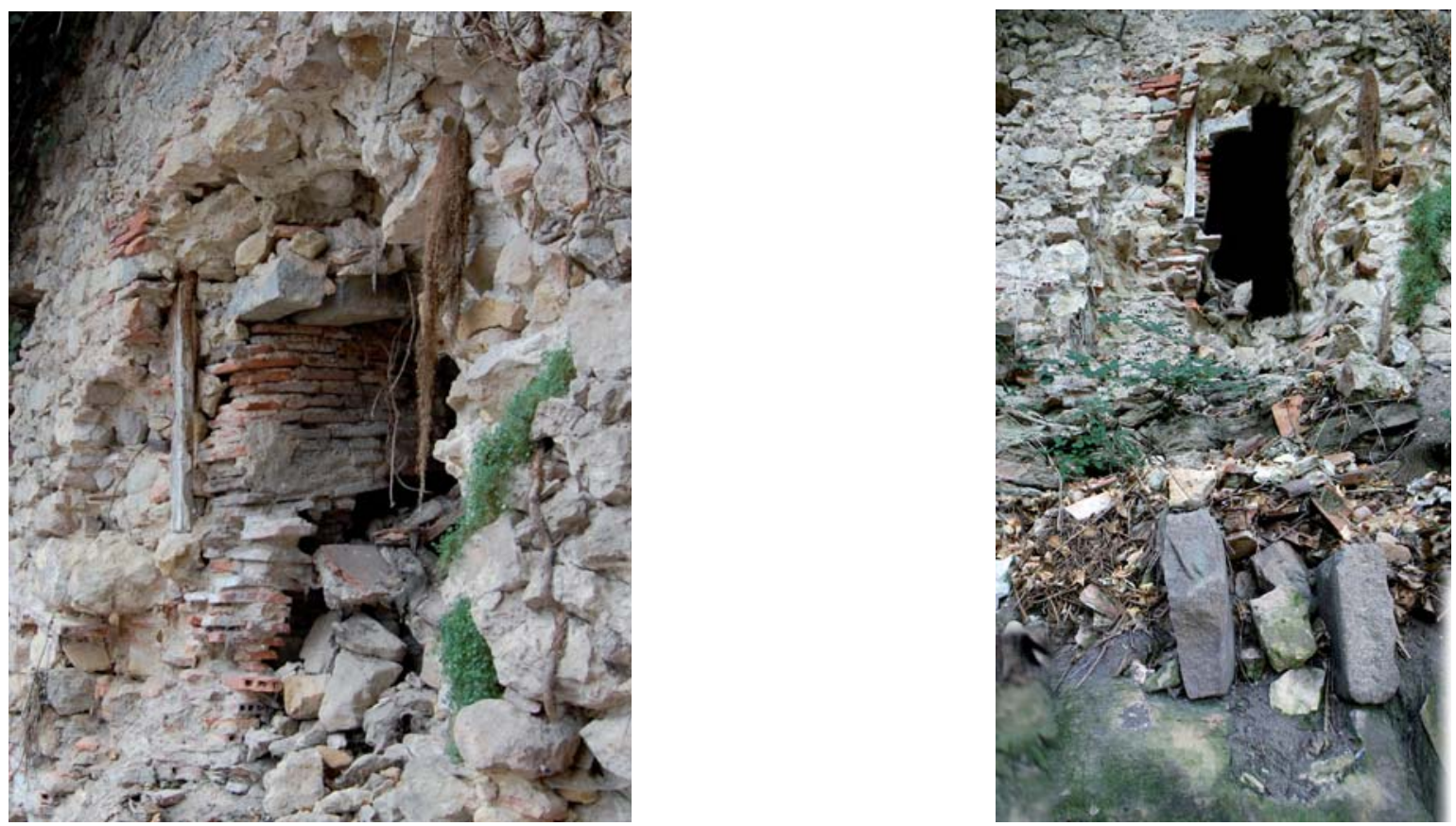

Figura 4.1.47: Extraña abertura en el lienzo de la muralla bajo el edificio del Hospital de la Misericordia. Podría tratarse de un antiguo desagüe o bien de la fuente cercada, manantial que brotaba desde la roca y que se preservó al construir la muralla.

Figura 4.1.48: Detalle frontal mediante montaje de ortofotos del hueco que suponemos era la fuente cercada. Bajo el hueco se aprecian dos grandes piedras de granito colocadas de canto sobre un canal tallado en la roca, que estamos convencidos era el desagüe de la fuente. Todo ello está actualmente derruido, e inaccesible por lo abrupto del desnivel, topografía que coincide con lo representado por Meunier en su imagen de 1666.

Creemos haber aportado suficientes evidencias para poder aventurar que el perdido postigo de la fuente cercada se encuentra enterrado en ese quiebro que realiza la muralla y por las características y dimensiones que hemos observado estamos convencidos de que en realidad se concibió más bien como una puerta de la muralla y no como un postigo. Incidiendo en la importancia arquitectónica de esta "puerta" y las dimensiones de la torre que la protegía, encontramos una referencia en que se describen los tramos de muralla a reparar y se utiliza esta torre como referencia para dividir en sectores la parte norte, desde la puerta de San Cebrián hasta la torre de la fuente cercada... (Asenjo González, 1986: 65)

${ }^{119}$ Debo la sugerencia de este posible significado toponímico al personal del Archivo Municipal de Segovia. 


\subsubsection{UN CAMINO PREVIO, UN POSTIGO Y DOS TORRES}

Entre la torre T59 y la verja del Alcázar se han descubierto una serie de vestigios que nos hacen plantearnos algunas hipótesis, como son la existencia de dos torres adicionales, la T61 y la T61', en la muralla y un posible postigo o camino previo.

En el lienzo L60-61 se ha localizado una antigua cantera, que aparentemente estuvo en funcionamiento para la construcción del barrio de las Canonjías, en el siglo XII, estando ya en desuso en el siglo XVI (OT- 189/2013-11: 76).

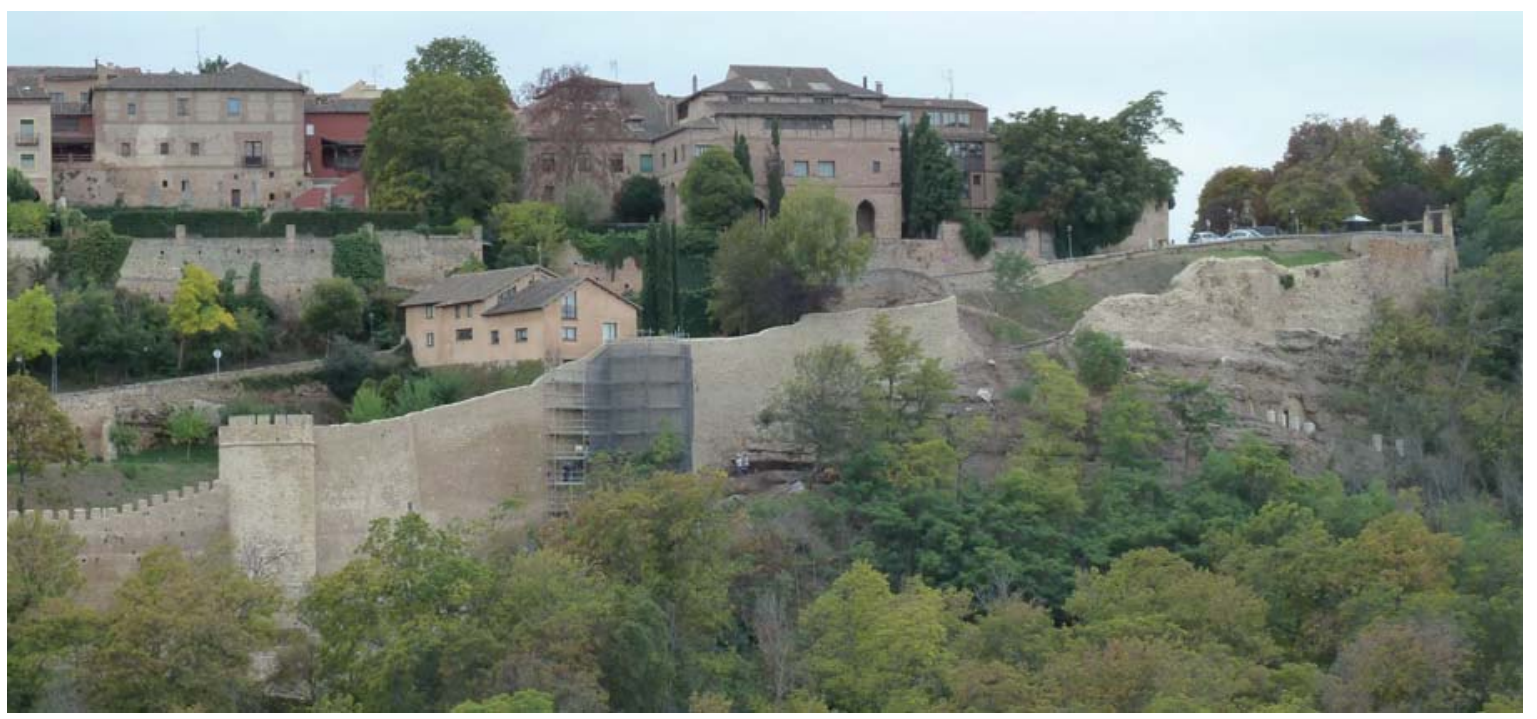

Figura 4.1.49: Vista del tramo de muralla desde la T59 hasta la verja del Alcázar. Se observa como la muralla va descendiendo por la ladera al alejarse del Alcázar. Torres y lienzos están arruinados o reconstruidos prácticamente en su totalidad.

Muy cercano a este lugar, en el L59-60, se encuentra en la muralla un posible postigo o al menos un camino previo que podríamos datar de época celtibera o romana (OT- 189/201311: 45-46) pero que también podría haberse usado como paso provisional durante las obras de construcción tras la repoblación, tanto de la cerca urbana como del barrio de las Canonjías.

Por sus dimensiones de paso, evidentemente, es un paso peatonal, no apto para carros ni ningún tipo de vehículos. Su acceso por la ladera, debería ser un camino serpenteante, como hemos visto en otros postigos, pudiendo coincidir en algunos tramos con los dos accesos actuales cercanos, la puerta de Santiago, el más probable, o la conocida como cuesta de la cueva de la zorra. La situación de la torre T60, adyacente al mismo, lo hace amoldarse a otra de las características que hemos visto en los demás postigos, una torre flanqueándolo.

La disposición de los sillares de granito en el zócalo muestra bien a las claras que durante la construcción de la muralla hay una voluntad de mantener el paso abierto. Sin embargo, esta discontinuidad en el zócalo, no podemos confirmarla en el resto del lienzo. No existen huellas de jambas. En la mampostería se observa una gran discontinuidad, que denota que ha sido reconstruido prácticamente en su totalidad, conservándose en su posición, quizá, sólo los sillares del zócalo y la parte de lienzo adosada a la torre T60. 

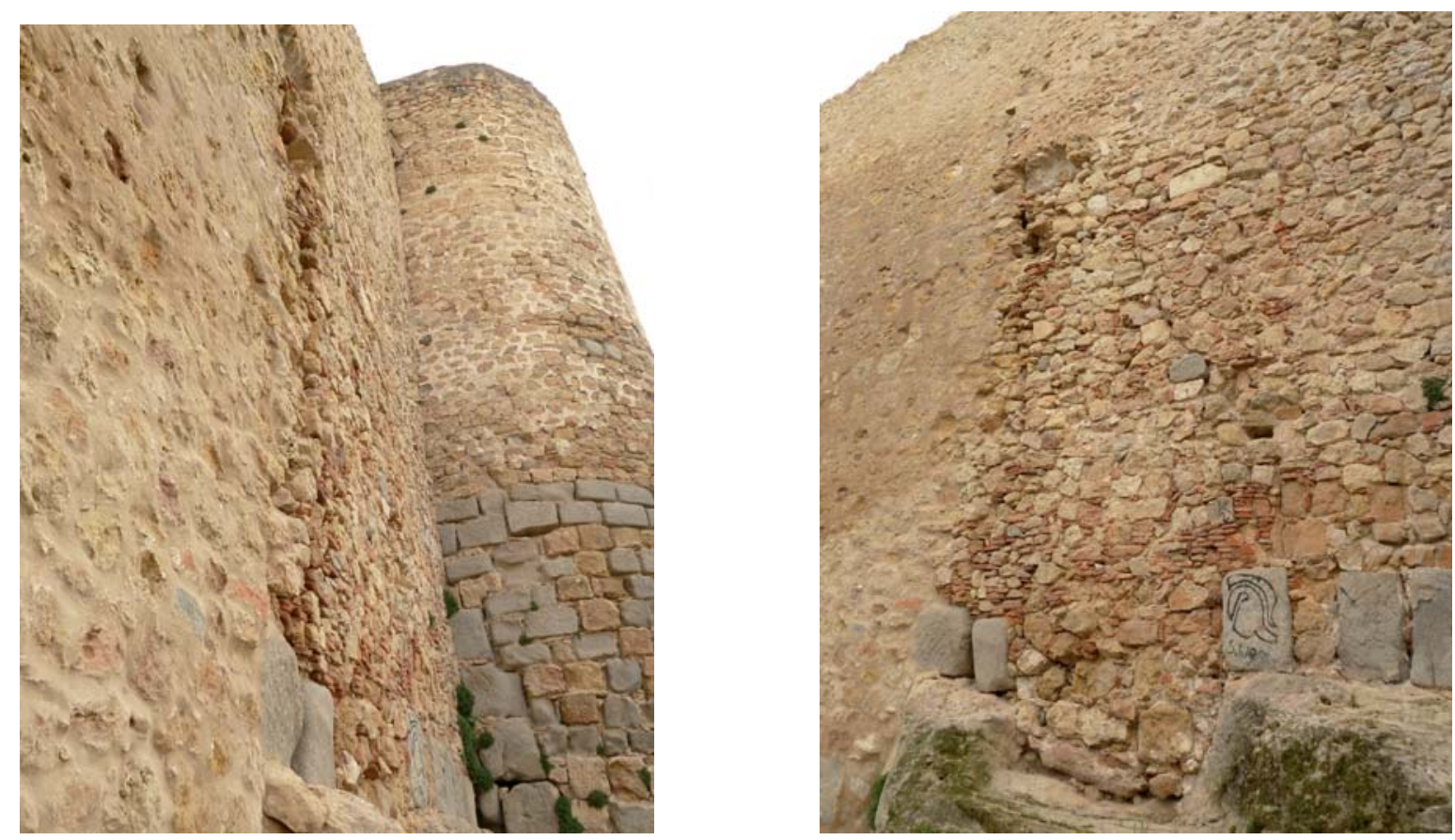

Figura 4.1.50: Se observa el lienzo desplomado junto a la torre T60. El resto del lienzo, vuelto a aplomar es una reconstrucción.

Figura 4.1.51: Posible postigo junto a T60. Observamos como los sillares que constituyen el zócalo de la muralla se interrumpen en un punto donde se ha tallado un corte en la roca en forma de rampa peldañeada. En el fragmento donde existiría el posible postigo, observamos otra discontinuidad en forma de arco de descarga, partiendo del sillar situado en la jamba derecha. Esto aumenta la probabilidad de que existiese un hueco en este punto formándose la línea de rotura por el punto más débil del muro, el postigo. El lienzo se halla completamente reconstruido. Se aprecia el desplome en la línea de separación entre ambas partes.

La forma de rotura del lienzo, cuya línea de fractura y desplome llega al suelo en el punto donde se sitúan la jamba del hueco, nos hace pensar que en esa parte del lienzo existió un punto débil, un paso. Creemos que si llego a construirse dicho postigo, de forma que el lienzo, se rompe por el punto más débil. Entonces, ¿por qué no aparece en la documentación histórica ninguna referencia a este postigo? ¿Se condenó en tiempos muy iniciales tras la repoblación o nunca se consideró como acceso civil y sólo era para explotación de la cantera?

Ese postigo viene a dar continuidad a un camino previo de época celtibera o romana (OT189/2013-11: 45-46), que posiblemente se usó como paso provisional vinculado a la explotación de la cantera y que se condena con la construcción de la muralla, aunque, dudaron antes de su clausura ${ }^{120}$.

Avanzando en dirección hacia el Alcázar, encontramos un leve quiebro en el trazado de la muralla, coincidiendo con un importante desnivel en la roca. No lejos de este punto, existe actualmente la que se conoce como la cuesta de la cueva de la Zorra, que es la que comunica de forma más directa con el arrabal de San Marcos. Junto a la escalera actual, existen restos de una escalera previa, tallada en la roca, en la que se engastaron unas piezas, quizá de madera, que harían de peldaños. No hay ninguna aproximación arqueológica posible, ya que no hay ningún resto datable.

${ }^{120}$ Esta hipótesis se desarrollara posteriormente en el capítulo 6 al estudiar la configuración urbana. 


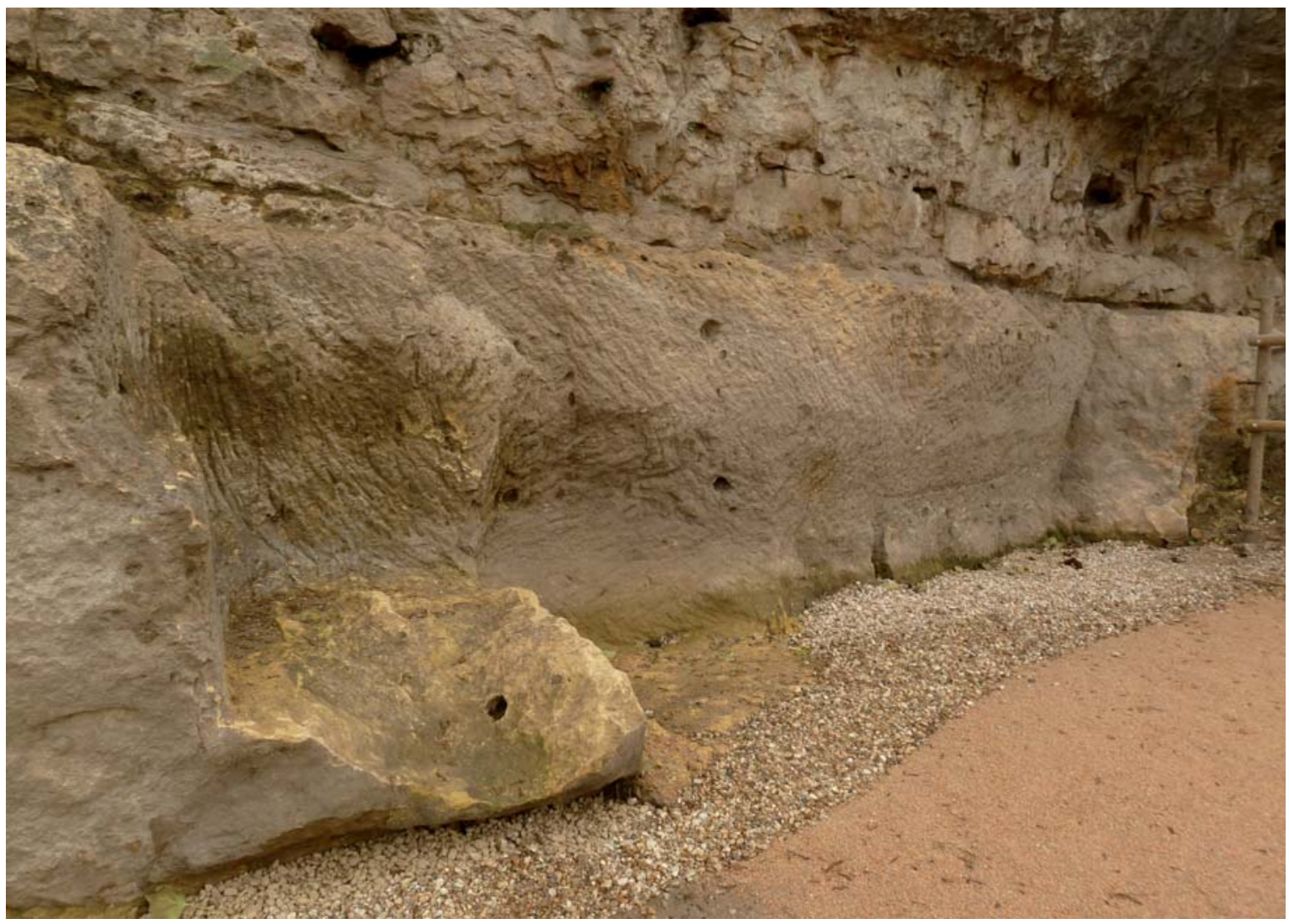

Figura 4.1.52: Imagen del frente de cantera existente por debajo del lienzo L60-61. Su explotación se vincula, en el informe arqueológico (OT-189/2013-11), a la construcción del barrio de las Canonjías en la etapa de la repoblación. Esta cantera confirma la práctica habitual de extraer piedra y arena de la base de la muralla, algo que se prohíbe reiteradamente en los documentos históricos.
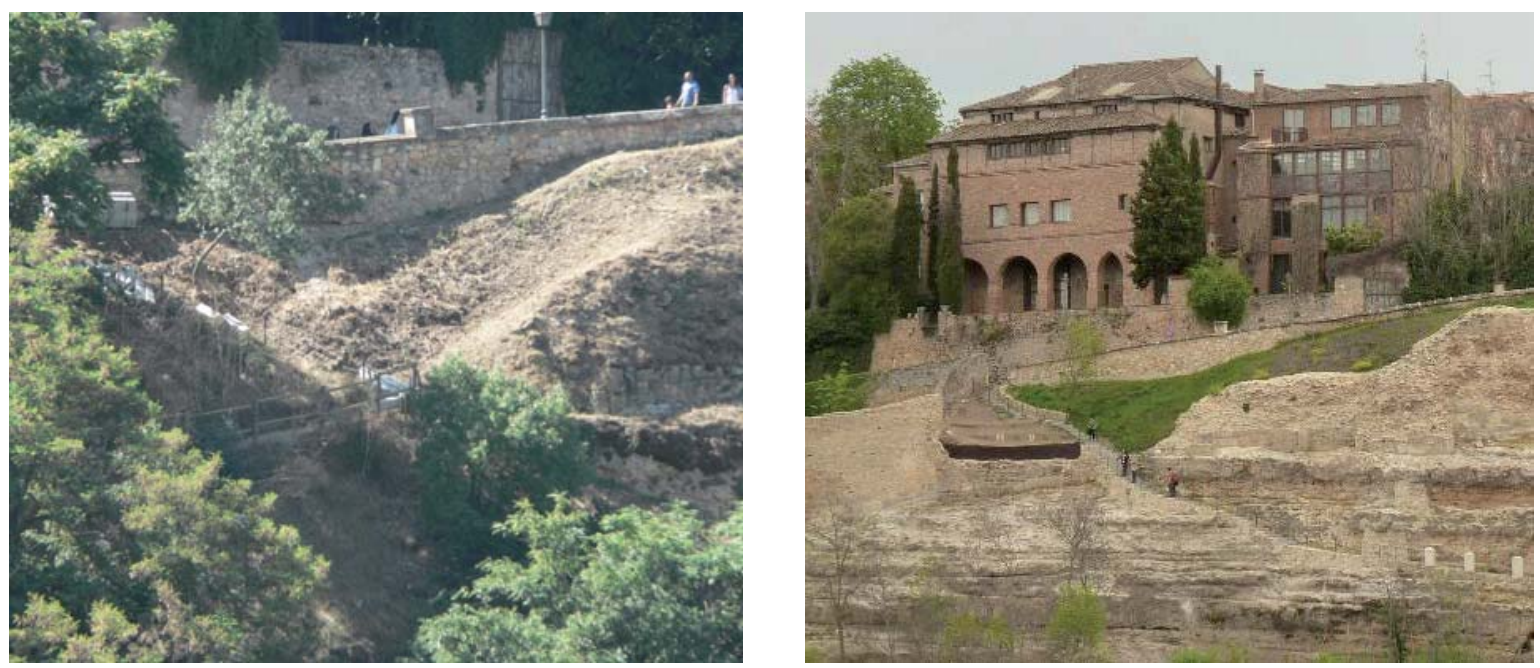

Figura 4.1.53: Lienzo L60-61: Importante cono en el terreno que nos hace suponer que se ha producido un derrumbe en este punto, en el que podría encontrarse la desaparecida torre T61, arruinada por un derrumbe de la roca, dado que en este punto los lienzos de muralla se sitúan prácticamente en el borde del cortado.

Figura 4.1.54: El mismo lienzo tras la limpieza efectuada en 2014. Se observa la brecha abierta en la muralla en el punto donde creemos que se situaba la torre T61. La escalera actual de subida aprovecha dicha abertura en la muralla como paso. 
Un poco más adelante en dirección al Alcázar, el Plan Director sitúa la torre T61, pero en las obras recientes (PH: P0205) no se han encontrado restos de su existencia, ni su ubicación. Señalar que la zona parece haber sufrido un importante derrumbe por el cono que presenta en la actualidad el terreno. De existir, posiblemente la torre T61 estaría en ese punto, totalmente arruinado y desaparecido en el que en la actualidad no se conservan ningún resto, ni de la torre ni de los lienzos adyacentes. Esta hipótesis nos permitiría estar de acuerdo con la hipótesis del Plan Director, dado que por métrica, el lienzo resultante en caso de considerar una torre en este punto encajaría, frente a la medida actual de 57 metros, muy largo, por lo cual sí parece razonable que hubiese existido una torre por esta zona. Pero no deja de ser una hipótesis que no se puede respaldar con ninguna prueba consistente, sólo la lógica de la métrica constructiva. No parece estar representada ni en el plano de 1820 ni en el de 1837, ya que en ambas aparecen sólo 4 torres entre la puerta de Santiago y la verja del Alcázar. Por lo que de existir su desaparición debió ser anterior a estas fechas.

El saliente $\lambda$, según el Plan Director, aparece reflejado como torre en el plano de Antonio de la Iglesia 1837. Actualmente es un mirador hacia el valle del Eresma, como una gran torre. Sus dimensiones son mucho mayores en comparación con las demás torres de la muralla. Sin embargo solo presenta resalto hacia el interior de la verja del Alcázar, porque hacia el otro lado, ese paño enrasa con la cara exterior del lienzo que se ha descubierto a continuación de la T61'. Este lienzo al estar derruido, está abandonado, construyéndose el peto actual varios metros remetido, por lo que adquiere esa imagen de mirador saliente. Es la continuación del lienzo, no se trata de ninguna torre.
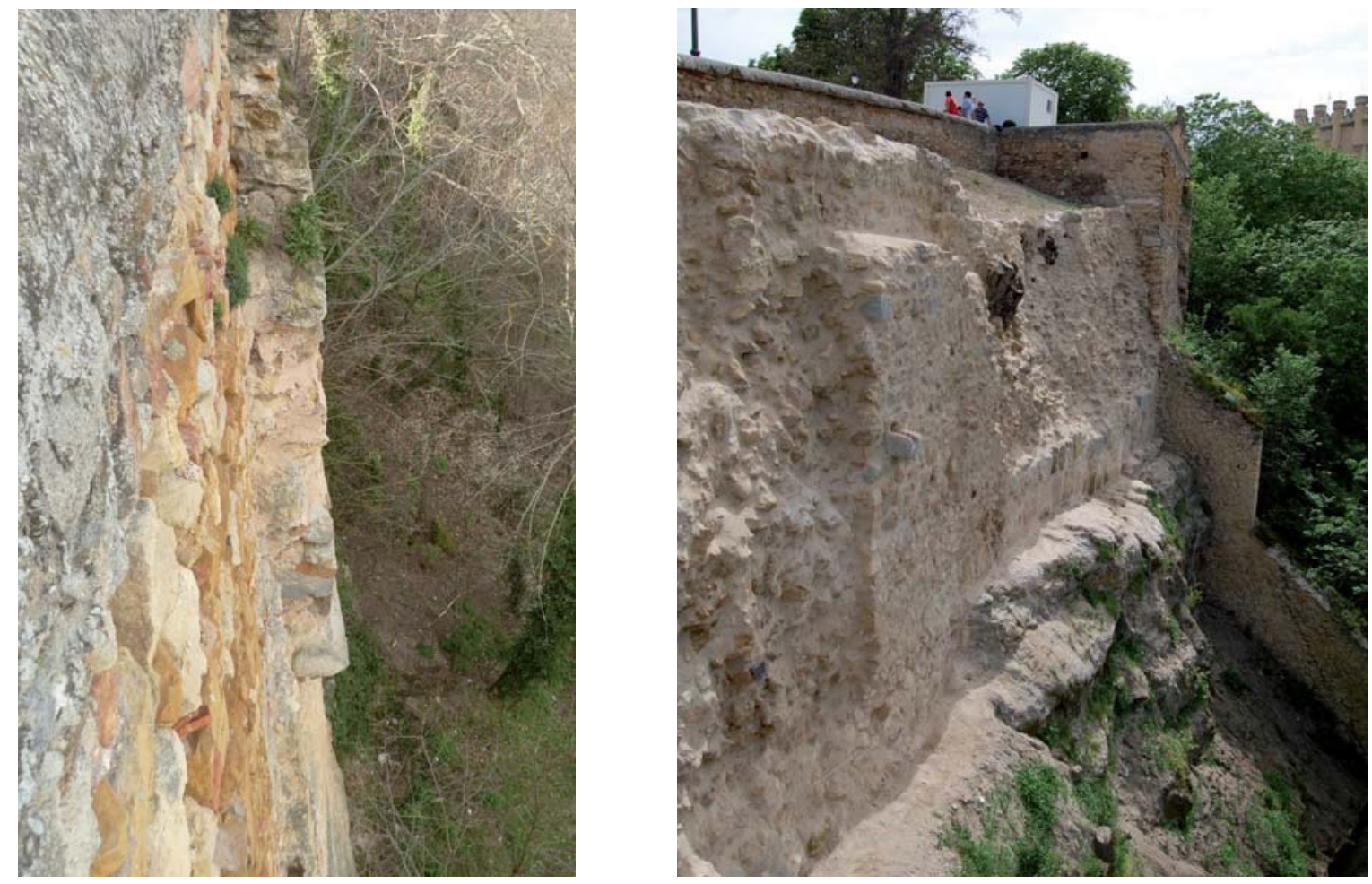

Figura 4.1.55: Lienzo 61'-62. Imagen donde se aprecia la discontinuidad con el desplome de parte del paño.

Figura 4.1.56: Lienzo L61-61'. El actual mirador, no es sino una continuación del lienzo de muralla. Su hoja exterior conserva la alineación del lienzo previo, en el que el derrumbe de la muralla ha hecho que se remetiese la alineación del peto de la calle en el resto del lienzo y por eso este trozo parece un mirador saliente como si fuese una torre (Foto: Estefanía Herrero García). 
En su cara frontal se observa un resalto en mitad de la fábrica que es una discontinuidad con una de las partes desplomada respecto a la otra. Por ello creemos que posiblemente se trate de una reconstrucción del lienzo, ligeramente retranqueado de su alineación original, que incluso en la parte inferior presenta una especie de zarpa, un zócalo escalonado, que envuelve los restos desplomados del lienzo anterior y oculta buena parte de su fábrica original. Al ser inaccesible y solo visible desde la lejanía es difícil apreciar sus paramentos, medio tapados por la vegetación. El resalto en planta de todo el lienzo interior a la verja del Alcázar creemos que es motivado porque también esta reconstruido, remetiéndose de la alineación original.

\subsubsection{LOS POSTIGOS DEL ALCÁZAR}

En la parte del Alcázar, se conoce la existencia de dos postigos, solo por fuentes documentales, ya que ninguno de los dos se conserva en la actualidad y se venían a situar uno a cada lado del foso delante de la fachada principal. En la cara norte, el postigo del Parque, mencionado por algunos escritores como Colmenares o Góngora, que le sitúan perdido y próximo a la antigua Huerta del Rey.

Colmenares cita un Postigo junto a la cava, por donde los habitantes del arrabal de la Puente Castellana subían a los oficios de la catedral. Góngora lo menciona y le sitúa en un plano, perdido, en el punto Z. Puede admitirse la hipótesis de que se trate del mismo, y que correspondiera a la salida que desde la fortaleza, y junto al foso, permite el descenso a los parques, antigua Huerta del Rey. La primera mención que sobre él he hallado ha sido en el libro de Pitanzas de 1373: buerto...fondón del postigo del alcázar (Ruiz Hernando, 1982: 25-26)

En el dibujo de Wyngaerde de la cara norte de la ciudad, reconocemos una puerta, ya cercana al Alcázar, que José Miguel Merino interpreta como el postigo del parque, entrando al Alcázar desde la Puente Castellana... el cubo más occidental, de tamaño muy superior al resto y rematado en cubierta de pabellón, acercaba la puerta del patio, bundido en el siglo XVII y reconstruido como revellín en 1673, cuando se colocó la "caponera" que lo une con el Alcázar, cerrando el foso en su extremo norte. (Merino de Cáceres, 2014: 19).

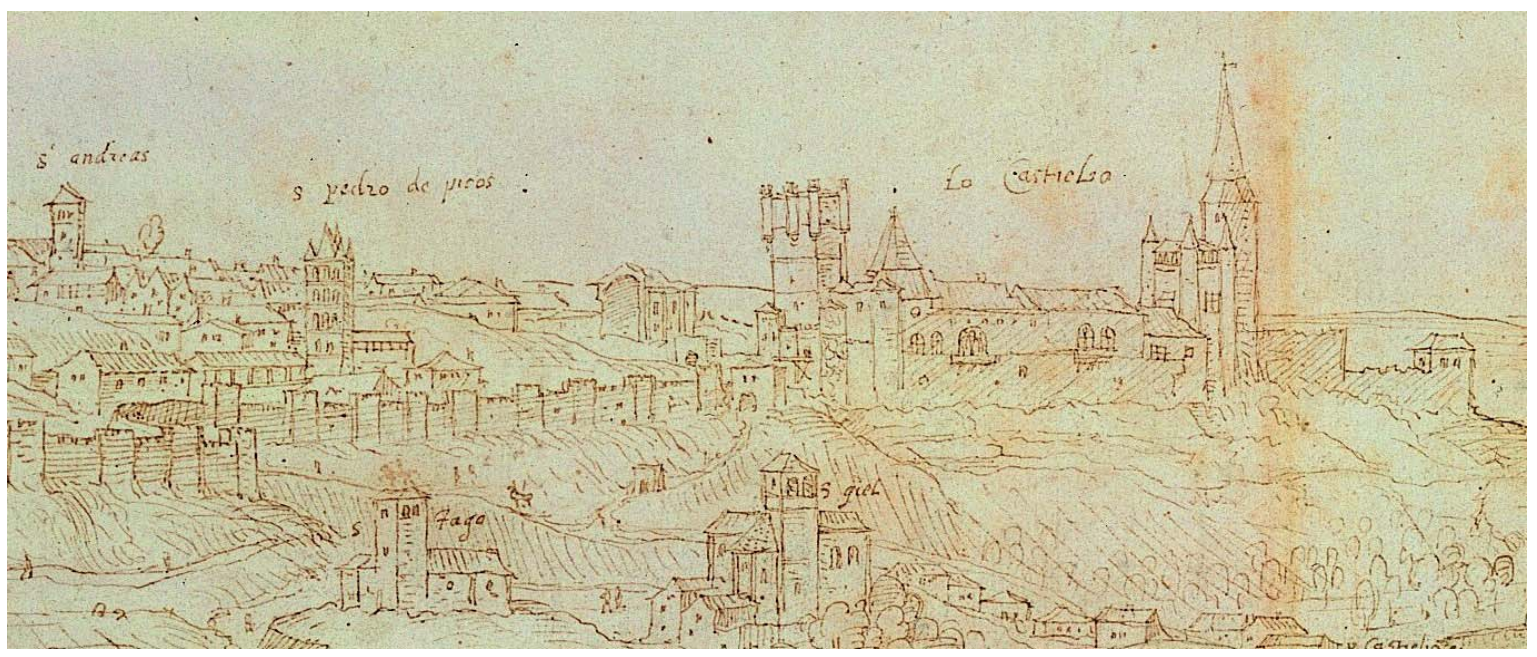

Figura 4.1.57: Detalle del dibujo de Wyngaerde (Fuente: AMS). Se aprecia un arco delante del Alcázar, que algunos autores (Merino de Cáceres, 2010) relacionan con el postigo del parque. 
Desde el postigo, el desnivel hasta la cota de la plaza de la Catedral o del Alcázar se salvaba mediante una rampa de la que aún quedaban restos a principios del siglo XX (Oliver-Copons, [1916] 1989: 386). Hay que señalar que se aprecia otro arco o puerta, exenta, mucho más abajo, por la que pasa el camino hacia el postigo. Podría tratarse de una puerta de control (Merino de Cáceres, 2014: 19), aunque este arco no se ve flanqueado por ningún cerramiento.

El segundo postigo, que tampoco ha llegado hasta nosotros, se encontraba en la cara sur. El Postigo del Obispo, situado junto al antiguo Palacio Episcopal, que le da su nombre, era salida del personal del mismo edificio y del propio Alcázar hacia el valle del Clamores. Así llamado por abrirse junto al antiguo palacio episcopal, junto al foso del Alcázar. Servía exclusivamente como salida de emergencia del personal de ambos edificios, ya que conducia al fondo del valle del Clamores por su parte más angosta y nunca babitada. Sabemos su aspecto por el grabado de Roberts, si bien con un aire en exceso romántico (AMS: 4810-3; I: 20). Disponemos de otra imagen, desde un punto de vista muy similar, por un dibujo de Avrial fechado en 1843 (1979: Lámina 52).

El postigo primitivo ha desaparecido y en la actualidad en su emplazamiento se ha recuperado una simple puerta adintelada para uso interno del personal del Alcázar, pero sin ninguna conexión con el exterior. Este postigo desapareció en la segunda mitad del XIX ${ }^{121}$, posiblemente al perder toda utilidad tras la destrucción del puente del piojo que era el que permitía el acceso después de cruzar el arroyo Clamores y la comunicación con el territorio circundante. De este puente sólo se conservan algunos restos. No está muy claro cuando fue destruido. Eduardo Oliver nos da la fecha de 1837, durante la primera guerra carlista (Oliver Copons, [1916] 1989: 318). Sin embargo el puente aparece representado en el dibujo de Avrial datado en 1843 y en el del cadete Serra Basas de 1853, lo que nos hace sospechar que aún se conservaba en uso en esa fecha (VVAA, 2010: 233).

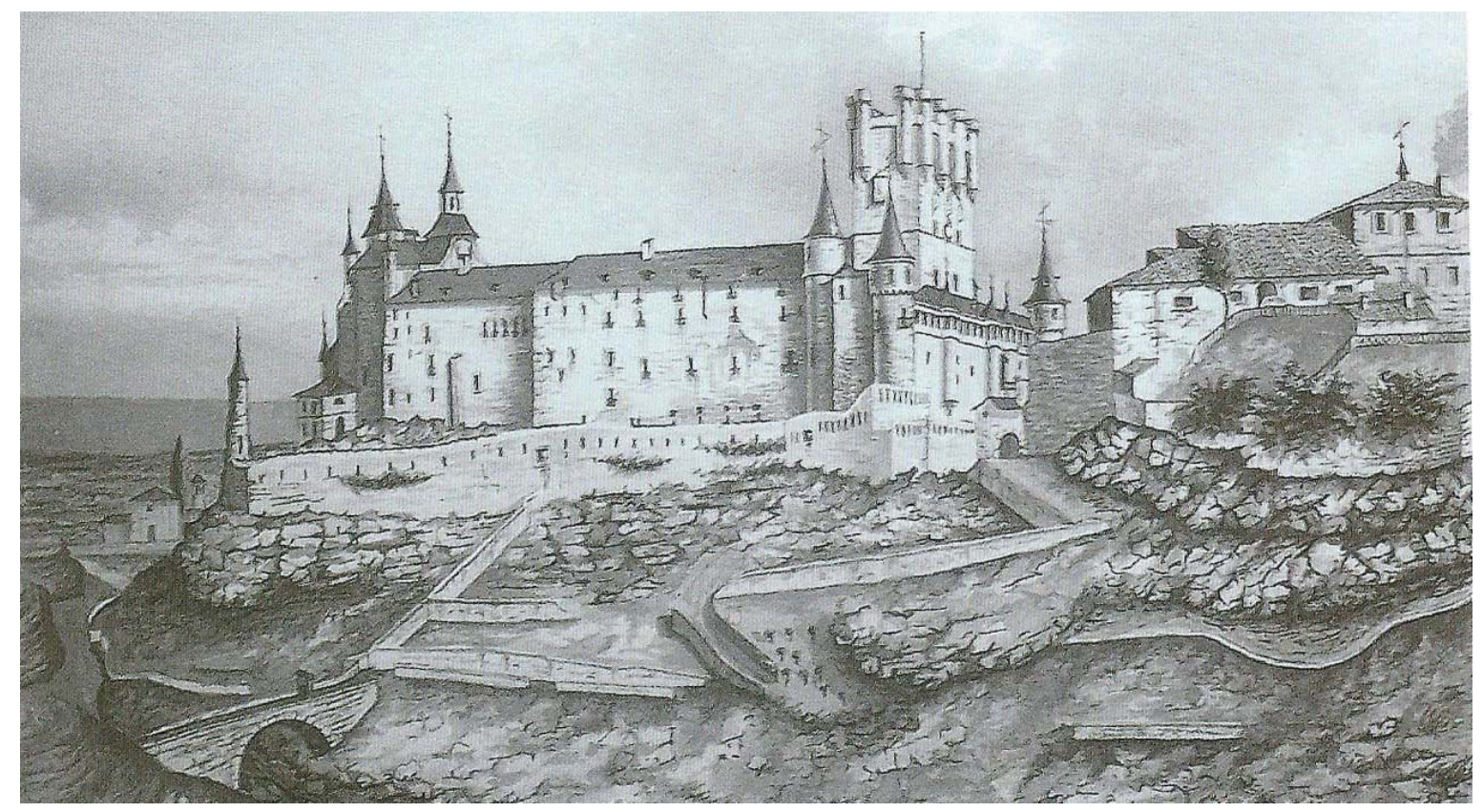

Figura 4.1.58: Dibujo de Serra Basas. 1853. Se observa en primer término el puente del Piojo, el camino de subida hacia el alcázar y el postigo que se identifica con el del obispo. (Martínez-Falero del Pozo, 2010: 233)

${ }^{121}$ Hay una foto de dicho postigo en la obra de Oliver-Copons ([1916] 1989: 379). 
En ambas obras aparece el puente y el postigo, ambos en perfecto estado y siendo transitados por diversas personas, lo que debe considerarse como prueba de que ambos elementos no se destruyeron en la fecha de 1837. Tuvo que ser en algún momento posterior, pero no hemos encontrado ninguna otra referencia que nos permita fechar la destrucción del puente y la consiguiente inutilización del postigo.

En junio de 2016, unas obras acometidas en las proximidades de la torre T71, ha dejado al descubierto lo que parece ser realmente dicho postigo, según José Miguel Merino de Cáceres, arquitecto director de dichas obras. Este descubrimiento cambia completamente el conocimiento que se tenía de este postigo, que erróneamente se situaba, en base a las afirmaciones de Oliver Copons, junto al foso del Alcázar y se relacionaba con los grabados de Roberts y de Avrial.

Sin embargo este nuevo emplazamiento del postigo no aparece reflejado en los grabados de estos autores, lo que nos induce a pensar que el postigo desapareció antes que el puente del piojo, o sea antes de 1837, y que el postigo representado en estos grabados es un paso que se realiza posteriormente para sustituir al postigo desaparecido.
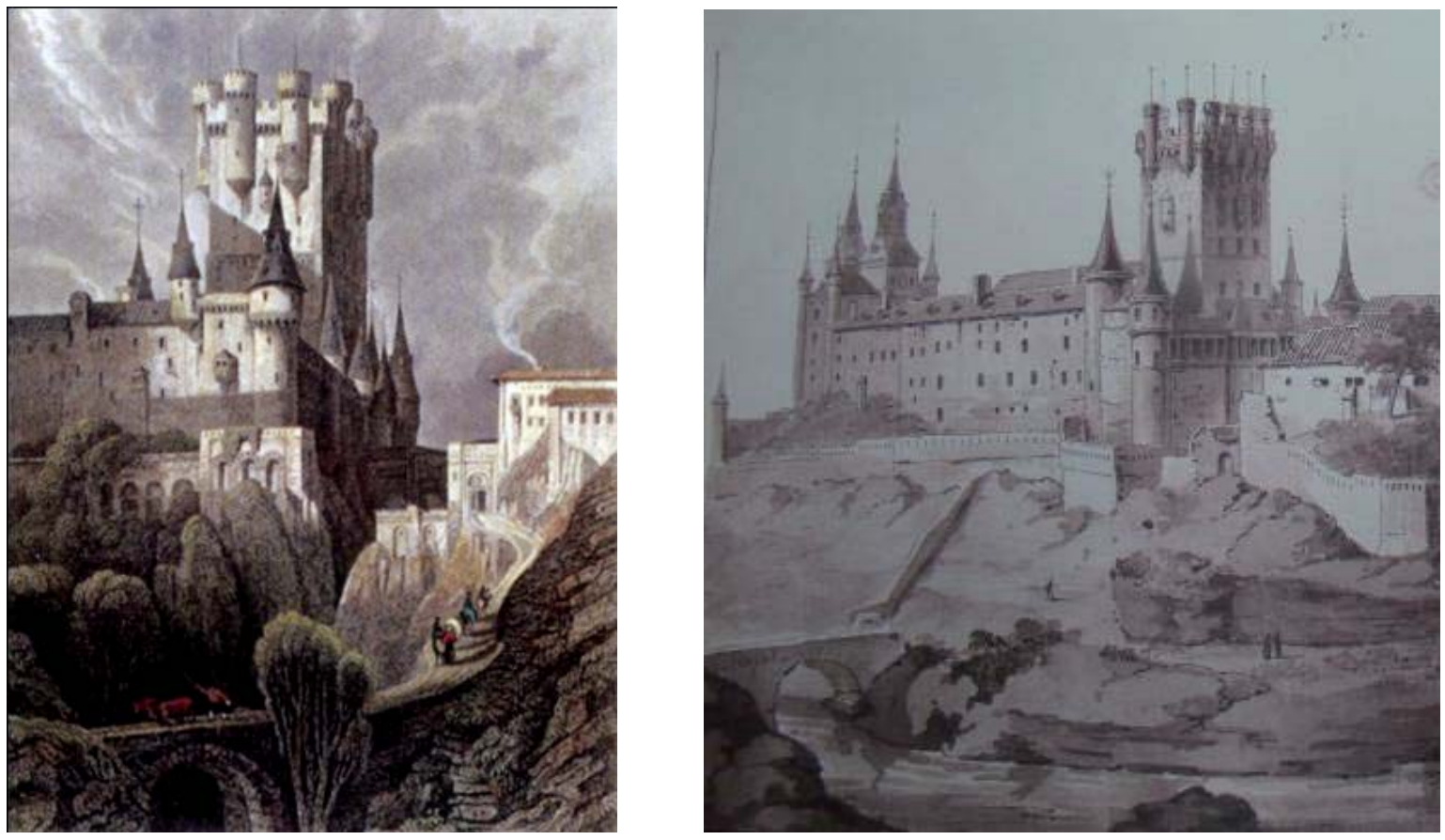

Figura 4.1.59: Grabado de Roberts. 1836 (Santamaría López, 2004: 39). Una visión menos realista que el dibujo de Basas, pero en el que apreciamos los mismos elementos, puente del piojo, camino de subida y postigo del obispo. Obsérvese lo exagerado que se representa el foso del Alcázar, así como la decoración de arcos y la monumentalidad del postigo, en comparación con las representaciones de los otros dos autores (figuras 4.1.58 y 4.1.60).

Figura 4.1.60: Imagen de Avrial. 1843 (Avrial y Flores, 1979: Lámina 52). Con un punto de vista muy similar, en que vemos los tres mismos componentes del acceso a la ciudad desde la cuesta de los Hoyos

Gracias, también a unas obras realizadas recientemente, se ha descubierto otro postigo en la parte posterior del Alcázar, por debajo de la terraza de los Reyes, que no se menciona en la 
documentación histórica ${ }^{122}$. Diversos autores lo denominan puerta falsa (Martínez-Falero del Pozo, 2011, I: 19) (Merino de Cáceres, 2014: 20). En el plan Director aparece reflejada en ese punto una torre, T67, de tal suerte que lo que parecía una torre maciza es una pequeña puerta peatonal con entrada en recodo. Este paso da acceso exclusivamente al Alcázar, por lo que a pesar del nombre que le han dado, no es propiamente un postigo de la muralla, sino una poterna del Alcázar.
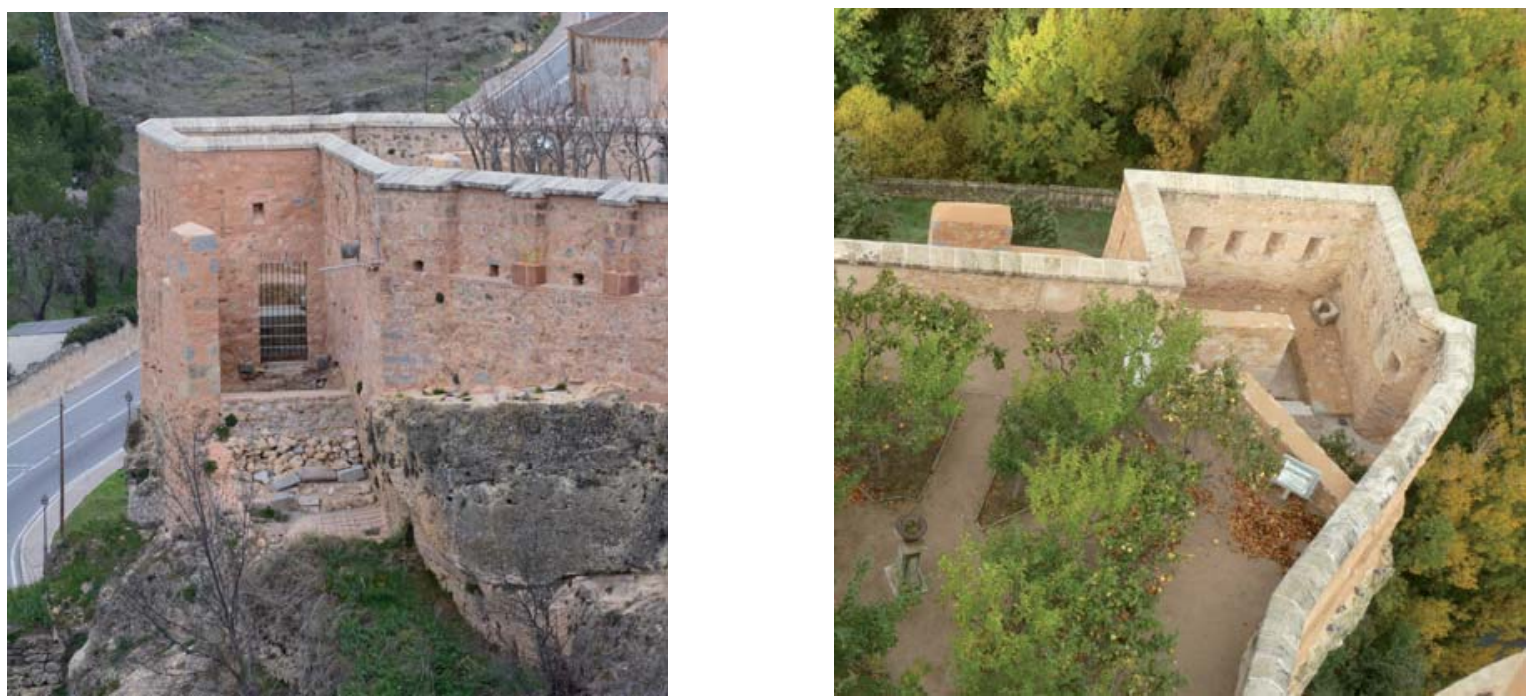

Figura 4.1. 61: Imagen del postigo, oculto al exterior por el muro lateral que lo esconde.

Figura 4.1.62: Vista del interior de lo que parecía una torre y disimulaba una entrada en recodo.

Se trata de una pequeña puerta adintelada, oculta desde el exterior por un muro que lo cierra lateralmente y protegido por un foso tallado en la roca delante de ella. La torre presenta un aparejo de mampostería organizada en hiladas horizontales de tamaño muy similar, lo que implica una concienzuda selección previa de los mampuestos. Las esquinas se refuerzan con sillares. La parte superior es un recrecido, en el que abunda el ladrillo, material con el que se ejecutan las fusileras, que aparecen en distinto número en todas las caras exteriores. Por el interior, a media altura, se observa otro nivel de merlones, también ejecutado en ladrillo, tabicado por este añadido. La puerta muestra restos de haber dispuesto de puente levadizo sobre el foso.

El conjunto es mucho más complejo que el simple portillo, destacando varios elementos que entendemos componen un todo y que están relacionados para cumplir la misión de acceso, y a la vez defensa, al Alcázar por la parte posterior. El camino en rampa zigzagueando, esta defendido por otra torre adelantada, actualmente arruinada, que flanquea dicha subida. Estas rampas se configuran mediante muros de contención que históricamente levantaban por encima de la rasante y estaban almenados. La roca se halla tallada en numerosos puntos donde queda vista, tanto en vertical en las rampas, como en horizontal a los pies de la torre adelantada o en forma de escalera en la llegada al foso. En la parte inferior descubrimos una

122 Antonio Ruiz no lo recoge en su obra sobre la historia del urbanismo de Segovia, (Ruiz Hernando, 1982) lo cual no deja de ser curioso que no haya aparecido ninguna referencia documental al mismo, cuando aparece reflejado en varios grabados. Entendemos que por su ubicación, completamente vinculado al Alcázar y sin posibilidad de uso cotidiano por los habitantes de la ciudad, se le haya considerado como acceso privado del Alcázar en lugar de como postigo de la muralla y por ello no se menciona en los diferentes libros (de protocolos, acuerdos, actas, etc) de la ciudad. 
muralla con cubos semicirculares realizada en una mampostería de tamaño medio grande y la conexión con el exterior, al otro lado del arroyo Clamores, se efectuaba por, el hoy en día desaparecido, puente del piojo. Para añadir más complejidad al conjunto, existe una puerta en la cara posterior de la torre, que se abre al vacío, sobre el rio Eresma.

Como puede verse este caso no guarda ninguna relación constructiva, ni de diseño de accesos con los postigos de la muralla. Es una puerta adintelada con entrada en recodo, tiene puente levadizo, foso, rampas con petos almenados, etc... Su disposición más bien parece guardar similitud con la entrada principal al Alcázar, eso sí, realizado todo a menor escala.

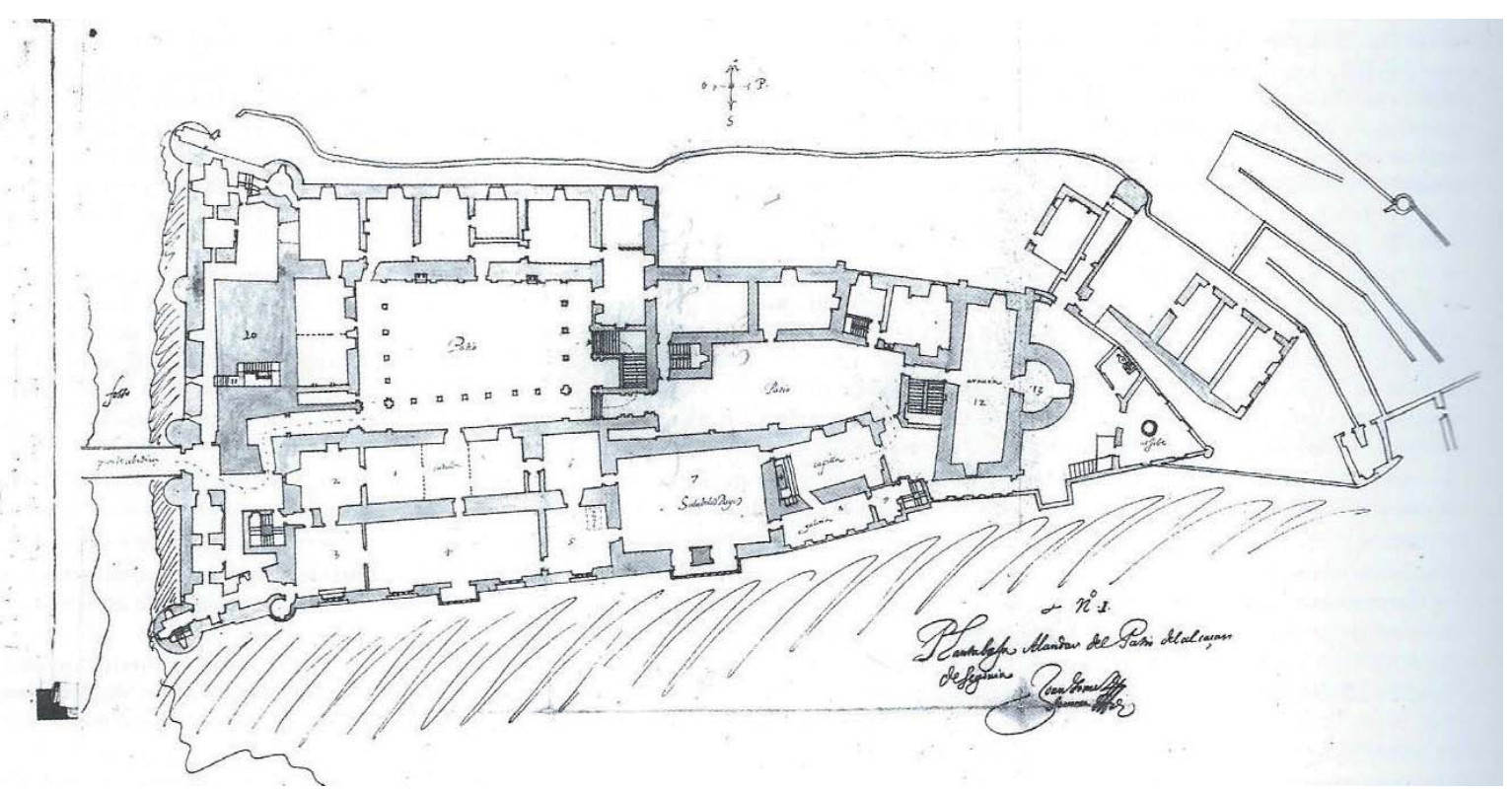

Figura 4.1.63: Plano de Juan Gómez de Mora. 1626 (Merino de Cáceres, 2010: 120). Obsérvese el conjunto de rampas para acceder al postigo en la parte posterior del Alcázar.

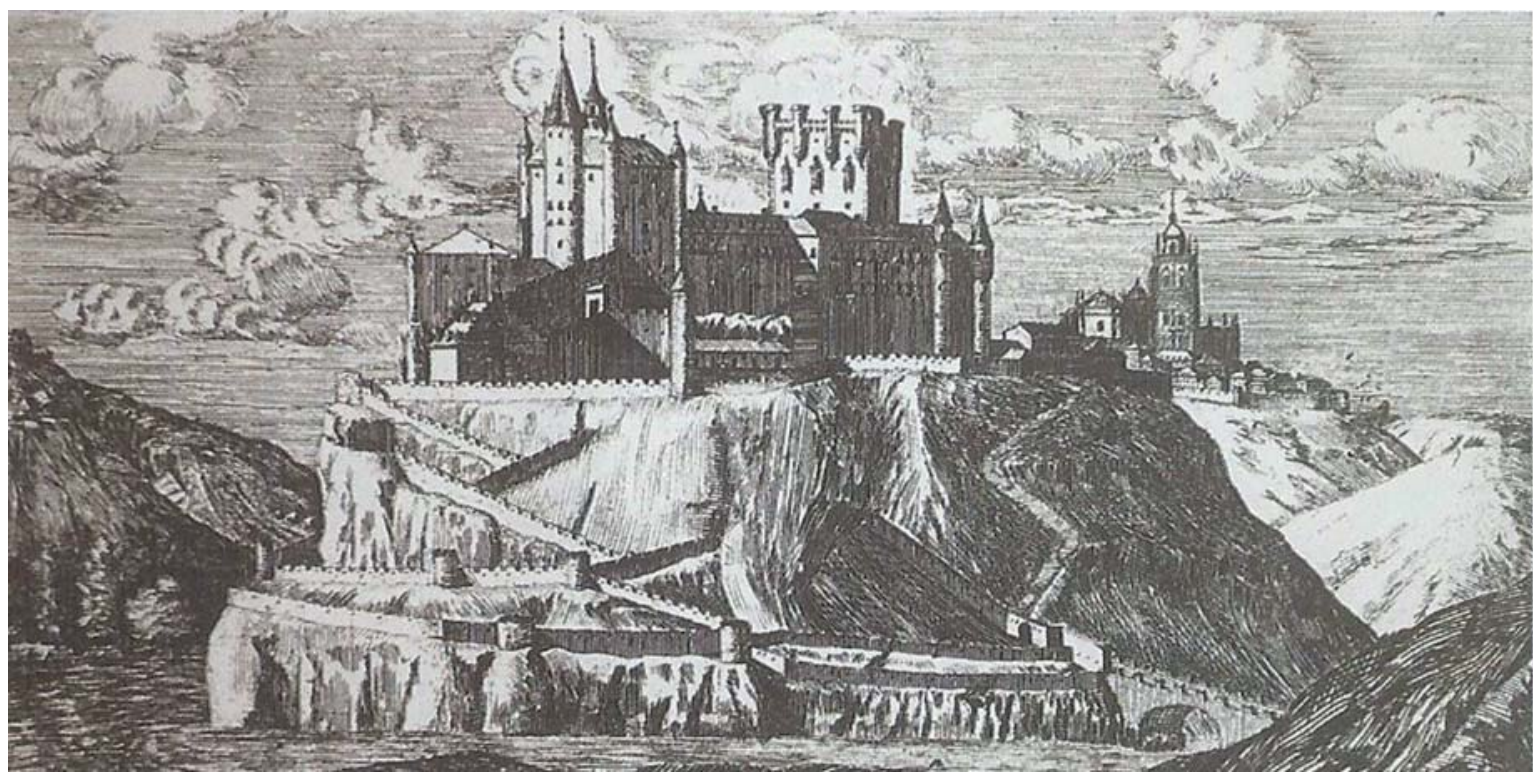

Figura 4.1.64: Vista por detrás del Alcázar. Meunier, ca. 1666 (Santamaría López, 2004: 70). Llama la atención lo aparatoso que se representa el sistema de rampas de acceso al postigo, completamente almenado. 
Este postigo aparece completamente definido, con las rampas zigzagueantes, ya en 1626, en el plano de Gómez de Mora (Merino de Cáceres, 2010: 120). Es la primera noticia irrefutable que tenemos de su existencia. Su aspecto nos lo muestra la imagen de Meunier, de ca.1666 en su vista por detrás del Alcázar. (Santamaría López, 2004: 70). Aparentemente está en funcionamiento hasta la mitad del XIX. Indudablemente con la destrucción del puente del Piojo, pierde todo sentido, ya que queda incomunicado del exterior, por lo que se procedería a su amortización.

\subsubsection{CASA FUERTE EN LA CASA DEL SOL}

Pocas pruebas se pueden aportar a mayores de lo ya comentado en el capítulo anterior, en relación a la posibilidad de que en este emplazamiento con tan singular disposición se situase una casa fuerte o algún tipo de fortificación. Varios son los autores que califican su emplazamiento como estratégico y de carácter defensivo, construido sobre un saliente rocoso conocido como el "Espolón" (Vera y de la Torre, 1950: 461). El Marqués de Lozoya, en su obra sobre la casa segoviana, en su apartado de las casas fuertes torreadas, se refiere a este edificio: En un recinto torreado, contemporáneo de la muralla y que servía para su defensa de la parte de la Judería, cerca de la puerta de San Andrés, la llamada Casa del Sol, donde habia habido un convento de monjas Agustinas de la humildad labraron su morada, hacia 1600, los Ibáñez de Segovia, luego Marqueses de Mondéjar (Contreras y López de Ayala, 2010: 276). Su carácter militar no ha pasado desapercibido a otros autores, e incluso durante las guerra carlistas, 1834-1836, se dice que el emplazamiento se fortifica (AMS: 4810-3, I: 57).

La existencia de unos curiosos elementos, una especie de mirillas o saeteras realizadas con dos tejas, cuya finalidad desconocemos, es otro dato de que disponemos. Su ejecución parece realizada contemporáneamente con el lienzo de muralla donde se encuentra. Sólo hemos encontrado algo similar en otros dos edificios de marcado carácter defensivo de la ciudad, la Casa Cadenas y el antiguo Palacio de Don Alimán, lo que nos reafirma en la posible función militar de este edificio.
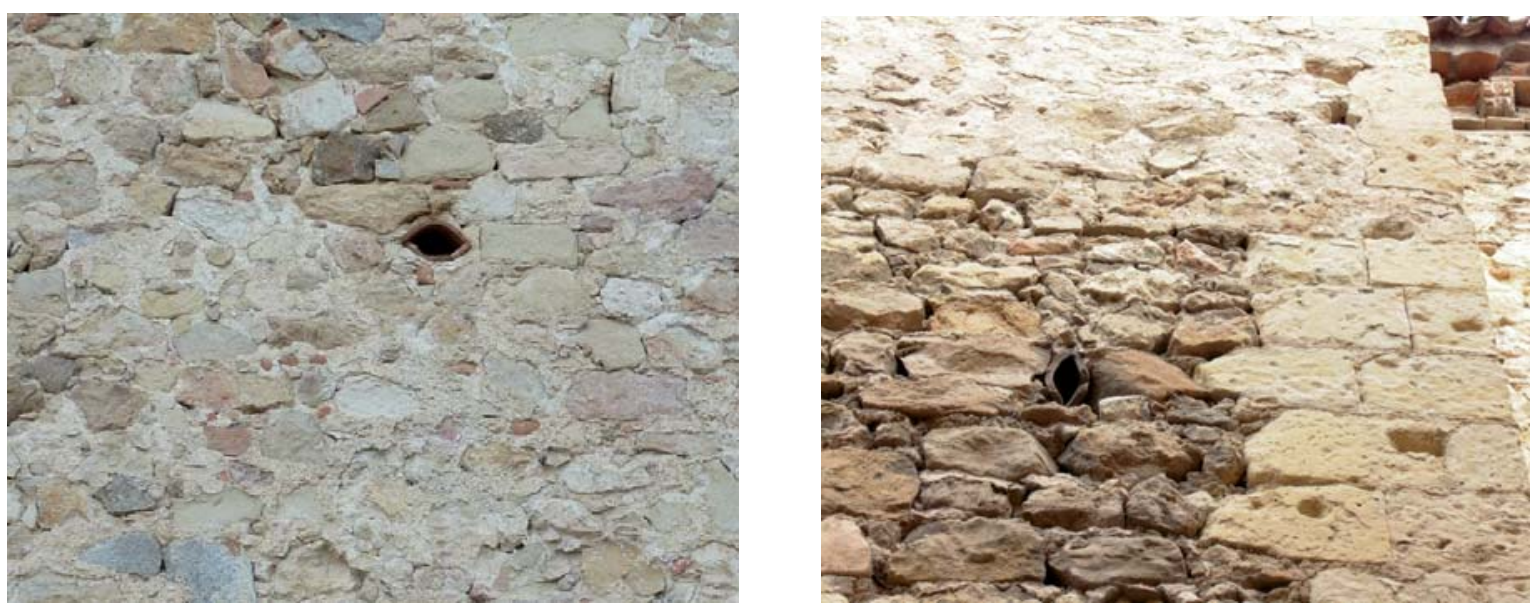

Figura 4.1. 65: La disposición de este curioso elemento, constituido por dos tejas, aparentemente está realizada simultáneamente con el resto del lienzo. No se aprecian discontinuidades en la fábrica en su entorno.

Figura 4.1.66: Imagen del elemento existente en el muro de las Dominicas, antiguo palacio de Don Alimán, constituido por dos tejas, similar al ejemplar localizado en la Casa del Sol. 
Sin embargo, en este caso el aparejo en el que se encuentra insertada este curiosos elemento es imposible de datar y no tiene ningún parecido con el que da a la calle Trinidad del antiguo palacio de Don Alimán. En este muro del antiguo palacio, estos elementos se disponen rítmicamente a lo largo de toda la fachada, constituyendo una línea muy clara a la altura del primer nivel del edificio. Al aparejo de este muro, si lo encontramos paralelismos, relacionándolo con el de las torres atalayas musulmanas de los siglos IX y X y este singular muro algunos autores lo consideran como obra previa a la Repoblación (Zamora Canellada, 2008).

Si bien, desde que se tiene conocimiento documental de la existencia de este edificio, ya se empleaba como matadero, creemos que esta disposición tan intencionada de la muralla, albergó en algún momento una casa fuerte o fortificación, si no en la etapa cristiana, si antes de la repoblación.

La investigación documental nos ha permitido identificar las intervenciones que realiza Joaquín Odriozola a finales del siglo XIX y principios del XX. La posterior conversión del edificio en Museo prácticamente no ha alterado los lienzos de la muralla, cuya imagen exterior es prácticamente la misma que generó Odriozola con su proyecto, sin fecha ${ }^{123}$, (AMS: 811.8) ejecutado entre 1870 y $1913^{124}$. Sin embargo, no nos ha permitido remontarnos más allá en el tiempo, en lo referente a la configuración exterior de la muralla.

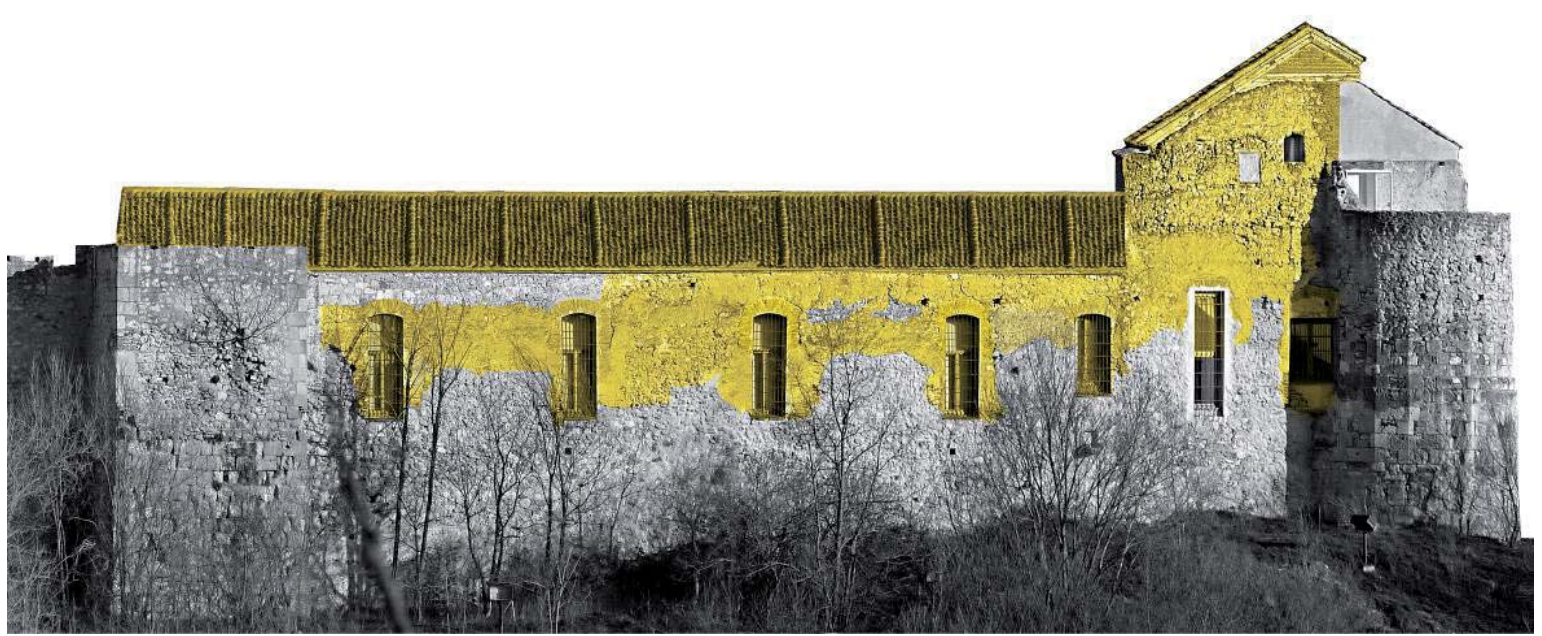

Figura 4.1.67: Lienzo L80-81: Alzado hacia el alcázar. Se resaltan en color amarillo las partes afectadas por el proyecto de Odriozola, consistente en la apertura de las ventanas, realización de la cubierta y el recrecido de la nave que mira hacia el pinarillo, entre las torres T81 y T82.

123 En 1870 está fechado un proyecto para la ampliación del toril del Matadero (AMS: 881-5). Se trata de una obra de mínima entidad y que no afecta a los lienzos de muralla, pero que nos resulta un referente muy útil dado que en este proyecto sin datar, dicha ampliación del toril aparece ya ejecutada en el plano titulado como "Estado Actual", lo que nos lleva a establecer que este proyecto se redacta posteriormente a 1870 y antes de 1913, año en que muere Odriozola.

${ }^{124} \mathrm{El}$ hecho de que en los años sucesivos se planteen varias obras de reparaciones menores, (1872 (AMS: 841-5) para reparaciones de pavimentos, 1889 (AMS: 1280-12) para reparaciones varias y 1897 (AMS 4810-3, Tomo I: 21) para reparación del pretil de entrada respectivamente) induce a pensar que la gran obra de reforma integral que plantea este proyecto sin fecha no se había ejecutado aun. Por contra el hecho que dos intervenciones de mayor entidad, como son la creación de una vivienda para el portero y el derribo del muro norte, para aumentar la capacidad del matadero se planteen en 1909 (AMS: 528-21), hace pensar que se están realizando obras de mayor entidad. Aparentemente ninguna de estas dos propuestas se ejecutaron. 
Este proyecto, sin fecha (AMS: 811.8) plantea la apertura de numerosos huecos en las murallas, si bien no se corresponden con los actualmente existentes, posiblemente motivados porque se producirían modificaciones durante la obra, así como la construcción de cubiertas sobre las dos edificaciones que se asoman por encima de los lienzos L80-81 y L81-82 y la desmochada torre T82.

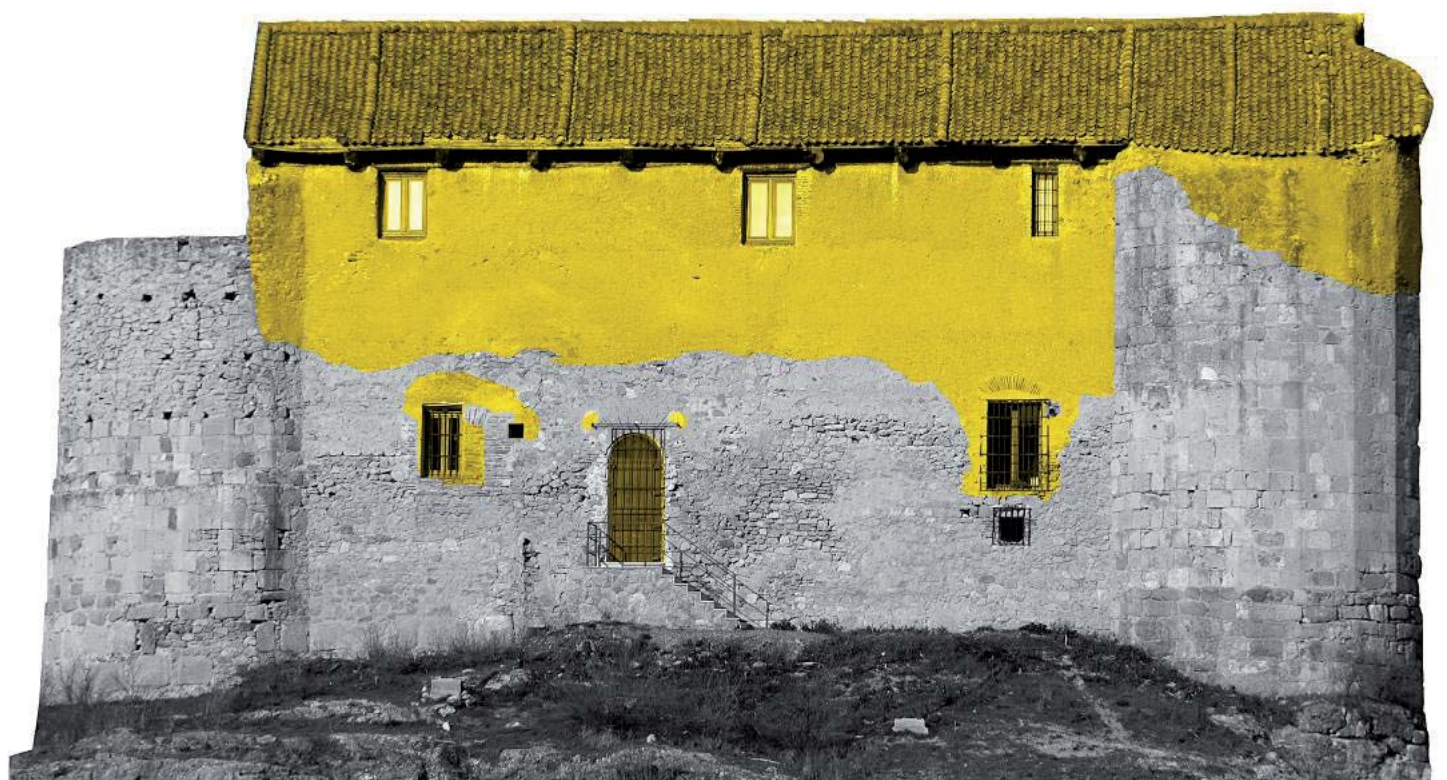

Figura 4.1.68: Lienzo L81-82: Alzado hacia el pinarillo. Se resaltan en color amarillo las partes afectadas por el proyecto de Odriozola. En dichas obras se recrece la segunda planta, construyendo un faldón de cubierta sobre la torre desmochada T82, abriendo los 3 huecos del piso superior y agrandando las dos ventanas de planta baja. El ventanuco bajo la ventana de la derecha es de posterior apertura. Se aplican revocos parciales sobre la fachada y la torre de la derecha, T82.

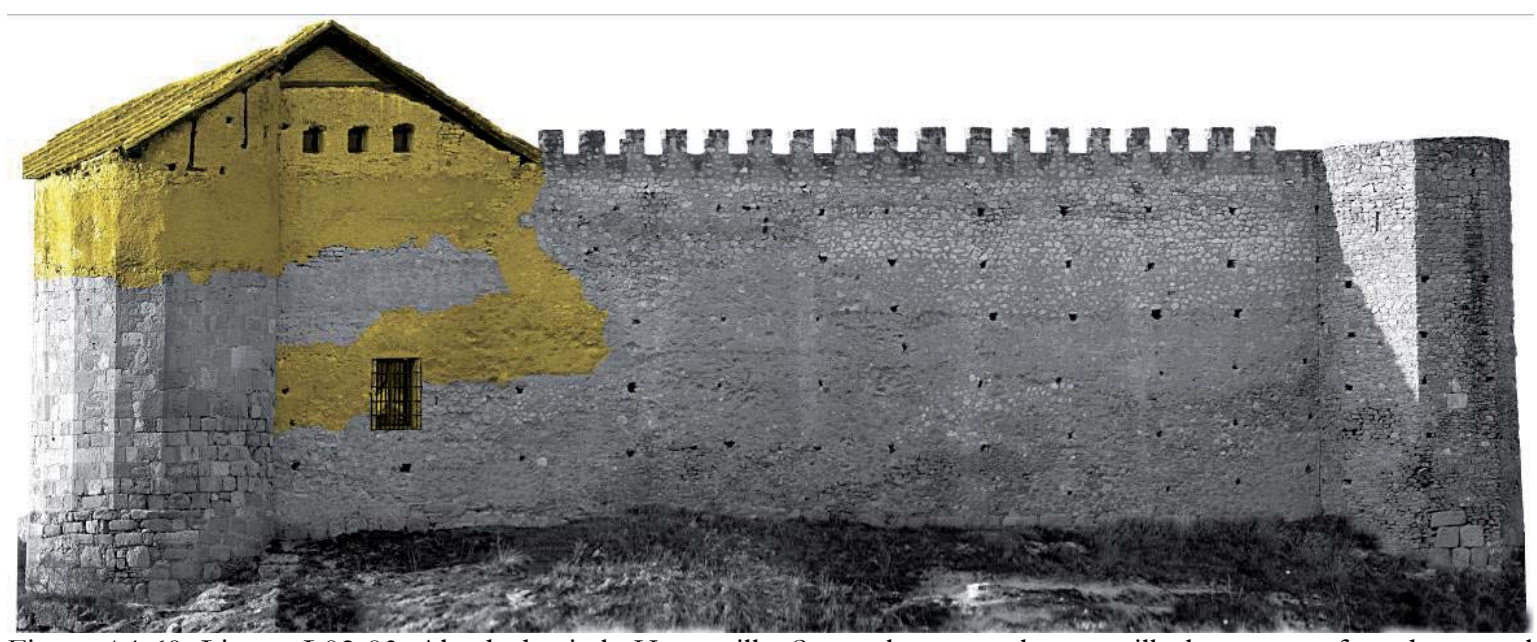

Figura 4.1.69: Lienzo L82-83: Alzado hacia la Hontanilla. Se resaltan en color amarillo las partes afectadas por el proyecto de Odriozola. Recrecido del hastial, con apertura de huecos aprovechando el almenado de la muralla, nueva ventana en la planta baja y revocos parciales. 



\section{2.- CARACTERÍSTICAS ARQUITECTÓNICAS Y CONSTRUCTIVAS DE LAS EVIDENCIAS MATERIALES}

\subsection{1.- LA FORMA DE LAS TORRES.}

Las torres de flanqueo se adosan a los lienzos de las murallas como refuerzos de éstas ya que su situación prominente permite hostigar a los posibles asaltantes lateralmente y reducir el número de vigías necesarios para controlar los distintos tramos.

La forma que adoptan estas torres no es exclusiva de una cronología o etapa histórica concreta, pero si puede ser un dato a tener en consideración y a confrontar con otras evidencias y el estudio de otras variables. Los romanos mostraron una cierta predilección por las torres de planta semicircular. También mostraron preferencia por las torres de trazado semicircular en las murallas que construyeron en su avance hacia el sur los reinos cristianos medievales del norte de la Península. La torre semicircular es bastante frecuente en las murallas urbanas de repoblación, como por ejemplo en Ávila Berlanga, Soria, Almazán, Toro, Zamora, Ledesma, o Salamanca, villas que según la historiografía, se repoblaron tras las razzias de Almanzor, aproximadamente en la mismas fechas que el caso segoviano, si bien en los dos últimos ejemplos encontramos muy pocas torres e incluso en Salamanca también encontramos alguna torre de forma semicircular. En otros casos, como Cuellar, Arévalo, Coca, los restos conservados son escasos y difíciles de valorar. 
Sin embargo, los hispanomusulmanes optan mayoritariamente por las torres de planta rectangular. Toledo, Cáceres, Mérida, Badajoz, Talavera de la Reina, Talamanca del Jarama, Vascos, Gormaz, por citar algunos ejemplos.

Pero también encontramos murallas de inequívoca cronología cristiana con las torres de planta rectangular, así como torres de adscripción musulmana y planta semicircular (Aljafería, Toledo, Zafra, Zorita de los Canes), (Pavón Maldonado 1999: 239) si bien este caso se consideraba poco frecuente, hasta hace poco, como ya afirmaba Leopoldo Torres, la torre semicircular es excepcional en la España musulmana (Torres Balbás 1985: 580).

Menos frecuente es la existencia de torres de planta poligonal. Existen ejemplos en Carmona, Calatayud, Cáceres, Talavera de la Reina, en esta última, como en Segovia se alternan con torres rectangulares. (Pavón Maldonado 1999: 239). Todos estos casos son de cronología bastante tardía, ya en plena Baja Edad Media, a partir del XII. (Torres Balbás 1985: 569)

En la muralla de Segovia encontramos tres tipos de torres, atendiendo a su forma en planta,

- rectangulares,

- semicirculares,

- poligonales.

Históricamente a la muralla de Segovia se le asigna una cronología de finales del siglo XI, como una intervención realizada a raíz la repoblación efectuada por el Rey Alfonso VI tras la toma de Toledo. Sin embargo, la existencia de tres tipos de torres distintos en una misma muralla, nos hace sospechar que no se trata de una construcción unitaria, ya que dudamos que una única etapa constructiva pueda ejecutarse de forma tan aparentemente caprichosa. Nos está evidenciando que estamos ante distintas fases de ejecución, distintas murallas. La coexistencia de torres de distinta planta en una misma muralla, es un hecho habitual en ciudades que poseían una muralla previa, realizada por otra cultura o civilización anterior y que es reforzada posteriormente, como por ejemplo en Coca, San Esteban de Gormaz, Toledo, Valencia (Pascual 2001: 305-306) y Talavera de la Reina. (Valdés Fernández 2003: 129) por citar algunos ejemplos.

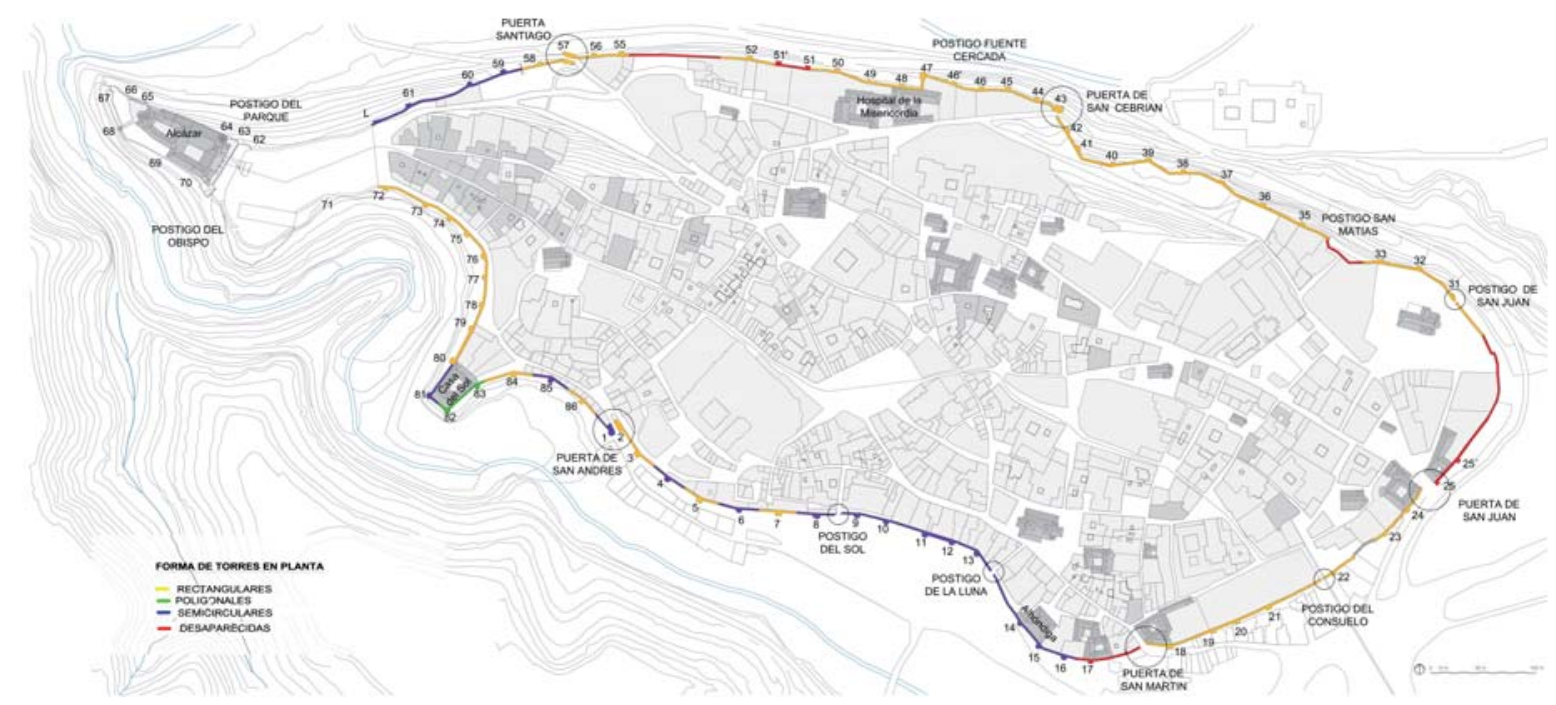

Figura 4.2. 1: Esquema de la distribución de las torres de la muralla en función de su forma en planta, según el Plan Director (PH: P0035). 
En el punto anterior 4.1.2, hemos visto como el estudio de la documentación histórica gráfica y documental, nos orientaba en las inspecciones in situ, gracias a lo cual descubríamos que bajo la apariencia de la muralla actual, algunas torres de la muralla tuvieron en origen otra forma en planta distinta.

Recapitulamos brevemente las transformaciones detectadas en aquellas torres en que se muestran evidencias de que tuvieron una forma distinta de la que exhiben en la actualidad.

\subsubsection{A.- TORRES SEMICIRCULARES}

Encontramos torres de planta semicircular en 4 zonas, la zona 2 del Salón, la zona 3 de la Alhóndiga, zona 9 y en el Alcázar, zona 10. En total son 17 torres $^{125}$, la T9, T10, T11, T12, T13, T14, T15, T16, T59, T60, T62, T63, T64, T66, T68, T69 у T70.

El grupo más homogéneo y unitario lo constituyen las torres de la zona del Salón, o sea entre los postigos del Sol y la Luna, las torres desde la T9 hasta la T13. Son 5 torres de unos 3,40 metros de radio. Es la única zona de la muralla donde todas sus torres son semicirculares y no existe ninguna torre con otra forma distinta a la circular, por lo que a falta de conocer la configuración de sus zócalos, que están enterrados en los cinco casos, podemos considerarlo como un grupo homogéneo y claramente diferenciado del resto de la muralla. El estudio, en próximos capítulos, de la métrica y las técnicas constructivas de estas torres nos deparará nuevos indicios de la singularidad de este grupo respecto al resto de la muralla.

Si damos por cierta, la existencia de una torre T13' adosada al postigo, de trazado semicircular como hemos supuesto, posiblemente deberíamos incluirla en esta zona 2, dentro de este grupo por su trazado en planta y la métrica de sus lienzos adyacentes que veremos más adelante.

En la zona 3, se conservan 3 torres de trazado semicircular. Las dos adyacentes a la Alhóndiga miden también 3,40 metros de radio, mientras la torre T16, mide solo 2,64 metros de radio. Sin embargo, ya hemos observado por el grabado de Wyngaerde, que la T16 es una construcción posterior al 1562 con dimensiones muy pequeñas en relación con el resto de la muralla y las otras dos torres, a pesar de la similitud de dimensiones en torno a los 3,40 metros de radio, no se pueden considerar como una continuidad de las torres de la zona del Salón. Entre ellas, existía una torre de trazado rectangular. Además la T15 era originalmente una torre de planta rectangular, tal y como aún se observa en su zócalo prácticamente oculto, pero muy visible en la foto de Mariano Moreno, ca. 1900 (VVAA, 2006: 88) y en el propio Wyngaerde.

Por lo tanto queda sólo como torre circular, la T14, que por el dibujo de Wyngaerde, sospechamos que también pudo tener un basamento rectangular, y que presenta unas franjas de sillería encintando la torre que consideramos están ejecutadas simultáneamente con la fábrica de la torre, por lo que toda la torre sería una construcción unitaria. El perfil de estas molduras, hoy muy deteriorado, nos infunde a pensar que es obra bastante tardía, posiblemente de finales del XV o principios del XVI y desde luego es un elemento único que

125 Según el Plan Director, las torres de planta semicircular son 18 torres, al considerar como circular la T49, que según nuestra toma de datos es una torre rectangular en la que se han redondeado las esquinas, al igual que ocurre en la T7. 
no vemos en ningún otro punto del resto de la muralla. Por lo tanto, la forma original de las torres de la muralla medieval de esta zona nos queda un tanto desdibujada por las transformaciones, si bien nos atreveríamos a pensar que posiblemente en origen fuesen todas ellas rectangulares, como predomina en la mayor parte de la cerca.

En la zona 9 encontramos dos torres. La torre T59, construida sobre un zócalo rectangular, es una reconstrucción desde los cimientos del año 2000 (AMS: 5132-5), aunque en un grabado de mediados del XIX, ya se la aprecia de forma semicircular sobre zócalo rectangular (Avrial y Flores 1953: lámina 51).

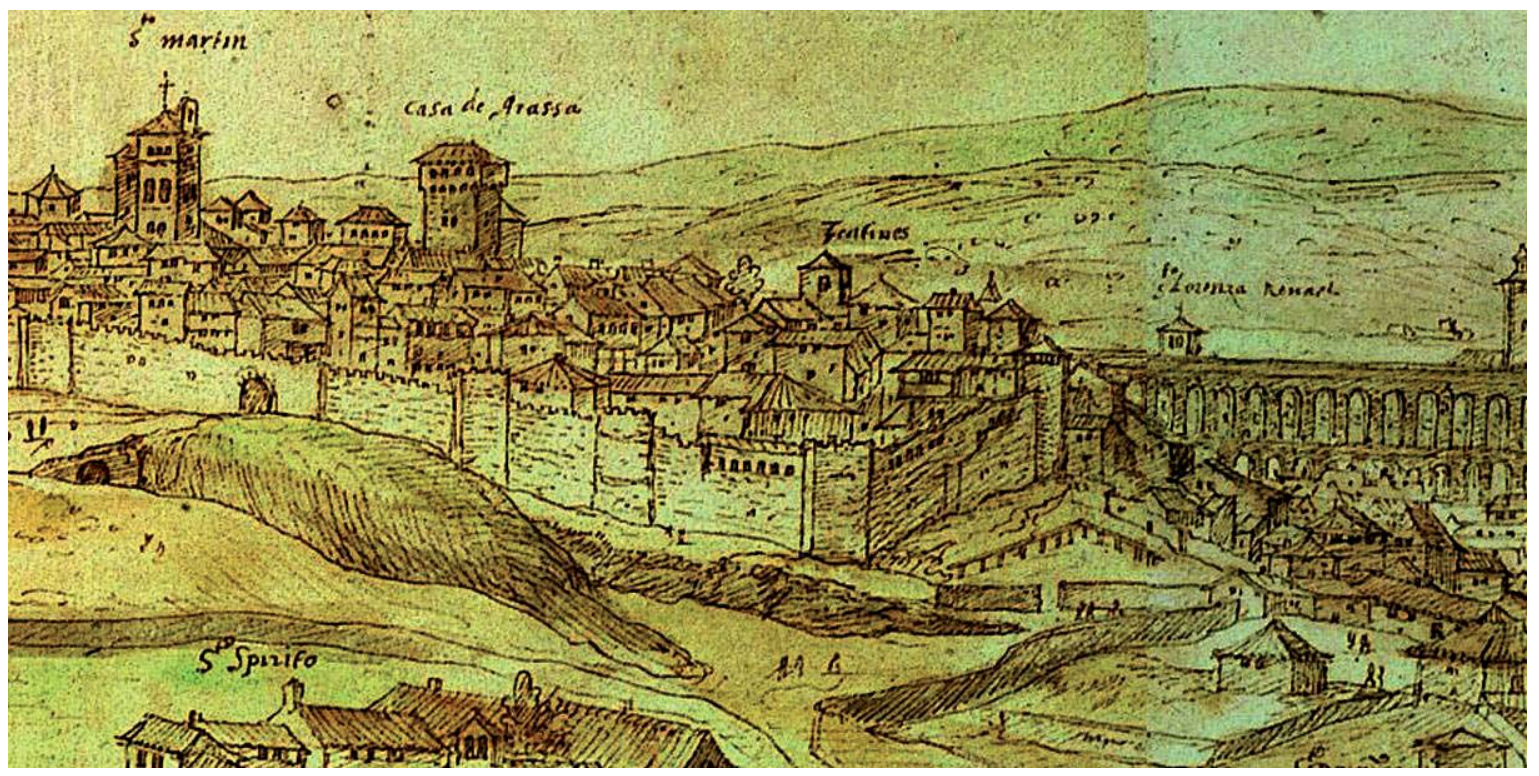

Figura 4.2. 2: Detalle de vista sur de Wyngaerde (Fuente: AMS). Si recorremos visualmente la muralla desde el postigo de la Luna hacia la derecha, apreciamos dos torres rectangulares, una torre circular, junto a la Alhóndiga, el edificio de la Alhóndiga, el cambio de dirección de la muralla en la torre T15, de forma rectangular y la actual torre T16 que no existe en 1562.

La torre T60, que como hemos visto, se han descubierto en su cimentación restos de una alineación de sillares de granito de trazado rectangular, posiblemente de una torre anterior con esa forma, aunque hay autores que opinan que se trata de un recalce pero la forma original de la torre era circular (STCSG: OT-189/2013-11: 47). Esto podría encajar con el hecho de que se conserven cuatro sillares de granito de grandes dimensiones, mayores que todos los demás con que se construye esta torre, en el encuentro con el lienzo de la muralla. Su discontinuidad con el resto del aparejo parecen indicar que fuese una preexistencia, de una torre previa que, según parece, tendría trazado semicircular y puede ser el motivo de que la torre medieval, reaprovechando lo existente, se adaptase a esta forma. Desde luego su aparejo actual de sillares reutilizados, mezclando granito y sedimentaria, hasta una considerable altura presenta todas las características de las torres reconstruidas después de la Edad Media.

En la zona 10, encontramos actualmente 7 torres de trazado circular. Como ya se ha indicado, las torres correspondientes al Alcázar, presentan unas características constructivas que poca 
relación tienen con la muralla. Tan sólo algunos restos que aparecen en sus zócalos pueden tener algún interés para los objetivos de nuestra investigación.

En los zócalos de las torres T62 y T63 hemos descubierto restos de distinta entidad de la existencia de trazados rectangulares previos. Arrancan sobre una base rectangular, transformándose en planta semicircular. La T64 tiene el zócalo no visible ni accesible, por lo que no podemos afirmar nada, aunque sospechamos que estemos en el mismo caso que las torres T62 y T63. Sus características constructivas parecen tener más relación con las del edificio que con el resto de la muralla. Posiblemente se pueda relacionar con la ampliación del Alcázar realizada por Alfonso X en 1258, ocupando la liza hacia el valle del Eresma y recreciendo los nuevos muros del edificio sobre los lienzos de la muralla (Merino de Cáceres, 2010: 129).

La T66, no presenta dimensiones ni características propias de la muralla. Se trata de una pequeña garita en el remate del patio, de escasa entidad constructiva.

En la torre T68, nos encontramos el mismo caso que en la T63 y T64. Se ha recrecido una torre de planta ovalada, sobre un zócalo rectangular que llega hasta a la altura del adarve de los lienzos adyacentes.

También son de trazado semicircular la T69 y T70, pero ambas son reconstrucciones muy recientes, dado que no existían en 1900, (VVAA, 2006: 33) como ya hemos visto.

Recapitulando, existen actualmente 17 torres de trazado semicircular en la muralla, de las cuales, tan sólo las 5 del grupo detectado en la zona 2, del Salón, parece presentar unidad constructiva, siendo el resto de las torres circulares, reconstrucciones ya de época moderna y contemporánea, que en algunos casos se efectúan sobre los restos de torres previas que podrían pertenecer a la muralla medieval. En estos casos, apoyan siempre sobre restos de torres de planta rectangular. Tan solo nos plantearía alguna duda la T60, que quedaría como caso aislado en la ladera norte.

\subsubsection{B.- TORRES POLIGONALES}

Hemos contabilizado en total 9 torres poligonales, de las cuales se conservan solo 8, que se distribuyen principalmente en la cara sur de la muralla, 4 en la zona 1, Leopoldo Moreno, 1 en la zona 3, Alhóndiga y 4 en la zona 12, Museo-Hontanilla. Son las torres T1, T4, T6, T8, T17”, T81, T82, T83 у T85.

En la zona 1, se disponen alternas con otras de trazado rectangular, desde la T81 hasta la T8. La T1, que forma parte del conjunto de la puerta de San Andrés, tiene un radio de 3,87 metros, mayor que las demás torres poligonales de esta zona. Presenta un zócalo resaltado, de trazado también poligonal de 11 lados. Sus características constructivas nos llevan a datarla a finales del XIV (Rodríguez Marín, 2013: 31), en el reinado de los Reyes Católicos (Quadrado, 2007: 427).

Las torres T4, T6 y T8 se disponen alternas con las torres rectangulares en la zona de la calle Leopoldo Moreno. Las dos primeras presentan un zócalo de trazado semicircular ligeramente resaltado sobre el que se eleva la torre poligonal, que muestran 8 o 9 lados. La tercera tiene su 
zócalo enterrado y lo que vemos aflorar ya es la fábrica de forma poligonal. Desconocemos si su zócalo es igual que las otras dos, aunque sospechamos que sí, constituyendo un grupo bastante homogéneo, ya que las tres presentan el mismo radio, 3,40 metros. La T4 presenta la peculiaridad de apoyarse sobre los restos de una zarpa de trazado rectangular, lo que nos permite conjeturar que estas torres poligonales, son reconstrucciones que se realizan sobre los restos de antiguas torres de planta rectangular.

La única torre de la zona 3, la T17", que ya no se conserva, se situaba flanqueando la puerta de San Martín y toda la información que tenemos de ella, se basa en la acuarela de Pérez de Castro. Su disposición era por lo tanto, muy similar a la de la T1, y al igual que en ésta, la forma poligonal llega hasta el suelo. No disponemos de más información de ella.

Las 4 torres de la zona 12 presentan mayor disparidad. Por una parte las torres T81 y T82 presentan un radio, 3,87 metros, igual al de la T1, superior al de las demás que miden 3,40 metros. Sin embargo sus zócalos son de trazado circular como el resto de las torres poligonales, lo que las diferencia de la T1. Tienen 11 y 13 lados, lo que las vuelve a aproximar a la T1, frente a los 8 o 9 que presentan las demás, algo que puede justificarse por ser los tres casos, torres en esquina.

La T83 es una torre poligonal de 5 lados, caso también excepcional en la muralla. Su aspecto y sus aparejos, como veremos más adelante, nos confirman que se trata de una reconstrucción, relativamente reciente por la uniformidad de la fábrica y la ausencia de discontinuidades.

La T85, vuelva a presentar las mismas características que hemos visto en las 3 torres de la zona 1 , radio de 3,40 metros, con zócalo semicircular resaltado y polígono de 9 lados.

Concluyendo, tenemos un grupo homogéneo de torres poligonales en las zonas 1 y 12, que arrancan sobre zócalo semicircular y que consideramos reconstrucciones sobre torres previas de traza rectangular, por lo que cronológicamente debemos encuadrarlas como posteriores a las torres rectangulares. Luego tenemos las torres flanqueando las puertas de San Andrés y San Martín como elementos singulares diferenciados y por último las dos torres que forman las esquinas de la casa del Sol, que parecen ser una especie de eslabón entre ambos grupos, ya que comparten características con ambos.

\subsubsection{C.- TORRES RECTANGULARES}

En la muralla se conservan 56 torres rectangulares, repartidas a lo largo de todo su perímetro, excepto en la zona del Salón, donde no existe ninguna. Hay 4 en la zona 1, 1 en la zona 3, 7 en la zona 4, 2 en la zona 5,12 en la zona 6, 5 en la zona 7, 9 en la zona 8, 2 en la zona 9, 3 en la zona 10, 8 en la zona 11 y 3 en la zona 12. A pesar del gran número de casos, encontramos muy pocas características, desde la geometría, que nos permitan diferenciar grupos o sectores de muralla homogéneos.

Sin embargo el análisis de otras variables nos va a permitir matizar este conjunto tan numerosos. Hemos encontrado dos variables que nos aportan una diferenciación más ordenada, la configuración de los zócalos y la métrica de la muralla. Posteriormente estudiaremos estas variables de manera más pormenorizada. 


\subsubsection{D.- UN ORDEN LÓGICO EN UNA APARENTE ALEATORIEDAD}

Según el Plan Director (ver Figura 4.2. 1), la disposición de las torres de la muralla atendiendo a su forma en planta presentaba una disposición casual. Tras el estudio realizado hasta el momento vemos que existe un orden lógico, donde antes apreciábamos una aparente aleatoriedad. Parece existir un orden más claro en la configuración de la muralla. (Ver Figura 4.2. 3)

A modo de conclusión podemos decir que existen tres tipos de torres por su forma en planta, en el que las torres de trazado rectangular predominan mayoritariamente en prácticamente todo el trazado excepto en la zona del salón que se constituye un grupo de torres de trazado semicircular claramente diferenciado.

Estas se organizan en sectores claramente diferenciados. Sobre estos primeros grandes bloques diferenciados, veremos que sucesivos análisis de otras variables nos definen una clasificación más matizada.

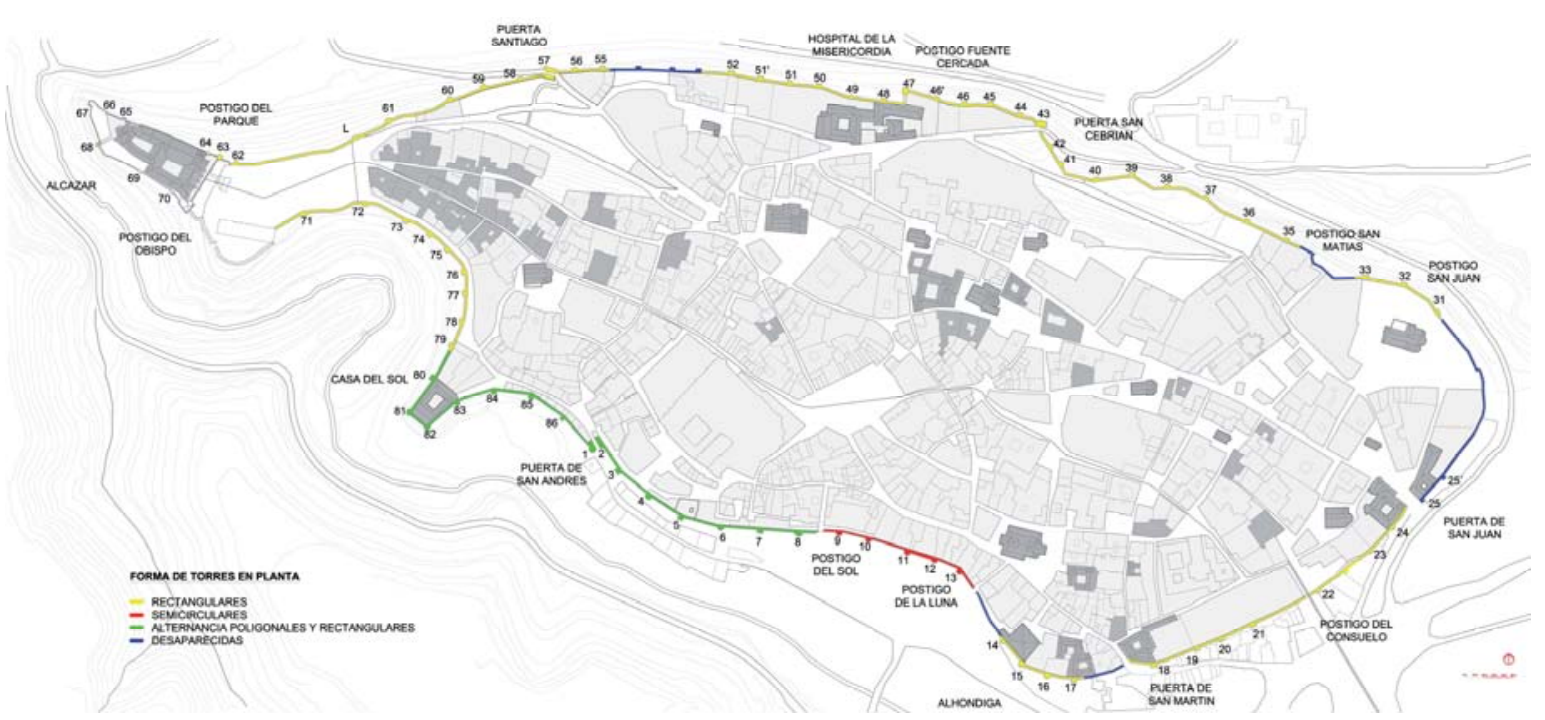

Figura 4.2. 3: Esquema de la distribución de las torres de la muralla en función de su forma en planta, según nuestra toma de datos. Compárese con la Figura 4.2. 11.

Las más abundantes, son las torres de trazado rectangular, que son las que encontramos por toda la ladera norte y hacia oriente. En la zona sur vemos un fragmento de la muralla en que las torres rectangulares se alternan con otras de forma poligonal, que solo aparecen en esta parte de la muralla. Por último las torres de planta semicircular aparecen dispersas por distintos puntos de la muralla, en las laderas norte y sur.

Así pues, las torres de planta rectangular parecen ser cronológicamente anteriores a las poligonales y las semicirculares de la ladera norte, ya que estas últimas se levantan sobre restos de trazado rectangular en prácticamente todos los casos, menos las excepciones indicadas. Respecto a las torres semicirculares de la zona del salón, al estar sus zócalos enterrados, no disponemos de relaciones estratigráficas que nos las relacionen con las rectangulares. Esta zona 2, es la única de toda la muralla que no tiene ninguna torre de planta rectangular. Es una 
singularidad más que la diferencia. Vemos que las principales singularidades se producen en las zonas 1,2 y 12.

\begin{tabular}{|c|ccc|}
\hline \multirow{2}{*}{ ZONA } & \multicolumn{3}{|c|}{ FORMA DE LAS TORRES } \\
\cline { 2 - 4 } & RECTANG & CIRC & POLIG \\
\hline \hline 1 & $\mathrm{X}$ & & $\mathrm{X}$ \\
2 & & $\mathrm{X}$ & \\
3 & $\mathrm{X}$ & $\mathrm{X}$ & \\
4 & $\mathrm{X}$ & & \\
5 & $\mathrm{X}$ & & \\
6 & $\mathrm{X}$ & & \\
7 & $\mathrm{X}$ & & \\
8 & $\mathrm{X}$ & & \\
9 & $\mathrm{X}$ & $\mathrm{X}$ & \\
10 & $\mathrm{X}$ & $\mathrm{X}$ & \\
11 & $\mathrm{X}$ & & \\
12 & $\mathrm{X}$ & & $\mathrm{X}$ \\
\hline
\end{tabular}

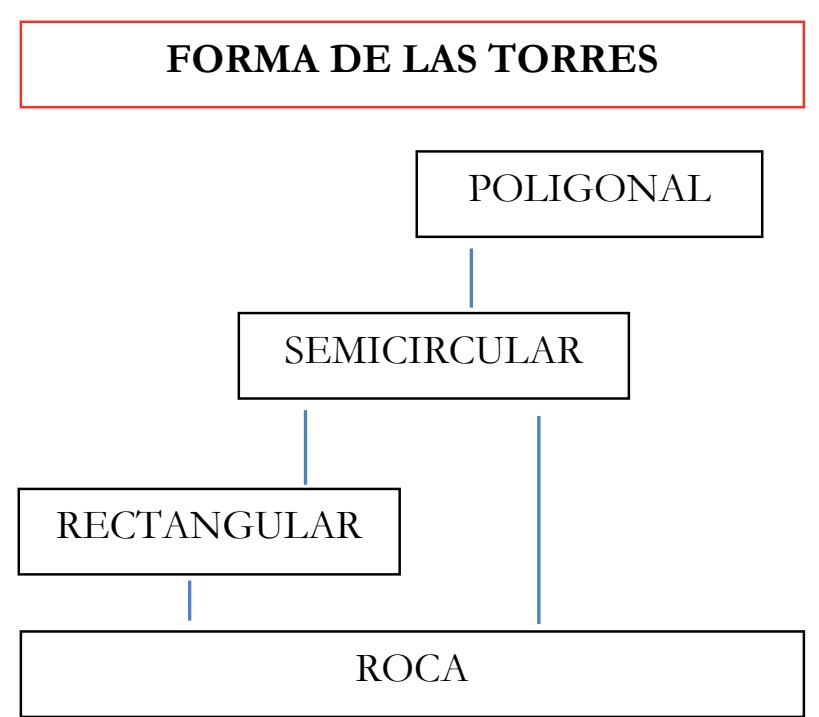

Figura 4.2.4: Tabla de clasificación de las formas de las torres así como la diferenciación de los zócalos. Se aprecian algunas pautas claras, como por ejemplo que en la zona 2 es la única donde no existen torres rectangulares, al igual que en las zonas 1 y 12 son las únicas donde existen torres poligonales.

Figura 4.2.5: Esquema secuencial de la relación entre las distintos tipos de torres en función de su forma en planta. Las torres de panta rectangular parecen ser las más antiguas, ya que las semicirculares apoyan sobre bases de torres rectangulares en todos los casos, excepto en la zona 2. Todas las poligonales apoyan en restos de trazado rectangular o en zócalos semicirculares. 


\subsection{2.- MÉTRICA DE LA MURALLA.}

La separación entre las torres de las murallas viene determinada principalmente por la poliorcética y el alcance de las armas de la época en que se construyen, para que esas torres de flanqueo cubran su función de defender los lienzos que las separan.

Así, podríamos pensar que la distinta separación de las torres puede verse influida por la época de construcción de las murallas, considerando que en épocas más antiguas, con menor potencia de fuego, las torres se situarían más próximas entre sí. Esto no siempre se cumple. (Pavón Maldonado, 1999: 247-248) y (Paz Peralta, 2014: 164-177). Incluso en el mismo estado o reino, estas torres se han construido más separadas que en otras murallas construidas coetáneamente (Paz Peralta, 2014: 95-97) si bien creemos que la aparente dispersión de valores puede estar motivada por la desaparición de algunas torres. En otros casos, el abanico de valores en que se mueven estas separaciones de torres es bastante acotado, como por ejemplo en las torres de las murallas construidas en Astorga, León, y Zamora (Paz Peralta, 2014: 154)

El estudio comparativo de las dimensiones de torres y lienzos de distintas murallas, sin consideración de cronologías ni otras variables, produce una dispersión de los datos que aporta pocas conclusiones. Así en nuestro estudio, excluimos del análisis las torres y lienzos de la zona del Alcázar por responder sus condiciones a los parámetros del edificio y no a los de la muralla. También excluimos la zona 5 , ya que no se conservan más que dos torres, ambas creemos que reconstruidas, por lo que no hay valores suficientes para realizar un análisis científico y obtener conclusiones fiables. 
Es posible que se tuviesen en cuenta otros factores, como por ejemplo la topografía del asentamiento o la capacidad militar del posible adversario contra el que se construyen esas murallas. Por lo tanto parece difícil establecer conclusiones definitivas, solo en base a la métrica de las murallas, por comparación de unas murallas con otras. Lo que sin embargo sí que no da unas pistas de regularidad es la métrica dentro de una misma muralla, cuando se construye unitariamente.

Si bien la topografía puede haber condicionado la disposición y dimensiones de algunas torres, creemos que el conjunto presenta una regularidad que nos permite establecer claramente cuando dos zonas de muralla no se han construido con la misma métrica y que casos se salen de la norma y cuáles son las pautas compositivas de su trazado.

\subsubsection{A.- DIMENSIONES DE LAS TORRES}

Las dimensiones de las torres presentan unos valores bastante homogéneos, con menores oscilaciones de lo que podrían aparentar la mera observación de los datos numéricos sin considerar las distintas circunstancias que producen esos resultados.

Así encontramos valores que se producen en algunas torres de manera individualiza y que se salen del elenco predominante en la zona, para las que creemos haber encontrado justificación. Muchas de ellas veremos que son motivadas por tratarse de reconstrucciones que, creemos, han alterado la geometría de la muralla original. Veamos las más significativas.

La T17, con unas dimensiones de 6,08 x 3,43 metros, esta reconstruida y ahuecada para adaptarla a vivienda. Las torres T20 (resalto de 1,98 metros) y la T23, con un frontal de solo 4,52 metros, son ambas torres reconstruidas en el siglo XX, tal y como se ha demostrado en el punto 4.1.4. Las torres T25 y T25'de dimensiones inferiores a los 3,50 metros de ancho, son también reconstrucciones, tal y como se ha indicado en el punto 4.1.5. La T31 con solo 1,80 metros de resalto, motivado por estar reconstruida en una posición más remetida de la original, tal como ya hemos justificado en el punto 4.1.7. La T45 de resalto 1,95 metros es también una reconstrucción, ya explicado en el punto 3.2.7. La T46 que mide 5,02 metros en su frontal, ligeramente menor en comparación con las demás, motivado por encontrarse sobre un peñasco aislado, que limita su tamaño. La T49 de 4,07 x 1,70 metros, es una torre muy deteriorada en que se han perdido los sillares esquineros, lo que dificulta su medición. El hecho de que no encaje en las medidas de las torres cercanas puede ser simplemente un error de medición y posiblemente sus dimensiones reales entran en el rango en el que se encuentran las demás. La T59, con un zócalo de 6,89 x 4,00, reconstruida en el año 2000, al igual que la T60, también reconstruida y con un zócalo de 5,35 x 3,50 metros, sobre el que se construye una torre semicircular de 2,95 metros de radio. Por último, la extraña proporción de la T84 con un frente de 5,40 y un resalto de 3,72 metros también puede ser motivada por ser una reconstrucción.

Analizando los valores característicos, obviando estas excepciones que se han motivado, encontramos cuatro tipos de torres atendiendo a su forma y sus dimensiones. Por la forma, ya teníamos definidos tres tipos en el apartado anterior, pero al analizar las dimensiones de la torres encontramos dos tipos de torres rectangulares. 
Las torres circulares presentan un radio de unos 3,40 metros, oscilando los valores entre 3,00 y 3,60 metros, con alguna excepción en casos de torres claramente reconstruidas (2,64 metros en la T16 y 2,95 metros en la T60). En el caso de las torres poligonales, el radio más frecuente también son los 3,40 metros y existen también tres excepciones, justificables por su singular posición, cuyo radio es de 3,87 metros, en las dos torres que hacen esquina en la Casas del Sol y la que flanquea la puerta de San Andrés.

\begin{tabular}{|c|c|c|c|c|c|c|}
\hline \multirow{3}{*}{ ZONA } & \multicolumn{4}{|c|}{ RECTANGULARES } & \multirow{3}{*}{$\begin{array}{c}\text { POLIGONAL } \\
\text { RADIO }\end{array}$} & \multirow{3}{*}{$\begin{array}{c}\text { CIRCULAR } \\
\text { RADIO }\end{array}$} \\
\hline & \multicolumn{2}{|c|}{ FRENTE } & \multicolumn{2}{|c|}{ RESALTO } & & \\
\hline & MEDIA & EXTREMOS & MEDIA & EXTREMOS & & \\
\hline 1 & 6,20 & $6,00-6,30$ & 3,60 & $3,30-3,70$ & 3,40 & \\
\hline 2 & - & - & - & - & & $3,00-3,60$ \\
\hline 3 & - & - & - & - & & 3,40 \\
\hline 4 & 5,40 & $5,30-5,70$ & 2,20 & $2,10-2,40$ & & \\
\hline 5 & - & - & - & - & - & - \\
\hline 6 & 5,30 & $5,10-5,60$ & 2,20 & $2,00-2,40$ & & \\
\hline 7 & 5,20 & $5,00-5,50$ & 2,20 & $2,20-2,40$ & & \\
\hline 8 & 5,20 & $5,15-5,30$ & 2,20 & $2,20-2,50$ & & \\
\hline 9 & 5,20 & $5,10-5,40$ & 2,10 & $2,00-2,10$ & & - \\
\hline 10 & - & - & - & - & - & - \\
\hline 11 & 5,22 & $5,10-5,40$ & 2,65 & $2,45-2,70$ & & \\
\hline 12 & 6,00 & $6,00-6,20$ & 3,70 & $3,50-3,77$ & 3,40 & \\
\hline
\end{tabular}

Figura 4.2. 6: Tabla de medidas de las torres de la muralla atendiendo a su forma en planta. Para cada zona, se dan los valores medios así como los extremos que acotan el conjunto. Para el cálculo del valor medio, se han excluido las excepciones justificadas en el texto que desvirtúan esa horquilla de valores. No se han considerado las zonas 5 y 10 .

Los frentes de las torres rectangulares en las zonas 1 y 12 superan los 6 metros con valores medios de 6,20 (entre 6,00 y 6,30 metros) mientras los resaltos predominantes son de 3,60 (entre 3,30 y 3,77 metros). En el resto de los tramos, los frontales de las torres rectangulares miden en torno a los 5,20 (entre 5,00 y 5,60 metros) y los resaltos 2,20 (entre 2,00 y 2,40 metros), si bien existen varias excepciones que salen de estos valores. En la zona 11, Ronda de Juan II, todas las torres presentan un resalto ligeramente superior al señalado, alrededor de 2,65 metros.

Por último hay tres torres que presentan unas dimensiones mayores que las demás, la T43 $(5,70 \times 4,20)$, la T47 $(5,80 \times 5,60)$ y la T57 $(11,80 \times 8,00)$, las tres vinculadas a puertas, respectivamente San Cebrián, Fuente Cercada y Santiago. Esta singularidad motivada por la presencia de las puertas la veremos más detenidamente en el punto 4.2.3. 


\subsubsection{B.- MEDIDAS DE LOS LIENZOS.}

El análisis de la longitud de los lienzos nos va a aportar nuevos datos que refirman la diferenciación en 5 sectores, 4 más el Alcázar, que hemos establecido atendiendo a la forma y dimensiones de las torres. Nuevamente excluimos la zona del Alcázar del estudio. Las dimensiones de sus lienzos hacen sospechar que faltan varias torres entre la verja y el foso y la modulación de otros lienzos se ha efectuado en base a otras claves diferentes a las de la muralla.

Para poder extraer conclusiones es necesario obviar los valores que desvirtúan la norma constructiva. Hemos encontrado numerosos tramos desproporcionadamente largos que coinciden con zonas donde hemos confirmado que originariamente había existido una o más torres que han desaparecido. El incorporar estas torres, cuya existencia ya se ha justificado en el punto 4.1.2, aunque en algunos casos su ubicación exacta sea estimada, nos permite clarificar enormemente la métrica de los lienzos que varía sensiblemente de lo que la muralla nos muestra en la actualidad.

En la zona 3, el grabado de Wyngaerde nos ha permitido situar dos torres, la T13'y la T13" entre el postigo de la Luna y la alhóndiga. La primera, completamente adosada al postigo y la segunda en el límite de la parcela del hotel Las Sirenas. Por otra parte, también hemos situado la torre poligonal que se encontraba junto a la puerta de San Martín, la T17”.

\begin{tabular}{|c|c|c|c|}
\hline \multicolumn{4}{|c|}{ ZONA 3 } \\
\hline $\begin{array}{c}\text { LIENZOS } \\
\text { ACTUALES }\end{array}$ & $\begin{array}{c}\text { LONGITUD } \\
\text { ACTUAL }\end{array}$ & $\begin{array}{c}\text { LONGITUD } \\
\text { ESTIMADA }\end{array}$ & $\begin{array}{c}\text { LIENZOS } \\
\text { HIPOTÉTICOS }\end{array}$ \\
\hline \hline & & 23,00 & $13^{\prime}-13^{\prime}$ \\
$13-14$ & 82,00 & 25,00 & $13^{\prime}-13^{\prime \prime}$ \\
& & 22,00 & $13^{\prime \prime}-14$ \\
\hline $14-15$ & 25,00 & 25,00 & $14-15$ \\
$15-16$ & 23,00 & 23,00 & $15-16$ \\
$16-17$ & 24,00 & 24,00 & $16-17$ \\
\hline & & 25,00 & $17-17^{\prime}$ \\
$17-18$ & 83,00 & 25,00 & $17^{\prime}-17^{\prime \prime}$ \\
& & 21,00 & $17^{\prime \prime}-18$ \\
\hline
\end{tabular}

Figura 4.2. 7: Estimación de las longitudes de los lienzos de la zona 3 en los que hemos detectado que han desaparecido 3 torres. Se presentan las medidas estimadas para los lienzos conforme a las conclusiones obtenidas del análisis efectuado en el punto 4.1.2.c.

De esta forma un lienzo que en la actualidad mide 82 metros, si incluimos dos torres de unos 5,50 metros de frente, se no generarían tres lienzos de aproximadamente 23-24 metros de largo, muy cercano a los valores que presentan los demás lienzos de esta zona.

Del mismo modo, la inclusión de la torre poligonal demolida junto con la puerta de San Martín y la hipótesis de la existencia de otra torre entre ésta y la T17, nos permite dividir el lienzo actualmente existente en otros tres, de dimensiones más cercanas a la modulación de la muralla. 
En zona 4, también hemos localizado 2 torres actualmente desaparecidas, T21'y T22', cuya inclusión en la métrica nos arroja unos valores, para los lienzos actualmente desproporcionadamente largos, algo más cercanos a los de los lienzos adyacentes, si bien esta zona parece ser más irregular, con algunas longitudes muy dispares como el lienzo L18-19, para las que no encontramos explicación.

\begin{tabular}{|c|c|c|c|}
\hline \multicolumn{4}{|c|}{ ZONA 4} \\
\hline $\begin{array}{l}\text { LIENZOS } \\
\text { ACTUALES }\end{array}$ & $\begin{array}{l}\text { LONGITUD } \\
\text { ACTUAL }\end{array}$ & $\begin{array}{l}\text { LONGITUD } \\
\text { ESTIMADA }\end{array}$ & $\begin{array}{c}\text { LIENZOS } \\
\text { HIPOTÉTICOS }\end{array}$ \\
\hline $18-19$ & 42,00 & 42,00 & $18-19$ \\
\hline $19-20$ & 22,00 & 22,00 & $19-20$ \\
\hline $20-21$ & 30,00 & 30,00 & $20-21$ \\
\hline \multirow{2}{*}{$21-22$} & \multirow{2}{*}{70,00} & 34,00 & $21-21^{\prime}$ \\
\hline & & 31,00 & $21^{\prime}-22$ \\
\hline \multirow{2}{*}{$22-23$} & \multirow{2}{*}{61,00} & 30,00 & $22-22^{\prime}$ \\
\hline & & 26,00 & $22^{\prime}-23$ \\
\hline
\end{tabular}

Figura 4.2. 8: Estimación de las longitudes de los lienzos de la zona 4 en los que hemos detectado que han desaparecido 2 torres, conforme a las medidas obtenidas del análisis efectuado en el punto 4.1.2.e.

Al igual que en el apartado anterior que hemos visto las dimensiones de las torres, encontramos algunos lienzos, que de manera individualizada alteran la modulación predominante, excepciones para las que en también hallamos alguna regla que las justifica, como es el caso de los lienzos adyacentes a las puertas de la muralla. En todos los casos hemos comprobado que estos lienzos son más cortos que las dimensiones de los lienzos de la zona en que se encuentra emplazada.

Así son más cortos en la zona 1, el L2-3, previo a la puerta de San Andrés; en la zona 3, el L17" -18, previo a la puerta de San Martín; en la zona 4, el L24-24', contiguo a la puerta de San Juan; en la zona 6, los dos lienzos previos a la puerta de San Cebrián, L40-41 y L41-42, en la zona 7, L47-48, desde el que se flanquea el acceso al postigo de la fuente cercada y en la zona 9, el L57-58, contiguo a la puerta de Santiago. Estos lienzos que se disponen lateralmente a lo largo del camino de acceso, tienen un valor defensivo para la puerta. Al ser más cortos, la torre esté más cerca de la puerta, amenazando la espalda de quien pretenda franquear el acceso, lo que es un aspecto de gran lógica defensiva, claramente intencionado.

También hemos identificado dos lienzos, vinculados a las puertas, que son más cortos que la moda de cada zona, estos son los lienzos que continúan la muralla una vez superada la puerta, pero que ya no flanqueaban el camino de acceso. Pero esto sólo lo hemos encontrado en dos de las puertas, San Cebrián, en que el lienzo L43-44, mide 18,17 metros y en la de Santiago, en que el lienzo L56-57 mide 16,90 metros, cuando el lienzo medio en su zona mide en torno a los 25 y 26,50 metros respectivamente. Posiblemente obedezca también a una lógica militar de defender la puerta con el apoyo de una torre más cercana, aunque el camino de acceso se encuentre al otro lado de la puerta. Esto lo estudiaremos con más detenimiento en el punto 4.2.6. 
Más corto de la media, es el lienzo de la casa del Sol, en la zona del Museo-Hontanilla, el L8182 que mide 18,13 metros. La adaptación a la topografía de la implantación es su explicación. Otro caso de lienzo atípicamente corto es el L76-77, en la zona 11, para el que encontramos una posible justificación, en la existencia en ese lienzo del denominado foso celtíbero y que en algún momento fuese considerado como un acceso al que defender con dos torres más cercanas, una de ellas, la T76 apoyada en su borde, de modo que el posible paso queda a los pies de la torre. También en esta misma zona, encontramos el L74-75, que mide solo 19,30 metros.

La única explicación lógica que encontramos para justificar la heterogeneidad de la longitud de los lienzos de esta zona es la topografía impuesta por el marcado meandro que realiza el arroyo Clamores.

En otras zonas hallamos tramos que exceden de la longitud media en los que creemos que se ha alterado la modulación de los lienzos por la desaparición de alguna torre, aunque no tenemos pruebas documentales, ni restos materiales tangibles para poder demostrarlo, como hemos podido hacerlo en otros casos, como por ejemplo los lienzos de la zona 6 , con la estimación de la posición donde se encontraban las desaparecidas torres, T29 y T30.

Este es el caso de la zona 5, donde solo se conservan dos torres reconstruidas, y donde no hay posibilidad de saber cuántas torres existían entre la puerta de San Juan y el paseo de Colmenares. De acuerdo con la estimación del Plan Director hemos considerado que existirían 5 torres, algo que encaja en la métrica de la muralla, pero aun así, pensamos que es bastante probable que existiese otra torre coincidiendo con el quiebro, o muy próximo a él, que hace la muralla en el remate de dicho paseo. En la zona 8 también han desaparecido un porcentaje significativo de torres, por lo que, en base a la modulación, optamos por aceptar la propuesta del plan Director, de que son tres las torres desaparecidas.

Otros lienzos para los que no encontramos motivo para su longitud, por encima de la media, son los lienzos L10-11 en la zona 2, el L18-19 en la zona 4, L35-36 y L36-37 en la zona 6 y el L72-73 en la zona 11.

En la tabla de la Figura 4.2. 9 vemos los valores medios y la horquilla de las longitudes de los lienzos de la muralla. Observamos algunos datos que nos permiten extraer conclusiones.

En la muralla distinguimos claramente dos métricas, cuyo valor de separación podemos establecer en la barrera de los 30 metros. Una con lienzos por encima de los 30 metros, que constatamos en las zonas 1, 6 y 12 y otra con lienzos de menos de 30 metros, que es la que modula el resto de los zonas.

Las zonas 1 y 12, tienen todos sus lienzos por encima claramente de los 30 metros de longitud, excepto las dos excepciones señaladas, del lienzo de la casa del Sol y el adyacente a la puerta de San Andrés. La zona 6, salvo el entorno del tapiado postigo de San Matías, que presenta unas medidas más irregulares, el resto de los lienzos hasta la puerta de San Cebrián, es muy unitario, con longitudes de lienzo también claramente por encima de los 30 metros, salvo los dos últimos lienzos que flanquean el camino de acceso a la puerta, más cortos como ya se ha visto. En la tabla se han excluido las zonas 5 y 10, la primera por la escasez de medidas reales disponibles al haber desaparecido la mayoría de la torres y la segunda por ser la del Alcázar, cuya métrica, ya hemos explicado es ajena a la del resto de la muralla. 


\begin{tabular}{|c|c|c|}
\hline \multirow{2}{*}{ ZONA } & \multicolumn{2}{|c|}{ LONGITUD DE LOS LIENZOS } \\
\cline { 2 - 3 } & MEDIA & EXTREMOS \\
\hline 1 & 34,00 & $34,00-35,00$ \\
2 & 23,00 & $22,00-36,60$ \\
3 & 25,00 & $23,00-28,00$ \\
4 & 30,00 & $22.00-42,00$ \\
5 & - & - \\
6 & 35,00 & $32,00-44,00$ \\
7 & 25,00 & $21,50-28,50$ \\
8 & 24,50 & $23,80-26,40$ \\
9 & 28,00 & $22,00-31,00$ \\
10 & - & - \\
11 & 24,00 & $17,00-35,00$ \\
12 & 34,00 & $33,30-36,00$ \\
\hline
\end{tabular}

Figura 4.2. 9: Tabla con las longitudes de los lienzos de la muralla. Para cada zona, se dan los valores medios así como los extremos que acotan el conjunto. Para el cálculo del valor medio, se han excluido las excepciones justificadas en el texto que desvirtúan esa horquilla de valores. No se han considerado las zonas 5 y 10.

Sin embargo, algunas zonas presentan dimensiones de lienzos muy distintas, que falsean las longitudes medias, dato que hay que tener en consideración. La zona 4 tiene unas medidas muy variables, con longitudes de lienzo muy irregulares, como se puede ver en la Figura 4.2. 8, por lo que aunque la media se aproxima a los 30 metros, el hecho de basarnos en nuestra estimación, en vez de en medidas reales, nos obliga a ser cautos, a la hora de encuadrar esta zona en un métrica u otra. Hay varios lienzos que no llegan a los 30 metros.

La zona 9, solo presenta cuatro torres de 5 totales que se presumen, por lo que tenemos tres lienzos con medida real y el resto son estimaciones no válidas para obtener conclusiones en su análisis. Sin embargo de esos tres lienzos, uno es más corto, justificado por ser el adyacente a la puerta de Santiago, pero los otros dos tienen un largo superior a los 30 metros, que elevan la media. La zona en sí, no modula, aparentemente, con métrica superior a los 30 metros, aunque parece que esas dos torres, sí lo hacen. El ser sólo dos torres, nos aporta pocas referencias para ser más concluyentes en el análisis.

En el resto de las zonas, contando con las nuevas torres descubiertas, la longitud de los lienzos oscila en torno a los 24-25 metros, salvo algunas excepciones que nos hacen sospechar que falte alguna torre más en dichos lienzos, vista la regularidad que muestra el resto del trazado.

\subsubsection{C.- DiFERENTES MODULACIONES. DiSTINTAS MURALLAS.}

El análisis de la métrica subyacente, más difícilmente alterable por una intervención que la imagen exterior de los paramentos, nos depara una información que pasaría desapercibida con el estudio sólo de los materiales, sistemas y técnicas constructivas. Si conjugamos los resultados obtenidos en el análisis de la forma de las torres y las dimensiones que presentan junto con las de los lienzos, obtenemos unos resultados muy interesantes. 
Por una parte, detectábamos tres tipos de torre atendiendo a su forma en planta, rectangular, semicircular y poligonal. El análisis de las dimensiones en planta de las torres y la longitud de los lienzos que las separan, constata que las modulaciones de lienzos y torres son distintas, dependiendo de la zona en que se encuentren, produciéndose las coincidencias más significativas en la cara sur, (zonas 11, 12, 1 y 2). En esta parte sur de la muralla, tanto las torres poligonales como las semicirculares presentan un radio muy parecido, en torno a los 3,40 metros, (excepto tres torres de la muralla, T1, T81 y T82, que se disponen en un emplazamiento singular, cuyo radio es de 3,87 metros) mientras las torres de planta rectangular presentan dos dimensiones diferentes, según en qué sector se encuentren. Las de la zona 11, donde sólo aparecen torres rectangulares (de la T72 a la T79) su largo es entre 5,10 y 5,40 metros, (con longitudes de lienzo de unos $24 \mathrm{~m}$ ) mientras las situadas en el sector 12 y 1 , entre la T80 y la T8 miden entre 5,90 y 6,30 metros, con longitudes de lienzo entre 33 y 35 metros.

Si consideramos el resalto respecto del lienzo de la muralla de estas torres rectangulares, las dimensiones vuelven a diferenciarnos los mismos grupos. Con un resalto superior a los 3 metros, las situadas en las zonas 12 y 1 y con un resalto superior a 2,5 metros (y menor de 3 m) las de la zona 11, desde la T73 hasta la T79. Por último el resto de las torres rectangulares de la muralla, tienen su dimensión frontal similar a las de la zona 11, pero muestran un resalto inferior a 2,5 metros.

La principal conclusión a la que llegamos con estos datos es que las torres de la zona 12 y 1 parecen responder a una métrica distinta de la que presenta el resto de la muralla, redundando en la singularidad que ya nos indicaba el análisis de la forma en planta de sus torres. Sus torres rectangulares son sensiblemente más grandes y están más separadas entre sí. Entre ellas alternan unas torres poligonales, que solo existen en este sector. En el resto de la muralla, las torres presentan la misma modulación de lienzos y las rectangulares tienen unas medidas muy parecidas, mientras en la zona 11 se diferencian por tener un resalte mayor y presentar zócalo escalonado en la mitad de los casos. Por último en la zona 2 sólo encontramos torres de trazado semicircular, siendo la única zona donde no existe ninguna torre rectangular.

Tan solo hay una excepción curiosa, la zona 6 presenta unos lienzos de longitud superior a 30 metros. Sin embargo ninguna de sus torres mide 6 metros de frente ni tiene un resalto superior a 3 metros. Las medidas de sus torres, encajan perfectamente en las dimensiones de la modulación de lienzos menores de 30 metros, con frentes de torres menores a 5,60 y resaltos que no superan los 2,40 metros. Algo parecido sucede en la zona 4, si bien en ésta las medidas de los lienzos no son tan uniformes. No encontramos justificación al porque sus torres están tan separadas, salvo que pueda faltar alguna torre o debido a que lo vertical del acantilado a sus pies, permitiese, sin afectar a su defensa, unas mayores distancias.

El análisis de estas características nos lleva a diferenciar 5 sectores de muralla atendiendo a su geometría. En la Figura 4.2. 10, se presentan los distintos sectores homogéneos en que dividimos la muralla atendiendo a la métrica de sus lienzos, la dimensiones de sus torres y la configuración de sus zócalos.

El sector I se corresponde íntegramente con la zona 11. El sector II, comprende las zonas 12 y 1. El sector III, con la zona 3. El sector IV engloba la zona 6 y con ciertas dudas la zona 4 (debido a las irregularidades comentadas) y el sector $\mathrm{V}$ corresponde con las zonas 7 y 8 . 
Se excluyen las zonas 3, 4, 5, 9 y la 10. Las zonas 3, 5 y 9, es muy difícil incluirlas de manera categórica en uno u otro sector dado que han desaparecido varias torres. En la zona 9, las torres T58, T59 aparentemente modulan con lienzo de más de 30 metros, pero sólo esas dos. Del mismo modo se excluye la zona 3 porque, aunque hemos confirmado la existencia y sabemos la posición aproximada de sus torres desaparecidas, desconocemos sus dimensiones reales y su composición material original. Aparentemente modulan con menos de 30 metros de lienzo, pero las torres que observamos en la actualidad son mayoritariamente reconstruidas. La zona 10 correspondiente al Alcázar, ya hemos visto que tiene unas reglas compositivas muy transformadas por su adaptación a las del edificio, diferentes a las de la muralla.

El tipo de torre más abundante es el de planta rectangular, ya que se despliega a lo largo de $2 / 3$ de la longitud total de la muralla, se extiende a lo largo de toda la cara norte de la muralla y del que denominamos sector I, en la cara sur. Las de traza poligonal que solo aparecen en el sector II, también en la fachada sur, disponiéndose de forma alterna con otras torres rectangulares y el último tipo, las de planta semicircular que se sitúan en el sector III.

De esta forma, se entiende que existen, al menos, tres fases constructivas de los lienzos de la muralla segoviana, que se corresponden con tres sectores homogéneos, nítidos y perfectamente diferenciados en el alzado sur. Con este estudio, creemos haber demostrado que no se trata de una muralla realizada de una sola vez de manera unitaria, sino que se trata de al menos tres "murallas", tres tipologías distintas, con morfologías, sistemas constructivos, dimensiones, modulaciones y proporciones diferentes. Aunque, como se ha indicado, no hay datos arqueológicos asociados que permitan datar de forma precisa, todo parece indicar que se trata de tres cronologías diferentes, o tres fragmentos parciales de murallas diferentes subyacentes, aunque las intervenciones realizadas a lo largo de tiempo haya uniformizado su aspecto en la actualidad.

\begin{tabular}{|c|c|c|c|c|c|c|c|c|}
\hline \multirow{2}{*}{ SECTORES } & \multirow{2}{*}{ ZONA } & \multirow{2}{*}{ TRAMO } & \multicolumn{4}{|c|}{ TORRES } & \multicolumn{2}{|c|}{ LIENZOS } \\
\hline & & & FORMA & RADIO/FRENTE & RESALTO & ZOCALO & LONGITUD & ZOCALO \\
\hline SECTOR I & 11 & $73-79$ & RECT & 5,22 & 2,65 & NR & 24,00 & $\mathrm{DE}$ \\
\hline \multirow{2}{*}{ SECTOR II } & 12 & $80-1$ & ALTER & $\varnothing \dot{\varnothing} 3,40$ - 6,00 & 3,70 & NR & 34,00 & $\mathrm{~N}$ \\
\hline & 1 & $2-9$ & ALTER & $\varnothing \dot{~ 3,40 ~-~ 6,20 ~}$ & 3,60 & NR & 34,00 & N \\
\hline SECTOR III & 2 & $10-13^{\prime}$ & SEMICIR & 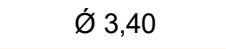 & & $\mathrm{N}$ & 23,00 & N \\
\hline SECTOR IV & 6 & $31-41$ & RECT & 5,30 & 2,20 & N/D & 35,00 & NE/D \\
\hline \multirow{2}{*}{ SECTOR V } & 7 & $41-47$ & RECT & 5,20 & 2,20 & D & 25,00 & 1 \\
\hline & 8 & $47-57$ & RECT & 5,20 & 2,20 & D & 24,50 & 1 \\
\hline & 3 & $14-17$ & RECT & - & - & - & 24,00 & 1 \\
\hline & 4 & $18-24$ & RECT & 5,40 & 2,20 & - & 30,00 & I \\
\hline & 5 & $25-30$ & RECT & - & - & - & 25,00 & - \\
\hline & 9 & $58-61$ & RECT & 5,20 & 2,10 & - & 28,00 & 1 \\
\hline
\end{tabular}

Figura 4.2. 10: Tabla la clasificación de la muralla en sectores homogéneos, atendiendo a la geometría de sus torres y lienzos, su métrica y la configuración de sus zócalos. Se excluyen las zonas 3, 4, 5, 9 y 10. 
Desgraciadamente no abundan claras líneas de interfacies separando las discontinuidades de las fábricas. Los múltiples rejuntados y reparaciones que han sufrido estos muros, (Contreras Jiménez, 1986) en que se ha añadido abundante ripio, han unificado el aspecto de los lienzos, ocultando mucha información, como por ejemplo los encuentros de las torres con los lienzos, dándose la circunstancia de que con elevada frecuencia no es posible distinguir que elemento se adosa a cual, dificultando la lectura de las relaciones estratigráficas entre los elementos que configuran estas discontinuidades y la interpretación constructiva de la muralla.

Aunque los aparejos y estado actual de los paramentos, no permiten en muchos casos intuir estas diferencias, la métrica subyacente si nos aporta esta información que habrá que cotejar con otros niveles de análisis.

Esta modulación de los diferentes tramos de muralla, con dimensiones de torres y lienzos distintos nos muestran unas discontinuidades en la construcción de la muralla, independientemente del aspecto exterior de las fábricas que han podido verse alteradas por reconstrucciones y reparaciones, que evidencian distintas lógicas constructivas y nos hacen sospechar que estamos ante distintas fases constructivas de la misma muralla o ante distintos fragmentos de murallas de cronologías diversas que aprovechan fábricas preexistentes. Esto nos obliga a distinguir los diferentes sectores de muralla y acotarlos perfectamente, en base a la métrica subyacente. El posterior análisis de las fábricas y aparejos ayudará a interpretar esta clasificación, si bien el análisis de los zócalos ya nos ha dado unas pistas muy claras.

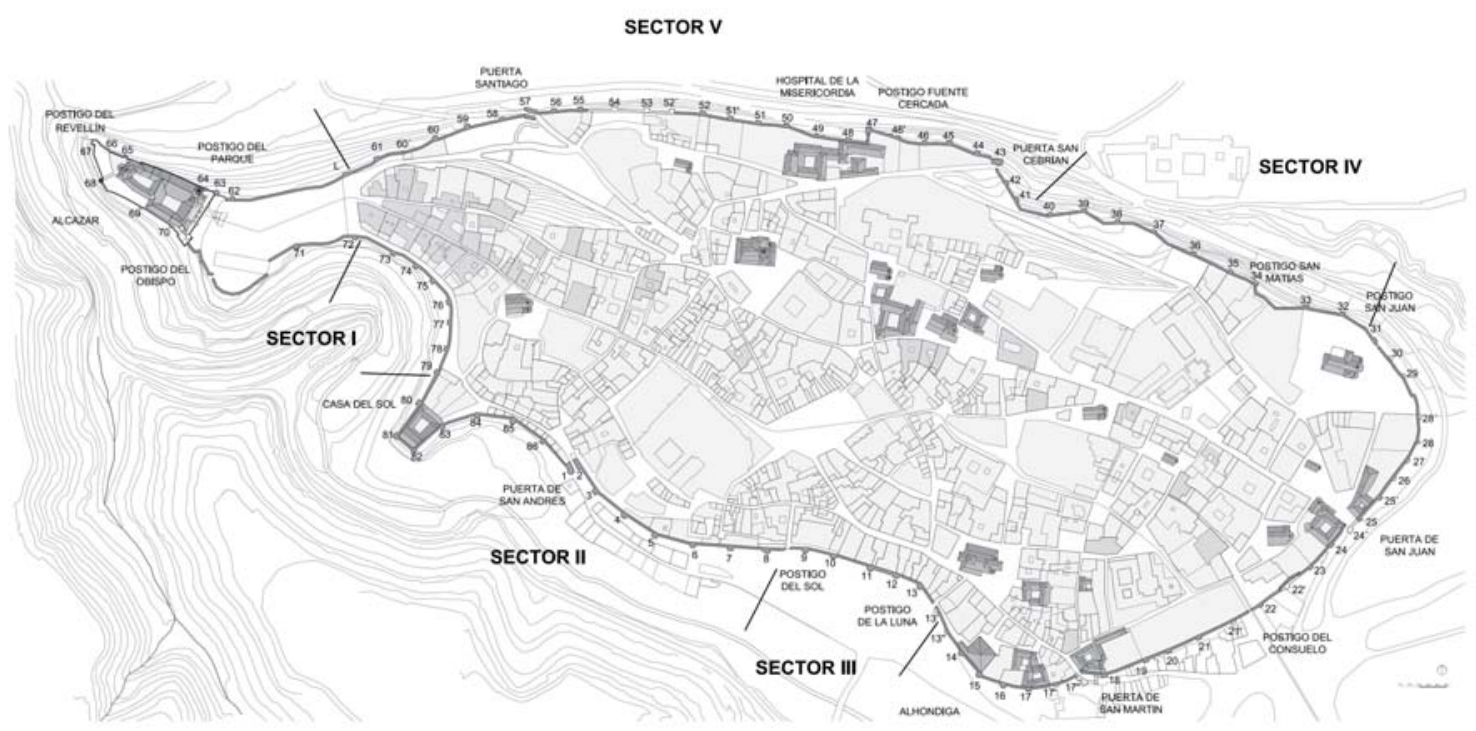

Figura 4.2. 11: Plano con clasificación de la muralla en sectores homogéneos, atendiendo a la geometría y dimensiones de sus torres y lienzos. Véase las características de cada sector en la tabla de la Figura 4.2. 6.

Para conocer el límite exacto de cada sector es necesario examinar la métrica de las torres y lienzos para compararlos con los dos adyacentes y encuadrarlo en uno u otro. Veamos las características de cada sector de manera pormenorizada, especialmente las dimensiones de lienzos y torres en los límites, para poder acotarlos con exactitud, dado que en algunos casos, difieren de la división en zonas que se ha efectuado para la toma de datos. 
SECTOR I: Desde la torre T73 a la T79. Largo aprox 130 metros.

El sector I presenta torres de planta rectangular construidas en una fábrica de mampostería de roca sedimentaria, que en algunos casos apoya sobre una hilada de piezas de granito colocado sin voluntad de formación de zócalo de nivelación, disponiendo simplemente una hilada de separación con el terreno, que en muchos casos ni siquiera genera un tendel horizontal superior. No existen fábricas de ladrillo, ni de sillería, aunque en el caso de las torres es frecuente el empleo de sillares de piedra sedimentaria para reforzar las esquinas.

Las dimensiones de las torres son de 5,20-5,30 metros en el lado frontal por 2,65 m de resalto, respecto al lienzo de la muralla. En algunos casos (T74, T75, T78 y T79) presentan zócalo nivelado y resaltado, mientras los lienzos tienen los zócalos diferenciados pero no perfectamente nivelados, más bien paralelos al terreno. Como se ha indicado, esta zona presenta la singularidad de realizar quiebros en los trazados de los lienzos en todos ellos excepto el L79-80, en lugar de efectuar ese cambio en las torres. Creemos que esto es motivado por lo pronunciado del meandro del arroyo Clamores y la topografía. El trazado al intentar adaptarse a las curvas de nivel es demasiado cerrado y obligaría a colocar demasiadas torres y muy juntas. Esto motiva la existencia de quiebros en los lienzos así como la irregularidad en la longitud de estos.

\begin{tabular}{|cccc|}
\hline TORRE & FORMA TORRES & LARGO & ANCHO \\
\hline \hline 72 & RECTANGULAR & 5,10 & 2,45 \\
73 & RECTANGULAR & 5,22 & 2,60 \\
74 & RECTANGULAR & 5,20 & 2,65 \\
75 & RECTANGULAR & 5,22 & 2,65 \\
76 & RECTANGULAR & 5,38 & 2,55 \\
77 & RECTANGULAR & 5,22 & 2,65 \\
78 & RECTANGULAR & 5,36 & 2,72 \\
79 & RECTANGULAR & 5,29 & 2,66 \\
80 & RECTANGULAR & 5,86 & 3,50 \\
\hline
\end{tabular}

\begin{tabular}{|cc|}
\hline LIENZO & LONGITUD \\
\hline \hline $72-73$ & 35,10 \\
$73-74$ & 24,00 \\
$74-75$ & 19,30 \\
$75-76$ & 23,20 \\
$76-77$ & 16,82 \\
$77-78$ & 23,90 \\
$78-79$ & 21,57 \\
$79-80$ & 33,28 \\
\hline
\end{tabular}

Figura 4.2. 12: Tabla de las características del sector I. En fondo de color, se señalan las torres y los lienzos que limitan a este sector, pero ya no pertenecen a él.

Como puede observarse los lienzos L72-73 y L79-80, en los extremos superior e inferior de la tabla, pertenecen a la métrica superior a 30 metros y ambas torres tienen unas dimensiones que las relacionan con otros sectores, especialmente por el resalto. Esto nos delimita el sector, indicándonos que en ese punto cambia el tipo de torre y de métrica. La T72 debemos encuadrarla en la métrica del sector del Alcázar, situando el límite de este sector en el quiebro que efectúa el lienzo L72-73. Por el otro extremo, la T80 debemos incluirla en el sector II vista la longitud del lienzo L79-80.

La regularidad del zócalo del lienzo L79-80, perfectamente diferenciado y nivelado, nos induce a relacionarlo con los zócalos del sector II en lugar de con los del sector I, por lo que creemos que la T79 es una torre reconstruida con las dimensiones del sector I, pero para su ubicación se mantuvo la métrica de más de 30 metros, la del sector II. 


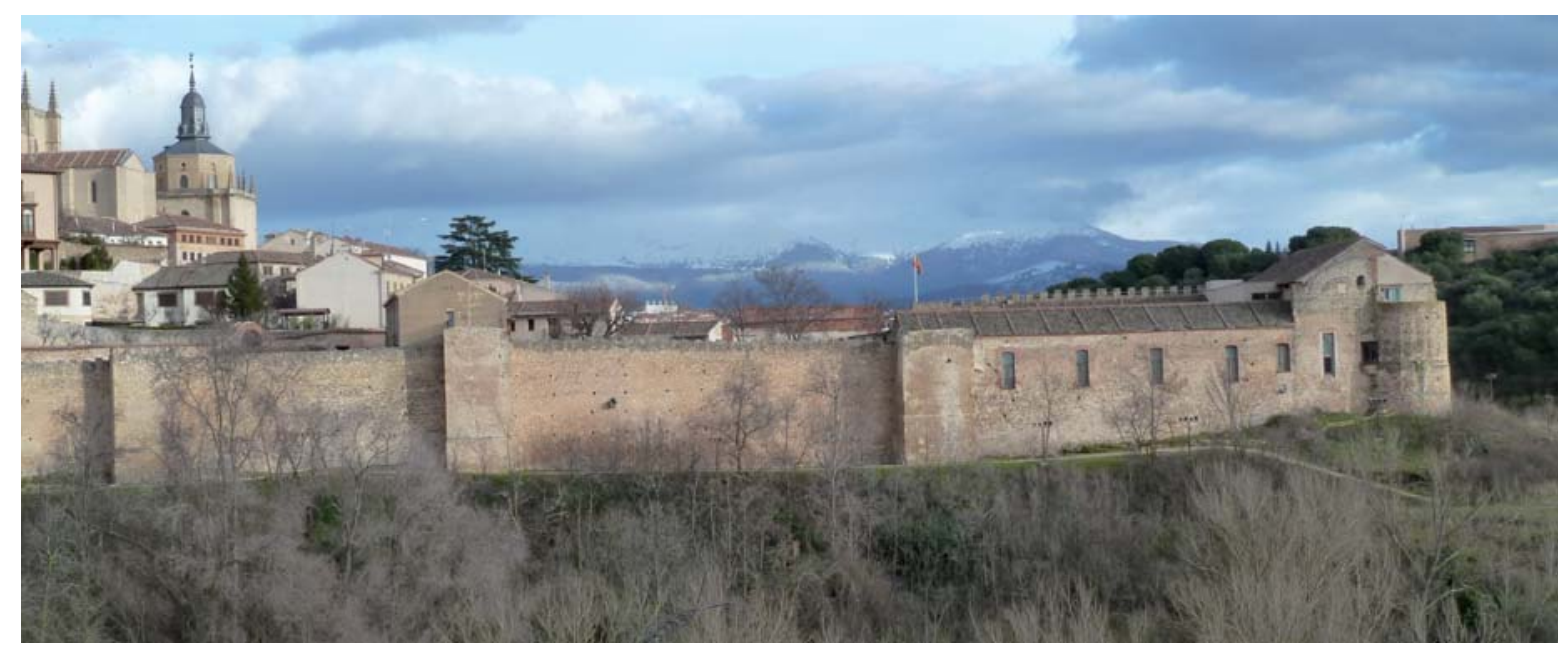

Figura 4.2. 13: Imagen de los lienzos L78-79, L79-80 y L80-81 en que se percibe el cambio de métrica en esta zona de la muralla. Es muy visible la diferencia de longitud entre los lienzos que modulan a mas de 30 metros, L79-80 y L80-81 a la derecha, y el L 78-79 a la izquierda, claramente más corto. Por otra parte, también se aprecia la diferente proporción entre las dos torres centrales, con frontal de más de 6 metros, la T80 en el centro a la derecha, en comparación con la T78 y T79, en el centro a la izquierda.

SECTOR II: Desde la torre T80 a la T9. Largo aprox 500 metros.

En el sector II encontramos torres de planta rectangular y de planta poligonal dispuestas de forma prácticamente alterna, ejecutadas en sillería aparejada a soga y tizón, en algunas torres, completamente hasta el adarve, mientras en el resto encontramos en sus partes altas también mampostería y fábrica de ladrillo de claras connotaciones mudéjares en su configuración de arquillos ciegos. Por lo tanto en este sector II encontramos los tres sistemas constructivos, dándose la circunstancia de que sólo es en este sector donde existen aparejos de sillería, en todas las torres excepto la T83 y encontramos fábricas de ladrillo que se hallan exclusivamente en unas torres cercanas a la Puerta de San Andrés. Por otra parte, entre el espolón del museo T80 y la puerta de San Andrés varias de las torres, al menos 2 están reconstruidas en intervenciones modernas, por lo que sus fábricas no resultan útiles a nuestros análisis.
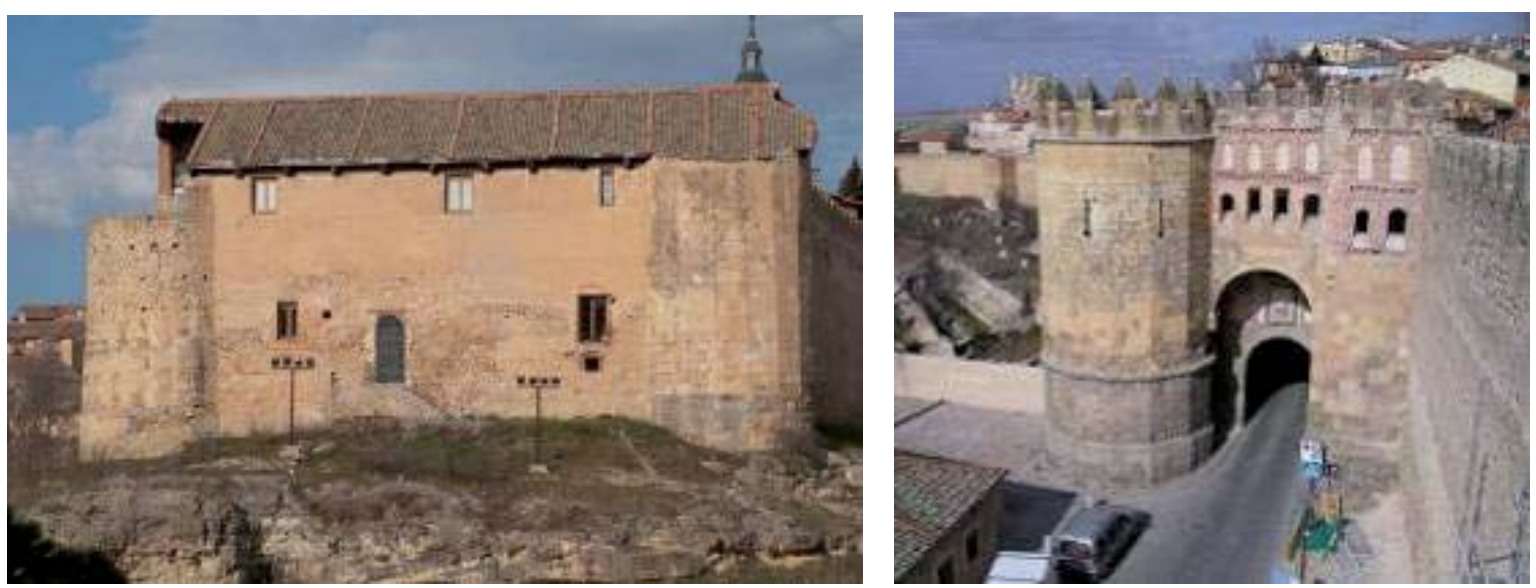

Figura 4.2. 14: Torres T81 y T82, flanqueando el edificio del actual museo de Segovia. Las dimensiones del lienzo L81-82 se adaptan a la topografía.

Figura 4.2. 15: Torres T1 (poligonal a la izquierda) y T2 (rectangular a la derecha), flanqueando la puerta de San Andrés, denominado lienzo L1-2. La singular disposición de las tres torres poligonales justifica su mayor dimensión así como la menor longitud de los lienzos que flanquean. 
Presenta una alternancia de torres de planta poligonal y torres de planta rectangular. El radio de las primeras es 3,40 metros con 3 excepciones y las dimensiones de las segundas son frontales de más de 6 metros y resaltos de más de 3, separadas por lienzos de longitud superior a los 30 metros. Presentan zócalos nivelados y resaltados y algunas de ellas, también zarpas. Los zócalos de los lienzos también son nivelados, aunque no resaltados, excepto el L67 que se conforma escalonado a modo de zarpa.

Las torres T81 y T82 flanquean el frontal del actual museo de Segovia, en el conocido como espolón. Esta disposición tan singular tiene claras connotaciones defensivas que justifican la alteración de la modulación para adecuarse a la topografía y las dimensiones del enclave a defender.

El lienzo L2-3 es claramente más corto, de modo que la torre T3 se sitúa más próxima a la puerta de San Andrés, medida de carácter defensivo que se repite en todas las puertas de la muralla, como ya hemos visto. Las dimensiones de las torres rectangulares oscilan alrededor a los 6 metros (siendo la torre T84, reconstruida en el siglo XX, la más pequeña, con 5,40 m) por 3,70 metros de resalto (la torre T2 y la T7 solo 3,40 metros).

\begin{tabular}{|c|ccccc|}
\hline TORRE & FORMA TORRES & RADIO & N ${ }^{\circ}$ LADOS & LARGO & ANCHO \\
\hline \hline 80 & RECTANGULAR & & & 5,86 & 3,50 \\
81 & POLIGONAL & 3,87 & 13 & & \\
82 & POLIGONAL & 3,87 & 11 & & \\
83 & POLIGONAL & 3,35 & 5 & & \\
84 & RECTANGULAR & & & 5,40 & 3,72 \\
85 & POLIGONAL & 3,40 & 9 & & \\
86 & RECTANGULAR & & & 6,13 & 3,77 \\
1 & POLIGONAL & 3,87 & 11 & & \\
2 & RECTANGULAR & & & & 3,39 \\
3 & RECTANGULAR & & & 5,90 & 3,70 \\
4 & POLIGONAL & 3,40 & 9 & & \\
\hline 5 & RECTANGULAR & & & 6,11 & 3,68 \\
6 & POLIGONAL & 3,40 & 8 & & 3,35 \\
7 & RECTANGULAR & & & & \\
8 & POLIGONAL & 3,40 & 8 & & \\
9 & CIRCULAR & 3,40 & & & \\
\hline
\end{tabular}

\begin{tabular}{|cc|}
\hline LIENZO & LONGITUD \\
\hline \hline $79-80$ & 33,28 \\
$80-81$ & 36,03 \\
$81-82$ & 18,13 \\
$82-83$ & 33,80 \\
$83-84$ & 35,00 \\
$84-85$ & 34,00 \\
$85-86$ & 33,35 \\
$86-1$ & 33,43 \\
$1-2$ & 3,95 \\
$2-3$ & 25,95 \\
$3-4$ & 33,95 \\
$4-5$ & 35,00 \\
$5-6$ & 34,86 \\
$6-7$ & 35,01 \\
$7-8$ & 34,27 \\
$8-9$ & 34,92 \\
\hline
\end{tabular}

Figura 4.2. 16: Tabla de las características del sector II. El cambio de la forma de la torre T9, nos hace excluirla de este sector, sin embargo la longitud del lienzo L8-9 nos indica que si pertenece a este sector.

Respecto a las torres poligonales, señalar la similitud existente entre las 3 torres en disposición singular por una parte (T81, T82 y T1) y por la otra, las de las otras cuatro torres restantes (torres T85, T4, T6 y T8). Resulta significativa la regularidad que presentan las tres torres T4, T6 y T8, que estilísticamente también presentan una unidad muy evidente y que las diferencia de las demás. Sus medidas son idénticas tanto en lo que se refiere a radio, longitud del lado y 
arco o ángulo que forma con los lienzos de muralla. Queda como excepción a este agrupamiento la torre T83, cuya técnica constructiva también la diferencia completamente de todas las demás, lo que nos hace suponer que se trate de una reconstrucción completa, y posiblemente la forma que presenta en la actualidad, no era la original.

El cambio de forma de la torre T9 nos hace excluirla de este sector, aunque la longitud del lienzo nos indica que este tramo aún está realizado con la métrica del sector II. Como veremos más adelante, el siguiente lienzo mide solo 24,83 metros, lo que nos reafirma en que el límite entre el sector II y el III es la torre T9, que ya pertenece al sector III.

Como ya hemos visto, el límite entre ambos sectores se sitúa en el postigo del Sol, donde hemos detectado el quiebro en el trazado de la muralla. El hecho de que este lienzo podamos adscribirlo con total claridad a la métrica en el sector II, de los lienzos de más de 30 metros, nos induce a pensar que este sector es posterior al sector III, al que se adosa, situándose la primera torre, la T8, a más de 30 metros de la T9, manteniendo la métrica imperante en su momento constructivo, conforme con la misma lógica constructiva de todo el sector II. En caso contrario, si el sector III fuese cronológicamente posterior al sector II, con toda lógica la T9 se hubiese construido a unos 23-25 metros de la T8, conforme a la métrica del sector III.

SECTOR III. Desde la torre T9 a la T13. Largo aprox 130 metros.

El sector III presenta torres de planta semicircular sobre algunas de las cuales se apoyan los edificios de la ciudad, habiéndose revocado la mayor parte de sus paños por lo que los datos disponibles no resultan suficientemente significativos para extraer conclusiones. En las partes visibles solo encontramos aparejos de mampostería, dispuesta a sardinel. Encontramos torres semicirculares de radio 3,40 metros, separadas por lienzos de unos 23 metros. Los zócalos están ocultos, pero la fábrica visible en la parte inferior esta diferenciada y nivelada tanto en los lienzos como en las torres.

\begin{tabular}{|c|cc|}
\hline TORRE & FORMA TORRES & RADIO \\
\hline \hline 9 & CIRCULAR & 3,40 \\
10 & CIRCULAR & 3,00 \\
11 & CIRCULAR & 3,23 \\
12 & CIRCULAR & 3,57 \\
13 & CIRCULAR & 3,40 \\
\hline
\end{tabular}

\begin{tabular}{|cc|}
\hline LIENZO & LONGITUD \\
\hline \hline $9-10$ & 24,83 \\
$10-11$ & 36,63 \\
$11-12$ & 22,75 \\
$12-13$ & 22,32 \\
$13-13^{\prime}$ & 23,00 \\
\hline
\end{tabular}

Figura 4.2. 17: Tabla de las características del sector III. La desaparición de la T13', no nos permite modular bien el siguiente lienzo, lo que nos obliga a limitar el sector con el postigo de la Luna. El lienzo L13-13' con fondo de color, quedaría fuera de este sector.

En este caso nos hemos encontrado con la singularidad de que el lienzo entre las torres T10 y T11 es significativamente mayor que el resto de los existentes de este sector. En base a nuestra interpretación del dibujo de Wyngaerde, la desaparición de la torre T13" de planta rectangular, de la T13', aparentemente semicircular y adosada al postigo de la Luna, nos impide delimitar correctamente el área al que se extiende este sector. No podemos saber de 
forma tajante si esa torre T13 pertenecería a este sector o no ${ }^{126}$. El límite optamos por situarlo en el postigo de la Luna, dejando fuera el hipotético lienzo L13-13'. No disponemos de datos cuantitativamente suficientes sobre sus zócalos para poder caracterizarlos.

La desaparición de las torres que ya se han comentado desde el postigo de la Luna hasta el postigo de San Juan, nos deja muy pocos datos fiables para realizar una clasificación con visos de ser realista, ya que no nos permite disponer de una representatividad mínima en los datos.

Podemos intuir una modulación de menos de 30 metros en la zona de la Alhóndiga, lo que nos lleva a presuponer su inclusión en el sector $\mathrm{V}$, que veremos más adelante. En la zona del acueducto, la desaparición de las torres, T21'y T22' nos divide la zona en tres ámbitos, con la torre T22 aislada en el centro, lo que imposibilita establecer su métrica con exactitud. Aparentemente, sus lienzos podrían ser todos de más de 30 metros, mientras las dimensiones y forma de sus torres son similares, lo que nos lleva a relacionarlo con el sector IV. En la zona de San Juan, es imposible hacer conjeturas, al haber desaparecido la mayor parte de las torres.

SECTOR IV. Desde la torre T31 a la T40. Largo aprox 380 metros.

Torres rectangulares de frente 5,20-5,60 y resalto menor de 2,50 metros, separadas por lienzos de más de 30 metros. Los zócalos de las torres son diferenciados, si bien unos están nivelados, otro porcentaje representativo no lo está. En los lienzos nos ocurre lo mismo, la mayoría son diferenciados, pero no encontramos un grupo predominante, encontrando zócalos que se nivelan escalonadamente y otros que no se nivelan.

\begin{tabular}{|c|ccc|}
\hline TORRE & FORMA TORRES & FRENTE & RESALTO \\
\hline \hline 31 & RECTANGULAR & 5,08 & 1,80 \\
32 & RECTANGULAR & 5,60 & 2,30 \\
33 & RECTANGULAR & 5,44 & 2,10 \\
34 & DESAPARECIDA & - & - \\
35 & RECTANGULAR & 5,27 & 2,00 \\
36 & RECTANGULAR & 5,30 & 2,12 \\
37 & RECTANGULAR & 5,17 & 2,05 \\
38 & RECTANGULAR & 5,30 & 2,15 \\
39 & RECTANGULAR & 5,50 & 2,15 \\
40 & RECTANGULAR & 5,20 & 2,00 \\
41 & RECTANGULAR & 5,20 & 2,39 \\
42 & RECTANGULAR & 5,22 & 2,32 \\
43 & RECTANGULAR & 5,70 & 4,20 \\
\hline
\end{tabular}

\begin{tabular}{|cc|}
\hline LIENZO & LONGITUD \\
\hline \hline $31-32$ & 41,24 \\
$32-33$ & 34,93 \\
$33-34$ & 34,00 \\
$34-35$ & 45,00 \\
$35-36$ & 40,00 \\
$36-37$ & 44,00 \\
$37-38$ & 37,24 \\
$38-39$ & 35,07 \\
$39-40$ & 32,36 \\
$40-41$ & 38,08 \\
$41-42$ & 16,39 \\
$42-43$ & 19,63 \\
\hline
\end{tabular}

Figura 4.2. 18: Tabla de las características del sector IV. La desaparición de la T34, nos obliga a realizar una estimación de la longitud de los lienzos adyacentes a esa torre. La secuencia de dos lienzos cortos antes de una puerta, nos indica una excepción en la modulación de la muralla. La torre T43 es una torre puerta.

\footnotetext{
$126 \mathrm{Al}$ estar situada junto al postigo, que podemos estimar bastante aproximada la longitud del lienzo y ser de planta semicircular, nos atrevemos a suponer que pertenecería al sector II.
} 
La T31, hemos visto que esta rehecha remetida respecto a su posición primigenia, por lo que su resalto actual no es el original y posiblemente también se haya reducido su dimensión frontal. La desaparición de la T34, nos obliga a realizar una estimación de la longitud de los lienzos adyacentes a esa torre. El forzado quiebro que realiza la muralla en el entrante donde se sitúa el postigo de San Matías, que también altera la métrica de esos lienzos, nos hace suponer que hubo un trazado distinto al actual, como ya se ha comentado. Por último, la secuencia de dos lienzos cortos antes de una puerta, nos indica una excepción en la modulación de la muralla, coincidiendo con un brusco quiebro en el que cambia de dirección la muralla en el L40-41. Veamos como el siguiente lienzo nos confirma esa discontinuidad, por lo que lo incluimos ya en el sector V. Así el límite de esta zona debemos colocarlo coincidiendo con ese quiebro que efectúa la muralla en el lienzo L40-41.

SECTOR V. Desde la torre T41 a la T51. Largo aprox 310 metros.

Torres rectangulares de frente 5,00-5,50 y resalto menor de 2,50 metros, separadas por lienzos de menos de 30 metros. Sus zócalos son diferenciados, pero sin nivelar, en las torres e indiferenciados en los lienzos.

En este sector encontramos varias excepciones. Por una parte, las torres T45 y T46', son reconstrucciones, que posiblemente han alterado las dimensiones del original. La T49, está parcialmente arruinada con las esquinas redondeadas como ya se ha indicado, por lo que creemos que las dimensiones reales serían mayores de lo anotado en la toma de datos. Las torres T43 y T47 son torres puerta, lo que justifica sus mayores dimensiones.

Por otra parte, los lienzos L47-48 y L42-43 son más cortos por ser adyacentes, flanqueando respectivamente las puertas de San Cebrián y Fuente Cercada, como hemos visto ocurre en todos los casos de la muralla.

\begin{tabular}{|c|ccc|}
\hline TORRE & FORMA TORRES & FRENTE & RESALTO \\
\hline \hline 41 & RECTANGULAR & 5,20 & 2,39 \\
42 & RECTANGULAR & 5,22 & 2,32 \\
43 & RECTANGULAR & 5,70 & 4,20 \\
44 & RECTANGULAR & 5,54 & 2,18 \\
45 & RECTANGULAR & 6,01 & 1,95 \\
46 & RECTANGULAR & 5,02 & 2,39 \\
$46^{\prime}$ & RECTANGULAR & 4,35 & 1,73 \\
47 & RECTANGULAR & 5,80 & 5,60 \\
48 & RECTANGULAR & 5,13 & 2,20 \\
49 & RECTANGULAR & 4,07 & 1,70 \\
50 & RECTANGULAR & 5,13 & 2,50 \\
51 & RECTANGULAR & 5,25 & 2,23 \\
$51^{\prime}$ & RECTANGULAR & 5,26 & 2,19 \\
52 & RECTANGULAR & 5,12 & 2,17 \\
\hline
\end{tabular}

\begin{tabular}{|cc|}
\hline LIENZO & LONGITUD \\
\hline \hline $41-42$ & 16,39 \\
$42-43$ & 19,63 \\
$43-44$ & 18,17 \\
$44-45$ & 27,29 \\
$45-46$ & 21,51 \\
$46-46^{\prime}$ & 25,19 \\
$46^{*}-47$ & 28,56 \\
$47-48$ & 17,70 \\
$48-49$ & 30,15 \\
$49-50$ & 30,66 \\
$50-51$ & 24,23 \\
$51-51^{\prime}$ & 26,36 \\
$51^{\prime}-52$ & 25,50 \\
\hline
\end{tabular}

Figura 4.2. 19: Tabla de las características del sector V. Las torres T43 y T47 poseen unas dimensiones excepcionales ya que se trata de dos torres puerta, la de Santiago y la de fuente cercada. 
Sin embargo en el caso de lienzos más cortos por ser adyacentes a la muralla encontramos dos excepciones. En el sector II, que también presenta lienzos de más de 30 metros, el lienzo previo a la puerta de San Andrés, mide más 25 metros. En este caso, su longitud es excesivamente corta, por debajo de 20 metros, que es la medida aproximada de los lienzos previos a las puertas de San Martín y San Juan, cuyos sectores modulan con lienzos de menos de 30 metros. Pero además, encontramos que el siguiente lienzo a la puerta, el L43-44, también es más corto de la norma para este sector, algo que sólo ocurre en otra puerta, la de Santiago y que diferencia ambos casos del resto de las puertas. Veremos esto con más detenimiento en el punto 4.2.7.

Este sector debemos acotarlo en la T52, ya que las siguientes torres han desaparecido. A partir de este punto, tan solo se conservan dos torres antes de la puerta de Santiago y otras dos después, lo que no permite estudiar la métrica de los lienzos.

Así pues la separación de este sector respecto al sector 4 debemos situarlo entre las torres T40 y T41, incluyendo cada una a un lado de la línea de división, haciéndolo coincidir con el quiebro en el que la muralla cambia bruscamente de dirección, del que ya hemos hablado en el punto 4.1.3. 


\subsection{3.- CONFIGURACIÓN DE LOS ACCESOS.}

En la muralla de Segovia se distinguen dos tipos de accesos, las puertas y los postigos. Tradicionalmente se mencionan 5 puertas, de las cuales actualmente se conservan 3, San Andrés, San Cebrián y Santiago; habiendo desaparecido San Martín y San Juan. Del mismo modo existieron 8 postigos, de los cuales se conservan 4 el del Sol, el de la Luna, el del Consuelo, el de San Juan, habiendo desaparecido el de San Matías, el de la fuente cercada, el del parque y el del obispo. Por último, a efectos de este análisis se ha incluido el postigo recientemente descubierto en el revellín del Alcázar.

Para el análisis de las puertas y postigos vamos a considerar las siguientes variables:

- Configuración del camino de acceso.

- Configuración del paso de entrada.

- Configuración arquitectónica del elemento de paso.

- Dimensiones del paso, distinguiendo el ancho y el fondo del mismo.

- Disposición y dimensiones de lienzos y torres adyacentes.

- Características poliorcéticas del elemento de paso.

Por último, se incluya una variable que hace referencia a su estado de conservación actual, diferenciando los ejemplares que han llegado hasta nuestros días de los desaparecidos y de los primeros, se aporta una datación aproximada, en base a los datos disponibles, en que se le proporciona la configuración actual. 
Vamos a describir en qué consisten estas variables y las distintas opciones que encontramos en nuestra muralla para cada una de ellas, resultados que recogemos en la Figura 4.2. 24.

\section{CONFIGURACIÓN DEL CAMINO DE ACCESO.}

La configuración del camino de acceso se refiere a la forma en que se produce la aproximación hacia el paso a través del cual se accede al interior de la muralla. Básicamente distinguimos dos modalidades:

- R: Recta: El camino de aproximación discurre de manera lineal con un trazado de varias decenas de metros en paralelo a lo largo de los lienzos de la muralla, de modo que el posible asaltante se encuentra expuesto debajo de la muralla, al hostigamiento de los defensores situados en los adarves. En este caso, el camino es bastante recto y con pendiente relativamente uniforme y tendida.

- Z: Zigzagueante: El camino de acceso acomete hacia la muralla de manera mucho más directa, casi frontal, zigzagueando para afrontar la pronunciada pendiente que ocasiona una aproximación de tan corto recorrido.

\section{CONFIGURACIÓN DEL PASO DE ENTRADA.}

El paso de entrada, la forma en que se traspasa la muralla, se produce de dos maneras:

- P: Perpendicular al trazado de la muralla, a través de una abertura practicada en el lienzo, sin que el trazado de la muralla sufra ninguna alteración por la abertura de acceso.

- Q: Quiebro: El paso de acceso se efectúa en paralelo al recorrido de la muralla, ya que la muralla traza un quiebro ortogonalmente a su trazado, como si una parte de la muralla avanzará, se deslizara en paralelo a su posición, creando la abertura de paso entre ambos lienzos, en el que se sitúa el paso. De esta forma, la muralla se configura de una manera predeterminada para alojar, de manera protegida, el punto de acceso.

\section{CONFIGURACIÓN ARQUITECTÓNICA DEL ELEMENTO DE PASO.}

La configuración arquitectónica del acceso se refiere a la forma en que se materializa ese elemento de paso que atraviesa la muralla. Para simplificar la sistematización hemos agrupado en dos tipos, clasificándolos como configuración sencilla, cuando se trata de elementos arquitectónicos de escasa complejidad y configuración compleja, cuando se genera un elemento arquitectónico de mayor entidad para resolver este acceso. Entre los primeros incluimos los pasos que se resuelven como una simple abertura en el lienzo, frente a los segundos como por ejemplo la puerta de San Andrés, en la que el acceso se configura como un conjunto formado por dos torres unidas por un cuerpo que contiene un importante aparato poliorcético. Reflejamos en la tabla sólo aquellos casos que presentan una significativa complejidad arquitectónica, dejando en blanco los casos que tienen una configuración sencilla.

\section{CARACTERÍSTICAS POLIORCÉTICAS DEL ELEMENTO DE PASO.}

La existencia o no de un aparato poliorcético que apoye la defensas del acceso es otra de las variables que empleamos. Vamos a distinguir exclusivamente dos grupos, los que disponen de un complejo sistema defensivo y los que no lo poseen, sino que presentan unas características defensivas muy elementales o sencillas. El primer caso veremos que es el característico de las puertas, donde encontramos distintas soluciones, como la existencia de doble puerta, 
buhedera, rastrillo, u otros elementos poliorcéticos. En el caso de los postigos, no existe este refuerzo defensivo adicional, encontramos tan solo los adarves almenados, como en cualquier otra parte de la muralla y en algunos casos, se han practicado fusileras en el siglo XIX. Consignamos únicamente los casos en que existe esa mayor capacidad defensiva, quedando en blanco los que no la presentan.
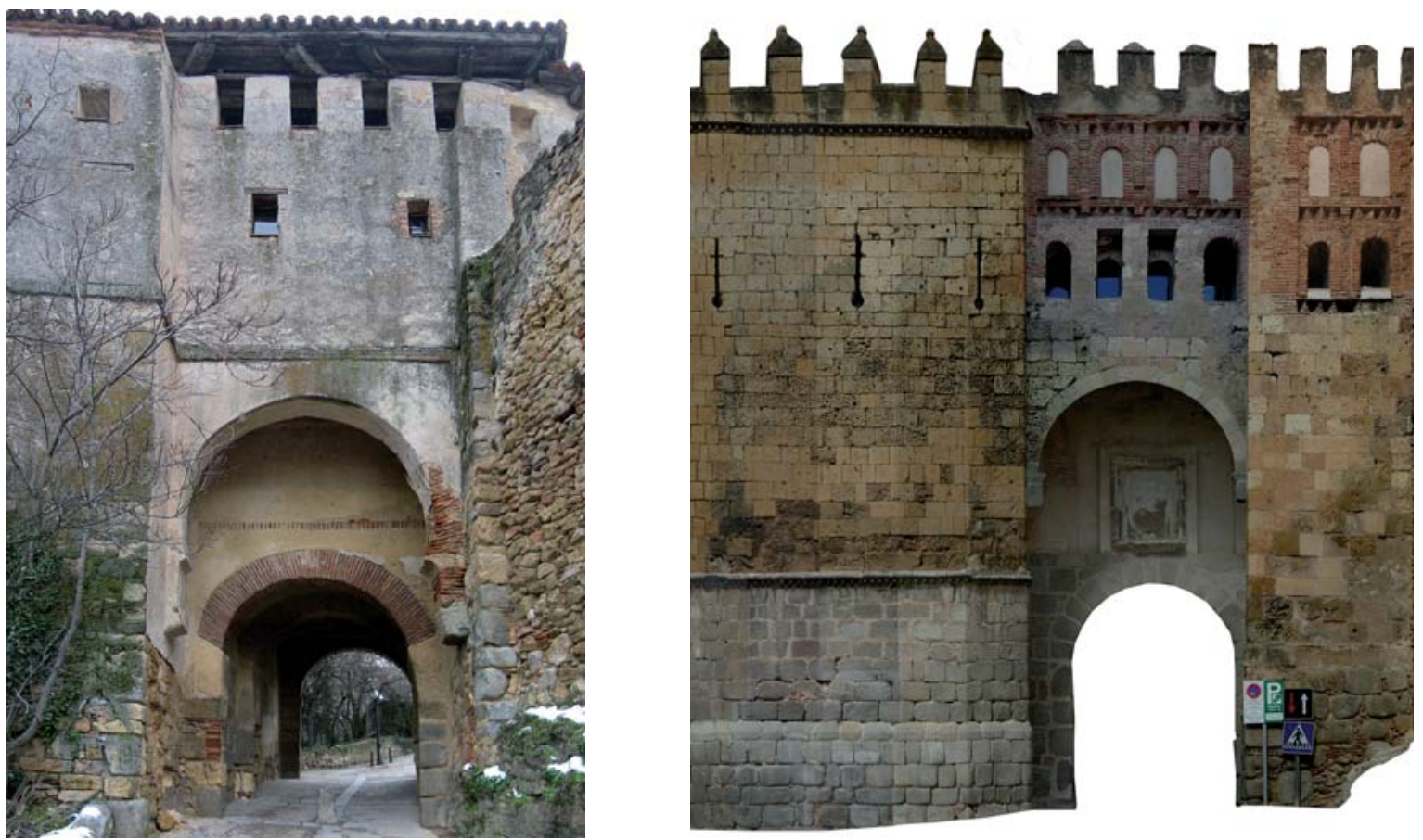

Figura 4.2. 20: Puerta de Santiago. El acceso se configura como un elemento de cierta complejidad arquitectónica, con una anchura que tolera el paso de vehículos y un profundidad de paso que permite alojar un aparato poliorcético de cierta entidad.

Figura 4.2. 21: Puerta de San Andrés. Ortofoto. Alzado exterior de la puerta de San Andrés, extraído del proyecto de restauración (PH: P0159-A0117). Al igual que la puerta de Santiago, se sitúa en un quiebro que efectúan los lienzos de la muralla, protegiendo lateralmente el acceso con una torre. El acceso se realiza avanzado en paralelo a los lienzos de la muralla.

\section{DIMENSIONES DEL PASO, DISTINGUIENDO EL ANCHO Y EL FONDO DEL MISMO.}

Las dimensiones del paso nos permiten clasificar estos en base a sus dos dimensiones principales, el ancho y el fondo. Respecto al ancho de paso, hay dos grupos claramente diferenciados, los que permiten el paso de vehículos rodados, $(\mathrm{R})$ o bien los que por su escasa dimensión no permiten el paso más que de personas $(\mathrm{P})$. Los primeros son de un ancho de paso mayor a los 2,5 metros, mientras los segundos no llegan a esta medida. Respecto al fondo del paso, encontramos dos situaciones, aquellos que no presentan mayor fondo que el espesor del lienzo de la muralla no tienen un fondo que permita una fortificación adicional para defender ese acceso y los que sí presentan un fondo mayor de los 2,5 metros. Se consignan sólo los datos afirmativos, dejando en blanco los casos en que el fondo del paso coincide con el espesor de la muralla. 

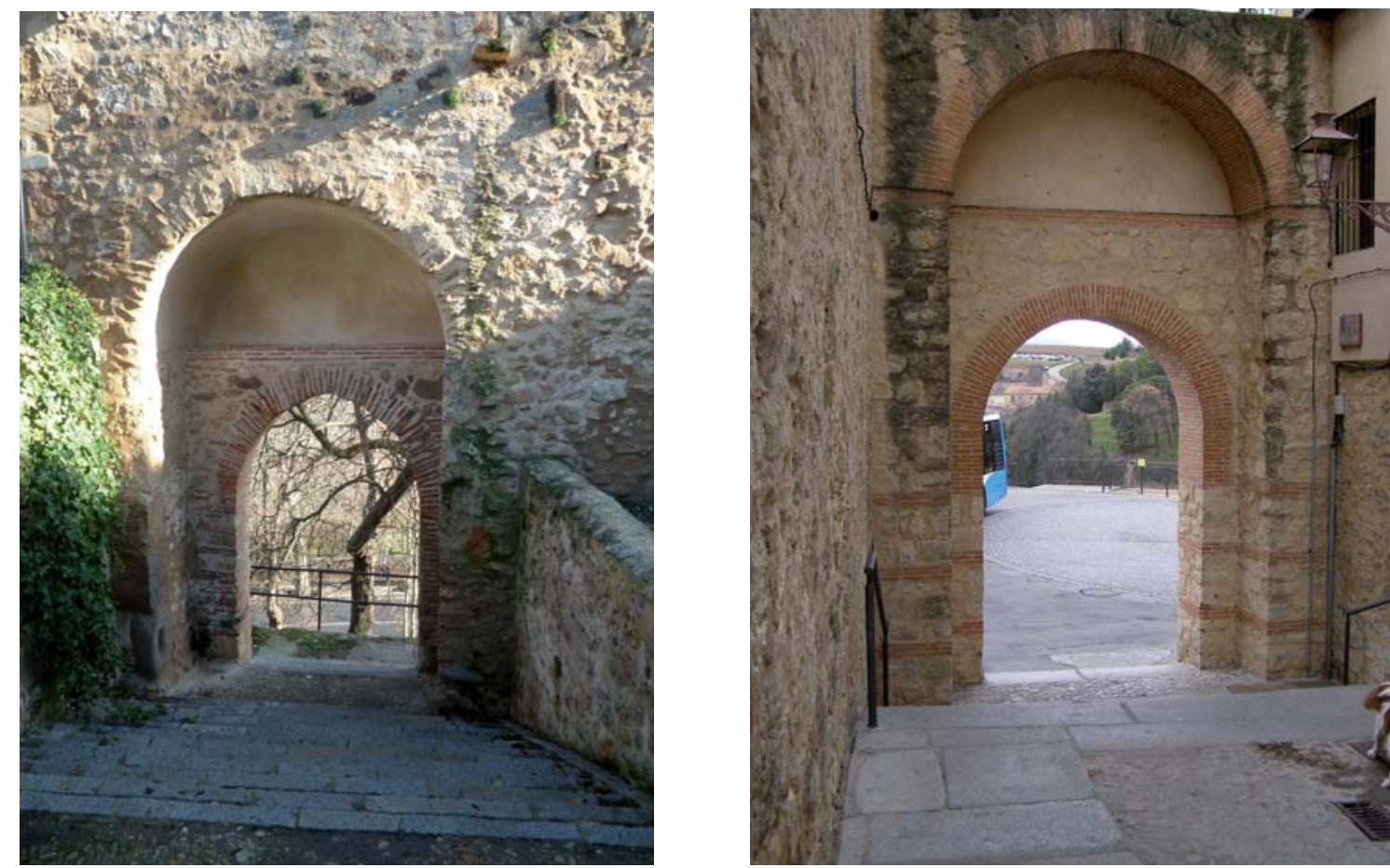

Figura 4.2. 22: Postigo de San Juan. La anchura del paso sólo permite el acceso peatonal o con algún animal de carga, pero en ningún caso el paso de vehículos. La profundidad del paso se reduce al espesor de la muralla, presentando una gran sencillez en su configuración arquitectónica, por lo que las características poliorcéticas para la defensa del acceso se reducen a la disposición de una puerta.

Figura 4.2. 23: Postigo del Sol. Si bien reconstruido en el siglo XX, presenta las mismas características que el resto de los postigos.

DISPOSICIÓN Y DIMENSIONES DE LIENZOS Y TORRES ADYACENTES.

Las dimensiones y disposición de los elementos constituyentes de la muralla en las proximidades de estos accesos es el último criterio de clasificación que vamos a emplear. En el caso de los lienzos se consignan aquellos en que el lienzo previo al acceso es más corto que los lienzos del mismo sector de la muralla, mientras que respecto a las torres se señalan los casos en que existe una torre adyacente, contigua al acceso.

A la vista de los resultados recogidos en la tabla de la Figura 4.2. 24, observamos que todas los resultados nos agrupan a todos los elementos en dos grupos, como no podía ser de otra manera en función de las variables empleadas. Vemos que las consideradas como puertas, así como los calificados como postigos se agrupan en dos bloques claramente diferenciados. Sin embargo descubrimos algunas singularidades que son las que más nos van a interesar por la información que nos aportan, permitiéndonos plantearnos alternativas que no se han considerado hasta hoy en día y obtener algunas conclusiones novedosas.

Así el denominado postigo de fuente cercada, se aparta claramente de las características de los postigos, compartiendo muchas de las características de las puertas. Creemos que en origen se trataba de una puerta de la muralla, de forma que en la muralla de Segovia existieron seis puertas, en lugar de las cinco que se mencionan tradicionalmente en la historiografía. Por otra parte, el recientemente descubierto postigo del revellín, presenta elementos comunes tanto con las puertas como con los postigos, demostrando tratarse de un elemento de acceso más 
complejo que un simple postigo, por lo que lo hemos incluido en un grupo diferenciado, que hemos calificado como poterna.

\begin{tabular}{|c|c|c|c|c|c|c|c|c|c|}
\hline \multirow{2}{*}{ ACCESOS } & \multicolumn{3}{|c|}{ CONFIGURACION } & \multicolumn{2}{|c|}{ DIMENSIONES } & \multicolumn{2}{|c|}{ ADYACENTES } & \multirow{2}{*}{\begin{tabular}{|c|} 
CONFIG \\
POLIORCETIC
\end{tabular}} & \multirow{2}{*}{$\frac{\text { ACTUAL }}{\text { DATACION }}$} \\
\hline & APROX & PASO & ARQUIT & $\mathrm{ANCHO}$ & FONDO & LIENZO & TORRE & & \\
\hline SAN ANDRES & $\mathrm{R}$ & Q & $x$ & $\mathrm{R}$ & $x$ & $x$ & - & $x$ & $X V-X V I$ \\
\hline SOL & $?$ & $\mathrm{P}$ & - & $P$ & - & - & $x$ & - & $x x$ \\
\hline LUNA & $?$ & $\mathrm{P}$ & - & $\mathrm{P}$ & - & - & $?$ & - & $x x$ \\
\hline SAN MARTIN & $\mathrm{R}$ & Q & $x$ & $\mathrm{R}$ & $x$ & $x$ & - & $x$ & - \\
\hline CONSUELO & Z & $\mathrm{P}$ & - & $P$ & - & - & $x$ & - & $x x$ \\
\hline SAN JUAN (PUE) & $\mathrm{R}$ & $Q$ & $x$ & $\mathrm{R}$ & $x$ & $x$ & - & $x$ & - \\
\hline SAN JUAN (POS) & z & $P$ & - & $P$ & - & - & $x$ & - & $?$ \\
\hline SAN MATIAS & Z & $P$ & - & $P$ & - & - & $?$ & - & - \\
\hline SAN CEBRIAN & $\mathrm{R}$ & Q & M & $\mathrm{R}$ & & $x$ & - & - & XVIII \\
\hline FUENTE CERCADA & $?$ & Q & $\mathrm{M} ?$ & $\mathrm{R} ?$ & $?$ & $x$ & - & $?$ & - \\
\hline SANTIAGO & $\mathrm{R}$ & Q & $x$ & $\mathrm{R}$ & $x$ & $x$ & - & $x$ & $\mathrm{XVI}$ \\
\hline PARQUE & - & - & - & - & - & - & - & - & - \\
\hline REVELLIN & Z & Q & $x$ & $\mathrm{P}$ & $x$ & - & $x$ & $x$ & $\mathrm{XIX}$ \\
\hline OBISPO & $?$ & $\mathrm{P}$ & - & - & - & - & - & - & - \\
\hline
\end{tabular}

Figura 4.2. 24: Tabla resumen de las características de las puertas y postigos de la muralla. Con fondo de color los accesos que históricamente se han considerado puertas.
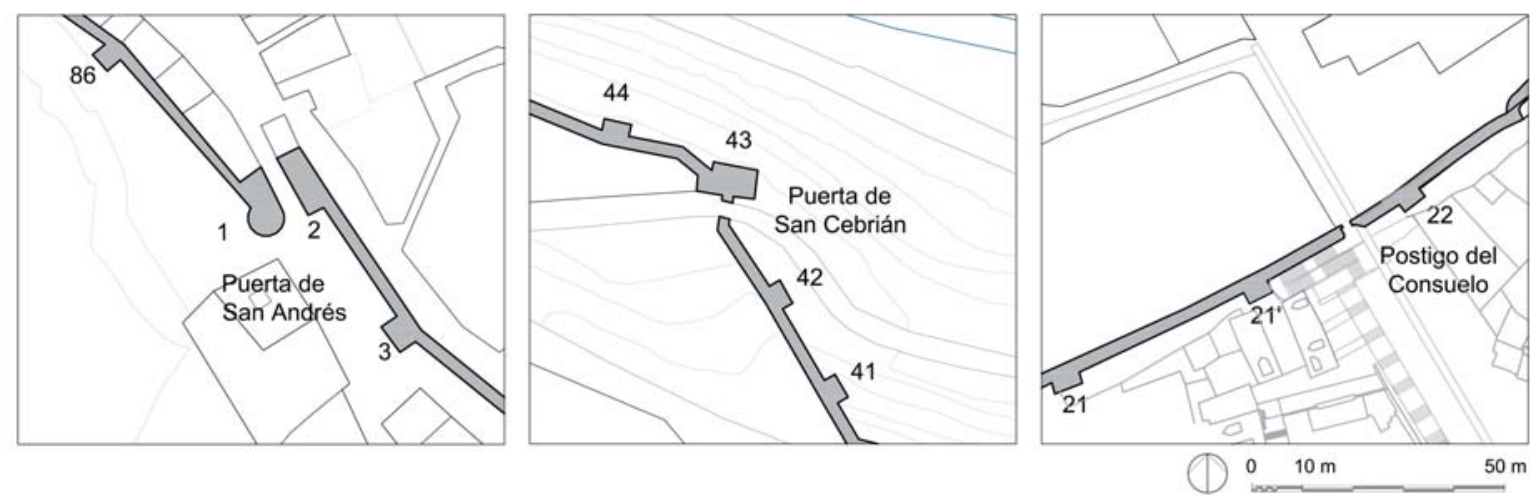

Figura 4.2. 25: Planta de las puertas de San Andrés y San Cebrián y el postigo del Consuelo. Obsérvese como la configuración del posible postigo de Fuente Cercada, coincide perfectamente con la configuración de las puertas. Camino de aproximación lineal y tendido, paso de entrada paralelo a la muralla, escondido en un recodo y protegido por una torre avanzada y sus dimensiones de paso permiten la entrada de vehículos rodados. En el Postigo del Consuelo sin embargo el acceso se realiza manera frontal a la muralla y perpendicular al lienzo de muralla, afrontando la pronunciada pendiente de manera más directa, en este caso con una escalera, pero en origen seguramente sería mediante un trazado zigzagueante por la ladera. 

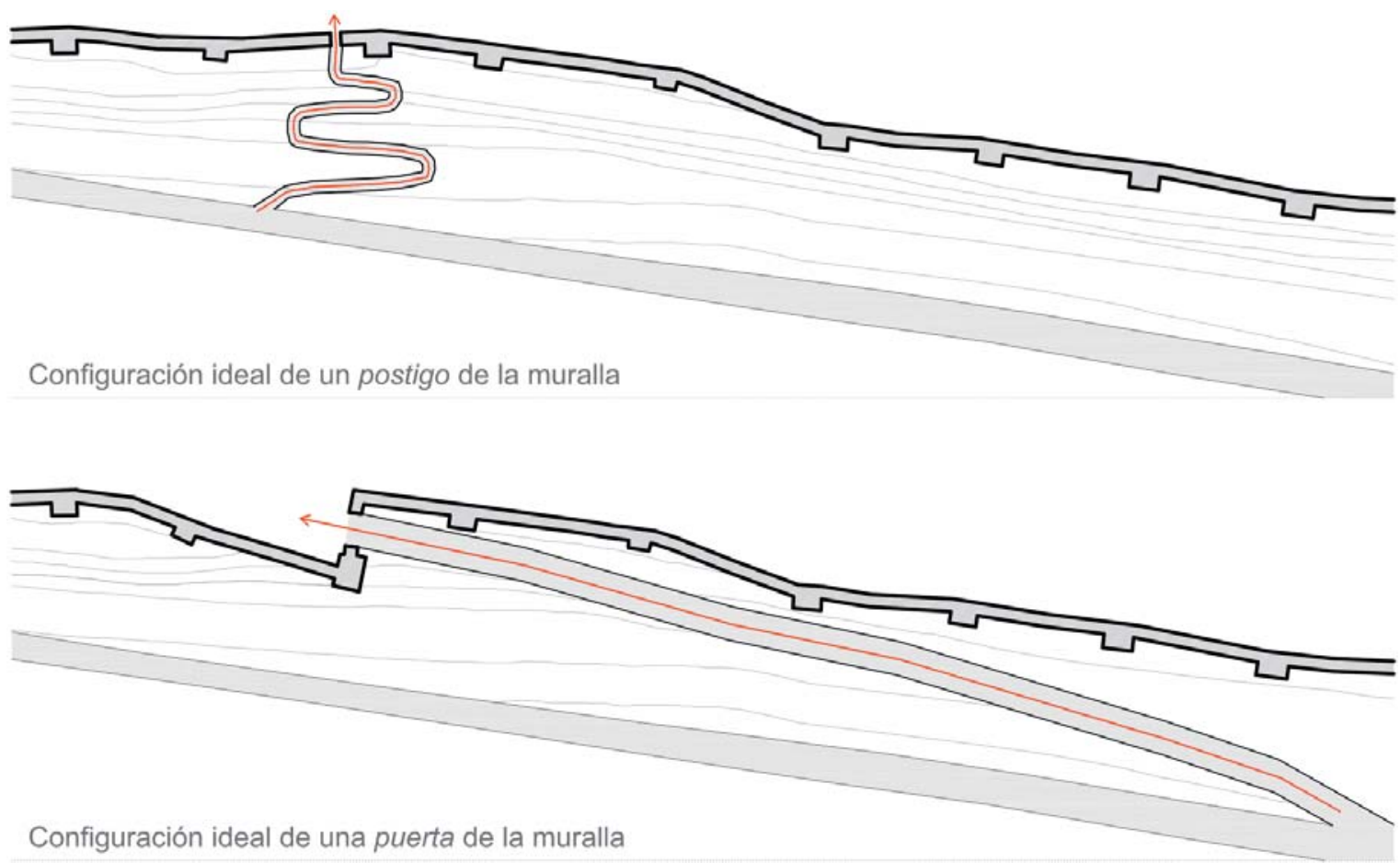

Figura 4.2. 26: Esquema comparativo de las características de las puertas y los postigos. En el primer caso, el camino de aproximación es zigzagueante y con gran pendiente, el paso de entrada es frontal y sus dimensiones no aptas para el paso de vehículos. En el segundo caso, el camino de aproximación es lineal y tendido, el paso de entrada paralelo a la muralla, escondido en un recodo y protegido por una torre avanzada y sus dimensiones de paso permiten la entrada de vehículos.

\subsubsection{A.- PUERTAS.}

Veamos las características que presentan las puertas, así como las singularidades y matizaciones que detectamos dentro de este grupo y que nos permitirán plantearnos algunas hipótesis. Tal y como vemos en la tabla de la Figura 4.2. 24, las excepciones que más nos van a interesar son la puerta de San Cebrián y la de Santiago, aparte del ya mencionado caso del hasta ahora conocido como postigo de fuente cercada.

Las principales características que presentan las puertas y que nos permiten diferenciarlas de los postigos son las siguientes:

- El camino de aproximación es de trazado recto, de pendiente relativamente suave y uniforme, desarrollándose en paralelo por debajo de la muralla a lo largo de más de un lienzo. Esto lo comprobamos en las 5 puertas que existieron.

- El paso de acceso es directo y se sitúa en un quiebro de la muralla, que se genera deslizando los lienzos, disponiéndose la puerta en un plano perpendicular a la dirección de los lienzos de la muralla. Esto vuelve a evidenciarse en los 5 casos y en fuente cercada.

- Las dimensiones del paso permiten el acceso de carros y vehículos de transporte. Siempre es superior a los tres metros. Por ellas entrarían las mercancías, al igual que 
hoy en día son las que por sus dimensiones, permiten el acceso de vehículos. El fondo del paso puede haberse alterado, aunque creemos que desde el origen ya tenía una dimensión mayor que las de los postigos y permitía alojar una doble puerta. Evidencias de la doble puerta aun vemos en las de San Andrés y Santiago, no así en San Cebrián, donde su escaso fondo de paso no lo permite.

- La ubicación de la puerta en un quiebro permite defenderla, situando una torre en el lado exterior del recodo, que flanquea el acceso. La puerta queda remetida en un rincón, de forma que la torre la oculta. Esta torre suele ser más grande de lo habitual y ligeramente adelantada de la posición de la puerta. Lo vemos claramente en la puerta de San Andrés, San Cebrián y en fuente cercada. Presentaron esta misma disposición las desaparecidas puertas de San Juan y San Martín.

- El lienzo anterior a la puerta es más corto que los demás, por lo que la torre previa está más cercana a la muralla, permitiendo hostigar por la espalda a los posibles asaltantes. Como hemos visto en el apartado 4.2.2 dedicado a la métrica de la muralla, hemos constatado esta característica en las 5 puertas y en fuente cercada.

- Las puertas creemos que inicialmente eran arquitectónicamente más sencillas pero su importancia hace que se hayan transformado y reforzado a lo largo de los siglos. Desconocemos la configuración de las puertas altomedievales. La anchura del paso posiblemente no se haya transformada. El fondo del paso, creemos que se ha ido aumentando con las sucesivas intervenciones, volando cuerpos sobre el paso, para incluir buhardas, rastrillos y demás elementos de defensa. De las que tenemos datos, se trata de ejemplares de finales de la Edad Media, transformadas en siglos posteriores. Pensamos que, basándonos en la puerta de Santiago, inicialmente eran más bajas y rematadas en terrazas abiertas que posteriormente se van recreciendo y reforzando con el añadido de distintos elementos de carácter poliorcético. Si bien estos elementos no son muy abundantes ni complejos, hay que decir que las puertas son los únicos puntos de la muralla donde encontramos elementos de carácter defensivo, pero es defensa pasiva, por posición (Cairns, Conrad, 2010: 17-20).

En el resto de la muralla tan solo encontramos los adarves almenados y en algunos puntos, generalmente en puertas y postigos, algunos grupos de fusileras que se practicaron en el siglo XIX. Sabemos que las fusileras en la puerta San Martín se realizan durante la guerra carlista (Peñalosa, 1949). Creemos que las fusileras colocadas en el postigo consuelo, así como las que vemos en los grabados de Avrial de la vista sur del Alcázar, posiblemente sean de la misma época.

Una peculiaridad que se cumple en todos los casos es la menor longitud de los lienzos que se encuentran justo delante de la puerta. Así son más cortos en la zona 1, el L2-3, previo a la puerta de San Andrés; en la zona 3, el L17"'-18, previo a la puerta de San Martín; en la zona 4, el L24-24', contiguo a la puerta de San Juan; en la zona 6, los dos lienzos previos a la puerta de San Cebrián, L40-41 y L41-42, en la zona 7 el L47-48, desde el que se flanquea el acceso al postigo de la fuente cercada y en la zona 9, el L57-58, contiguo a la puerta de Santiago. Estos lienzos que se disponen lateralmente a lo largo del camino de acceso a la puerta, tienen un valor defensivo para la puerta y al ser más cortos, la torre correspondiente se encuentra más próxima a la puerta, lo cual es un aspecto de gran lógica defensiva, claramente intencionado. 

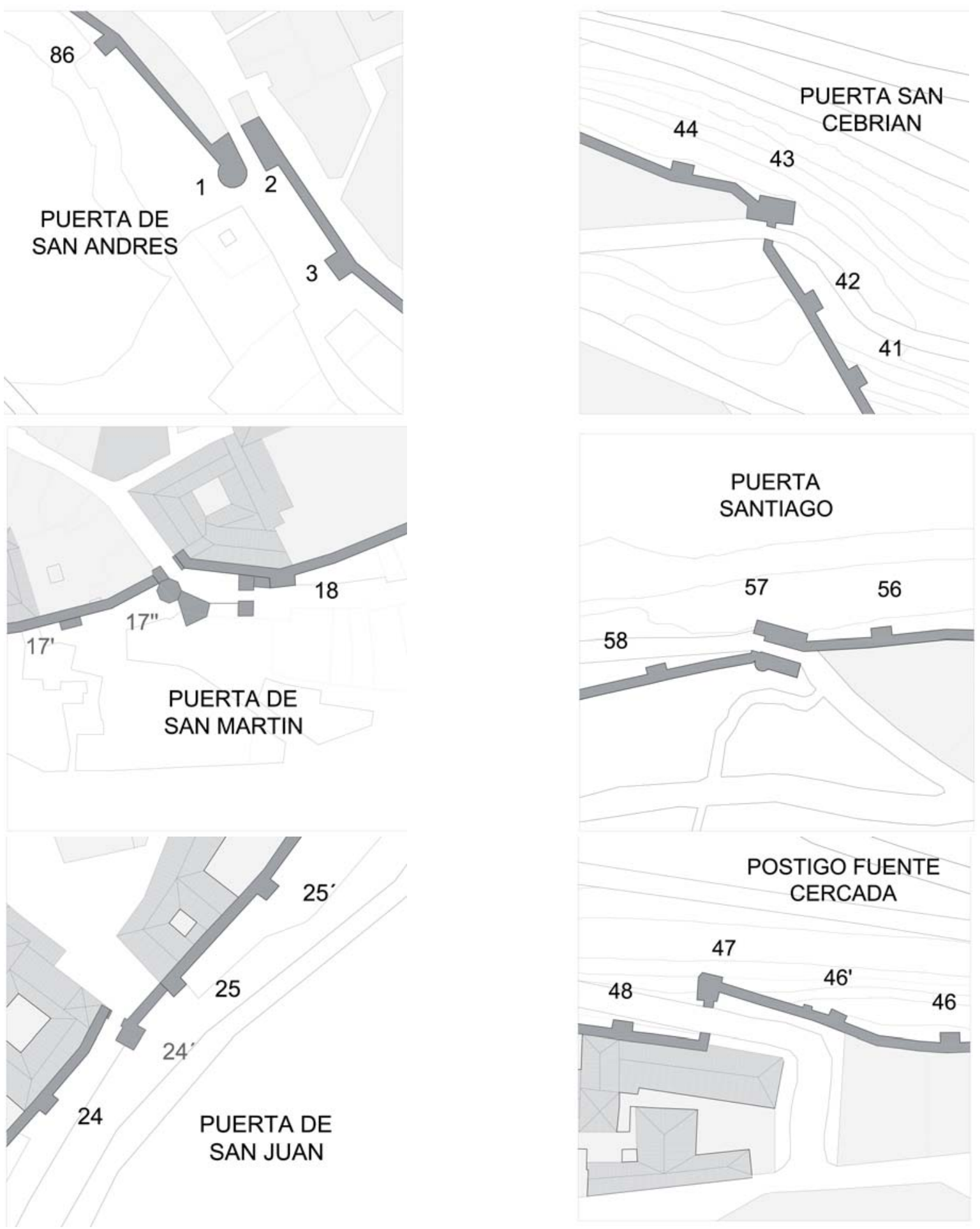

Figura 4.2. 27: Comparativa en planta de la restitución de todas las puertas de la muralla, a la misma escala. Se incluye el postigo de la fuente cercada. Se aprecian perfectamente las características de su configuración. Camino de aproximación lineal en paralelo a la muralla a lo largo de varios lienzos y de pendiente tendida y uniforme, paso de entrada paralelo a la muralla, escondido en un recodo de los lienzos y protegido por una torre avanzada que lo flanquea. Las dimensiones de paso permiten la entrada de vehículos rodados. Obsérvese como la configuración del postigo de fuente cercada, coincide perfectamente con las características de las puertas. Compárese con la Figura 4.2. 32 en la que se exponen los postigos. 

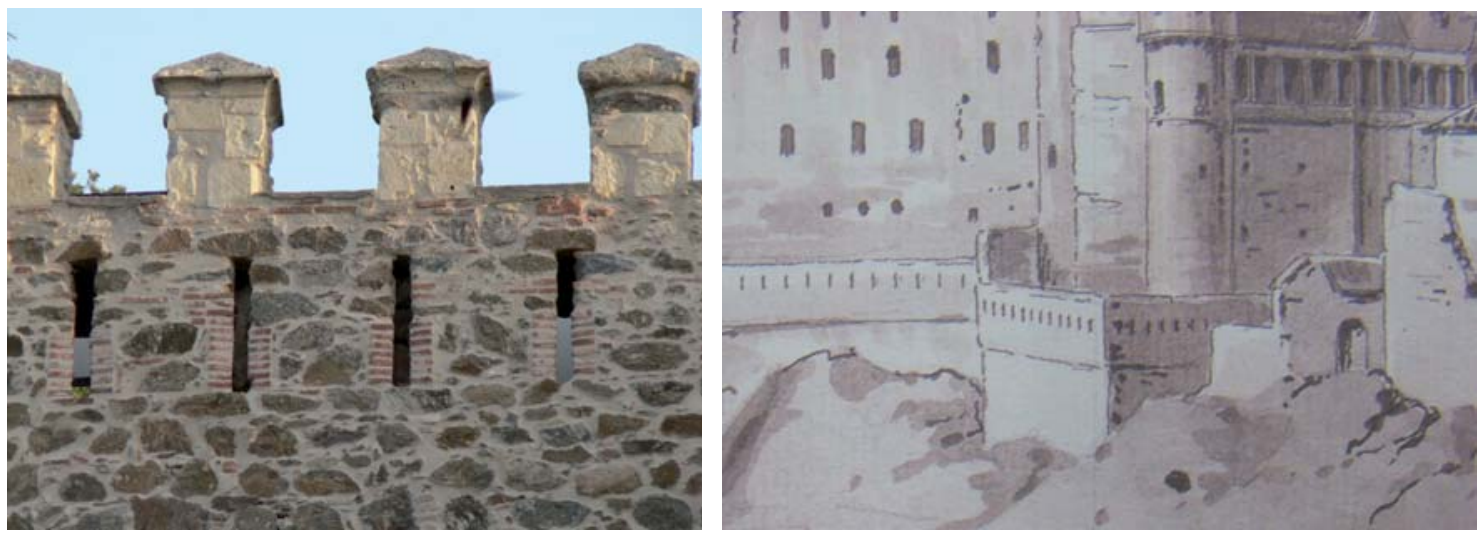

Figura 4.2. 28: L21-22. Fusileras en el lienzo de la muralla sobre el postigo del consuelo.

Figura 4.2. 29: Fusileras en los lienzos del Alcázar, próximos al postigo del obispo, en una lamina de Avrial, (Avrial y Flores, 1979: 143).

También hemos identificado dos lienzos, vinculados a las puertas, que son más cortos que la moda de cada zona, estos son los lienzos que continúan de la muralla una vez superada la puerta, pero que ya no flanquean el camino de acceso. Pero esto solo lo hemos encontrado en dos de las puertas, San Cebrián, en que el lienzo L43-44, mide 18,17 metros y en la de Santiago, en que el lienzo L56-57 mide 16,90 metros, cuando el lienzo medio en su zona mide en torno a los 25 y 26,50 metros respectivamente.

La puerta de San Andrés está situada entre dos torres en un quiebro de la muralla, presenta el camino de aproximación y el acceso característico. La torre T1, la flanquea exteriormente y el lienzo L2-3 es más corto que la media. El paso, directo, tiene un fondo de unos 6,5 metros, más 2,5 de vuelo para la buhedera y una anchura ligeramente superior a los tres metros.

También con una torre poligonal adelantada flanqueando por el exterior y una casa fuerte adosada por el otro lado, la puerta de San Martín presentaba el quiebro habitual en el trazado de la muralla, si bien la puerta se disponía en el mismo plano de la muralla, ligeramente remetida, en lugar de disponerse en el plano perpendicular. La desaparición de la puerta no nos permite recabar datos para intentar explicar esta irregularidad. Estimamos que tendría una anchura de paso entre los 3 y 3,20 metros y un fondo de aproximadamente 4 metros, en su lado corto, el de la casa de los Picos.

La desaparecida puerta de San Juan, creemos que presentaba una configuración muy similar a lo ya visto en la puerta de San Martín. La aproximación se realiza desplazándose longitudinalmente a lo largo de la muralla, en el lado en que se le adosa la casa fuerte y con la torre T24 flanqueando al asaltante desde muy cerca de la puerta, haciendo más corto el lienzo previo. La puerta se disponía sobre el tramo perpendicular a la dirección de los lienzos. Una torre flanqueaba el conjunto por el exterior, la que hemos denominado 'T24'. El paso de la puerta mediría unos 7,5 metros de fondo, por lo que sería muy parecida a la de San Andrés. El acceso posiblemente sería directo.

La puerta de San Cebrián presenta un camino de aproximación a lo largo de 5 torres y sus respectivos lienzos. El paso es directo y situado en un quiebro. Una torre más grande de lo habitual, flanquea el conjunto por el exterior. Hasta aquí, el mismo esquema que las demás puertas. Sin embargo, encontramos varias singularidades en esta puerta que no hemos visto en 
las anteriores. La muralla realiza en esta zona varios quiebros en los lienzos, en L40-41, L4243, y L43-44, en lugar de efectuarlos en las torres. Uno de ellos se sitúa en el lienzo posterior a la puerta, cerca de la posición donde se emplaza la torre exterior que flanquea la puerta, la cual se conecta con el lienzo formando un ángulo agudo, algo completamente atípico en la muralla. Tanto este lienzo posterior a la puerta, como los dos previos a la misma, son más cortos que la media. Hasta ahora, sólo el lienzo previo a la puerta era más corto. En este caso, son dos de los anteriores. En el lienzo previo a la puerta descubrimos, intramuros, otro quiebro. Pocos metros más adelante, ya junto a la puerta, existe un machón de mampostería, que está trabada con la fábrica del lienzo, que no llega a alcanzar la altura total del lienzo. Aparentemente ese machón parece sugerir que en un principio el lienzo iba a continuar recto, pero que se cambió el proyecto, realizando un quiebro en el que se inserta la puerta.

Ambos elementos, lienzo y machón, se han ejecutado conjuntamente. La roca a ambos lados del camino esta tallada en vertical, prácticamente a plomo con la vertical de la cara interior de la torre T43 y el plano de este machón. Curiosamente los sillares esquineros aparecen en la parte alta de los muros, pero no en la baja que se realiza todo en mampostería de escaso tamaño. Para ello se emplean indistintamente sillares de granito y sedimentaria, sin orden.

La anchura del paso presenta una medida de 3,15 metros aproximadamente, en la línea de las demás puertas. Sin embargo el fondo del paso se reduce al espesor de la muralla. La puerta queda, de esta manera, con un nulo valor defensivo, al tener un fondo de paso como el de los postigos, reducido al espesor del lienzo de la muralla. Véase Figura 4.2. 30.

El hecho de ser la única puerta que no se ha reforzado a posteriori, como las de San Martín, San Andrés o Santiago, recreciéndose y añadiendo elementos defensivos quizá nos permite imaginar el aspecto de las puertas medievales originales, rematadas en una terraza superior a la altura del adarve de los lienzos contiguos, tal y como tenía la puerta de Santiago inicialmente y como sospechamos que eran las de San Andrés, San Martín y San Juan ${ }^{127}$. La diferencia estriba en este caso en el fondo del paso de la puerta.

Aventuramos una hipótesis. Los hechos nos hacen pensar que, aparentemente, la puerta iba a ejecutarse con una configuración distinta de la que presenta actualmente, pero parece que no llego a concluirse. Sospechamos que no se ha llegado a ejecutarse la pared lateral que insinúa ese machón, sobre la que voltearía una bóveda que aumentaría el fondo de paso y permitiría crear una amplia terraza superior y aumentar la capacidad defensiva de la puerta. Se adaptaría al modelo al que creemos que se ajustaban todas las puertas de la muralla segoviana. En el apartado 4.3.1.b veremos esta hipótesis con más detenimiento.

\footnotetext{
${ }^{127}$ La puerta de Santiago se recreció el piso superior a mediados del XVII (PH: P0165), San Andrés presenta el cuerpo superior en fábrica de ladrillo, como un claro recrecido datado a finales del XV o principios del XVI. Lo que conocemos de la de San Martín, también es una reconstrucción del XVI. Posiblemente, en la Edad Media, todas eran de solo planta baja con terraza abierta, como San Cebrián (y el postigo de fuente Cercada) y luego se recrecieron y cubrieron para hacer habitables. Nos queda la duda de la de San Juan.
} 

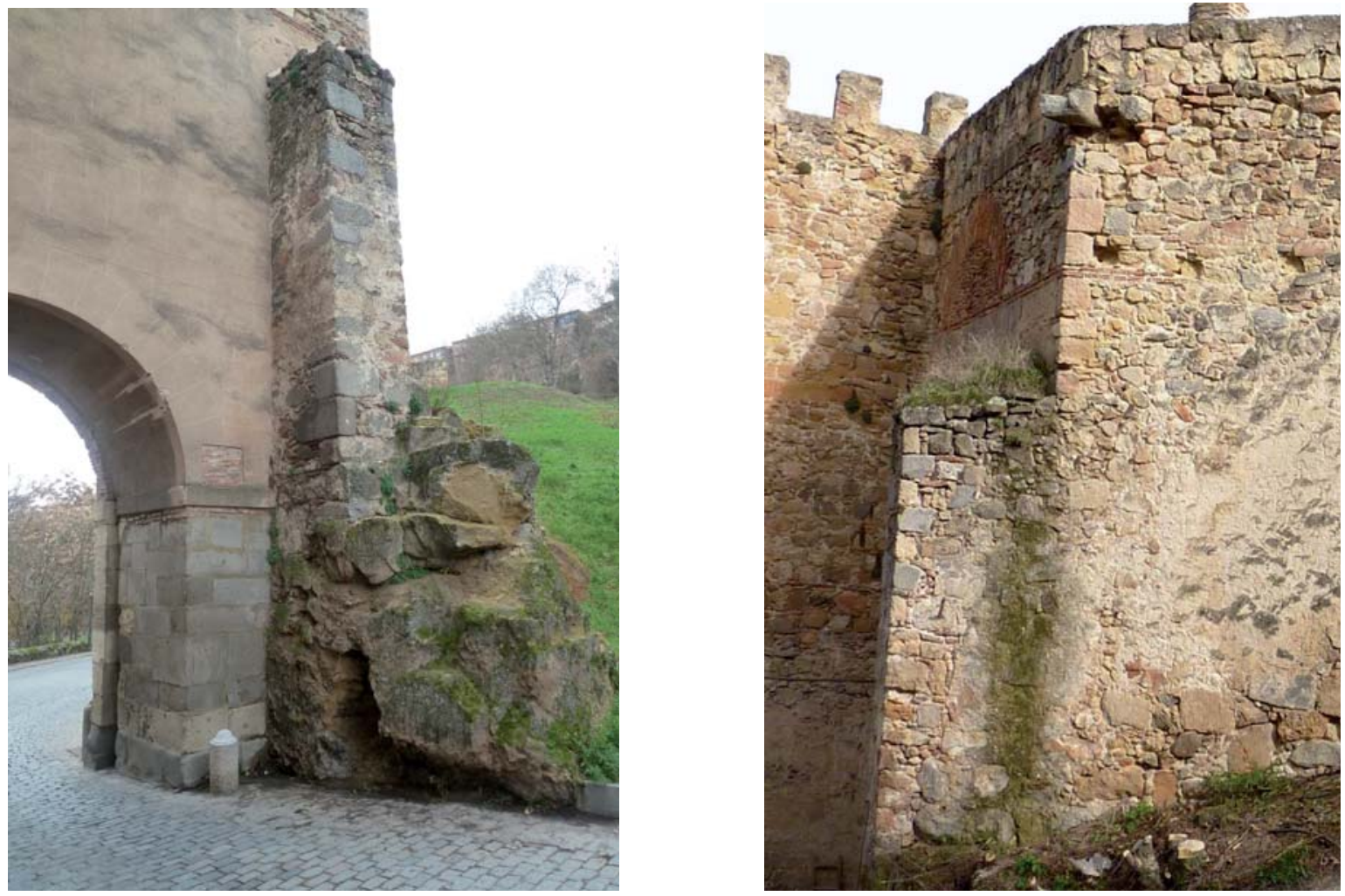

Figura 4.2. 30: Puerta de San Cebrián. Machón de mampostería por la cara intramuros que da continuidad al trazado del lienzo previo a la puerta. El fondo del paso de la puerta se reduce al espesor de la muralla.

Figura 4.2. 31: Puerta de San Cebrián. Vista del mismo elemento desde el otro lado. La fábrica es continua con la del lienzo de la muralla, por lo que ambos elementos se ejecutaron simultáneamente. Aparentemente la puerta iba a ejecutarse con otra configuración.

La puerta de Santiago se adecua a las reglas que hemos detectado para todas las puertas. El paso se efectúa en paralelo al lienzo de muralla, tras una aproximación a lo largo de la muralla por un camino relativamente recto y de pendiente uniforme. El lienzo anterior a la puerta es más corto, por lo que la ultima torre está más cerca. El paso es ancho y profundo, lo que permite la implantación de algunos elementos poliorcéticos como es la buhedera, que también existe en San Andrés y el rastrillo, único caso en la muralla segoviana. Presenta una diferencia notable con las demás puertas. No se trata de una puerta situada en un quiebro de la muralla entre una torre y el lienzo, como el resto de las puertas de la muralla, sino de un modelo más evolucionado, ya que en realidad se trata de una torre-puerta. Es la única que presenta la torre hueca en planta baja, donde encontramos un habitáculo abovedado, que posiblemente era el cuerpo de guardia, lo que indica que no se ejecuta adosándose a una torre convencional, maciza, de la muralla.

Por último, el conocido como postigo de fuente cercada, y que tal y como se ve en la tabla de la Figura 4.2. 24, se adecua a las características que definen a las puertas, en lo relativo a la existencia de un quiebro, existencia de una torre mayor de lo habitual flanqueando la puerta por el exterior, ocultándola, la métrica, al ser más corto el lienzo previo, la configuración del paso, el trazado del camino de aproximación paralelo a la muralla, etc. Al estar completamente enterrado desconocemos las dimensiones del ancho y el fondo del paso, así como las características poliorcéticas que pudiera presentar. Por las dimensiones del quiebro, el ancho de paso podría ser perfectamente superior a los 3 metros, como en las demás puertas. No se 
adecua a las características que encontramos en los sencillos postigos. Por todos estos motivos, creemos que se trata en realidad de una puerta y no de un postigo.

Podemos concluir que lo que distingue a las puertas de los postigos es que las primeras están previstas en el trazado de la muralla. Sólo esto puede explicarnos que se produzcan una serie de constantes en todos los casos. La construcción de una torre exterior más grande flanqueando por fuera, la métrica de los lienzos que son más cortos en el lienzo previo a la puerta, el deslizamiento de los lienzos para acceder en paralelo a la muralla. Su implantación tiene tantas repercusiones en el trazado y métrica de la muralla que no es posible pensar en el replanteo de la muralla sin saber donde se iban a situar estos elementos tan importantes ${ }^{128}$.

Es más, la regularidad con que se repiten las reglas nos hace pensar que lo primero que se planteaba era la posición de la puerta y desde ella se trazaban los lienzos y se disponían las torres. De lo contrario, creemos que difícilmente podría plantearse una modulación regular de los lienzos situados entre dos puertas.

Por último señalar que distinguimos dos tipos de puerta, las flanqueadas por una torre y las situadas en una torre. De ambos tipos encontramos ejemplos en numerosas villas amuralladas. Del primer caso, encontramos otros ejemplos en Ávila, la puerta de Urueña (Cervera Vera, 1989), San Martin en Arévalo (Guerra Sancho, 2003), Del segundo tipo, la puerta de la villa en Arévalo (Guerra Sancho, 2003).

\subsubsection{B.- Postigos}

Tal y como vemos en la Figura 4.2. 24 las características que presentan los postigos son las siguientes:

- El camino de acceso se aproxima a la muralla frontalmente con una fuerte pendiente zigzagueando por la ladera. En la actualidad en numerosos casos existen escaleras para salvar la pendiente con que se trazan estos caminos de aproximación muy cortos y directos. Tan solo en los actuales postigos del Sol y de la Luna, se nos plantean dudas respecto a este punto, al existir en la actualidad el Paseo del Salón. Ya en el dibujo de Wyngaerde parece existir una plataforma bastante nivelada en este lugar que permitía un acceso sencillo por estos dos postigos, sin camino zigzagueante de aproximación.

- El acceso se realiza frontalmente, de manera perpendicular al trazado de los lienzos de la muralla.

- El paso presenta el fondo del espesor de la muralla y una anchura que sólo permite el paso de una persona o una animal de carga. En la actualidad los postigos del Sol, de la

\footnotetext{
128 Edward Cooper tratando otros aspectos, llega a una conclusión parecida. Considera que Raimundo de Borgoña pretende construir una línea de fortificaciones protegiendo, ante cualquier intento almorávide, el valle del Duero. Para ello construye las murallas de Ávila y Berlanga de Duero como un importante aparato disuasorio y propagandístico. Construidas sobre un proyecto planificado, de trazado predeterminado y que se empieza simultáneamente por cinco puntos distintos. Sospecha que la muralla de Segovia, podría parecerse a la de Ávila en algunos aspectos. (Cooper, 2014: 61-63). Para nosotros, las murallas de Segovia tienen su trazado previsto de antes de iniciarse la construcción.
} 
Luna y del Consuelo presentan una dimensión de paso más ancha, similar a la de una puerta. Desconocemos cual era su anchura original.

- Existe siempre una torre adyacente al postigo, desde la que se domina perfectamente el camino zigzagueante que asciende hacia dicho postigo. De hecho en varios casos, el camino realiza más de un quiebro a los pies de dicha torre adyacente. En algunos casos, como en el postigo de San Juan, parece que la torre podría presentar un resalto mayor del habitual. Esta torre no existe en la actualidad, en el caso de los postigos de San Matías y de la Luna, pero creemos haber demostrado su existencia en ambos casos.

- La configuración de los postigos es muy sencilla, de forma que tienen poca presencia, como queriendo pasar desapercibidos o ser poco visibles desde el exterior. En todos los casos se reducen a un sencillo arco perforando el lienzo de la muralla. No existe ningún elemento poliorcético que contribuya a su defensa, salvo esa torre adyacente, más bien pensada posiblemente con funciones de vigilancia. En el postigo del Consuelo y en el del Obispo permanecen, o tenemos constancia documental, de unas fusileras realizadas durante el siglo XIX, pero no tenemos testimonio de que se realizase ningún elemento de estas características en la Edad Media para defensa de los postigos. En los demás postigos no tenemos evidencia de ningún tipo ni época.

Por lo tanto los postigos son sencillos, de acceso directo y frontal, constituidos por una simple abertura en el lienzo. No hemos encontrado ninguna regla compositiva que diferencie un lienzo donde se abre un postigo de los demás. Tampoco en los lienzos adyacentes. Lo que es evidente es que su ubicación no influía en el diseño y trazado de la muralla, al contrario de lo que hemos visto que ocurre en las puertas. Sus escasas características arquitectónicas no permiten dar una datación cronológica para ninguno de ellos. Pueden ser contemporáneos con los lienzos en que se abren, pero también podrían abrirse a posteriori en cualquier lienzo de la muralla, siempre con la precaución de situarlos adyacentes a una torre.

Tan sólo el postigo de San Juan puede tener alguna traza de su configuración medieval. Los demás que nos han llegado son reconstruidos, como el del Sol (1992), la Luna (1993), el del Consuelo (1947) o el del Obispo ${ }^{129}$. Del postigo de San Matías, se conserva un arco tapiado, pero como se ha comentado, sospechamos que no sea el original. El postigo del parque sólo lo conocemos por el dibujo de Wyngaerde, que parece representarlo como una torre puerta. Es una lástima porque en ese caso podría remitirnos a la tipología de puerta que hemos comentado en el caso de la puerta de Santiago, lo que permitiría sin duda, plantear nuevas posibilidades.

\footnotetext{
${ }^{129} \mathrm{El}$ postigo recientemente descubierto junto a la torre T71, viene a reforzar las conclusiones obtenidas ya que en contraposición con la disposición del anterior paso que se identificaba como postigo, este nuevo descubrimiento confirma la colocación de los postigos adosados a una torre.
} 


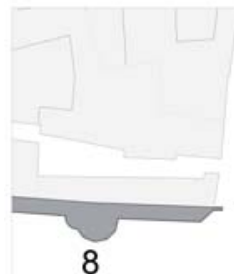

8

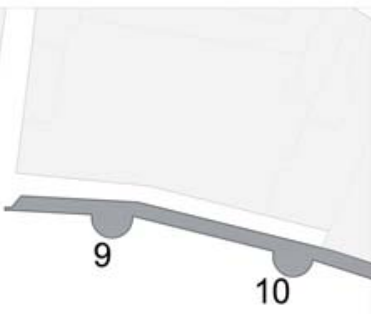

POSTIGO DEL SOL

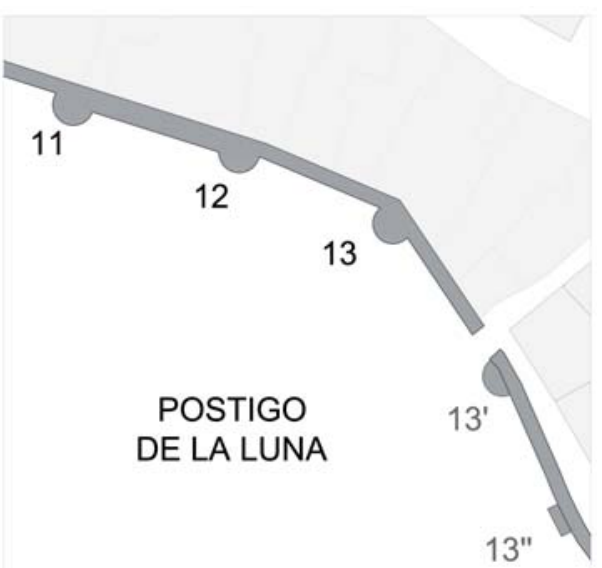

32

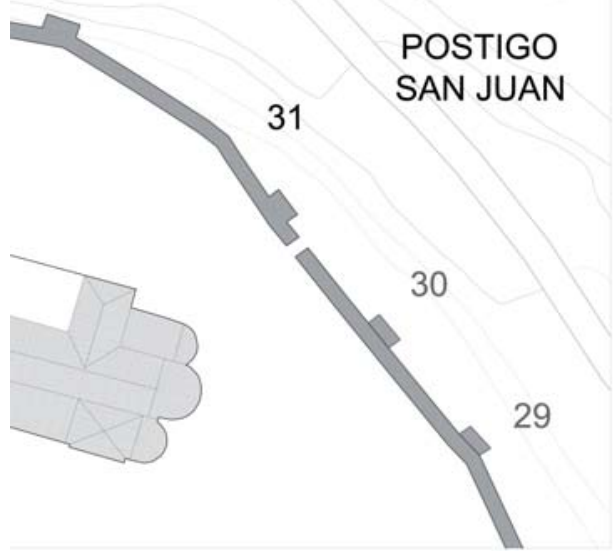

POSTIGO FUENTE CERCADA
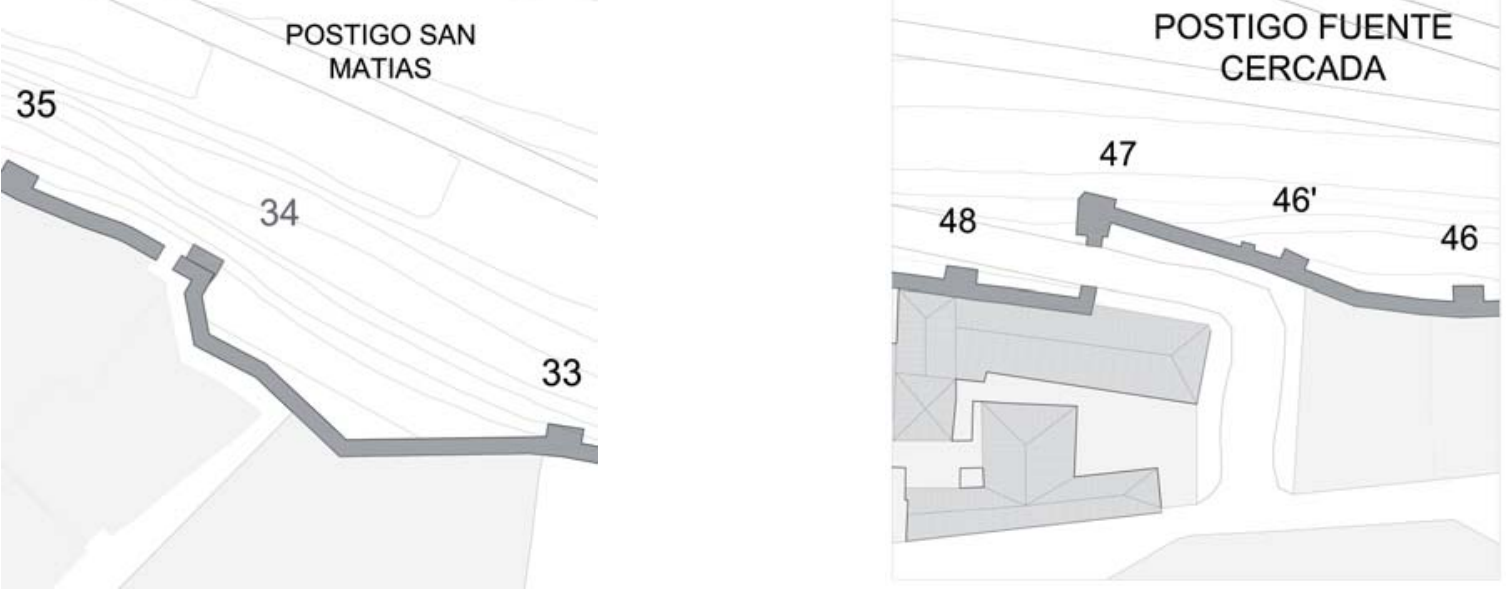

Figura 4.2. 32: Comparativa en planta de algunos de los postigos que se conocen de la muralla, a la misma escala. Se incluye el postigo de la fuente cercada. Se aprecian perfectamente las características de su configuración. El camino de aproximación es corto. El acceso se realiza de manera frontal a la muralla y perpendicular al lienzo, afrontando la pronunciada pendiente, mediante un trazado zigzagueante por la ladera, que bordea una torre cercana al postigo. Las dimensiones de paso sólo permiten la entrada de personas y animales, pero no vehículos rodados. Obsérvese como la configuración del postigo de fuente cercada es completamente distinta a la sencillez arquitectónica que presentan los postigos. Compárese con la Figura 4.2. 27 en la que se exponen las características de las puertas. 

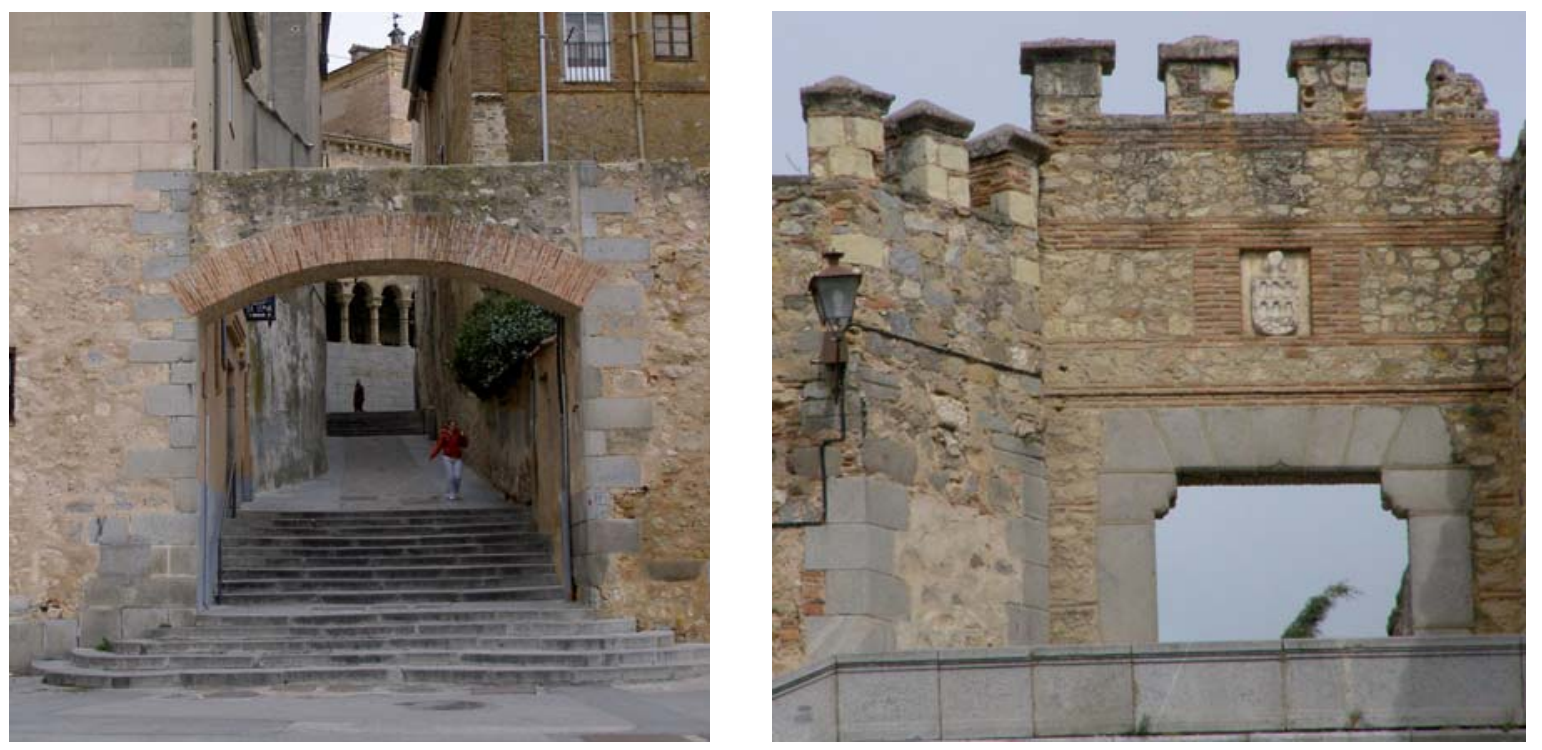

Figura 4.2. 33: Postigo de la Luna. Actualmente presenta una anchura de paso superior a los tres metros, dimensión más acorde con las de las puertas que las de los postigos. Desconocemos su configuración original.

Figura 4.2. 34: Postigo del Consuelo. También reconstruido en el siglo XX, del que también desconocemos su configuración medieval.

Por último recordar la existencia de dos posibles postigos, a los que ya hemos hecho alusión, uno junto a la torre T60, y que se ha vinculado a la explotación de la cantera extramuros, al pie de la muralla. El otro caso, una hipótesis con menos datos que la respalden, en el tallado en la roca que detectamos en el lienzo L75-76, junto a la torre T76.

\subsubsection{C.- POTERNA}

En un apartado diferente estudiamos el caso del acceso del revellín, cuyas características observamos igualmente en la tabla de la Figura 4.2. 24. Como hemos señalado, lo consideramos un caso especial que se adecua a algunas características de los grupos anteriores, pero no cumple la totalidad de ninguno de los dos. El acceso se realiza por una rampa de fortísima pendiente que asciende realizando varios recodos, en zigzag, como en los postigos. Por sus dimensiones de paso, claramente peatonal, podríamos considerarlo un postigo y no una puerta, pero tipológicamente está más cerca de éstas últimas que de los primeros. Su configuración arquitectónica, con el paso ubicado en un quiebro de la muralla, flanqueado por una torre, de forma que el acceso es en paralelo al lienzo de la muralla, es idéntica a la de las puertas. Además sus características poliorcéticas, con entrada en recodo, foso tallado en la roca que se salva por un puente levadizo, independientemente de la presencia de fusileras que indudablemente datamos en el siglo XIX, suponen un esfuerzo defensivo que no vemos en ninguno de los postigos de la muralla. Adicionalmente vemos los restos de una torre que se adosa por delante de la puerta, que flanquea la rampa de acceso y un muro, que cierra lateralmente el foso, oculta la puerta. Indudablemente se trata de un gran esfuerzo defensivo para un simple postigo, o una puerta muy pequeña para dicho despliegue de medios. 
Por otro parte, este acceso comunica exclusivamente con el Alcázar, no con la ciudad, por este motivo lo consideramos una poterna ${ }^{130}$ o puerta falsa del Alcázar y no una comunicación de la ciudad. Además encontramos varios paralelismos entre este acceso y la puerta principal del Alcázar. Ambos cuentan con foso y puente levadizo, algo que no existe en ningún otro punto de la muralla. Ambos presentan una entrada en recodo, algo tampoco visto en los accesos urbanos. En definitiva, estamos ante una poterna que permitía a los defensores del Alcázar comunicarse con el exterior, de manera completamente independiente de la ciudad.

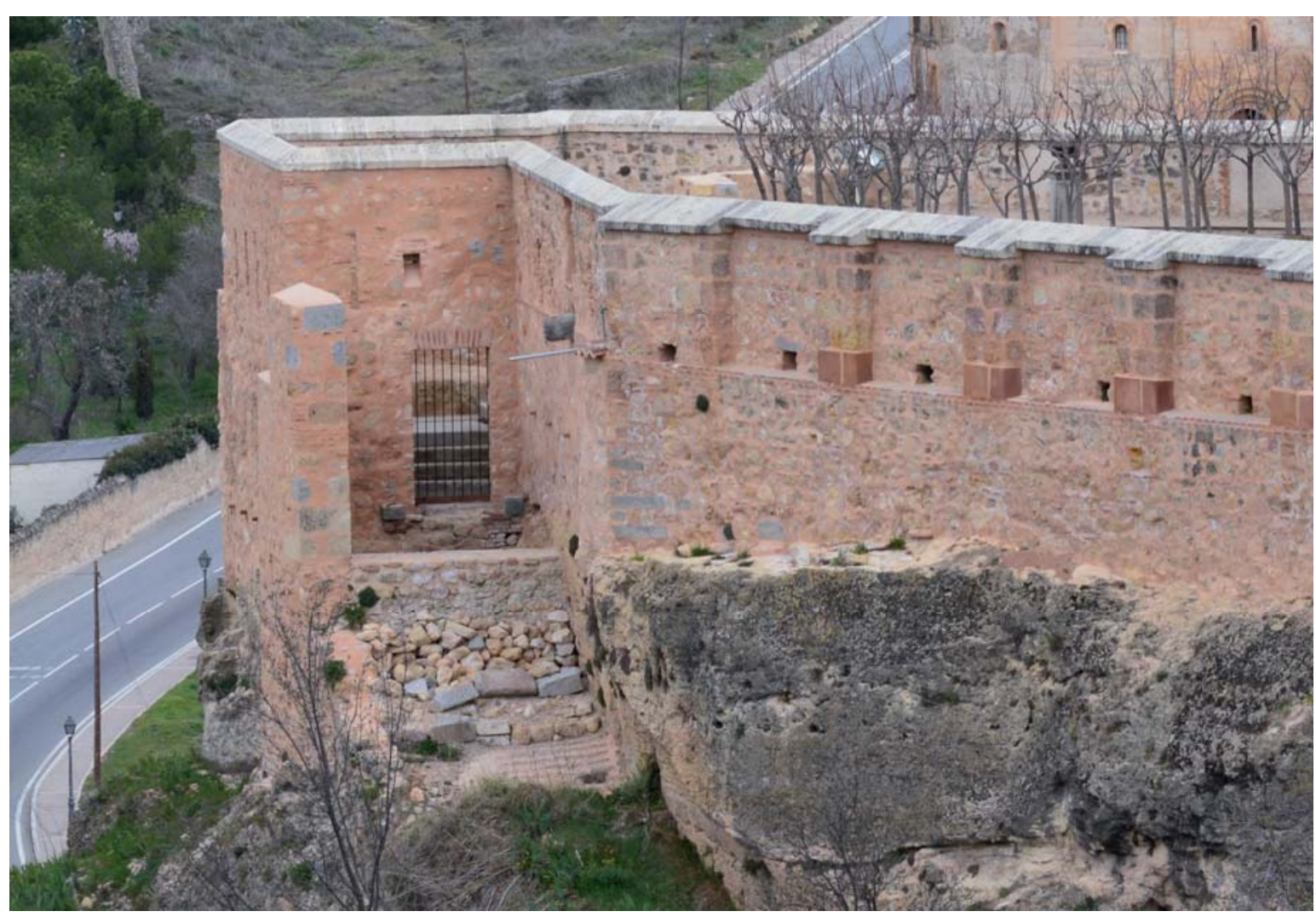

Figura 4.2. 35: Torre T67. Imagen de la poterna descubierta en la torre posterior del Alcázar. En este acceso se conjugan las características de las puertas y las de los postigos.

\footnotetext{
${ }^{130}$ Poterna: Puerta pequeña para acceder del recinto a los aproches y destinada a entradas y salidas discretas, por lo que suele abrirse en sector áspero y poco frecuentado e incluso en ocasiones a cierta altura sobre el terreno exterior (Mora Figueroa, 1996: 160).
} 


\subsection{4.- LA CONFIGURACIÓN DE LOS ZÓCALOS.}

Es frecuente la existencia de una distinción constructiva en la parte baja de las murallas, más manifiesta en las torres que en los lienzos. Esta diferencia puede materializarse bien mediante el cambio de material o de sistema constructivo, o en forma de resalto, escalonado o no, que podemos entender como la voluntad de marcar un zócalo, como elemento arquitectónico diferenciado, bastante frecuente en las murallas urbanas de Repoblación (Malalana Ureña, 2009: 101). Esta discontinuidad constructiva no implica necesariamente en todos los casos una discontinuidad temporal en la ejecución de la obra, mientras en otros casos como por ejemplo, el cambio de la forma en planta de la torre, la discontinuidad en la ejecución de la obra es innegable.

Las principales evidencias de la existencia de distintas etapas constructivas las encontramos en los zócalos y partes bajas de los lienzos y torres y es aquí donde, con toda lógica, vamos a descubrir las pervivencias históricas más antiguas de la construcción.

La forma que adquieren los zócalos, en el caso de los cubos, en comparación con la de la torre que se emplaza encima, nos permite diferenciar nuevas discontinuidades constructivas entre la parte inferior y superior de la torre, muy evidentes en el caso de que ambos elementos presenten formas completamente distintas, como por ejemplo zócalos rectangulares sobre los que se asientan torres semicirculares o poligonales, como en las torres T4, T7, T59 y T60, por citar algunos ejemplos que ya hemos visto. 
Sin embargo, además de la forma en planta, que nos ayudan a distinguir discontinuidades y fases constructivas, encontramos en la muralla segoviana tres tipos de conformación de los zócalos y partes bajas. Estos son:

- los zócalos nivelados, claramente diferenciados con una línea horizontal.

- los zócalos diferenciados no nivelados, marcado por un cambio de material o por el tamaño de las piezas.

- los zócalos indiferenciados, que es cuando no existe tratamiento específico diferente de la fábrica del resto de la muralla y podríamos calificarlo como sin zócalo.
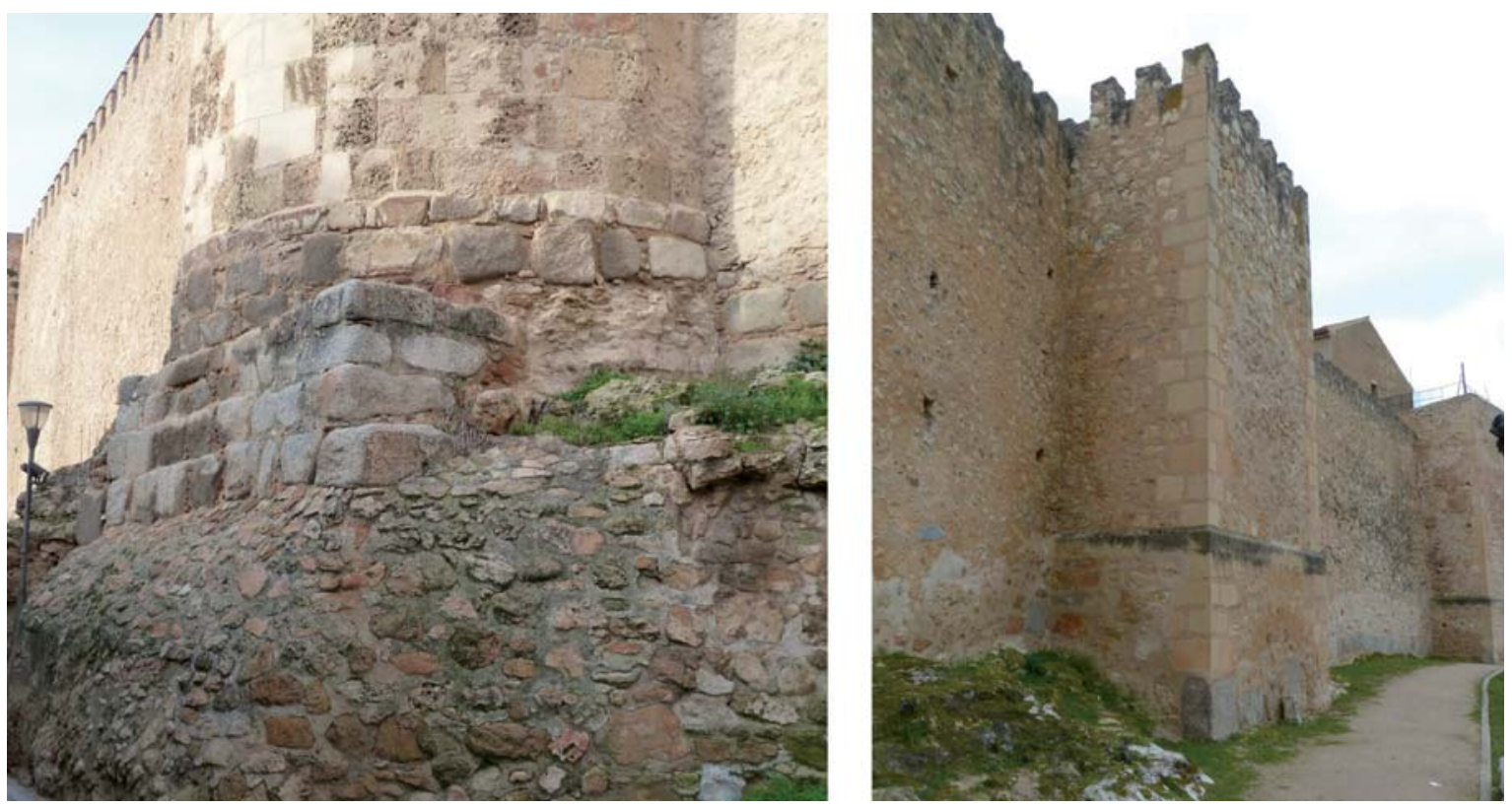

Figura 4.2. 36: Torre T4. Evidencia de discontinuidad constructiva en la forma del zócalo. Resto de una zarpa de planta rectangular medio derruida, constituida por 4 hiladas de sillería de granito colocada a soga, que se aprovecha como base para construir sobre ella una torre de trazado poligonal. Prueba irrebatible de la anterioridad de las torres rectangulares respecto a las de trazado poligonal.

Figura 4.2. 37: Torre T78. Tipo característico de torre en la zona 1. Torre rectangular con zócalo resaltado y nivelado, realizada toda ella en una mampostería de piedra sedimentaria, con esquinas de sillería.

El primer tipo, los zócalos nivelados, se caracterizan por la existencia de un basamento diferenciado del resto de la construcción por el empleo de piezas de mayor tamaño, a veces sillares reutilizados con abundante presencia de piezas de granito, que se disponen sobre la roca constituyendo una o varias hiladas que se rematan en una línea horizontal, nivelada, sobre la que apoya el resto de la fábrica. En el caso de los lienzos en número de hiladas predominante es de una o dos, mientras que para las torres el número de hiladas suele ser tres, cuatro y a veces alguna más. En éstas, los zócalos nivelados también pueden estar resaltados por un ligero escalón, de modo que las dimensiones de este zócalo son ligeramente mayores a las de la parte superior de la torre. Como variante de este tipo, existen algunos ejemplos en que ese zócalo nivelado se constituye a modo de zarpa, con varias hiladas escalonadas, más frecuentemente en las torres que en los lienzos. 
La configuración de los aparejos también permite diferenciar estos zócalos y partes bajas del resto de la construcción. Así en las torres el zócalo nivelado suele configurarse con un aparejo de sillería o, al menos, piezas de mayor tamaño bastante regularizadas, que lo diferencia del resto de la fábrica que se ejecuta habitualmente en una mampostería desconcertada de piedra sedimentaria de pequeño tamaño. El aparejo predominante es a soga, aunque también hay casos de piezas colocadas a tizón. En el caso de los lienzos el remate horizontal del zócalo se consigue con una pieza también colocada a soga, a modo de albardilla, si bien debido a las irregularidades y desniveles de la roca de apoyo, es habitual encontrar las piezas bajo ese remate, colocadas a tizón.

El segundo tipo de zócalo, el diferenciado, evidencia la existencia de ese elemento de base bien por el cambio del material o por el tamaño de las piezas con que se construye, pero no se genera una línea horizontal que lo delimite. Se caracteriza por el empleo de piezas de mayor tamaño, con frecuencia de granito, por lo que el tratamiento de esa base de apoyo se distingue claramente del resto de la fábrica, que como hemos dicho se ejecuta en una mampostería desconcertada de piedra sedimentaria de pequeño tamaño, a pesar de que en ningún caso generan una línea de separación horizontal nivelada. El contraste se fundamenta en el cambio del material y las dimensiones de las piezas lo que genera un aparejo diferenciado.

El tercer tipo, cuando el zócalo es indiferenciado del resto de la fábrica, no se marca un elemento de basamento mediante el resalto escalonado, ni el empleo de distintos materiales ni aparejos. La fábrica se construye con el mismo material y técnica constructiva desde su apoyo en la roca, hasta la coronación.

Por último, indicar que en numerosos casos, la roca de apoyo no está visible por lo que los zócalos están ocultos, desconociendo su configuración. En otros casos la vegetación o la presencia de edificaciones adosadas delante nos oculta dichos zócalos, total o parcialmente, por lo que hay un considerable número de ocasiones en que no disponemos de una información completa fiable.

En la Figura 4.2. 38 presentamos una tabla resumen en que se contabilizan los distintos casos que existen en cada zona de la muralla. Como puede verse, se ha obviado la zona 10 correspondiente al Alcázar. En una primera aproximación, si descontamos los casos en que los zócalos están completamente ocultos, no vemos el apoyo sobre la roca en ningún punto de su trazado, y consideramos dos grandes bloques, zócalos nivelados y los no nivelados, incluyendo en estos últimos a los indiferenciados, los datos son bastante clarificadores.

En las torres, los zócalos nivelados aparecen de manera predominante en las zonas 1, 2, 9 y 12 , siendo en el cómputo total de la muralla, aproximadamente la mitad de los casos nivelados y la otra mitad no nivelados. En el caso de los lienzos es aún más perceptible. Sólo hay zócalos nivelados en las zonas 1, 2 y 12 .

Vemos que las zonas en las que se produce esta diferencia, vuelven a repetirse, con las ya vistas en el apartado 4.2.1, reforzando la singularidad ya detectada en el estudio de la forma en planta de las torres. Vamos a ver más en detalle estos datos, ya que el estudio pormenorizado de cada caso nos aporta una explicación que matiza esta primera aproximación y veremos cómo algunos de estos casos se deben a reconstrucciones documentadas de torres y lienzos, que ya hemos demostrado, lo que nos va a permitir conocer mejor la configuración original de cada zócalo. 


\begin{tabular}{|c|c|c|c|c|c|c|c|c|}
\hline \multirow[b]{2}{*}{ ZONA } & \multicolumn{4}{|c|}{ TORRES } & \multicolumn{4}{|c|}{ LIENZOS } \\
\hline & NIVELADO & NO NIVELA & OCULTO & SUMA & NIVELADO & NO NIVELA & OCULTO & SUMA \\
\hline 1 & 8 & 0 & 0 & 8 & 6 & 0 & 1 & 7 \\
\hline 2 & 3 & 1 & 1 & 5 & 2 & 0 & 3 & 5 \\
\hline 3 & 2 & 1 & 1 & 4 & 0 & 2 & 3 & 5 \\
\hline 4 & 3 & 2 & 2 & 7 & 0 & 3 & 3 & 6 \\
\hline 5 & 0 & 2 & 0 & 2 & 0 & 2 & 2 & 4 \\
\hline 6 & 3 & 9 & 0 & 12 & 0 & 9 & 4 & 13 \\
\hline 7 & 2 & 7 & 0 & 9 & 0 & 9 & 0 & 9 \\
\hline 8 & 1 & 4 & 0 & 5 & 0 & 2 & 3 & 5 \\
\hline 9 & 3 & 1 & 0 & 4 & 0 & 6 & 0 & 6 \\
\hline 10 & - & - & - & - & - & - & - & - \\
\hline 11 & 5 & 3 & 0 & 8 & 0 & 7 & 0 & 7 \\
\hline 12 & 6 & 1 & 0 & 7 & 2 & 4 & 2 & 8 \\
\hline SUMA & 36 & 31 & 4 & 71 & 10 & 44 & 21 & 75 \\
\hline
\end{tabular}

Figura 4.2. 38: Tabla resumen de los tipos de zócalos identificados en las torres y lienzos de cada zona.

\subsubsection{A.- LOS ZÓCALOS DE LAS TORRES}

La configuración del zócalo no está directamente relacionada con la forma de la torre que se emplaza encima. Como hemos visto existen varios casos de torres, tanto poligonales como circulares, que se construyen sobre zócalos de planta rectangular. Esto hace que el análisis de la relación entre la configuración del zócalo y la forma de la torre que se emplaza encima carezca de sentido, ya que nos produce series de datos aleatorios. Igualmente nos desvirtúa algunos de los resultados, ya que al existir un cambio de forma entre el basamento y la torre, la separación entre ambos elementos es siempre resaltada, pero desconocemos la configuración del zócalo original cuando la torre era rectangular, al igual que el zócalo. Por este motivo estudiaremos la forma de los zócalos sin tener en consideración la forma de la torre que se les apoya encima. Ese dato nos va a servir para identificar torres que han sido reconstruidas, por la evidente discontinuidad constructiva que representa la pervivencia de un zócalo de distinta forma geométrica que la de la torre que se ubica encima.

En la tabla de la Figura 4.2. 39 se presentan los tipos de zócalos de manera más matizada, diferenciando las variantes dentro de cada bloque y señalando, adicionalmente en el caso de los ocultos, los casos en el que el zócalo está parcialmente oculto y los casos en que lo está completamente, por lo que la información disponible es parcial y futuras excavaciones arqueológicas podrían dejar a la luz una realidad distinta a la que los datos actualmente disponibles nos ofrecen.

Se han considerado 71 torres, obviando las pertenecientes a la zona del Alcázar. El número de casos de zócalos nivelados es muy similar al de zócalos no nivelados, y el de estos últimos se divide en dos mitades entre los que presentan el zócalo diferenciado sin nivelar de los que no presentan ese zócalo diferenciado. El porcentaje de torres en los que el zócalo está parcialmente oculto, superior al $50 \%$, nos da una idea de la representatividad de esta muestra. Vamos a analizar individualizadamente cada uno de los tipos de zócalo que hemos identificado. 


\begin{tabular}{|c|c|c|c|c|c|c|c|c|c|c|}
\hline TORRES & \multicolumn{4}{|c|}{ NIVELADO } & \multicolumn{3}{|c|}{ NO NIVELADO } & \multicolumn{2}{|c|}{ OCULTO } & \multirow{2}{*}{$\begin{array}{c}\mathrm{N}^{\circ} \\
\text { TOTAL }\end{array}$} \\
\hline ZONA & ZARPA & RESALTA & MARCADO & TOTAL & MARCADO & INDIFEREN & TOTAL & PARCIAL & COMPLETO & \\
\hline 1 & 4 & 3 & - & 7 & - & - & 0 & 2 & 1 & 8 \\
\hline 2 & - & 0 & 3 & 3 & - & 1 & 1 & 4 & 1 & 5 \\
\hline 3 & - & 2 & - & 2 & - & 1 & 1 & 3 & 1 & 4 \\
\hline 4 & - & 1 & 2 & 3 & 2 & - & 2 & 5 & 2 & 7 \\
\hline 5 & - & 0 & - & 0 & - & 2 & 2 & 2 & 0 & 2 \\
\hline 6 & - & 3 & - & 3 & 6 & 3 & 9 & 9 & 0 & 12 \\
\hline 7 & - & 1 & 1 & 2 & 4 & 3 & 7 & 6 & 0 & 9 \\
\hline 8 & - & 0 & 1 & 1 & 1 & 3 & 4 & 4 & 0 & 5 \\
\hline 9 & - & 2 & 1 & 3 & 1 & - & 1 & 1 & 0 & 4 \\
\hline 10 & - & - & - & - & - & - & - & - & - & - \\
\hline 11 & - & 4 & 1 & 5 & 1 & 2 & 3 & 1 & 0 & 8 \\
\hline 12 & 1 & 5 & 0 & 6 & 1 & - & 1 & 3 & 0 & 7 \\
\hline SUMA & 5 & 21 & 9 & 35 & 16 & 15 & 31 & 40 & 5 & 71 \\
\hline
\end{tabular}

Figura 4.2. 39: Tabla resumen de los tipos de zócalos que apreciamos en las torres de las distintas zonas.

\section{ZÓCALO DIFERENCIADO Y NIVELADO}

Como hemos indicado los zócalos nivelados, marcan claramente la separación con el resto de la fábrica por una línea horizontal que separa dos fábricas diferenciadas, que en algunos casos se recalca con la existencia de un leve resalto o un escalonado de varias hiladas.

En la zona 1 todos los zócalos visibles, 7 de 8 , son nivelados y además 4 de ellos presentan zarpa. Las tres excepciones son la T1, la T2 y la T6, las dos primeras son las que flanquean la puerta de San Andrés y la tercera es una de las torres poligonales.

En la zona 2 tenemos 5 casos de los cuales, 4 están parcialmente ocultos. Desconocemos si existe un zócalo diferenciado enterrado. No sabemos si lo que vemos en la actualidad en la parte baja es el zócalo de dichas torres o se nos oculta una discontinuidad constructiva en la fábrica y existe un zócalo debajo. Los datos constatados son los de la primera opción, pues es lo visible, aunque creemos que es más probable la opción segunda y en realidad no tenemos información alguna de los zócalos de esta zona.

En la zona 3 tenemos dos casos de zócalos nivelados, la T14 y la T15, las dos torres que flanquean la Alhóndiga. Ambas hemos visto que no son originales, ya que la primera data de los siglos XV-XVI y la segunda se levanta sobre un zócalo de planta rectangular.

En la zona 4, otros tres casos que, además de nivelado, el zócalo esta resaltado, la T18, la T20 y la T24, esto es, las vinculadas a las casas fuertes que protegían respectivamente las puertas de San Martín y la de San Juan y la T20 que es una reconstrucción del XX.

En la zona 6 encontramos con zócalo nivelado y resaltado la T32, T33 y T36 mientras en la zona 9 están la T58, T59 y T60, resaltado sólo las en las dos últimas, que son reconstrucciones.

En la zona 11, 5 torres de un total de 8, presentan el zócalo nivelado. Todas estas torres, al igual que veremos luego en los lienzos, están muy renovadas, apreciándose numerosas piezas sustituidas o recolocadas. A pesar de presentar el zócalo resaltado, este zócalo esta realizado 
en mampostería de piedra sedimentaria, no en piezas de granito. Por otra parte, hay que señalar que en la torre T77, que presenta un zócalo indiferenciado por estar ejecutado en mampostería desconcertada en su totalidad, se conserva en su base una hilada de sillares de granito, a modo de zócalo diferenciado nivelado, restos de una torre anterior que tenía una alineación distinta.

En la zona 12, todas las torres, menos la T83, presentan zócalo diferenciado nivelado y resaltado. Incluso una de ellas presenta el zócalo escalonado a modo de zarpa, la T84. Esta última es la única de la zona 12 y está completamente reconstruida en el siglo XX, por lo que hay que confiar en que la restauración sea realista y la zarpa existiese en la torre original. La T83 presenta unos sillares de granito en su zócalo recolocados, mientras el resto de la torre está realizado en mampostería concertada en lajas, aparentando ser toda la torre completamente reconstruida. En origen la torre pudo tener un zócalo diferenciado y nivelado de granito como las demás de la zona.
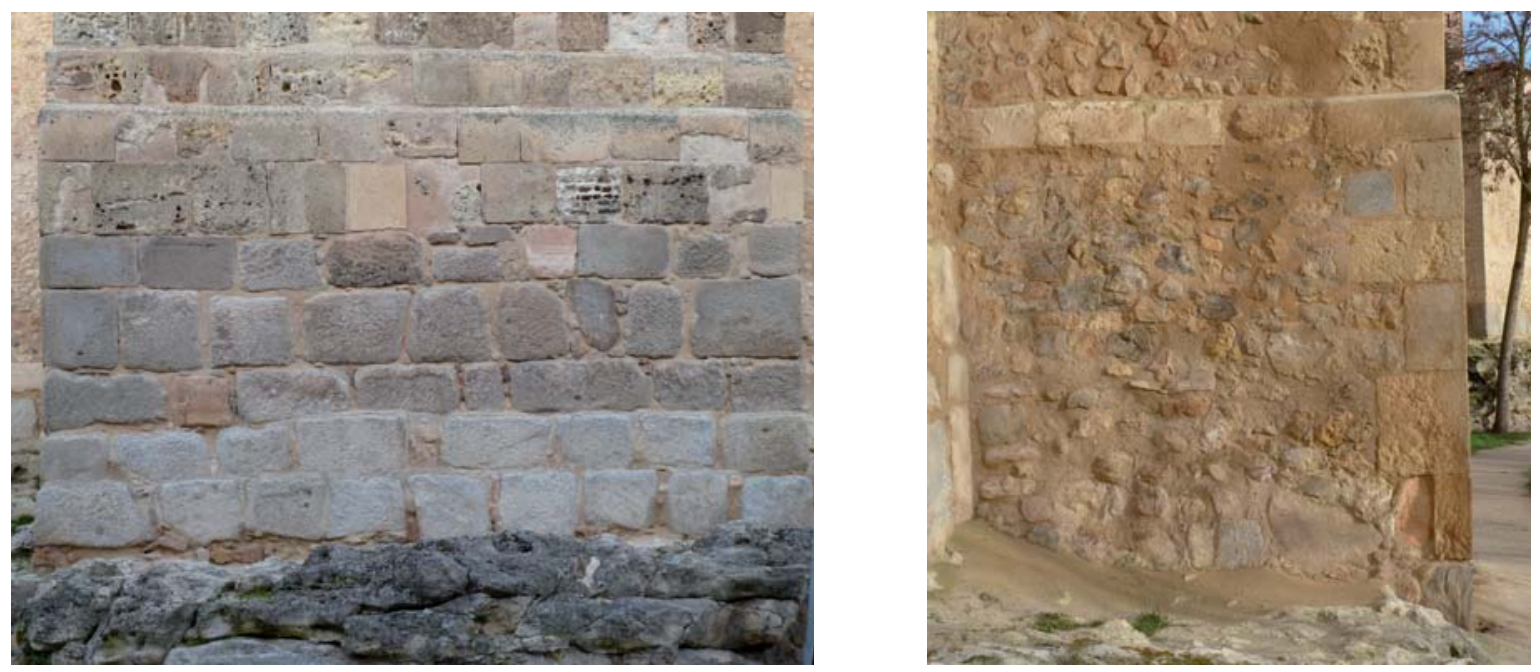

Figura 4.2. 40: T3: Zócalo nivelado y resaltado, ejecutado con abundante granito bien aparejado en hiladas de sillería conformando una zarpa escalonada.

Figura 4.2.41: T75: Zócalo nivelado y resaltado, pero ejecutado en mampostería desconcertada con sillares en las esquinas, tanto el zócalo como el resto de la torre. Es el modelo característico de la zona 11.

En el resto de las zonas, la existencia de zócalos nivelados, se produce de manera esporádica, solo en algunas torres sueltas y no como característica común a la zona, dándose el caso de que en algunas torres, el nivelado se genera por una reconstrucción de la torre sobre un zócalo previo de distinta forma, tamaño o aparejo.

A modo de resumen podemos decir que la presencia de zócalos nivelados y resaltados en las torres se concentra en tres zonas que presentan una mayor uniformidad de casos, las zonas 1, 11 y 12, Leopoldo Moreno, Ronda de Juan II y Museo-Hontanilla, respectivamente. En las dos zonas más próximas a la puerta de San Andrés, todos los zócalos son resaltados y con numerosas piezas de granito en su aparejos, generalmente bien organizados, mientras en la zona 11 la presencia de piezas de granito es muy poco relevante y los zócalos se realizan en mampostería desconcertada. En las zonas 1 y 12 encontramos cinco casos que presentan zarpa, pero en la zona 11, no hay ningún ejemplo. En el resto de las zonas, la existencia de 
zócalos resaltados, se produce de manera esporádica, en algunas torres, pero no vemos una uniformidad que nos caracterice un grupo diferenciado. Tan solo en las zonas 6 y 9 podrían existir algunos indicios de homogeneidad en la aparición de un mayor número de casos de zócalos nivelados que deberán confirmarnos otras fases del análisis.

\section{ZÓCALO DIFERENCIADO NO NIVELADO}

Dentro de este grupo hemos incluido todas las torres que presentan el zócalo diferenciado por el cambio de material o de técnica constructiva, pero no existe una línea horizontal clara de separación entre este basamento y el resto de la torre.

Las características comunes que nos identifican a este grupo son la existencia de zócalos en los que abundan los sillares y piezas medianas y grandes de forma bastante regular y con abundancia de piezas de granito. En numerosos casos se trata de torres reconstruidas, sino total si al menos parcialmente, desde el zócalo y generalmente presentan el material entremezclado. Se aprecian en varias de ellas discontinuidades en el aparejo de ese zócalo, con una clara asimetría vistas desde el frente, así en una parte de la torre vemos un zócalo diferenciado por una sillería nivelada y en la otra parte de la torre, no existe esa delimitación horizontal, lo que evidencia el derrumbe de media torre y su posterior reconstrucción, como por ejemplo la T44, T45, T49 y T50. Por este motivo ahora no hay una línea nivelada en todo el perímetro, pero quizá en origen si pudieron haber presentado el zócalo nivelado. Estas reconstrucciones se caracterizan por la reutilización de numerosos sillares y piezas regularizadas, pero mal aparejadas, sin componer una sillería organizada en hiladas horizontales, sino empleando los sillares como si fuesen mampuestos.

En la zona 4, encontramos la T21 y la T22, ambas presentan abundantes piezas de granito en su zócalo pero mal aparejadas, sin constituir una sillería de hiladas horizontales. En la zona 6, incluimos la T31, reconstruida, la T38, T39, T41, T42 y T43 que presentan distintos tipos de material entremezclados y mal aparejados. Emplean sillares en las esquinas, pero el resto, a pesar de ser piezas regularizadas, posibles sillares reutilizados, los emplean como si fuesen mampuestos. En la zona 7, la T44, evidencia una mitad nivelada y la otra mitad sin nivelar con material mezclado fruto de una reconstrucción en que abunda el ladrillo de la fábrica Carretero. Algo similar descubrimos en la T45, la T49, (con zócalo de sillería sedimentaria nivelado en parte central de su frontal que ha desaparecido en el resto de la torre, reconstruida en mampostería redondeando las esquinas) y en la T50, donde se conservan restos de un zócalo nivelado en sillería de granito en un lateral que no continúa en el resto de la torre, que presenta el material entremezclado y un aparejo mampostería encintada con ladrillo fruto de reconstrucción. En la zona 8, la T56 completamente reconstruida en el XX pero, por los restos, podría haber tenido zócalo nivelado, al igual que hemos visto en las anteriores. Lo mismo apreciamos en la T61', en zona 9, arruinada, de la que sólo quedan dos hiladas de sillería, incompletas, que en su origen podría haber constituido un zócalo nivelado. En la zona 11, la T76 muestra en un lateral una parte aparentemente nivelada, muy oculta por rejuntados posteriores y en el frontal y el otro lado no hay pruebas de esa nivelación, conservándose algunos grandes bloques de granito. En la zona 12 sólo encontramos la T83, que está completamente reconstruida en mampostería aparejada en lajas, entre las que han permanecido algunos sillares de granito en su parte frontal inferior. 


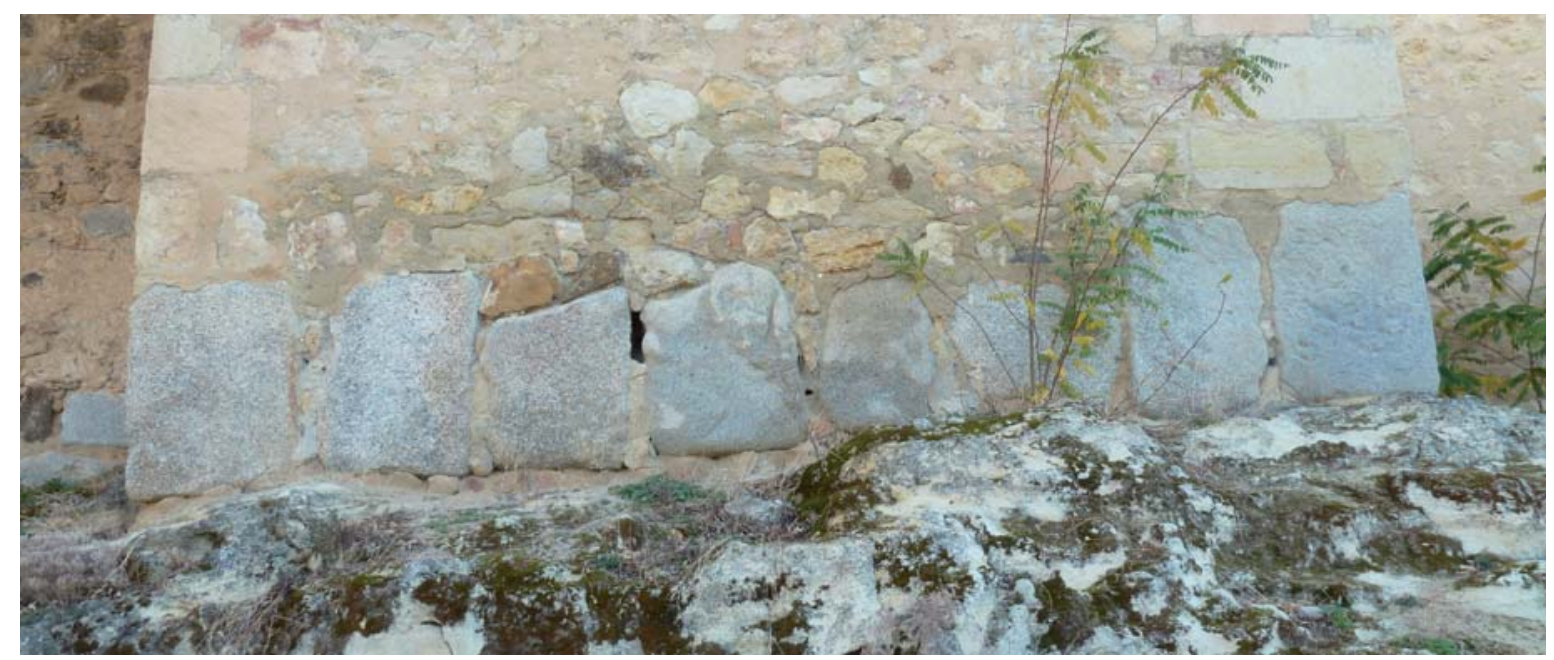

Figura 4.2. 42: T76: Zócalo diferenciado por el cambio de material, pero no nivelado, ya que no genera una línea horizontal de separación.
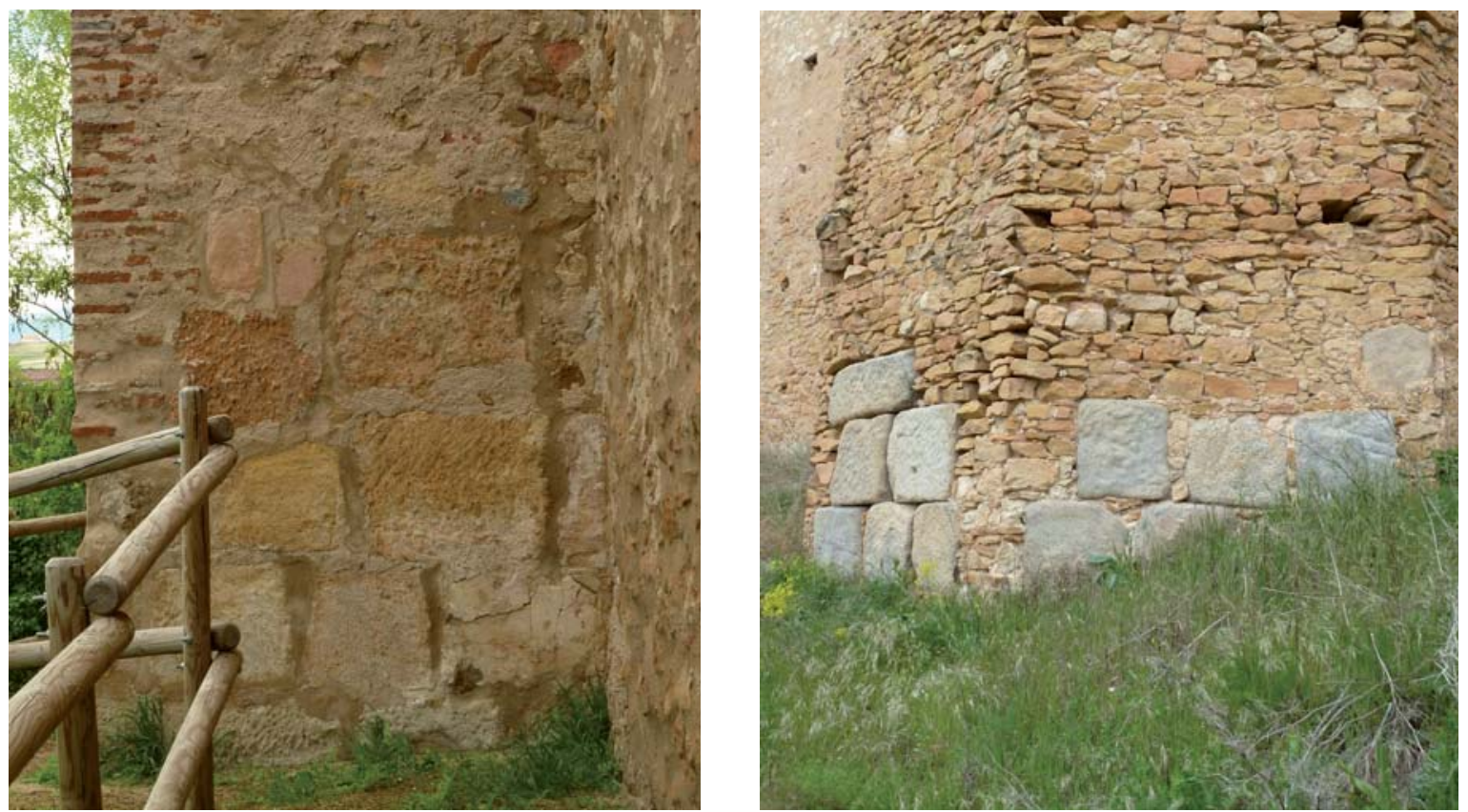

Figura 4.2. 43: T39: Zócalo diferenciado por el cambio de material, pero no nivelado, ya que no genera una línea horizontal de separación.

Figura 4.2. 44: T83: Otro ejemplo de zócalo diferenciado por el cambio de material, pero no nivelado. La regularidad de los sillares de granito puede inducir a pensar que el zócalo se nivela. Sin embargo la disposición de las piezas no genera una línea horizontal de apoyo para la fábrica.

Como vemos, los numerosos derrumbes y reconstrucciones han alterado el estado inicial sustancialmente y aparentemente pudieron haber existido más casos de zócalos nivelados que actualmente observamos incompletos, habiendo perdido la línea de nivelación horizontal superior, por lo que los apreciamos diferenciados pero sin nivelar. Es una sospecha pero con los datos disponibles a día de hoy, no podemos afirmarlo categóricamente. 


\section{ZÓCALO INDIFERENCIADO O SIN ZÓCALO}

Se incluyen todas aquellas torres en las que, lo que apreciamos actualmente es que la torre se realiza con el mismo material y técnica constructiva desde el arranque en el terreno, del que prácticamente en ningún caso vemos la roca sobre la que apoya, por lo que el zócalo está oculto parcialmente y deberán realizarse futuras excavaciones arqueológicas para sacar a la luz la realidad, quizá distinta de la que los datos hoy disponibles nos ofrecen. La mayoría de los casos se trata de torres reconstruidas en mayor o menor grado, en intervenciones relativamente recientes. Los casos más abundantes se encuentran en las zonas 6,7 y 8 , no existiendo ninguno en las zonas 1, 2 y 12.

Enumerando muy rápidamente, en la zona 2, encontramos la T13, de la que no apreciamos el apoyo sobre la roca, en zona 3 la T16 que está reconstruida, en la zona 5, la T25 y T25'ambas reconstruidas y de las que no está visible el apoyo en la roca, en la zona 6, la T35, T37 y T40, las tres reconstruidas. En la zona 7, la T46' reconstruida y cuyo apoyo en la roca está oculto, la T47 arruinada y reconstruida, (que quizá podría haberlo tenido por los restos visibles en su cara norte) y la T48 cuyo apoyo tampoco esta visible. En la zona 8 la T51' con zócalo oculto, la T55 reconstruida y T57 que constituye la puerta de Santiago. Por último en la zona 11, la T72 y T77 ambas reconstruidas, aunque la T77 podría haberlo tenido, tal y como ya se ha comentado en relación a la hilada de sillares que se sale de la alineación, restos de una torre anterior.
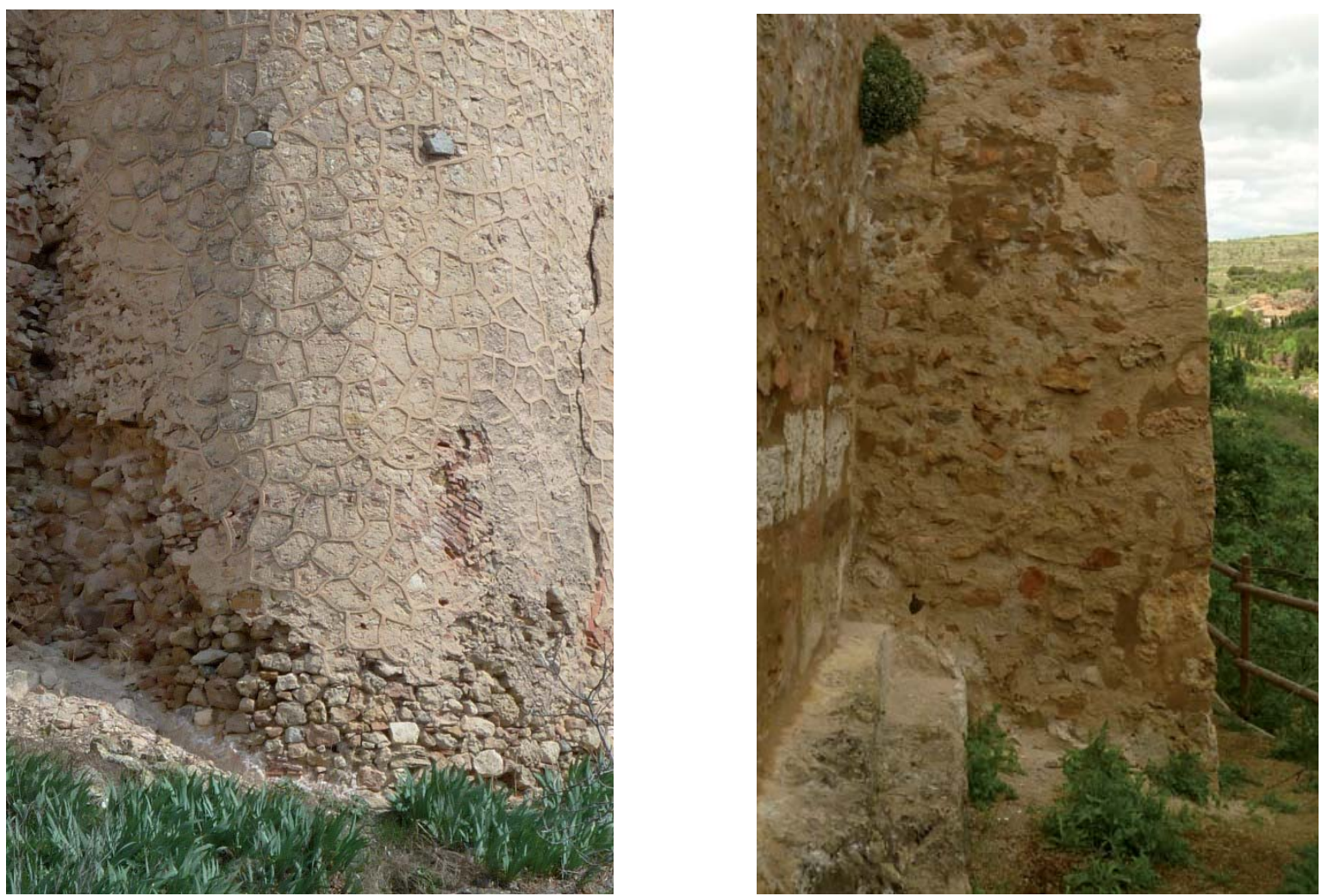

Figura 4.2. 45: T16: Zócalo indiferenciado. La construcción se ejecuta con el mismo material y sistema constructivo desde el arranque en el terreno hasta la coronación de la torre. Torre reconstruida.

Figura 4.2. 46: T37: Zócalo indiferenciado, pero del que no se ve el apoyo en la roca completo. Nuevamente la totalidad de la torre se realiza en mampostería desconcertada. Se trata de una torre reconstruida. 


\subsubsection{B.- LOS ZÓCALOS DE LOS LIENZOS.}

Se ha considerado un total de 75 lienzos de los 86 que se contemplan en el plan Director, excluyendo de este estudio los 11 correspondientes al Alcázar, por considerar que su construcción, en su mayor parte, está directamente vinculada con la del propio edificio.

De estos, en 21 de los casos no tenemos información de los zócalos por estar completamente ocultos. De los 54 restantes, en 31 de los casos la información es incompleta ya que los zócalos están parcialmente ocultos, no los vemos en la totalidad de su longitud o de su altura. En estos casos, al igual que hemos visto en las torres, son necesarias excavaciones arqueológicas para saber si realmente la fábrica apoya directamente sobre la roca o si existe un zócalo diferenciado como apoyo y separación del terreno. Así sólo disponemos de un porcentaje de ejemplos representativo, superior al $50 \%$ de zócalos no ocultos totalmente, en las zonas 1, 6, 7, 9, 11 y 12, y aún en algunas de estas, el porcentaje de los zócalos ocultos parcialmente también es muy significativo. Veamos con detenimiento cada uno de los tipos y zonas, porque, a pesar de esta aparente escasez de información, pueden extraerse algunas conclusiones.

\begin{tabular}{|c|c|c|c|c|c|c|c|c|c|}
\hline LIENZOS & \multicolumn{3}{|c|}{ NIVELADO } & \multicolumn{3}{|c|}{ NO NIVELADO } & \multicolumn{2}{|c|}{ OCULTO } & \multirow{2}{*}{ № TOTAL } \\
\hline ZONA & ZARPA & MARCADO & TOTAL & MARCADO & INDIFEREN & TOTAL & PARCIAL & COMPLETO & \\
\hline 1 & 1 & 5 & 6 & - & - & 0 & - & 1 & 7 \\
\hline 2 & - & 2 & 2 & - & - & 0 & 4 & 3 & 5 \\
\hline 3 & - & - & 0 & - & 2 & 2 & 1 & 3 & 5 \\
\hline 4 & - & - & 0 & 1 & 2 & 3 & 2 & 3 & 6 \\
\hline 5 & - & - & 0 & - & 2 & 2 & 2 & 2 & 4 \\
\hline 6 & - & - & 0 & 7 & 2 & 9 & 3 & 4 & 13 \\
\hline 7 & - & - & 0 & - & 9 & 9 & 8 & 0 & 9 \\
\hline 8 & - & - & 0 & - & 2 & 2 & 2 & 3 & 5 \\
\hline 9 & - & - & 0 & 4 & 2 & 6 & 2 & 0 & 6 \\
\hline 10 & - & - & - & - & - & - & - & - & - \\
\hline 11 & - & - & 0 & 7 & - & 7 & 2 & 0 & 7 \\
\hline 12 & - & 4 & 4 & 2 & - & 2 & 5 & 2 & 8 \\
\hline SUMA & 1 & 11 & 12 & 21 & 21 & 42 & 31 & 21 & 75 \\
\hline
\end{tabular}

Figura 4.2. 47: Tabla resumen de los tipos de zócalos que apreciamos en los lienzos de las distintas zonas.

\section{ZÓCALO DIFERENCIADO Y NIVELADO}

Como hemos indicado los zócalos nivelados, marcan claramente la separación con el resto de la fábrica por una línea horizontal que separa dos fábricas diferenciadas, bien por las dimensiones, o el tipo de material o por la técnica constructiva empleada. A diferencia del caso de las torres, no encontramos en los lienzos la existencia de resaltos para recalcar dicha separación, salvo el L6-7. Sólo existen 10 lienzos en los que el zócalo visible está nivelado, 
repartidos en 3 zonas, la 1, la 2 y la 12. Así la proporción en los lienzos, 10 nivelados frente a 44 que no lo están, queda muy lejana de la paridad que encontramos en el caso de las torres.

En la zona 1, todos los lienzos, presentan un zócalo diferenciado y nivelado. La línea horizontal de nivelación que marca la separación entre zócalo y el resto del lienzo es totalmente continua desde una torre hasta la siguiente. Además hay que señalar que en todos los casos el zócalo se constituye con piezas de tamaño medio y grande con gran proliferación de granito, aspecto que nos diferencia a los zócalos de esta zona de los demás de la muralla, incluso de los que también están nivelados. En esta zona encontramos el único caso de zócalo escalonado a modo de zarpa que existe en los lienzos de la muralla, el L6-7.

En la zona 2, descubrimos dos casos, el L8-9 y el L9-10 que presentan una discontinuidad en la fábrica. Es la misma situación que hemos comentado en la torres T9 y T10. Creemos que de existir un zócalo, éste debe estar enterrado, de modo que lo que apreciamos es una discontinuidad entre dos fábricas. La configuración de este zócalo es completamente distinta al que hemos visto en la zona 1.
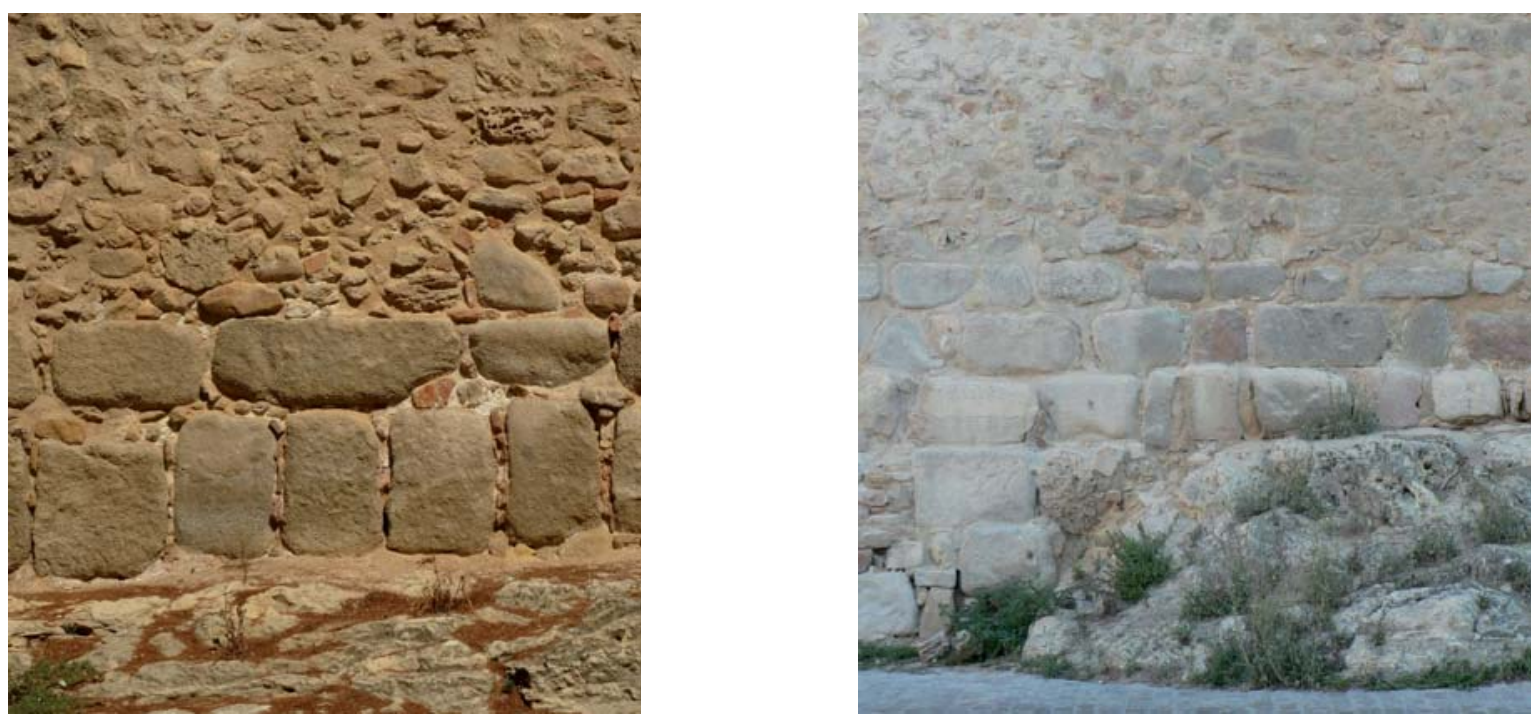

Figura 4.2. 48: L5-6: Zócalo diferenciado y nivelado. Aparejos muy cuidados, principalmente a base de granito, caracterizan los zócalos de la zona 1.

Figura 4.2. 49: L6-7 Zócalo diferenciado, nivelado y caso único de escalonado, a modo de zarpa. Ningún autor se ha percatado de la existencia de una zarpa en este lienzo de la muralla, claramente asociado a los que vemos en las torres cercanas.

En la zona 12 tan sólo descubrimos dos lienzos con zócalo nivelado, el L79-80 y el L83-84, ambos parcialmente ocultos, pero claramente nivelados en la parte visible. Nos plantea dudas similares el L82-83, que también se halla parcialmente oculto pero que parece estar nivelado en la parte visible. El L86-1, completamente enterrado en la actualidad pero que en las últimas intervenciones realizadas (PH: A0160) hemos descubierto en la parte excavada que presenta un zócalo de sillares de granito nivelado (OT-10/2010-11) muy similar a los que vemos en los lienzos L2-3, L3-4, L4-5 y L5-6. Este dato nos va a resultar de gran utilidad, ya que nos permite relacionar estilísticamente los lienzos de ambos lados de la puerta de San Andrés, 
como pertenecientes a una misma tradición constructiva, en los zócalos, al igual que ya hemos visto que ocurre con las dimensiones de lienzos y torres.

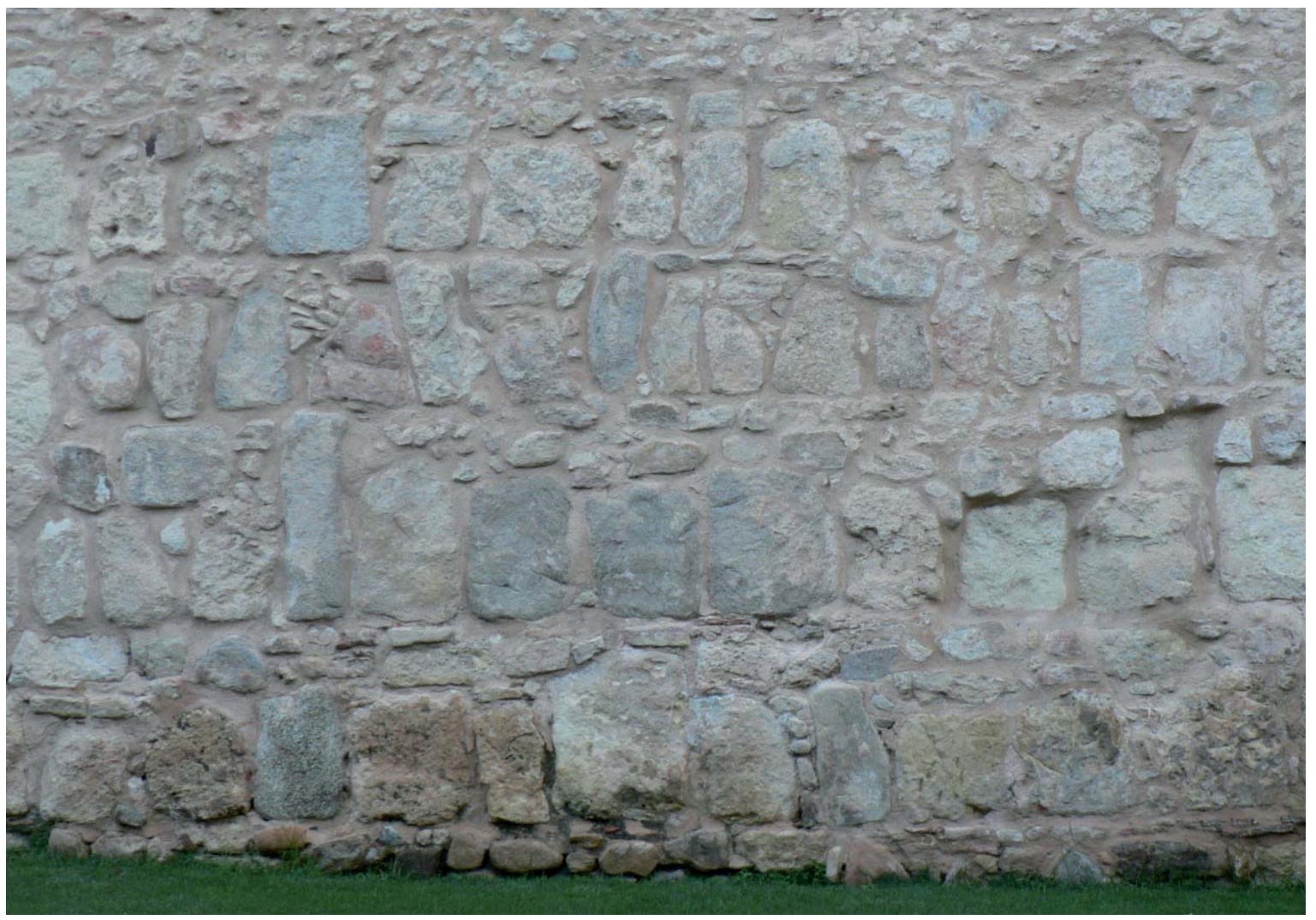

Figura 4.2. 50: L9-10. Zócalo nivelado. Posiblemente lo que vemos es una discontinuidad en la fábrica. Sus dimensiones son considerables para ser un zócalo. El zócalo, de existir, estará enterrado y lo que observamos es el lienzo que se ejecutó con este aparejo.

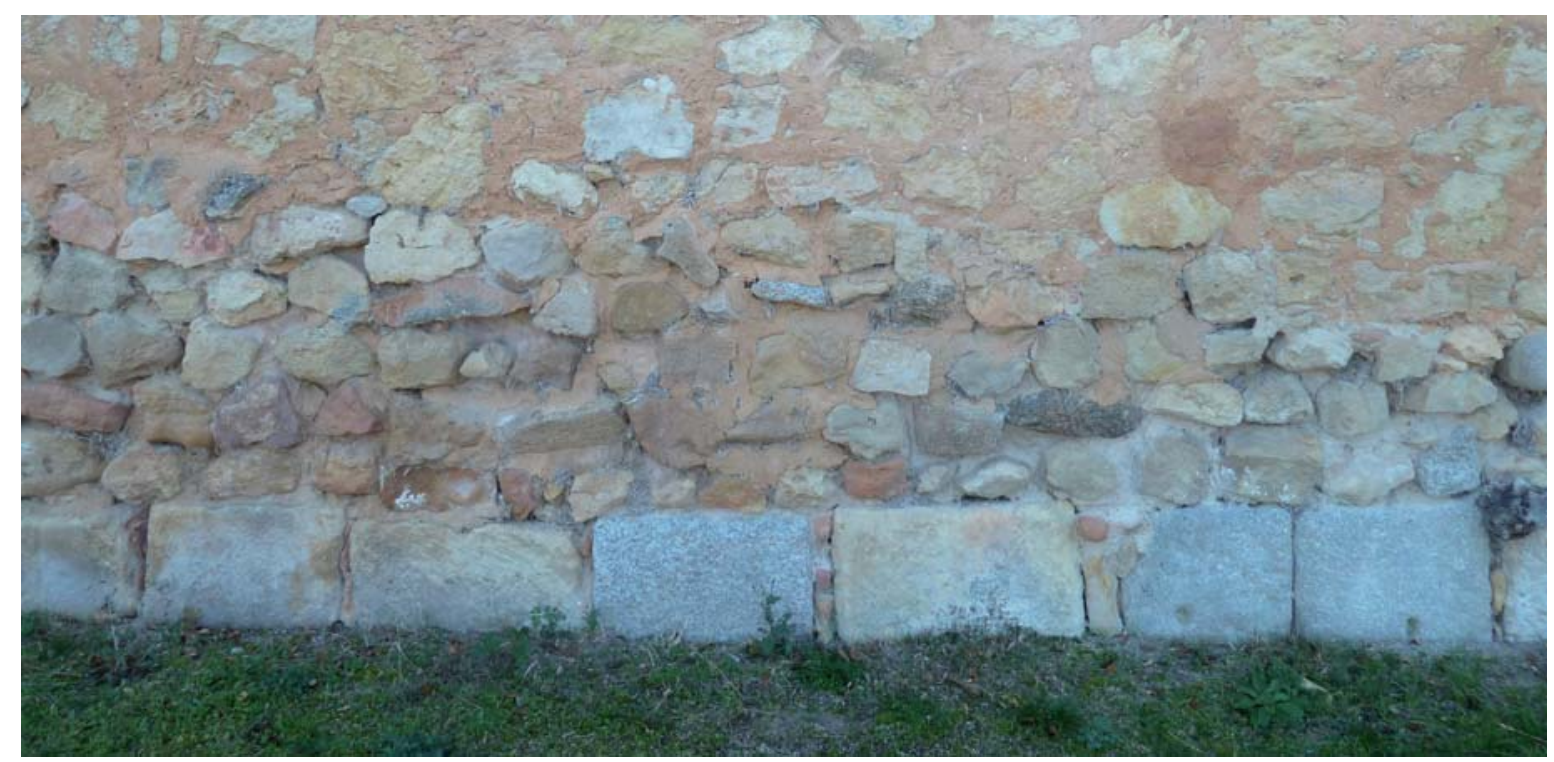

Figura 4.2. 51: L79-80: Zócalo diferenciado y nivelado, en su remate superior, aunque no observamos su apoyo sobre la roca, por estar parcialmente enterrado. 
ZÓCALO DIFERENCIADO NO NIVELADO.

Los zócalos diferenciados, que no están nivelados, se definen por el cambio de material o de aparejo. Aparecen en cinco zonas de la muralla, la zona 4, la 6, la 9, la 11 y la12.

Las características que identifican este grupo son la existencia de zócalos en los que abundan los sillares procedentes del expolio y las piezas reutilizadas de tamaño medio y grande de forma bastante regular. Se entremezclan los materiales, viéndose indistintamente piezas de granito y de piedra sedimentaria. Estos zócalos presentan un aparejo bastante descuidado, en el que a pesar de la profusión de sillares y piezas regulares, estos se emplean sin componer una sillería organizada en hiladas horizontales, sino empleando los sillares como si fuesen mampuestos, apareciendo a veces, el granito por encima de la piedra sedimentaria. En algunos casos el sillar ni siquiera apoya sobre la roca sino que existen varios mampuestos de menor tamaño debajo.
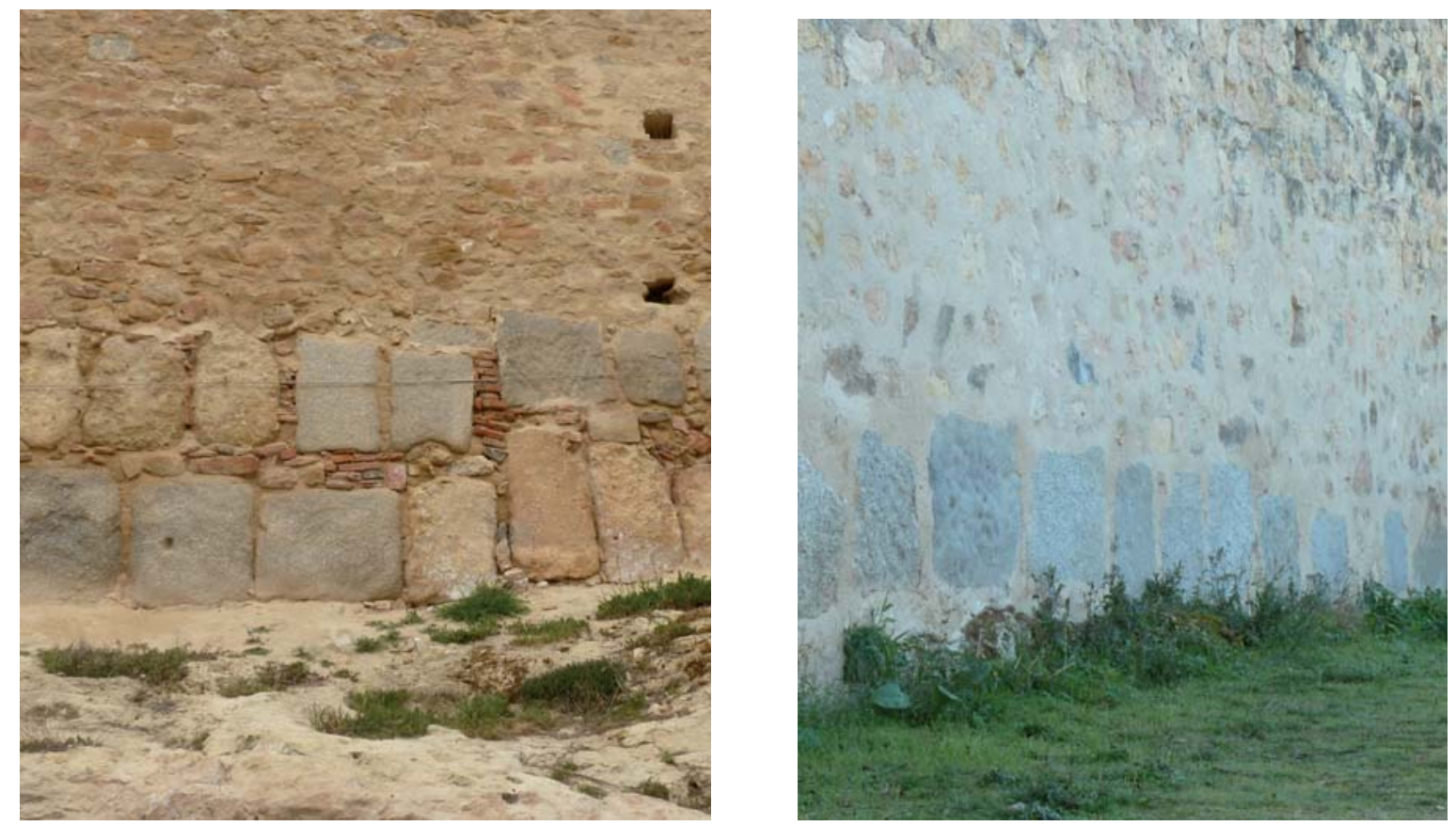

Figura 4.2. 52: L73-74: Zócalo diferenciado no nivelado. Podría haber estado nivelado porque las piezas aparentan estar removidas. Disposición entremezclada de una parte de la hilada con granito por debajo de la sedimentaria y otra parte a la inversa.

Figura 4.2. 53: L78-79: Zócalo diferenciado no nivelado. Las piezas se colocan sin un criterio constructivo, salvo levantar la fábrica de mampostería para evitar su contacto con el terreno.

Distinguimos dos soluciones, un zócalo continuo a todo lo largo del lienzo y uno que se organiza en tramos discontinuos. El primer tipo lo encontramos sólo en las zonas 6 y 12. En el segundo caso, el más frecuente, el zócalo parece estar nivelado por partes, como por módulos, que van subiendo y bajando con el perfil del terreno, en lugar de buscar la horizontal desde un extremo a otro, en lugar de crear un zócalo nivelado de torre a torre.

Podemos ver algunos tramos en los que varias hiladas se nivelan, pero el conjunto no presenta continuidad. En ocasiones el aparejo nos hace pensar que eran zócalos nivelados, como los de zona 1, pero que una reconstrucción los ha alterado parcialmente, al remover las piezas y descomponer los aparejos y los niveles de los zócalos. Pero creemos que en realidad el 
concepto es distinto al que presenta el zócalo nivelado. No se busca una base de apoyo horizontal para la fábrica de mampostería, solo una separación del terreno con piezas más grandes ${ }^{131}$. Cada pieza se coloca sin tener en consideración la adyacente. En lugar de una línea horizontal se procura una paralela al terreno. La intención no es nivelar el arranque de la mampostería, sino elevarla, evitar el contacto con el terreno.

En la zona 4 aparece un único caso, L21-22. Este lienzo tiene el zócalo parcialmente oculto y sólo se configura como diferenciado en una parte de su trazado. En ninguno de los lienzos adyacentes encontramos zócalos diferenciados, nivelados o no, sin embargo sí los encontramos en las torres de esa zona, T20, T21, T22 y T24. Si además consideramos que, según nuestra hipótesis, en esta zona falta una torre y la mayor parte del lienzo está completamente reconstruido, nos infunde la sospecha de que la existencia de este zócalo diferenciado no sea una característica de la muralla primigenia, sino más bien, los sillares provienen de la torre desaparecida y su actual disposición en el lienzo es fruto de la reconstrucción.
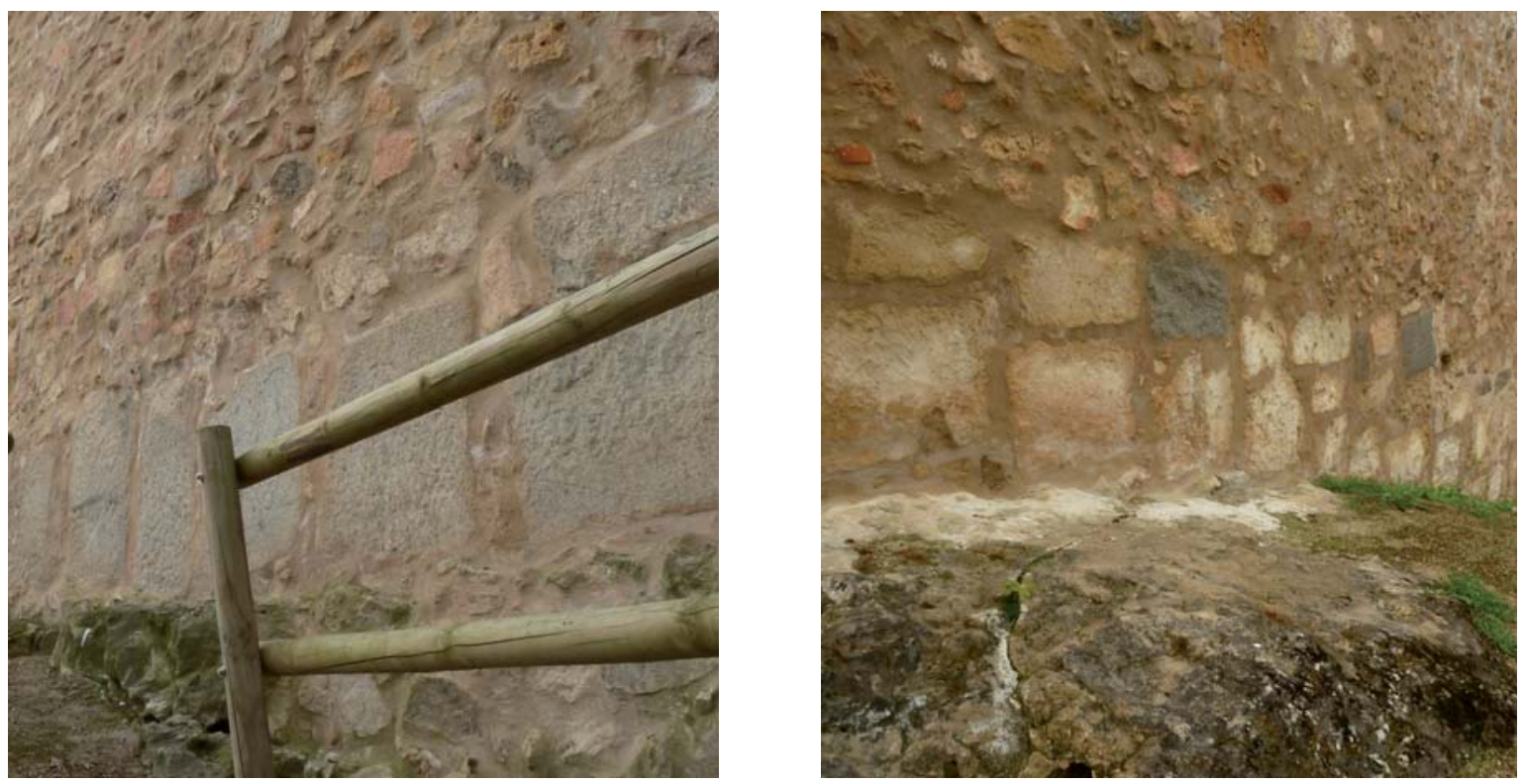

Figura 4.2. 54: L32-33. Zócalo marcado no nivelado. Las piezas se disponen adyacentes a la contigua, pero no se busca un remate de zócalo nivelado, sino más bien un remate paralelo al terreno.

Figura 4.2. 55: L37-38: Zócalo marcado no nivelado. La línea de remate del zócalo va descendiendo con el terreno formando algunos escalones.

En la zona 6 encontramos 7 casos, el L32-33, L33-34, L34-35, L35-36, L36-37, L37-38 y L3839. En todos ellos aparecen numerosas piezas de gran tamaño reutilizadas, algunas de ellas sillares, pero no se apareja como sillería. Se emplean como mampuestos mezclando indistintamente los materiales. En ninguno de ellos llegamos a ver el apoyo sobre la roca. Todos estos lienzos, presentan el zócalo parcialmente enterrado y prácticamente continuo,

131 En el apartado 4.2.5.c Sistemas constructivos, fábrica encofrada, se justificará como esta diferente configuración del zócalo creemos que está motivada por la utilización de una técnica constructiva distinta para la fábrica de mampostería que se ejecuta encima. 
desde una torre hasta la otra, pero su trazado es escalonado. Esto caracteriza a todos estos lienzos, que constituyen un grupo homogéneo.

Constatamos dos casos, el L35-36 y el L38-39, que podría tratarse de un zócalo nivelado pero no los vemos en todo su trazado, al estar una parte enterrada. Presentan el zócalo diferenciado aparentemente continuo en todo su trazado, desde una torre hasta la siguiente, pero no están escalonados, ni correctamente nivelados. Parece que se ha tirado una línea de nivelación pero con una cuerda sin tensar. La línea de remate hace ligeramente curvada, de modo que el zócalo es más bajo en el centro que en los extremos. Como puede observarse en la Figura 4.2. 56, el aparejo compuesto por piezas grandes es de muy baja calidad, por lo que no se genera un basamento intencionado, sino mas bien, expresa una voluntad de colocar en la parte inferior las piezas más grandes. Por último recordar que en el L38-39, las piezas del zócalo apoyan en una parte de su trazado sobre los restos de una fábrica previa, que consideramos musulmana.

En la zona 9 encontramos 4 lienzos, el L58-59, el L59-60, L60-61 y L61-61.' Muestra las mismas características que lo comentado en la zona 6. Hay que destacar la abundancia de sillares romanos reutilizados, claramente spolia, especialmente de piedra sedimentaria, entremezclado con granito, que posiblemente procedan del edificio romano, cuyos restos de han descubierto debajo de este lienzo.

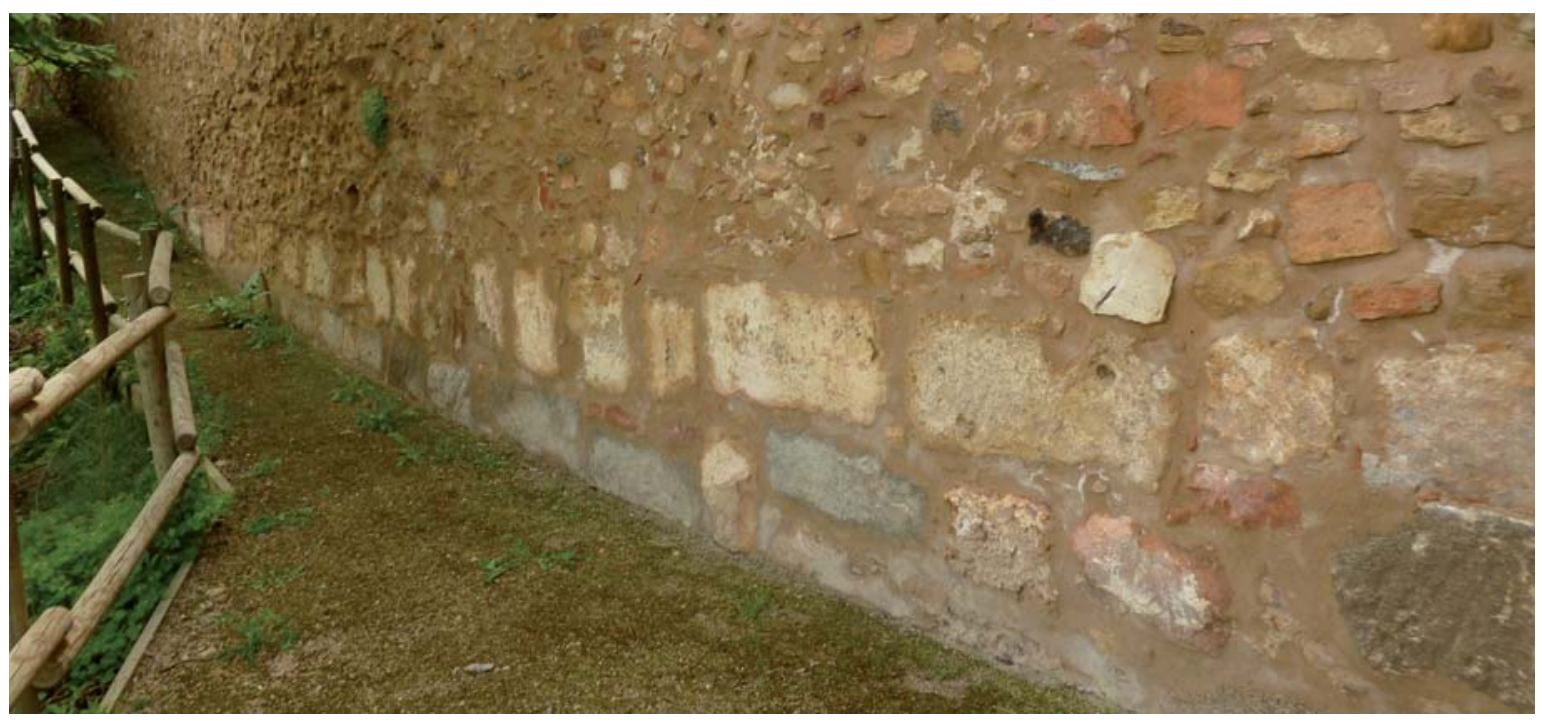

Figura 4.2. 56: L35-36. Zócalo nivelado y parcialmente enterrado, ya que no vemos el apoyo sobre la roca. Abunda la piedra sedimentaria entremezclada con alguna pieza de granito. El zócalo acaba enterrándose por lo que desconocemos si su trazado es continuo entre ambas torres.

En la zona 11 detectamos 7 lienzos, es decir todos los de la zona, que presentan zócalo diferenciado, pero no nivelado. En este caso, si que encontramos algunos lienzos que presentan el zócalo diferenciado continuo en todo su trazado, desde una torre hasta la siguiente, pero no están correctamente nivelados. Estamos ante el mismo caso de la cuerda destensada que hemos comentado en los lienzos de la zona 6. Esto ocurre con los tres más cercanos al Alcázar, L72-73, L73-74, L74-75. Podría parecer que restauraciones posteriores han remozado algunas piezas, descolocando el remate superior, pero que en origen si eran zócalos nivelados. A partir de la T76, la configuración del zócalo en los lienzos siguientes en 
dirección al Museo, L76-77, L77-78, L78-79, cambia, haciéndose discontinuo. No aparece en todo el tramo entre las dos torres y su altura es menor, reduciéndose a una única pieza de pequeño tamaño.

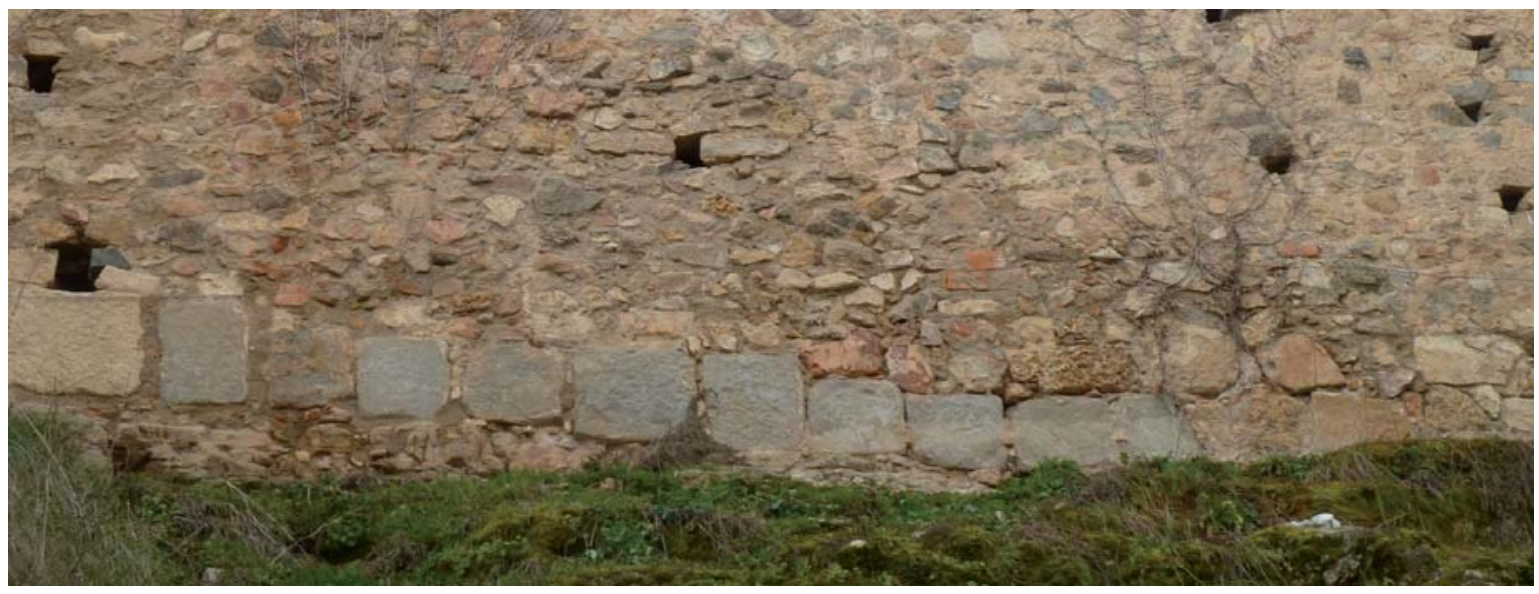

Figura 4.2. 57: L33-34: Zócalo marcado no nivelado. Las piezas se disponen como base de apoyo de la mampostería del lienzo, pero en ningún momento se busca intencionadamente crear un basamento nivelado y horizontal. El zócalo va descendiendo con el terreno adaptándose a la rasante.

En la zona 12, 4 lienzos no están nivelados. Todos ellos están parcialmente ocultos, en ninguno vemos el apoyo sobre la roca en todo su trazado y sólo observamos algunos sillares, todos ellos de granito, asomar en escasos puntos, algunos de cuyos tramos están nivelados. Por esta apariencia los incluimos en este tipo de zócalo discontinuo y no siempre nivelado, aunque con algunas dudas. Todos estos lienzos están muy renovados, el L85-86 está reconstruido completamente y el L84-85 está oculto completamente por un recalce de hormigón en la mayor parte de su trazado. El hecho de que la mitad de los lienzos de la zona sean nivelados y los otros 4 no, entremezclándose los lienzos adscritos a cada tipo, considerando esas posibles remociones de piezas que pueden haber sufrido en las restauraciones, nos hace pensar que en origen posiblemente fueron lienzos nivelados. Esto se corroborará con el análisis de otras variables.

\section{ZÓCALO INDIFERENCIADO O SIN ZÓCALO.}

Lo encontramos en todas las zonas menos en la 1, 211 y 12. La fábrica de mampostería se muestra como sistema constructivo desde el arranque en el terreno. En muchos casos, como se ha indicado, no vemos el apoyo sobre la roca, por lo que podría darse el caso de que alguno de los lienzos presentase en realidad otro tipo de zócalo, actualmente oculto.

Pero encontramos lienzos y tramos muy claros donde la roca está completamente descubierta y el zócalo se construye exactamente igual que el resto del lienzo, mampostería desconcertada, sin ninguna voluntad de diferenciar un elemento de basamento. En el tramo de lienzo L60-61 que estaba enterrado comprobamos, gracias a la excavación arqueológica (OT-189/2013-11), que la fábrica original de la muralla se ejecuta de esta manera. No se trata de una reconstrucción posterior. 

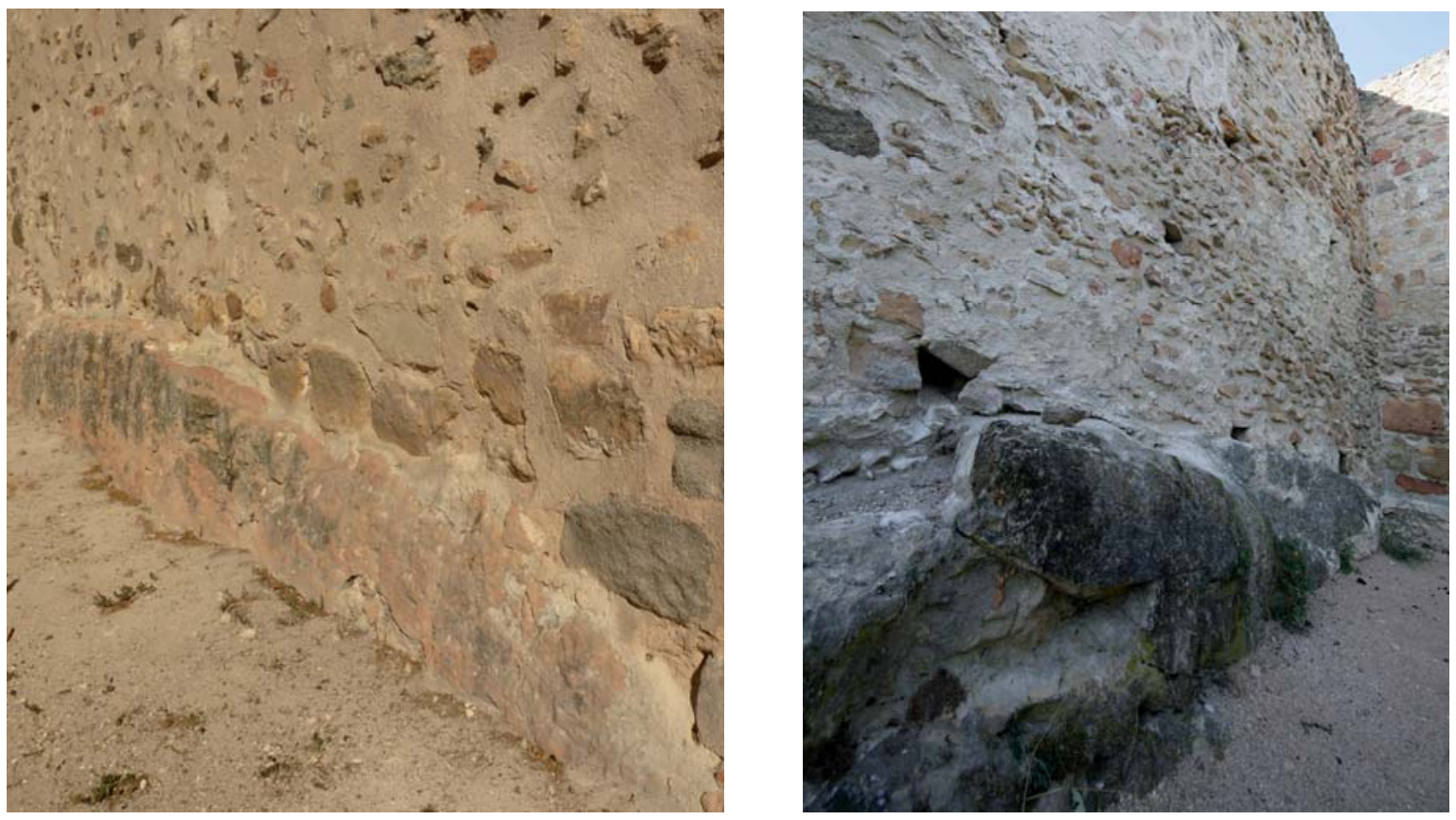

Figura 4.2. 58: L20-21: Zócalo indiferenciado. La roca tallada en vertical hace de zócalo, sobre el que apoya directamente la fábrica de mampostería.

Figura 4.2. 59: L46-46’ Zócalo indiferenciado. El muro de mampostería apoya directamente sobre la roca sin preparar.

\subsubsection{C.- ZARPAS.}

La existencia de resaltos en la verticalidad de las torres es un elemento habitual en las murallas urbanas de Repoblación, (Malalana Ureña 2009, 101) si bien, en la mayoría de los casos se trata de un resalto puntual, un basamento para diferenciar el zócalo del resto de la torre.

Sin embargo, especialmente en asentamientos en ladera y mucho más frecuente en las torres que en los lienzos, algunos arranques de las murallas desde la roca natural presentan una disposición de hiladas escalonadas, a modo de zarpas. La zarpa es un elemento considerado muy frecuente en el mundo musulmán (Pavón Maldonado 1999, 248).

En el caso segoviano encontramos el resalto del basamento constituyendo un zócalo de 2 o 3 hiladas consecutivas escalonadas muy similares a los ejemplos de la fortaleza califal de Gormaz. Juan Zozaya ya hace referencia a la existencia de zarpas en algunas de las torres segovianas, (aunque no relaciona cuantas ni cuáles) y lo considera como elemento netamente musulmán relacionándolo con las zarpas de Mérida (datado en 835 en tiempos de Abd-alRahman II) y las de las murallas del castillo de Trujillo (construidas en el siglo X, ya en época califal) (Zozaya Stabel-Hansen, 1987: 399). Esto ocurre en las torres T3, T4, y de forma menos evidente, que hayamos descubierto en la T5 y la T7. Este elemento de zarpa, que solo se había mencionado su existencia en las torres, también lo hemos localizado en el lienzo entre las torres T6 y T7, el lienzo L6-7. En este caso se trata de un fragmento de lienzo con un resto de zarpa mutilado por una intervención posterior, al empotrar en la muralla una bajante. Este es el único ejemplo de zarpa constatado en los lienzos de la muralla segoviana. 

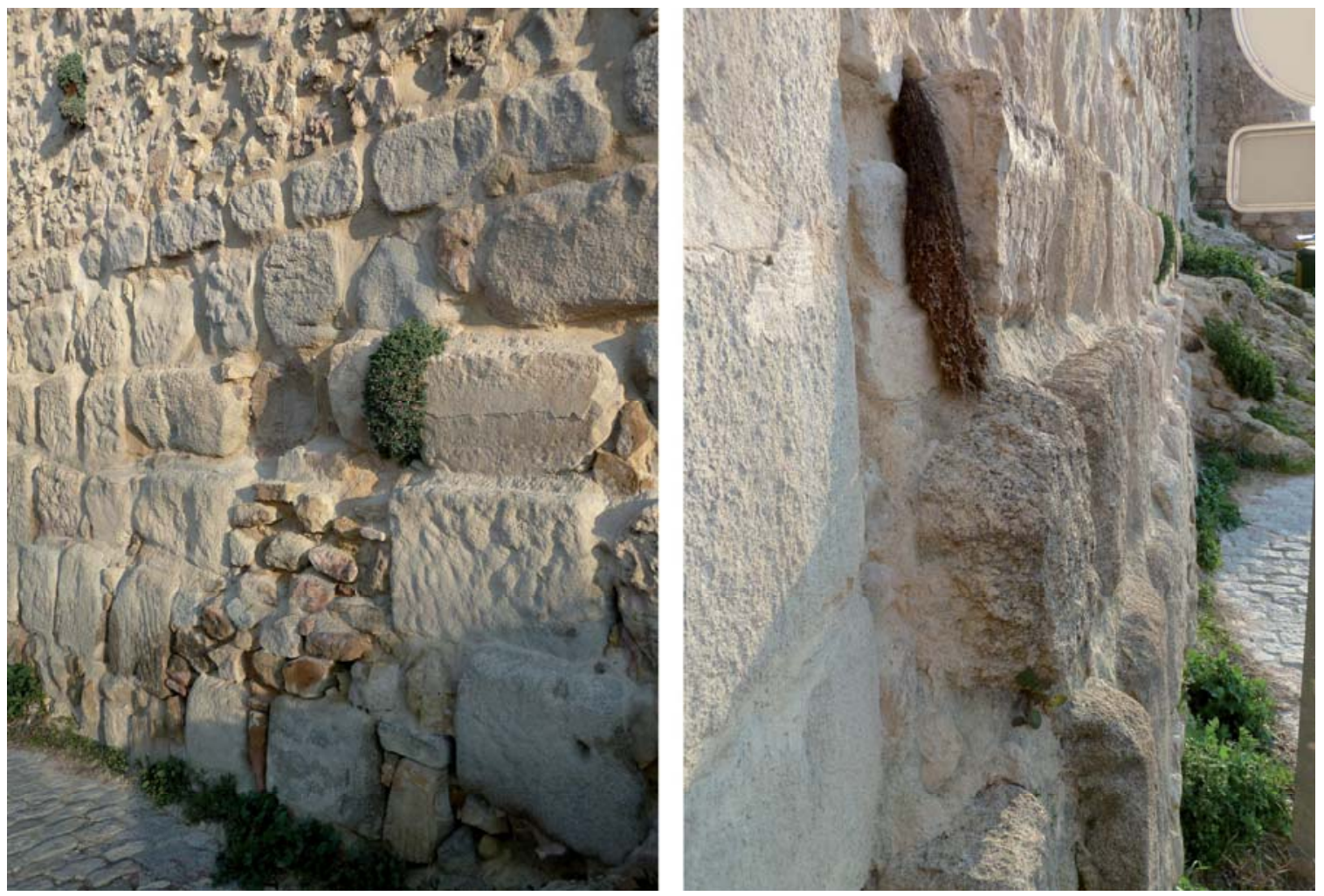

Figura 4.2. 60: Lienzo entre las torres T6 y T7. Vista lateral de los restos de una zarpa escalonada, constituida por tres hiladas de sillería de granito colocada a soga. Único caso que hemos encontrado de zarpa en los lienzos de la muralla. Este elemento se encuentra mutilado lateralmente evidenciando la discontinuidad constructiva del zócalo de la muralla.
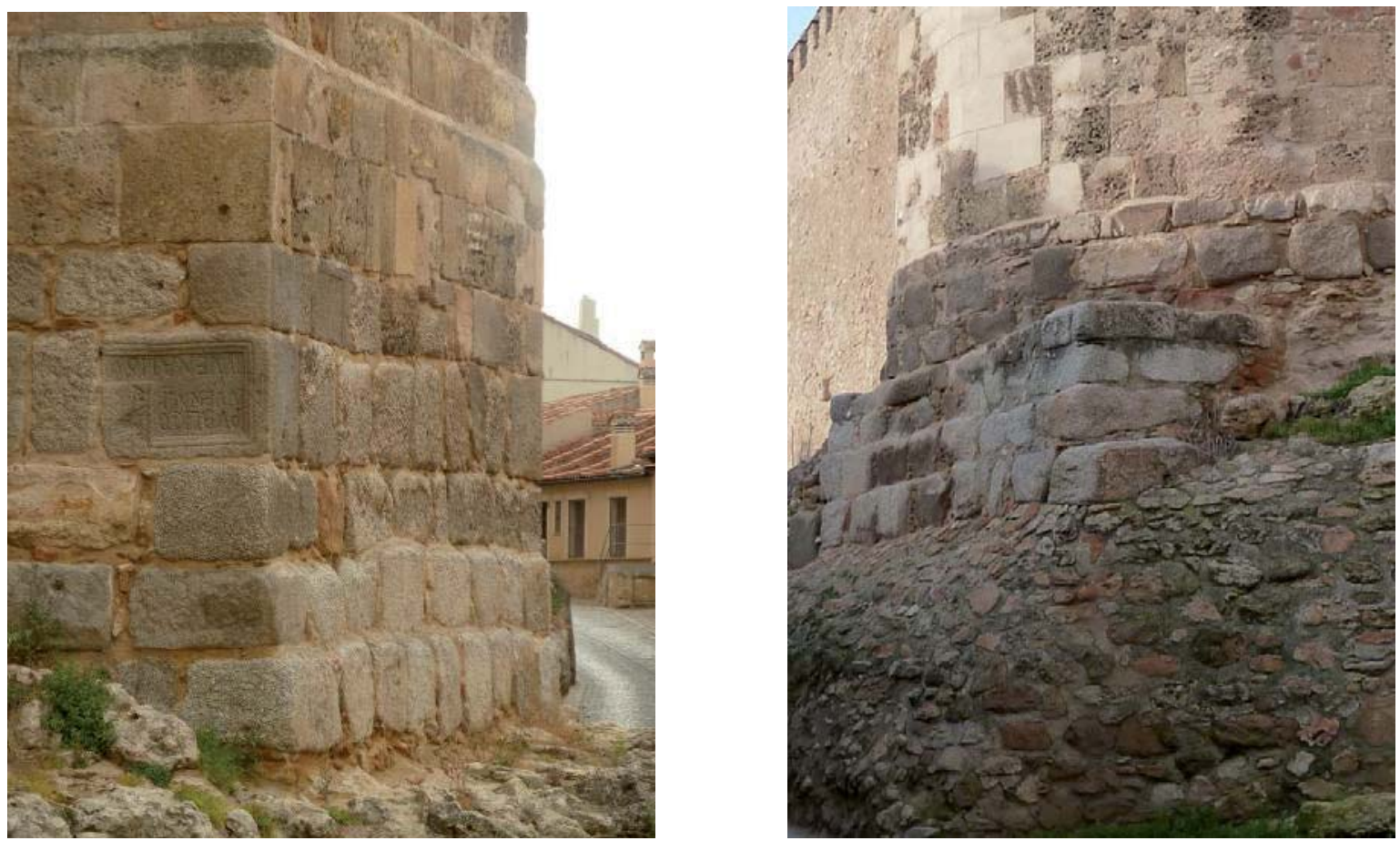

Figura 4.2. 61: Torre T3. El arranque de la torre en zarpa.

Figura 4.2. 62: Torre T4. Restos de una zarpa de planta rectangular sobre la que se ha levantado una torre de trazado poligonal. 
Sin embargo no hay unanimidad entre los autores a la hora de datar estas fábricas. Para Basilio Pavón (Pavón Maldonado, 1999, II: 239), se trata de obra cristiana, mientras para Alonso Zamora son claramente musulmanas, aunque los restos son demasiado escasos como para poder diferenciar entre emirato, califato o incluso épocas posteriores (Zamora, Vela, 2005: 1138). Estos autores las relacionan con las de Ayllón y Sepúlveda como los casos más cercanos, también en la provincia de Segovia.

La presencia de zarpas, como las aquí vistas, similares a Gormaz, Trujillo y Mérida, nos da suficiente apoyatura para partir de la premisa de que esos fragmentos son de origen musulmán.

Lo que si nos permite esta primera conclusión, es considerar que todos los fragmentos de fábricas que presentan las características constructivas de los aparejos con que se ejecutan las zarpas, diferenciándose con claridad del resto de la muralla, podemos asignarles cronologías muy cercanas o al menos la misma adscripción cultural. Por lo tanto, podemos considerar todas estas fábricas, con todas las precauciones y como primera hipótesis, como de origen musulmán y datarlas a partir de la segunda mitad del siglo IX o ya en el X. Creemos que deben ser posteriores a las de la fortaleza de Gormaz, quizá pocos años después, por lo que deberían ser de la segunda mitad del X. El estudio de los sistemas constructivos y los aparejos nos permitirá hacerlo con mayor exactitud en estadios más avanzados de la investigación.
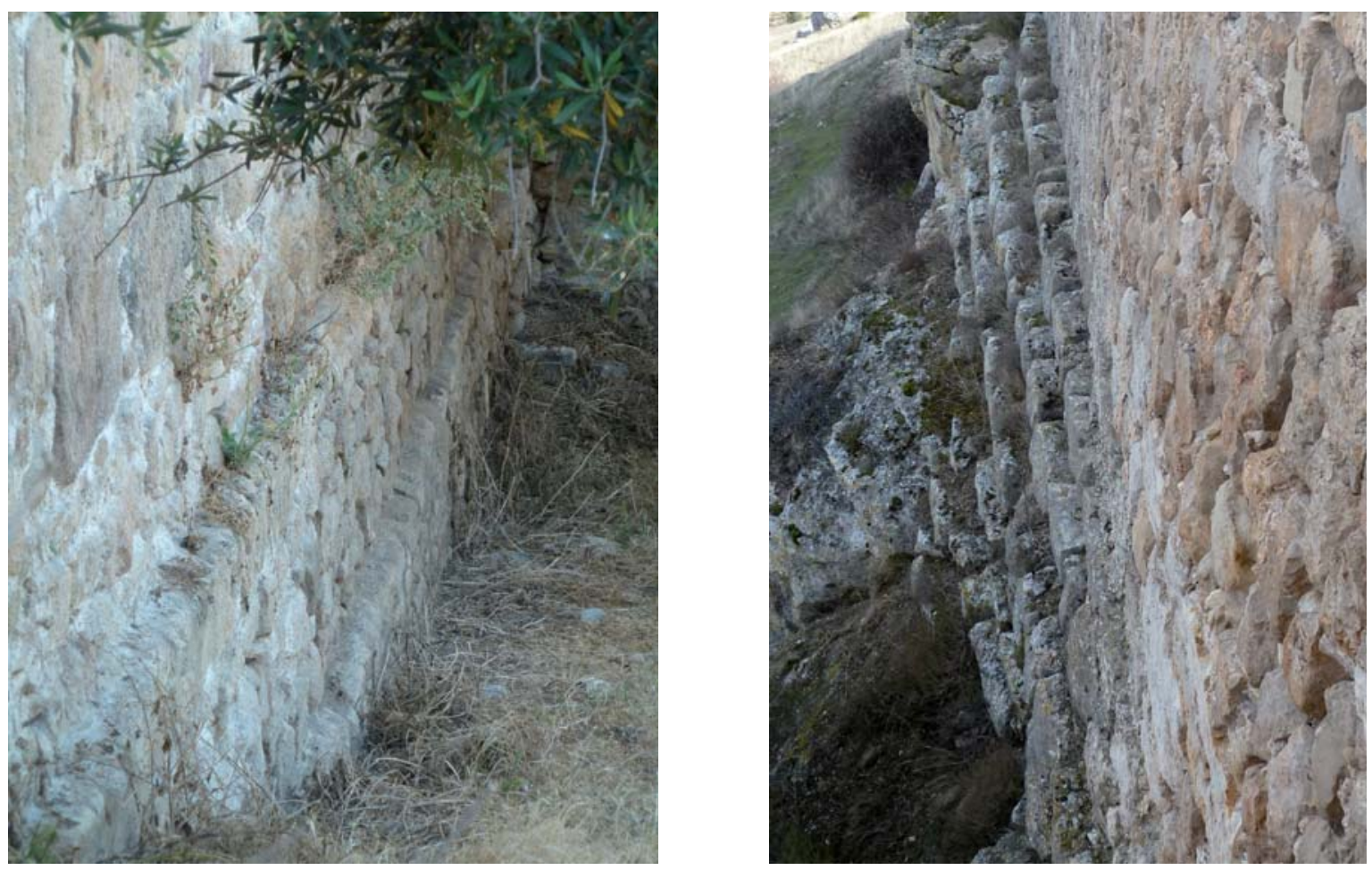

Figura 4.2. 63: Zarpa escalonada en el castillo de Trujillo.

Figura 4.2. 64: Zarpa escalonada en la base de las torres de la fortaleza califal de Gormaz. 

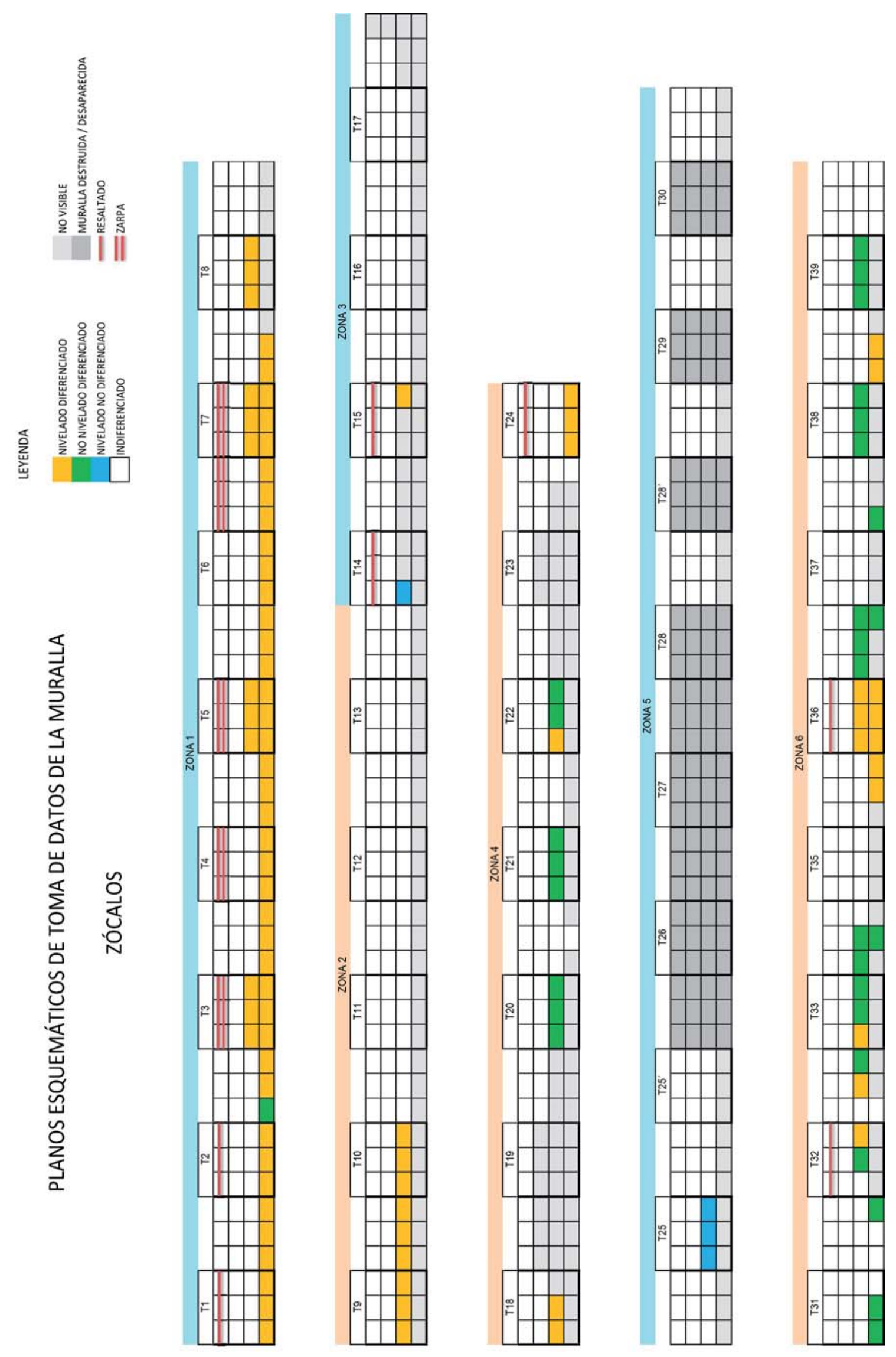

Figura 4.2. 65: Plano esquemático de la toma de datos de la muralla. Configuración de los zócalos. 


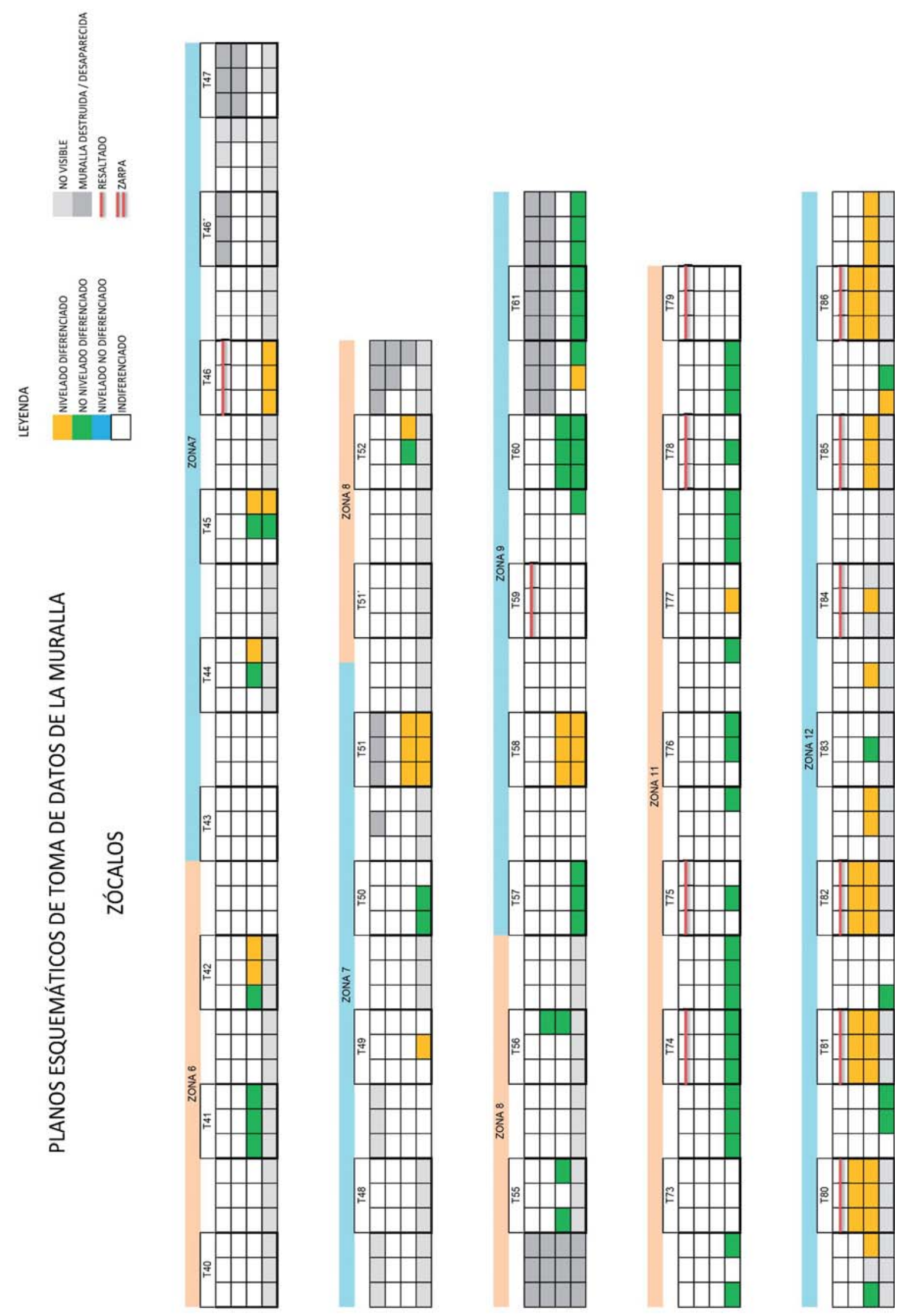

Figura 4.2. 66: Plano esquemático de la toma de datos de la muralla. Configuración de los zócalos. 


\subsection{5.- MATERIALES CONSTRUCTIVOS Y SU DISTRIBUCIÓN.}

La muralla segoviana está construida prácticamente en su totalidad en piedra. Las más abundantes son las rocas sedimentarias (calizas, dolomías, areniscas, calcarenitas, conglomerados, limolitas, etc) y los granitoides (Diez Herrero, 2007: 203-225) si bien encontramos entremezclados otros tipos de piedras (pizarras, mármoles, pórfidos, cuarcitas y gneis), la mayoría de ellas procedentes de las diversas canteras del entorno de la ciudad. Otros materiales empleados son el ladrillo, los cantos rodados, ripios, escombros y desecho de canteras del entorno. Por último y como importante elemento de estudio, destacar la presencia de abundantes lápidas funerarias procedentes de los cementerios romanos.

La mayor parte de estos materiales no va a resultar relevante para extraer conclusiones, dado que puede tratarse muy habitualmente de elementos reutilizados (mampuestos, spolia, sillares, etc) dispuestos en posición secundaria, lo que hace imposible la datación de su disposición, pues pueden haber sido recolocadas en más de una ocasión. Todos estos materiales se encuentran distribuidos por la muralla de manera bastante aleatoria, salvo algunas excepciones en cuya colocación pueden rastrearse unas pautas de composición, (véase aparejos), una lógica constructiva y unas reglas de disposición que nos permiten establecer diferencias y similitudes en el análisis pormenorizado de estas variables torre a torre y lienzo a lienzo.

En el análisis exclusivamente a nivel de presencia de los distintos materiales, tenemos otras variables que también pueden aportarnos información. Dado que la mayor parte de la muralla está construida con piedra sedimentaria, mediante una mampostería indeterminada de piezas de tamaño pequeño, las variables que nos permiten ahondar en el conocimiento de la muralla son la presencia de spolia romanas y altomedievales y el empleo de piezas de granito. En 
capítulos posteriores, atendiendo a los sistemas constructivos, prestaremos atención a la existencia de fábricas de ladrillo y de fábricas de sillería así como los distintos aparejos en que éstas se organizan.

A los objetivos de nuestro estudio, no nos van a interesar identificar perfectamente los distintos materiales empleados y conocer sus características mecánicas. El análisis de los tipos de piedra y los materiales empleados en la muralla no resulta tan revelador, como el estudio de la distribución de estos materiales por los lienzos y torres de la muralla. Dado que lo que buscamos son las posibles discontinuidades constructivas de la muralla, nos vamos a fijar en tres aspectos fundamentalmente

- la disponibilidad de material a la hora de ejecutar las fábricas,

- la distribución de los materiales empleados,

- la disposición relativa entre las distintas zonas (discontinuidades horizontales) y las diversas partes de la muralla (discontinuidades verticales).

El análisis de estas tres variables lo centraremos principalmente en los dos materiales indicados al ser los más excepcionales, spolia y granito.

La disponibilidad de abundante material permite el empleo homogéneo del mismo, mientras una escasez de medios conlleva una mezcla de piezas, utilizando todo aquello disponible, empleando piezas más pequeñas y aparejos de menor calidad. Es evidente que la abundancia de spolia va a ser más significativa en las obras de los tiempos más antiguos que en los más recientes, ya que el saqueo de edificios, ruinas y cementerios agota la disponibilidad de estas piezas, que no se "regeneran". Existen otras spolia, datables después de 1088, que es la fecha de referencia de la construcción de la muralla de Repoblación de Alfonso VI, por lo que es fundamental diferenciar dentro del grupo de las spolia, las antiguas, romanas y altomedievales, de las que encuadramos en la etapa bajomedieval, moderna y contemporánea. Su significado es totalmente contrapuesto y pueden ayudarnos a datar las intervenciones.

Esto nos permitirá intuir posibles reconstrucciones de tramos derruidos en las que existe poco material reutilizado o todo lo contrario, tramos de muralla en los que se engloban partes de cercas preexistentes correspondientes a cronologías anteriores, en las que había una mayor disponibilidad de ese material de expolio.

La distinta presencia de piezas dentro de un mismo sector, salvo las diferencias de sensatez constructiva entre las torres y los lienzos, difícilmente puede deberse a un capricho contrario a la lógica constructiva, sino que creemos es motivado por la disponibilidad de dichos materiales en las diferentes etapas constructivas de la muralla.

En una obra de conjunto y planificada, los materiales se colocan de una manera ordenada, intentando aprovechar las mejores cualidades de cada material. Así, la lógica constructiva lleva a disponer las piezas más grandes y pesadas, como el granito, en las partes bajas, o a reservar los sillares y piezas regularizadas para las esquinas de las torres. Frente a este orden razonado que reconocemos en algunas partes de la muralla, encontramos otras distribuciones de materiales que contravienen esta lógica constructiva. Por este motivo resulta de especial 
importancia el estudio de la distribución de los materiales, diferenciando claramente entre los materiales que se disponen en las partes bajas y las partes altas.

Igualmente el modo de cómo se disponen éstas, constituyendo una fábrica homogénea o lo inverso, formando una fábrica heterogénea de materiales entremezclados puede ser orientativo de una fábrica ejecutada con mayor disponibilidad frente a otra ejecutada entremezclando materiales diversos. Así por ejemplo en los zócalos circulares de las torres poligonales se constata mezcla del granito con la roca sedimentaria, mientras en las torres de planta rectangular próximas, el zócalo se ejecuta todo en granito y la roca sedimentaria se emplea en la parte superior. Claramente nos está indicando una diferente disponibilidad de material y unas consideraciones constructivas cambiantes.

En el caso de derrumbes, el material de la parte alta de la fábrica original, queda por encima y el de la parte inferior queda abajo, enterrado. Esta afirmación tan obvia es importante, dado que en las reconstrucciones, vemos como la reutilización del material del derrumbe, supone que el disponible para ejecutar la parte inferior de la nueva obra es el que se sitúa en la parte alta antes del derrumbe y viceversa, por lo que las partes reconstruidas, en muchos casos, se caracterizan por la disposición de los materiales en el orden inverso al que se realiza en las partes originales. De este modo, la diferente disposición de los materiales en unas torres o lienzos respecto a lo que se observe en los adyacentes será un claro indicio de una discontinuidad constructiva.

El hecho de realizar en ámbitos tan próximos dos fábricas tan distintas, como por ejemplo no emplear hilada de arranque en la base, frente a la ejecución de varias hiladas continúas, nos indica un cambio de criterio constructivo que nos hace sospechar en la diferente factura ( $\mathrm{y}$ posiblemente también cronología) de los tramos que presentan estas diferencias.

La misma comparativa podemos realizar entre dos torres contiguas, cuando en una torre encontramos varias hiladas de sillería reaprovechada y en las torres adyacentes no existe ninguna o muy pocas o entremezclándose con otros tipos de piedra, como por ejemplo la torre T6. La sospecha inmediata es que esa torre es muy probablemente fruto de una reconstrucción posterior. (Ver Figura 4.2. 71).

Las diferencias que detectamos en relación con estos aspectos, nos van a permitir localizar las discontinuidades e identificar las características de cada una de estas fases de ejecución, que posteriormente ampliaremos y concretaremos con el estudio de los sistemas constructivos y los aparejos empleados y con ello reconocer la secuencia lógica de disposición de los materiales en las torres y lienzos de la muralla, lo que a su vez nos va a llevar a diferenciar las reconstrucciones posteriores de la fábrica original.

\subsubsection{A.- GRANITO.}

El granito se emplea de forma masiva en la construcción en la ciudad de Segovia en tres momentos históricos, la etapa romana, en torno a finales del siglo XV y principios del XVI y a partir del XIX, cuando se empiezan a explotar unas canteras nuevas en San Lorenzo-Sotillo, que no se habían explotado antes, de las que sale el granito gris azulado, claramente distinguible de los granitos anteriores (PH: P0178). Según eso, todos los granitos azulados son del siglo XIX o posteriores. Sin embargo la mayoría de los granitos romanos que encontremos 
pertenecen a las canteras de San Lorenzo y la Lastrilla (Diez Herrero, 2007, I: 215). Este es un primer dato que nos permite la datación de las distintas fábricas de granito, en función de la cantera de procedencia.

El granito, si bien aparece de forma minoritaria en prácticamente todas las ubicaciones de la muralla, su uso más frecuente lo encontramos principalmente en las partes bajas, constituyendo un zócalo asentado sobre la roca, en el que se apoya el resto de la construcción. En la mayor parte de los casos, sobre este granito, encontramos la fábrica de piedra sedimentaria. Cuando hemos encontrado piezas de granito de forma numerosa en las partes altas, se trata de partes reconstruidas o reparadas. En las zonas derruidas, que se ha perdido el paramento exterior y queda visto la mampostería interior de la muralla, nunca hemos visto piedra granítica en el relleno.

En la zona 1, Leopoldo Moreno, encontramos granito muy abundante en los zócalos de todas las torres y en los lienzos, especialmente en las torres T1, T2, T3, T5, donde no aparece mezclado con ningún otro material. Posiblemente sea la zona de la muralla donde mayor cantidad de granito encontramos, todo ello, siempre en los zócalos. En la T4, T6 y T7 aparece mezclado con piedra sedimentaria. En la T8, ya no lo observamos, al estar los zócalos enterrados.

En la zona 2, correspondiente al Salón, los zócalos están enterrados, por lo que desconocemos si existe granito en el apoyo sobre el terreno. Encontramos granito en las jambas del postigo del Sol, rehecho a finales del XX cuando se recuperó este postigo, y también en los muros bajo la sinagoga entremezclado con piedra sedimentaria, aunque en un porcentaje poco representativo. En el resto de los lienzos, el revoco, oculta los paramentos.
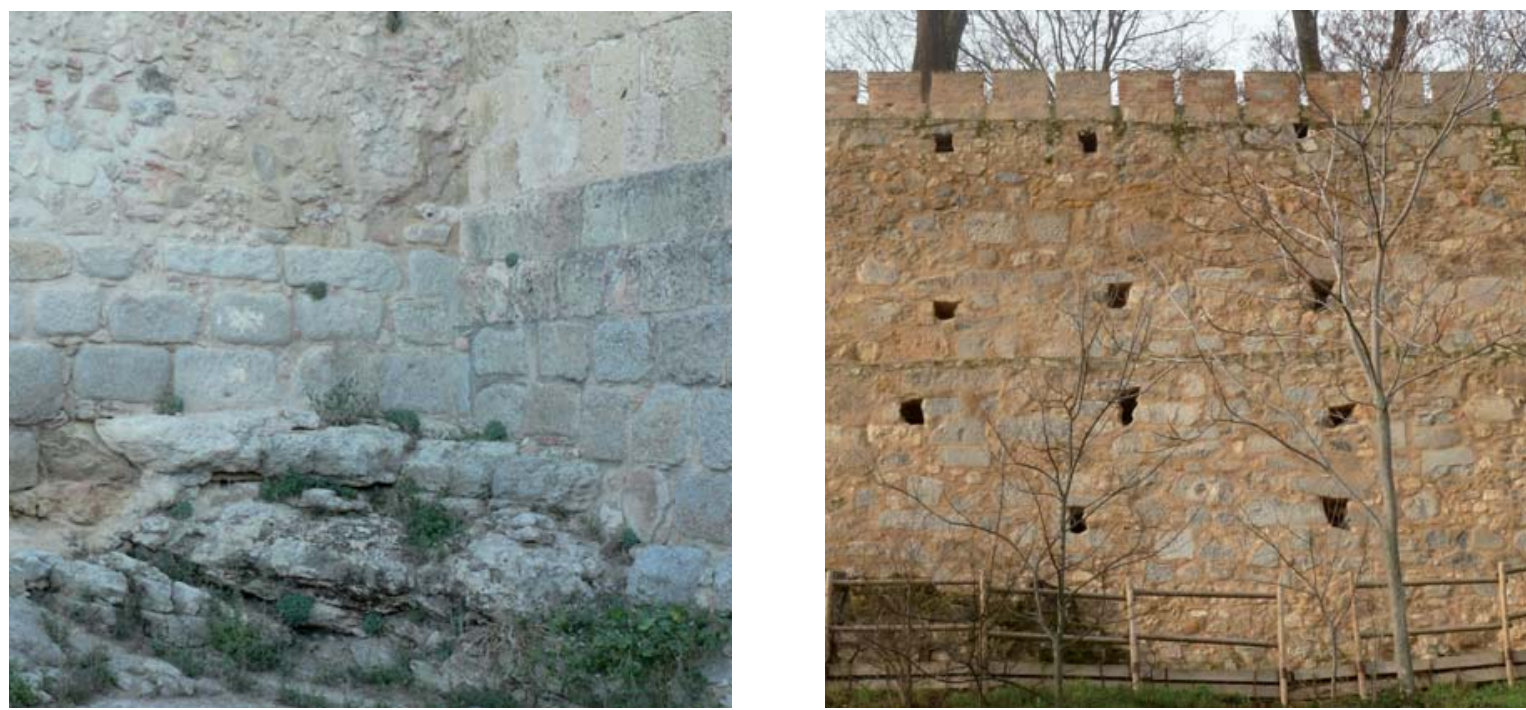

Figura 4.2. 67: Torre T5. Encuentro de la torre con el lienzo. El granito constituye un zócalo de entidad tanto en el lienzo como en la torre. Aparece sin mezclar y sólo en el zócalo.

Figura 4.2. 68: Lienzo L29-30. El granito se distribuye homogéneamente por la fábrica, predominando en las partes medias del lienzo, cuando no existe zócalo de dicho material. Se trata de un lienzo reconstruido totalmente, desde la base. 
En la zona Santa Cruz, zona 6, encontramos una distribución del granito un tanto irregular. Junto a lienzos y torres donde aparece de forma significativa, hay lienzos y torres adyacentes donde no hay prácticamente nada, tan solo alguna pieza esporádica. Abunda más en los zócalos de las torres que en los de los lienzos. En las torres T32 y T38 lo vemos hasta la mitad de la altura de la torre, entremezclado con piedra sedimentaria. En las demás sólo algunas piezas en los zócalos, excepto en la T39 y T40 en que no lo hemos detectado. Por el contrario en los lienzos lo vemos escasamente en los zócalos, excepto en L34-35 que está repartido uniformemente en toda la altura de la fábrica entremezclado con piedra carbonatada, lo que evidencia la completa reconstrucción de este lienzo. En otros casos, como L30-31 y L39-40 no advertimos ninguna pieza o se utiliza exclusivamente para la realización de unos arcos de descarga embebidos en la mampostería como en el L40-41. Por lo tanto en los lienzos solo aparece mínimamente, de forma más apreciable en partes reconstruidas que asciende hasta la mitad de la altura, entremezclado con piedra carbonatada. Más abundante en las torres, no llega a constituir fábricas de entidad significativa en los zócalos, como hemos visto en la zona 1. Contradictoriamente es más abundante en las torres reconstruidas, que lo muestran hasta bastante altura, entremezclado con otros materiales.

En la zonas 7 y 8, apreciamos que en los zócalos de los lienzos no existe granito en ningún caso. Tan solo es abundante en los lienzos y partes que han sido reconstruidas, en los que aparece en las partes altas y entremezclado con piedra sedimentaria, como en el L44-45, en la parte aplomada del L46-46' así como en L46'-47. En el resto de los lienzos, sólo aparece alguna pieza esporádica. Se trata de piezas de poco tamaño, recolocadas en alguna reparación, no ejecutadas simultáneamente con el resto de la fábrica. En las torres encontramos el granito de forma un poco más habitual, especialmente en las esquinas de los zócalos. Al igual que en los lienzos, aparece de forma más frecuente en las torres reconstruidas, en las que se emplea entremezclado de forma homogénea con piedra sedimentaria y ladrillo, hasta la mitad de la altura de la torre, como en T45, T46' y T47. Tan solo la T50 y T51 presentan zócalo claramente constituido por granito. Las demás torres, T46, T48 y T49 prácticamente no muestran ninguna pieza de granito.
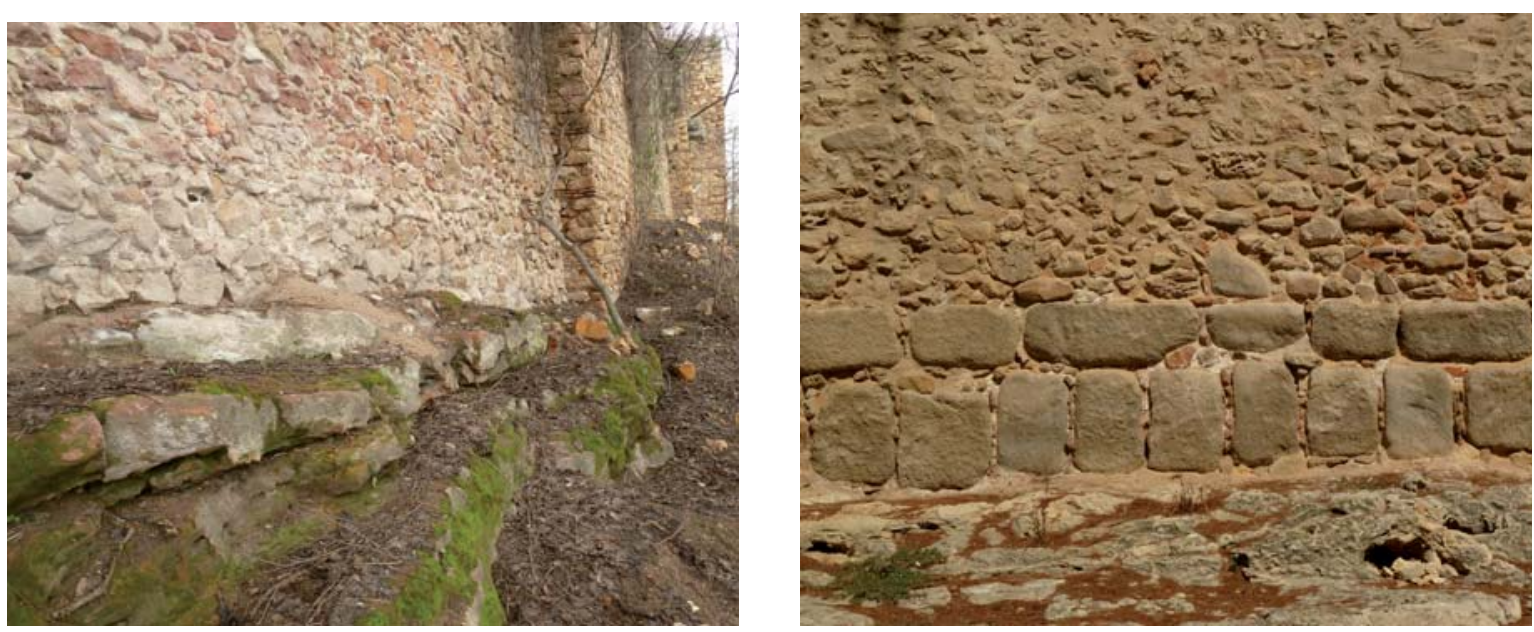

Figura 4.2. 69: Lienzo L49-50. En la zona 7 no existe ningún tipo de zócalo de granito. Este material se emplea escasamente. La práctica totalidad de la fábrica se realiza en piedra sedimentaria. El granito de aparecer se emplea entremezclado, sin constituir aparejos diferenciados.

Figura 4.2. 70: Lienzo L5-6. Granito constituyendo un zócalo en lienzo. 
En la zona 11, el zócalo se ejecuta en todos los lienzos con piezas de granito, en algunos casos mezcladas con piedra sedimentaria. Son piezas de tamaño medio grande. Existen zonas donde la fábrica de roca sedimentaria apoya directamente sobre la roca. Cuando hemos encontrado piezas de granito en las partes altas de los muros, coincide con partes reconstruidas o reparadas, como por ejemplo en L73-74 donde encontramos spolia modernas, piezas de granito talladas datables a partir del siglo XV, embebidas en la mampostería con que se ejecuta la parte más alta del lienzo, que es fruto de una reconstrucción del siglo XX (AGA: 70.737). Vemos también numerosas piezas de granito en las partes altas en los lienzos L73-74 y L74-75, fruto de las mismas intervenciones que se efectuaron sobre esta zona (IPCE: PI 611.03; IPCE: PI 611.04; IPCE: PI 611.05 y IPCE: PI 611.06). Observamos mayor abundancia de granito en los zócalos de los lienzos y torres entre las torres T73 y la T76, que desde ésta hasta la T80. Curiosamente en esta zona, el granito es más abundante en los lienzos que en las torres, dándose el caso de que este material solo aparece de modo testimonial, como en las torres T73, T75, T78 y T79. Con zócalo claramente constituido de granito, si bien no es el material exclusivo sino que aparece mezclado, sólo vemos las torres T74, T76 y T77. Esto hace patente lo alterado de estos lienzos y torres a lo largo de los siglos.

En la zona 12, Hontanilla-Museo, el granito se encuentra en las partes bajas, a modo de zócalo en todas las torres y contrariamente al caso anterior es menos abundante en los lienzos. Especialmente escaso en los lienzos L81-82, L83-84, L84-85. En las torres T80 y T81, el granito del zócalo aparece mezclado con piedra sedimentaria.

En el resto de la muralla, al tratarse de zonas muy reconstruidas, zonas 3, 4, 5 y 9, lo observamos sólo de manera muy secundaria, mezclado con la piedra sedimentaria y en las partes altas de los lienzos. Prácticamente no existe un zócalo diferenciado de piezas de granito en ningún punto de estas zonas. En la zona 3, alhóndiga, no parece ni en lienzos ni torres, solo en las jambas del postigo de la Luna y en las piezas de ménsula de la Alhóndiga, donde apoyaría el posible cuerpo volado. En la zona del acueducto lo vemos en la T18 en el zócalo, aunque mezclado y en la T22. En el resto de los lienzos vemos algún mampuesto suelto en los petos y almenados, pero de manera testimonial y sin constituir una fábrica, siempre mezclado con sedimentaria y a veces también con ladrillo. En la zona 9, tan solo en la torre T58 lo vemos constituir un zócalo de entidad. Abunda en la T60 pero muy disperso y entremezclado con la piedra sedimentaria hasta bastante altura, en lugar de agruparse en el zócalo. En los lienzos vemos algunas partes donde varias piezas consecutivas forman un zócalo diferenciado, como en L60-61, pero parecen haber sido recolocadas, mientras en las demás sólo aparecen algunas piezas sueltas de forma esporádica principalmente en los zócalos, como en L57-58 y L59-60 o bien abundantes piezas en las partes altas, muy mezclado con la piedra sedimentaria, como en la parte central de L58-59, lo que demuestra esa parte también esta reconstruida.

Para el estudio de la distribución del material de granito en las distintas partes de la muralla hemos considerado tres opciones, cuando

- el granito es el material predominante,

- el granito está mezclado con otro tipo de piedra,

- encontramos granito de la variedad gris azulado. 
El primer caso evidencia una amplia disponibilidad de material de granito durante la ejecución de las obras. En estos casos encontramos aparejos de sillería relativamente bien ejecutados. La construcción de fábricas homogéneas, nos constata un carácter y una voluntad de conjunto. Suponemos que se trata de intervenciones de mayor envergadura. En el segundo caso el granito aparece entremezclado otros tipos de piedra, generalmente sedimentaria. Esto genera fábricas heterogéneas, que nos hacen sospechar que se trata de una intervención parcial, ya que existe una menor disponibilidad de material, una reparación que reutiliza los restos disponibles, posiblemente de un derrumbe previo. El tercer tipo, la aparición de granito gris azulado, evidencia que se trata de una reconstrucción de los siglos XIX o XX. Este dato nos permite datar los elementos en que hallemos esta variedad de piedra, como reconstrucciones de los últimos 200 años.

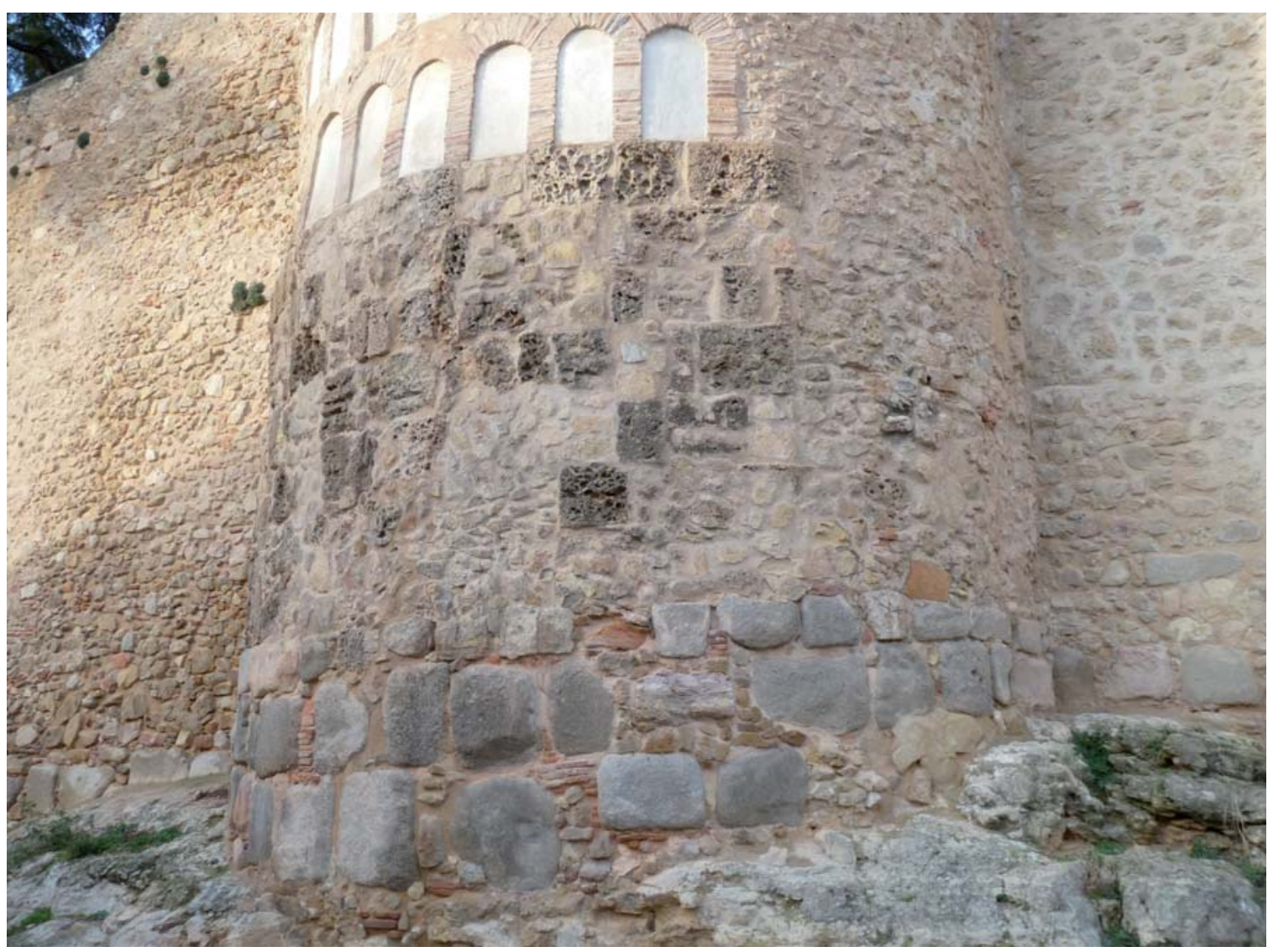

Figura 4.2. 71: Torre T6. Torre de trazado poligonal sobre zócalo de forma semicircular. Observamos la secuencia de disposición de materiales, habitual en la muralla. Granito en el zócalo, sedimentaria en la parte central y ladrillo con sedimentaria en la coronación. El zócalo se realiza en piezas de granito, algunas de ellas sillares, toscamente aparejadas. Se aprecia la mezcla de distintos tipos de piedra, lo que denota una menor disponibilidad de granito en comparación con los zócalos de las torres y lienzos contiguos. La reutilización de todo el material disponible, incluso piezas de geometría poco regularizada, produce aparejos de baja calidad, en claro contraste con las torres adyacentes.

El granito aparece como material predominante en los zócalos de las zonas 1, 6, 11 y 12, según puede verse en la tabla Figura 4.2. 72 y Figura 4.2. 73. Está presente en el mismo número de torres que de lienzos. Sin embargo, mezclado con otros tipos de piedra, se muestra con mayor asiduidad en las torres que en los lienzos, 49 frente a 25. 
Por otra parte su presencia en las partes altas, tanto de torres como de lienzos, es muy poco significativa, pero de gran interés para nuestro estudio. La existencia de granito en las partes altas nos evidencia que se trata de un elemento reconstruido, parcialmente si sólo lo encontramos en las partes altas, o puede tratarse de una reconstrucción total del elemento si el aparejo no nos denota la discontinuidad entre las fábricas.

\begin{tabular}{|c|c|c|c|c|c|c|c|}
\hline \multirow{2}{*}{ ZONA } & \multicolumn{3}{|c|}{ ZOCALOS } & \multirow{2}{*}{ No TOTAL } & \multicolumn{3}{|c|}{ PARTES ALTAS } \\
\cline { 2 - 4 } \cline { 6 - 8 } & PREDOMINA & MEZCLADO & $\begin{array}{c}\text { GRIS } \\
\text { AZULADO }\end{array}$ & TORRES & PREDOMINA & MEZCLADO & $\begin{array}{c}\text { GRIS } \\
\text { AZULADO }\end{array}$ \\
\hline \hline 1 & 6 & 2 & - & $\mathbf{8}$ & - & - & - \\
2 & - & 3 & - & $\mathbf{5}$ & - & - & - \\
3 & - & 1 & - & $\mathbf{4}$ & - & 1 & - \\
4 & 3 & 3 & - & $\mathbf{7}$ & - & 1 & - \\
5 & 1 & 2 & 1 & $\mathbf{2}$ & 2 & 2 & 1 \\
6 & 3 & 8 & - & $\mathbf{1 2}$ & 1 & 3 & - \\
7 & 2 & 9 & 1 & $\mathbf{9}$ & - & 3 & 1 \\
8 & - & 5 & - & $\mathbf{5}$ & - & 1 & - \\
9 & 2 & 3 & 1 & $\mathbf{4}$ & - & - & - \\
10 & - & - & - & - & - & - & - \\
11 & 3 & 8 & 1 & $\mathbf{8}$ & - & 1 & - \\
12 & 5 & 5 & - & $\mathbf{7}$ & - & - & - \\
\hline \hline SUMA & $\mathbf{2 5}$ & $\mathbf{4 9}$ & $\mathbf{4}$ & $\mathbf{7 1}$ & $\mathbf{3}$ & $\mathbf{1 2}$ & $\mathbf{2}$ \\
\hline
\end{tabular}

Figura 4.2. 72: Tabla resumen de la presencia de piezas de material de granito en las torres de la muralla.

Esto ocurre por ejemplo en las torres T25, T25' y T38. Son los tres casos en que el granito predomina en las partes altas de las torres, las dos primeras en zona 5 y la tercera en zona 6. En el caso de los lienzos, el granito predomina en las partes altas en 4 casos, L28-L29, L29-30, L34-35 y L46-46.' En la zona 2, los lienzos L8-9 y L9-10; en la zona 3 L16-17 y T16, en la zona 4, L22-23 y T24; en la zona 5, L28-30; en la zona 6, L34-35 y T33, T38 y T42; en la zona 7 T45, T46', T50 y el lienzo L46-46'; en la zona 8 'T52 y en la zona 11 la T74. Todos ellos, torres y lienzos son elementos reconstruidos, parcial o totalmente.

Así encontramos granito gris azulado en las partes bajas de la zona 5 en la T25 y en el lienzo L 29-30; en la zona 7 en T45 y el lienzo L46'-47; en la zona 9 en la T59 y en la zona 11 en la T75. Todos ellos son, por lo tanto, elementos reconstruidos totalmente, desde sus apoyos sobre la roca, a partir del siglo XIX. Descubrimos granito gris azulado en las partes altas de las zonas 4, en el L22-23, en la zona 5 en T25'y en el lienzo L28-30, en la zona 7 en L46-46' y T46', en la zona 9, L57-58 y en la zona 12 el lienzo L85-86, por lo que todos estos elementos son reconstruidos, en principio sólo parcialmente.

La identificación de estos elementos reconstruidos nos va a permitir asociar los aparejos de estas fábricas no históricas, lo cual será de gran utilidad en los capítulos sucesivos, 4.2.5 y 4.2.6 para datar los aparejos de la muralla. 


\begin{tabular}{|c|c|c|c|c|c|c|c|}
\hline \multicolumn{8}{|c|}{ GRANITO EN LIENZOS } \\
\hline \multirow[b]{2}{*}{ ZONA } & \multicolumn{3}{|c|}{ ZOCALOS } & \multirow{2}{*}{$\begin{array}{l}N^{0} \text { TOTAL } \\
\text { LIENZOS }\end{array}$} & \multicolumn{3}{|c|}{ PARTES ALTAS } \\
\hline & PREDOMINA & MEZCLADO & $\begin{array}{c}\text { GRIS } \\
\text { AZULADO } \\
\end{array}$ & & PREDOMINA & MEZCLADO & $\begin{array}{c}\text { GRIS } \\
\text { AZULADO } \\
\end{array}$ \\
\hline 1 & 7 & - & - & 7 & - & - & - \\
\hline 2 & - & 1 & - & 5 & - & 2 & - \\
\hline 3 & - & - & - & 5 & - & 1 & - \\
\hline 4 & - & 1 & - & 6 & 1 & 1 & 1 \\
\hline 5 & - & 2 & 1 & 4 & 1 & 1 & 1 \\
\hline 6 & 2 & 9 & - & 13 & 1 & 1 & - \\
\hline 7 & - & 3 & 1 & 9 & 1 & 4 & 1 \\
\hline 8 & - & - & - & 5 & - & 2 & 1 \\
\hline 9 & 1 & 3 & - & 6 & - & 1 & 1 \\
\hline 10 & - & - & - & - & - & - & - \\
\hline 11 & 7 & 6 & - & 7 & - & 2 & - \\
\hline 12 & 8 & - & - & 8 & - & 3 & 1 \\
\hline
\end{tabular}

Figura 4.2. 73: Tabla resumen de la presencia de piezas de material de granito en los lienzos de la muralla.

\subsubsection{B.- PIEDRA SEDIMENTARIA O CARBONATADA.}

Es el material más utilizado en la construcción de la muralla. Empleamos esta designación dado que en los lienzos y torres de la muralla encontramos numerosos tipos de piedra sedimentaria entremezclada, caliza, arenisca, conglomerados, etc. Incluimos todas como un único tipo. De forma genérica se dispone por encima del granito, ya que como hemos visto éste se emplea especialmente en los zócalos, salvo en reconstrucciones. La gran variedad de tipos de piedra que se incluyen en esta denominación hace completamente inviable su análisis desde el punto de vista exclusivamente del material. El material por sí solo no nos va a confirmar nada. Solo nos puede ayudar a distinguir lienzos por exclusión cronológica, si encontramos algún tipo de spolia cuya datación sea posterior a la teórica de construcción de la muralla. En el resto de los casos necesitamos imbricar con otros datos y cotejar con el análisis de otras variables. Este análisis se efectúa más adelante cuando se estudien los sistemas y técnicas constructivas (Ver puntos 4.2.5 y 4.2.6).

Las canteras de procedencia de las rocas que reconocemos son siempre del entorno de la ciudad e incluso de la propia base de la muralla, ya que como hemos visto, en numerosos puntos la roca esta tallada verticalmente por delante de la línea de apoyo de la muralla o el ejemplo de la cantera descubierta delante del lienzo L60-61. Tan solo existe una excepción de una piedra no existente en las proximidades de Segovia, denominada caliza con gasterópodos, procedente de Campaspero-Cuellar, y que se sospecha que posiblemente provengan del expolio de un edificio arruinado previo (PH: P0178: 137-153). Este tipo de piedra aparece en unos pocos lienzos de la cara norte, entre las torres T35 y T38.

El uso de las canteras de la zona y de la base de la muralla es una actividad que se remonta a varios siglos. Las denuncias y prohibiciones de extraer roca y arena de la base de la muralla se repiten en numerosas ocasiones en la documentación histórica. La primera que tenemos datada se remonta a 1451 (AMS: Leg 31-1). 


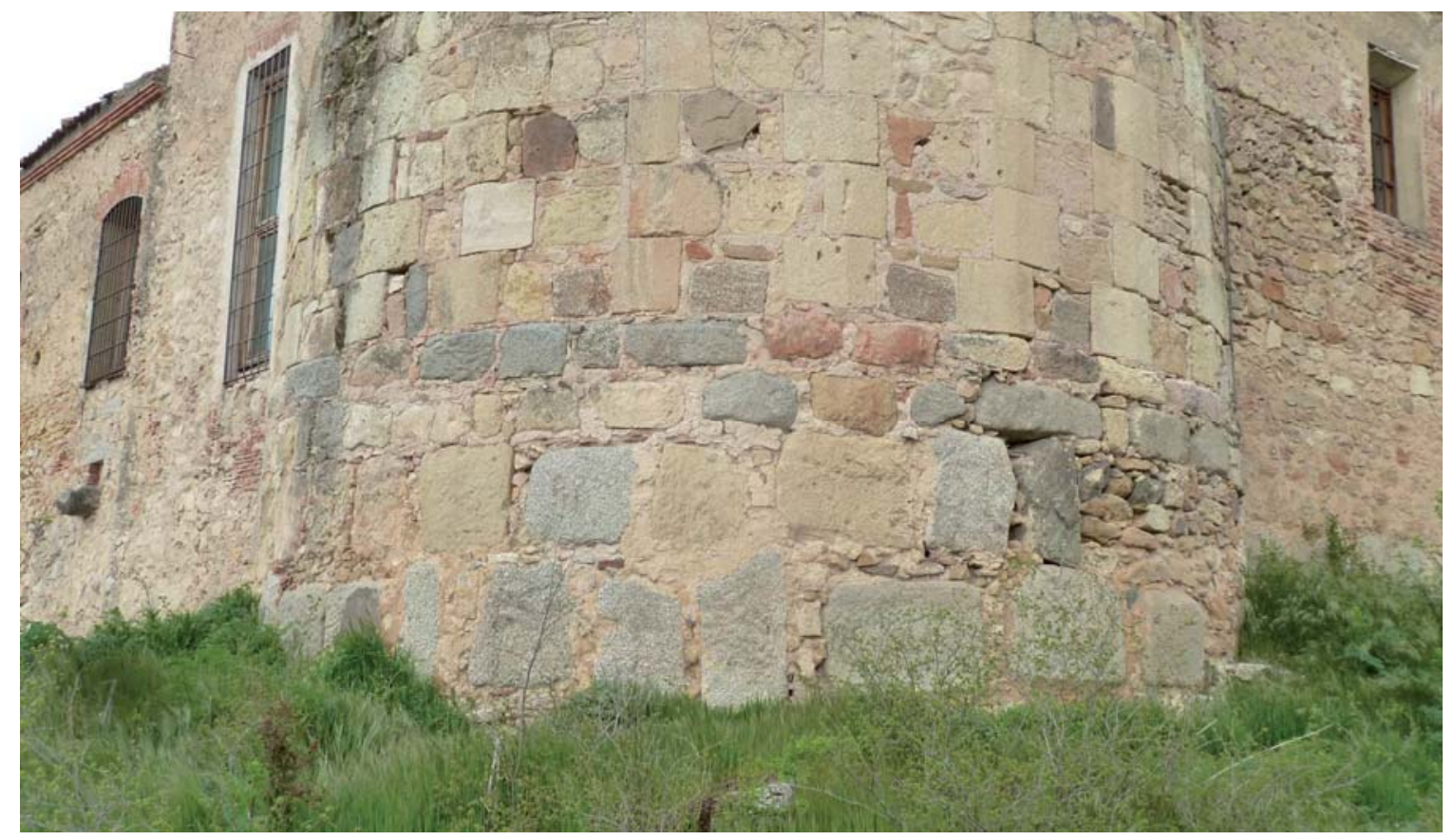

Figura 4.2. 74: Torre T81. Zócalo con abundante mezcla de distintos tipos de piedra, incluso mampostería, algo poco común en las torres de la muralla sur, lo que evidencia una menor disponibilidad de granito y de piezas de tamaño mayor en el momento de la ejecución de esta torre.

\subsubsection{C.- LADRILLO.}

Su empleo, constituyendo fábricas completas es relativamente poco extenso. Encontramos claramente distinguibles, básicamente dos tipos de ladrillo. El ladrillo de tejar tradicional y un ladrillo perforado, producido por la fábrica Carretero, cuyo periodo de actividad fabril va desde la mitad del XIX hasta la mitad del XX. Este dato nos va a permitir ubicar temporalmente todas las intervenciones en que aparece este tipo de ladrillo. Existe un tercer tipo de ladrillo, aparejado en bloques imitando sillares, que sólo hemos visto en la reconstrucción de la torre T84, intervención datada en la segunda mitad del XX.

La fábrica de ladrillo la reconocemos siempre colocada sobre la piedra sedimentaria, salvo excepciones en que se ha reconstruido completamente el lienzo, como en el L49-50, o toda la torre, como en el caso de la T84. Aparece, por lo tanto, en la parte más alta de la secuencia de materiales. En algunos casos, como en las torres de la calle Leopoldo Moreno, sobre la fábrica de ladrillo se han reconstruido posteriormente los petos en mampostería.

El ladrillo como material constructivo presenta tres funciones muy diferenciadas en que se emplea en la construcción de la muralla,

- como calzos y ripios, para nivelar piezas de mayor tamaño.

- como reparaciones puntuales de poca entidad.

- constituyendo una fábrica aparejada de una mínima entidad para poder valorar e identificar unas características. 
De los dos primeros casos tenemos ejemplos en prácticamente todos los lienzos y torres de la muralla. La utilización de ripios en las fabricas de sillería de los zócalos, o su empleo en las reparaciones y reposiciones en las juntas que requerirían mucho mortero, hacen que su presencia se contemple en todos las zonas de la muralla, como parte de la fábrica original y como reparaciones repartidas a lo largo de los siglos difícilmente datables. Del mismo modo vemos reparaciones de pequeña entidad, reponiendo perdidas, sillares esquineros, pequeñas oquedades o bien se ha empleado el ladrillo, complementando con piedra sedimentaria, realizando mamposterías encintadas, como en L2-3 o T50.
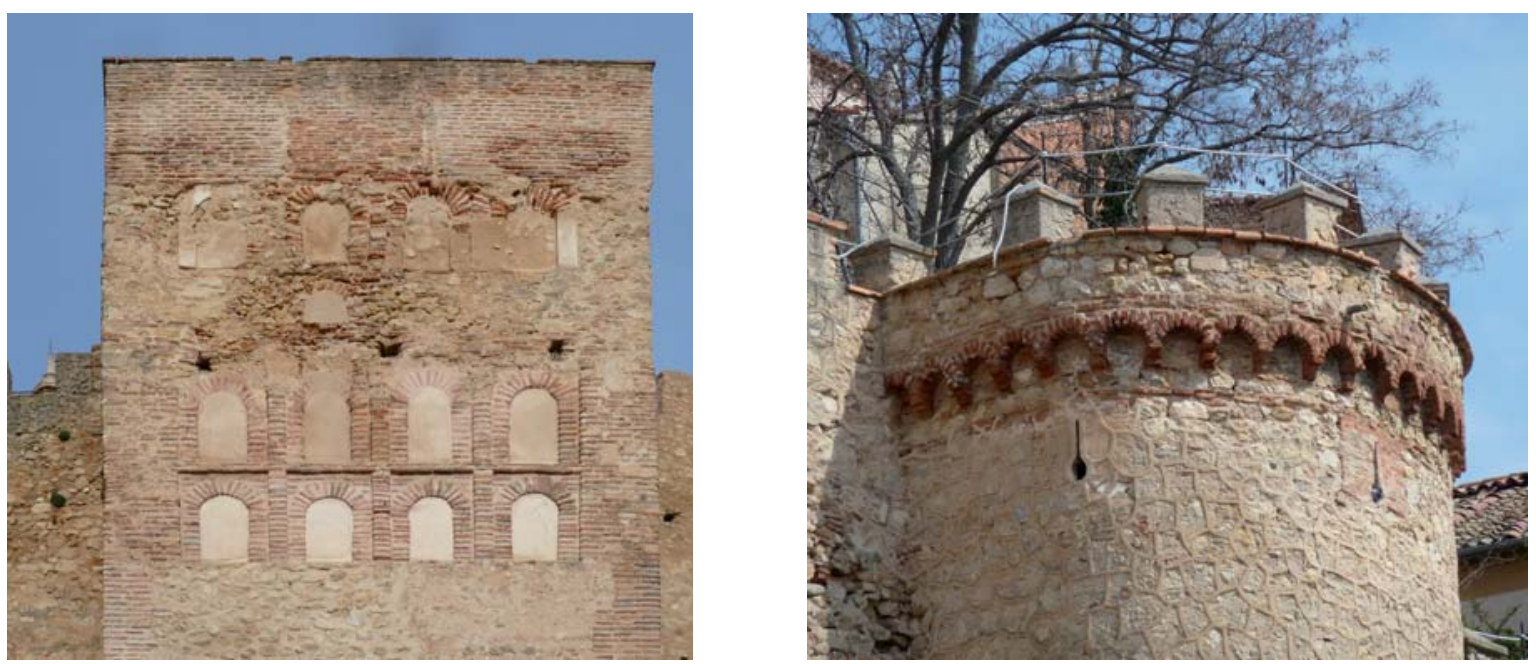

Figura 4.2. 75: T3. Fabrica de ladrillo de arquillos ciegos que encontramos en la mayoría de las torres de la zona 1.

Figura 4.2. 76: Falso matacán volado formado por arquillos de ladrillo, en el remate de la T16.

Del tercer caso encontramos ejemplos en 17 torres y 6 lienzos. Enumerando muy someramente, en la zona 1, lo vemos en T2, T3, T4, T5, T6 y en el lienzo L1-2; en la zona 2, la T9; en la zona 3, en T16, T19 y L16-17; en la zona 6, en T31, T38 y T39; en la zona 7, lo vemos en T43, T44, T46, T48 y en L49-50; en la zona 9, en T57 y L58-59 y en la zona 12, lo encontramos en T84, L80-81 y L81-82.

El ladrillo de tejar lo vemos de manera más profusa en la zona 1, Leopoldo Moreno, en la parte alta de las torres y de la puerta de San Andrés, en 5 de las 8 torres, constituyendo una fábrica de arquillos ciegos de indudable aire mudéjar. El ladrillo de la fábrica Carretero lo vemos en las reparaciones del siglo XIX-XX, de manera muy abundante especialmente en la ladera norte de la muralla, constituyendo distintos tipos de aparejos, que estudiaremos más adelante.

La fábrica cerámica aparece constituyendo algunos elementos puntuales, como el arco de descarga en la parte alta de la puerta de San Cebrián y del postigo de fuente cercada o realizando los recercados de los huecos de la sinagoga en la T9, la secuencia de arquillos del falso matacán de T16 y del lienzo L16-17 y de forma muy frecuente en petos, almenados, fusileras, recercados de huecos y arcos de puertas y postigos. Se trata en todos los casos de funciones de escasa entidad y relevancia en el conjunto de la muralla. 


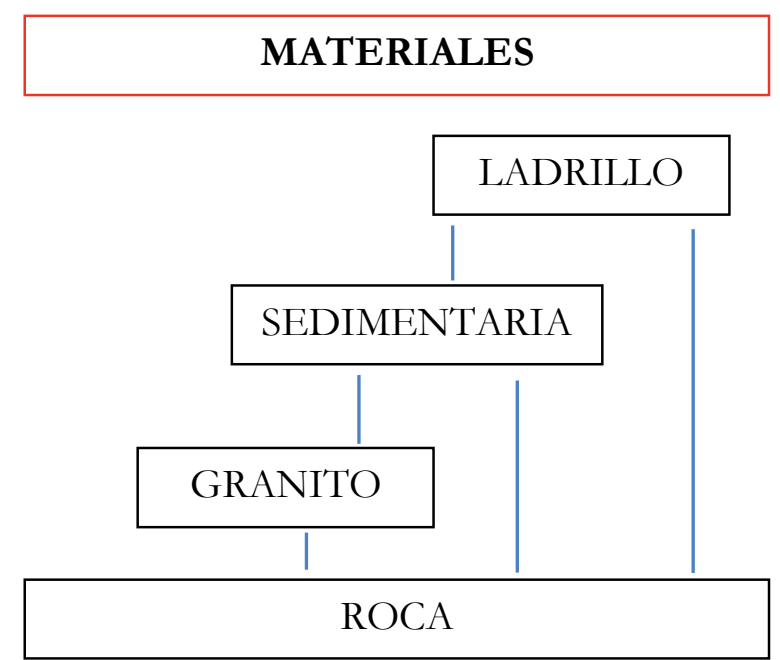

Figura 4.2. 77: Esquema secuencial de la disposición de los materiales constructivos, tal y como se encuentran en la muralla.

No se han estudiado los tipos distintos de ladrillo de tejar existentes en la muralla. Entendemos que la toma de muestras para hacer análisis químicos del material cerámico o de los morteros, así como la toma de medidas de cada uno de los aparejos existentes supone un volumen de trabajo adicional que aportaría un conocimiento muy limitado a los objetivos de esta tesis, ya que se encuentra en las partes altas de la muralla, por tanto pertenece a etapas constructivas posteriores a la repoblación oficial, como veremos más adelante.

\subsubsection{D.- SPOLIA. LA REUTILIZACIÓN DE MATERIALES.}

El aprovechamiento de ruinas romanas, especialmente fortalezas o edificios públicos, de gran solidez, para usos defensivos era algo habitual (Heers, 1978: 204). La existencia como tal de spolia en los lienzos de la muralla no va a ser significativa para extraer conclusiones. El hecho de tratarse de elementos reutilizados, dispuestos en posición secundaria, hace imposible la datación de su disposición, pues pueden haber sido recolocadas en más de una ocasión.

La distribución asimétrica de las piezas procedentes del expolio de los cementerios puede explicarse, según algunos autores, por la proximidad de estas necrópolis que se expoliaron sus lapidas para la construcción de la muralla. Se han identificado 3 ubicaciones, la zona de Santi Spiritu, entre San Andrés y el Alcázar y entre la puerta de Santiago y el postigo de San Juan, como emplazamientos de cementerios romanos, coincidiendo con los lienzos donde mayor número de spolia aparece en la muralla (Santos Yanguas et alli, 2005: 149-219) ${ }^{132}$. Tienen localizadas un total de 67 lápidas en estos tres sectores, que se corresponden aproximadamente con las zonas $1,2,3,6,7,8,10,11$ y 12 en que hemos dividido la muralla para nuestro estudio y toma de datos.

132 Por la misma lógica, pensamos que el expolio de los edificios que estarían en ruinas en la Edad Media aportaría los sillares, tambores de columna, molduras y otro tipo de piezas talladas que están embebidas en la muralla. 
Sin embargo, aún dentro de estas zonas próximas a las necrópolis, la distribución de las spolia no es homogénea sino que aparecen de manera más abundante en unas torres que en otras y asoman de forma generalizada en las partes bajas de las torres, mientras que su utilización en las partes altas de las torres resulta muy poco frecuente.

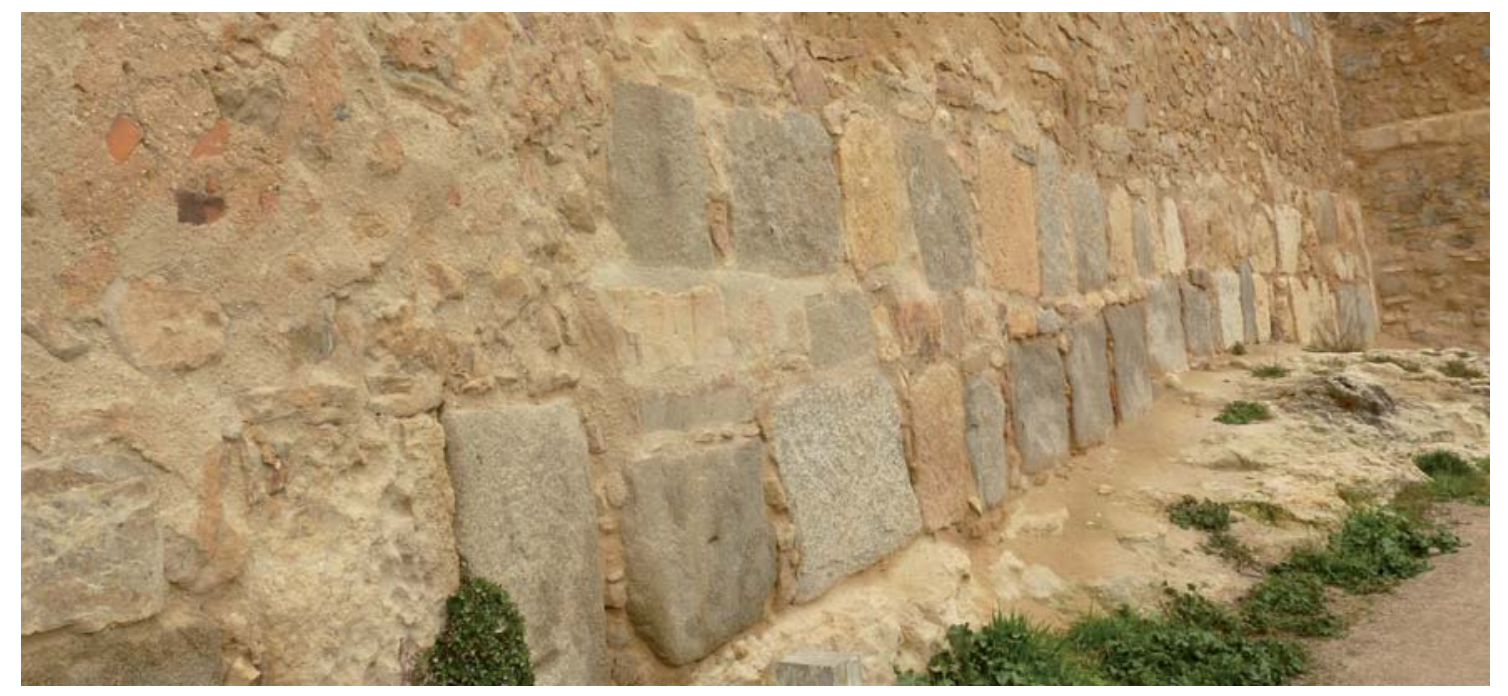

Figura 4.2. 78: Discontinuidad constructiva en el lienzo entre torres T74 y T75. El lienzo de muralla presenta un quiebro en el cual se produce una interrupción del zócalo que se configura como un aparejo de tres hiladas a la derecha de la imagen y de solo una a la izquierda de dicho quiebro.

A efectos de nuestro estudio el término spolia va a tener una afección más amplia, no sólo a las que presenten inscripciones reconocibles, dado que sospechamos que existen muchas piezas cuya inscripción está oculta, hacia el interior de la muralla. Además no nos van a interesar sólo las lápidas con inscripciones de alto valor histórico epigráfico, sino todas aquellas piezas reutilizadas integradas en el aparejo, procedentes de edificios y construcciones que poseen características formales, estilísticas, técnicas o epigráficas reconocibles que las identifiquen cronológicamente de forma inequívoca y nos permitan establecer una fecha postquam para datar las fábricas. Así por ejemplo consideramos Spolia, las piezas con garras para su elevación, que estén colocadas en posición secundaria, los sillares colocados como mampuestos en una fábrica de mampostería y todas aquellas piezas que evidencian unos trabajos de preparación y talla innecesaria para la ubicación en la que se encuentran. Con total obviedad son evidentemente piezas reutilizadas. El análisis de los aparejos nos permite interpretar las discontinuidades para ver si lo que podemos datar por medio de esa spolia es todo el lienzo o solo una parte de él, por tratarse de una reparación puntual.

Como puede verse en la Figura 4.2. 79 el número de torres y lienzos que presentan spolia antiguas en sus fábricas es muy significativo, siendo más representativo su presencia en las torres. Resulta evidente que su empleo es mayoritario, en ambos casos, en las partes bajas. Es la lógica constructiva como ya hemos indicado, pero nos va a interesar mucho más la existencia de spolia antiguas en las partes altas, ya que nos está señalando los elementos excepcionales, que contradicen esa lógica constructiva. Al igual que hemos visto ya en la disposición de los granitos, estas excepciones son elementos reconstruidos. Cruzando estos datos con los obtenidos anteriormente, el listado de elementos reconstruidos identificados sigue ampliándose. 
Localizamos spolia antiguas en las partes altas, en 5 torres y 6 lienzos distribuidos de la siguiente manera: en la zona 2, en el L9-10, correspondiendo con la reconstrucción del postigo del Sol y la sinagoga, en la zona 4 en la T22 y en el lienzo L23-24; dentro de la zona 5, en la T25 y en el lienzo L28-L29; en la zona 6, en el L34-35 y en la T38; en la zona 7 en el L44-45 y en las torres T45 y T46 y por último en la zona 9 en el lienzo L58-59.

\begin{tabular}{|c|c|c|c|}
\hline \multicolumn{5}{|c|}{ SPOLIA EN TORRES } \\
\hline ZONA & ZOCALOS & $\begin{array}{c}\text { PARTES } \\
\text { ALTAS }\end{array}$ & $\begin{array}{c}\text { N }{ }^{0} \text { TOTAL } \\
\text { TORRES }\end{array}$ \\
\hline \hline 1 & 7 & - & $\mathbf{8}$ \\
2 & 2 & - & $\mathbf{5}$ \\
3 & 1 & - & $\mathbf{4}$ \\
4 & 1 & 1 & $\mathbf{7}$ \\
5 & 2 & 1 & $\mathbf{2}$ \\
6 & 10 & 1 & $\mathbf{1 2}$ \\
7 & 3 & 2 & $\mathbf{9}$ \\
8 & 1 & - & $\mathbf{5}$ \\
9 & 3 & - & $\mathbf{4}$ \\
10 & - & - & - \\
11 & 5 & - & $\mathbf{8}$ \\
12 & 6 & - & $\mathbf{7}$ \\
\hline \hline SUMA & $\mathbf{4 1}$ & $\mathbf{5}$ & $\mathbf{7 1}$ \\
\hline
\end{tabular}

\begin{tabular}{|c|c|c|c|}
\hline \multicolumn{5}{|c|}{ SPOLIA EN LIENZOS } \\
\hline ZONA & ZOCALOS & $\begin{array}{c}\text { PARTES } \\
\text { ALTAS }\end{array}$ & $\begin{array}{c}\text { N }^{0} \text { TOTAL } \\
\text { LIENZOS }\end{array}$ \\
\hline \hline 1 & 7 & - & $\mathbf{7}$ \\
2 & 2 & 1 & $\mathbf{5}$ \\
3 & - & - & $\mathbf{5}$ \\
4 & 1 & 1 & $\mathbf{6}$ \\
5 & - & 1 & $\mathbf{4}$ \\
6 & 6 & 1 & $\mathbf{1 3}$ \\
7 & 1 & 1 & $\mathbf{9}$ \\
8 & - & - & $\mathbf{5}$ \\
9 & 3 & 1 & $\mathbf{6}$ \\
10 & - & - & - \\
11 & 6 & - & $\mathbf{7}$ \\
12 & 6 & - & $\mathbf{8}$ \\
\hline \hline SUMA & $\mathbf{3 2}$ & $\mathbf{6}$ & $\mathbf{7 5}$ \\
\hline
\end{tabular}

Figura 4.2. 79: Tabla resumen de la existencia de spolia en las torres de la muralla. Se indica el número de torres en que los encontramos.

Figura 4.2. 80: Tabla resumen de la existencia de spolia en los lienzos de la muralla. Se indica el número de lienzos en que los encontramos.

Hasta ahora hemos hablado de spolia antiguas, las del mundo antiguo y altomedieval, pero podemos hallar otros elementos que nos pueden dar una referencia cronológica posterior a la fecha de construcción "oficial " de la muralla. Otras spolia, correspondientes a las épocas bajo medieval, moderna o contemporánea. Piezas que poseen características reconocibles que las identifican cronológicamente de forma inequívoca, con una datación posterior a la construcción de la muralla. Las referimos como "material moderno datable". Las primeras, spolia romanas y altomedievales, pueden encontrarse en la muralla tal y como se dispusieron originalmente o bien haber sido recolocadas posteriormente. Las segundas, ineludiblemente nos están datando esos lienzos y torres, como intervenciones posteriores a la construcción de la muralla.

En el caso de piezas que por los mismos criterios podamos encuadrar cronológicamente en etapas posteriores a la muralla, por ejemplo siglo XV, XIX o XX, nos van a permitir identificar reconstrucciones. Si estos spolia aparecen repartidos por todo el lienzo desde abajo, se trata de una reconstrucción total. Si sólo aparecen en la mitad superior, se trata de una reconstrucción parcial o de una reparación.

Como puede verse en la Figura 4.2. 85, el número de casos que encontramos en las torres y lienzos de la muralla es poco significativo. Tenemos material datable moderno en 10 torres, 3 de los casos en zócalo y 7 en las partes altas, mientras en los lienzos sólo hemos hallado 3 
ejemplos, todos ellos en las partes altas. En principio estos 3 lienzos y las 7 torres que presentan el material moderno en su mitad superior, son reconstrucciones parciales, pero los tres casos de torres que los presentan en sus zócalos son reconstrucciones totales. Se trata de la T14, la T46 y la T56, situadas en las zonas 3, 7 y 8 respectivamente.

Como elementos reconstruidos, en principio, sólo parcialmente, consideramos en la zona 2, el lienzo L8-9, que ya hemos visto anteriormente, la parte correspondiente al postigo del Sol y la sinagoga; en la zona 4 la torre T22 y el lienzo L22-23; en la zona 5 la T25; en la zona 6 la T38; en la zona 7, la T45 y la T46 y en la zona 11, el lienzo L73-74.

Como puede verse algunas torres y lienzos se repiten en los distintos listados, considerándose como elementos reconstruidos parcialmente en unos casos y totalmente en otros. Esto nos confirma, por distintos análisis que el elemento no es original, que es un elemento reconstruido. Falta evaluar, que porcentaje del mismo es una restauración. La recapitulación de los elementos reconstruidos en el capítulo 5.1 nos permitirá reagrupar esta información.
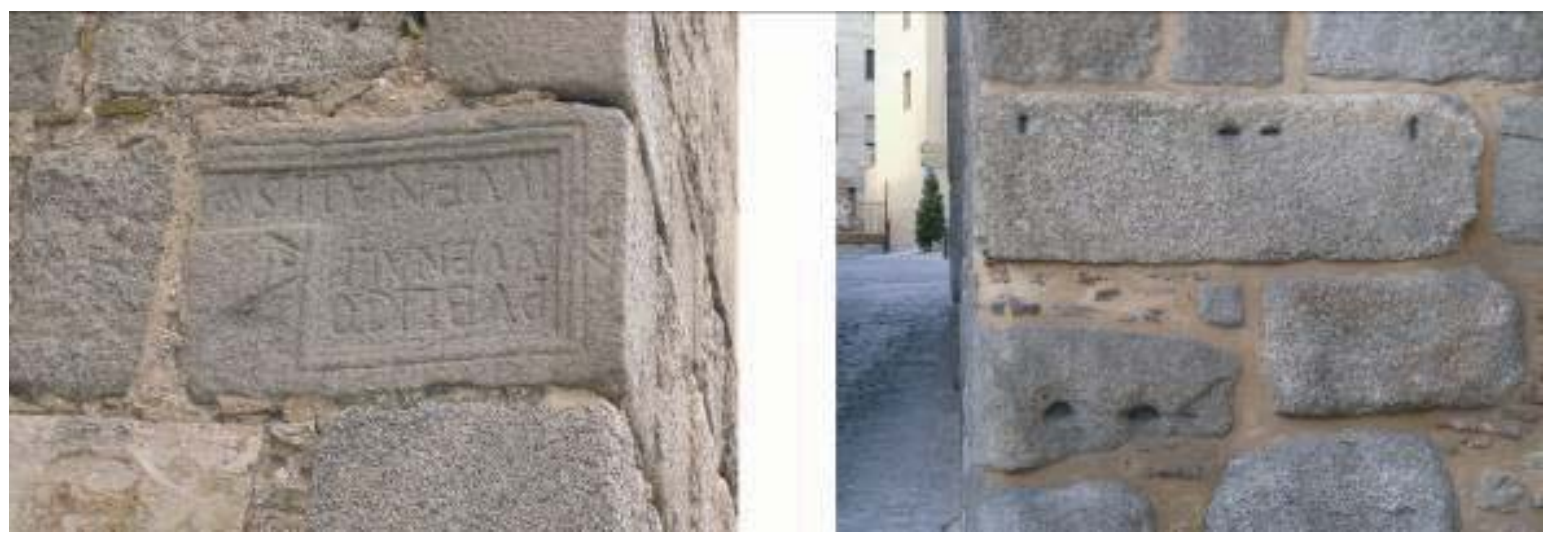

Figura 4.2. 81: Detalle de la torre T3. Lápida romana reutilizada en la muralla de Segovia.

Figura 4.2. 82: Detalle de la torre T2. Otras piezas reutilizadas de difícil datación.
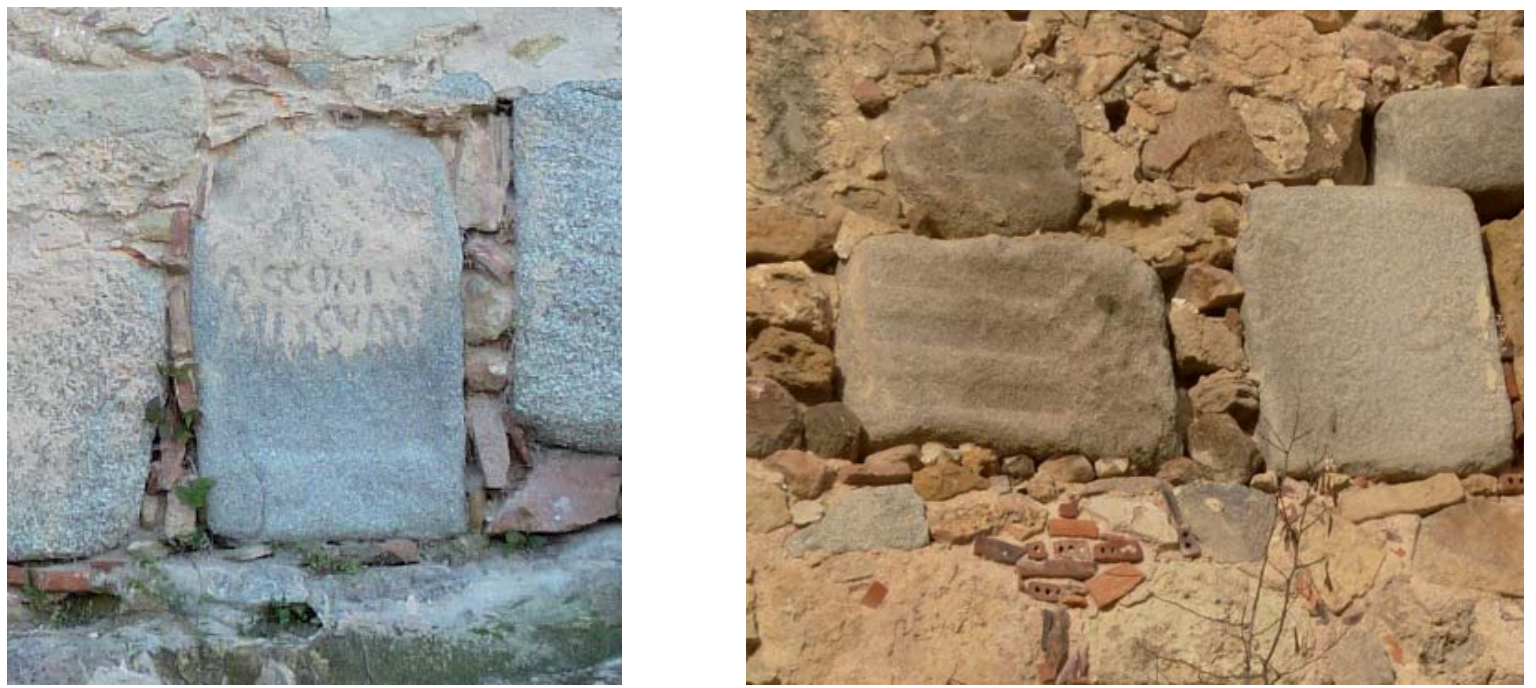

Figura 4.2. 83: Detalle del zócalo del lienzo L80-81. Lápida romana reutilizada en la muralla de Segovia.

Figura 4.2. 84: Detalle del lienzo L28-28’. Otras piezas reutilizadas de filiación romana entre las que distinguimos distintos sillares y un lapida con un acueducto tallado. 


\begin{tabular}{|c|c|c|c|}
\hline \multicolumn{4}{|c|}{ MATERIAL DATABLE MODERNO EN TORRES } \\
\hline ZONA & ZOCALOS & $\begin{array}{c}\text { PARTES } \\
\text { ALTAS }\end{array}$ & $\begin{array}{c}\text { N }{ }^{\circ} \text { TOTAL } \\
\text { TORRES }\end{array}$ \\
\hline \hline 1 & - & - & $\mathbf{8}$ \\
2 & - & 1 & $\mathbf{5}$ \\
3 & 1 & 1 & $\mathbf{4}$ \\
4 & - & - & $\mathbf{7}$ \\
5 & - & 2 & $\mathbf{2}$ \\
6 & - & - & $\mathbf{1 2}$ \\
7 & 1 & - & $\mathbf{9}$ \\
8 & 1 & 1 & $\mathbf{5}$ \\
9 & - & - & $\mathbf{4}$ \\
10 & - & - & - \\
11 & - & - & $\mathbf{8}$ \\
12 & - & 2 & $\mathbf{7}$ \\
\hline \hline SUMA & $\mathbf{3}$ & $\mathbf{7}$ & $\mathbf{7 1}$ \\
\hline
\end{tabular}

\begin{tabular}{|c|c|c|c|}
\hline \multicolumn{4}{|c|}{ MATERIAL DATABLE MODERNO EN LIENZOS } \\
\hline ZONA & ZOCALOS & $\begin{array}{c}\text { PARTES } \\
\text { ALTAS }\end{array}$ & $\begin{array}{c}\text { No TOTAL } \\
\text { LIENZOS }\end{array}$ \\
\hline \hline 1 & - & - & $\mathbf{7}$ \\
2 & - & 1 & $\mathbf{5}$ \\
3 & - & - & $\mathbf{5}$ \\
4 & - & 1 & $\mathbf{6}$ \\
5 & - & - & $\mathbf{4}$ \\
6 & - & - & $\mathbf{1 3}$ \\
7 & - & - & $\mathbf{9}$ \\
8 & - & - & $\mathbf{5}$ \\
9 & - & - & $\mathbf{6}$ \\
10 & - & - & - \\
11 & - & 1 & $\mathbf{7}$ \\
12 & - & - & $\mathbf{8}$ \\
\hline \hline SUMA & $\mathbf{0}$ & $\mathbf{3}$ & $\mathbf{7 5}$ \\
\hline
\end{tabular}

Figura 4.2. 85: Tabla resumen de la existencia de material datable moderno en las torres de la muralla.

Figura 4.2. 86: Tabla resumen de la existencia de material datable moderno en los lienzos de la muralla.
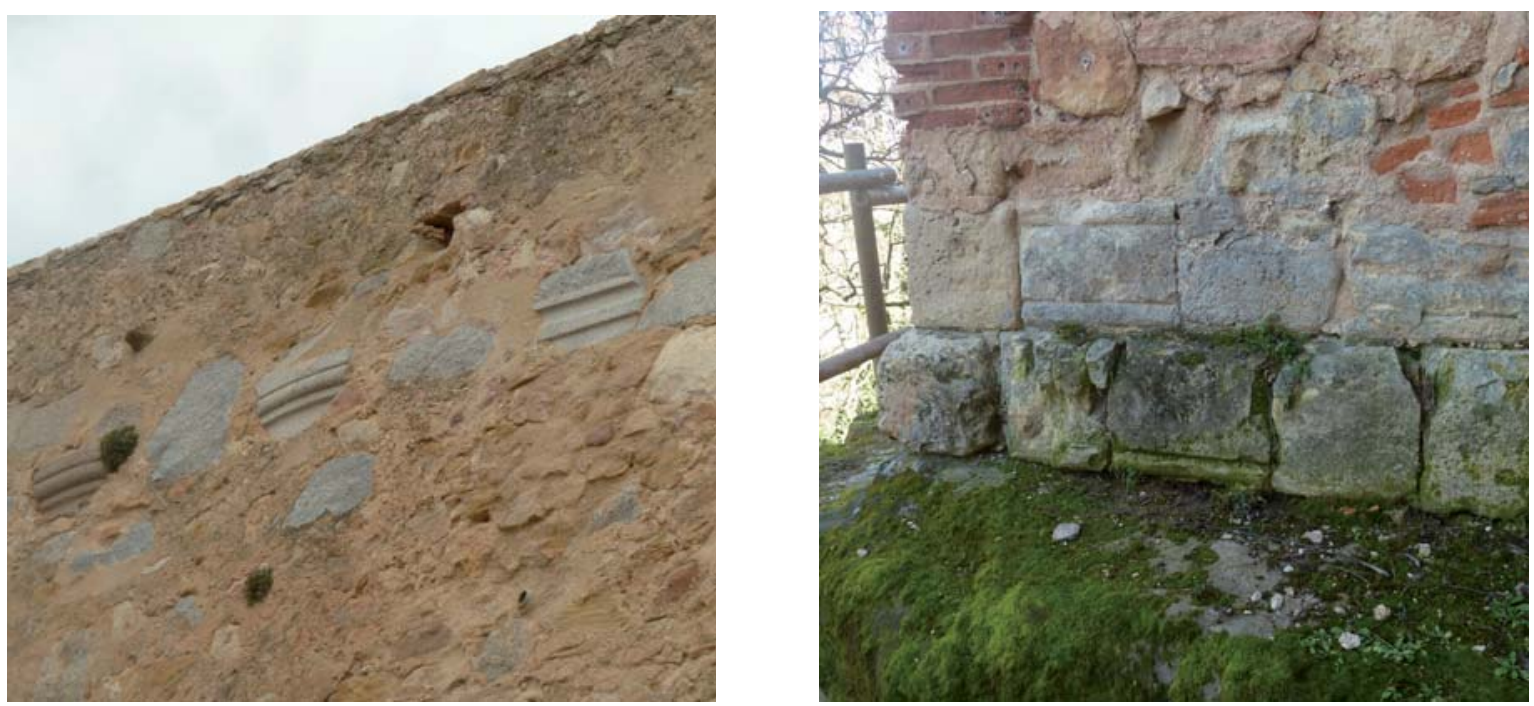

Figura 4.2. 87: Dovelas con boceles y molduras talladas en granito, recolocadas en el remate superior del lienzo L73-74. Sus características nos llevan a datar esas piezas como muy temprano en el siglo XIV o XV.

Figura 4.2. 88: Molduras y jambas con bocel talladas en piedra sedimentaria recolocadas en el zócalo de la torre T46. Sus características nos hacen suponer que provengan de la ruina de alguna iglesia románica, datando dichas piezas como muy tempranas en el siglo XII. Su colocación en la muralla es necesariamente posterior e esa fecha. 


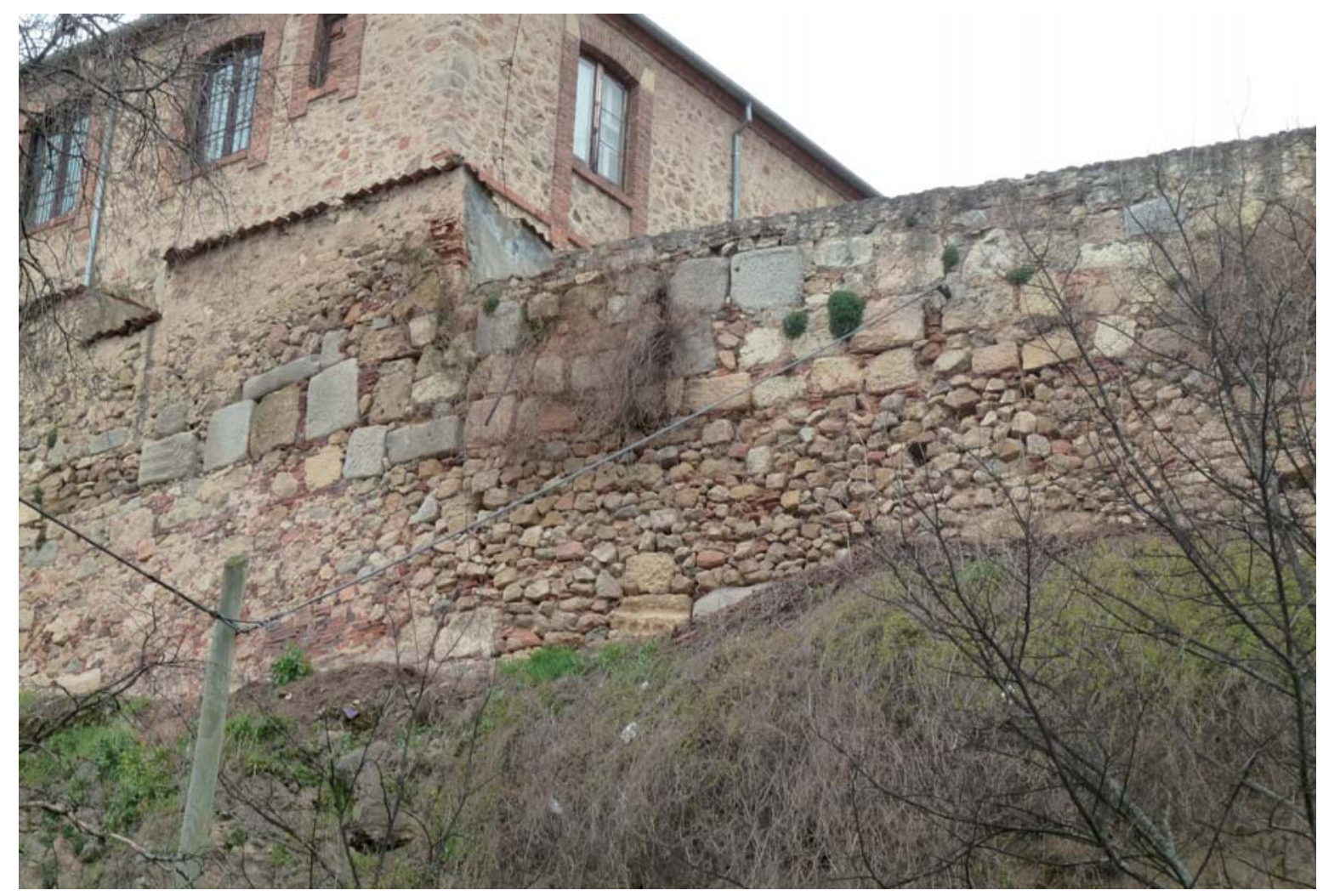

Figura 4.2. 89: L28-28’: Abundancia de sillares y spolia romanas reutilizadas en la parte alta del lienzo.

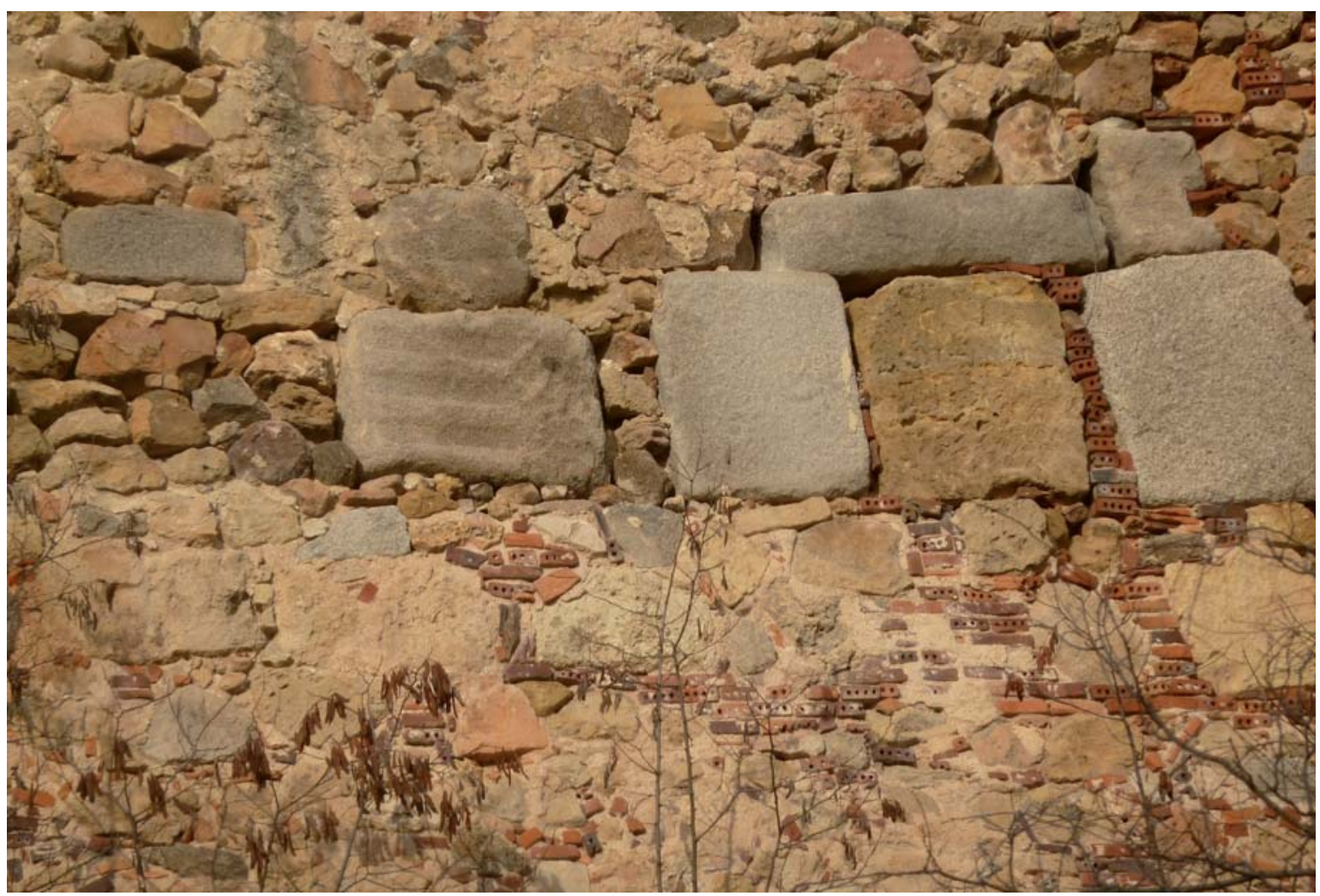

Figura 4.2. 90: L28-28’: Detalle de la figura anterior. Se observa la figura deteriorada de un acueducto sobre uno de los sillares. La abundancia de ladrillos de la fábrica Carrereo evidencia que están recolocados, fruto de una reconstrucción de la etapa contemporánea. 

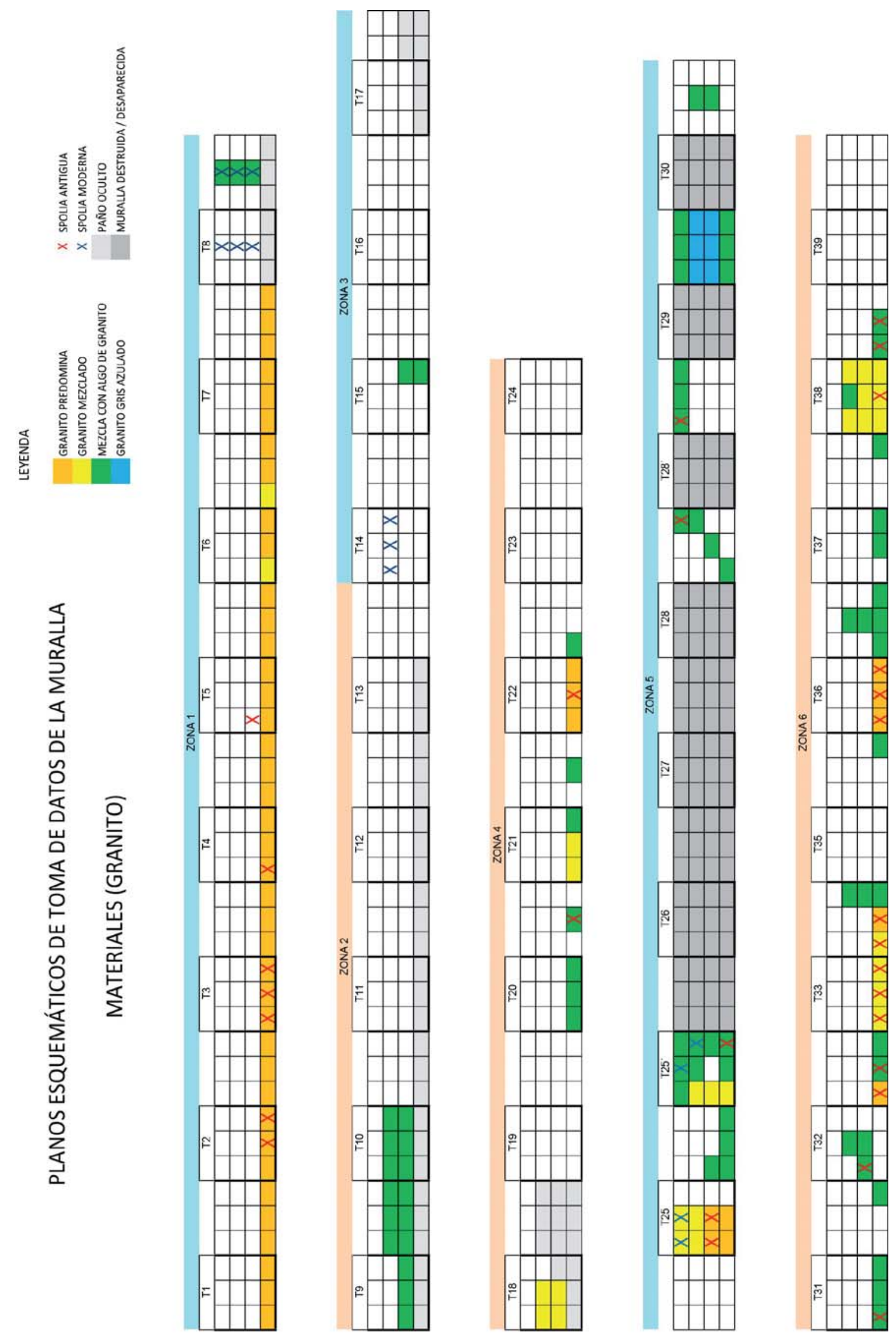

Figura 4.2. 91: Plano esquemático de la toma de datos de la muralla. Materiales empleados. 

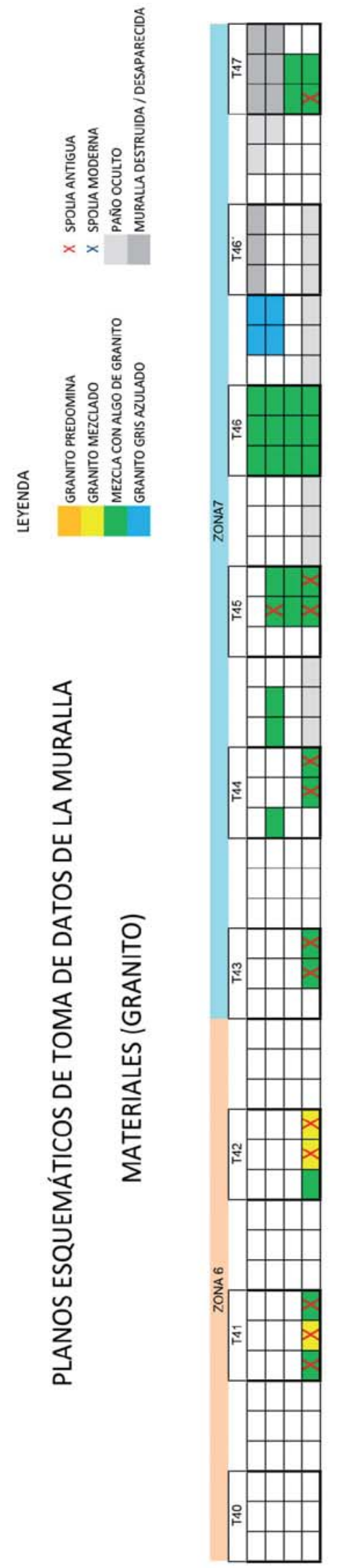

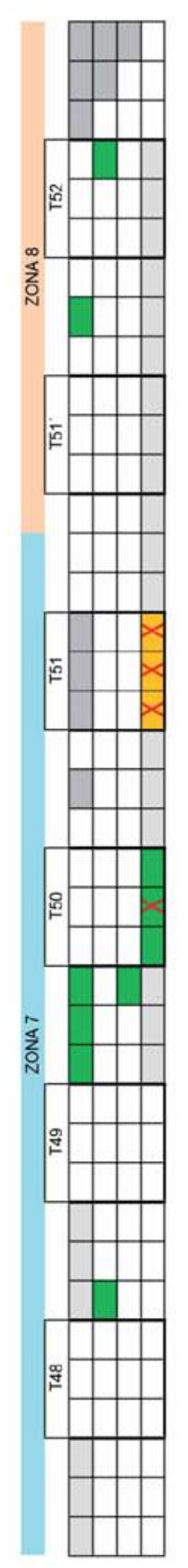

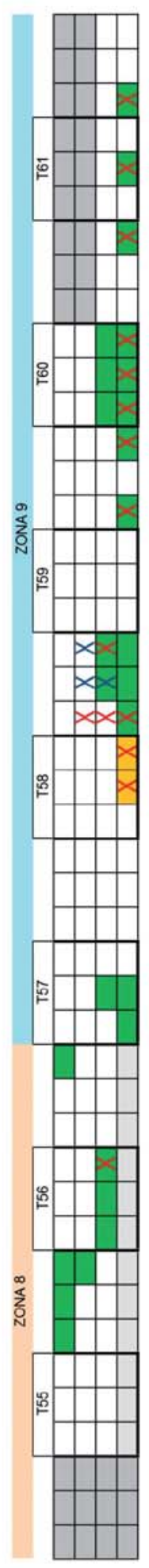
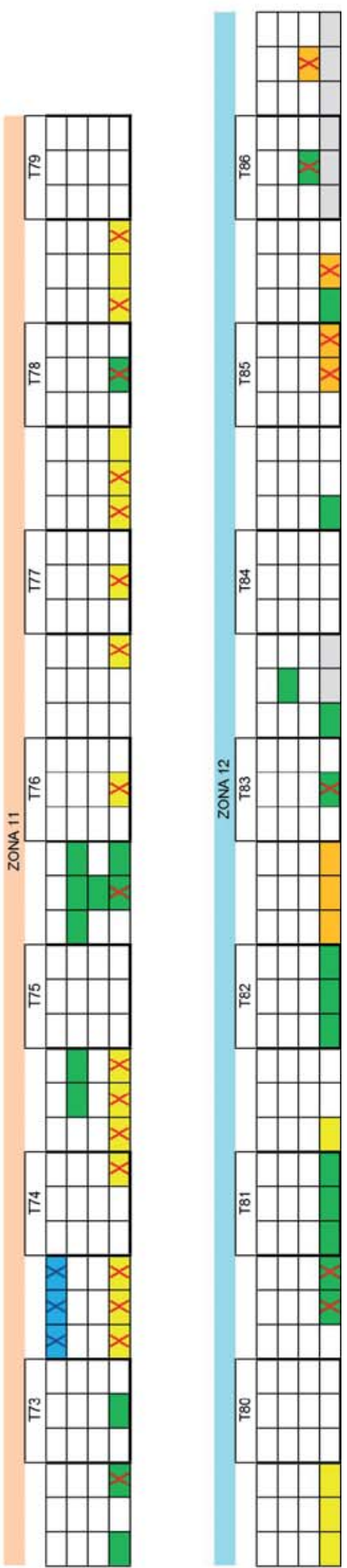

Figura 4.2. 92: Plano esquemático de la toma de datos de la muralla. Materiales empleados. 
